\title{
DOE/CS/05438-T1
}

Volume 3 of 3 Volumes

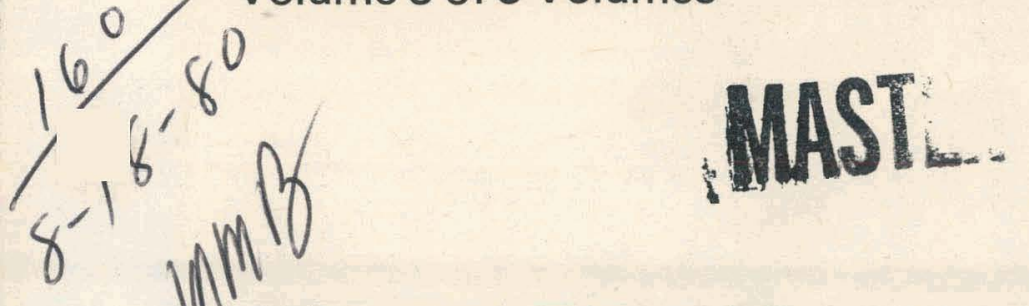

\section{Alternative Energy Sources} for Non-Highway Transportation

\author{
Appendices
}

June 1980

Prepared for

U.S. Department of Energy

Assistant Secretary for Conservation

and Solar Energy

Office of Transportation Programs

Contract No. DE-AC05-77CS05438 


\section{DISCLAIMER}

This report was prepared as an account of work sponsored by an agency of the United States Government. Neither the United States Government nor any agency Thereof, nor any of their employees, makes any warranty, express or implied, or assumes any legal liability or responsibility for the accuracy, completeness, or usefulness of any information, apparatus, product, or process disclosed, or represents that its use would not infringe privately owned rights. Reference herein to any specific commercial product, process, or service by trade name, trademark, manufacturer, or otherwise does not necessarily constitute or imply its endorsement, recommendation, or favoring by the United States Government or any agency thereof. The views and opinions of authors expressed herein do not necessarily state or reflect those of the United States Government or any agency thereof. 


\section{DISCLAIMER}

Portions of this document may be illegible in electronic image products. Images are produced from the best available original document. 
DOE/CS/05438-T1

Volume 3 of 3 Volumes

Dist. Category UC-96

\title{
Alternative Energy Sources for Non-Highway Transportation
}

\author{
Appendices
}

June 1980

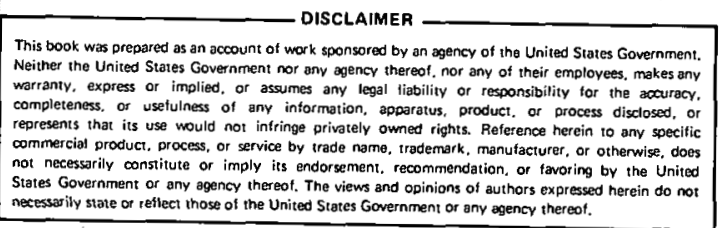

Prepared for

U.S. Department of Energy

Assistant Secretary for Conservation and Solar Energy

Office of Transportation Programs

Washington, D.C. 20585

Prepared by

Exxon Research and Engineering Company

Government Research Laboratories

Linden, New Jersey 07036

Contract No. DE-AC05-77CS05438 


\section{NOTICE}

This report was prepared as an account of work sponsored by the United States Government. Neither the United States nor the United States Department of Energy, nor any of their employees, makes any warranty, express or implied, or assumes any legal liability or responsibility for the accuracy, completeness; or usetulness of any information, apparatus, product, or process disclosed, or represents that its use would not infringe privately owned rights. Reference herein to any specific commercial product. process. or service by trade name, mark, manufacturer, or otherwise, does not necessarily constitute of imply its endorsement, recommendation, or favoring by the United States Government or any agency thereof. The views and opinions of au thors expressed herein do not necessarily state or reflect those of the United States Government or any agency thereof. 


\section{Acknowledgment}

This report was edited by $E$. N. Cart, Jr. and is based on work performed by E. N. Cart, Jr., D. Carter, A. R. Cunningham, M. H. Farmer, W. Herbst, B. Kraus, E. M. Magee, E. W. Nicholson and J. Percival. 
TABLE OF CONTENTS

PEVIEW

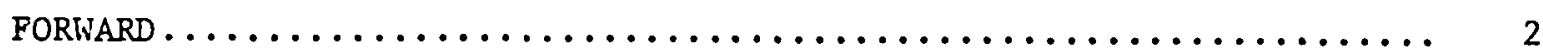

1. PRIME MOVERS AND FUELS USED IN NON-HIGHWAY TRANSPORTATION...... 1-1

1.1.1 Alrcraft Engines and Aviation Fuels............ 1-1

1.1.1.1 Types of Aircraft Turbine Engines.......... 1-1

1.1.1.2 Aircraft Engine Fuel Consumption.......... 1-2

1.1.1.3 Critical Engine Components............... 1-6

1.1 .1 .3 .1 The Combustion System............ 1-8

1.1 .1 .3 .2 The Fuel system................ 1-9

1.1 .1 .4 Fuels for Aircraft................... 1-10

1.1.1.4.1 Aviation Gasoline............... 1-10

1.1.1.4.2 Alrcraft Turbine Fuels............ 1-11

1.1.2 Marine Prime Movers and Marine Fuels.............. 1-18

1.1.2.1 The Diesel Englne.................... 1-18

1.1.2.1.1 Diesel Engine Fuel Requlrements...... 1-19

1.1.2.1.2 Performance Characteristics

of Diesel Fuels................. 1-22

1.1.2.2 The Steam Turbine................... 1-25

1.1.2.2.1 Steam Turbine Fuel Requirements

for Marine Applications........... 1-25

1.1.2.3 The Gas Turbine Engine................ 1-26

1.1.2.3.1 Gas Turbine Fuel Requirements....... 1-26

1.1.3 Ra1lroad Prime Movers and Fuels................. 1-29

1.1.3.1 The Railroad Diesel Engine.............. 1-30

1.1.3.2 Diesel Engine Fuel Requirements........... 1-31

1.1.3.3 Railroad Gas Turbine Engine............. 1-33

1.1.3.4 Railroad Electric Motive Power............ 1-34

1.1.4 Pipeline Prime Movers and Fuel Interaction........ 1-34

1.1.4.1 Gas Engine Prime Movers............... 1-35

1.1.4.1.1 Gas Engine Fuel Requirements........ 1-35

1.1 .4 .2 Gas Turbine Primary Movers............... 1-36

1.1.4.3 Electric Motor Prime Movers.............. 1-37

1.1.5 Other Engines with Possible Application

to Non-Highway Transportation................. 1-37

1.1.5.1 Free P1ston Engine.................... 1-37

1.1 .5 .2 St1rling Engines........................ 1-41

1.1.5.3 Closed Cycle Gas Turbine............... 1-41

2. CRITERIA TO BE USED TO EVALUATE

AND RATE FUELS AND PRIME MOVERS ...................... 2-1

2.1 Fuel Manufacture Criteria...................... 2-2

2.2 Fuel Performance Criteria

from Designer/User Viewpoint..................... $<-2$

2.3 Fuel Logistics Criteria............................ 2-4

2.4 Overall Rating............................... 2-5 
Page

3. PHYSICAL AND CHEMICAL PROPERTIES OF ALTERNATE FUELS $\ldots \ldots \ldots \ldots \ldots$. .

3.1 Combustion Properties....................... 3-1

3.2 Vehicular Storage Requirements of Fuels.............. 3-7

3.3 Bulk Handling and Storage of Fuels................ 3-9

3.4 Engine Maintenance............................ 3-14

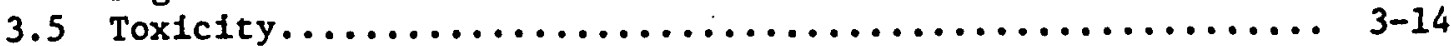

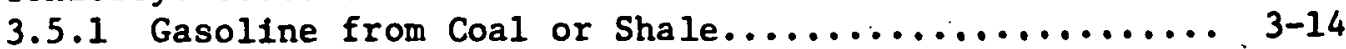

3.5.2 Dist1llates from Coal or Shale.............. 3-17

3.5 .3 Methanol............................. 3-18

3.5 .4 Ethanol........................................ 3-18

3.5 .5 Higher Oxygenates....................... 3-19

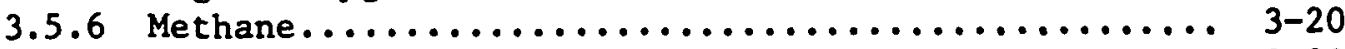

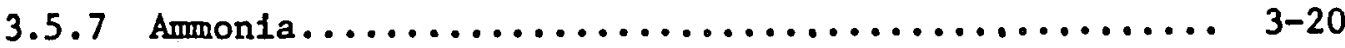

3.5 .8 Hydrogen.................................. 3-21

3.6 Safety........................................... 3-21

3.7 Properties of Non-Highway Fuels

from Coal syncrudes and Shale $011 \ldots \ldots \ldots \ldots \ldots . \ldots \ldots$ 3-22

Appendix 3-1: significance of Fuel Properties............. 3-25

Appendix 3-2: Properties of Non-Highway Fuels

from Shale and Coal Syncrudes............. 3-30

4. PRIME MOVER-FUEL INTERACTION $\ldots \ldots \ldots \ldots \ldots \ldots \ldots \ldots \ldots \ldots \ldots \ldots \ldots \ldots$ 4-1

4.1 Diesel Engines............................ $4-2$

4.2 Gas Turbines............................... $4-4$

4.3 Free Piston Engine.......................... 4-6

4.4 0tto Cycle Engines........................... 4-7

4.5 Externally Fired Engines...................... 4-8

4.6 Fuel Cells................................. 4-9

4.7 Unconvent1onal Fuel-Prime Mover Combinations........... 4-9

4.8 Fuel and Maintenance Costs........................ 4-10

5. REVIEW OF 'POTENTIAL FOR ALTERNATE

ENERGY FORMS FOR NON-HIGHWAY TRANSPORTATION............. 5-1

5.1 Possible Applications of Fuel Cells.................. 5-1

5.1 .1 The Fuel Cell system...................... 5-2

5.1 .1 .1 Types of Fuel Cells.................. 5-4

5.1.2 Fuel Cells to Consider for Non-Highway Transportation Applications.......... 5-6

5.1:2.1 1978-1985 Period..................... 5-6

$5.1 .2 .2 \quad 1985-2000$ Period................... 5-7

5.1.3 Applicability of Fuel Cells to

Non-Highway Transportation Systems............. 5-8

5.1 .3 .1 Aircraft........................ 5-8

5.1 .3 .2 Rallroad Locomotives................. 5-9

5.1.3.2.1 Characteristics of Diesel Electrics.. 5-11

5.1.3.2.2 Possibllities for Fuel Cells....... 5-11

5.1 .3 .3 Marine........................... 5-13

5.1.3.3.1 Possibilities for Fuel Cells....... 5-18 
5.1 .3 .4 Pipelines........................ 5-19

5.1 .4 Conclusions............................ 5-21

5.2 Nuclear................................ 5-22

5.2 .1 Marine............................... 5-22

5.2 .1 .1 Economics.............................. 5-23

5.2 .1 .2 Indemnification and Llability........... 5-23

5.2.1.3 Port Entry and International Clearance..... 5-2,3

5.2 .2 Alrcraft............................. 5-24

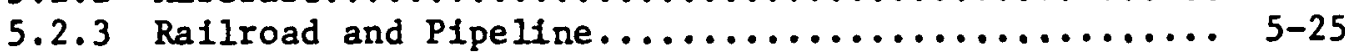

5.3 Direct Solar Radiation.......................... 5-26

5.3 .1 Marine............................... 5-26

5.3 .2 Railroad.............................. 5-26

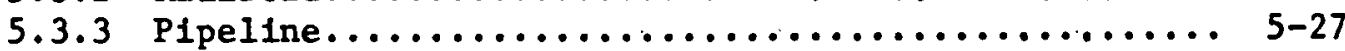


TABLE OF CONTENTS

Page

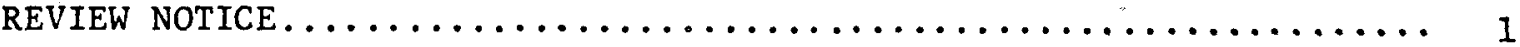

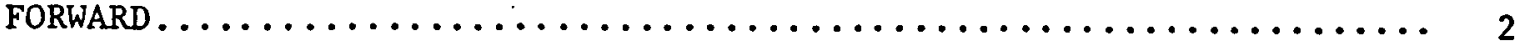

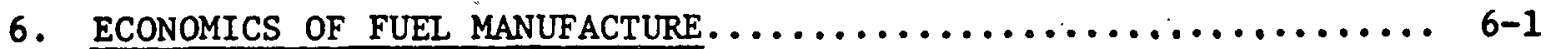

6.1 Introduction and overall sumary.................. 6-1

6.2 Basis for Economic Evaluation.................... 6-8

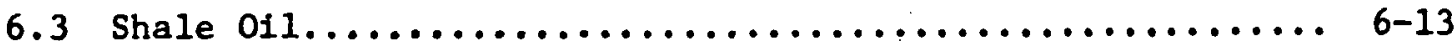

6.3.1 Shale 011 Process Description................ 6-13

6.3 .1 .1 Shale 011. Properties................. 6-15

6.3.2 Production Economics for Raw

Raw Shale 011 and Syncrude................. 6-15

6.3 .3 Syncrude Upgrading/Refining................ 6-17

6.4 Coal Cost................................... 6-20

6.5 Coal Liquids............................... $6-21$

6.5.1 General Process Classification................ 6-21

6.5 .1 .1 Pyrolysis......................... 6-21

6.5 .1 .2 Liquefaction..................... 6-21

6.5 .1 .3 Indirect Liquef action................. 6-24

6.5.2.1 Product Yields - General................6 6-26

6.5.2.2 Pyrolysis Products: Ylelds and Properties.. 6-26

6.5.2.3 Liquefaction Products:

6.5 .2 .4 Indirect Liquefaction:

Yields and Properties................ 6-38

6.5.3 Economics of Producing Coal Liquids............. 6-43

6.5.3.1 Total Costs of Coal Liquids

from Direct Liquefaction.............. 6-44

6.5.3.2 Capital Investment for

Direct Coal Liquefaction Processes........ 6-45

6.5.3.3 Operating Cost/Co-Product Credits......... 6-45

6.5 .3 .4 Feedstock Cost......................6 6-46

6.5.3.5 Variation of Total Cost with Plant Size.... 6-46

6.5.3.6 Variation of Total Cost w1th Coal Type..... 6-47

6.5 .4 Coal Liquids Upgrading...................... 6-49

6.5.4.1 Coal Liquids Upgrading Costs............ 6-50

6.5 .4 .2 Coal Liquids Overall Cost.............. 6-50

6.5 .5 Pyrolysis Liquids Costs.................... 6-51

6.5.6 Indirect Liquefaction Product Cost.............. 6-54

6.6 Coal-1n-011 slurry.......................... $6-55$

6.6 .1 Process Description...................... 6-55

6.6.2 Costs of Colloldal Fuel................... 6-56

6.7 Methanol.................................. 6-56

6.7 .1 .1 Coal............................. 6-57

6.7.1.2 Economics of Methanol

Manufacture from Coal................ 6-57

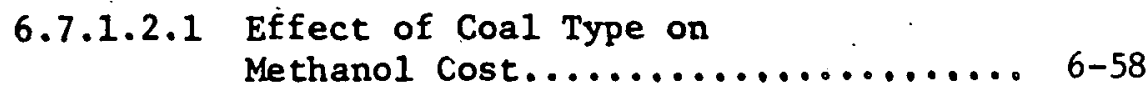

6.7.2.1 Methanol from Biomass................. 6-58

6.7 .2 .2 Process Route..................... 6-58

6.7.2.3 Methanol from Biomass: Process Economlcs... 6-59 
6.7.3 Methanol from Other Sources................. 6-60

6.7 .3 .1 Solid Waste Pyrolys1s................. 6-60

6.7.3.2 Ocean Thermal Energy Conversion (OTEC) ..... 6-60

6.7.3.3 Cost of Methanol Production

from Other Sources.................... 6-61

6.7.4 Summary of Methanol Cost from Different Sources.... 6-61

6.8 Hydrogen $\ldots \ldots \ldots \ldots \ldots \ldots \ldots \ldots \ldots \ldots \ldots \ldots \ldots \ldots \ldots \ldots \ldots \ldots \ldots \ldots$

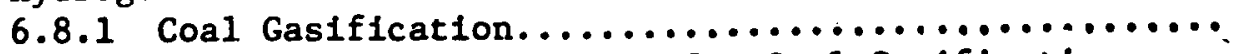

6.8.1.1 Process Economics for Coal Gasification.....
6.8 .1 .2 Effect of Coal Cost on Hydrogen Cost........

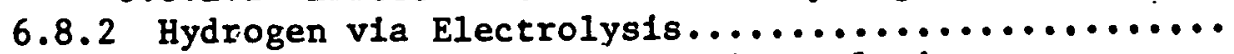

6.8.2.1 Hydrogen Costs v1a Electrolysis...........

6.8.3 Comparison of Alternative Hydrogen Processes........

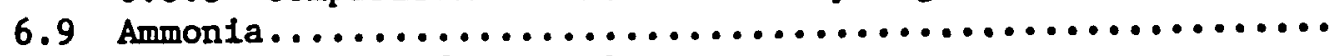

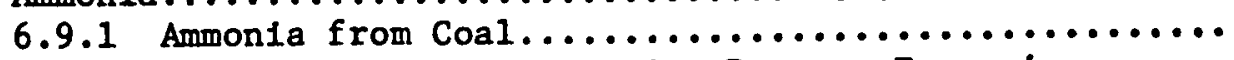

6.9.1.2 Ammonia from Coal: Process Economics.......

6.9 .26 .9 .2 .1 Ammonia from Sugarcane................

6.9.2.2 Ammonia from Biomass: Process Economics....

6.9.3 Comparison of Ammonta from

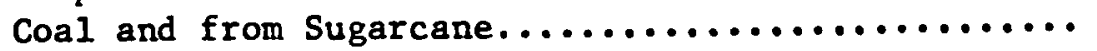

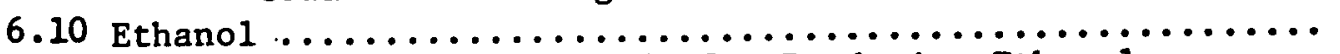

6.10 .1 Aiternative Methods for Producing Ethanol.........

6.10 .2 The Cost of Producing Ethanol.................

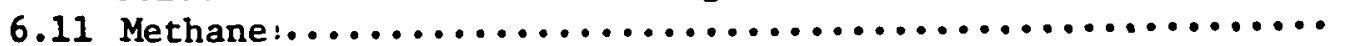

6.11 .1 .1 Methane (SNG) from Coal..............

6.11 .1 .2 SNG Production Economics...............

6.11 .2 SNG from Blomass and Sewage Algae..............

6.11.2.1 SNG Via Biomass and Algae Conversion.......

6.12 other Alternate Fuels.........................

6.12 .1 Synthetic 011 from Organic Waste.............

6.12 .2 Hydrazine.............................

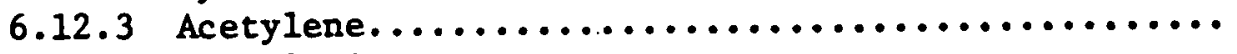

6.12 .4 Methylamine..........................

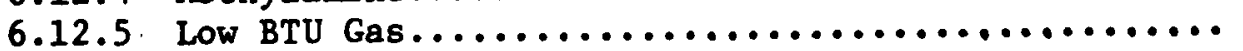

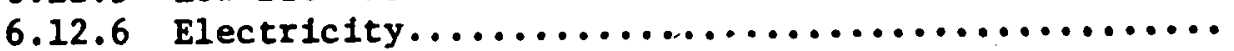

6.13 The Cost of Fuels: Variation with Time ...............

6.14 Cost of Upgrading Coal Liquids ....................

6.14.1 Upgrading Cost and We1ght Percent Hydrogen........

6.15 Raw Shale 011 Upgrading Cost ......................

6.16 Possible Impact of Process Improvement on Cost of

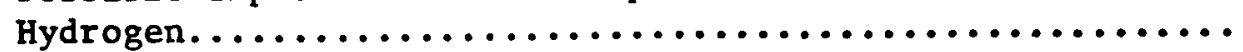

6.17 Broadcut Petroleum Jet Fuel......................

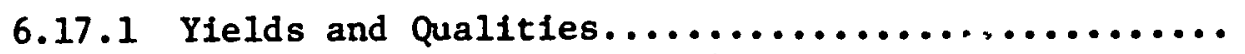

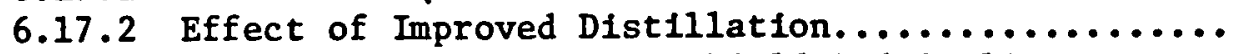

6.17.3 Broadcut Implications on Yield and Quality........

6.17.4 Additional Broadcut Specification...............

6.18 Processing of Shale 011 and Coal Liquids in a

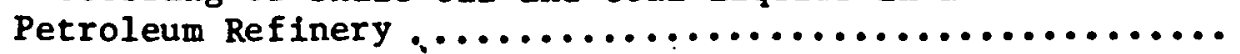

6.18 .1 Processing of Shale 011 Liquids...............

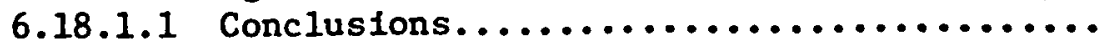

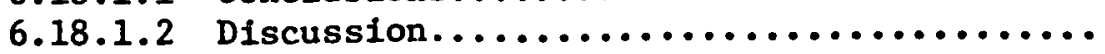

6-63

6-63

6-63

6-65

6-65

6-65

$6-67$

6-69

6-69

6-69

$6-70$

6-70

6-73

6-73

6-74

6-75

6-76

6-77

6-77

6-78

$6-79$

6-80

6-80

6-81

6-81

6-82

6-82

6-83

6-84

6-89

6-89

6-93

6-96

6-96

6-97

6-97

6-98

6-99

6-103

6-103

6-103

6-104

6.18.2 Processing Coal Liquids.................... 6-105 
7. TRANSPORTATION, DISTRIBUTION AND

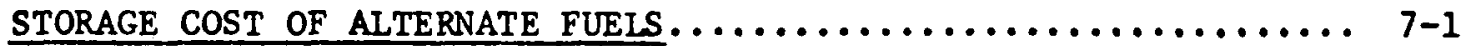

7.1 Introduction and Summary...................... $7-1$

7.2 Coal Transportation Costs........................ $;-4$

7.3 Coal/011 slurry Transportation.................... 7-6

7.4. Coal Liquids................................. 7-9

7.4.1 Transportation Cost8......................... 7-9

7.4 .2 Storage and Distribution Costs............... 7-9

7.4.3 Total Delivered Cost to Customer.............. 7-12

7.5 Shale 011 Liquids............................. 7-14

7.5.1 Transportation Costs...................... 7-14

7.5.2 Storage and Distribution Costs............... 7-14

7.5.3 Total Dellvered Cost to Customer............... 7-14

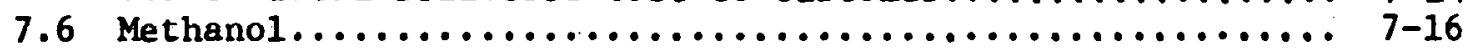

7.6 .1 Transportation Costs...................... 7-16

7.6.2 Storage and Distr1bution Cost-Methanol......... 7-19

7.6.3 Total Delivered Cost to Customer............... 7-19

7.7 Oxygenated Compound - Ethanol.................... 7-21

7.7 .1 Transportation Costs.................... 7-21

7.7 .2 Storage and Distribution Costs............... 7-21

7.7.3 Total Dellvered Cost to Customer.............. 7-21

7.8 Hydrogen.................................. 7-23

7.8.1 Transportation Costs....................... 7-23

7.8 .1 .1 Gas Plpeline...................... 7-23

7.8 .1 .2 Liquid Hydrogen................... 7-28

7.8.1.3 Literature Studies on Systems Optimlzation.. 7-28

7.8 .2 Liquefaction Costs..................... 7-29

7.8.3 Distribution Costs for

Hydrogen at Major Alrport Facilities............ 7-31

7.8.4 Total Dellvered Cost to Customer................ 7-31

7.9 Methane...................................... 7-34

7.9 .1 Transportation Costs...................... 7-34

7.9 .2 LIquefaction Costs...................... 7-36

7.9 .3 Storage and Distribution Costs.............. 7-36

7.9.4 Total Delivered Cost to Customer.............. 7-38

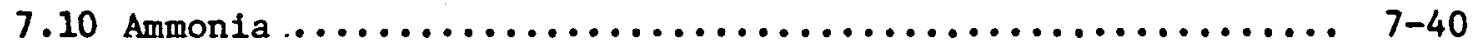

7.10 .1 Transportation Costs.................... 7-40

7.10 .2 Storage and Distribution Costs............... 7-40

7.10.3 Total Delfvered Cost to Customer.............. 7-43

7.11 More Exotic Fuels3............................ 7-43

7.11 .1 Acetylene.......................... 7-43

7.11 .1 .1 Transportation Costs................. 7-43

7.11 .1 .2 storage and D1stribution Costs.......... 7-45

7.11 .1 .3 Total Delivered Cost to the User.......... 7-45

7.11 .2 Hydrazine............................. 7-45

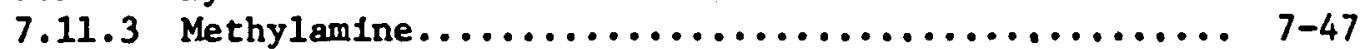

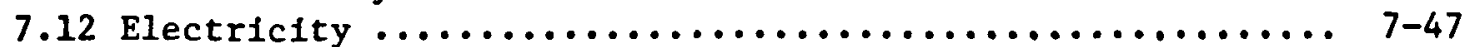

7.12 .1 Transmission............................. 7-47

7.12 .2 Distribution Cost....................... 7-50

7.12 .3 Total Delivered Cost..................... 7-50 
REVIEW NOTICE. ...................................

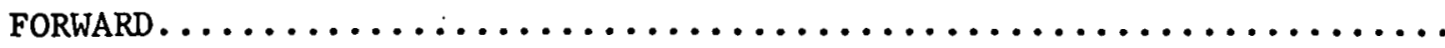

Page

8. ENVIRONMENTAL IMPACT IN PRODUCTION $\ldots \ldots \ldots \ldots \ldots \ldots \ldots \ldots \ldots \ldots \ldots$

8.1 Air Impacts.................................

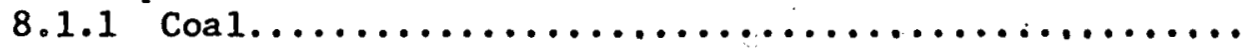

8.1 .2 Coal Liquids.............................

8.1 .3 Raw Shale.............................

8.1 .4 Shale Syncrude.........................

8.1.5 Methanol from Coa 1........................

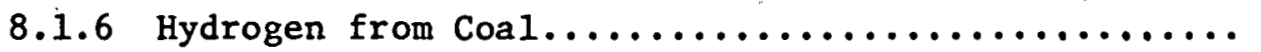

8.1 .7 Ammonia from Coal........................

8.1 .8 Methane from Coal........................

8.1 .9 Electricity from Coal......................

8.2 Emissions in Water............................

8.2 .1 Coal..................................

8.2 .2 Coal Liquefaction.........................

8.2 .3 Raw Shale..............................

8.2 .4 Shale Syncrude.........................

8.2.5 Methanol from Coal........................

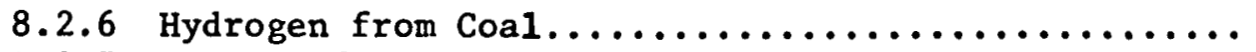

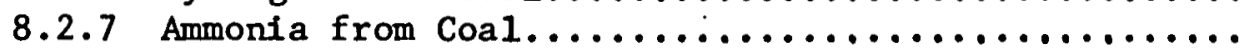

8.2 .8 Methane from Coal ........................

8.2 .9 Electriclty from Coal....................

8.3 Solids....................................

8.3 .1 Coa1................................

8.3 .2 Coal Liquefaction.........................

$8: 3.3$ Shale.................................

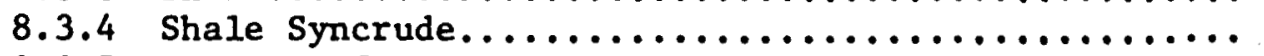

8.3 .5 Methanol from Coal.......................

8.3 .6 Hydrogen from Coal......................

8.3.7 Ammonia from Coal.......................

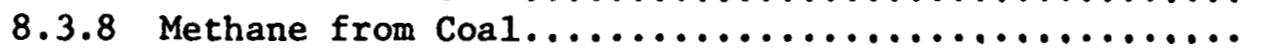

8.3 .9 Electricity from Coal.....................

8-1

8-2

8-2

8-2

8-2

8-2

8-2

$8-5$

$8-5$

$8-5$

$8-5$

$8-5$

$8-5$

$8-5$

$8-6$

$8-6$

8-6

$8-6$

8-6

8-6

$8-6$

$8-6$

$8-7$

$8-7$

$8-7$

$8-7$

$8-7$

$8-7$

$8-7$

$8-7$

8-8

9. IN-USE EMISSIONS WITH ALTERNATIVE FUELS . . . . . . . . . . . . 9-1

9.1 Non-Highway Transportation

Contribution to U. S. Emissions................... 9-1

9.2. Emissions of Various Engine/Fuel Systems............... 9-4

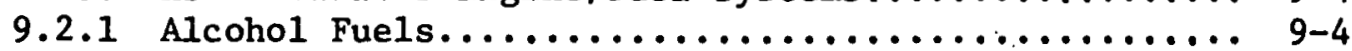

9.2 .2 Hydrogen.................................... 9-5

9.2 .3 Other Gaseous Fuels....................... 9-6

9.2.4 Coal and Shale 01l LIquid Fuels................ 9-6

9.2.5 Coal and Coal/slurries...................... 9-6

9.3 Summary of Emissions Ef fects of Fuels and Prime Movers.... 9-7 
10. ENERGY EFFICIENCY IN PRODUCING

AND TRANSPORTING ALTERNATE FUELS ................... 10-1

10.1 Introduction and Summary...................... 10-1

10.2 Thermal Effictency of Manufacturing

Process for Alternate Fuels.................... 10-7

10.2.1 Basis for Thermal Efficiency................ 10-7

10.2 .2 Coal/0i.1 slurry........................ 10-9

10.2 .3 Coal Liquefaction....................... 10-9

10.2 .4 Coal Liquids Upgrading.................... 10-11

10.2.5 Shale 0il Retorting and Upgrading.............. 10-11

10.2.6 Methanol (Coal Derived).................... 10-14

10.2.7 Ammonia (Coal Derived)..................... 10-14

10.2.8 Acetylene (Coal Based)..................... 10-14

10.2 .9 Hydrogen........................... 10-17

10.2 .9 .1 Coa1.............................. 10-17

10.2 .9 .2 Electrolysis....................... 10-17

10.2 .9 .3 Liquefaction..................... 10-17

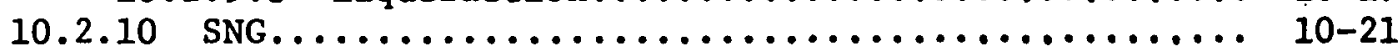

-10.2 .10 .1 Coal.............................. 10-21

10.2 .10 .2 Liquefaction..................... 10-21

10.2.11 Electric Power Generation................. 10-25

10.2.12 Biomass-Derived Fuels.................... 10-25

10.2.12.1 Ethanol from Sugarcane.............. 10-27

10.2.12.2 Ethanol from Corn................... 10-27

10.2.12.3 Methanol......................... 10-30

10.2 .12 .4 Ammonia......................... 10-31

10.3 Energy Requirements for Transportation of Fuels........ 10-31

10.4 Total Resource Requirements for Various Alternate Fuels.. 10-35

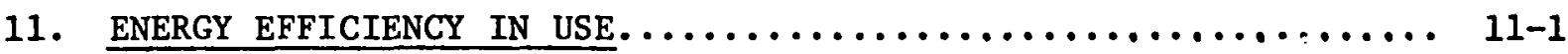

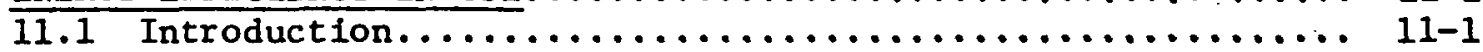

11.2 Methods of Expressing Energy Efficiency in Engines...... 11-1

11.3 Thermal Efficlency of Varlous Prime Movers............ 11-3

11.3 .1 Diese1 Engines.......................... 11-4

11.3 .2 Free Piston Engines..................... 11-7

11.3 .3 Gas Turbine............................ 11-7

11.3.4 Spark or P1lot Ignited Engines............... 11-9

11.3 .5 Externally Fired Engines................... 11-10

11.3 .6 Fuel Cell/Electric Motor.................. 11-12

11.4 Fuel/Engine Incompatibilities - Diesel Engines ......... 11-13

11.5 Fuel Properties that Enhance Efficiency................ 11-14

11.6 Combined Cycles............................. 11-16

12. FUEL LOGISTICS. . ............................. 12-1

12.1 Compatibility with Present Fuels

and the Current Distribution System................ 12-1

12.2 Internetional and Milftary Considerations............ 12-2 
12.3 Resource Ava1lability........................ 12-2

12.3.1 Primary Energy Resources................... 12-5

12.3.2 Documentation of S1ze of Primary Resource Base.... 12-9

12.3.3 Logistics of the Principal Primary

Energy Resources....................... 12-10

12.3.4 Discussion of Representative

NHT Intermediates and Products............. 12-12

12.3.5 Fuel Logistics Criteria.................. 12-12

13. OVERALL RATINGS OF FUELS/PRIME MOVERS ................ 13-1

13.1 Rating Scale Used (Likert Scale) ................... 13-1

13.2. Fuels Manufacture Ratings..................... 13-2

13.3 Fuel Performance Ratings from Designer/User Viewpoint.... 13-6

13.3 .1 Toxicity............................... 13-6

13.3 .2 Safety.............................. 13-6

13.3.3 Materials Compatibility................... 13-8

13.3 .4 Storage Requirements..................... 13-8

13.3.5 Convenience in Handling and Storage............ 13-9

13.3.6 Environmental Impact During Use............... 13-9

13.3 .7 Overall Ratings........................ 13-9

13.4 Compatibility of Fuels and Prime Movers.............. 13-10

13.5 Fuel Logistics Ratings......................... 13-13

13.6 Overal1 Fuel Ratings........................ 13-16

14. SELECTION OF FUELS AND PRIME MOVERS FOR MORE DETAILED STUDY.... 14-1 14.1 Selection of Fuels for Each Type of Prime Mover........ 14-1

14.2 Final Selection of Fuels and Prime Movers

for Each Mode of Non-Highway Transportation............ 14-i

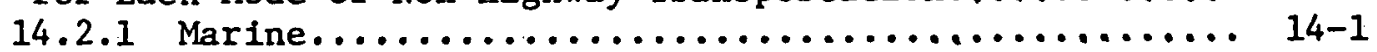

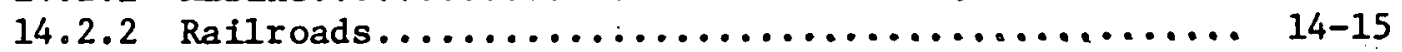

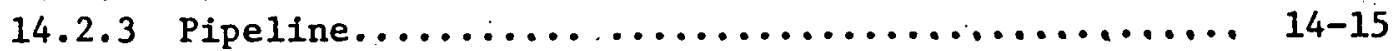

14.2 .4 Alrcraft.................................. 14-15 


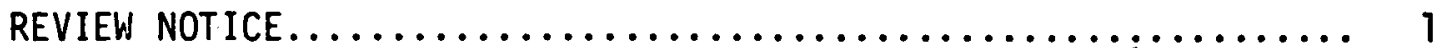

FORWARD.

15. ENERGY SUPPLY/DEMAND PROJECTIONS.................. 15-1

15.1 EIA Projections............................. 15-1

15.2 Transportation Energy Conservation (TEC) Projections.. 15-15

16. MILITARY AND INTERNATIONAL CONSIDERATIONS $\ldots \ldots \ldots \ldots \ldots \ldots$ 16-1

16.1 Military Considerations........................ 16-1

16.2 International Considerations................... 16-5

16.2.1 Air Transportation System................ 16-5

16.2.2 Marine Transportation System.............. 16-7

16.2.3 Railroad Transportation System.............. 16-10

17. INSTITUTIONAL ISSUES AND CONSTRAINTS............... 17-1

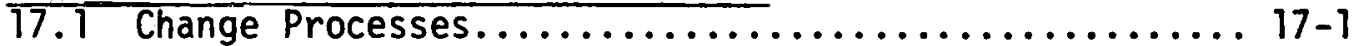

17.2 National Research Council Report................ 17-1

17.3 Institutional Problems of Introducing A New Fuel..... 17-2

18. . EXPERIMENT IN PROBABILISTIC FORECASTING............. 18-1

18.1 Pattern of Responses......................... 18-2

18.2 Discussion And Interpretation of Experimental

Results................................. 18-2

APPENDIX 18-1 NOTES ON CROSS-IMPACT ANALYSIS .............. 18-1-1 APPENDIX 18-2 QUEST IONNAIRES USED IN FORECAST ING EXPERIMENT.... 18-2-1 APRENDIX 18-3 RESULTS OF DELPHI-TYPE AND CROSS-IMPACT TYPE 
THIS PAGE

\section{WAS INTENTIONALLY LEFT BLANK}




\section{FORWARD}

For convenience, the material covered in this study is divided into several reports. Volume $I$ is an executive summary covering the highlights of the study. Volume II is the technical section that covers a summary of the data used in the preliminary screening of the alternate fuels and prime mcjers as well as the detailed evaluation of each of the four modes from the standpoint of the user, fuel supplier and the engine designer. The detailed discussion and documentation of the data base is in Volume III, which has been subdivided into four areas due to the size of the report. Volume III contains all of the references for the data used in the prelininary screening. The information in the four volumes is as follows.

Volume IIIA contains Sections 1 through 5, and çovers the background information on the various prime movers used in the non-highway transportation area, the physical property data, the fuel-prime mover interaction and a review of some alternate energy forms. The five sections are as follows:

Section 1--Prime Movers and Fuels Used in Non-Highway Transportation

Section 2--Criteria to be Used in Evaluating and Rating of Fuels and Prime Movers

Section 3--Physical Property Data

Section 4--Prime Mover-Fuel Interaction

Section 5--Review of Potential for Alternate Energy Forms for NonHighway Transportation--Fuel Cells, Nuclear and Direct Solar

Volume IIIB covers the economics of producing, transporting, and distributing the various fuels. There are two sections in this volume.

Section 6--Economics of Production

Section 7--Economics of Transportation, Distribution and Storage

Volume IIIC is' concerned with the environment issues in production and use of the fuels, the energy efficiency in use and production, the fuel logistics considerations, and the overall ratings and selection of the fuels and prime movers for the detailed evaluation. The seven sections in this volume are as follows:

Section 8--Environmental Impact in Production

Section 9--In-Use Emissions with Alternate Fuels

Section 10--Energy Effictency in Production

Section 11--Energy Efficiency in Use 
Section 12--Fuel Logist1cs--Resource Avallability, Compatibility with Present Fuel and Distribution System, International/ Military Considerations

Section 13--Overal1 Ratirg of Fuels/Prime Movers

Section 14--Selection of Fuels for Detalled Evaluation

Volume IIID covers the demand-related issues. The four sections are:

Section 15--Energy Supply/Demand Projections

Section 16--Miltary and International Considerations

Section 17--Institutional Issues

Section 18--Experiment in Probabilistic For ecasting 
E. N. Cart, .Jr. J. Perclval

This section covers the prime muver and fuels in use currently in each of the modes of non-highway transportation. The critical fuel propertles for each prime mover are also discussed. A fundamental understanding of the technology in use in each mode and the interaction between the fuel and the prime movers is necessary to evaluate how any alternate fuel could be introduced into the system.

\subsubsection{Aircraft Englnes and Aviation Fuels}

The principal prime mover for alrcraft is the avlation gas turbine. In 1976, jet fuel accounted for $95 \%$ of the fuel consumed by domestic civil aviation. (1-1) The distribution of fuel usage between domestic civil aviation and military usage in 1976 was $68 \%$ used by lomestic carriers and $32 \%$ used by the military. (1-1)

\subsubsection{Types of Alrcraft Turbine Engines}

Each aircraft turbine engine employs the basic Brayton thermodynamic cycle--adiabatic compression, heat addition (combustion) at near constant pressure, and adiabatic expansion through the turbine. Thrust is derived by expanding the turbine discharge gases through a nozzle to produce high velocity resulting in a significant momentum increase and resulting force.

The evolution of the alrcraft gas turbine engine over the past forty years has involved many variations of compressor types, combustion configurations and turbine designs and the operating conditions (cycle temperatures and pressures) have changed dramatically. Today's commercial and military aircraft inventory includes a very broad varlety of engines which may be categorized into the following six types.

- Turbojet - thrust is derived entirely by expanding the turbine discharge gases through a nozzle to achieve high exhaust velocity. This results in a large momentum Increase causing the response force (thrust).

- Turboprop - thrust ls derived primar1ly by a propeller which 18 driven by the turbine. Consequently, in a single shaft engine the turbine can drive both the compressor and the turbine. Dual shaft englnes allow separate turbine stages to supply torgue to the compressor and turbine. 
- Turboshaft - these engines are utilized in helicopter applications. The transmission of torgue to the rotor involves an extremely complicated transmission. Again both single and dual shaft engines may be considered.

- Turbofan - air entering the engine is aplit nto two separate flows-some alr proceeds through the maia or core engine (and participates in the Brayton cycle), the remaining alr is compressed only slightly (to pressures up to three times amblent) and bypassed arourd the core engine. Thrust is derived from the combined momentum increase of the core and fan gas flows. Modern turbofan engines derive most of their thrust from the fan airflow which can be up to 6 times the core mass flow rate (a bypass ratio of 6 ).

- Afterburning turbojet - thrust of the turbojet cycle can be augmented by the release of additional energy (combustion of additional fuel) downstream of the turbine discharge. The increased temperature expands the gases resulting in additional exhaust velocity and thrust. This technique allows oubstantial increases in thrust for little increase in engine weight.

- Afterburning turbofan - additional heat release in the fan stream or in the mixed $f$ an and core streams provides additional exhaust velocity and thrust as in the case of the afterburning turbujet.

Each of these engine types is schematically 1llustrated in Figure 1-1. Table 1-1 lists some important engine characteristics and applications. Thts illustration highlights the wide varlations of existing engine types and different characteristics necessary for specific applications.

\subsubsection{Alrcraft Engine Fuel Consumption}

Introdaction of the first comerclal jet aircraft brought about large Increases in the fuel consumed by commercial aviation (see Figure 1-2). Although today's high pressure ratio turbofan engines are far more efficlent than earlier jets, fuel consumption is still higher than in piston engines.

Operating characteristics of the alrcraft gas turbine are significantly different than the piston engine. The reciprocating engine achieves maximum economy at about half maximum power, but the jet engine becomes more economical at maximum output. Fuel consumption per pound of thrust decreases with Increasing flight speed, wereas efficiency of the piston/propeller combination decreases with flight speed. This comes about because of the "ram" effect, 1.e., as the alrcraft approaches the speed of sound, the inlet air is compressed causing higher inlet pressure, which in turn results in 
FIGURE 1-1

TYPICAL JET ENGINES IN USE CURRENTLY

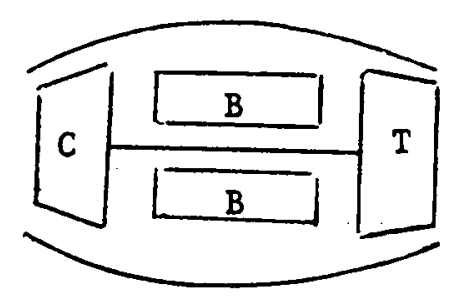

Turbofet.

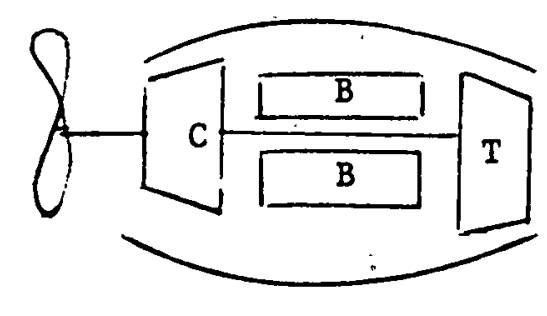

Turboprop

C - comp

- T - furbine

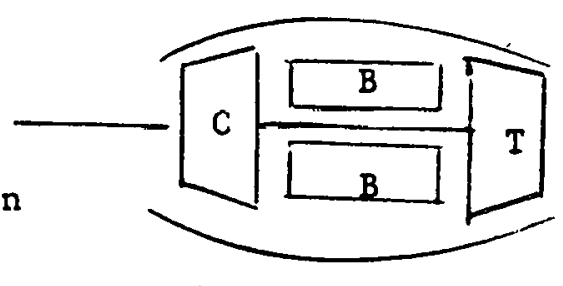

Turboshaft

Helicopter

Transmission

B - Burner

F - Fan

A/B - Afterburner
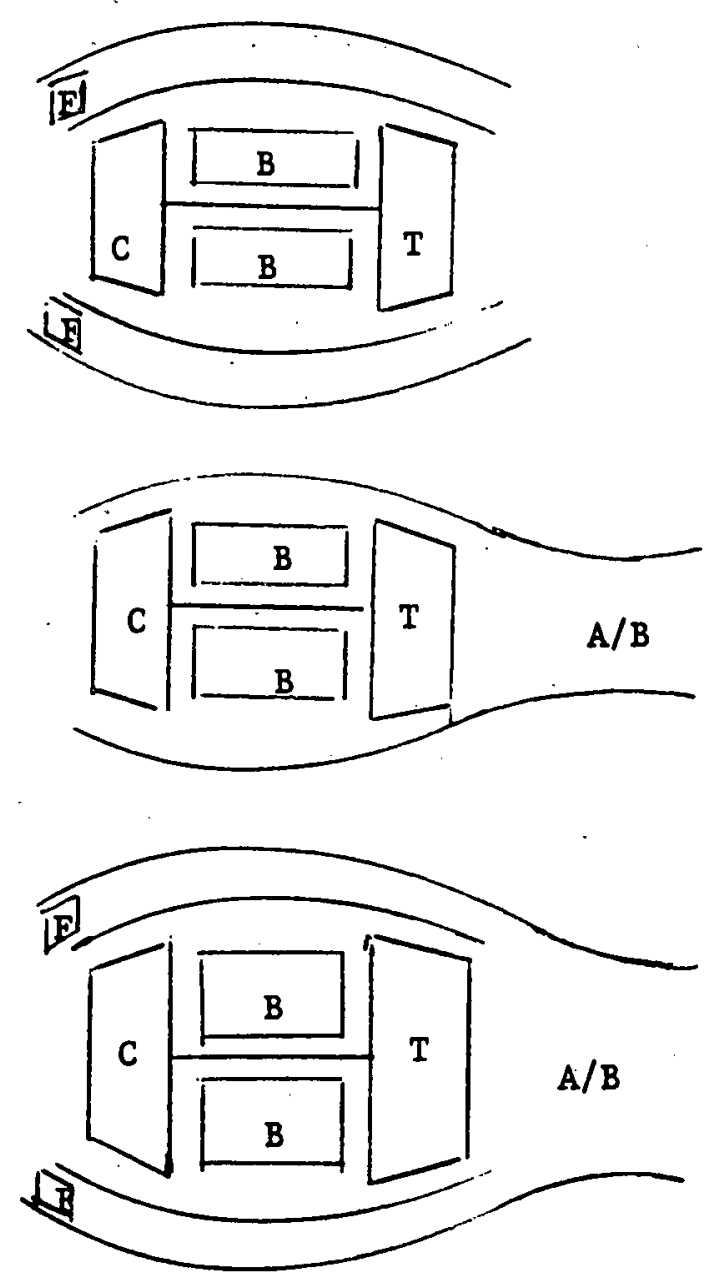

Turbofan

Afterburning Turbojet

Afterburning Turbofan 
TABLE 1-1

AIRCRAFT ENGINE CHARACTERISTICS AND APPLICATIONS

\begin{tabular}{|c|c|c|c|c|}
\hline Type Englne & Examples & $\begin{array}{c}\text { Max } \\
\text { Compressor } \\
\text { Ratio } \\
\end{array}$ & $\begin{array}{l}\text { Bypass } \\
\text { Rat10 }\end{array}$ & Application \\
\hline Turbojet & JT3C, J57 & $\sim 13$ & 0 & $\begin{array}{l}\text { Older Commercial Alrcraft, High } \\
\text { Speed Military Alrcraft, Second } \\
\text { Generation SST }\end{array}$ \\
\hline Turboprop & T56, TPE 331 & $\sim 7$ & 0 & $\begin{array}{l}\text { Commerclal and MAlitary Short Haul } \\
\text { and Transport A1rcraft }(M=0.6)\end{array}$ \\
\hline Turboshaft & T53, T63 & $\sim 7$ & 0 & Hellcopters \\
\hline Turbofan & JT3D, JT8D, JT9D, CF-6 & $13-30$ & $1-6$ & $\begin{array}{l}\text { Current and Modern Subsonic Trans- } \\
\text { port Alrcraft }(M=0.9)\end{array}$ \\
\hline A/B Turbojet & $\mathrm{J} 85, \mathrm{~J} 79$ & $6-13$ & 0 & $\begin{array}{l}\text { Military Aircraft, First Genera- } \\
\text { tion SST }\end{array}$ \\
\hline A/B Turbofan & TF30, F100, F101 & -- & - & $\begin{array}{l}\text { Advanced Military Alrcraft, Second } \\
\text { Generation SST }\end{array}$ \\
\hline
\end{tabular}


FIGURE 1-2

U. S. FLEET FUEL EFFICIENCY

CERTIF IED U. S. CARRIERS

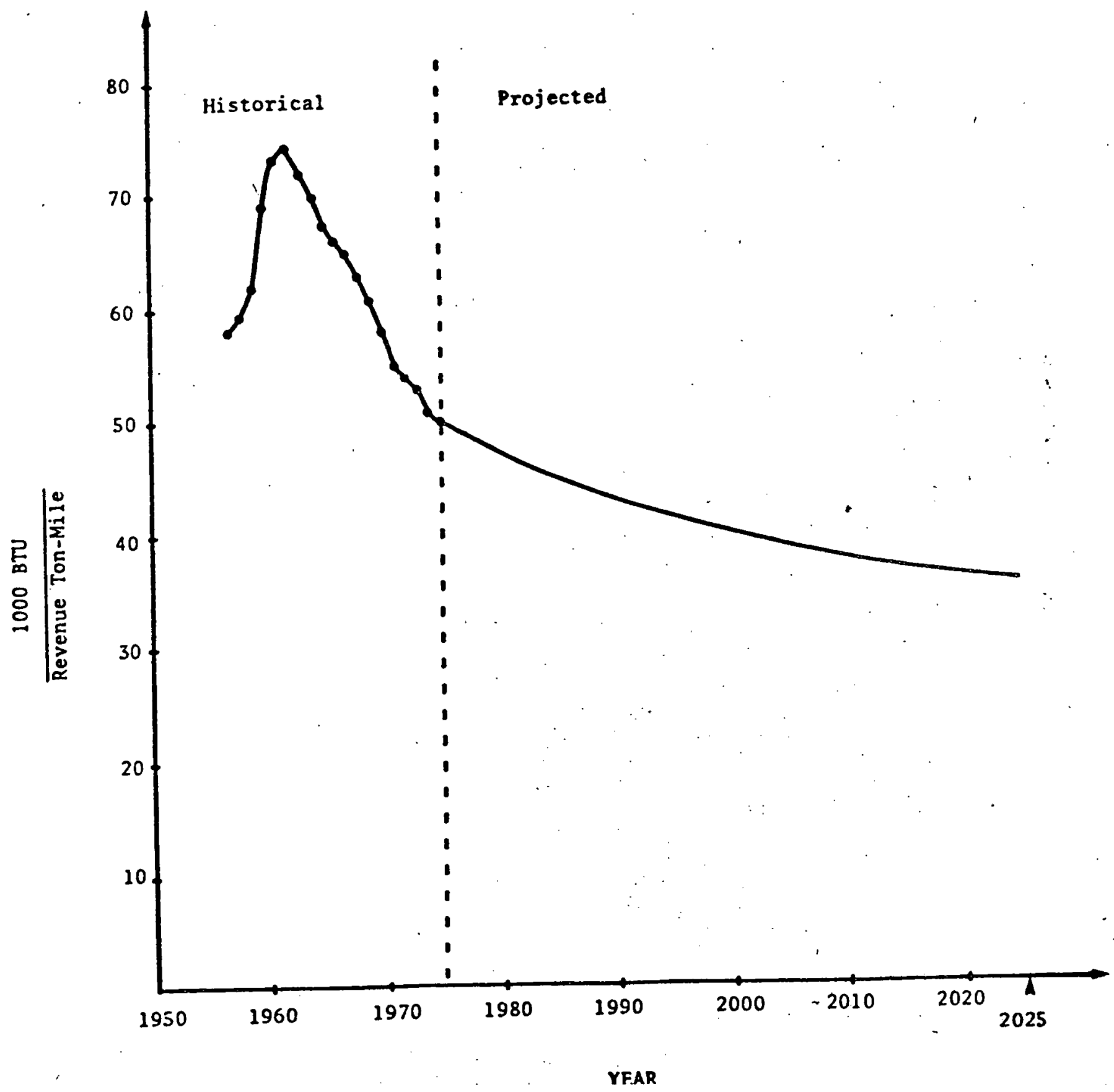

Source: Reference 1-2. 
higher compressor discharge pressure and a more efficient thermodynamic cycle. At an altitude where the alr is thin and much less thrust 18 required to overcome alrcraft drag, the overall jet alrcraft efficlency is highest. It follows therefore that a jet plane must be operated at 1ts design altitude and opeed whenever possible to be the most economical in fuel. Wuch lower cellings are specified for piston powered alrcraft which have severely reduced power at altitude and are not afforded the air compression advantages of the jet's higher flight speed.

Table 1-2 summarizes and compares some important efficiency-related characteristics of various engine types. The turbojet with its increasing efficiency at high speed is suited for supersonic aircraft -- its use in early subsonic commerclal aircraft was due to the lack of turbofan technology In the $1950^{\prime} \mathrm{s}$, In fact, these engines were decendants of the mllitary J57 turbojet used in supersonic military aircraft.

Adding the propeller to the turbine engine (1-e., the turboprop engine) vastly improves fuel economy, i.e., consumption per pound of thrust. Current turboprop engines (most of which are older designs) are roughly equivalent in fuel consumption to piston engines of the same size, about $0.5 \mathrm{lb}$. of fuel per horsepower per hour.

The turbofan mates the Increased flight speed advantages of the turbofet with the efficiency of the turboprop. Advanced technology in the newer engines of the wide-body aircraft (747, DC-10, L-1011) allows compressor pressure ratios of 23-30 and turbine inlet temperatures of $2500^{\circ} \mathrm{F}$ which results in a very efficient thermodynamic cycle.

Afterburning turbojets and turbofans have characteristics very similar to the corresponding non-afterburning types during the portion of their operation when the afterburner is not in use. However, during afterburning operation significant thrust augmentation (up to $50 \%$ ) can be achieved. This augmentation is inefficlent on a specific fuel consumption basis requiring approximately $2 \mathrm{lb}_{\mathrm{m}}$ fue? $/ 1 \mathrm{~b}_{\mathrm{f}}$ thrust-hr, but is necessary to accomplish certain types of flight profiles.

From the fuel consumption standpoint, future alrcraft operation will be predominantly those of subsonic cruise which utilize turbofan engines. Additional advanced technology can further improve the efficiency of the engines as is recognized by active NASA efforts to develop an energy efficient engine. The $\mathrm{E}^{3}$ (Energy Efficient Engine) program will attempt to demonstrate improved specific fuel consumption through the use of even higher pressure ratios, turbine inlet temperatures, and bypass ratios. Other NASA programs are considering airframe technology advancements to promote overall alrcraft fuel conservation.

\subsubsection{Critical Engine Components}

While all the above described engine types are of interest to the subject program, the largest amount of jet fuel currently and in the future will be consumed by commercial transport aircraft with non-afterburning engines. Consequently, the fuel characteristics will affect the engine malnly through influences in the main burner and the fuel system. 
TABLE $1-2$

TYPICAL PERFORMANCE CHARACTERISTICS OF AVIATION ENGINES

Crulse Specific

Fuel Consumption

\begin{tabular}{|c|c|c|c|}
\hline Eng1ne Type & $\begin{array}{l}\text { Take off Thrust/ } \\
\text { Engine Weight }\end{array}$ & $\begin{array}{l}\text { Lbs. Fue } 1 / \mathrm{Hr} \text { per } \\
\text { Lb Thrust }\end{array}$ & $\begin{array}{c}\text { Mach Number } \\
\text { LIm1t }\end{array}$ \\
\hline Turbojet & 4.0 & 0.84 & 3.5 \\
\hline Turboprop & 6.0 & 0.53 & 0.6 \\
\hline Turbofan & 5.0 & $0.7-0.45$ & 0.9 \\
\hline A/B Turbojet & $4.5-7$ & * & 3.5 \\
\hline A/B Turbofan & 5.0 & * & 2.5 \\
\hline Piston & 2.4 & 0.5 & 0.5 \\
\hline
\end{tabular}

*This characteristic would depend upon the amount of thrust augmentation desired. In non-afterburning operation, these engines have SFC simflar to their non-afterburning relatives. The SFC, the add1tlonal thrust resulting from afterburning operation, is 2.0 .

Source: Complled by ER\&E from published information. 


\subsection{The Combustion System}

The function of the main burner is to provide for the mixing of fuel and air within the proper environment to ensure their nearly complete reaction to desirable combustion products. Can, cannular, and modern annular eombustors are adequately described in the figure below. In the "primary zone,"

\section{Conventional Main Combustor}

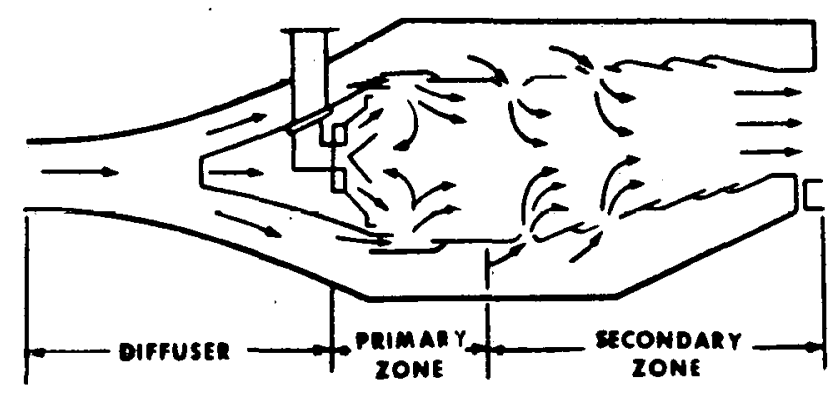

fuel and oxidizer are mixed, usually in slightly fuel-rich proportions. Approximately 90 percent of the fuel is burned in this zone. Fuel oxidation is completed in the "secondary zone". In modern engines, turbine inlet temperatures are close to the temperature at which significant chemical reactions cease $\left(\sim 1600^{\circ} \mathrm{K}\right)$ and no further dilution is required. However, older designs with reduced turbine inlet temperatures utilize a "dilution zone" to further reduce temperature. No significant reaction occurs within this zone.

The purpose of the primary zone is to stabilize combustion. High temperatures resulting from stoichiometric operation promote rapld fuel consumption reactions. Primary zone flow 18 dominated by a strong recirculation region (established by swirling the air entering the head end or dome of the burner) which furthers combustion stability. In practically all current gas-turbine combustors, the fuel is injected as a liquid. The formation of a well distributed dispersion of small droplets is desirable to promote rapid evaporation of the fuel and intimate mixing of the fuel and air.

The secondary zone introduces additional air to further chemical reactions which consume the products of incomplete combustion passing from the primary zone. Air participating in these chemical reactions is introduced normal to the main flow direction. The remaining air enters parallel to the main flow at the combustor walls to provide a film of cool air which protects the combustor liner. Design of the combustor liner hole pattern to accomplish this requirement traditionally involves a costly development effort to avoid a number of possible detrimental effects. Excessive addition of alr may result in quenching chemical reactions (especially carbon monoxide and soot oxidation) essential in reducing emissions. Further, air introductio must be accomplished in a manner which results in a unfform temperature profile entering the turbine; a $25^{\circ} \mathrm{K}$ Increase in gas temperature at a critical 
region of a turbine blade can result in a four-fold decraae in blade life. These design objectives must be met within a prescribed combustor length. Although increasing combustor size might facilitate the design task, this would cause undesirable Increases in engine length, main shaft size, bearing requirements and engine weight.

A broad list of combustion system performance and design objectives 15 required of all combustors. Although this list can be quite lengthy, the more important requirements are given below:

- Performance Obfectives

a. High combustion efficlency (100\%) at all operating conditions.

b. Low overall system total pressure loss.

c. Stable combustion at all operating conditions:

d. Reliable ground-level ignition and altitude rellght capability.

- Design Objectives

Q. Minimum size, weight, and cost.

f. Combustor exit temperature profile consistent with turbine design requirements.

g. Good maintainability and reliability.

h. Minımum exhaust emissions consistent with current specifled indtations and regulations.

\subsection{The Fuel System}

The fuel system as described here consists of: a) fuel tanks, b) fuel piping, valves, pumps, meters, and filters, c) the fuel oil heat exchanger, and d) fuel injection equipment. The demands on each of these system components is discussed below.

a. Fuel Tanks. Aircraft cruising at high altitude are exposed to extremely cold temperatures, care must be taken to prevent fuel from freezing or from attaining a high viscosity. Generally this - requires system temperatures to remain above $-40^{\circ} \mathrm{C}$. However, for certain aircraft flight paths Jet $A-1$ with a freezing point of $-50^{\circ} \mathrm{C}$ must be used. Other important fuel tank criteria relate to safety aspects of fuel handling, crash safety, and ability to withstand lightning strikes.

b. Fuel Piping, Valves, Pumps, Meters, and Filters. These components must be designed to avoid excessive wear and provide rellability and easy maintainability. The system must prevent plugging from fuel impurfties or vapor lock and avold unexpected pressure drops such as those which might occur across filters.

c. Oil/Fuel Heat Exchangers. Cooling for the oil in the aircraft turbine engine is provided by the fuel on its way to the combustor. The temperature of the fuel in the oll/fuel heat exchanger can reach $300^{\circ} \mathrm{F}$. Poor heat exchanger design resulting in temperature exceeding this level can result in fuel breakdown and deposit formation. Such behavlor can result in 108 of heat transfer effectiveness as well as plugging problems. 
d. Fuel Injection Equipment. Both pressure atomizing and air blast (utilizing the momentum of alr flowing into the combustor) type fuel infection systems are utilized in today's aircraft turbines. In each case the design must maintain the temperature of tne 1iquid fuel below its thermal stability limit to prevent deposition. This Is a very difficult task in todays high temperature systems, especially during engine shut down when heat is transferred to the fuel tank and nozzle under zero fuel flow conditions. Additional dificulties are anticipated in future designs intended to satisfy low pollutant emission requirements. Staged designs for this purpose will not always operate with fuel flow to all injectors. Heat soaking of the fuel during transient operations can cause difficulties directly analogous to afterburner spraybar plugging. A final fuel injection associated problem is carboning or caking within the combustor (1.e. In the presence of oxygen). Carbon formation and deposition can occur if fuel is allowed to implnge on metal parts at certain temperature and pressure conditions.

\subsubsection{Fuels for Alrcraft}

\subsection{Aviation Gasoline}

The U. S. milltary has standardized its remalning plston aircraft operations to utilize three fuel grades. Recently the lead content of Grade 100 was lowered from 4.6 to $3 \mathrm{ml} / \mathrm{gallon}$ to accommodate the smaller engines used in military utility aircraft. ASTM Specification D 910 serves general aviation primarlly; a speclal low lead Grade $100 \mathrm{LL}$ (2 ml TEL/gal) is sold commerclally for small plston alrcraft as an alternate to Grade 80 which is being phased out of production.

The significant factors in the performance of fuels in aviation piston engines and the important quality features of fuels are:

Significant Engine Factor

a. Combustion Characteristics (Detonation)

b. Fuel Metering and Alrcraft Range

c. Combustion and Vaporization

d. Corrosion of Fuel System and Engine

e. Fluidity at Low Temperature

f. Cleanllness, Handling Stability
Principal Quality

Feature Controlled.

Ant1knock Rating

Net Heat of Combustion

Volatility

Sulfur, Copper Strip

Freezing Polnt

Water Reaction Potential Gum 


\subsection{Alrcraft Turbine Fuels}

Three jet fuel rypes are in wide use throughout the free world. They vary significantly in their distillation characteristics (see Figure 1-3). Specifications for each fuel are listed in Table 1-3. JP-4 is the $f$ : used by the air forces o: NATO, Including the United States. Jet B, a fuel essentially identical to $\mathrm{JP}-4$, is used by Canadian commercial airlines. Tr fuels can be grossly represented as $B$ blend of kerosene and gasoline. The it, volatility of $\mathrm{JP}-4$ results in a vapor pressure of about 0.17 atm (2.5 psia) at $310^{\circ} \mathrm{K}\left(100^{\circ} \mathrm{F}\right)$, and a flash point below room temperature.

Jet $A$ is the kerosene-based fuel used by most of the world's comercial arilines, including the United States. It has a much lower volatility than $3 P-4$ resulting in a flash point of about $52^{\circ} \mathrm{C}$. Because of the reduced probability of post crash fires and the reduction of combat vulnerabllity, the NATO nation air forces are considering conversion to JP-8. (1-3,1-4;1-5) This fuel is nearly 1dentical to Jet A-1, a commercial fuel simflar to Jet $A$ in all respects except freeze point $\left(-50^{\circ} \mathrm{C}\right.$ versus $-40^{\circ} \mathrm{C}$ for Jet A). The combustion characteristics of JP-8, Jet A, and Jet $A-1$ are virtually 1dentical.

The unique problems associated with shipboard jet fuel use cause the U. S. Navy to use a third fuel type, JP-5, which has an even higher flash point $\left(>63^{\circ} \mathrm{C}\right)$.

JP-7 is a special fuel intended for supersonic applications. High flight speed causes additional head load requirements to be imposed on the fuel requiring additional thermal stability. Recent work at Exxon has shown that standard fuels (such as JP-5) can be processed by removing especlally troublesome hydrocarbons and deoxygenating the fuel to achieve very high thermal stability.

The fuel characteristics and their potential impart on the engine performance are summarized in Table 1-4. Note that some specification fuel characteristics have been omitted in favor of other fuel descriptions which are considered to be more meaningful measures of the fuel variation. Most notable in this respect is the use of fuel hydrogen content rather than. Luminometer numbers or smoke volatility index.

The most serfous fuel impacts are on combustion stability and ignition, durability/rellabllity/malntalnabllity, smoke emission, and fuel system components. Combustion stability and ignition can be influenced by viscosity which detrimentally affects ability to achieve a uniform distribution of small fuel droplets; this prevents rapid vaporization to an ignitable fuel-air mixture. Altitude ignition requirements are particularly critical in this respect. A viscosity of 12 centistokes is usually considered to be the maximum for aircraft applications.

Durabllity/rellabllity/maintalnability can be serfously iffected by fuel hydrogen content or aromatic content. Each of these fuel characteristics affects carbon formation within the combustor. Carbon within the high temperature primary zone causes the flame to be highly luminous with ignificantly increased emissivity. Radiation from 
FIGURE 1-3

DISTILLATION CHARACTERISTICS OF COMMON JET FUELS

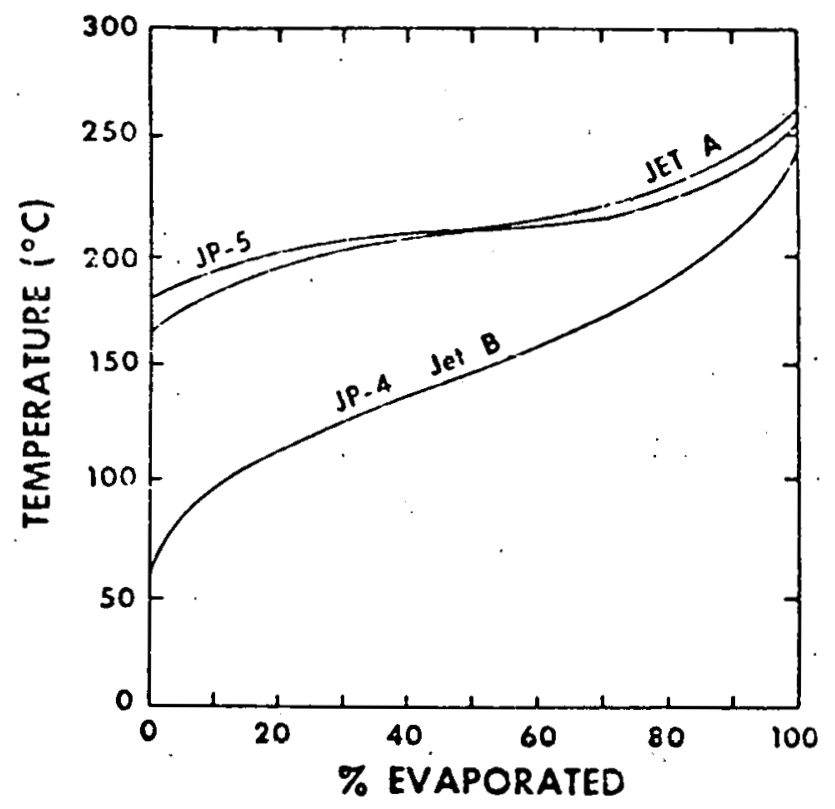

Source: Compiled by ER\&E from published data. 
TABLE 1-3

JET FUEL SPECIFICATIONS

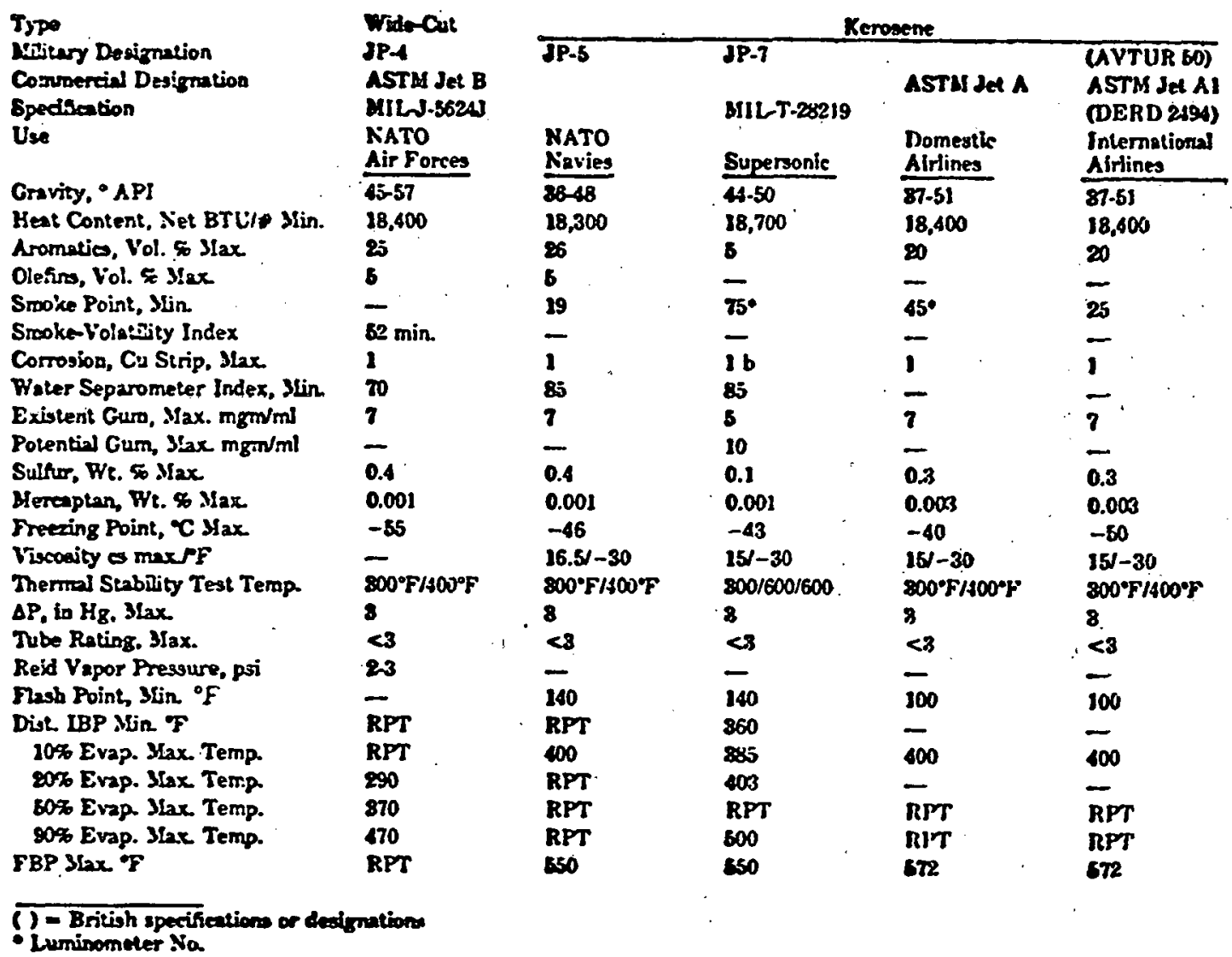

Source: Comp1led by ER\&E from publ1,shed data. 
TABLE 1-4

FUEL CHARACTERISTICS AND POTENTIAL IMPACT

Combustion System

- Combustion Efficiency

- Combustion Stability

- Ignition (Ground and Attitude)

- Size, We1ght, Cost

- Durability/Maintainabllity/ Reliability

- Exhaust Emission

\section{Fuel System}

- Fuel Tanks

- Piping, Valves, Pump, Meters

- 011/Fuel Heat Exchangers

- Fuel Injection Equipment
Principal Quality Feature

Viscosity

Hydrogen Content Aromat1c Content

Vapor Pressure

Flash Point

Distillation Characteristics

Aromatics

olefins

Thermal Stability

Freeze Polnt

Gum 
the flame zone can significantly increase the thermal loading on the combustor liner and increases 1 ts temperature. This change can significantly reduce component life. Figure 1-4 1llustrates the relationship between combustor liner temperature and hydrogen content for a number of engines. The ordinate of this graph is the difference between liner temperature with the given hydrogen content fuel and the liner temperature with a standard fuel (in this case JP-4 with $14.5 \%$ hydrogen) normalized by the difference between the JP-4 liner temperature and the combustor inlet temperature. The parameter represents the increased thermal loading on the liner due to the use of a lower hydrogen content fuel. Significant increases in heat transfer are observed. Iiner temperature increases of up to $200^{\circ} \mathrm{F}$ were determined.

The Increased carbon formation brought about by lower hydrogen content also results in increased smoke emissions. Figure 1-5 illustrates the significance of this effect for a T56 can type combustor. These results are expressed in terms of SAE Smoke Number, the standard for the aircraft engine industry. (1-6) Viscosity can also detrimentally affect smoke emission by causing maldistribution of fuel resulting in fuel rich operation which also promotes carbon particle formation.

It should be noted that current specifications do not allow the lower hydrogen contents illustrated in Figures 1-4 and 1-5. A jet fuel with the current specification limit aromatic content would have a hydrogen content of 13.5 to $13.8 \%$. Even this level of reduction, however, would seem to have a significant effect on liner temperature and on smoke visibility In the case where the smoke emission with current fuel is on the threshold of Invisibility. (1-7)

Key factors affecting the fuel system are aromatics, olefins, and thermal stability as well as freeze point and gum content. Potential problems include fuel breakdown to form deposits and/or gum, plugging fuel system components, depositing of carbon within the combustor, reduction of oll cooling capacity, and viscosity increase or freezing of fuel within the system.

One impact which has been considered previously and is not mentioned in the foregoing discussion is the influence of significantly increased fuel bound nitrogen on $\mathrm{NO}_{x}$ emissions. It is known that nitrogen chemically bound to the fuel molecule is very effectively converted to $\mathrm{NO}_{\mathbf{x}}$ (30-90\% effictency of conversion). Present levels are generally less than $20 \mathrm{ppm}$ and contribute negligibly to $\mathrm{NO}_{\mathbf{x}}$ formation in comparison with that found from $\mathrm{N}_{2}$ and $\mathrm{O}_{2}$ in the combustion a1r. Previous studies with aircraft type combustors have confirmed this finding in practical hardware. $(1-9,1-10)$ However, discusstons at the NASA Hydrocarbon Fuels Workshop generally concluded that fuel storage and thermal stability considerations would limft fuel nitrogen concentration to less than $100 \mathrm{ppm}$ and that this level was broad enough to not limlt avallabilility in consideration of petroleum sources. Even this level would not represent a significant contribution to $\mathrm{NO}_{x}$ formed. However, the situation must be re-examined in considering fuels from other sources such as shale oll or coal which are naturally much higher in bound nitrogen. In this case; the possiblitty 
FIGURE 1-4

LINER TEMPERATURE CORRELATION

FOR MANY COMBUSTOR TYPES (1)

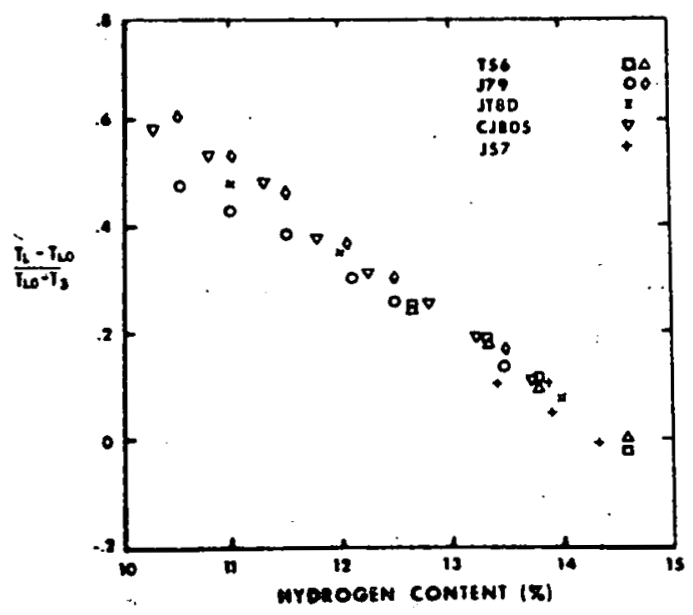

(1) Source: Reference 1-8. 
FIGURE 1-5

SMOKE EMISSION DEPENDENCE ON FUEL HYDROGEN CONTENT (1)

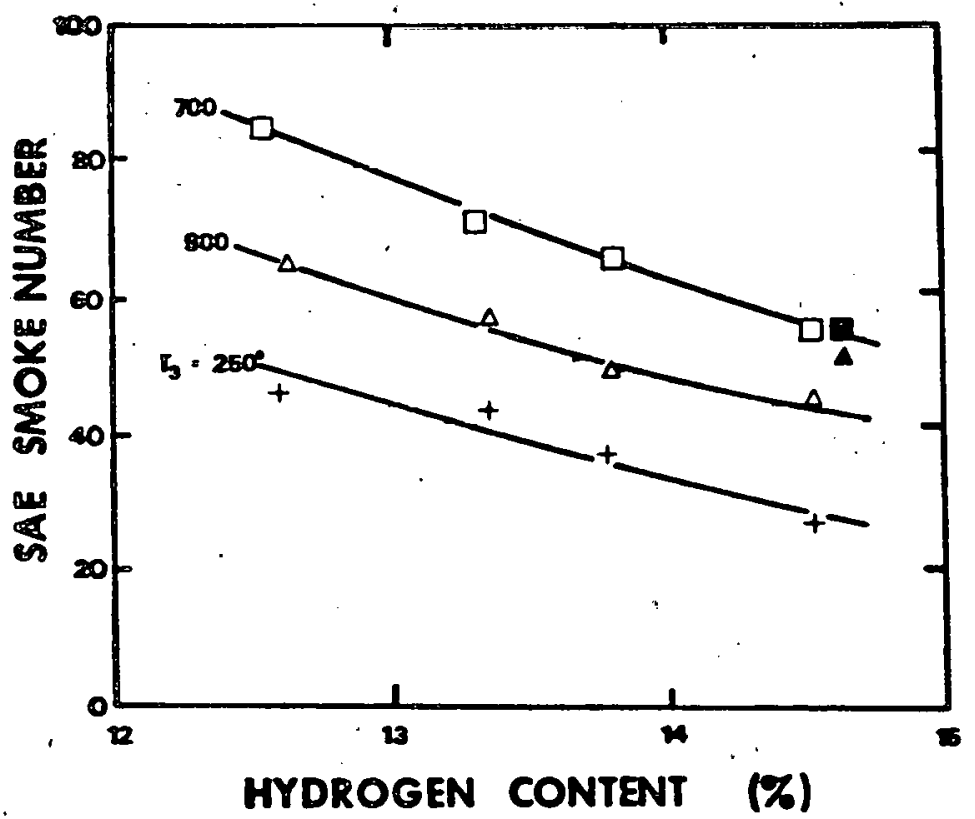

(1) Source: Reference 1-8. 
that research on methods of improving stability and reducing fuel nigrogen conversion may provide technology which allows nitrogen to remain in the fuel must be examined. The pursuit of the most cost effective and efficient energy atrategy is the true cijective.

\subsubsection{Marine Prime Movers and Marine Fuels}

The principal prime movers at sea currently are steam turbines and diesel engines. Gas turbines are used to a very limited extent.

The primary consilerations in choosing the type of prime mover Include capital cost, efficlency, cost of fuel, maintenance, scheduling, size of engine room and manpower requirements. While capital cost of a gas turbine installation is generally lower than for a steam turbine or diesel, efficlency is significantly lower (approx. $22 \%$ vs approx. $40 \%$ for diesel and approx. $35 \%$ for steam). Steam 1s relatively insens1tive to fuel quality; diesel can burn a range of fuels-anywhere from relatively clean automotive diesel oil to Bunker $c$. On the other hand, the gas turbine generally requires a very clean, salt-free fuel. Of the three prime movers for marine applications, diesels require the highest malntenance, but with modern engines, maintenance can be done cylinder by cylinder whtle the ship is in motion. The gas turbine has inherently low maintenance and high avallabllity, in the sense that a ship can carry a spare engine; switch when necessary, and perform maintenance by the engine manufacturer on shore. A gas turbine also has small space requirements compared to diesel and steam turbine and is relatively automatic.

The interplay of these factors has influenced trends in the choice of motive power for marine use. Practically all new ships are diesel except for naval vessels which are equipped with gas turbines. The Navy is always concerned with the possibility of Ingesting sea-water and losing the engine in a relatively short time during high-speed pursuit. The only way that a gas turbine can be brought up to the efficlency of a diesel is by increasing inlet temperature. Currently, manufacturers have R\&D programs underway to develop materials that are not degraded by the high temperatures. Ceramics are seen as the most viable approach. It should be mentioned that the higher the inlet temperature, the more vulnerable is the gas turbine to impurities in the fuel.

\subsubsection{The Diese1 Engine}

The diesel engine is a high compression, self-ignition engine. The fuel is ignited by the heat of the high compression and no spark plug is used. The diesel cycle consists of charging the combustion chamber with air; compressing the air; infecting the fuel, which ignites spontaneously; expanding the burned gases; and expelling the products of combustion.

Diesel engines may be grouped according to their speed range in three general classifications as follows:

$$
\begin{aligned}
& \text { Slow Speed --Up to } 500 \text { RPM } \\
& \text { Medium Speed-500 to } 1000 \text { RPM } \\
& \text { High Speed --Over } 1000 \text { RPM }
\end{aligned}
$$


High speed engines of current design and manufacture operate at speeds up to 3000 RPM, and experimental englnes have been operated at higher speeds.

The type of service for which the engine will be used determines the speed range. Engines in the slow speed range are built to develop $1000 \mathrm{HP}$ per cylinder at speeds of appruximately 80 to $150 \mathrm{RPM}$. Cylinder bore sizes range up to 36 . Inches in diameter. Applications for these engines are limited chiefly to large stationary and marine power plants.

Medium speed diesels are avallable which develop from 100 to 200 HP per cylinder with speeds ranglng from 500 to 1000 RPM and cylinder sizes up to 12 inch bore. The applications for this class have been expanding in the smaller stationary and marine power plants, as well as in various industrial installations where flexibility of multiple small units is required. Its chlef and greatest volume usage has been in the railroad locomotive fleld.

The high speed diesel engine has been universally applied to all types of automotive equipment such as trucks, buses, tractors, shovels, :F construction machinery, power generating sets, small boats, etc. The diversity of application has shown a steady increase. Some developments indicate that speeds of engines normally classified in the medium RPM range will be increased into the high speed classification.

\subsection{Diesel Engine Fuel Requirements}

Selection of the proper fuel for diesel engines is not a simple procedure but depends upon many variables, the most important of which are:

- Operating speed and load ranges

- Engine size and design

- Frequency of speed and load changes

- Maintenance considerations

- Atmospheric conditions

- Fuel price and avallability

Each of the foregoing factors play a part in dictating the fuel to be chosen, the relative influence of each being determined by the specific application and installation involved.

The bolling range of distillate diesel fuels is approximately $300^{\circ} \mathrm{F}$ to $725^{\circ} \mathrm{F}\left(150^{\circ} \mathrm{C}\right.$ to $\left.385^{\circ} \mathrm{C}\right)$. The relative merits of the diesel fuel types to be considered will depend upon the refining practices employed, the nature of the crude olls from which they are produced, and the additive package (If any) used.

Under the broad definition of diesel fuel, there exist many possible combinations of various characteristics such as volatility, ignition quality, viscosity, gravity, stability, and other properties. To characterize diesel fuels and thereby establish a framework of definition and reference, various classifications are used in different countries. One of the most widely used is that of the American Soclety for Testing and Materials, 
Committee D-2 on Petroleum Products and Lubr1cants, known as ASTM D 975-74, Standard Classification of Diesel Fuel 011s. This classification, shown in Table 1-5, covers three grades of diesel fuel o1ls, No. 1-D, No. 2-D, and No. 4-D. It should be emphasized that Table 1-5 is a classification and not a complete set of quality specifications. In general, it presents certain minfmum requirements necessary to assure reasonabl: operation under the conditions described. Grades 1-D and 2-D are distlilate fuels, the type most commonly used in high speed engines of the mobile type, medium speed stationary engines, and raflroad engines. Grade 4-D covers the class of more viscous distillates and, at times, blends of these distillates with residual fuel oils. These fuels are applicable for use in low and medium speed engines, employed in services involving sustained loads at substantially constant speed.

While the foregoing classifications deal principally with distillate fuels, residual fuels are used extensively in large, slow speed, marine main propulston engines and stationary land based engines, principally because of lower fuel cost. More recently, the lower cost aspect has promoted the increasing popularity of residual fuels in some smaller, medium speed marine auxiliary engines. Mixtures of distillate and residual fuels are used in installations where a compromise is sought between the more desirable properties of the former and the lower cost of the latter.

Table 1-6 summarizes the relationship between engine type and fuel quality requirements.

Table 1-7 gives a comparison of distillate and residual marine diesel fuels.

TABLE 1-6

TYPICAL INSPECTIONS OF DIESEL FUELS

\begin{tabular}{|c|c|c|c|c|}
\hline \multirow[b]{2}{*}{ Fuel Property } & \multicolumn{4}{|c|}{ Fuel Type } \\
\hline & Kerosene & Premien Diesel & Railroed Diesel & $\begin{array}{c}\text { Marine Distillate } \\
\text { Diesel }\end{array}$ \\
\hline $\begin{array}{l}\text { Cetane Number } \\
\text { Boiling Range. 'F. } \\
\text { Viscosity, SSU @ } 100^{\circ} \mathrm{F} \text {. } \\
\text { Gravits. } A \text {. AI } \\
\text { Sulfur. Wt. \% } \\
\text { Uses }\end{array}$ & $\begin{array}{c}60 \\
325-550 \\
.83 \\
12 \\
0.12 \\
\text { High Speed } \\
\text { City buses }\end{array}$ & \begin{tabular}{l}
\multicolumn{1}{c}{47} \\
$860-675$ \\
85 \\
87 \\
0.30 \\
High Sneed \\
Buses \\
Trucks \\
Tractors \\
Light Marine Engines
\end{tabular} & 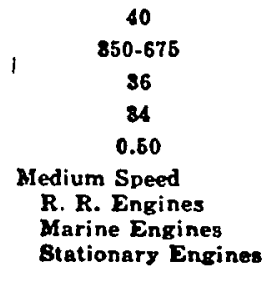 & $\begin{array}{c}38 \\
850-500(90 \%) \\
47 \\
26 \\
1.2 \\
\text { Low Speed } \\
\text { Heavy Narine } \\
\text { Engines } \\
\text { Large Stationary } \\
\text { Engines }\end{array}$ \\
\hline
\end{tabular}

Sourre: Complled by ER\&E from published Information. 
TABLE 1-5

\section{LIMITING REQUIREMENTS FOR DIESEL FUEL OILS ${ }^{a}$}

(ASTM D 975-74)

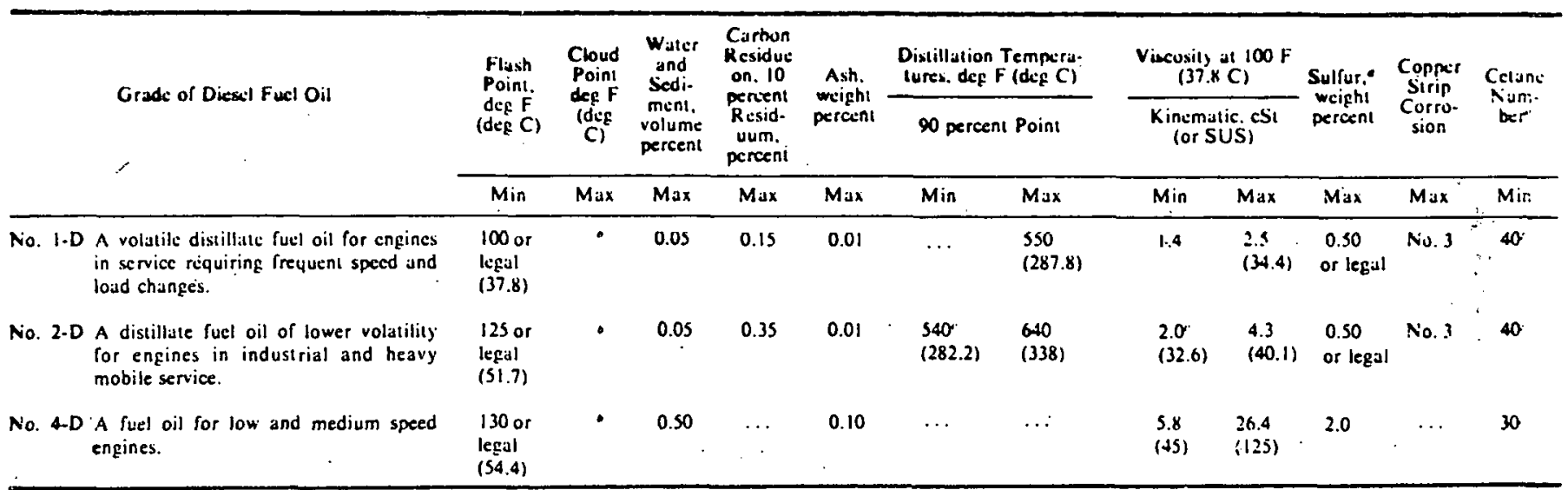

- To meet special operating conditions. modifications of individual limiting requirements may be agrced upon between purchaser. seller. and munufacturer.

- It is unrealistic to specify low-lemperature properties that will ensure satisfactory operation on a broad basis. Satisfactory operation should be achieved in most cases if the cloud point (or wax appearance point) is specified at $10 \mathrm{~F}$ jbove the tenth percentile minimum ambient temperature for the area in which the fuel will be used. The tenth perient. ile minimum ambient temperatures for the U.S. are shown in Appendix A2. This guidance is of a general nature: some equipment designs, use flow improver additives. fuel prop. arties, and/or operations may allow higher or require lowet cloud point fuels. Appropriate low temperature operability properties should be agreed on between the fuel supplier and purchaser for the intended use and expected ambient iem peratures.

. When cloud point less than $10 \mathrm{~F}(-12.2 \mathrm{C})$ is apecified. the minimum viscosity shall be $1.8 \mathrm{cS}$ and the 90 percent point shall be waived.

In countries outside the U.S.A.. other sulfur limits may apply.

- Where ectane number by Method D 613 . is not available. ASTM Method D 976. Caleutated Cetane Index of Distillate Fuels" may be used as an approximation. Where there is disagreement. Method D 613 shall be the referee method.

' Lou-atmospheric temperatures us well as engine operation at high altitudes may require we of fuels with higher cetane ratings.

\section{Source: Compiled by ER\&E from published information.}


TABLE $1-7$

COMPARISON OF́ DISTILLATE AND

RESIDUAL MARINE DIESFIL FUELS

\begin{tabular}{|c|c|c|}
\hline Fwel Property & $\begin{array}{c}\text { Dist. Late } \\
\text { Marine Diesel } \\
\text { Fael }\end{array}$ & $\begin{array}{l}\text { Lou' Cost } \\
\text { (Reridaal) } \\
\text { Diesel Farls }\end{array}$ \\
\hline $\begin{array}{l}\text { Gravity. 'AFI } \\
\text { Viscosity. SSU \& } 100^{\circ} \text { F. } \\
\text { Hot Filtration Sediment. Wt. } \% \\
\text { Carbon Residue. Wt. } \% \\
\text { Ash. Wt. \%́ }\end{array}$ & $\begin{array}{l}26 \\
87 \\
<2.01 \\
<0.1 \\
<0.01\end{array}$ & $\begin{array}{c}12-16 \\
1800-5000 \\
0.02-0.16 \\
10-13 \\
0.05-0.10\end{array}$ \\
\hline
\end{tabular}

Source: Complled by ER\&E from published 1nformation.

The selection of the appropriate fuel is dependent upon the specific engine and instaliation involved, and is influenced greatly by the operating conditions prevailing. Because of this, the varfous fuel properties and their interrelationshlp with performance are highly important.

\subsection{Performance Characteristics of Diesel Fuels}

Performance features desired of all diesel fuels, and the physical properties most directly related to them are summarized below. Fuel properties are presented in the order in which they are seen by the engine as the fuel flows from the storage tank, through the fuel system, to the combustion chamber.

\section{Performance Feature Destred}

1. Safety in handiing

2. Pumpability at low temperatures

3. Freedom from all suspended matter

4. Readily atomized

5. Readily Ignitable

6. Clean burning

7. Good fuel economy

8. Major effect on engine wear and deposits
Ind 1cated By

Flash point

Pour or cloud point, viscosity

Storage stability, suspended sediment tests

Viscosity

Cetane No.

Volatilitý, Cetane No.

${ }^{\circ}$ API Gravity

Sulfur

The relationships between fuel characteristics and the performance of the engine, including its accessories, are summarized in Table 1-8. 
TABLP: $1-B$

ILELATIONSHIP OF FUEL PROPFIITIFS TO ENGINE PERFORMANCE

\begin{tabular}{|c|c|c|c|c|c|c|c|c|c|c|}
\hline \multirow[b]{2}{*}{$\begin{array}{c}\text { FUEL } \\
\text { PROPERTY }\end{array}$} & \multicolumn{10}{|c|}{ ENGINE PERFORMANCE CHARACTERISTIC } \\
\hline & Power Output & $\begin{array}{c}\text { Fuel } \\
\text { Consumption }\end{array}$ & Starting & Warmop & $\begin{array}{l}\text { Combestion } \\
\text { Chomber } \\
\text { Deposins }\end{array}$ & $\begin{array}{l}\text { Power } \\
\text { Assembly } \\
\text { Weat }\end{array}$ & $\begin{array}{c}\text { Injection System } \\
\text { Deposits } \\
\text { and } \mathbb{W} \text { ear }\end{array}$ & $\begin{array}{l}\text { Pumpability } \\
\text { and } \\
\text { Fillerability }\end{array}$ & $\begin{array}{c}\text { Exbaust Smoke } \\
\text { and Odor }\end{array}$ & $\begin{array}{c}\text { teabricant and } \\
\text { Lubricution }\end{array}$ \\
\hline $\begin{array}{c}\text { Volatiiity } \\
\text { (Boiling } \\
\text { Rnnge) }\end{array}$ & $\begin{array}{l}\text { Lnw vilntility } \\
\text { muy reduce } \\
\text { nower due to } \\
\text { poor atomiza- } \\
\text { tlon. High } \\
\text { volatility may } \\
\text { result in innde. } \\
\text { qunte droplet } \\
\text { penetration or } \\
\text { cruse vanor } \\
\text { lock. niso re } \\
\text { ducing power. }\end{array}$ & $\begin{array}{l}\text { Low or high } \\
\text { vointility may } \\
\text { result in high } \\
\text { fuel consump- } \\
\text { tion due to } \\
\text { improper } \\
\text { mixing of } \\
\text { fuel and air. }\end{array}$ & $\begin{array}{l}\text { Too high a } \\
\text { temperature } \\
\text { for } 10 \% \\
\text { evaporated } \\
\text { may ndversely } \\
\text { affect starting. } \\
\end{array}$ & $\begin{array}{l}\text { Fnst warmup } \\
\text { is. as wcll as } \\
\text { Cetane No. } \\
\text { (C.N.), di- } \\
\text { rectly related } \\
\text { to the front } \\
\text { end volatility } \\
\text { chnracteristica } \\
\text { of the fuel. } \\
\text { The lower the } \\
\text { temperature } \\
\text { for the 10-c0\% } \\
\text { evaporated. } \\
\text { the faster } \\
\text { the warmup. }\end{array}$ & $\begin{array}{l}\text { Too high a } \\
\text { boiling range } \\
\text { or too high a } \\
\text { 90\% point and } \\
\text { end point } \\
\text { (E.P.) mas } \\
\text { cnuse incom- } \\
\text { plete combus } \\
\text { tion and } \\
\text { excessive } \\
\text { combustion } \\
\text { chamber } \\
\text { deposits. }\end{array}$ & $\begin{array}{l}\text { Carlion de- } \\
\text { posits coupled } \\
\text { with incom- } \\
\text { pletely burned } \\
\text { fuel may } \\
\text { promote ring } \\
\text { nnd liner } \\
\text { wear. }\end{array}$ & $\begin{array}{l}\text { No dircet } \\
\text { effect except } \\
\text { for possible } \\
\text { wenr due to } \\
\text { vapor lock. }\end{array}$ & $\begin{array}{l}\text { No direct } \\
\text { cffect. }\end{array}$ & $\begin{array}{l}\text { More volatile } \\
\text { fuels tend to } \\
\text { redure exhaust } \\
\text { smoke during } \\
\text { idle and } \\
\text { ncceleration. } \\
\text { Related to } \\
\text { C:N. }\end{array}$ & $\begin{array}{l}\text { Ireomplete } \\
\text { comiustion } \\
\text { due to too } \\
\text { low volatillty } \\
\text { may cause } \\
\text { lube oil } \\
\text { dilution. }\end{array}$ \\
\hline Fleah Point & \multicolumn{10}{|c|}{ Relates to handllng hazards. Low flash point may indieate contamination with gasollne or naphtha. } \\
\hline $\begin{array}{l}\text { Ignition } \\
\text { Quality }\end{array}$ & $\begin{array}{l}\text { No effect if } \\
\text { C.N. is hish } \\
\text { enough for fuel } \\
\text { ignition under } \\
\text { light load and } \\
\text { lowv temnern- } \\
\text { ture onerntion. } \\
\text { Excessively } \\
\text { hish C.N. mny } \\
\text { reutuire re- } \\
\text { iuljustument of } \\
\text { injection timing. }\end{array}$ & $\begin{array}{l}\text { Same effect } \\
\text { as on power } \\
\text { output. }\end{array}$ & $\begin{array}{l}\text { Directly af- } \\
\text { fected by C.N. } \\
\text { The higher the } \\
\text { C.N... the } \\
\text { better the } \\
\text { starting. }\end{array}$ & \begin{tabular}{|l|} 
Direct effect. \\
Coupled with \\
high front \\
end volntility. \\
the higher the \\
C.N.. the \\
fnster the \\
wnrmup. \\
\end{tabular} & $\begin{array}{l}\text { Combustion } \\
\text { chnmber de- } \\
\text { losits are } \\
\text { usunlly } \\
\text { nufifier and } \\
\text { more readily } \\
\text { purged from } \\
\text { engines } \\
\text { opernted on } \\
\text { hirh C.N. } \\
\text { purrallinic } \\
\text { fuels. } \\
\end{array}$ & $\begin{array}{l}\text { No direct } \\
\text { effect except } \\
\text { ns C.N. } \\
\text { nffects com. } \\
\text { pleteness of } \\
\text { combustion. }\end{array}$ & No effect. & $\begin{array}{l}\text { No direet } \\
\text { effect. High } \\
\text { C.N. fuels } \\
\text { mas have } \\
\text { high cloud } \\
\text { and pour } \\
\text { moints. }\end{array}$ & $\begin{array}{l}\text { Direct effect. } \\
\text { Incrense in } \\
\text { C.N. Usually } \\
\text { reduces ex- } \\
\text { hnust smoke } \\
\text { and odor at } \\
\text { idle and light } \\
\text { lond, Relinted } \\
\text { to volatility. } \\
\end{array}$ & $\begin{array}{l}\text { No direet } \\
\text { effect except } \\
\text { ns C.N. } \\
\text { anects com } \\
\text { pleteness of } \\
\text { combustion. }\end{array}$ \\
\hline VImeosity & 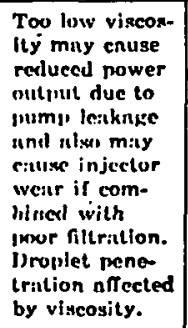 & $\begin{array}{l}\text { Snme ns for } \\
\text { mower output. }\end{array}$ & $\begin{array}{l}\text { No direet } \\
\text { effect excent } \\
\text { ns relnted to } \\
\text { volitilitity. } \\
\text { - }\end{array}$ & $\begin{array}{l}\text { No direct } \\
\text { efrect exeept } \\
\text { ns related to } \\
\text { voliatility. }\end{array}$ & $\begin{array}{l}\text { No direct } \\
\text { effect execpt } \\
\text { ?Is reluted to } \\
\text { volatility. }\end{array}$ & \begin{tabular}{|l} 
No direct \\
effect except \\
ns relnted \\
to volatility. \\
-
\end{tabular} & $\begin{array}{l}\text { Too low vis- } \\
\text { cosity eom- } \\
\text { linined with } \\
\text { nonr filtrntion } \\
\text { mayy accelerste } \\
\text { b:arrel and } \\
\text { bllunger wear. }\end{array}$ & $\begin{array}{l}\text { Too hlgh } \\
\text { viscosity may } \\
\text { cnuse fuel } \\
\text { filter colludse. } \\
\text { or cnuse } \\
\text { cavitntion nt } \\
\text { Inw tern. } \\
\text { ierntures. }\end{array}$ & $\begin{array}{l}\text { No direct } \\
\text { enect excent } \\
\text { as reluted to } \\
\text { volntility. }\end{array}$ & 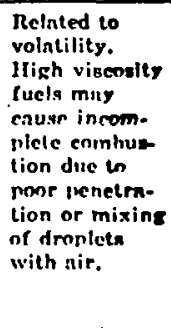 \\
\hline Cloud Point & No elteel. & No erect. & $\begin{array}{l}\text { High cloud } \\
\text { fuel mny plug } \\
\text { filter and } \\
\text { nrevent fuel } \\
\text { from reaching } \\
\text { enmbustion } \\
\text { clinmber. }\end{array}$ & No effect. & No effeet. & No effect. & \begin{tabular}{|l|} 
High cloud \\
fuel mny nlug \\
fliter. thus \\
preventing \\
fuel from \\
renehing in- \\
jection gystem \\
nnd euusing \\
wear.
\end{tabular} & $\begin{array}{l}\text { High cloud } \\
\text { fuel mny } \\
\text { cuuse niter } \\
\text { nlugkeing. }\end{array}$ & No effect. & No effeet. \\
\hline Pour Point & No effect. & No cfleet. & $\begin{array}{l}\text { Illixh pour } \\
\text { mny plus niter } \\
\text { and prevent } \\
\text { fuel from } \\
\text { renching } \\
\text { combustion } \\
\text { ehambar. }\end{array}$ & No efrect. & No effeet. & No etreet. & \begin{tabular}{|l|} 
Ilikh pour \\
fucl mny plug \\
filter, thus \\
preventing \\
fuel from \\
reaching in- \\
foction orytem \\
and eavaing \\
wear.
\end{tabular} & $\begin{array}{l}\text { lligh mour } \\
\text { fuel many } \\
\text { eavac fllter } \\
\text { nlugging. }\end{array}$ & No eteet. & No plfeet. \\
\hline
\end{tabular}


TABLE $1-8$ (Continued)

RELATIONSHIP OT FUEU PROPERTIES TO ENGINE PERFORMANCE

\begin{tabular}{|c|c|c|c|c|c|c|c|c|c|c|}
\hline \multirow[b]{2}{*}{$\begin{array}{c}\text { FUEL } \\
\text { PROPEETY }\end{array}$} & \multicolumn{10}{|c|}{ ENGINE PERFORMANCE CHARACTERISTIC } \\
\hline & Power Output & $\begin{array}{c}\text { Fuel } \\
\text { Consumption }\end{array}$ & Slarfing & Warmup & $\begin{array}{l}\text { Combustion } \\
\text { Chamber } \\
\text { Deposits }\end{array}$ & $\begin{array}{c}\text { Power } \\
\text { Assembly } \\
\text { IF'ear }\end{array}$ & $\begin{array}{c}\text { Injection System } \\
\text { Deposits } \\
\text { and W Weat }\end{array}$ & $\begin{array}{l}\text { Pumpalility } \\
\text { and } \\
\text { Fillerability }\end{array}$ & $\begin{array}{c}\text { Exhanus Smoke } \\
\text { and Odor }\end{array}$ & $\begin{array}{l}\text { Lubricent and } \\
\text { Lubrication }\end{array}$ \\
\hline $\begin{array}{l}\text { Sulfur } \\
\text { Content }\end{array}$ & $\begin{array}{l}\text { Possible in- } \\
\text { crense in } \\
\text { combustion } \\
\text { chamber de } \\
\text { posits and } \\
\text { wear may } \\
\text { eventually } \\
\text { reduce power } \\
\text { output }\end{array}$ & $\begin{array}{l}\text { Same effect } \\
\text { ns on power } \\
\text { output. }\end{array}$ & No effect. & No effect. & $\begin{array}{l}\text { High sulfur } \\
\text { fuel may cauge } \\
\text { high tempera- } \\
\text { ture denosit } \\
\text { formation. } \\
\text { Deposit for- } \\
\text { mation mng } \\
\text { also be re- } \\
\text { lated to lube } \\
\text { oil properties } \\
\text { and oil drain } \\
\text { intervals. }\end{array}$ & $\begin{array}{l}\text { High sulfur } \\
\text { fuel may } \\
\text { cause increased } \\
\text { ring and liner } \\
\text { wenr. particu- } \\
\text { lnrly nt light } \\
\text { londs. }\end{array}$ & $\begin{array}{l}\text { High sulfur } \\
\text { fuel mny } \\
\text { cause injec- } \\
\text { tion system } \\
\text { deposits and } \\
\text { wear. }\end{array}$ & $\begin{array}{l}\text { No dircet } \\
\text { eflect. High } \\
\text { sulfur content } \\
\text { may be re- } \\
\text { lated to fuel } \\
\text { Instability. a. } \\
\text { cause of fuel } \\
\text { filter } \\
\text { plugging. }\end{array}$ & $\begin{array}{l}\text { High sulfur } \\
\text { fucl may } \\
\text { ndversely } \\
\text { affect odor } \\
\text { and } \\
\text { Inchrymation. } \\
\end{array}$ & $\begin{array}{l}\text { High sulfur } \\
\text { fuel mny } \\
\text { adversely af- } \\
\text { feet lubriennt } \\
\text { performance. }\end{array}$ \\
\hline $\begin{array}{c}\text { Corrosion } \\
+ \\
+\end{array}$ & No effect. & No effect. & No eflect. & No effect. & $\begin{array}{l}\text { No direct } \\
\text { effect. May. } \\
\text { Increase fuel } \\
\text { gum due to } \\
\text { nittack on } \\
\text { brnss or } \\
\text { copner. } \\
.\end{array}$ & No effect. & $\begin{array}{l}\text { May cause } \\
\text { corrosion of } \\
\text { brnss or } \\
\text { conner parts } \\
\text { in the } \\
\text { system. }\end{array}$ & $\begin{array}{l}\text { Mny cause cor- } \\
\text { rosion of filter } \\
\text { assemblies } \\
\text { contrining } \\
\text { brnss or } \\
\text { conper. High } \\
\text { gum formation } \\
\text { necelernted by } \\
\text { brass or } \\
\text { conper oarts } \\
\text { mny cause } \\
\text { nlugging. }\end{array}$ & No eflect. & $\begin{array}{l}\text { May haive ad- } \\
\text { verse effect on } \\
\text { lubrication } \\
\text { due to gum } \\
\text { formntion. }\end{array}$ \\
\hline Senbility & No direct effect. & No direct eflect. & No effect. & No effect. & $\begin{array}{l}\text { Instability } \\
\text { may result } \\
\text { in denosit } \\
\text { formntion. }\end{array}$ & $\begin{array}{l}\text { No direet } \\
\text { eflect. }\end{array}$ & $\begin{array}{l}\text { Mny cause } \\
\text { lacquering } \\
\text { of pump and } \\
\text { injector parts. }\end{array}$ & $\begin{array}{l}\text { May enuse } \\
\text { filter } \\
\text { DluggIng. }\end{array}$ & $\begin{array}{l}\text { No direct } \\
\text { effect. }\end{array}$ & $\begin{array}{l}\text { May affect } \\
\text { lubrication } \\
\text { adverscly } \\
\text { due to gum } \\
\text { formation. }\end{array}$ \\
\hline $\begin{array}{l}\text { Carbon } \\
\text { Renldue }\end{array}$ & $\begin{array}{l}\text { Mng cause } \\
\text { injector tlp } \\
\text { delosits. } \\
\text { disturbing } \\
\text { itomization. }\end{array}$ & $\begin{array}{l}\text { Same eflect } \\
\text { na with } \\
\text { nower output. }\end{array}$ & No eflect. & No effect. & $\begin{array}{l}\text { Mny increase } \\
\text { deposits if } \\
\text { compression } \\
\text { rntio is } \\
\text { too high. }\end{array}$ & $\begin{array}{l}\text { Many eause 1n- } \\
\text { crensed wenr. }\end{array}$ & $\begin{array}{l}\text { Mny cause } \\
\text { injector tip } \\
\text { deposits nnd } \\
\text { seizure of } \\
\text { injection } \\
\text { system parts. }\end{array}$ & $\begin{array}{l}\text { May cruse } \\
\text { filter } \\
\text { plussing. }\end{array}$ & $\begin{array}{l}\text { Mny enuse } \\
\text { incrensed } \\
\text { smoking. }\end{array}$ & $\begin{array}{l}\text { Mny increase } \\
\text { burden on } \\
\text { the lube oll. }\end{array}$ \\
\hline Ash & $\begin{array}{l}\text { May cause } \\
\text { wear which } \\
\text { will indirectly } \\
\text { affect power } \\
\text { output. }\end{array}$ & $\begin{array}{l}\text { Snme as for } \\
\text { power output. }\end{array}$ & No effect. & No effect. & $\begin{array}{l}\text { Excessive ash } \\
\text { may increase } \\
\text { deposit level } \\
\text { and affect } \\
\text { nature of } \\
\text { denosits. }\end{array}$ & $\begin{array}{l}\text { Excesslve ash } \\
\text { may aggravate } \\
\text { wear. }\end{array}$ & $\begin{array}{l}\text { High nsh may } \\
\text { cause abrasion } \\
\text { of injector } \\
\text { system parts. }\end{array}$ & $\begin{array}{l}\text { No direct } \\
\text { ellect. }\end{array}$ & $\begin{array}{l}\text { No direet } \\
\text { effeet. }\end{array}$ & $\begin{array}{l}\text { No direct } \\
\text { effect. }\end{array}$ \\
\hline $\begin{array}{l}\text { Water and } \\
\text { Bediment }\end{array}$ & No effect. & No effect. & No effeet. & No effect. & $\begin{array}{l}\text { No dlrect } \\
\text { effect. }\end{array}$ & $\begin{array}{l}\text { Mny Inerease } \\
\text { wenr if ma- } \\
\text { terinl passes } \\
\text { into combus- } \\
\text { tion chamber. }\end{array}$ & $\begin{array}{l}\text { May increase } \\
\text { deposits and } \\
\text { wear. }\end{array}$ & $\begin{array}{l}\text { Mny cause } \\
\text { nlter } \\
\text { plugging. }\end{array}$ & $\begin{array}{l}\text { No direct } \\
\text { efiect. }\end{array}$ & $\begin{array}{l}\text { No direct } \\
\text { effect. }\end{array}$ \\
\hline Gravity & $\begin{array}{l}\text { Low gravlty } \\
\text { (API) fuels } \\
\text { may increase } \\
\text { nower output } \\
\text { due to higher } \\
\text { heating value } \\
\text { ner unit } \\
\text { volume. }\end{array}$ & $\begin{array}{l}\text { Fuel economy } \\
\text { may Improve } \\
\text { for given } \\
\text { throttle get- } \\
\text { ting for low } \\
\text { gravity (API) } \\
\text { fuels due to } \\
\text { higher heat } \\
\text { content per } \\
\text { unit volume. }\end{array}$ & $\begin{array}{l}\text { No direct } \\
\text { eftect. } \\
\text { Reiated to } \\
\text { C.N. and } \\
\text { volatility. }\end{array}$ & $\begin{array}{l}\text { No direct } \\
\text { effect. Re- } \\
\text { Inted to C.N. } \\
\text { and volatility. }\end{array}$ & $\begin{array}{l}\text { No direct } \\
\text { effect. } \\
\text { Related to } \\
\text { C.N. and } \\
\text { volatility. }\end{array}$ & $\begin{array}{l}\text { No direct } \\
\text { effect. }\end{array}$ & $\begin{array}{l}\text { No dircet } \\
\text { effect. }\end{array}$ & $\begin{array}{l}\text { No direct } \\
\text { effect but } \\
\text { relnted to } \\
\text { volntility and } \\
\text { viscosity. }\end{array}$ & $\begin{array}{l}\text { No direct } \\
\text { efect. but } \\
\text { relnted to } \\
\text { C.N. nnd } \\
\text { volntility. }\end{array}$ & $\begin{array}{l}\text { No direet } \\
\text { effect. hut } \\
\text { relnted to } \\
\text { C.N.. vointll- } \\
\text { ity, and } \\
\text { viscosity. }\end{array}$ \\
\hline
\end{tabular}

Source: Comp1led by ER\&E from published information. 


\subsubsection{2, The Steam Turbine}

The earliest steamships were mostly fitted with fire-tube cylindrical boilers termed the Scotch marine type. S1mple water-tube boilers consisting of inclined tubes between headers were widely used from 1897 right through the first and second World Wars.

Bollers are designed to meet specific requirements of many types of vessels, ranging from tugboats to ocean liners, battleships, and alrcraft carriers. Steam conditions vary widely, from 150 psi to about 2700 psi design pressure, and up to steam temperatures of about $1000^{\circ} \mathrm{F}\left(538^{\circ} \mathrm{C}\right)$. Steam demand may range from 2000 to $300,000 \mathrm{lb} /$ hour. Operation will vary with the type of ship and its service. Passenger vessels, cargo ships, and tankers, which operate on schedule may be expected to place a steady load on the boilers at the designed normal power rate. The steam load for dredgers and tugs fluctuate greatly, and for that kind of operation the boiler should be fitted with large steam drums and have an effectlve method of superheat control. Navy combat ships are designed to have maximum efficlency at about$25 \%$ of rate horsepower since such ships cruise at this power most of their service lives. However, the bollers must be capable of sustained operation at $120 \%$ of full power rating without undue maintenance.

In a general way, the main difference between marine boilers and their counterparts on land is that the marine equipment is fired at a much higher heat release rate. For example, heat release rates within the furnaces of many land-based boilers are between 25,000 and $30,000 \mathrm{BTV} /$ cubic foot/hour, whereas at sea a common rate would be 60,000 to 70,000 and in Navy yessels it could be as high as 500,000 .

In the burning of Bunker $C$ fuel oil at such high inputs, certain minimum clearances are required around the burners to prevent flame impingement and carbon deposits on the furnace walls.

\subsection{Steam Turbine Fuel Requirements for Marine Applications}

Steam driven ships usually require Bunker $C$ fuel. International bunker fuel is Bunker $C$, in effect the heaviest member of the intermediate fuels class. A viscosity of 4000 Redwood No. 1 or $175 \mathrm{SSU}$ at $122^{\circ} \mathrm{F}\left(50^{\circ} \mathrm{C}\right.$ ) is normally considered maximum. The principal requirement for Bunker $C$ which might differentlate it from the corresponding heavy fuel oil for land use is that of gravity. A minimum of $12.5^{\circ} \mathrm{API}$ is normally required to insure good separation from sea water contamination.

Sulfur content cannot be Ignored but it is less important at sea than on land, especially in some urban areas.

Marine boilers are almost Invariably designed to fire Bunker C and to withstand the deleterious effects of a reasonable amount of ash components and sulfur in the fuel. Obviously, boller maintenance can be reduced by purchasing fuels containing less of these normal contaminants, but the economies so effected will seldom pay for the premium fuel. Several 
shipping companies have elected to use the heaviest fuels avallable, and it is not too uncommon to find $400 \mathrm{SSF} / 122^{\circ} \mathrm{F}$ fuels being used by tanker companies. These heavier fuels simply need to be heated to a slightly higher temperature for atomization than do the conventional 100 to $175 \mathrm{SSF} / 122^{\circ} \mathrm{F}$ fuels.

\subsubsection{The Gas Turbine Engine}

A simple gas-turbine engine consists of a compressor, a combustion chamber and a turbine. The aim is to convert heat energy of fuel into mechanical energy. The compressor and combustion chamber produce a highenergy working fluid that can be expanded in the turbine which develops mechanical energy.

Manufacturers are offering a wide range of gas turbine power plants for non-aviation applications. The engines range from approximately $2500 \mathrm{hp}$ to approximately $20,000 \mathrm{hp}$. Applications have been studied and designed in many fields including gas transmission power generation, marine propulsion, railroad propulsion, factory standby power, and process applications. In most cases, the final component, whether 1 t be a generator, compressor, a ship's propeller, or other device, is driven by a power turbine. This power turbine has no direct connection with the alrcraft gas turbine engine but utilizes the gases from the gas turbine engine as its source of energy. Thus, the gas turbine engine becomes, in effect, a gas generator. This system offers the advantage of eliminating the monumental problems which are encountered in a direct shaft drive which requires elaborate gearing for speed reduction.

The advantages offered by this type of prime mover are significant for many applications. Of principle interest is the considerably lower capital investment required for a gas turbine installation when compared to a reciprocating installation of equivalent output. Published articles have cited figures as high as a 50\% saving. In many cases, the possibility of automation or remote control brings about significant savings in direct operating cost which in many applications offset the higher fuel consumption which is, at present, a basic shortcoming of the gas turbine engine. Other published articles have, cited the ability of the gas turbine powered generating units to go "on stream" in a matter of minutes as compared to many hours required for a steam turbine unit.

\subsection{Gas Turbine Fuel Requirements}

The growing use of alrcraft turbine engines in a variety of Industrlal applications ralses questions as to just how these engines perform on fuels other than conventional aviation gas turbine fuels. The indications are that although bolling point, specific gravity, surface tension and heat of vaporization all theoretically influence burning time requirement, these factors are so interrelated in normal petroleum fuels that they cancel one another. Thus, for a given viscosity, bolling range can be varied widely without changing burning time requirements apprectably.

The question of viscosity range is important, especially when the turbine is one which is fired through multiple small combustion chambers 
(combustion cans). It is less important for turbines with single large chambers. The smaller cans are fired by small pressure atomizing nozzles. The spray angle and the degree of atomization are adversely affected by too high a viscosity, this can be especially important at the moment of starting the engine. Once the turbine is running at full power, the fuel viscosity can be increased to 10 centistokes, or up to 20 centistokes if air atomizing nozzles are used. At the lower end of the viscosity range some manufacturers express concern for pump maintenance due to poorer lubricating properties of the fuel.

Another critical point in the gas turbine is the combustion can liner, which may become choked with carbon if the combustion is not clean, or which may become overheated if radiation from the flames to the walls of the can is excessive.

As was discussed under afrcraft fuels, the problem of flame radiation is controlled by specifying a maximum luminometer number (ASTM D1740), or a maximum smoke number (ASTM D1322). These tests correlate with the paraffinicity of the fuel, that is, better results are obtained the higher is the ratio of hydrogen to carbon in the fuel.

In the industrial turbine field, much of this criticality has been designed out by the introduction of cans which are larger and heavier than. those which are needed in aircraft. However, directionally there is an advantage for fuels of higher hydrogen content. The U. S. Navy specifies a minimum cetane number of 39 for distillate fuel for gas turbine use. The turbine is not critical to cetane rating as such (nor to octane rating since ignition is continuous), but the figure of 39 is intended to insure that the fuel does not contain too much aromatic component.

The American Society for Testing and Materlals has recently published a standard specification for gas turbine fuel o1ls (ASTM D 2880-76) for uses other than in aircraft. The properties selected for limitation are those that are believed to be of greatest significance in determining performance characteristics of the fuels in the various gas turbine applications. These are listed in Table 1-9.

The properties listed in this specification are those of greatest significance in obtaining acceptable performance of the turbine. However, trace metals, even in fractional parts per million, are detrimental to gas turbine service life. Information on the maximum concentration of critical metalif elements in the fuel as it enters the turbine combustor(s) is provided in Table 1-10. Distillate fuels are usually of satisfactory purity as refined, but suppliers rarely have control over possible contamination by trace metals in distribution and storage. The limits, although required as the fuel enters the combustor(s), do not apply to the fuel as delivered unless mutually agreed upon by the interested parties. Fuels may, therefore, require on-site clean-up, quality control procedures, spectal handling, or other arrangements. 
TABLE 1-9

DETAILED REQUIREMENTS FOR GAS TURBINE FUEL
OILS AT TIME AND PLACE OF CUSTODY TRANSFER TO USER.

(ASTM D 2880-76)

\begin{tabular}{|c|c|c|c|c|c|c|c|c|c|c|c|c|c|c|c|c|}
\hline \multirow{3}{*}{$\begin{array}{l}\text { Designa- } \\
\text { tiont }\end{array}$} & \multirow{3}{*}{$\begin{array}{c}\text { Grade of Gas Turbine } \\
\text { Fuel Oil }\end{array}$} & \multirow{3}{*}{\begin{tabular}{|c|}
$\begin{array}{c}\text { Flash } \\
\text { Point, } \\
\text { ('F) }\end{array}$ \\
\\
min \\
\end{tabular}} & \multirow{3}{*}{$\mid \begin{array}{c}\text { Pour } \\
\text { Point. } \\
\text { (F) }\end{array}$} & \multirow{3}{*}{$\begin{array}{c}\text { Water } \\
\text { and Sed- } \\
\text { iment. } \\
\text { vol \%o } \\
\\
\\
\max \end{array}$} & \multirow{3}{*}{\begin{tabular}{|c|} 
Corhon \\
Residuc \\
on $10 \%$ \\
Resid. \\
uum, wt \\
$\%$ \\
max \\
\end{tabular}} & \multirow{3}{*}{$\begin{array}{c}\text { Ash, wt } \\
\text { max } \\
\max \end{array}$} & \multicolumn{2}{|c|}{$\begin{array}{l}\text { Distillation } \\
\text { Temperature. } \\
90 \% \text { Point }\end{array}$} & \multicolumn{3}{|c|}{ Coybolt Vieconity. $8^{\prime \prime}$} & \multicolumn{3}{|c|}{$\begin{array}{c}\text { Kinematic Viscosity, } \\
\mathbf{m m}^{2} / s^{0}\end{array}$} & \multirow{3}{*}{\begin{tabular}{|c|} 
Gravity \\
API \\
$\min$ \\
\end{tabular}} & \multirow{3}{*}{$\begin{array}{l}\text { Sulfu: } \\
\text { w: } \AA_{1} \\
\max \end{array}$} \\
\hline & & & & & & & \multirow{2}{*}{ C (F) } & \multirow{2}{*}{\begin{tabular}{|c|}
${ }^{\circ} \mathrm{C}(\mathrm{P})$ \\
$\max$ \\
\end{tabular}} & \multicolumn{2}{|c|}{$\begin{array}{c}\text { Universal at } 38^{\circ} \mathrm{C} \\
\left(100^{\circ} \mathrm{F}\right)\end{array}$} & \multirow{2}{*}{$\frac{\begin{array}{c}\text { Furol at } \\
50^{\circ} \mathrm{C} \\
\left(122^{\circ} \mathrm{F}\right)\end{array}}{\max }$} & \multicolumn{2}{|c|}{$\begin{array}{l}\text { at } 38^{\circ} \mathrm{C} \\
\left(100^{\circ} \mathrm{F}\right)\end{array}$} & \multirow{2}{*}{$\frac{\begin{array}{l}\text { at } 50^{\circ} \mathrm{C} \\
\left(122^{\circ} \mathrm{F}\right)\end{array}}{\max }$} & & \\
\hline & & & & & & & & & $\min$ & $\max$ & & $\min$ & $\max$ & & & \\
\hline No. O-GT & $\begin{array}{l}\text { A naphtha or other low- } \\
\text { nash hydrocarbon liq- } \\
\text { uid. }\end{array}$ & $r$ & $\cdots$ & 0.05 & 0.15 & 0.01 & $\ldots$ & $\cdots$ & $c$ & $\cdots$ & $\ldots$ & $c$ & $\cdots$ & $\cdots$ & $\cdots$ & legal \\
\hline No. 1-GT & $\begin{array}{c}\text { A distillate for gas tur- } \\
\text { bines requiring a fuel } \\
\text { that burns cleaner } \\
\text { than No. } 2-G T \text {. }\end{array}$ & $\begin{array}{c}38 \\
(100 \text { or } \\
\text { legal }\end{array}$ & $\begin{array}{c}-18^{\prime \prime} \\
(0)\end{array}$ & 0.05 & 0.15 & 0.01 & $\ldots$ & $\begin{array}{c}288 \\
(550)\end{array}$ & $\ldots$ & $(34.4)$ & $\cdots$ & 1.4 & 2.5 & $\because$ & 35 & legal \\
\hline No. 2-GT & $\begin{array}{l}\text { A distillate fuel of low } \\
\text { ash suitable for gas } \\
\text { turbines not requiring } \\
\text { No. } 1-G T\end{array}$ & $\begin{array}{c}38 \\
(100) \text { or } \\
\text { legal }\end{array}$ & $\begin{array}{c}-6^{\circ} \\
(20)\end{array}$ & 0.05 & 0.35 & 0.01 & $\begin{array}{c}282 \\
(540)\end{array}$ & $\begin{array}{c}338 \\
(640)\end{array}$ & $(32.6)$ & $(40.2)$ & $\cdots$ & 2.0 & 4.3 & $\cdots$ & 30 & legal \\
\hline No. 3-GT & $\begin{array}{l}\text { A low-ash fuel that may } \\
\text { contain residual com- } \\
\text { ponents. }\end{array}$ & $\begin{array}{c}55 \\
(130) \text { or } \\
\text { legal }\end{array}$ & $\ldots$ & 1.0 & $\ldots$ & 0.03 & $\ldots$ & $\ldots$ & 45 & $\ldots$ & 300 & $(5.8)$ & $\ldots$ & (638) & $\because$ & legal \\
\hline No. $4-\mathrm{GT}$ & $\begin{array}{l}\text { A fuel containing resid- } \\
\text { ual components and } \\
\text { having higher vana- } \\
\text { dium content than } \\
\text { No. } 3-G T \text {. }\end{array}$ & $\begin{array}{c}66 \\
(150) \text { or } \\
\text { legal }\end{array}$ & $\ldots$ & 1.0 & $\cdots$ & $\ldots$ & $\ldots$ & $\cdots$ & 45 & $\ldots$ & 300 & $(5.8)$ & $\ldots$ & $(638)$ & $\ldots$ & legal \\
\hline
\end{tabular}

A No. O-GT includes naphtha, Jet B fucl, and other volatile hydrocarbon liquids. No. 1-GT corresponds in general to Specification D 396 Grade No. 1 fuel and Classification

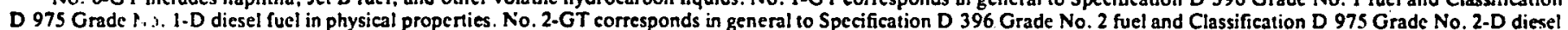

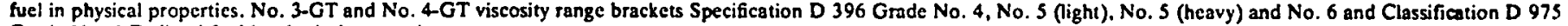
Grade No. 4D diesel fuel in physical properties.

- Viscosity values in parentheses are for information only and are not limiting; $\left(1 \mathrm{~mm}^{2} / \mathrm{s}=1 \mathrm{cSt}\right)$.

$r$ When flash point is below $100^{\circ} \mathrm{F}$, or when kinematic viscosity is below $1.4 \mathrm{cSt}$ at $100^{\circ} \mathrm{F}$, or when both conditions exist. the turbine inanufacturet should be consulted with respect to safe handling and fucl sysiem design.

${ }^{\circ}$ For cold weather operation. the pour point should be specified $5.6^{\circ} \mathrm{C}\left(10^{\circ} \mathrm{F}\right)$ below the ambient temperature at which the turtine is to be operated except where fuel heatine

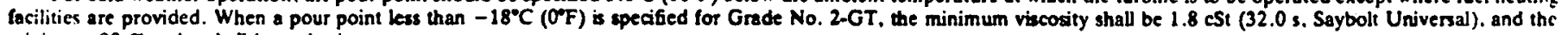
mirimum $90 \%$ point shall be waived.

\section{Source: Complled by ER\&E from published information.}

TABLE $1-10$

TRACE METAL LIMITS OF FUEL ENTERING TURBINE COMBUSTOR(S)

\begin{tabular}{|c|c|c|c|c|}
\hline \multirow[b]{2}{*}{ Daignation } & \multicolumn{4}{|c|}{ Trace Metal Limits (max), ppm by wt. } \\
\hline & Vanadium (V) & $\begin{array}{c}\text { Sodium plus Potas- } \\
\text { sium }(\mathrm{Na}+\mathrm{K})\end{array}$ & Calcium (Ca) & Lead (Pt) \\
\hline $\begin{array}{l}\text { No. 0-GT } \\
\text { No. 1-GT } \\
\text { No. 2-GT } \\
\text { No. } 3-G T \\
\text { No. } 4-G T\end{array}$ & $\begin{array}{l}0.5 \\
0.5 \\
0.5 \\
0.5\end{array}$ & $\begin{array}{c}0.5 \\
0.5 \\
0.5 \\
0.5 \\
\text { (Consult turbine }\end{array}$ & $\begin{array}{c}0.5 \\
0.5 \\
0.5 \\
0.5 \\
\text { nanufacturers) }\end{array}$ & $\begin{array}{l}0.5 \\
0.5 \\
0.5 \\
0.5\end{array}$ \\
\hline
\end{tabular}


Trace metal 11mits are significant in terms of affecting power output and turbine iffe. Vanadium can form low melting compounds such as vanadium pentoxide which melts at $691^{\circ} \mathrm{C}\left(1275^{\circ} \mathrm{F}\right)$, and causes severe corrosive attack on all of the high temperature alloys used for gas turbine blades.

- Lead can cause corrosion and in addition it can spoll the beneficial Inhibiting effect of magnesium additives on vanadium corrosion.

- Sodium, potasstum, and calclum--Fuel contaminants might also include fuel insoluble materials such as water, salt, or dirt, potentlal sources of sodium, potassium and calcium. These are normally removed at the gas turbine site, unless such contaminants are extremely finely divided.

- Sodium and potassium can combine with vanadium to form eutectics which melt at temperatures as low at $566^{\circ} \mathrm{C}\left(1050^{\circ} \mathrm{F}\right)$ and can combine with sulfur in the fuel to yield sulfates with melting points in the operating range of the gas turbine. These compounds produce severe corrosion, and for turbines operating at gas inlet temperatures above $649^{\circ} \mathrm{C}\left(1200^{\circ} \mathrm{F}\right)$ additives are not yet in general use: which control such corrosion.

- Calcium is not harmful from a corrosion standpoint; in fact, it serves to Inhiblt the corrosive action of vanadium. However, calcium can lead to hard-bonded deposits that are not self-spalling when the gas turbine is shut down, and that are not readily removed by water washing of the turbine.

- Sulfur, normally burning to sulfur dioxide, also can be oxidized partially to sulfur trloxide which then can combine with sodium and potassium compounds from the ash in the fuel to form sulfates, pyrosulfates, and such compounds as Bodium or potassium iron trisulfate. The pyrosulfates, and the trisulfates have melting polnts in the operating range of the gas turbine. Hence, the compounds produce severe corrosion of the turbine blading.

\subsubsection{Raflroad Prime Movers and Fuels}

The primary prime mover used by the railroads in the U. S. today is the diesel engine. The steam locomotive has all but disappeared, and the present trend is agalnst further expansion of electrical operation because of high initial costs. In replacing the steam locomotive, the modern diesel has lowered operating and maintenance costs and reduced the number of locomotives necessary to maintain adequate service. The distribution of locomotives as of January 1, 1976 is shown below. (1-11)

\section{LOCOMOTIVES OF U.S. CLASS I RAILROADS}

\begin{tabular}{lr}
\multicolumn{1}{c}{ Type } & Number \\
\hline Diesel & 27,925 \\
Electric & 215 \\
Steam & 1
\end{tabular}


Power is developed by a diesel engine driving a generator, which in turn feeds electric traction motors mounted on each axle. This type of power transmission is easy to control and accounts for the efficlency of the diesel at all speeds under most load conditions:

Raflroads have obtained greater use from diesels than from steam or electric unlts because the diesel can perform many different jobs efficiently and spends less time in the shop for maintenance, both routine and major. Diesel maintenance is less time-consuming because there are many Interchangeable parts--whole motor generator sets can be replaced and a unit quickly restored to service.

The type of diesel most frequently used is the general-purpose road switcher. It has been successful on all railroads, hauling fast passenger trains, long-haul frelghts, and local comuter trains, and is also used in both local and interchange yards. Other types are designed espectally for fast passenger or frelght service and differ primarily in gear ratios and horsepower ratings: Rallroads and coal companies have also considered using coal-burning steam turbines but an economically practical design has not been developed.

\subsubsection{The Railroad Diesel Engine}

Dlesel locomotive engines having continuous power capabilities from 500 to 4000 horsepower are avallable. The engines generally operate In an intermediate speed range, that 1s, from 600 to $2000 \mathrm{rpm}$, with 900 to $1000 \mathrm{rpm}$ belng most common in the larger sizes. On U. S. mainlines the most common locomotive is the diesel-electric. For the small and medium size shunting locomotives, diesel-mechanical or diesel-hydraulic systems are generally used. On the larger shunting locomotives the diesel-electric unit is popular, and in recent years an increased number of diesel-hydraulics have been put into service, particularly in Europe.

The diesel engine for railroad locomotives has been developed into an extremely rellable plece of machinery whose configurations and size fit In very well with the space limitations imposed by railroad requirements. Its outstanding feature is its relatively high thermal efficlency of 32 to $35 \%$, which is consistently maintained in service over a wide range of loads and speeds. Since fuel costs are a substantial part of locomotive operating costs, this is a very important attribute. Another major advantage is its operational availability due to its relatively low malntenance downtime.

Although the demand for diesel power has been high in all fields of application, the volume of diesel horsepower being channeled to rallroad diesel locomotives exceeds all other Industrlal applications. Some of the advantages of the diesel engine over the steam locomotive in railroad operation are 1llustrated in Table 1-11, whlch compares the performance of switching, freight, and passenger engines in terms of heat input per unit of useful work. 
TABLE 1-1]

COAL FIRED STEAM VS.

DIESEL LOCOMOTIVE OPERATION

$$
\begin{aligned}
& \text { Switching Engines } \\
& \text { Coal Fired Steam } \\
& \text { Diesel } \\
& \text { Ratio Coal/Diesel }
\end{aligned}
$$

Freight Engines

Coal Fired Steam

Diesel

Ratio Coal/Diesel

Passenger Engines

Coal Fired Steam

Diese1

Ratio Coal/Diesel

$$
\begin{gathered}
10^{6} \mathrm{BTU} / \text { Loco. Hr. } \\
\begin{array}{c}
11,300 \\
850 \\
13.3
\end{array}
\end{gathered}
$$

BTU/Ton Mile

1,665

224

7.4

$10^{6} \mathrm{BTU} / \mathrm{Car} \mathrm{Mile}$

232

39

6.0

Basis: Coal - 12,710 BTU/Lb. (Net)

Diesel Fuel - 132,200 BTU/Gal. (Net)

Source: Compiled by ER\&E from published information.

In switching service, a typical steam locomotive requires 13 times the heat input of a diesel englne per locomotive hour:

\subsubsection{Diesel Engine Fuel Requirements}

Information on diesel fuels in general can be found in the discussion of diesel fuel requirements for marine diesels (1.1.2.1.1). Most of the railroads in the U. S. use a falrly good grade of all-distillate ASTM No. 2 diesel fuel, as specifled in ASTM D 975-74. Specific recommendation supplementing these requirements are also made by major manufacturers. These are shown in Table 1-12.

The distillate fuels described in Table 1-12 give very good results. However, extensive test work has indicated that cheaper, lower quality distillate fuels can be utflized in rallroad diesel engines. Representative inspection data, comparing an economy grade dlesel fuel, are shown in Table 1-13. 


\section{TABLE $1-12$}

FUEL RECOMMENDATIONS - U.S. LOCOMOTIVE DIESEL ENGINES

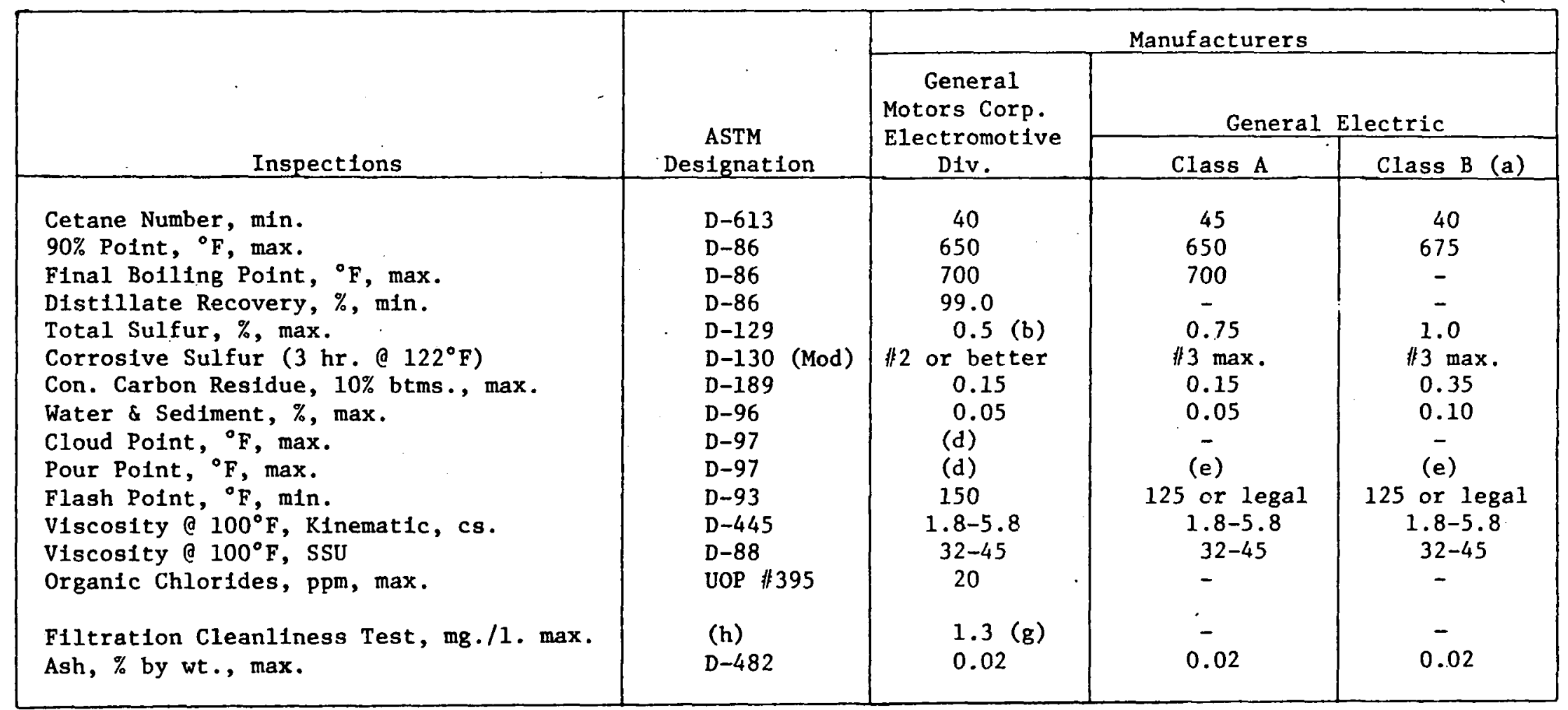

(a) Use of Class B fuels will require additional malntenance and more careful control and selection of lubricating ofl.

(b) The maximum total sulfur content has been set at $0.50 \%$ or legal. Fuels contalning larger amounts of sulfur can be used but w111 increase engine wear and maintenance.

(c) Low atmospheric temperature as well as engine operation at high altitudes may require use of fuels with higher cetane ratings.

(d) Prevalling ambient temperature.

(e) For cold weather operation, the pour point should be specifled $10^{\circ} \mathrm{F}$ below the amblent temperature at which the engine 18 to be operated, except where fuel ofl heating facilitles are provided.

(f) For normal summer operations, a pour point of $25^{\circ} \mathrm{F}$ maximum is satisfactory. For winter condltions the ofl should have a pour point not less than $10^{\circ} \mathrm{F}$ lower than the expected temperatures.

(g) Ash residue on 0.80 micron filter.

(h) 1962 ASTM D-2 Report, Append1x X, page 35. 
TABLE $1-13$

INSPECTIONS OF RAILROAD DIESEL DISTILLATE FUELS

\begin{tabular}{lcc}
\multicolumn{1}{c}{ Inspection } & Hig: Grade & Economy Grade \\
\cline { 1 - 2 } Cetane No, , min. & 50 & 40 \\
Sulfur, \%, max. & 0.2 & 0.75 \\
FBP, ${ }^{\circ}$ F, max. & 625 & 725 \\
Pour Point, ${ }^{\circ}$ F & $0-15$ & $30-70$ \\
Relative stability & Excellent & Good to Fair
\end{tabular}

Since fuel costs constitute over half the operating expense of the rallroad diesel locomotive, a reduction of unit fuel cost could result in large potential savings. As fuel quality is degraded, however, maintenance costs tend to increase. It thus becomes a matter of economics whether the price of the economy fuels is low enough to show a saving after paying for the added maintenance.

Use of economy grade distillate fuel may result in fuel cost savings from 5 to $10 \%$. Further reductions in the cost of these fuels are not possible as long as all-distillate fuels are specified, because even the lower grade distillates are well refined products which are in high volume demand for other commerctal purposes.

A great deal of work has been done on blends of distillates with lower cost residual fuels. The use of residual fuels in the diesel engine is as old as the engine itself. Throughout the years it has been comon practice to operate large slow-speed marine and stationary diesel engines (especially those of European design) on black fuels of various viscosities. In many instances, distillate fuels have been used for starting up, shutting down, and maneuvering under part load. In the shipping industry this practice has resulted in satisfactory economical operation. The majority of comercial motor vessels throughout the world are now using residual fuels in their main propulsion diesel engines, and there is a growing tendency toward using such fuels in their auxiliary engines also. In the U.S.A. residual fuels are used much less extensively in diesel power, espectally in medium and high speed engines.

The use of full viscosity Bunker $C$ fuel does not appear feasible in raflroad diesel engines, but blends of residual fuel with distillates have been fleld-tested.

\subsubsection{Railroad Gas Turbine Englne}

The gas turbine has appeal as a locomotive power plant because it is simple, compact and requires no cooling water. It has inherently low malntenance and high avaliability (low down-time) characteristics, and high-powered units can be bullt within a single cab. 
Amtrak has taken delivery of the first of seven turblne-powered trains from Rohr Corporation. These trains were bullt under a license agreement with the French firm which had supplied six Turboliners to Amtrak and contain many of the same French components. (1-12)

\subsubsection{Rallroad Electric Motive Power.}

Electric locomotives constitute only a small part of the total railroad prime mover population, and these are concentrated primarily in the Northeast Boston-New York-Washington corridor. Some views on the subject of electrics are given in a recent paper, "Electrification and New Electric Locomotive Designs," presented by M. Ephraim, Jr., Chief Engineer, and H. E. Quinn, Chief Electrical Engineer, of GM Electro-Motive Division.(1-13)

Ephraim and Quinn stated that, "Whereas European experience Indicates that electric locomotives are comparable in cost to diese1electric locomotives, this is definitely not the experience in the United States to date." Tooling expenses would be considerable to bring the Industry's electric locomotive manufacturing capabilities up to a level comparable with the equipment and plant the 1ndustry now has on-line after the more than 30 years of manufacturing diesel-electric locomotives:

"Electric locomotives to date have not been mass produced to the same degree as the diesel-electric locomotive, and it will be a long time before sufficient quantities of standardized models will be required to justify the enormous tooling expenditures to minimize production costs. As an example of higher costs of electric-powered cars produced in limited quantities, a typical Mu electric rail car in the United States costs approximately $60 \%$ more than a highhorsepower diesel locomotive, and an Amtrak Metroliner car is estimated to cost over twlce as much as a diesel-electric locomotive, if reordered today."

\subsubsection{Pipeline Prime Movers and Fuel Interaction}

The prime mover selected for developing the pumping pressure in pipelines is generally related to the fuel avallable. The 1deal situation Is to use some of the macerial being pumped as the fuel; thus, natural gas pipelines operate mostly with reciprocating spark ignited engines fueled by natural gas. Gas turbines can also be used, since they operate well on natural gas, but they are less efficlent, consuming approximately $35-40 \%$ more fuel. However, they are used in remote locations where cooling water is not available.

Crude and liquid product plpelines generally utilize centrifugal pumps run by electric motors. The distribution of prime movers used in pipelines in 1970-71 is shown in the following table. 
TYPE OF ENGINE/DRIVE USED TO TRANSPORT

PETROLEUM \& NATURAL GAS BY PIPELINE $(1-11)$

$1970-71$

$10^{12}$ BTU

Gas Reciprocating $\quad 420$

Gas Turbine 275

Diesel 45

Electric $\quad 328$

Source: Reference 1-1.

\subsubsection{Gas Engine Prime Movers}

Gas engines are bullt in size ranges up to 12,500 H.P. Approximately $80 \%$ are 2 cycle, and the remainder are 4 cycle engines. Besides the obvious operating difference, the main distinction between the two types is the design of the power cylinders. A two-cycle engine has two sets of ports or openings around each power cylinder wall. Fuel is injected through a nozzle at the top of the cylinder. On the other hand, four-cycle engines such as the Ingersol-Rand utilize inlet and exhaust valves to admit the air-fuel mixture and exhaust the products of combustion.

In operation, the four-stroke cycle gas engine works just like the engine in an automobile. The only significant difference is the nature of the fuel. Where the gasoline engine uses a vaporized petroleum fuel, the gas engine uses natural gas.

As in the carburetor of the automoblle engine, fuel and air are mixed together for delivery to the combustion chambers. In a gas engine, the equivalent of a carburetor is called a mixing valve. Spark plugs Igntte the fuel-air mixture in the power cylinders at the appropriate time. Electric impulses to the spark plugs are provided by magnetos. Inlet and exhaust valves are operated by cams and rocker arms just as in an automotive eriglne.

In actual practice, both the power and compressor cylinders are integrally constructed on the same frame and all pistons are connected to one crankshaft. Power developed in the engine cylinders is transmitted through connecting rods and the crankshaft directly to the compressor all within a comson engine-compressor frame.

\subsection{Gas Englne Fue1 Requirements}

In gas engines, resistance to detonation and knock is probably the major fuel performance consideration. Detonation is characterized by excessive and extremely rapid rises in combustion pressure. These violent rises signify uncontrolled combustion, accompanied by loss in efficiency. 
In addition, detonation leads to audible knock, a post-ignition phenomenon. Knock occurs when an advancing flame front compresses the remaining charge so that its temperature exceeds its ignition temperature, causing spontaneous Ignition to take place. Although occasional detonation is not harmful, prolonged periods of detonation can induce preignition. Preignition can generate excessively high temperatures within the combustion chamber 1 ia period of a few seconds, and in so doing, can destroy piston crowns and valves.

The following four factors influence detonation and knock:

- Fuel characteristics

- Compression ratio

- Ignition timing

- Mixture temperature

Definite relationships exist between these factors. These relationships are summarized briefly as follows:

- As the compression ratio increases, there is an increased tendency for the engine to detonate.

- There is an increased tendency for the engine to detonate as the spark ignition timing is advanced.

- An increase in mixture temperature increases the tendency of the engine to detonate.

- Detonation can be suppressed by an improvement in fuel antiknock properties.

The antiknock properties of gaseous fuels (and gasolines) determine their resistance to detonation. Antiknock properties vary with molecular size and structure. Antiknock quality decreases with increasing molecular welght for a given molecular configuration, and generally increases as the number of branched chains in the molecule increases. For example, methane, $\mathrm{CH}_{4}$, has less tendency to knock than has butane, $\mathrm{C}_{4} \mathrm{H}_{10}$.

\subsubsection{Gas Turbine Primary Movers}

Except for their lower efficiency (relative to gas engines), gas turbines make good prime movers for pipeline pumping. Experience has shown that they operate well as drivers for compressors (natural gas service) or centrifugal pumps (liquid product service). One current example of application of gas turbines in a remote location is the Alaska P1peline.(1-14) At full design capacity of $2 \mathrm{Mbpd}$, the system will have 12 pump stations. Centrifugal pumps powered by 13,500 hp alrcraft-type turbines w111, at full system capacity, provide almost $650,000 \mathrm{hp}$. Four of the pump stations will be fueled by natural gas from the Prudhoe Bay field; the remaining stations will use fuel derived from the crude.

The fuel requirements for a gas turbine engine discussed under the Marine section (1.1.2.3.1) generally apply here as well. 


\subsubsection{Electric Motor Prime Movers}

Crude and liquid product pipelines generally employ centrifugal pumps driven by electric motors. The motors are predominantiy in the 400500 H.P range, although they can be larger. For instance, some lines transporting liquid products employed motors up to $1,500 \mathrm{H} . \mathrm{P}$. at a speed of 1,780 revolutions per minute.

\subsubsection{Other Engines with Possible Application to Non-Highway Transportation}

include:

Engines which have not been discussed in foregoing sections

- Free piston engines

- Stirling engines

- Closed cycle gas turbines

The free piston engine has been tested in shipboard operation during the 1960's, and while it had drawbacks which precluded its more general adoption, it may have properties which would make it desirable in the future, particularly since 1t showed some capability of running on a wide variety of fuels.

The Stirling engine and the Closed Cycle Gas Turbine have some similarity with steam engines/turbines, because they are fired externally at a heat exchanger which performs a function similar to that of the boiler. While the Stirling engine has not been used since the 19th century in practical applictations, it is known to be able to use a wide variety of fuels, and has reached a high level in the development stage for englnes up to $2000 \mathrm{HP}$.

The closed cycle gas turbine is a developed engine which has found application to the concurrent production of heat and power, and which runs successfully on a variety of fuels including low rank coal.

Each of these engines is described briefly in the following sections.

\subsubsection{Free P1ston Engine} gas turbine.

A free piston engine is a combination of a gasifier with a companion

The basic elements of the gasifier part are:

- A pair of single-stage reciprocating compressors.

- A 2-stroke opposed piston diesel cycle cylinder, the two pistons being coupled to the compressors.

- A pair of "bounce cylinders" which convert kinet1c energy of the outward flying pistons, to potential energy of compressed afr. This compressed air then forces the pistons toward each other for the next cycle. 
Three possible configurations are shown in diagram form on the left-hand side of Figure 1-6. C represents the compressors, $D$ the volume between pistons which is essentially the diesel cylinder, and $B$ the bounce cylinders.

The events of each cycle of the pistons occur as follows (refer to the right-hand side of Figure 1-6). The composite pistons are driven outward by the expanding combustion gases of the diesel cylinder and by the expanding air of the compressor-cylinder clearance volumes. Air is drawn into the compressor cylinders, and afr contained within the bounce cylinders is compressed for storage of energy. Near the outer end of the stroke, first the exhaust ports and then the scavenge ports are uncovered by their respective diesel pistons, consequently releasing the combustion products to the turbine and permitting fresh high-pressure air from the bcavenge system to enter and purge the cylinder. The pistons are then returned Inward by the energy stored in the bounce cylinders. The ports are closed-off, the alr charge thus trapped within the diesel cylinder is compressed, and the air previously drawn into the compressor cylinders is compressed and delivered to the scavenge system. Near the inner end-point of stroke, a metered quantity of fuel is injected into the diesel cylinder, causing repetition of the entire process.

The work performed by the diesel cycle is that of compressing its own combustion air, and that of overcoming friction.

Some of the fuel energy is lost to cooling water around the diesel cylinder and the net remainder flows as hot compressed gas toward the companion gas turbine. A diagram of a free piston diesel-turbine unit is shown in Figure 1-7.

The operating temperature at the turbine inlet is never above $1000^{\circ} \mathrm{F}$ so the materials problems are not nearly as difficult as those which have to be overcome in open cycle direct fired gas turbines, firing at $2000^{\circ} \mathrm{F}$ and above.

The turbine converts about $80 \%$ of the work stored in the gas to shaft work. Thus, if the gasifier converts $40 \%$ of fuel heat into work stored In gas, the overall efficiency is likely to be $32 \%$ allowing for losses at the turbine.

A comparison between the operation of the free piston engine and the open cycle gas turbine (GT) reveals why the free piston can attain such relatively. high efficiency at such a low inlet temperature.

Both machines have to perform two functions:

- They must compress their own combustion a1r.

- They convert the energy that is left into shaft power.

In the open cycle GT, about $2 / 3$ of the work goes into compressing the air and $1 / 3$ is avallable as shaft power. The work required for compressic 
FIGURE 1-6

FREE PISTON ENGINE
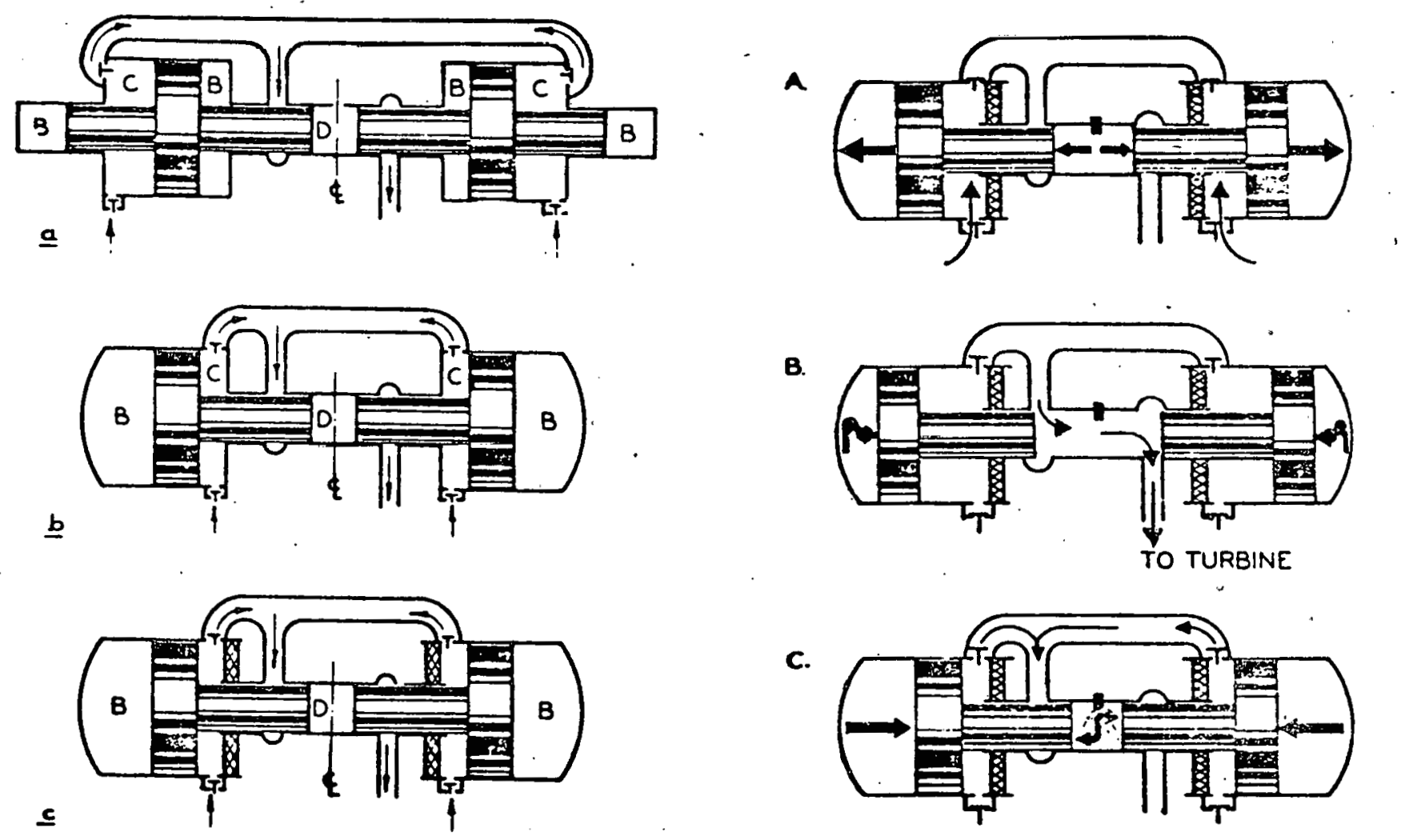

Source: Reference 1-15. 
FREE P-ISTON DIESEL--TURBINE UNIT DIAGRAM
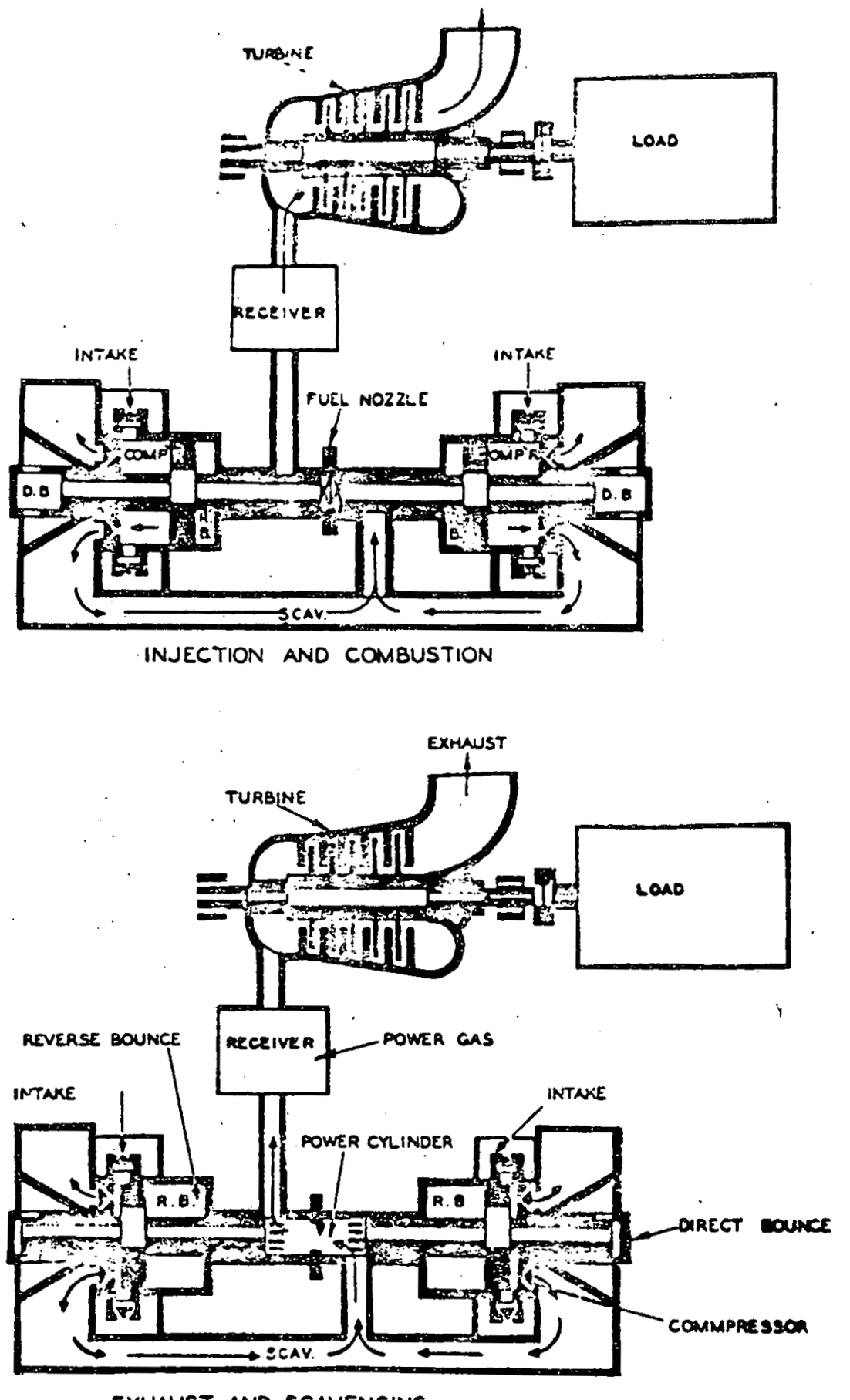

Source: Reference 1-15. 
has to come from within the gas turbine whether it be delivered to a common shaft or to a split shaft. To get any reasonable efficlency, the inlet temperature has to be high.

In the free piston englne, the turbine is relieved of the task of compressing air. That is done by the diesel cycle and the high temperatures required are handled in the water cooled diesel cylinder where materials problems are minimal.

Thus the free piston performs the work of compression by means of an efficlent diesel cycle unhampered by need to keep the working temperature low, and goes on to produce the shaft power in a gas turbine which is analogous to the later stages (the least vulnerable stages) of a direct fired gas turbine.

Its fallure to compete with other prime movers up to now is largely due to maintenance problems which might be overcome or be accepted if this engine proved to be compatible with low grade fuels, assuming those same fuels were not acceptable to other prime móvers.

\subsubsection{Stirling Engines}

The Stirling Engine is an external combustion, closed-cycle, pistontype power plant that uses a gaseous internal working fluld, usually hydrogen or helium. Figure 1-8 shows a simple diagram of a one-cylinder stirling engine. The working gas, heated by an external source, flows back and forth between the cold space and the hot space. Continuous external combustion of a fuel supplies the heat through the upper wall of a cylinder. The tandem displacer and the power pistons drive two yokes that are linked to twin connecting rods, which in turn drive two output shafts in opposite directions.

One of the advantages of a stirling engine is that it can operate on a variety of fuels, since $1 t$ is an external combustion device. The disadvantages are welght and cost. For automotive application, volume and packaging are also problems, but these may not be critical in some of the non-highway transportation applications.

\subsubsection{Closed Cycle Gas Turbine}

Figure 1-9.

A schematic diagram of a closed cycle gas turbine is shown in

At bottom right is an alr heater (though gases other than air, such as helium can be used as the working medium). This is analogous to the boiler in a steam system and has a simflar efficiency, viz $90 \%$. The hot gas so produced is essentially at the compressor outlet pressure shown upper left.

The hot gas expands through the turbine (upper right) delivering about $32 \%$ of the net heat input as shaft work to the generator. It also drives its own compressor.

At the heat recuperator, shown in the center, much of tiie waste heat in the turbine exhaust gas is recovered into the gas enroute to the "boller" (alr heater). 
FIGURE 1-8

STIRLING ENGINE

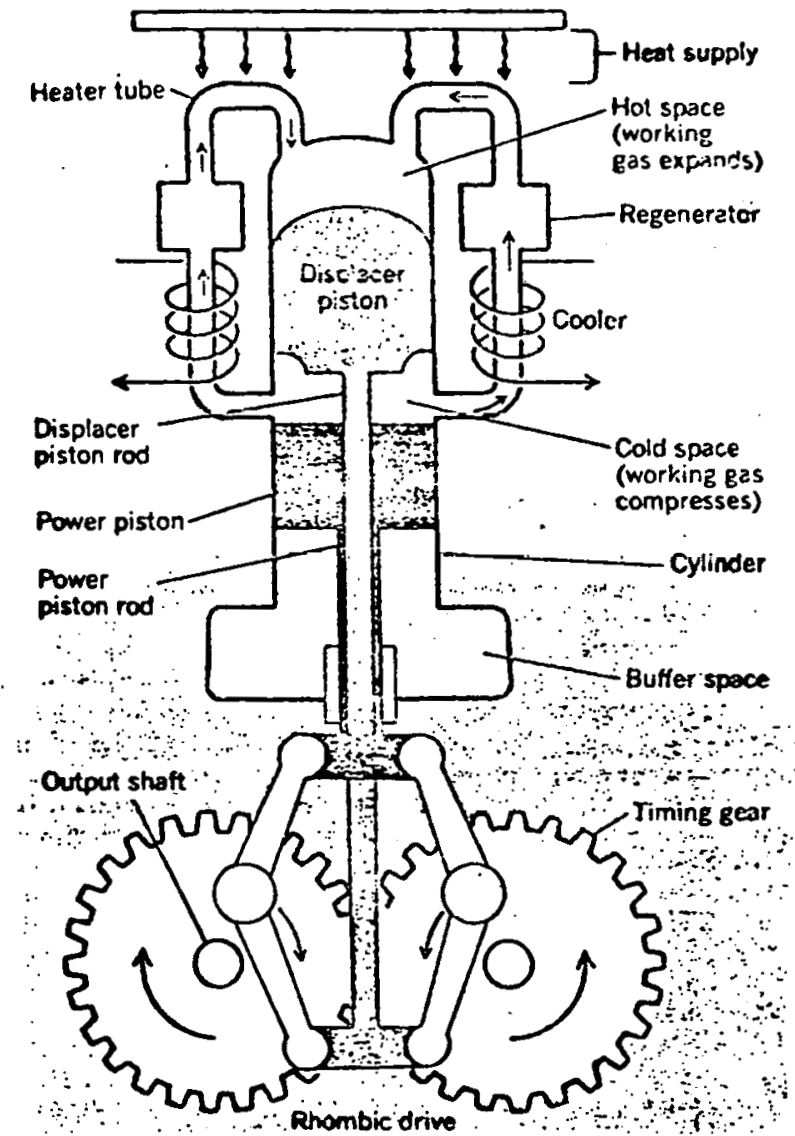

Source: Reference 1-17. 
FIGURE 1-9

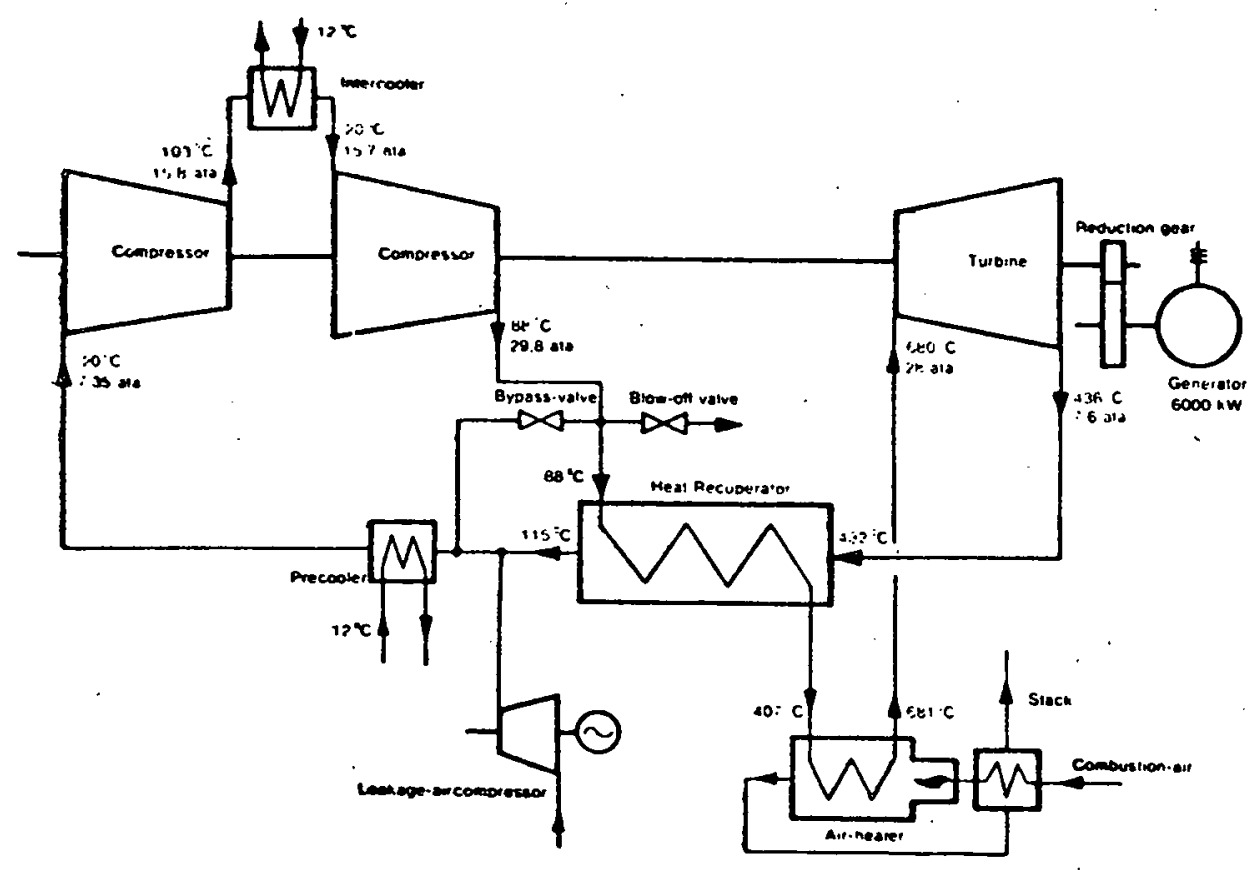

Source: Reference 1-16. 
Thus, to maintain good "boller" efficlency, the combustion air heater shown in the path of the stack gases is a very Important 1tem.

There are two water ccoled heat exchangers, a precooler before the compressor, and an intercooler between compressor stages.

In the diagram, both are shown recelving cooling water at $12^{\circ} \mathrm{C}$. However, if some useful purpose exists for the waste heat, some or all of the cooling water can be admitted at $40-50^{\circ} \mathrm{C}$ and taken out at a temperature close to $100^{\circ} \mathrm{C}$. Each of the coolers shown in the diagram can yield about $25 \%$ of the input fuel heat in the form of hot water at $90-100^{\circ} \mathrm{C}$.

By adjustment of the compressor inlet temperature, the ratio of shaft work to heat recovered can be varied as shown in Figure 1-10.

A small sacrifice in thermal efficiency of the work output (area A in the diagram) results in a large increase in heat avallable (area $B$ ). This flexibility has made a place for these engines in district heating schemes where both electricity and heat axe required concurrently.

The output of the machine is varied by putting in or taking out working fluid from the cycle, in other words by adjusting the overall system pressure.

The "leakage alr compressor" shown lower center in the schematic diagram, would serve to add working fluid (be it air or helium); the blow off valve, center, would serve to take 1 t out.

In the case of helium, of course, a storage system would be provided to hold that portion of the hellum inventory which was extracted for less than full power operation.

A list of working closed cycle gas turbine plants is given in Table 1-14. It will be noted that they cover a range from 2-30 MW, about 2000 to $40000 \mathrm{HP}$.

Turbine inlet temperatures are Intermediate between those of open cycle gas turbine plant, and those of the free-plston/turbine combination.

The fundamental difference is that the working gas, being heated externally, contains no combustion products nor ash residues, and the plant Is tolerant to any fuel which the air heater can handle. Lignite, coal blast furnace gas and natural gas have all been used. This engine could also use nuclear heat.

As an alternative to making hot water for district heat, the waste heat might be directed to drive an organic ranking bottoming cycle to generate more work from the same heat lnput and raise the efficiency into the $35-40 \%$ region. 
FIGURE $1-10$

DIAGRAM OF THE COMBINED CNERCY AND HEAT PRODUCTION. WITH A CLOSED-CYCLE GAS TURBINE PLANT

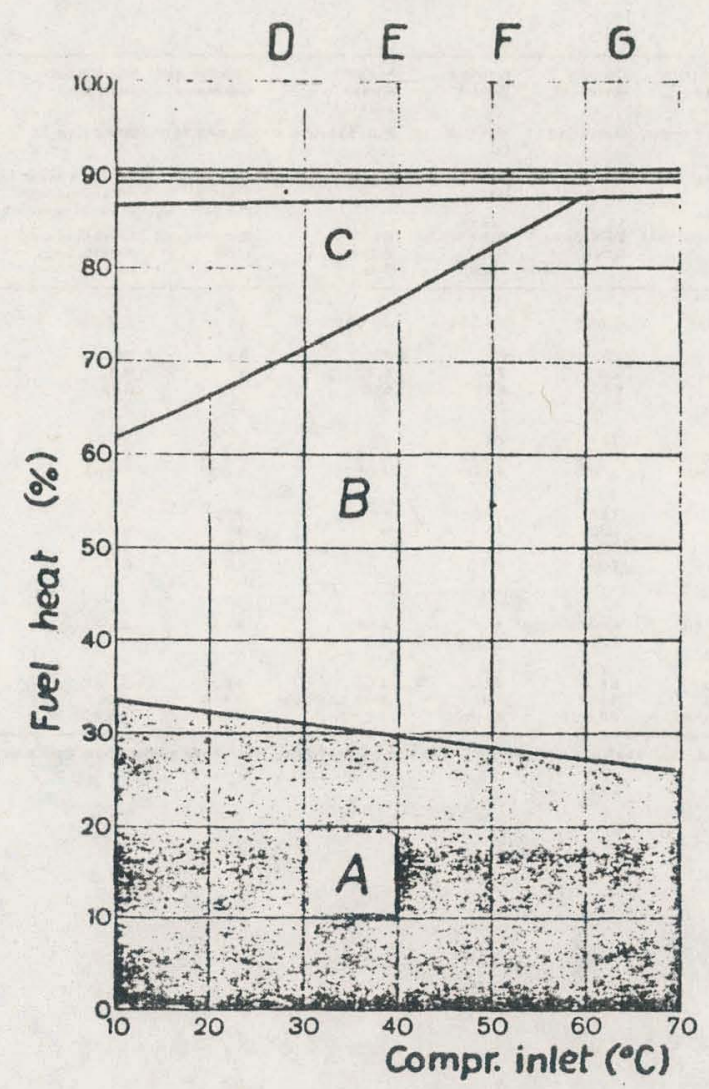

D Mechanical and electrical losses

$E$ Losses of auxiliary machines

F Unaccountable losses

G Air heater losses
A Net output (thermal efficiency)

A + 8 Total energ

efficiency

C Cooling water loss

Source: Reference 1-16. 
TABLE $1-14$

LIST OF SOME CONVENTIONAL CLOSED-CYCLE GAS TURBINE PLANTS

\begin{tabular}{|c|c|c|c|c|c|c|c|c|c|c|c|}
\hline Pient & & $\begin{array}{l}\text { Ravensburo } \\
\text { Cermany }\end{array}$ & $\begin{array}{l}\text { Toyotomi } \\
\text { depen }\end{array}$ & $\begin{array}{l}\text { Coburg } \\
\text { Eerminy }\end{array}$ & $\begin{array}{l}\text { Kashira } \\
\text { Russia }\end{array}$ & $\begin{array}{l}\text { Nipoon } \\
\text { Kokan } \\
\text { Lapan }\end{array}$ & Devernousen : & $\begin{array}{l}\text { Meus adeen } \\
\text { earminy }\end{array}$ & Goven. & $\begin{array}{l}\text { Dye Oxysene } \\
\text { Desonix, }\end{array}$ & $\begin{array}{l}\text { Soittelau, } \\
\text { Vionnas } \\
\text { Austria }\end{array}$ \\
\hline Monutacturer & & $\begin{array}{l}\text { EW LIO. } \\
\text { GHHLto. }\end{array}$ & $\begin{array}{l}\text { Fuji Electric } \\
\text { EW Lid. }\end{array}$ & OMHLId. & Ew Lta. & Fuit Eloctric & and Lee. & ener Lee. & OANH LIt. & $\begin{array}{l}\text { EW Lid. } \\
\text { LF Cord. }\end{array}$ & $\begin{array}{l}\text { EW + Wasoned } \\
\text { Bisco }\end{array}$ \\
\hline Une & & $\begin{array}{l}\text { Power - } \\
\text { Heat }\end{array}$ & Power & $\begin{array}{l}\text { Power t } \\
\text { Hest }\end{array}$ & $\begin{array}{l}\text { Power. } \\
\text { Heat }\end{array}$ & Dower & Power. & $\begin{array}{l}\text { Dawer - Heat } \\
\text { - Turbo-Com- } \\
\text { pressor arive }\end{array}$ & Power. & Cryogenic & Dower + Heat \\
\hline Fuel & & $\begin{array}{l}\text { Bituminous } \\
\text { cos! }\end{array}$ & Natural Gas & $\begin{array}{l}\text { Bituminous } \\
\text { Coal }\end{array}$ & Brown Coal & $\begin{array}{l}\text { Blas: } \\
\text { Furnace } \\
\text { Gas }\end{array}$ & $\begin{array}{l}\text { Bituminous } \\
\text { Coai }\end{array}$ & $\begin{array}{l}\text { Mine Gas and } \\
\text { Bituminous } \\
\text { Coal }\end{array}$ & $\begin{array}{l}\text { Biast } \\
\text { Furnace } \\
\text { Gas and Oil }\end{array}$ & motural Gas & Oit or Gas \\
\hline $\begin{array}{l}\text { Operating Data: } \\
\text { Cont inuous outtout } \\
\text { Tomperature at compressor }\end{array}$ & kW & 2300 & 2000 & 6600 & 12000 & 12000 & 14300 & 6370 & 17250 & - & $30 \cdot 000 / 22000$ \\
\hline 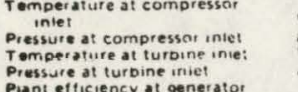 & $\begin{array}{l}{ }^{\circ} \mathrm{C} \\
\text { atd } \\
\text { oc } \\
\text { atd }\end{array}$ & $\begin{array}{l}20 \\
7.2 \\
660 \\
27\end{array}$ & $\begin{array}{l}20 \\
7.2 \\
560 \\
27\end{array}$ & $\begin{array}{l}20 \\
7.3 \\
680 \\
27.5\end{array}$ & $\begin{array}{l}20 \\
780 \\
29\end{array}$ & $\begin{array}{l}25 \\
6.7 \\
680 \\
25\end{array}$ & $\begin{array}{l}30 \\
310 \\
32\end{array}$ & $\begin{array}{l}20 \\
9.3 \\
680 \\
31\end{array}$ & $\begin{array}{l}20 \\
1022 \\
711 \\
38.5\end{array}$ & $\frac{20}{680}$ & $\begin{array}{l}20 / 60 \\
720 \\
44\end{array}$ \\
\hline $\begin{array}{l}\text { Pasnt efficiency at generator } \\
\text { retmimals } \\
\text { compressor sno turbine speec } \\
\text { Generator speed }\end{array}$ & $\begin{array}{l}\%_{0}, \mathrm{~s} \\
\text { r.p.m.m. }\end{array}$ & $\begin{array}{l}25 \\
12750 \\
3000\end{array}$ & $\begin{array}{l}26 \\
13000 \\
3000\end{array}$ & $\begin{array}{l}28 \\
8220 \\
3000\end{array}$ & $\begin{array}{l}28 \\
6500 \\
3000\end{array}$ & $\begin{array}{l}29 \\
6600 \\
3000\end{array}$ & $\begin{array}{l}295 \\
6600 \\
3000\end{array}$ & $\begin{array}{l}29.5 \\
8220 \\
1500\end{array}$ & $\begin{array}{l}30 \\
6640 \\
3000\end{array}$ & 18000 & $\begin{array}{l}31124 \\
6500 \\
3000\end{array}$ \\
\hline $\begin{array}{l}\text { Heating water: } \\
\text { Quantity } \\
\text { Temperature at cooler outlet } \\
\text { Temperature at cooler inlet } \\
\text { Amount of heat }\end{array}$ & $\begin{array}{l}m^{3 / n} \\
o_{c} \\
\text { oc } \\
\text { Gical } / \mathrm{h}\end{array}$ & $\begin{array}{l}70 \\
75 \\
45 \\
\text { n 2.1.3.5 }\end{array}$ & $\bar{\Xi}$ & $\begin{array}{l}110 \\
100 \\
80 \\
7.14\end{array}$ & $\begin{array}{l}280 \\
75 \\
45 \\
8 \cdot 10\end{array}$ & $\bar{z}$ & $\begin{array}{l}325 \\
90 \\
40 \\
16 \cdot 24\end{array}$ & $\begin{array}{l}130 \\
90 \\
40 \\
6.7\end{array}$ & $\begin{array}{l}200 \\
95 \\
40 \\
16.9\end{array}$ & $\bar{z}$ & $\begin{array}{l}710 \\
50 \\
25 / 50\end{array}$ \\
\hline $\begin{array}{l}\text { Design Cnaracteristics: } \\
\text { Compressor: } \\
\text { Type }\end{array}$ & & radial & radiat & $\begin{array}{l}\text { axial and } \\
\text { radiat }\end{array}$ & $2 \times 131$ & axial & $8 x+181$ & axia! & axial & extal & axial \\
\hline $\begin{array}{l}\text { Turbine: } \\
\text { Yyoe } \\
\text { in operation since } \\
\text { Running nours up to December } 19\end{array}$ & 970: & $\begin{array}{l}\text { oxial } \\
1956 \\
03.000\end{array}$ & $\begin{array}{l}\text { 0xia1 } \\
1957 \\
\text { es,000 }\end{array}$ & $\begin{array}{l}\text { Axtal } \\
1961 \\
64,000\end{array}$ & $\begin{array}{l}8 x+11 \\
196 \% \\
46,000\end{array}$ & $\begin{array}{l}\text { Exia } \\
\text { Ena of } 1961 \\
\text { as,oon }\end{array}$ & $\begin{array}{l}\cdots 101 \\
1900 \\
70,000\end{array}$ & $\begin{array}{l}47.2 \\
1963 \\
\$ 8,000\end{array}$ & $\begin{array}{l}\text { Exial } \\
\text { starting 1967 } \\
12,000\end{array}$ & $\begin{array}{l}\text { extal } \\
\text { staiting } 1966 \\
75,000\end{array}$ & $\begin{array}{l}\text { Oxtai } \\
\text { uterting } 1972\end{array}$ \\
\hline
\end{tabular}

Source: Reference 1-16. 
REFERENCES

1-1 Shonka, D. B., et al., "Transportation Energy Conservation Data Book," CoNS/7405-1, Edition 1.5, May 1977.

1-2 Marley, English, J., "Forecast of Future Aviation Fuels," presentation at Workshop on Jet Alrcraft Hydrocarbon Fuels Technology, June 7-9, 197.7. NASA-Lewis Research Center.

1-3 Church111, A. V., et al., "Fuels Standardization-Aviation Turbine Fuels," Joint Technical Coordinating Group on Fossil Fuels Standardization and Utilization Final Report, In review, March 1976.

1-4 Beery, G. T., Clodfelter, R. G., Gandee, G. W., McCoy, J. R., and Morris, J. L., "Assessment of JP-8 as a Replacement Fuel for the Air Force Standard Jet Fuel JP-4; Part 1: Assessment of JP-8/JP-4 Fuel in a Non-Combat Environment, AFAPL-TR-74-71, Part 1, June 1975.

1-5 Blazowsk1, W. S., "The Impact of JP-4/JP-8 Conversion on Aircraft Engine Exhaust Emissions," AFAPL-TR-76-20, May 1976.

1-6 Society of Automotive Engineers, "Afrcraft Gas Turbine Engine Exhaust Smoke Measurement," Aerospace Recommended Practice 1179, by Committee E-31, SAE, New York, New York, 1970.

1-7 - Champagne, D. L., "Standard Measurement of Aircraft Gas Turbine Exhaust Smoke," ASME Paper No. 71-GT-88, 1971.

1-8 Blazowski, W. S., "Combustion Considerations for Future Jet Fuels," 16th International Symposium on Combustion, the Combustion Institute, Pittsburgh, PA 1976.

1-9 Blazowski, W. S., Fahrenbruck, F. S., and Tackett, L. P., "Combustion Characteristics of Oil Shale Derived Jet Fuels," Paper 75-13 presented at the 1975 WSS/CI Fall Technical Meeting, Palo Alto, California, October 20-21, 1975.

1-10 Butze, H. F., and Ehlers, R. C., "Effect of Fuel Properties on Performance of a Single Aircraft Turbojet Combustor," NASA-TM-X-71789; presented at the 1975 WSS/CI Fall Technical Meeting, Palo Alto, Callfornia, October 1975.

1-11 ICC Transport Statistics in the United States.

1-12 ASME 76-WA/RT-6, "Progress in Ra1lway Mechanical Engineering 1975-76 Report of Survey Committee Locomotives," December 1976.

1-13 Ra1lway Age, January 31, 1977, p. 36. 
1-14 Pipeline Industry, August 1976, p. 54.

1-15 Ehrat, A. J., "Free Plston Gas Turbine Prime Movers--A Review of Basic Principles," ASME Paper No. 54-A-67, November 1957.

1-16 Sawyer's Gas Turbine Engineering Handbook, Vol. II, page 265.

1-17 Encyclopedia Americana, pages 718-719. 
2. CRITERIA TO BE USED TO EVALUATE

AND RATE FUELS AND PRIME MOVERS

E. N. Cart, Jr.

In the preliminary screening phase of the study on alternate

fuels for non-highway transportation, a method was used that allowed one to evaluate fuels and energy sources in a sound, logical and technical manner, and to select several fuels/prime movers for more indepth analysis. In the preliminary screening, the main emphasis was on the fuels/prime mover/user interactions and it was assumed that technology was available to produce and use the fuels. Technology is defined in this instance as the know-how required to produce the various products. It does not include the actual commercialization of the process.

The factors that were considered in the preliminary screening are as follows:

\section{Fuel Manufacture}

1. Cost of production, distribution and storage

2. Overall energy efficiency up to point of use

3. Environmental impact in production

Fuel Performance from Designer/User Viewpoint

4. Toxicity

5. Safety

6. Materials Compatibility

7. Potential type of prime mover that could use a given fuel

8. Storage on vehicle

9. Conventence in handling and storage

10. Environmental impact during use

Fuel Logistics

11. Resource avaliabllity

12. Compatibility with present fuel

13. Compatibility with current distribution system

14. International considerations

The general procedure that was used for the rating in each of these three areas is discussed in the following sections. 


\subsection{Fuel Manufacture Criteria}

In the fuel manufacture criteria area, it was necessary to consider the various raw material or energy sources for some of the fiels such as for methanol, hydrogen, etc.

The economics cover the cost of production, distribution and cost to liquefy the fuel, in the case of hydrogen and methane, expressed on a dollars per million BTU basis. All of the costs are on a conmo:r, consistent basis.

The overall system efficiency for the production of the resource, manufacture and distribution is the second item considered. This is expressed as the BTU's of energy in the basic resource, such as coal, that would be required to produce a BTU of energy in the fuel at the point of use. The fuel with the lowest value would be the most efficient one to use.

The environmental impact in production considered air pollutants $\left(\mathrm{SO}_{\mathrm{x}}, \mathrm{NO}_{\mathrm{x}}, \mathrm{CO}\right.$, particulates, etc.), water pollutants, and solid vaste.

Since the overall rating will be composed of several dissimlar indices, it is planned to use a likert scale for rating each category.* It will then be possible to arrive at an overall rating by combining each category (cost, energy efficiency, anvironment impact), assuming, an equal weighting of all three factors. A different weighting factor could also be used.

\subsection{Fuel Performance Critfria from Designer/User Viewpoint}

There are many factors to be considered in evaluating the various firels from a performance standpoint. The factors that were used in the screening of the various fuels are shown below.

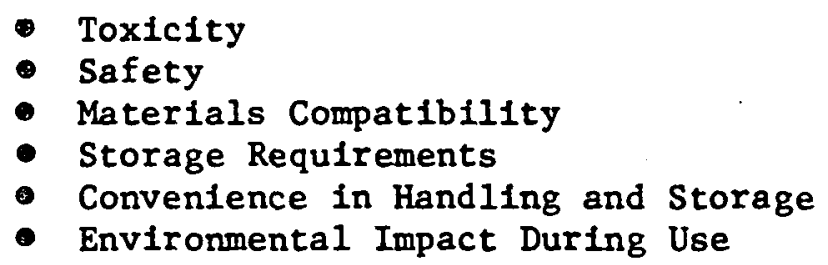

For this particular category, it is not necessary to consider the various raw material sources for producling each fuel. For example, it is only necessary to consider how hydrogen would perform, since the hydrogen would have the same properties whether it was produced from coal, nuclear (electric) power, or solar energy. In considering each fuel under this criteria, the designer's and user's viewpoints are the major considerations.

*The Likert scale is described in Section 13. 
The rating system to be used for toxicity will be low, medium or high toxicity, based on the detailed data that are presented in the physical property data section. The current petroleum specification will serve as a reference point for determining the degree of toxicity.

The physical property data from Section 3 were used to arrive at a rating of a low, medium or high safety hazard for the composite safety rating. The current petroleum fuel will serve as a reference point.

The materials compatibility will have a rating of satisfactory, borderline, and not suitable, based on the current engine design practices. It is very likely that with most of the fuels, very little data may be avallable, indlcating this is an area for future research, if a particular fuel shows promlse in the other categories.

In evaluating the performance potential for each fuel, it was necessary to consider the compatibility of the fuel and various prime movers. A table was prepared showing how the various fuels may operate In a given type of prime mover. It is well beyond the scope of this study to make any detalled engineering studies to design a prime mover for each fuef. However, estimates were made on how each fuel may operate in the current designs based on literature data on how fuels have performed in such an engine or based on the combustion properties of each fuel. It is recognized that an entireiy different type of engine could possibly be designed for the $2000+$ period, but for the preliminary screening it will be assumed that the fuels should be compatible with current designs. The numerical compatibility rating that will be used is defined as follows:

$$
\begin{aligned}
& 4=\text { No modifications required; could be used in current designs } \\
& 3=\text { Minor modifications required } \\
& 2=\text { Major modifications required } \\
& 1=\text { Not practical; would require an entirely new design }
\end{aligned}
$$

There are several other energy sources/prime mover combinations that were considered. These include the fuel cell, nuclear propulsion power, electric power and solar thermal and solar photovoltaic. Each of these forms of energy systems were evaluated separately since in each. case 1t was necessary to consider the mode of transportation in addition to the manufacture, performance and logistics factors.

The next performance factor that was considered is the storage requirements of the fuel on board the vehicle. A base quantity of fuel will be assumed required, based on current storage capacity. Admittedly this does not account for improved efficlency that may be possible with some fuels in a particular prime mover.

An Important performance factor to consider from the user's viewpolnt is the difficulty or ease of handling and storing fuels at the consumer's point of use. The physical property data shown in Section 3 was be used to arrive at an overall rating of excellent, good, falr, poor or unsat1sfactory for each fuel. 
In considering the environmental impact during use, it is really necessary to evaluate each fuel-prime mover combination and to consider the mode of transportation. However, for the preliminary screening, only emissions for the diesel and gas turbine engines, the major type of prime movers used in non-highway transportation were considered and the consideration of where the emissions occur--at high altitudes, near populated centers, or on the open seas was neglected. Only air pollutants were considered, and the detalled emission rates were summarized into an excellent, good, fair, poor rating.

The overall rating for the performance criteria is a combination of all seven factors, assuming an equal weighting.

\subsection{Fuel Logistics Criteria}

The third major area considered was the impact of the various fuels on the logistics of supply. For this category, it was necessary to consider the source of the raw material for producing the various fuels, since this can have a bearing on the overall rating. For example, methanol from coal may be an attractive option, but methanol from biomass may not be attractive due to resource availability. The factors that were considered from the logistical standpoint are as follows:

- Resource availability

- Compatibility with present fuel

- Compatibility with current distribution system

- International and military considerations

Two factors that were considered are compatibility with the present fuel and with the current distribution system. These are critical issues from a practical standpoint. While incompatibility of a given fuel would not ellminate it from further consideration, it would require consideration of how such a fuel would be introduced. Production, distribution and equipment user are all interdependent, in that one is not likely to occur without the other two. Different kinds of decision-makers would have to make coordinated decisions for a smooth development to occur and any one kind of decision-maker can "veto" the development.

Alr and marine operations involve international fueling and any new fuel should be available in the countries involved. This would require local production capability, which in turn would generally be dependent on suitable local resources. Another international factor considered was the export market for equipment using any new type of fuel or prime mover.

Resource availability may determine whether some raw materials or energy sources should be considered for non-highway transportation use. In the preliminary screening, it is shown whether a given energy source will be adequate, probably adequate, probably inadequate or inadequate to produce the fuels.

All four factors were combined into an overall logistics rating. 


\subsection{Overäl Rating}

The final rating is a combination of the three separate areas. All factors were given equal weight. Based on the overall ratings, the fuels and prime mover for in-depth analysis were selected. All three factors were considered as separate, non-interacting criteria, and were given equal weight to arrive at an overall rating.

In practice these criterla are not separable because they interact. For example, if a fuel or prime mover is "unsatisfactory" in any one criteria, it would likely mean that fuel or prime mover would not be used, unless the technology was improved to overcome the deficiencles or the institutional problems were solved. This will also serve to identify what R\&D is needed to make a given fuel attractive. The problem is how to combine the various criteria ratings in an interactive case. 


\section{PHYSICAL AND CHEMICAL PROPERTIES OF ALTERNATE FUELS}

W. Herbst

Experience has shown that many physical and chemical properties of a fuel influence its performance in the engine, acceptability to the user, impact on the environment, and methods of handiing and distribution.

The ideal fuel should permit easy equipment starting at amblent temperatures, give rapid warm-up and acceleration, provide trouble-free operation, have good fuel economy and adequate periods between refuelings, keep englne and equipment malntenance to a minimum, not be unduly hazardous and, or course, be economically attractive. Nelther the fuel nor the exhaust should have an objectionable odor. Environmental impact involves fuel emissions encountered in handling, storage, and refueling, as well as the nature and composition of the exhaust emissions. Storage and handing considerations also require that large volumes of the fuel be contained without serious deterioration or loss for perlods up to six months or longer, be moved through pipes and/or in tankers, barges and tank trucks, and be dispensed and metered to the user. This must be done safely, without serious environmental damage and without significant contamination with water, rust or dirt.

A discussion of the significance of various fuel properties is given in Appendix 3-1. It is evident that the properties of the fuel have an impact on many important criteria. The interrelationships are ommarized in Table 3.1, which serves as the gerberal Dasis far categorizing the property data collected in this study. Tables 3-2 to 3-7 list fuel properties related to combustion behavior, handling, atorage, and engine maintenance. These tables show properties for the fuels considered in this study and also give typical values for petroleum fuels for comparison. In quite a few instances, where data were not available, estimates were made, Identifled by parentheses around the value. In the case of the coal and shale liquids, the properties shown are for products produced from syncrudes by currently available refining methods. The properties of the fuels from shale and coal will vary with the syncrude characteristics and method of refining. This makes it extremely difficult to place all the available data within a convenient, standardized format. Accordingly, considerable additional information on various coal and shale liquids are presented in the appendices as discrete studies on specific syncrudes by specific refining operations.

\subsection{Combustion Properties}

A number of significant observations can be made regarding the combustion properties of the fuels shown in Table 3-2.

- The low boiling points of hydrogen, methane, ammonia, methylamine and acetylene Indicate that special equipment will be required to store and handle these materials. Storage could be either as 
TABLE 3-1

RELATION OF FUEL PROPERTIES AND FUNCTIONS

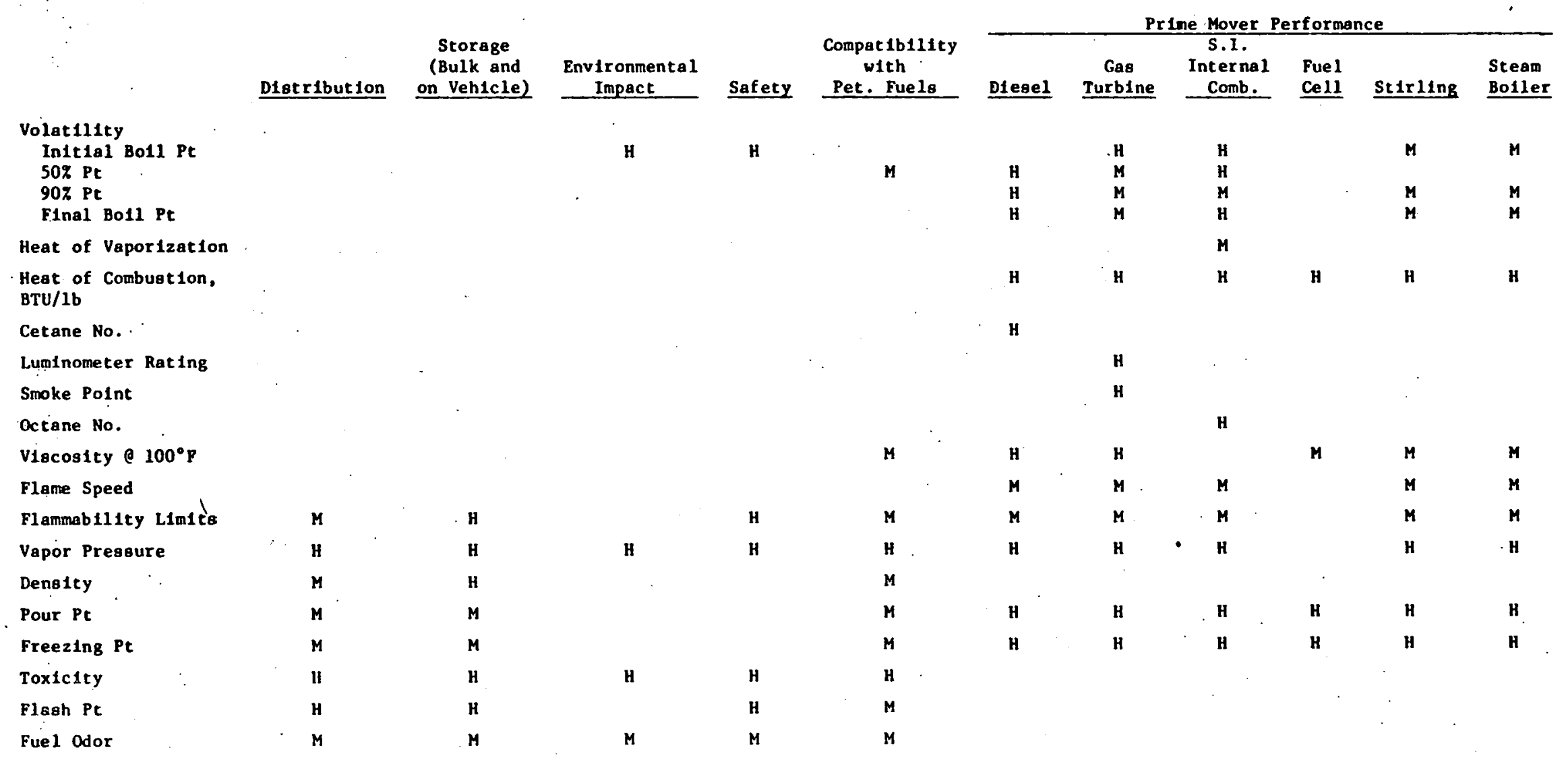

Code: $H=$ h1ghly Important; $M=$ moderately Important; Blank - not Important to function. 
TABLE 3-1 (CONTINUED)

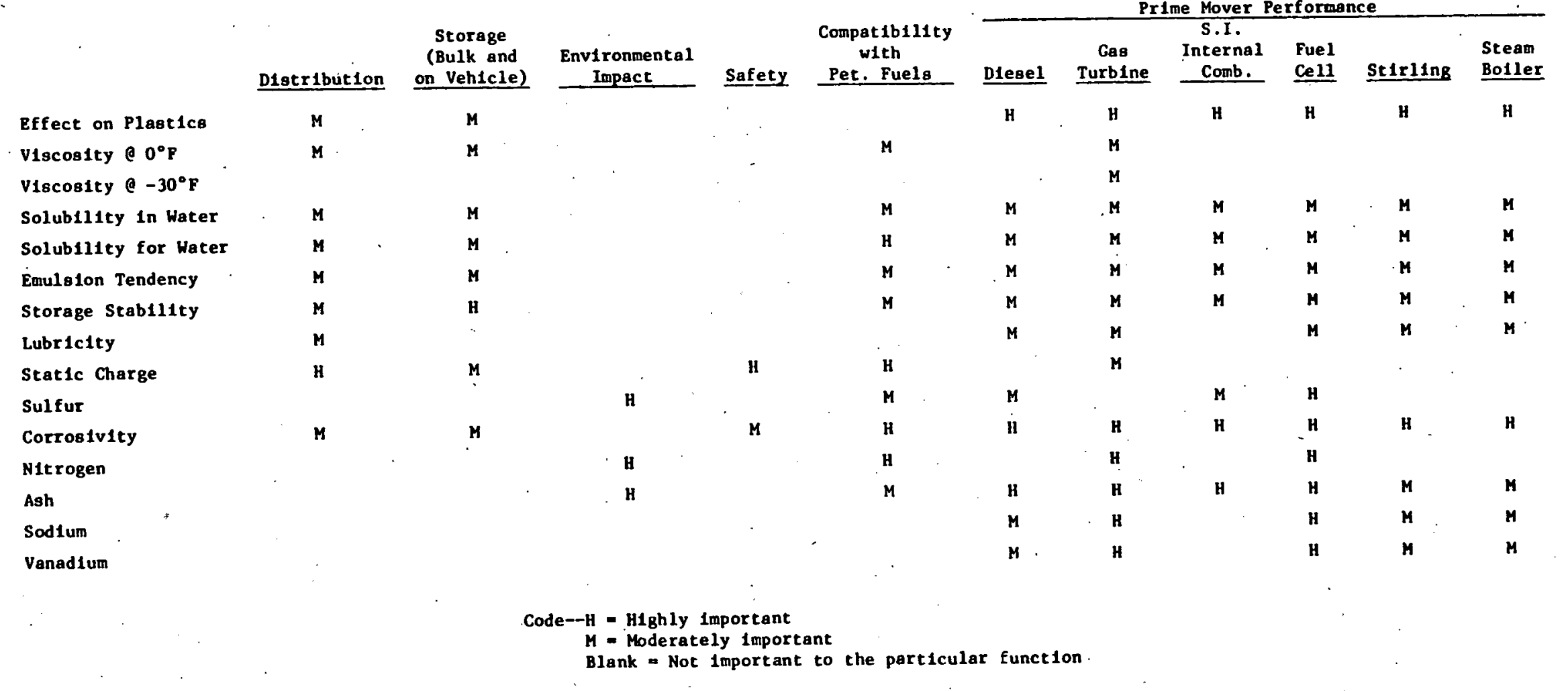


TABLE 3-2

FUEL CHARACTERISTICS RELATED TO COMBUSTION BEHAVIOR

\begin{tabular}{|c|c|c|c|c|c|c|c|c|}
\hline \multirow[b]{2}{*}{ Fuel } & \multicolumn{2}{|c|}{ Heat of Combustion (Net) } & \multirow{2}{*}{$\begin{array}{l}\text { Heat of Vap-BTU/lb } \\
\text { e Normal Boil PE }\end{array}$} & \multicolumn{4}{|c|}{ Volat1l1ty (Bo1ling $\mathrm{Pt})-{ }^{\circ} \mathrm{F}$} & \multirow{2}{*}{$\begin{array}{l}\text { Vapor Press } \\
\text { _e } 100^{\circ} \mathrm{F} . \mathrm{PB}\end{array}$} \\
\hline & BTU/1b & BTU/Ga1 & & In1t1a1 & $50 \%$ & $90 \%$ & FIna1 & \\
\hline $\begin{array}{l}\text { Petroleum } \\
\text { - Gasoline } \\
\text { - Jet Fuel (JP 4) } \\
\text { - Distillate }\end{array}$ & $\begin{array}{l}18,700 \\
18,600 \\
18,400\end{array}$ & $\begin{array}{l}114,000 \\
124,000 \\
129,400\end{array}$ & $\begin{array}{l}(150) \\
(110) \\
(100)\end{array}$ & $\begin{array}{l}100 \\
-\overline{375}\end{array}$ & $\begin{array}{l}210 \\
370 \\
500\end{array}$ & $\begin{array}{l}330 \\
470 \\
580\end{array}$ & $\begin{array}{l}400 \\
620\end{array}$ & $\begin{array}{l}8-12 \\
(2) \\
0.01\end{array}$ \\
\hline Coal & $12,000-15,000$ & -- & -- & -- & - & -- & $\therefore$ & - \\
\hline Coal/Methanol slurry $(40 / 60)(e)$ & $10,000-11,200$ & $(68,000)$ & -- & 149 & 149 & -- & -- & (4) \\
\hline Coal/011 slurry $(40 / 60)(e)$ & $15,800-17,000$ & $(140,000-150,000)$ & -- & -- & -- & -- & -- & $(0.01)$ \\
\hline $\begin{array}{l}\text { Coal Liquids }(\mathrm{c}) \\
\text { - Jet Fuel }(\mathrm{JP}-4) \\
\text { - Diesel } \\
\text { - Fuel 011 }\end{array}$ & $\begin{array}{c}18,400-18,500 \\
(18,300) \\
(17,400)\end{array}$ & $\begin{array}{c}(123,000-124,000) \\
(130,000) \\
(140,000)\end{array}$ & $\begin{array}{r}(110) \\
(100) \\
(70)\end{array}$ & $\begin{array}{l}190 \\
300\end{array}$ & $\begin{array}{l}306 \\
580\end{array}$ & $\begin{array}{l}380 \\
780\end{array}$ & $\begin{array}{l}427 \\
550\end{array}$ & $\begin{array}{l}(2) \\
(0.01) \\
(<0.01)\end{array}$ \\
\hline $\begin{array}{l}\text { Shale OAl L1quids } \\
\text { - Raw } \\
\text { - Syncrude }\end{array}$ & $\begin{array}{l}(18,200) \\
(18,500)\end{array}$ & $\begin{array}{l}(134,400) \\
(122,700)\end{array}$ & $\begin{array}{l}(75) \\
(105)\end{array}$ & (100) & $\begin{array}{l}(750) \\
(450)\end{array}$ & $\begin{array}{l}>1000 \\
(750)\end{array}$ & $\begin{array}{l}>1000 \\
(850)\end{array}$ & $\begin{array}{c}(4) \\
8\end{array}$ \\
\hline Methanol & 8,640 & 57,370 & 474 & - & 149 & -- & -- & 4.6 \\
\hline Hydrogen & 51,600 & 30,600 & 194 & -- & -423 & -- & -- & (d) \\
\hline Ammonia & 8,060 & 31,000 & 591 & -- & -28 & - & -- & 212 \\
\hline $\begin{array}{l}\text { Oxygenated Compound } \\
\text { - Ethanol } \\
\text { - H1gher Alcohols }\end{array}$ & $\begin{array}{l}11,550 \\
(11,600)\end{array}$ & $\begin{array}{c}76,000 \\
(76,100)\end{array}$ & $\begin{array}{l}360 \\
(350)\end{array}$ & $\overline{150}$ & 173 & 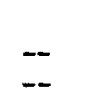 & -- & 0.28 (b) \\
\hline Methane & 21,500 & 80,000 & 219 & $\therefore$ & -259 & -- & - & (d) \\
\hline Hydrazine & 7,294 & 61,000 & 540 & -- & 236 & -- & -- & $0.28(\mathrm{a})$ \\
\hline Methylamine & 12,860 & 74,983 & 376 & - & 21 & -- & -- & \\
\hline Acetylene & 20,780 & -- & 323 & - & -119 & $1-$ & - & (d) \\
\hline Vegetable 011 (Cotton Seed) & 16,600 & $(128,000)$ & & & & & & \\
\hline
\end{tabular}

(a) At $77^{\circ} \mathrm{F}$; (b) At $68^{\circ} \mathrm{F}$; (c) Assumes trentment by known technology to meet current product spec1ficat lons; (d) Above critlcal temperature; (e) Weight percent coal/methanol ur coal/o11; ( ) Denotes estimated value. 
TABLE 3-2 (CONTINUEB)

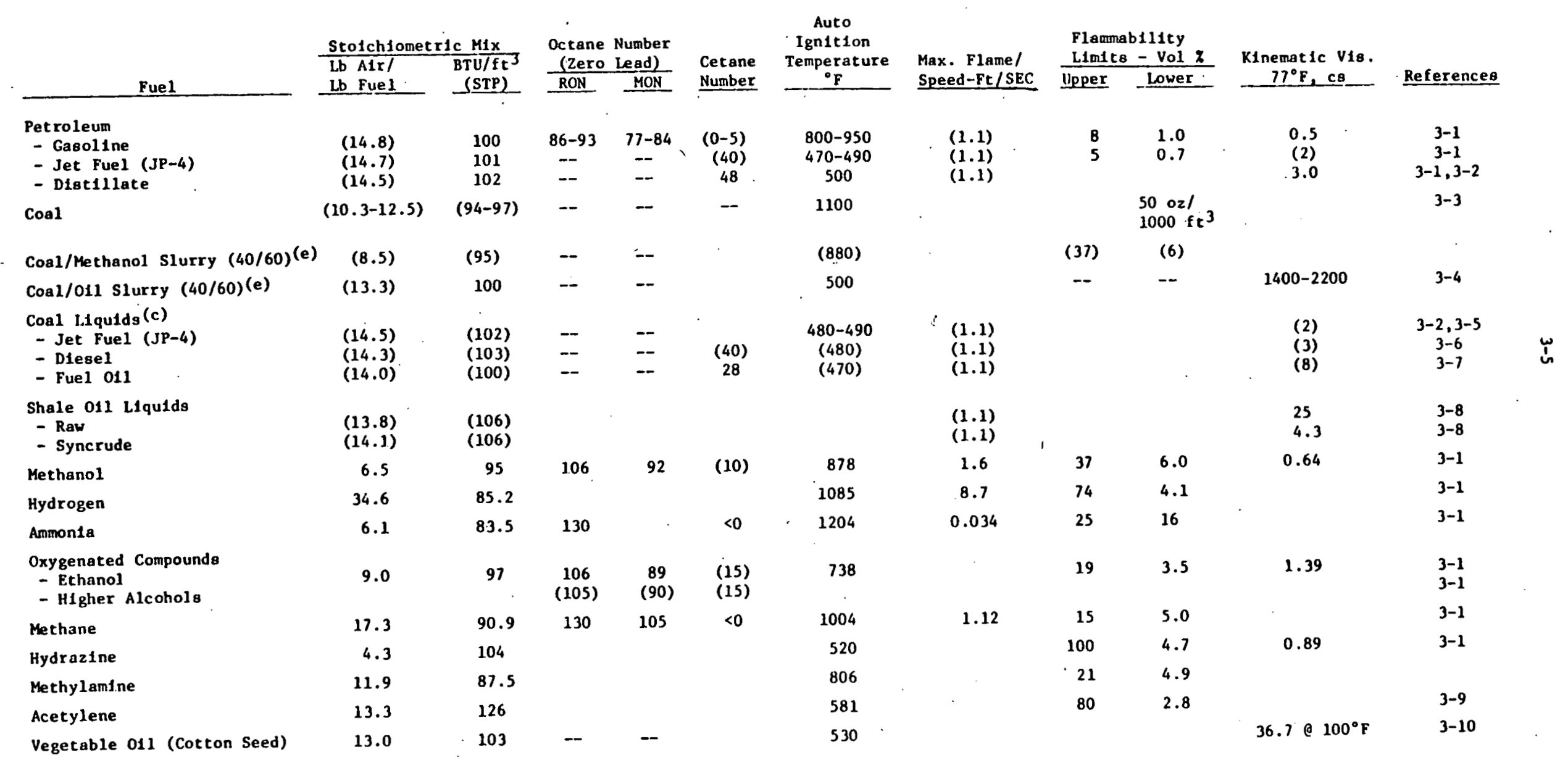

(a) At $77^{\circ} \mathrm{F}$; (b) At $68^{\circ} \mathrm{F}$; (c) Assumes treatment by known technology to meet current oroduct specifications; (d) Above critical temperature;

(e) Welght percent coal/metliamol or coal/o11; ( ) Denotes estimated value. 
cryogenic liquids or pressurized gases. In elther case, there may be problems in adapting these fuels to certain applications, as discussed further below.

- The relatively low volumetric heat of combustion (BTU/gal) of the alcohols, hydrazine, ammonia, methylamines, methane $(l)$ and hydrogen (l) is a significant disadvantage in that it will require the storage of relatively large volumes of these fuels for a given period of operation.

- The relatively high heat of vaporization of the alcohols, hydrazine, Iiquid ammonia, liquid methane, and liquid hydrogen, combined with their low heat content, means that with a carburetted engine, special pains must be taken to transfer adequate heat to the intake mantfold to vaporize the fuel. For example, it takes eight times as much heat to provide the same amount of combustion energy in the vapor form with ammonia as with a conventional gasoline. This is usually waste heat from the engine (In exhaust or water) and represents no thermal penalty to the engine. This heat exchange problem can be avoided by infecting the liquid fuel directly into the combustion chamber as is possible with diesel, gas turbine or similar injected engines.

- The BTU/ft ${ }^{3}$ of a stoichiometric fuel/air mixture relates to the amount of energy that can be inducted into the combustion chamber of a carburetted reciprocating piston engine of a given displacement. The higher this figure, the more power can be produced from a given displacement carburetted engine at a given engine speed. This assumes that each fuelils being burned with an amount of air theoretically required for complete combustion.

- The h1gh octane numbers of ammonia, methane, and methanol are noteworthy. With such fuels it should be possible to design an Otto cycle engine (high compression ratio) that would have a higher thermal efficlency than would be possible with the lower octane number fuels. However, this point will have to be demonstrated with ammonia and methanol, in view of the uncertainty in translating experience based on high octane hydrocarbon fuels to widely different compounds.

- Apparently the combustion characteristics of hydrogen are such as to make a rating by the accepted anti-knock methods difficult since no octane numbers have been published. Single-cylinder engine combustion studies have Indicated, (3-11) however, that hydrogen can be burned In an Otto cycle engine without knock over a compression ratio range from $6: 1$ to $16: 1$ by careful adjustment of spark advance and air/ fuel ratio. At a given compression ratio, say $8: 1$, combustion behavior varies as the amount of hydrogen in the air is increased. For example, a mixture containing less than $0.73 \mathrm{wt} \%$ hydrogen is too lean to burn and mixfire results. Between 0.73 and 1.5 wt\% hydrogen, sat 1sfactory knock-free operation is achieved. As the amount of hydrogen is Increased above $1.5 \mathrm{wt} \%$ knock is encountered and continues unt 11 the hydrogen reaches $16 \mathrm{wt} \%$. From here to the upper flamability limit 
(25 wt\%) knock-free operation is again experienced. It should be noted that above a hydrogen concentration of $2.81 \mathrm{wt} \%$ (stolchiometric mixture) hydrogen combustion will be incomplete because of insufficient afr. Thus, the feasible knock-free fuel/alr operating range at $8: 1$ compression ratio, according to these data, 18 in the range of 0.73 to $1.5 \mathrm{wt} \%$. At $16: 1$ compression ratio, this knock-free "operating window" ranges from 0.75 to 1.0 wt\% hydrogen. Evidently, it will require closer fuel/air ratio control to operate knock-free with hydrogen at high compression ratios than at low. However, there is some question about the validity of these results since knock-free operation over a wide range of fuel/air ratio has also been reported.(3-12,3-13) Problems of preignition(3-14) and backfire(3-15) with hydrogen have also been reported. Exhaust gas recycle has been used to modify and control the combustion of hydrogen in an Otto cycle engine. (3-16)

- The Cetane Number of all the fuels in Table 3-2, except for the distillates from petroleum, shale, and coal, are too low to make them attractive as fuels for an englne operating on the compression ignition principle. The use of cetane-improving additives, supplementary. sources of Ignition (e.g., a glow plug, pllot-1njection, or spark plug), blends with high-cetane number fractions, or the use of high compression ratios (say $22: 1$ ) are alternative ways by which this quality deficiency might be overcome.

- The high flame speed of hydrogen and the low flame speed of ammonia are noteworthy. They imply that the optimum engine operating cond1tions or design for these fuels will be different than for the more conventional hydrocarbon fuels.

- The exceptionally wide flammability limits of hydrogen are significant. This is the basis of the "Hydrogen Induction Technique(3-12,3-13) method of engine (Otto cycle) operation in which the engine power is varied by varying hydrogen-air ratio and not by throttling the fuel/ air mixture. In the Hydrogen Induction Technique the amount of air taken into the combustion chamber on each piston stroke is held constant (no alr throttling) while the amount of hydrogen inducted is increased for increased power. Higher efficlency is clalmed for this method of operation. (3-12) Unfortunately, the wide flammability limits adds to the hazard of using hydrogen as a fuel.

\subsection{Vehicular Storage Requirements of Fuels}

The low bolling points of amonia, methane, hydrogen, and acetylene present a problem w1th regard to the storage of these fuels. For acetylene it would be necessary to store the acetylene in acetone or use calcium carbide to directly generate acetylene. The magnitudes of the storage problem for each of the fuels being considered are summarized in Table 3-3. In comparing the welght advantage or disadvantage for each fuel, the table shows a ratio of the weight of fuel required to provide the same BTU output as a pound of petroleum distillate. For example, 2.13 pounds of methanol would be required to provide the same energy as a pound of petroleum distillate. The fuels that show a 
TABIE 3-3

STORAGE REQUIREMENTS OF FUELS

Welght

Lbs. Fuel/Lb. of
Petroleum Distillate for Same BTU Output

Petroleum--Jet
-Distillate

Coal

Coal/Methanol slurry

Coal/Oil slurry

Coal Liquids--Jet

--Diesel

--Fuel 0il

Shale 0il--Raw

--Syncrude

Methanol

Hydrogen (l)

Ammonia

Ethano1

Higher Alcohols

Methane (l)

Hydrazine

- Methylamine

Acetylene (1)

Vegetable 011
0.99

1.0

1.23-1.53

$1.64-1.84$

$1.08-1.16$

0.99-1

1.01

1.06

1.01

0.99

2.13

0.36

2.28

1.59

1.59

0.86

2.52

1.43

4.1

1.11
Volume

\begin{tabular}{l}
\hline Vol. Fuel/Vol. of \\
Petroleum Distillate \\
for Same BTU Output \\
\hline
\end{tabular}

1.04

1.0

1.2

1.9

$0.86-0.92$

1.04-1.05

1.0

0.92

0.96

1.05

2.26

4.23

4.17

1.7

1.7

1.62

2.12

1.73

1.01

(1) Includes weight of calcium carbide and water needed to generate the acetylene. 
major weight disadvantage ( $>1.5$ rat10) are coal/methanol slurry, some coals, methanol, ethanol, ammonia and hydrazine. The data for 11quid hydrogen shows why it is of interest as an alrcraft fuel, where weight is criticai. Liquid methane has a slight advantage over petroleum distillate.

While tie comparison of the weight ratio for fuel only is a good basis for most fuels, it is not valid for liquid hydrogen, liquid methane or 11quid ammonia. For these fuels, the welght of the container must also be considered. A direct comparison will depend on the specific mode of transportation. However, based on previous studies for storage of fuels in automotive application including the weight of the container can increase the ratio to 2.6 for liquid hydrogen, 1.78 for liquid methane and 3.4 for ammonia. $(3-1)$

The volume required to store a given fuel is compared to petroleum distillate as a ratio of the storage volume required to provide the same BTU output as a given volume of petroleum distillate. The fuels that would require substantially more space to store a given amount of fuel are methanol, liquid hydrogen, amonia, ethanol, liquid methane, and hydrazine. If the volume of the container is also considered, the ratio would be essentially the same, except for 11quid methane and liquid ammonia, where a larger volume would be required than for fust the fuel alone.(3-1)

The practicability of using hydrogen in vehicular applications, and to a lesser extent, methane, acetylene, and methylamine, will depend on solving the storage problems. Storage as a.cryogenic liquid is possible, but increases the cost of the storage container, and could create other problems, e.g., fuel losses due to evaporation, and the requirement for safe venting provisions from the fuel storage enclosure.

\subsection{Bulk Handling and Storage of Fuels}

Table 3-4 11sts the characteristics related to the handing and bulk storage of the fuels. Following are some observations regarding this table:

1. The high freezing point of hydrazine $\left(36^{\circ} \mathrm{F}\right)$ and vegetable olls $\left(26^{\circ} \mathrm{F}\right)$ indicates that 8 peclal means would be required to keep them liquid In storage tanks In many areas of the United States at various times of the year. One solution to the hydrazine problem may be to use it mixed with unsymmetrical dimethyl hydrazines (freezing point ca.- $-71^{\circ} \mathrm{F}$ ).

2. The water misciblifty of hydrazine, methylamine, methyl alcohol and ethyl alcohol 1ndicates that the storage and transportation system handling these fuels would have to be kept dry, to avold problems such as fuel instabllity, corrosion, etc., which could affect performance.

3. Storage stablilty of coal slurries would be expected to be troublesome because of settling of the solid coal from the liquid. Close control of coal particle size will be necessary. The use of stabilizing agents might be helpful. Some means of continuous mixing may be required. 
TABLE 3-4

CONVENIENCE IN HANDLING AND STORING VARIOUS ALTERNATE FUELS $(f)$

\begin{tabular}{|c|c|c|c|c|c|c|c|c|c|c|c|c|}
\hline Fuel & $\begin{array}{c}\text { Vapor } \\
\text { Pressure } \\
\text { po1 } \\
100^{\circ} \mathrm{F} \\
\end{array}$ & $\begin{array}{l}\text { Density } \\
1 \mathrm{bs} / \mathrm{ft} \\
\text { e } 60^{\circ} \mathrm{F}\end{array}$ & $\begin{array}{l}\text { Viscosity } \\
\text { Kin cs } \\
\text { e } 0^{\circ} \mathrm{F} \\
\end{array}$ & $\begin{array}{l}\text { Freezing } \\
\text { or Pour } \\
\text { Point }{ }^{\circ} \mathrm{F} \\
\end{array}$ & $\begin{array}{l}\text { Flagh Point, }{ }^{\circ} \mathrm{F} \\
\text { (Cloged Cup) }\end{array}$ & $\begin{array}{l}\text { Sol. in } \\
\text { Water } \\
068^{\circ} \mathrm{F} \\
W t \% \\
\end{array}$ & $\begin{array}{l}\text { Sol. for } \\
\text { Water } \\
\text { e } 68^{\circ} \mathrm{F} \\
\mathrm{ppm} \\
\end{array}$ & $\begin{array}{l}\text { Emulsion } \\
\text { Tendency } \\
\end{array}$ & $\begin{array}{c}\text { Storage } \\
\text { Stabll1ty }\end{array}$ & $\begin{array}{c}\text { Ef fecto } \\
\text { on } \\
\text { Metalo } \\
\end{array}$ & $\begin{array}{c}\text { Toxicity } \\
\text { Dangerous } \\
\text { for Prolonged } \\
\text { Exposure, PPM }\end{array}$ & References \\
\hline $\begin{array}{l}\text { Petroleum } \\
\text { - Gasoline } \\
\text { - Broadcut }\end{array}$ & $\begin{array}{l}8-12 \\
1-5\end{array}$ & $\begin{array}{l}(46) \\
(49)\end{array}$ & $\begin{array}{l}(1.0) \\
(2.5)\end{array}$ & $\begin{array}{l}(-40) \\
(-30)\end{array}$ & $\begin{array}{l}-30 \\
-30\end{array}$ & $\begin{array}{l}\text { N11 } \\
\text { N11 }\end{array}$ & & $\begin{array}{l}N P(m) \\
N P(m)\end{array}$ & $\begin{array}{l}\mathrm{NP}(\mathrm{m}) \\
\mathrm{NP}(\mathrm{m})\end{array}$ & $\begin{array}{l}\mathrm{NP}(m) \\
\mathrm{NP}(m)\end{array}$ & $\begin{array}{l}500 \\
500\end{array}$ & $3-1,3-9$ \\
\hline Cosl & & $42-57(k)$ & -- & -- & & N11 & & & & & Mon-toxic & (e), 3-9 \\
\hline Coal/Methanol Slurry & $(4.6)$ & (57) & & & $(50)(8)$ & & & & & & 200 & \\
\hline Coal/011 Slurry & $(<0.1)$ & (62) & $>1400$ & & $(>130)$ & Nil & & & & & & \\
\hline $\begin{array}{l}\text { Coal I,Iquids } \\
\text { - Jet Fuel (JP-4) } \\
\text { - DieseI } \\
\text { - Fuel OIJ. }\end{array}$ & $\begin{array}{c}2 \\
(0.01) \\
(<0.01)\end{array}$ & $\begin{array}{l}(51) \\
(53) \\
(59)\end{array}$ & $\begin{array}{r}(2.5) \\
(4.5) \\
(>8.0)\end{array}$ & $\begin{array}{c}-90 \\
(-20-+5)\end{array}$ & & $\begin{array}{l}\text { N11 } \\
\text { N11 } \\
\text { N11 }\end{array}$ & & & $\alpha^{\prime}$ & $\begin{array}{l}N P(m) \\
N P(m) \\
N P(m)\end{array}$ & $\begin{array}{l}(500) \\
(500)\end{array}$ & $\begin{array}{l}3-18 \\
3-18 \\
3-18\end{array}$ \\
\hline $\begin{array}{l}\text { Shale o1l Llquids } \\
\text { - Raw } \\
\text { - Syncrude }\end{array}$ & $\begin{array}{l}(4) \\
8\end{array}$ & $\begin{array}{l}(55) \\
(50)\end{array}$ & $\begin{array}{l}(>25) \\
(>45)\end{array}$ & $\begin{array}{l}75 \\
50\end{array}$ & & $\begin{array}{l}\text { N11 } \\
\text { N11 }\end{array}$ & & & & $\begin{array}{l}\mathrm{NP}(m) \\
\mathrm{NP}(m)\end{array}$ & $\begin{array}{l}(500) \\
(500)\end{array}$ & $\begin{array}{l}3-8 \\
3-8\end{array}$ \\
\hline Methanol & 4.6 & 49.7 & & -142 & $52(8)$ & Infinite & Inf init te & & & . & 200 & $3-1,3-9$ \\
\hline Hydrogen & (n) & $4.43(c)$ & & -435 & -- & & . & NP & $\mathbb{N P}$ & & Asphtxiant & $3-1,3-9$ \\
\hline Ammonia & 212 & $48.1(c)$ & & -108 & -- & 33.1 & & $\mathbf{N P}$ & & (h) & 100 & $3-1,3-9$ \\
\hline $\begin{array}{l}\text { Oxygenated Compound } \\
\text { - Ethanol } \\
\text { - HIgher Alcohols }\end{array}$ & $\begin{array}{l}0.28(a) \\
(0.3)(a)\end{array}$ & $\begin{array}{c}49.3 \\
(49.5)\end{array}$ & & $\begin{array}{l}-179 \\
(-170)\end{array}$ & $\begin{array}{r}65(8) \\
>65(8)\end{array}$ & Infinite & Infinite & & & & $\begin{array}{l}1000 \\
1000\end{array}$ & $\begin{array}{l}3-1,3-9 \\
3-1,3-9\end{array}$ \\
\hline Methane & (n) & 27.9 (c) & & -296 & - & & & NP & NP & & Asph1xiant & $3-1,3-9$ \\
\hline Hydrazine & $0.28(b)$ & 62.6 & $1.2(d)$ & 35.6 & $126^{(8)}$ & Infinite & Infinite & & NP & (1) & 1 & $3-1,3-9$ \\
\hline Methylamine & & $41.4(\mathrm{c})$ & & -136 & & Very & & & & & 10 & $3-9$ \\
\hline Acetylene & (n) & & & -115 & & & & NP & & & Asph $1 \times \tan t$ & $3-9$ \\
\hline $\begin{array}{l}\text { Vegetable } 011 \\
\text { (Cotton Seed) }\end{array}$ & $(<0.1)$ & $57(f)$ & $36.8^{(f)}$ & 26 & 275 & & & & & & & $3-24$ \\
\hline
\end{tabular}

See next page for footnotes. 

(a) At $68^{\circ} \mathrm{F}$.
(b) At $77^{\prime \prime} \mathrm{F}$.
(c) At normal bo1ling point.
(d) At 4$]^{\circ} \mathrm{F}$.
(e) Chemical Engineers Handbook, Perry and Chilton.
(f) At $100^{\circ} \mathrm{F}$.
(g) Open Cup.
(h) Corrodes copper, brass and zinc.
(1) Materials to be avolded Include cobalt, copper, pure Iron, lead, manganese, magnesium, tin and zinc.
(j) Code: NP - no problem.
(k) Broken.
(m) Can be controlled by careful refining and use of additives.
(n) Above critical temperature. 
4. The danger from explosions or fires set by static electric discharges generated in the handling of hydrogen, methane and ammonia is understood to be low. Static electric generation is a maximum with materials whose conductivities are in the range of $1014-10^{18}$ ohm centimeters. The conductivities of liquid methane and liquid hydrogen are selow this range. The conductivity of liquid ammonia is above this range.

5. It will probably be more hazardous to handle ammonia, methylamine and hydrazine: than petroleum fuels. The primary hazard with ammonia is from inhalation. With hydrazine, both inhalation and skin contact must be avolded. With liquefled ammonia, hydrogen, and methane, skin contact with the cold liquids must obviously be avolded.

6. The indications are that the coal liquids will probably contain a high concentration of aromatic hydrocarbons. It appears also that the benzene content of the naphthas may be appreclably higher than those from petroleum sources ( $1-5$ vol\%). In view of the toxic nature of benzene, the unblended coal gasolines may require more careful handling than current petroleum gasolines. Information on toxicity of the fuels being screened is given in Section 3.5 .

7. Ammonia and hydrazine are apparently the most corrosive fuels. Ammonia is corrosive to materials containing copper, brass and zinc. Methylamine would be expected to resemble ammonla. Hydrazine is corrosive to cobalt, copper, pure Iron, lead, manganese, magnestum, , tin and zinc. Corrosion due to the introduction of water into the fuel handling and storage system is also a potential problem. Hydrazine decomposition is also catalyzed by various metal contaminants.

8. Hydrogen can cause metal embrittlement at elevated pressures even at ambient temperatures. (3-1) This must be considered in designing systems for distributing and storing hydrogen.

9. Table 3-5 summarizes information on fuel compatibility with various elastomers and plastics which might be used. There is by now a good deal of industrial experience in handing liquid hydrogen, methane, ammonia and acetylene. This experience can serve as a suitable starting point for, selecting materials of construction for fuel systems to handle these compounds. However, stringent performance requirements centered around long-time, safe, and trouble-free operation, may impose new limitations on material selection. For example, the low viscosity and high diffusivity of gaseous hydrogen will make it extremely difficult to contain in equipment having any non-metallic parts.

A number of polymeric materials seem to have good resistance to the alcohols, e.g., chlorosulfonated polyethylene, butyl rubber, polydimethyl silicone with vinyl crosslinks, etc. There are no data on the effect of coal liquids on the various elastomers. A plastic resistant to the aromatic hydrocarbons is vinylidene fluoride-hexafluoro-propylene copolymer (Viton). Fluorosilicone rubber may also be a possibility. 
TABLE 3-5

EFFECT OF POTENTIAL AUTOMOTIVE FUELS

ON VARIOUS ELSSTOMERS AND PLASTICS

Swell, Vol $z$ (a) (c)

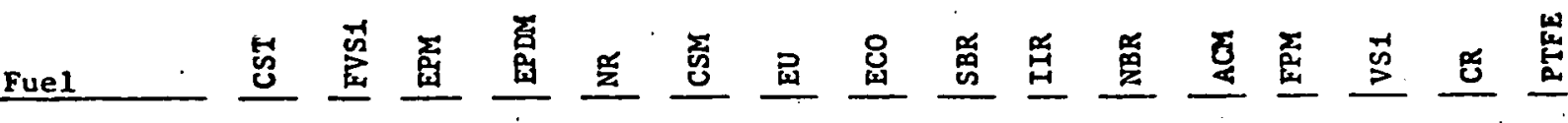

Hydrogen, (g)

Hyd rogen ( 1 )

Methane ( 8 )

Hethane (1)

Ammonia ( 8 )

Ammonia (1)

Hydrazine (1)

Methanol

Ethanol

$\begin{array}{rrrrrrrrrrrrrrr}15 & 8 & & & & 0 & & 27 & 2 & -2 & 18 & 140 & 68 & 0 & 8 \\ & & -1 & -4 & 4 & 6 & 75 & 25 & & 5 & 21 & & 13 & 5 & \end{array}$

Coal-Gasoline(b)

Coal-Distillate (b)

Shale-Gasoline

Shale-Distillate

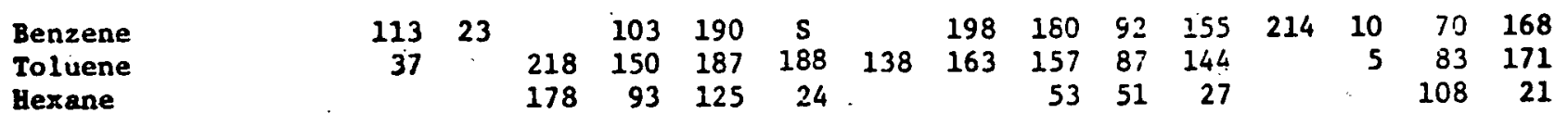

(a) Sultability criteria:
Not sultable
- swell above $25 \%$
Borderline - swell between 15-25\%
Satisfactory - swell below 15\%
S
- material softened excessively

(b) Data on benzene and toluene may be taken as a guide to behavior of these highly aromatic hydrocarbon mixtures.

(c) Code:

CST - polysulfide rubber

FVS1 - fluoros 11 icone rubber

BPM - ethylene-propylene rubber

EPDM - ethylene-propylene terpolymer

NR - natural rubber; polyisoprene, hevia

CSM - chlorosulfonated polyethylene

EU - urethane rubber

ECO - epoxychlorohydrin rubber

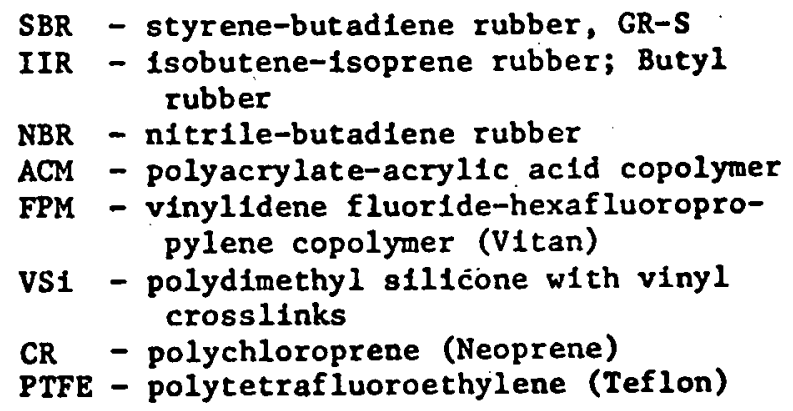

Blank spaces mean that data were not avallable.

Source: Ref. 3-1. 


\subsection{Eng1ne Maintenance}

Table 3-6 1ists the fuel properties that relate to engine maintenance requirements. The fly ash content of the coal will be particularly troublesome in many applications.

The sludge tendency listed in the sable refers to crankcase sludging in reciprocating piston engines. This usually arises because of unburned or partially burned high bolling fuel components which reach the crankcase by slipping by the piston rings. Shale and coal liquids would be expected to be quite simflar to petroleum-derived fuels in this regard. However, this remains to be confirmed by long-term engine tests. The combustion products of hydrogen and methane would be expected to be rather innocuous as far as crankcase conditions are concerned. However, the fuels rich in nitrogen, i.e., ammonia, hydrazine, and methylamine, might have bad effects because of reactive oxidation products (e.g., NOx) and incompatibility with the crankcase lubricants (e.g., reaction with lubricant additives).

The question of lubricant compatibility is also of concern with the alcohols. The unburned fuel or oxidation products and the lubricating ofl may form two phases in the crankcase, causing precipitation of the lubricant additives, or have other unexpected effects. These questions also can only be answered by long-term engine tests.

\subsection{Toxicity}

In judging the feasibility of alternative fuels, matters of toxicity and associated health hazards must be examined by the manufacturer and marketer for the potential impact upon employees, consumers, and the public at large. The following is a brief overview of these considerations for several fuels. In the absence of detalled specifications and composition data, it may turn out that additives or contaminants (trace or otherwlse) are likely to be of toxicological significance. Product types, where this assumption is of critical importance, is noted. For each fuel, a summary of toxicity information and a statement of risk is presented.

\subsubsection{Gasolines from Coal or Shale}

These gasolines would be expected to contain the same range of hydrocarbon types as petroleum derived gasolines. However, the concentration of aromatic hydrocarbons in the coal-derived fuels is expected to be relatively high. Experience has shown that gasolines of considerable difference in composition have the same general toxicological properties.

(a) Toxicity-Gasolines generally act as irritants to skin and mucous membrane and an anesthetics resulting from depression of the central nervous system. Mucous membrane (eye, nose, throat) irritation may be produced by vapor or 1iquid. Skin contact is irritating. On a prolonged or repeated basis this contact may produce defatting of the skin leading to dermatitis. The dermal toxicity of gasoline is low. It is doubtful that toxicologicelly significant amounts can be absorbed through the skin. 


\section{TABLE 3-6}

FUEL PROPERTIES RELATED TO MAINTENANCE

\begin{tabular}{|c|c|c|c|c|c|c|c|c|c|c|c|c|c|c|}
\hline & $\begin{array}{l}\text { Res } \\
\text { ON }\end{array}$ & $\begin{array}{l}\text { Motor } \\
\text { ON } \\
\end{array}$ & $\begin{array}{l}\text { Ash } \\
\text { WtX }\end{array}$ & $\begin{array}{r}\text { Na } \\
\text { PPM }\end{array}$ & $\begin{array}{c}\mathbf{v} \\
\underline{P M} \\
\end{array}$ & $\begin{array}{c}\text { Carbon } \\
\text { Res1due, } \\
\text { Ht\% (a) } \\
\end{array}$ & $\begin{array}{l}\text { Sulfur } \\
\text { WtX }\end{array}$ & Corrosivity & $\begin{array}{l}\text { Ef fect on } \\
\text { Plast1c日 }\end{array}$ & $\begin{array}{l}\text { Sol. for } \\
\text { Water } \\
\text { e } 68^{\circ} \mathrm{F} \\
\text { PPM } \\
\end{array}$ & $\begin{array}{l}\text { Emuls ion } \\
\text { Tendency }\end{array}$ & Lubrictey & $\begin{array}{c}\text { Storage } \\
\text { Stab1lity }\end{array}$ & $\begin{array}{c}\text { Sludge } \\
\text { Tendency }\end{array}$ \\
\hline $\begin{array}{l}\text { Petroleum } \\
\text { - Gasoline } \\
\text { - Broad Cut }\end{array}$ & -86-93 & $77-84$ & $\begin{array}{l}0 \\
0\end{array}$ & $\begin{array}{l}0 \\
0\end{array}$ & $\begin{array}{l}0 \\
0\end{array}$ & $\begin{array}{c}\text { N11 } \\
0\end{array}$ & 0.03 & NP & $\begin{array}{c}\text { See Table } \\
3-8\end{array}$ & $\begin{array}{l}0.02 \\
0.04\end{array}$ & NP & NP & NP(e) & NP(e) \\
\hline $\operatorname{Cos} 1$ & -- & - & $3-15$ & $\begin{array}{l}8,000- \\
30,000\end{array}$ & . & -- & $1-5$ & & . &.$^{--}$ & & - & -- & -- \\
\hline $\begin{array}{l}\text { Coal/Methanol slurry } \\
\text { Coal/o1l slurry } \\
:\end{array}$ & - & - & $\begin{array}{l}(1-6) \\
(1-6)\end{array}$ & $\begin{array}{l}(3,000- \\
10,000) \\
(3,000- \\
10,000)\end{array}$ & & - & $\begin{array}{l}0.4-2 \\
0.4-2\end{array}$ & & . & Infinite & . & . & $\begin{array}{l}\text { (P) } \\
\text { P }\end{array}$ & . \\
\hline $\begin{array}{l}\text { Coal L1quids } \\
\text { - Jet Fuel (JP-4) } \\
\text { - Diese1 } \\
\text { - Fue 1:011 }\end{array}$ & $\begin{array}{l}-- \\
--\end{array}$ & $\begin{array}{l}-- \\
\therefore-\end{array}$ & $\begin{array}{r}N 11 \\
N 11 \\
0.01\end{array}$ & $\therefore$ N11 & $\begin{array}{l}N 11 \\
<0.1\end{array}$ & $\begin{array}{l}\text { N11 } \\
>0.7\end{array}$ & 0.2 & . & . & . & & $\ddots$ & NP & . \\
\hline $\begin{array}{l}\text { Shale 011 Liquide } \\
\text { - Raw } \\
\text { - Syncrude }\end{array}$ & -- & -- & & . & . & & & . & . & & $\begin{array}{l}\cdots \\
. \\
.\end{array}$ & $\ddots$ & & . \\
\hline $\begin{array}{l}\text { Methanol } \\
\text { Hydrogen } \\
\text { Ammonia }\end{array}$ & $\begin{array}{l}106 \\
130\end{array}$ & 92 & $\begin{array}{l}\mathbf{0} \\
\mathbf{0} \\
\mathbf{0}\end{array}$ & $\begin{array}{l}0 \\
0 \\
0\end{array}$ & $\begin{array}{l}\mathbf{0} \\
\mathbf{0} \\
\mathbf{0}\end{array}$ & $\begin{array}{l}\mathbf{0} \\
\mathbf{0} \\
\mathbf{0}\end{array}$ & & $\begin{array}{l}\text { (h) } \\
\text { (b) }\end{array}$ & : & $\begin{array}{c}\text { Infinite } \\
:\end{array}$ & $\begin{array}{l}\mathbf{N P} \\
\mathbf{N P}\end{array}$ & $\cdots$ & NPP & NP \\
\hline $\begin{array}{l}\text { Oxygenated Compounds } \\
\text { - Ethanol } \\
\text { - Higher Alcohdls }\end{array}$ & $\begin{array}{r}106 \\
(105)\end{array}$ & $\begin{array}{c}89 \\
(90)\end{array}$ & $\begin{array}{l}0 \\
0\end{array}$ & & $\begin{array}{l}\mathbf{0} \\
\mathbf{0}\end{array}$ & $\begin{array}{l}\mathbf{0} \\
\mathbf{0}\end{array}$ & & (d) & . & $\begin{array}{l}\text { Inf Inite } \\
\text { Inf Inite }\end{array}$ & - & & $\therefore$ & . \\
\hline $\begin{array}{l}\text { Methane } \\
\text { Hydrazine } \\
\text { Methylamine } \\
\text { Acetylene } \\
\text { Vegetable } 011\end{array}$ & . & 105 & $\begin{array}{l}0 \\
0\end{array}$ & $\begin{array}{l}0 \\
0\end{array}$ & $\begin{array}{l}0 \\
0\end{array}$ & $\begin{array}{l}\text { 0 } \\
\text { o }\end{array}$ & & $\begin{array}{l}\text { (h) } \\
\text { (c) }\end{array}$ & & Infinite & $\stackrel{\text { NP }}{?}$ & $\begin{array}{c}\mathbf{N P} \\
\vdots \\
\vdots\end{array}$ & $\begin{array}{l}\mathbf{N P} \\
\mathbf{N P} \\
\end{array}$ & NP \\
\hline
\end{tabular}




\section{FOOTNOTES TO TABLE $3-6$}

(a) On $10 \%$ bottoms.

(b) Corrodes copper, brass, zinc.

(c) Materials to be avolded Include cobalt, copper, pure iron, lead, manganese, magnestum, tin, zinc.

(d) May contain small amounts of organic acids which may corrode certain materials.

(e) Can be controlled by careful refining and alded by the use of proper additives.

(f) Estimated assuming Fischer-Tropsch oxygenated compounds consist of $20 \%$ methanol, $50 \%$ ethanol, $20 \%$ propanol, $10 \%$ higher oxygen compounds.

(g) Code: NP - no problem; P - problem; ( ) - estimated value; blank space - data currently not available.

(h) Cryogenic hydrogen and methane require special materials to avoid embrittlement--not really corrosion. 
The oral toxicity of gasoline is low; however, the aspiration effects are significant. Minute amounts of liquid gasoline which may be drawn into the lungs during ingestion can be rapidly fatal.

The most important route of entry of gasoline is by inhalation. Excessive exposure to gasoline vapors may induce symptoms of alcoholic intoxication including a feeling of fullness in the head, headache, blurred vision, dizziness, unsteadiness, nausea, and allied symptoms. The time of onset and the severity of these signs and symptoms 1 s related to the concentration. The olefin and aromatic content of the gasoline is important as these materials are more potent anesthetics. The irritant properties of the vapor cannot always be relied upon to provide an adequate warning. The amount of benzene present in any gasoline is assumed to be important where prolonged or repeated low level exposure is possible. Benzene causes the destruction of the blood forming organs leading to aplastic anemla and has been implicated in certain cases of leukemia.

There have been recent changes in the standards of the Occupational Health and Safety Administration (OSHA) with respect to exposure to benzene, e.g., in chemical manufacturing operations. OSHA has sought an extension of these rules to petroleum operations that involve fractions containing benzene (e.g., motor gasoline). The American Petroleum Institute and the " National Petroleum Refiners Association have flled suit against certain of the rules promulgated by OSHA. The case is presently in the hands of the Fifth Circuit Court in Atlanta*. It is not possible to predict the outcome of the case. However, it is recognized there is a the possibility of an impact on any fuel containing benzene, whether derived from petroleum, coal or any other source.

\section{(b) Hazard}

- Oral ingestion - low apart from risk of aspiration

- Skin penetration - low

- Inhalation - high, particularly in confined spaces vhere vapor concentrations can rapidly build up

- Eye, skin, nose and through contact - moderate risk of irritancy

\subsubsection{Dist1llates from Coal or Shale}

These distillates would be expected to contain the same range of hydrocarbon types as petroleum distillates in the $325-650^{\circ} \mathrm{F}$ boiling range.

(a) Toxic1ty-Distillates generally act as irritants to skin and mucous membranes. Toxicity is low by the oral, dermal, and inhalation routes.

*Platts News Service, 4/21/78. 
However, asplration, the entry of amall amounts of Ilquid hydrocarbon directly into the lungs, rapldiy produces a severe Injury to lung tissues which may be fatal. The low volatility of distillates precludes vapor bulld-up unless the liquid has been heated.

Skin contact may be 1rritating and on a prolonged basis can remove sufficlent fat from the okin to result in dermatitis. Eye contact results in only slight, translent irritation.

\section{(b) Hazard}

- Oral 1ngestion - low apart from risk of aspiration which 1s very hazardous

- Sk1n penetration - low

- Inhalation - low

- Skin, eye, nose, and throat contact - low risk of 1rritancy; increasing with increased severity of exposure

\subsubsection{Methanol}

The following comments regarding methanol would also apply to blends containing significant amounts of the alcohol.

(a) Toxic1ty--Methanol is both an irritant and a central nervous system depressant. The low molecular welght alcohols share these properties although their anesthetic potency is definitely less than the comparable hydrocarbon. Toxic effects include dizziness, stupor, cyanosis, cramps, and gastric disturbances.

Prolonged vapor exposure may also lead to headache, ringing in the ears, tremor, and disturbances in nerve function. Methanol is unique among the alcohols in that it produces degeneration of the optic nerve and retina leading to complete and permanent blindness. There is apparently a wide varlation in individual susceptibility to methanol.

Acute toxicity studies in animals indicate" that the lethal oral dose is $18 \mathrm{ml} / \mathrm{kg} \mathrm{vs} .12 .5 \mathrm{ml} / \mathrm{kg}$ for ethanol. The toxic dose for man may be as low as $10 \mathrm{mg} / \mathrm{kg}$, and the lethal dose as $10 \mathrm{w}$ as $50 \mathrm{mg} / \mathrm{kg}$. Toxic effects, including blindness, have also been reported in man where skin absorption and/ or vapor Inhalation have been Involved. It is not always possible to eliminate ingestion as an additional route of exposure in such cases.

\section{(b) Hazard}

- Oral Ingestion - very high

- Skin penetration - moderate.

- Inhalation - low [industrial exposures should be controlled to meet a Threshold Value LImit (TLV) of $200 \mathrm{ppm}$ ]

- SkIn, eye, nose, and throat contact - slight to moderate

\subsubsection{Ethanol}

The chlef difficulty associated with ethanol exposure under Industrial circumstances Involves willful ingestion. 
(a) Toxicity--Ethanol is a local irritant to the mucous membrane and also a central nervous system depre:sant. The action first involves inhibition of higher functions and later increasing degrees of anesthetic action. In this respect, it is more potent than methanol.

Acute toxiclty studies in animals puint to e lethal dose of 6-8 $\mathrm{m} 1 / \mathrm{kg}$. The lethal dose for an adult man 18 stlmated to be $3 \mathrm{~g} / \mathrm{kg}$ body welght (approximately $1 / 2$ pint of absolute alcohol taken all at once). Although it Is possible to produce toxic effects by skin absorption, the necessary conditions of exposure are such as to make 1t most unlikely. Absorption of toxic amounts of ethanol by inhalation is normally not encountered because the odor and mucous membrane Irritation become intolerable before anesthetic concentrations are achieved. Repeated or prolonged exposures to ethanol vapor apparently have no chronlc effect in man.

(b) Hazard

- Oral Ingestion - moderate

- Skin penetration - low

- Inhalation - low (1ndustrial exposures should be controlled to TLV of $1.000 \mathrm{ppm}$ )

- Skin, eye, nose, and throat contact - slight (skin) to moderate (mucous membranes)

\subsubsection{Higher Oxygenates}

Processes such as the Fischer/Tropsch may yield mixtures of aliphatic alcohols, with lesser amounts of aldehydes and ketones. Certain general statements can be made regarding such products. With the lower alcohols, toxicity tends to increase. with increasing carbon number up through $\mathrm{C}_{6}$. Skin penetration and irritancy effects also increase. Although the volatility is less with increasing molecular weight, the toxicity and irritancy are also greater.

With respect to ketones, industrial exposure has occurred to a considerable degree without significant health effects. Although the ketones may be toxic, the irritancy of the materials provides fairly effective warning. The vapors are considered narcotic, but concentrations required to produce obvious effects are also irritating to mucous membranes of the eyes, nose, and throat. Lower concentrations, not likely to produce discomfort, may lead to some impalrment of judgment. In general, the toxiclty irritation and anesthet1c potency Increase with increasing molecular weight. Irritancy and toxicity also increase with increasing unsaturation. The liquids are painfully irritating to the eyes, and prolonged and repeated skin contact can irritate as well as lead to dermatitis from the defatting action of the solvent. Skin absorption is not likely to result in toxic effects from the common saturated ketones. 
Aldehydes have generally produced only local reactions without severe cumulative effects under occupational exposure conditions. The local reactions consist of irritation of skin and mucous membranes of the eyes, nose, and throat. The response is most characteristically seen with the lower M.W. aldehydes, particularly those with unsaturation in the aliphatic chain. Aromatic aldehydes tend to be less irrtating. Sensitization, a specific form of helghtened responsiveness, is vell known with formaldehyde and may also occur with other aldehydes. This effect is ordinarily assoclated with liquid contact and is only rarely reported from vapor inhalation. Some aldehydes have an anesthetic action but this would be at a low level for aldehydes likely to be present in automotive fuels. In general, the irritating properties of the aldehyde prevent voluntary exposure to toxic or anesthetic concentrations.

\subsubsection{Methane}

This hydrocarbon gas is a simple asphyxiant. The only physiological effects seen are the result of a decrease in the available oxygen due to the presence of methane. It has no warning properties. The limiting factor in exposure is the partial pressure of oxygen which should not go below 135 mo in atmospheres containing no toxic gases or vapors. Compounds such as methane and ethane can produce explosion hazards; whatever precautions are taken to avold this risk are adequate to protect against asphyxia.

\subsubsection{Ammonia}

The physiological effects of ammonia are directly traceable to its ability to produce local severe irritation of tissues.

(a) Toxicity--Amonia is extremely irritating and highly corrosive to the eyes and respiratory tract. Suffocation and death from pulmonary edema can result from exposure to high concentrations. The irritant propertles and pungent odor give adequate warning so that toxic exposures are not voluntari.ly permitted. Up to $500 \mathrm{ppm}$ in air may be tolerated for an hour. Irritation of mucous membranes of the eyes, nose, and throat have been reported at 400-700 ppm. Exposures of 2500-6500 ppm have been judged dangerous for 0.5 hour, and $5000 \mathrm{ppm}$ and above is belleved to be rapidly fatal. High concentrations of ammonia in addition to the corrosive action on eyes, throat, and respiratory tract may also affect heart reflexes and respiratory action. Molst atmospheres contalning $1 \%$ or more ammonia may cause increasing amounts of skin irritation including chemical burns with blistering. There is no evidence of cumulative or chronic toxic effects following prolonged or repeated exposures to tolerable atmospheric concentrations.

\section{(b) Hazard}

- Oral ingestion - unlikely for a gas

- Skin penetration - low

- Inhalation - moderate (Industrial exposures should be controlled to TLV of $25 \mathrm{ppm}$ ) 
- Skin, eye, nose, and throat contact - variable, depénding upon concentration; can be high where exposure is severe

Note is also taken of the fact that several accldents per year involve inhalation of ammonia released by rupture of vessels containing 1t (e.g., railroad tank cars) or by leaks from compressors, refrigerators, etc.

\subsubsection{Hydrogen}

This odorless, colorless gas acts as a simple asphyxiant. The physiological effects result from a decrease in available oxygen due to the presence of hydrogen. There are no warning properties, and the onset of asphyxia may be insidious. The precautions taken to prevent fire and explosion are more than adequate to protect against oxygen deprivation and consequent asphyxia.

\subsection{Safety}

The major issues in fuel safety, other than toxic1ty, are flammability and danger of accidental detonation.

The pertinent properties of the possible alternative fuels are listed in Table 3-7. Safety precautions required for hydrocarbon liquids derived from coal and oil shale will be similar to those established for conventional petroleum fuels. However, a variety of different precautions will be required for the other fuels:

(8) The lower flammability limits of methanol and ethanol are 6 vol. \% and 3.5 vol. \%, respectively, versus about 1 vol. \% for petroleum liquids. Moreover, the flash points of the pure alcohols are higher than typical values for gasoline, thereby indicating greater safety.

- Ammonia has relatively narrow limits of flammabllity and a high lower limit, thereby making it a comparatively safe fuel in these respects.

- Methylamine, which is more toxic than ammonia, also has somewhat wider flammablity limits but a higher bolling point. On balance, methylamine may be less hazardous than ammonia.

- Methane must be handled with great care, especially as a liquid. However, safe handling procedures for LNG have been devised by the gas industry. Nevertheless, vehicular applications of LNG would differ from current gas industry experience and may involve greate: hazard.

- Liquid hydrogen has been used extensively in the space program, but with rigorously controlled handing procedures. The widespre... use of liquid hydrogen in distribution netowrks, service depors, and on board vehicles is a cause for concern. 
- Acetylene is a hazardous gaseous fuel that has been handled safely in numerous industrial applications. Additional précautions and new techniques would be required to insure safety in transportation applications.

- Hydrazine is another fuel with serious safety problems, but has the advantage of being a liquid at ambient temperatures.

At present, it is an open question as to whether certain advantages of fuels such as hydrogen and methane are sufficlent to offset the disadvantages of the stringent safety procedures that would be required in commerclal transportation applications to control the hazardous nature of the fuels.

\subsection{Properties of Non-Highway Fuels}

from Coal Syncrudes and Shale 011

A considerable amount of work has been done in the recent past on producing various types of fuels from coal and shale. These studies vary widely with regard to resource source, treating conditions, and process which makes it difficult to condense the information. Accordingly, for completeness, the results of the work are presented as separate entities in Appendix 3-2. A major effort would be required to put all the data on a common, consistent, basis. To develop correlations relating coal or shale type, processing conditions and fuel properties is beyond the scope of this study. A brief summary of the pertinent article is included to give some idea of that commercial transportation fuels can be produced from coal and shale. 
TABLE $3-7$

FUEL PERFORMANCE CRITERIA--SAFETY (c)

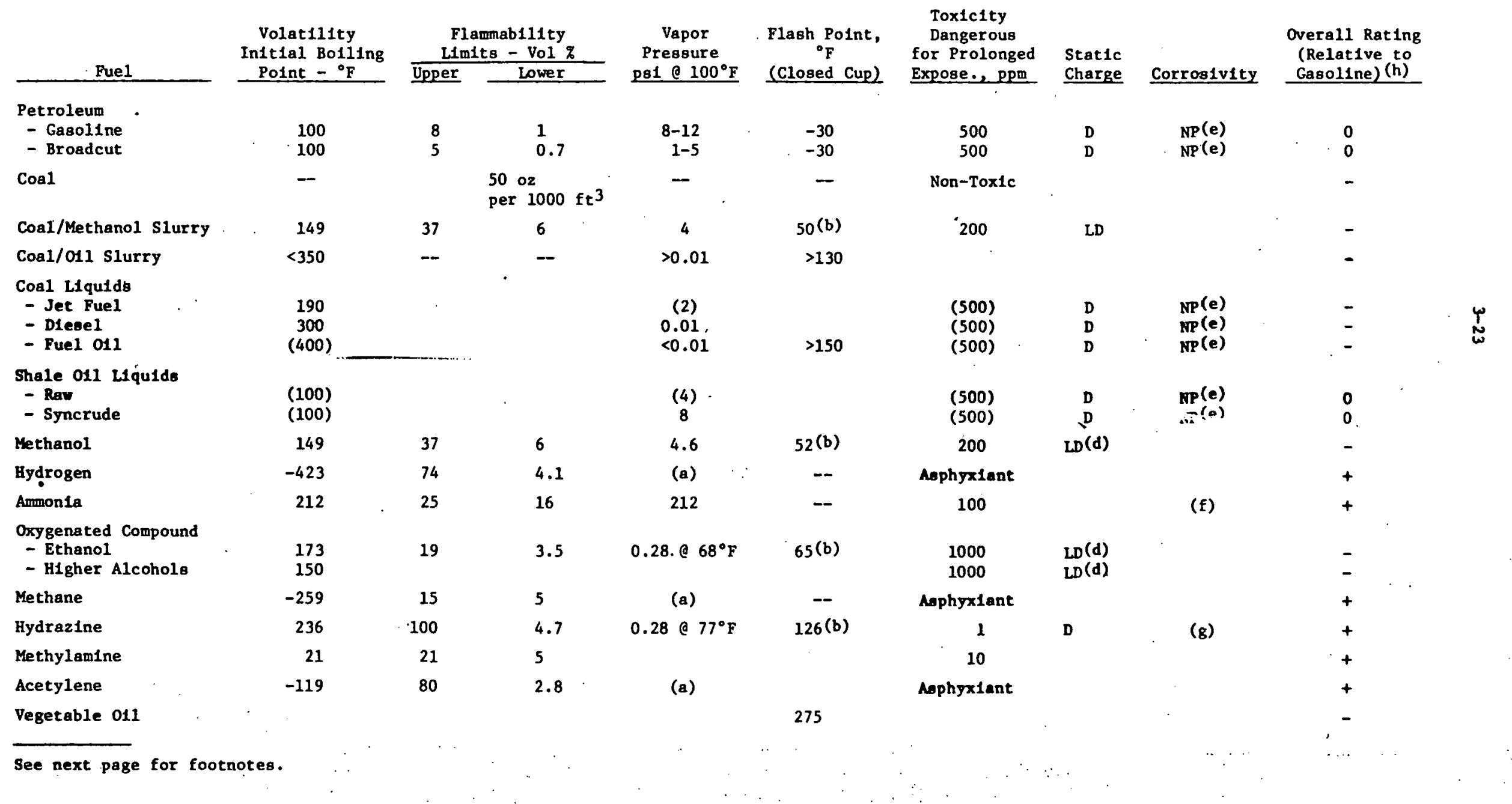



(a) Above critical temperature.
(b) Open cup.
(c) D - danger; NP - no problem; LD - less danger than petroleum hydro- carbons; blank spaces - data unavailable; ( ) - estimated data.
(d) Specific electric conductivity $10^{6}$ times higher than hydrocarbons.
(e) Can be controlled by careful refining and use of additives.
(f) Corrodes copper, brass and zinc.
(g) Materials to be avolded include cobalt, copper, pure iron, lead, manganese, magnesium, tin and zinc.
(h) + = more dangerous than gasoline; - = less dangerous than gasoline; $0=$ equal to gasoline. 
APPENDIX 3-1

SIGNIFICANCE OF FUEL PROPERTIES

Volatility

- Determines the ease with which a fuel can be vaporized. In carburetted engines, it controls ease of starting, warm-up, and acceleration. A final boiling point above about $400^{\circ} \mathrm{F}$. may result in excessive crackcase dilution and/or engine deposits. Excesively high volatility can give rise to vapor lock problems and/or carburetor icing.

- In fuel-injected engines (e.g., diesel, gas turbine) appreclably lower volatility (1.e., higher bolling point) can be tolerated: However, fuels with final bolling points above about $650^{\circ} \mathrm{F}$. nay not burn cleanly, particularly in high speed reciprocating piston engines where burning time is short:. The time available for burning is a function of engine speed in reciprocating piston engines and of combustor size and air rate in engines using steady atate combustion (e.g., gas turbine).

\section{Vapor Pressure}

- Another measure of fuel volatility. With carburetted engines, increasing vapor -pressure improves ease of starting, but enhances dangers. of vapor lock and carburetor icing.

Heat of Vaporization

- A measure of the energy required to convert a unit weight of fuel from a liquid to a vapor.

In carburetted engines, the higher the heat of vaporization, the lower will be the temperature of the fuel-air mixture in the intake manifold, the greater weight of fuel (and air) inducted into the combustion chamber, resulting in more power per cycle. However, if the fuel-air mixture temperature becomes too low, a heterogeneous fúel-air mixture may result, causing poor engine operation. In this case, heat must be added to the intake manifold to vaporize the fuel.

In the case of cryogenic liquids, it also represents the amount of heat that must be added to fuel storage to provide fuel vapor for the engine.

Heat of Combustion (Net)

- The amount of heat produced by burning a unit amount of fuel in air under stoichiometric conditions to gaseous products. The 
lower the heat of combustion, the more fuel that must be carried aboard a vehicle to provide a given level of energy storage.

Heat of Combustion (net) (BTU/ft $\mathrm{t}^{3}$ )

- The amount of heat that will be generated by burning 1 cubic foot of a stoichiometric mixture of air and fuel. Everything clse being equal, the higher this figure, the more power will be generated by a carburetted reciprocating engine of given displacement

Octane Number

- Measures the resistance of the fuel to detonation in an Otto cycle engine. As octane number of a fuel is increased, the allowable engine compression ratio increases. Thus, high octane fuels are capable of increased miles/gal., since engine thermal efficiency increases with an increase in compression ratio.

Research octane number measures knock resistance under less severe conditions than the Motor Octane Number. Heretofore, the roaf anti-knock performance of a gasoline could be correlated best with an average of the Research and Motor Octane Numbers.

Octane Number has no significance with regard to fuel performance in $a n$ engine using steady-state combustion (e.g., gas turbine). There is a rough inverse relationship between Octane Number and Cetミre number, which makes high octane fuels unsatisfactory for use in compression ignition englnes.

\section{Cetane Nusber}

- The higher the Cetane Number, the less the ignition delay in a compression ignition engine. Currently, 非 diesel fuels in the U.S. average 48 Cetane Number. A minimum Cetane Number of 40 is allowed by some diesel engine manufacturers. Lower Cetane Numbers may be used in heavy, slow-speed engines, particularly if auxiliary means of ignition is employed (e.g., spark or glow plug, or pilot fuel injection). It will be noted that spontaneous ignition temperature tends to decrease as Cetane Number increases.

Cetane Number has no significance regarding fuel performance in a continuous combustion engine.

Flame Speed.

- Current engines have been optimized to operate best with a hydrocarbon fuel (flame speed $1.1 \mathrm{ft} / \mathrm{sec}$ ). Wide variations in flame speed from this level would probably require that engine operation be modified for best results... For example, the high flame speed of hydrogen and the slow speed of ammonia suggest that expedients 
must probably be used with these fuels for best operation in reciprocating engines. In continuous combustion engines, combustor residence time (e.g., combustor size) for the fuel air mixture must be increased as flame speed decreases to ensure complete conbustion.

Flamonability Limits

- Represent the range in fuel-air mixtures that will support a flame. In general, wide limits are an advantage in engine operation, since the probability of misfire due to engine variability and heterogeneity of the fuel-air mixture is reduced. It will also allow greater flexibility in design of continuous combustors.

Kinematic Viscosity

- This property is primarily of concern where fuel injection and atomization is used to introduce the fuel into the combustion space. For pressure injection, the degree of atomization becomes poorer as $v$ iscosity increases. It is of particular concern in diesel engines where the degree of spray penetration is important.

Kinenatic Viscosity at $0^{\circ} \mathrm{F}$

- This property is important in giving guidance as to low teiperature handling properties. Pumping difficulties increase as viscosity increases.

Density

- The density of the liquid is of concern with regard to the size of storage vessels and lines in terminals, service stations, and vehicles. In general, the less dense fuel will require a greater storage volume for a given energy supply, unless the heat content (BTU/1b) compensates for the density difference.

Density is also of importance in fuel systems where the fuel is metered by volume (e.g., in diesel fuel injectors). In such a system, the more dense fuel will be supplied at a higher mass rate, which will influence fuel/air ratios, and power at a given injector setting.

Freezing Point (Pour Point)

- Represents the temperature below which the fuel becomes solid and cannot be pumped. This limits the minimum temperature at which the oil can be handled either at the terminal or aboard a vehicle.

\section{Flash Point}

- The temperature at which the bulk liquid can be ignited by an open flame. Fire hazard increases as flash point decreases. 


\section{Contact with Water}

- In the normal comercial storage and transportation of fuels, it is difficult to avoit some contact and introduction of water into the system. For example, storage tanks will "breathe" and thus moisture can be introduced into the storage system. Also, floating roof tanks, used in large bulk terminals can be another source of some small amount or water into the fuel. In marine transportation, by tanker or barge, some water invarlably gets into the tanks. While every precaution is taken to avold having water in the distribution system, It is a practical problem that must be recognized. Some of the problems that can be created by water in the distribution system are:

\section{Solubility for Water}

- If water is present. It can be precipitated when the fuel is cooled. As the solubility for water in a given fuel increases, the problems w1ll become more severe.

\section{Solubility in Water}

- If a given fuel (such as alcohols) are soluble in water then there can be fuel losses to the water phase.

\section{- Emulsion Tendency}

- This is the tendency for a fuel to form an emulsion when agitated with water. The greater this tendency, the greater the probability that $\in$ milsified water picked up in the fuel transportation and storage system will be carried from the storage tanks, through the fuel system, and, eventualiy, to the engine where it can cause engine malfunction by interfering with the smooth flow of fuel to the engine. The trouble in the engine may be caused by the poor flow characteristics of the emulsion itself, by deposit of water wher the enulsion breaks, by corrcsive salts dissolved in the water (e.g., sea water) or by dirt and rust suspended in the emulsion. Thus, a fuel with low tendency to emulsify or in which the emulsion breaks and settles rapidly is much easier to deliver clean to the engine than a fuel that emulsifies easily.

\section{Storage Stabllity}

- In the present fuel distribution system it is possible that six months or more may elapse between the time a fuel is produced at a refinery uniil it is burned in an engine. Thus, it is important that a fuel have the ability to retain its desirable characteristics and not degrade in storage over this period. Instablilty: In storage may take a number of forms, e.g., loss of volatile fuel components, formation of gum or sediment, change in color, etc. 


\section{Stat1c Charge}

- A static electric charge can be accumulated on a liquid of low, electric conductivity (e.g. a petroleum fuel) when 1 t is moved at high velocity through pipes, filters, etc. Under proper conditions the electric charge will discharge to a conductor of lower potential (e.g. a grounded tank wall) in the form of a spark capable of lgniting a combustible mixture of fuel vapor and air. Thus the tendency to develop a static charge (which is roughly an inverse function of its electrical conductivity) is of interest as one source of fire hazard in the handling of fuels.

\section{Toxicity}

- The toxicity of a fuel is of great concern and determines the precautions that must be taken in its safe handling and use. Three main types of toxicity are of interest: vapor inhalation, ingestion and skin contact. Vapor toxicity determines the care that must be taken to avoid breathing the funes. Irgestion indicates the hazard in case of accidental swallowing of the vapor or liquid. Skin toxicity represents the hazard connected with fuel coring in contact with skin.

\section{$\underline{\text { Lubricity }}$}

- Lubricity is the ability of a fuel to lubricate the equipment through which it flows. It is proportional to viscosity. The lubricity of the fuel can have an important effect on the type of pump used in handling. With sone pumps a fuel of poor lubricity can cause excessive wear (e.g., using a diesel fuel having an undesirably low viscosity). Accordingly, care must be used in correctly matching fuel and pump. In some cases, poor lubricity may be corrected by means of a fuel additive.

\section{Corrosivity}

- A reaction (chemical, dissolution, etc.) between a fuel and the materials of the fuel system in which it is used is, of course, undesirable. It may cause engine malfunction due to formation of fuel leaks, distortion of fuel system components, development of undesirable deposits in sensitive areas, staining and coating of finely finished surfaces in controls, pumps, etc. Thus it is important that a fuel be compatible with the fuel system in which it is used. The degree of compatibility must be high since the expected service life is long (10+ yrs.) and relative small changes in sensitive parts (e.g., in metering devices) can be very trouble8 ome.

\section{Effect on Plastics}

- In most engine fuel systems, plastic parts may be found perhaps as lines, diaphrams, gaskets, control parts, etc. It is important that the fuel be compatible. with such materials and not cause them to lose strength, swell or otherwise deteriorate. 
APPENDIX 3-2

PROPERTIES OF NON-HIGHWAY FUELS FROM SHALE AND COAL SYNCRUDES

The published Ifterature contalns a variety of data on the properties of fuels dertved from coal and ofl shale. In general, the properties are in terms of "inspection data", 1.e. the results of standardized analytical tests by procedures developed for quality control of conventional petroleum fuels. It should be recognized that such tests have been applied to the "alternative fußls" because these are the analytical procedures that are avallable; it does not follow that, in every case, the inspection data provide an accurate indication of the actual performance of the fuels in different end-uses.

Quality control of fuel manufacture requires that products meet established specifications* that are defined in terms of the Inspection data obtained on samples analyzed by standardized test procedures. If the inspection results for a päticular sample are within the prescribed range of the pertinent specification the batch of product from which the sample was taken is considered to be "on spec". In cases where the sample was "off spec", the batch of product would be reprocessed or reblended to produce "on spec" material.

Inspection data are also obtained routinely on samples produced during experimental work, e.g. samples obtained from pilot plant operations. In such cases, the usual purpose is to investigate the effects of process varlables rather than to produce "on spec" products. Hence, the fact that an experimental sample is "off spec" does not imply that fuel of satisfactory quality cannot be produced from a particular resource or by a particular process.

There is difficulty in interpreting numerical data excerpted from published 11terature. "In the absence of comerclal operations, all fuel samples of "alternative fuels" must be considered experimental. The difficulty is that numerical data, per se, do not convey the purpose of a given experiment. For example, was the sample taken from an experimental "run" In which the goal was to approximate an established specification as closely as possible, or was the goal to investigate process varlables (such as pressure, temperature, space velocity, 'different catalysts, etc.)?

In reviewing the data that follow, the reader is cautioned that there is a lack of comparability among many of the samples tested, since the samples may have been produced for quite different purposes. In consequence, the analytical results should be regarded as lilustrative and not as definitive.

\#Such specifications are always employed by the fuel manufacturer to meet his own needs and/or the needs of a purchaser (In which case the specification may be a "procurement" or "purchasing" spectefcation). 


\section{A. Miltary Fuels from Crude Shale 011 (3-16)}

The production of 5,765 bbl of various milltary operational fuels (JP-4, JP-5/Jet A, DFM/DF-2, gasoline, Heavy Fuel 011) from 10,000 bbl of crude shale oil was accomplished in a commercial refinery having a capactity of about 9,000 BPSD.

The $10,000 \mathrm{bbl}$ of crude shale o11 was produced by the Paraho process using the shale mined from the Naval 011 Shale Reserve located near Anvil Points, Colorado.

The various fuels produced met a majorlty of the military, federal, and commercial specifications requirements (see Tables 3-8, 3-9, 3-10 and 3-11). However, these fuels tended to exhlbit storage and thermal instabilities. In addition, the fuels contalned a high wax content, high particulate matter, and high gum content. It is belleved that a higher pressure In the hydrogenation stage (about 1500 to 3,000 psi), along with clay treatment of the final products, would reduce or eliminate some or most of these problem areas.

It is concluded that it is feasible to obtain military and clvilian operational fuels from shale oil crude using a commercial refinery. However, additional effort has to be expended to overcome some refinery and operational problems to obtain maximum yields and improved properties.

\section{B. Jet Fuels from Synthetic Crudes $(3-6)$}

Three syncrudes were used, one from shale and two from coal, chosen as representative of typical crudes from future comerclal production. From them, jet fuels of varying specifications were produced by distillation, hydrotreating and hydrocracking. The crudes were fractioned at atmospheric pressure and under vacuum prior to hydroprocessing. The ylelds for each fraction (and some of the properties) are shown in Table 3-12. Table 3-13 ( 11sts the product specification targets used to guide the processing. Table 3-14 shows the properties of the fuels prepared to varying spectfications.

Certain problem areas have been identified. The yleld of the $300-500^{\circ} \mathrm{F}$ fraction was unexpectedly low from the shale oll and additional processing (e.g., delayed coklng) is required to convert high bolling fractions to the jet fuel range with some shale o1ls. The H-coal materlal used in this study was also deficient in the distillate range and may indicate the need for processing of the high bolling fractions. Rapld catalyst deactivation of the hydrovisbreaking and hydrocracking catalysts was observed with the COED syncrude. The reason for this is not reported. 
TABLE 3-8

UNINHIBITED HYDROGENATED NAPHTHA FRACTION:

GASOLINE SPECIFICATION TESTS

Sample No.

API Grav1ty

ASTM Dist. ${ }^{\circ}$ F

IBP

10 percent recov.

50 percent recov.

90 percent recov.

EP

Vol. percent res.

Vol. percent loss

R.V.P. p81

Exdstent gum, mg/100 ml

Corrosion, 3 hrs. C $50^{\circ} \mathrm{C}$

Sulfux, Wt. percent

Oxldation Stab111ty, hrs.

R.O.N.

M.O.N.

Lead, $8 / 1$

\section{Additives}

Ox1dation Inh1b1tors

Metal Deactivators

Corrosion Inhibitors
Eydrotreated

Napheha*

1512

66.7

110

165

223

285

333

1.0

1.0

5.5

9.6

3B

$<0.002$

$>24$

47.6

48.0

none

none

none

none
NATO $P-46$

Gasoline Spec.

$$
\begin{aligned}
& 122-158 \\
& 190-239 \\
& 270-356
\end{aligned}
$$

¿Sample prepared by Hypercal fractionation to an IBP - 300\% cut from Sample 1714 , BDN Run 1 Product.

Source: Ref. 3-16 
IABLE 3-9

UNINHIBITED HYDROGENATED JET FUEL FRACTIONS:

SPECIFICATION TESTS

Sample No./Product

Dist1llation, IBP

10 percent

50 percent

90 percent

EP

Fercent Res.

Fercent Loss

RVP, \#IN ${ }^{2}$

F1ash PT, OF (TCC)

Freeze $P T, O_{F}$

V18cosity \& $-30^{\circ} \mathrm{F}$, CS

Water To1. - Vo1. Change rinterface Rating

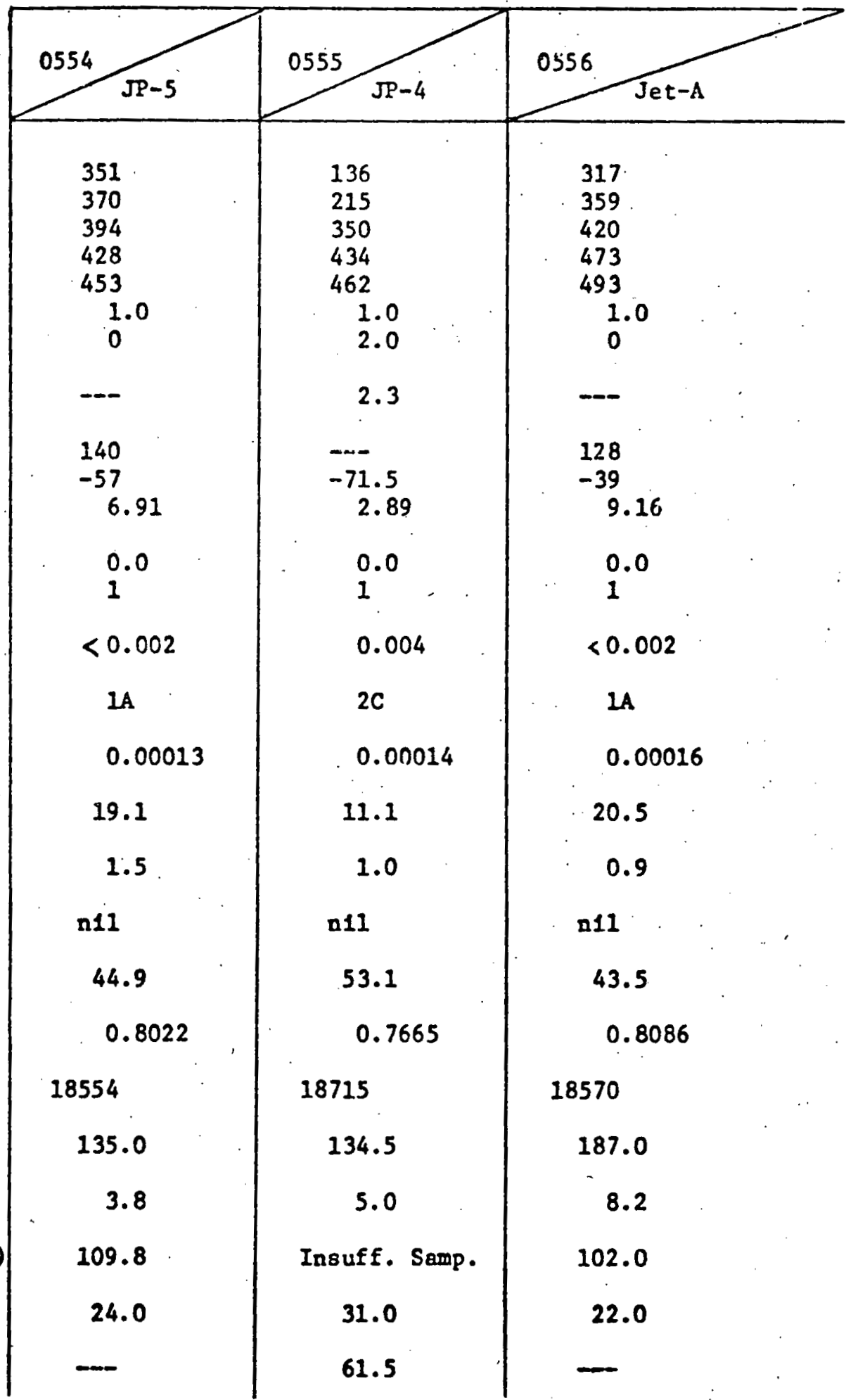

Total S, wt. percent

Copper Corros1on (2ihrs. (212)

RSB-S, Wt. percent

Aromat1cs, vol. percent

olefins, vol. percent

Ac1d NO, MgKOH/ml

API Grav.

Spec. Grav.

liet Heat of Combustion, BTO/LB

Anlline PT, ${ }^{O}$

Folstent $C=m, m / 100 \mathrm{ml}$

Potent1al Gum, mg/100 ml (16 br)

Sroke PT.

Swoke Volat1lity Index

.


TABLE $3-10$

UNINHIBITED HYDROGENATED DIESEL FRACTIONS :

SPECIFICATION TESTS

\section{Code}

Sample

TBP Cut PTS $\mathbf{O}_{\mathbf{P}}$

Color

API Gravlty

ASTM DIst. OF

IBP

5

10

50

90

95

EP
Diesel (DF -2)
$75-1510-4$
$440-600$

\section{5}

30.4

496

508

510

531

563

572

578

$-10$

$-10$

0.002

0.2

IA

NIL

3.31

Insuff. Sample

228

NII

Insuff. Sample
DFM 75-1506-4 $440-640$

3.0

30.2

497

517

523

554

597

604

612

$+12$

$+15$

0.002

0.2

18

NII

4.06

Insuff. Sample 230

NIL

Insuff. Sample

Source: Ref. 3-16 
TABLE 3-11

NO. 6 FUEL OIL BLENDING SPECIFICATION TESTS

Sample No.

Component

Inspect10n8:

oAPI.

Wt. percent $S$

Pour, ${ }^{\circ}$ F
1646

Total Feed in Tank after Coking Run 12
2595

$600-700^{\circ}$ Raw

HDN $\$ 3$ Feed
50-50 Volumetr1c Blend Samples \$1646\& \$1595

(Sample 11511)
15.2

0.46

90
21.8

0.60

50
oAPI

Flash, ${ }^{\text {F }}$

V1s. 'ं 122 $\mathrm{F}, \mathrm{SSU}$

Ash, Wt. percent

$B_{2} \mathrm{O}$ by d1st' $r$, Wt. percent

Pour, . ${ }^{\circ} \mathbf{P}$

Carbon Res1due, Wt. percent

Sediment by est., Wt. percent

Sulfur, Wt. percent

Thermal Stab111ty - NBTL

Explosivenes8, percent
18.4

330

164.5

0.033

trace

75

0.04

0.55

not run

not run
MIL-F-859E

Bumer Fuel 011

Specifications

Source: Ref, 3-16 
TABLE 3-12

\section{CRUDE OIL COMPOSITE FEED AND FRACTIONS}

\section{A. TOSco Shale 011}

\section{Feed $19 P 422 K \cdot 42210561 K$ S6110616K 616 to700K $70010783 \mathrm{~K}$} $\left(18 P-300^{\circ} \mathrm{F}\right),\left(300\right.$ to $\left.550^{\circ} \mathrm{F}\right)(550$ to 650 $\mathrm{F})\left(650\right.$ to $\left.800^{\circ} \mathrm{F}\right) \quad\left(800\right.$ 10 $\left.950^{\circ} \mathrm{F}\right)$

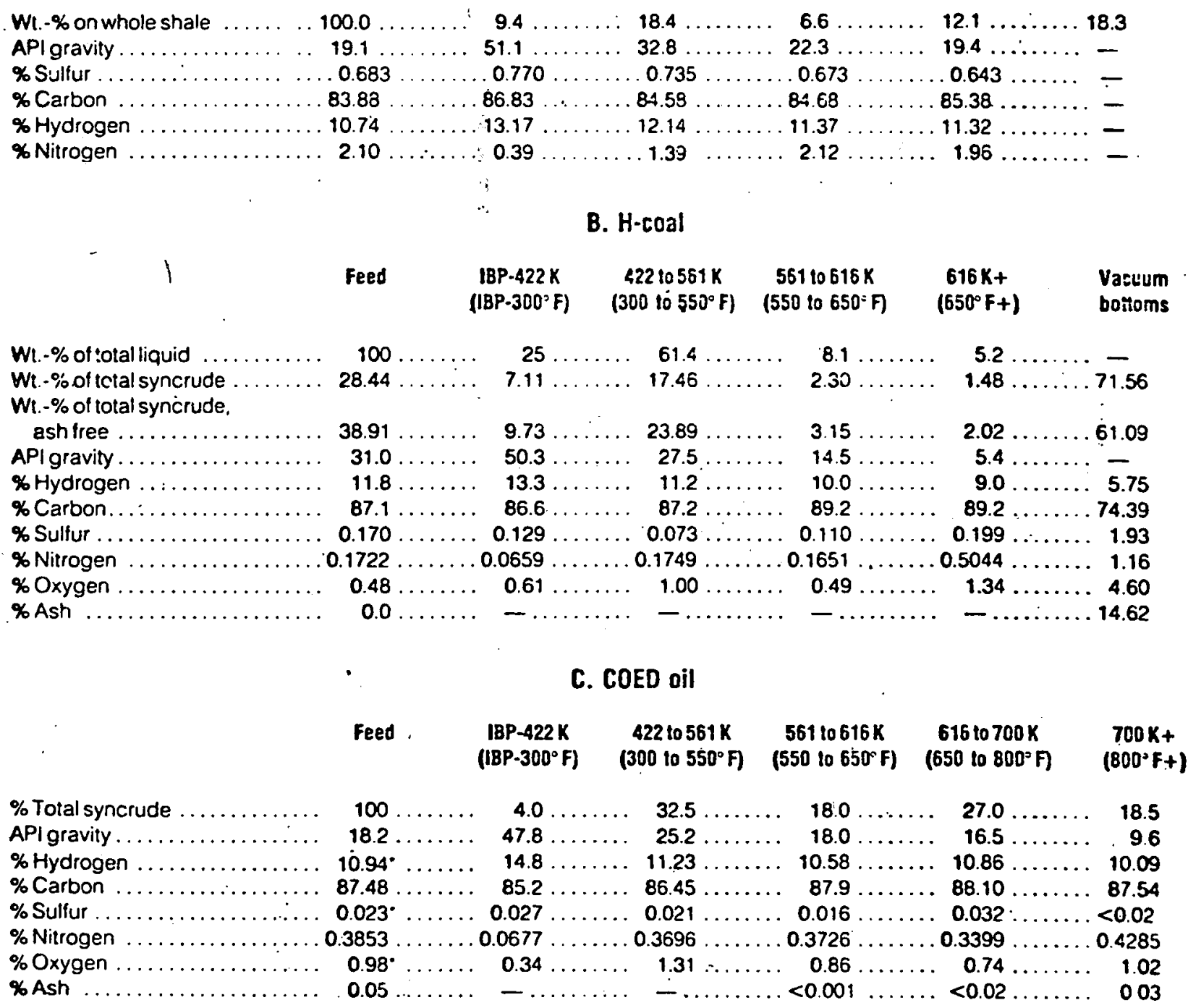

'Back calculated from analyses of fractions

Source: Ref. 3-6 


\section{TABLE $3-13$}

\section{PRODUCT SPECIFICATION TARGETS TO} GUIDE PROCESSING

Yield of $300-550^{\circ} \mathrm{F}$ fraction, wt\% on Crude (Min.).

Hydrogenation Severity:

Aromatics, \% max

Hydrogen, \% min

Sulfur, \% max

Nitrogen, \% $\max$

Volatility Specifications,

Final Boiling Polnt ${ }^{\circ} \mathrm{F}$

Re1d Vapor Press, PSI max

Flash Point ${ }^{\circ} \mathrm{F}$ (min)

Source: Ref. 3-6
20

40

High

20

12.75

0.5

0.2

\begin{tabular}{cc} 
A & B \\
\hline 550 & 650 \\
3 & 3 \\
- & --
\end{tabular}

C

550

13.5

0.2

0.1

$\underline{D}$

650

100

100 
TABLE 3-14

FINAL PRODUCT INSPECTIONS

(o) Low yleld shale products

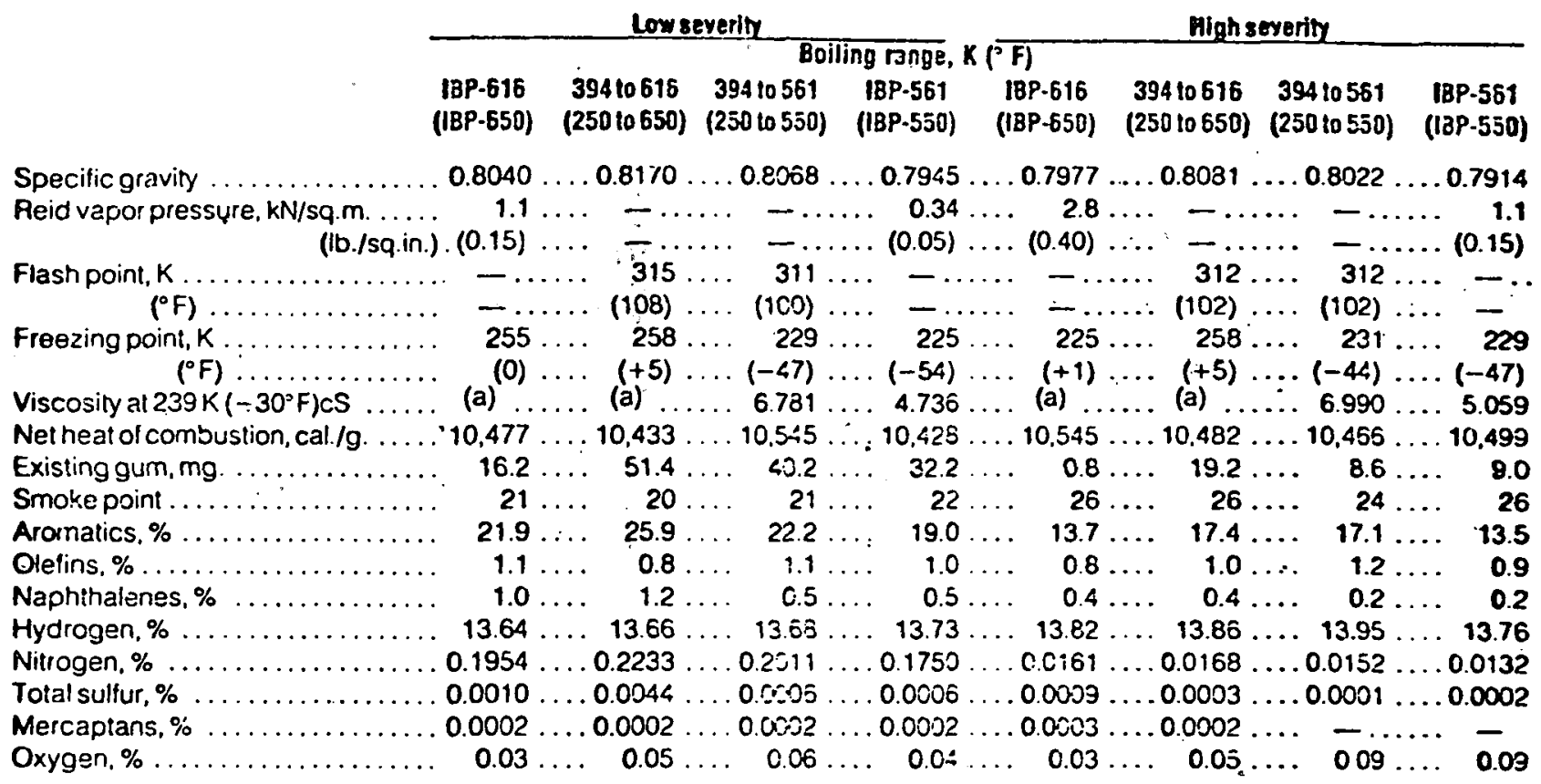

(b) High yield shale products

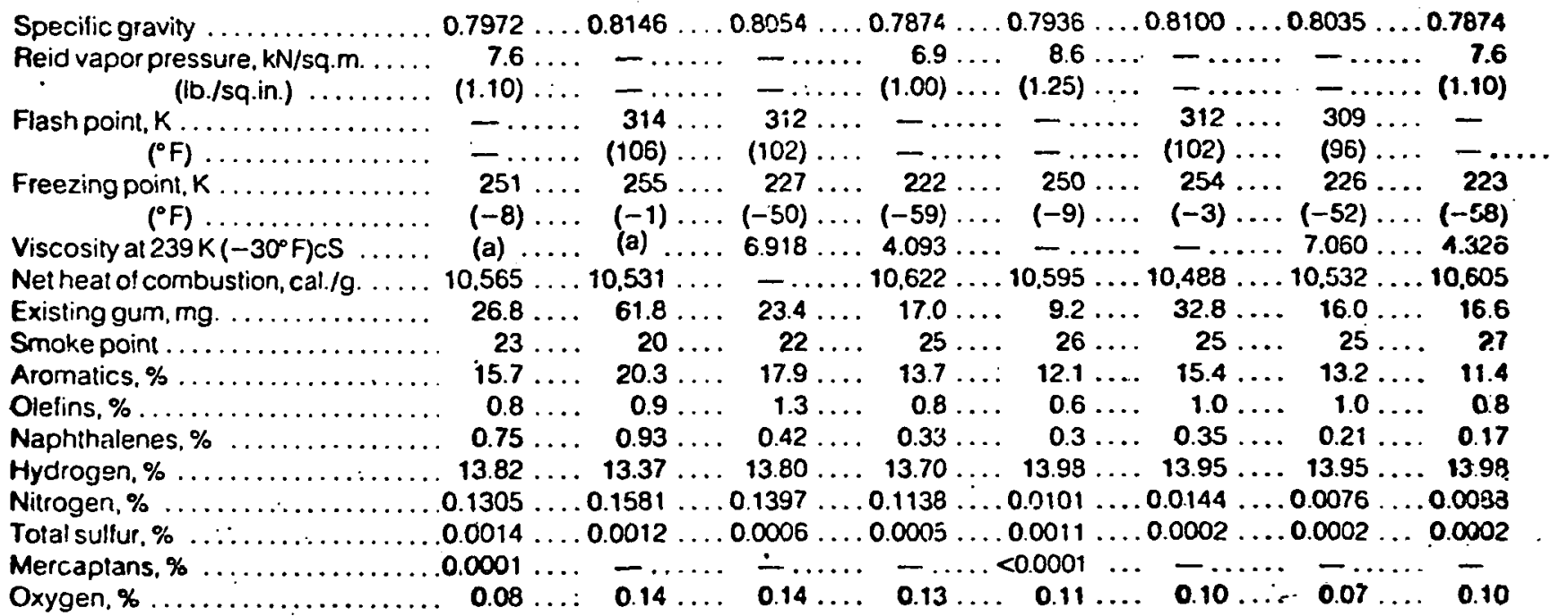


TABLE 14 (Continued)

(c) Low yield H-COsi products

\begin{tabular}{|c|c|c|c|c|c|c|c|}
\hline \multicolumn{4}{|c|}{ High severity } & \multicolumn{4}{|c|}{ Low severity } \\
\hline & & & & & & & \\
\hline $\begin{array}{l}8 P-616 \\
8 P-650)\end{array}$ & $\begin{array}{c}394 \text { to } 616 \\
(250 \text { to } 650)\end{array}$ & $\begin{array}{c}394 \text { to } 561 \\
(250 \text { to } 550)\end{array}$ & $\begin{array}{c}\text { IBP-561 } \\
\text { (IRP-550) }\end{array}$ & $\begin{array}{c}\text { IBP-616 } \\
\text { (IBP-650) }\end{array}$ & $\begin{array}{l}394 \text { to } 616 \\
(250 \text { to } 650)\end{array}$ & $\begin{array}{c}394 \text { to } 551 \\
(250 \text { to } 550)\end{array}$ & $\begin{array}{c}\text { IBP-561 } \\
\text { (IBP-550) }\end{array}$ \\
\hline
\end{tabular}

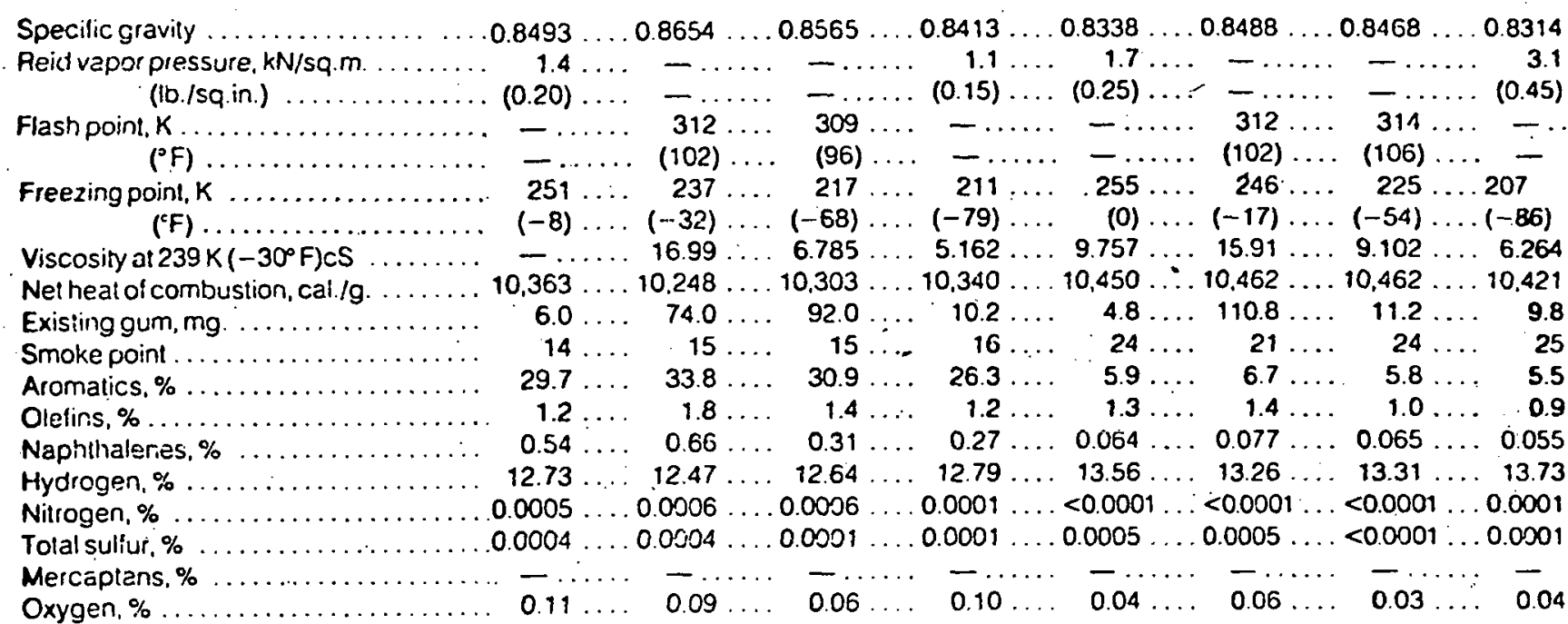

(d) High yield COED products

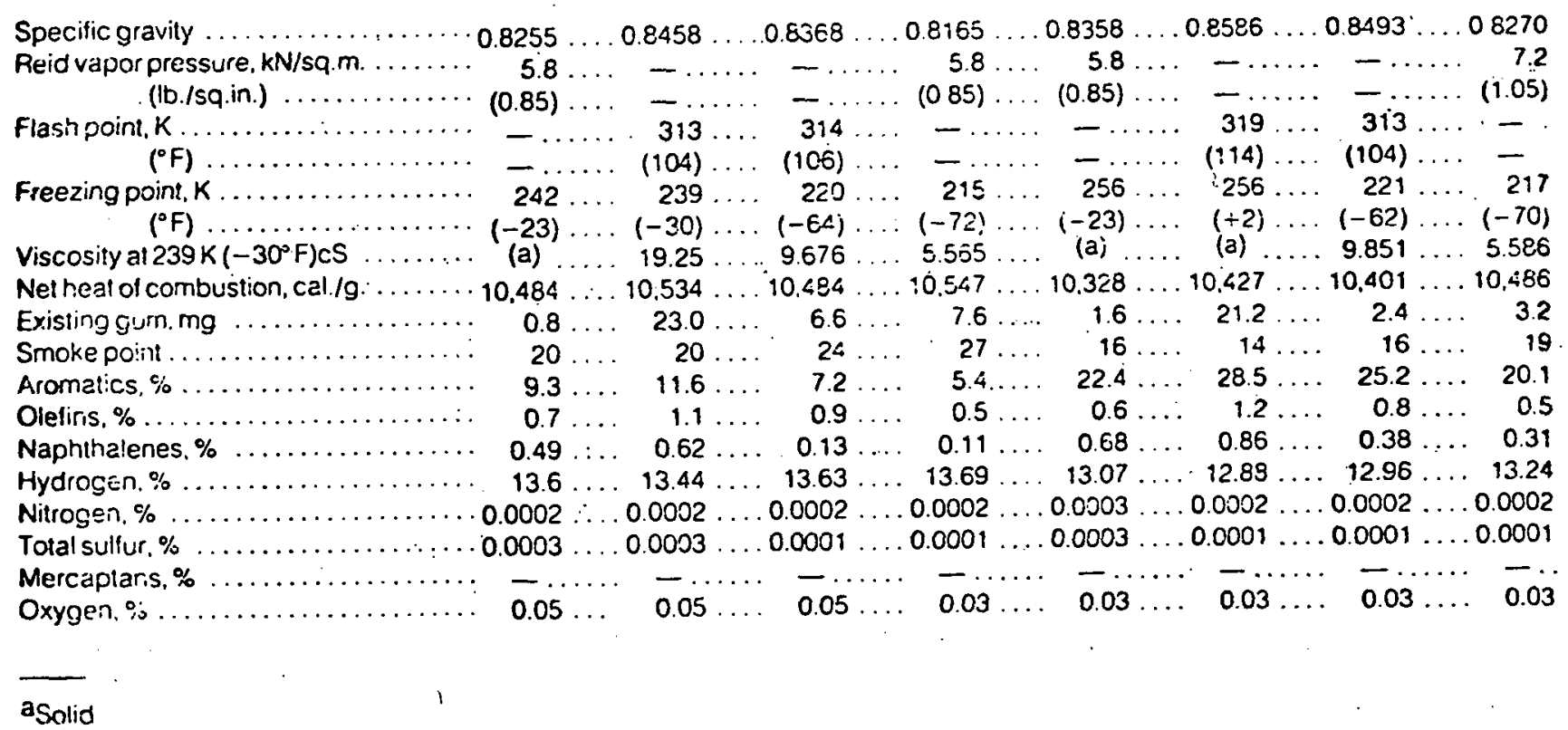


Regarding product quality, the inspections in Table 3-14 indicate that the requirement for 1 imits on aromatics $(<20 \%,<40 \%)$ were met. The requirements for percent hydrogen were met for all shale products and for most of the coal products. The requirements for sulfur were met for all of the products, and with one or two exceptions the requirements for nitrogen content were met for all products. The existing gum levels were high in some cases and may Indicate a stability problem that requires further study.

C. Jet A from Shale 011 (3-8)

A 300-gal. sample of Jet A quality aviation turbine fuel was produced from a $310 / 500^{\circ} \mathrm{F}$ kerosine cut from raw Paraho shale ofl by hydrofining using a commerclally avallable NiMo catalyst (HD8-3A). The processing conditions were as follows:

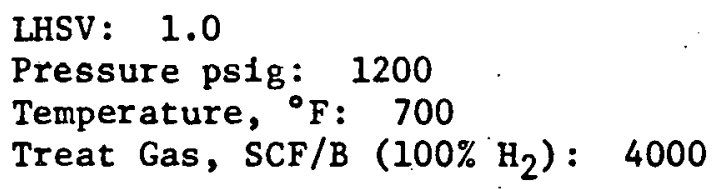

As shown in Table 3-15, the composite sample inspections met all those required for Jet A aviation turbine fuel.

D. Flammability and Ignition Properties of $\mathrm{JP}-5$ Fuels from Various Sources $(3-2)$

The flamability and ignition properties of JP-5 from various sources are shown in Table 3-16. The tar-sand, shale-oil and one of the coal samples had flash points which were below the $140^{\circ} \mathrm{F}$ min specification requirement. The remaining fuels from coal had.flash point higher than specification requirements and also higher than the usual run of petroleum JP-5. Flammability indices of the alternate fuels differ somewhat from that of petroleum fuels. In general, the flammability properties of the JP-5 from alternate sources were not significantly different from that of JP-5 from petroleum.

E. Gasoline from Coal and Shale (3-17)

Experimental batches of gasolines and naphthas were prepared from syncrudes derived from coal and ofl shale. The data in Table 3-17 compares the composition of gasoline from shale oll to petroleum derived gasoline. Table 3-18 gives published data for syncrude naphthas. Although In actual practice the synfuels may have compositions different from those shown, these data do. give an indication of what might be expected. The indications are that the naphtha composition is very dependent on coal or shale oll sources and the liquefaction processes. The H-coal hydrogenation produced more $2+$ ring aromatic compounds than the COED process and the Wyoming subbituminous coal produced naphtha with a higher concentration of nitrogen compounds than the Illinois bituminous. The last two naphthas would probably be refined further to remove nitrogen and $2+$ ring aromatics before using in comercial gasolines. 
TABLE 3-15

PRODUCT QUALITY OF HYDROTREATED PARAHO SHALE OIL

Total Sulfur Content, wppm

FIA Aromatics, Vol.\%

PM Closed Cup Flash Pt., ${ }^{\circ} F$

Freeze Pt., ${ }^{\circ} \mathrm{F}$

Smoke Pt.,

Kin. Viscosity $-30^{\circ} \mathrm{F}$, cs

ASTM D-86

$10 \%,{ }^{\circ} \mathrm{F}$

$50 \%,{ }^{\circ} \mathrm{F}$

FBP

AP'I Gravity
Jet A Spec

Max. 3000

Max. 2:

Min. 105

Max. -36

Min. 25

Max. 15

Max. 400

Max. 450

Max. 550

39-51
Hydrotreated Paraho Shale Oll

115

14.3

127.6

$-42.7$

26.6

9.13

366

407

496

46.0

Source: Ref. 3-8 
TABLE $3-16$

FLAMMABILITY PROPERTIES OF JP-5 FUELS FROM ALTERNATE SOURCES

\begin{tabular}{|c|c|c|c|c|c|c|}
\hline SOURCE & $\begin{array}{l}\text { NRL } \\
\text { No. }\end{array}$ & $\frac{\text { FLASH }}{\text { TAG }}$ & $\frac{\text { POINT }\left({ }^{\circ} \mathrm{F}\right)}{\frac{. \mathrm{PMCC}}{2}}$ & $\begin{array}{l}\text { FLAM. INDEX* } \\
\text { at } 125^{\circ}(\%)\end{array}$ & AIT & $\left({ }^{\circ} \mathrm{F}\right)^{3 * *}$ \\
\hline Tar Sands & $75-7$ & 131 & 135 & 91.0 & & 478 \\
\hline Shale Oil & $75-12$ & 134 & 137 & 87.8 & & 466 \\
\hline Coal (HAK) & $75-13$ & 136 & 139 & 86.0 & & 487 \\
\hline Coal (LAK) & $75-5$ & 169 & 170 & 31.5 & & 487 \\
\hline Coal (LAU) & $75-6$ & 169 & 172 & 30.2 & & 478 \\
\hline Coal (HAK) & $75-3$ & 173 & 174 & 22.8 & $\cdot$ & 486 \\
\hline Coal (HAU) & $75-4$ & 175 & 181 & 21.9 & & 489 \\
\hline Petroleum & $73-1$ & 141 & 143 & 56.0 & & 469 \\
\hline Petroleum & $70-9$ & 141 & 149 & 62.0 & & 489 \\
\hline
\end{tabular}

\footnotetext{
Notes: 1 - Tag Closed Cup, ASTM D-56

2 - Pensky-Martens Closed Cup, ASTM D-93

3 - Minimum autolgnition temperature, ASTM D-2155

* Ratio of vapor conc. In air to that at lower inflammability IImit

** Autoignition temperature
}

Source: $\operatorname{Ref}$. 3-2 
TABLE $\quad 3-17$

COMPOSITION OF SYNTHETIC GASOLINE

FROM THE PARAHO PROCESS

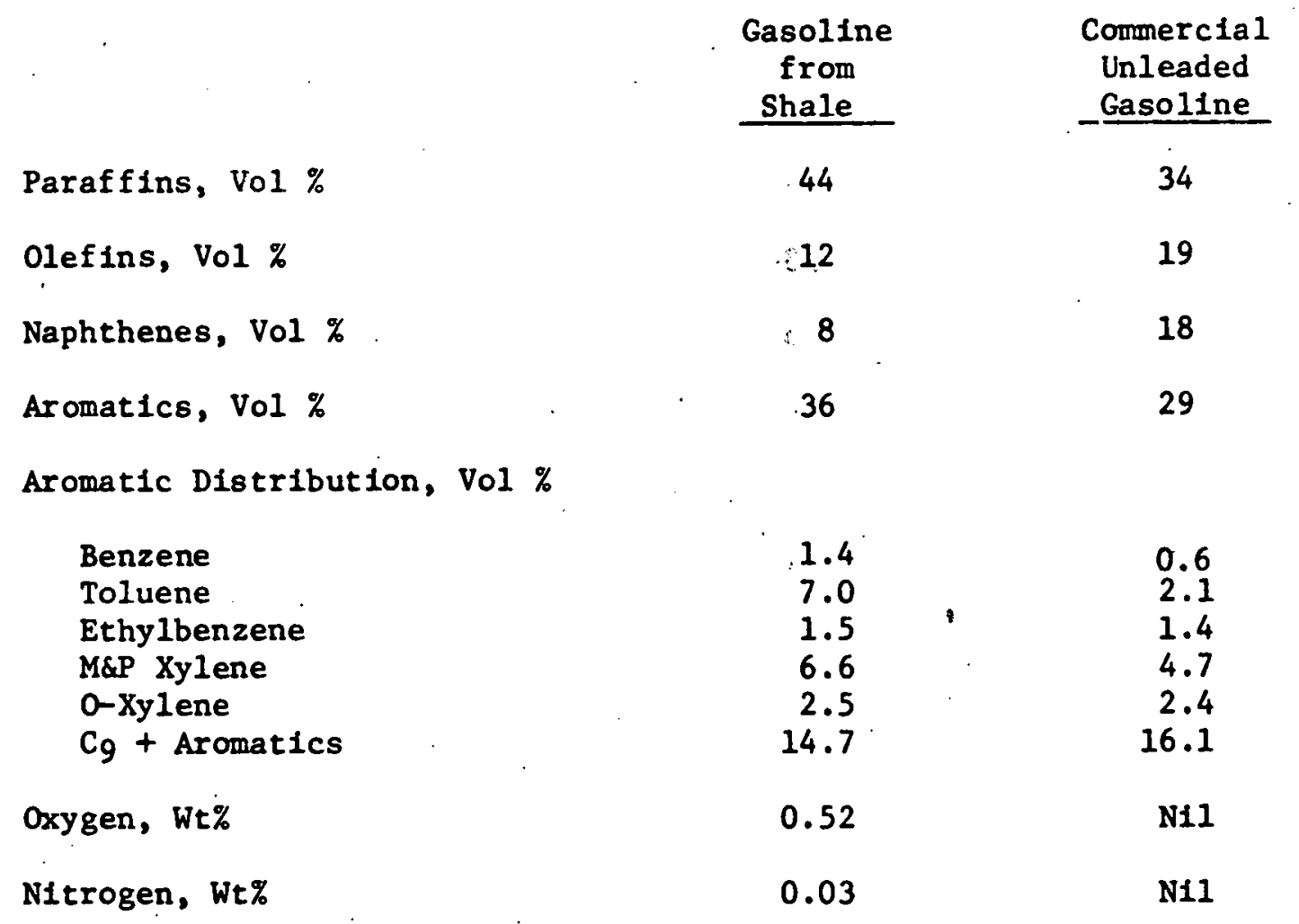

Source: Ref. 3-17 
TABLE 3-18

PROPERTIES AND EYDROCARBON COMPOSITION OF NAPHTHAS FROM SYNCRUDES

\begin{tabular}{|c|c|c|c|c|c|}
\hline Soutic: & Oil Shale, Wjoming & Oil Sliale, Colorado & $\begin{array}{l}\text { Bituminous coul. } \\
\text { Illinois }\end{array}$ & $\begin{array}{l}\text { Bituminosus Coal, } \\
\text { Illinois }\end{array}$ & $\begin{array}{l}\text { Subbiluminous coul. } \\
\text { W'yoming }\end{array}$ \\
\hline Liquelation process & In Situ Combustion & Combustion Reiont & COED. Pyrolysis & $\begin{array}{l}\text { H-Coal. } \\
\text { Hydrngchation }\end{array}$ & $\begin{array}{l}\text { HCoal } \\
\text { liydrogination }\end{array}$ \\
\hline Trestmeill of crude oil & $\begin{array}{l}\text { Coked and } \\
\text { Hydrogenated }\end{array}$ & $\begin{array}{l}\text { Coked and } \\
\text { Hydrogenated }\end{array}$ & Ilydrogindicd & $\ldots$ & $\cdots$ \\
\hline 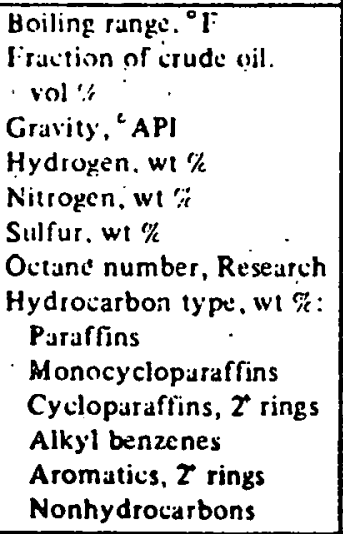 & $\begin{array}{c}175^{\circ} \cdot 350^{\circ} \mathrm{F} \\
22.4 \\
52.6 \\
- \\
0.0001 \\
0.001 \\
- \\
42.8 \\
43.4 \\
13.8 \\
<0.001\end{array}$ & $\begin{array}{c}180^{\circ}-400^{\circ} 1: \\
\\
34.5 \\
51.3 \\
14.2 \\
0.024 \\
0.001 \\
32.8 \\
47.7 \\
34.5 \\
2.4 \\
13.2 \\
2.2 \\
-\end{array}$ & $\begin{array}{c}180^{\circ}-390^{\circ} \mathrm{F} \\
\\
33.1 \\
43.8 \\
\cdots \\
0.013 \\
0.009 \\
70.1 \\
7.1 \\
58.9 \\
12.5 \\
19.8 \\
1.7 \\
-\end{array}$ & $\begin{array}{c}C .400^{2} \mathrm{I} \\
33 \\
49.2 \\
\cdots \\
0.10 \\
0.099 \\
\cdots \\
12.0 \\
47.9 \\
14.5 \\
17.6 \\
7.0 \\
0.9\end{array}$ & $\begin{array}{c}.-400^{\circ} \mathrm{F} \\
57 \\
50 \\
\cdots \\
0.20 \\
<0.07 \\
- \\
18.9 \\
44.5 \\
15.0 \\
14.2 \\
5.9 \\
1.7\end{array}$ \\
\hline
\end{tabular}

Source: Ref. 3-17 
F. JP-5 Fuels from Coal ${ }^{(3-5)}$

The properties of JP-5 type fuels derlved from Western Kentucky and Utah coals are shown in Tables 3-19 to 3-22 inclusive. The syncrudes from each coal were processed to produce a high aromatic (20-25 vol\%) (single-stage hydrotreat) and low aromatic (0-5 vol\%) (two-stage hydrotreat) product.

In general, the API gravity of all these products was below minimum specifications and the viscosity was slightly high. The smoke point was too low with all samples except the low aromatic fuel from Utah coal. The acid number tended to be relatively high for the high aromatic products. It appears to be more difficult to meet the freezing point with the Utah coal product than with that from Western Kentucky.

Figure 3-1 shows that a high hydrogen content will usually be accompanied by a high smoke point.

Table 3-23 from another source (3-18) also indicates that it may. be difficult to meet smoke point with a gas turbine engine fuel produced from a Western Kentucky coal.

G. Navy Boiller Fuel from Coal (3-7)

The Naval Ship Research and Development Center has determined the characteristics of Navy Distillate type boiler fuel that might be produced from coal. The data are shown in Table 3-24. The coal-derived samples tested are deficient in the cetane number and API gravity requirements of MIL-F-24397 fuel specifications.

\section{H. Gas Turbine Fuels from Synthetic Crude 011s (3-19)}

"Synthetic" jet fuels from both shale and coal syncrudes were produced by a processing sequence employing fractional distillation and catalytic hydrogenation. Feed fractions encompassing the jet fuel bolling range were distilled from the starting crude olls and hydrotreated at varying severity over nickel and/or cobalt-molybdenum catalysts. Final narrow cut (Jet A) and/or wide-cut (JP-4) fuels were blended from the hydrotreated products and their properties determined. These inspections are listed in Tables 3-24 to 3-29. It appears that the production of aircraft jet fuels from shale oil-derived crude is technically feasible and should be more straightforward than would be the comparable production from coal-derived ofls. Hydroprocessing severity is important to the production of specification fuels. Production of spectfication jet fuel from shale liquids will require moderate severity hydroprocessing e 1500 psi total pressure. Coal-derived fueis, however, will not meet density specifications unless hydrotreated at 2200 ps1. Increasing processing severity, in general, improved the thermal stability and decreased the aromatic hydrocarbon and nitrogen content of the product fuel. Sulfur levels of the processes fuels were all well below specifications at all processing severitles. 
Fue 1: No. 0001, High Aromatic (20-25 vol 3), Coal Source: Western Kentucky

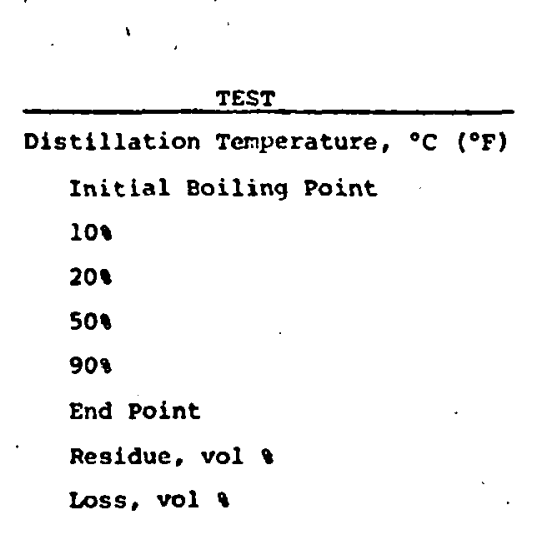

Gravity, $A P I$

Freezing Point, ${ }^{\circ} \mathbf{F}$

Axomatics, vol s

Smoke Point, $\mathrm{mm}$

Flash point, ${ }^{\circ} \mathrm{C}\left({ }^{\circ} \mathrm{F}\right)$

Existent Gum, mg/100 ml

sulfur, wt.

Heạting Value, MJ/kg (BTU/1b)

viscosity, est $-34^{\circ} \mathrm{C}\left(-30^{\circ} \mathrm{F}\right)$

olefins, vol

Partlculate Matter, mg/l

Total Acid No.

Nitrogenn, wt.

Carbesn, wt.

Hydrogen we.

-Valuo taken Irom MIL-T-5624J.
Thermal stablilty

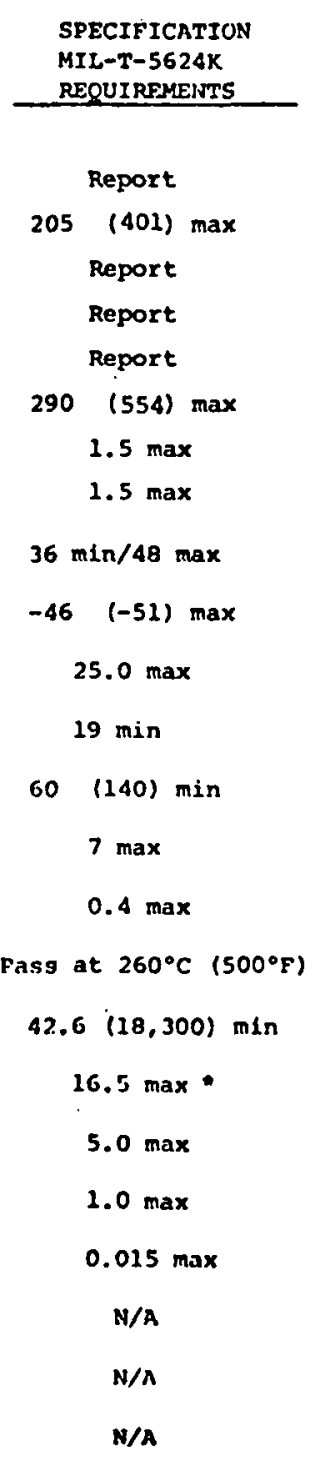

D-287

D-2386

D-1319

D-1322

D-93

D-381

D-1266

D-3241

$D-240$

$D-415$

D-1319

D-2276

$0-974$

$-$

$-$

$-$

\begin{tabular}{cccc}
\multicolumn{3}{c}{ RESULTS } \\
\hline SUN O1L COMPANY & \multicolumn{2}{c}{ NAPTC } \\
\cline { 3 - 4 } $188(371)$ & 202 & $(396)$ \\
212 & $(414)$ & 213 & $(416)$ \\
217 & $(423)$ & 219 & $(426)$ \\
234 & $(453)$ & 237 & $(458)$ \\
266 & $(510)$ & 267 & $(513)$ \\
279 & $(535)$ & 283 & $(542)$ \\
1.0 & 1.0 \\
1.0 & 0.0 \\
30.8 & 30.2 \\
-56 & $(-68)$ & -48 & $(-54)$ \\
22.7 & 24.8 \\
11 & 17.0 \\
80 & $(176)$ & 80 & $(176)$ \\
2 & 0.0 \\
0.001 & 0.05
\end{tabular}

1
$\frac{1}{a}$

$\begin{array}{lc}43.0(18,470) & 42.6(18.294) \\ 23.5 & 23.69 \\ 1.1 & 1.0 \\ 0.04 & 1.0 \\ 0.0 n 1 & - \\ 0.05 & - \\ 86.82 & 89.00 \\ 12.73 & 12.85\end{array}$

s ce: Ref. 3-5 
rual, Mo. 0003, High Aromatic (20-25 voli), coal sourcer Utah

\begin{tabular}{l} 
TEST \\
\hline Distillation Temper \\
Initial Bolling \\
10 s \\
208 \\
508 \\
904 \\
End Point \\
Residue, vol \\
Loss, vol
\end{tabular}

Gravity, 'API

Freezing Point, ${ }^{\circ} \mathrm{C}\left({ }^{\circ} \mathrm{F}\right)$

Aromatics, vol

Smoke Point, mm

rlash Point; ' $\mathrm{C}\left({ }^{\circ} \mathrm{F}\right)$

Existent Gum, mg/100 ml

sulfur, wt.

Thermal Stability

Heating value, MJ/KG (BTU/Lb)

viscosity, cst $-34^{\circ} \mathrm{C}\left(-30^{\circ} \mathrm{F}\right)$

Olefins, vol.

Partikulate Matter, mg/l

Sotal Acid No.

Nitrogen, wt.

Carbon, wt.

Hydrogen, wt.

-valui: taken from MIL-T-5624J.

\begin{tabular}{l} 
SPECIFICATION \\
MIL-T-5624K \\
REQUIREMENTS \\
\hline
\end{tabular}

ASTM

STANDARD

D-86

Report

205 (401) max

Report

Report

Report

290 (540) max

$1.5 \max$

$1.5 \max$

D-287

D-2386

D-1319

D-1322

D-93

D- 381

D-1266

D-3241

D-240

D-445

D-1319

D-2276

D-974

-

$-$

\section{$36 \min / 48 \max$}

$-46(-51) \max$

$25.0 \max$

$19 \max$

60 (140) min

$7 \max$

$0.4 \max$

Pass at $260^{\circ} \mathrm{F}\left(500^{\circ} \mathrm{C}\right)$

$42.6(18,300) \mathrm{min}$

$16.5 \max *$

$5.0 \max$

$1.0 \max$

$0.015 \max$

$\mathrm{N} / \mathrm{n}$

N/A

N/A

\begin{tabular}{cccc}
\multicolumn{3}{c}{ RESULTS } \\
\cline { 1 - 1 } SUN OIL COMPANY & \multicolumn{2}{c}{ NAPTC } \\
\cline { 2 - 3 } $207 \quad(405)$ & 209 & $(408)$ \\
$217 \quad(423)$ & 219 & $(426)$ \\
$221 \quad(430)$ & 223 & $(434)$ \\
$234 \quad(454)$ & 238 & $(460)$ \\
$262 \quad(503)$ & 264 & $(508)$ \\
$284 \quad(543)$ & 279 & $(535)$ \\
1.0 & 1.2 \\
1.0 & 0.0 \\
32.8 & 32.4 \\
$-43 \quad(-46)$ & -40 & $(-40)$ \\
21.8 & 24.1 \\
11 & 17.0 \\
80 & $(176)$ & 81 & $(178)$ \\
1 & 0.1 \\
$<0.0001$ & 0.04
\end{tabular}

pass at $263^{\circ} \mathrm{C}\left(505^{\circ} \mathrm{F}\right)$

$42.7 \quad(18,372)$

22.94

1.20

1.45

$-$

84.90

13.40

Source: Ref. 3-5 


\section{SPECIFICAT ION ANALYSIS OF PHASE I JP-5 TYPE FUEL DERIVED FROM COAL}

ruel, No. 0003 Low Aromatic (0-5 vol I), Cosl sources

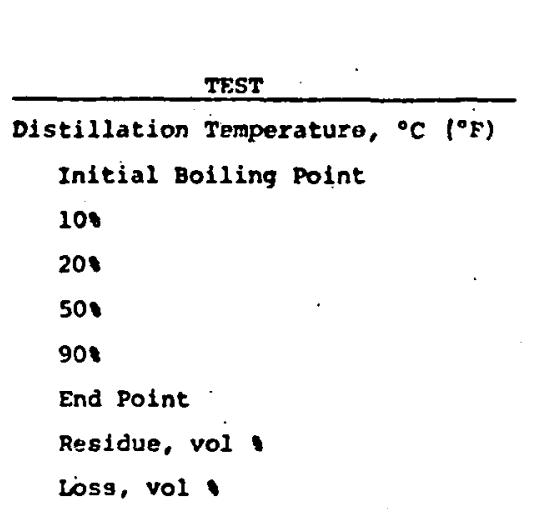

Gravity, ${ }^{\circ}$ API

Freezing Point, ${ }^{\circ} \mathrm{C}\left({ }^{\circ} \mathrm{P}\right)$

Aromatics, vol :

smoke Point, sm

rlash Point, ${ }^{\circ} \mathrm{C}\left({ }^{\circ} \mathrm{F}\right)$

Existent Gum, $\mathrm{mg} / 100 \mathrm{ml}$

Sulfur, wt.

Thermal stability

Heating Valuc, $M J / k g$ (BTU/Lb)

Viscosity, est $-34^{\circ} \mathrm{C}\left(-30^{\circ} \mathrm{F}\right)$

Olefins, vol:

Partioulate Matter, mg/1

rotal Acld No.

Nitrogon, WL.

Carbon, wt.

Hydroyen, wt.

-Value taken from HIL-T-5624J.
Mostern Kontucky

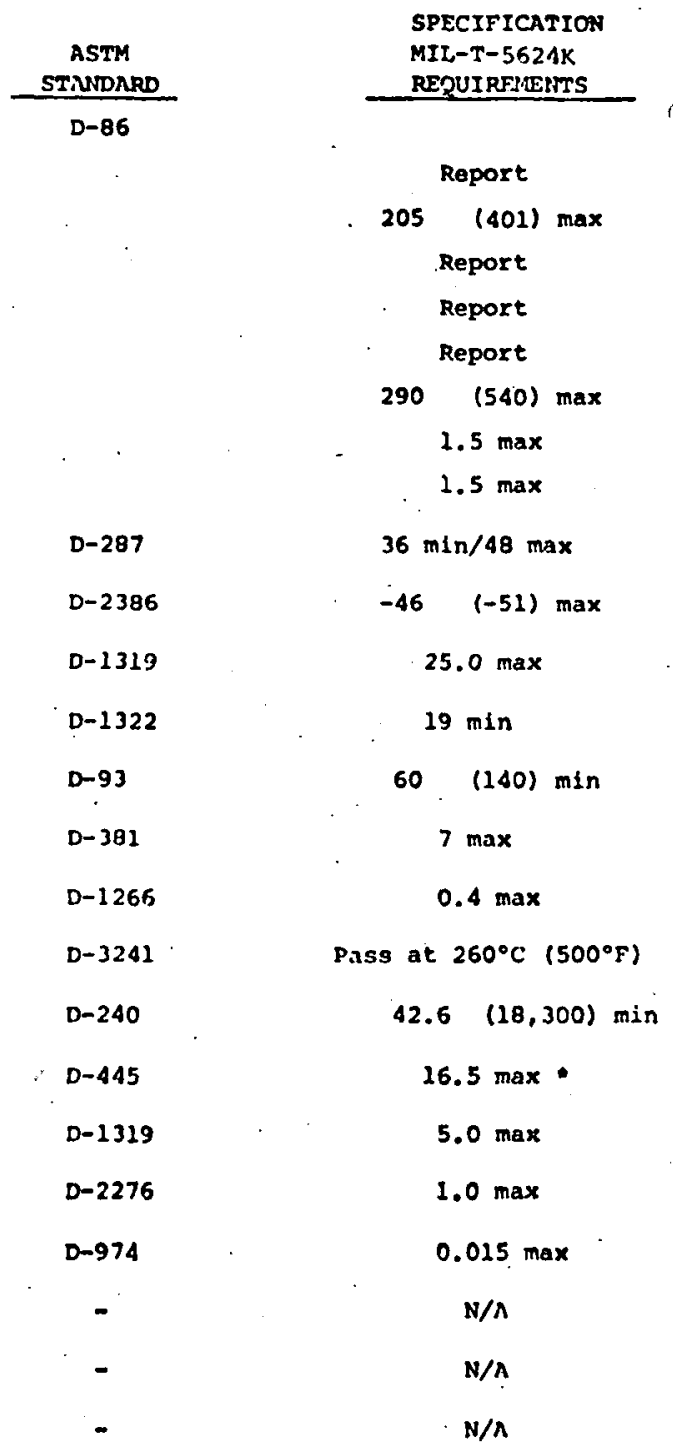

\begin{tabular}{|c|c|c|c|}
\hline \multicolumn{4}{|c|}{ PESULTS } \\
\hline \multicolumn{2}{|c|}{ SUN OIL COMPANY } & \multicolumn{2}{|c|}{ NAPTC } \\
\hline 199 & $(309)$ & 200 & (392) \\
\hline 212 & (413) & 213 & (416) \\
\hline 217 & $(423)$ & 219 & (426) \\
\hline 235 & (455) & 238 & $(460)$ \\
\hline 268 & $(515)$ & 270 & (518) \\
\hline 277 & $(530)$ & 286 & (546) \\
\hline \multicolumn{2}{|c|}{0.4} & \multicolumn{2}{|c|}{1.0} \\
\hline \multicolumn{2}{|c|}{1.6} & \multicolumn{2}{|c|}{0} \\
\hline \multicolumn{2}{|c|}{32.4} & \multicolumn{2}{|c|}{31.8} \\
\hline-54 & $(-65)$ & -50 & $(-58)$ \\
\hline \multicolumn{2}{|c|}{3.1} & \multicolumn{2}{|c|}{4.69} \\
\hline \multicolumn{2}{|c|}{16} & \multicolumn{2}{|c|}{22} \\
\hline 76 & (168) & 79 & (174) \\
\hline \multicolumn{2}{|c|}{1} & \multicolumn{2}{|c|}{0} \\
\hline \multicolumn{2}{|c|}{$<0.0001$} & \multicolumn{2}{|c|}{.005} \\
\hline
\end{tabular}

Pass at $>371^{\circ} \mathrm{C}\left(700^{\circ} \mathrm{F}\right)$

$42.8 \quad(18,383)$

25.95

1.56

0.93

0.39

0.005

0.13

85.75

85.6

14.11 


\section{SPECIFICATION ANALYSIS OF PHASE I JP-5 TYPE FUEL DERIVED FROM COAL}

Fuel: No. 0004, Low Aromatic (0-5 vol. 1), Coal sourcel Utah

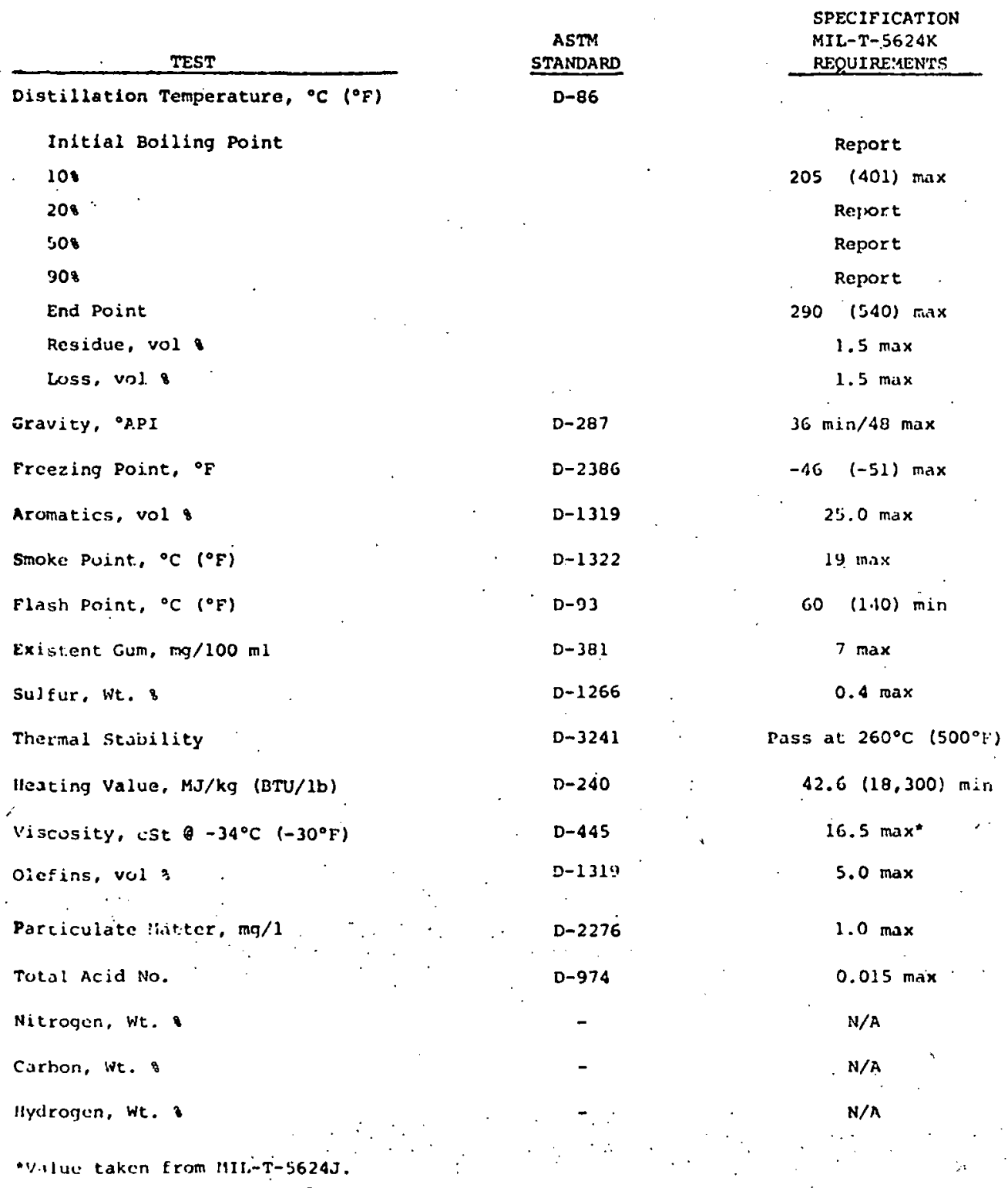

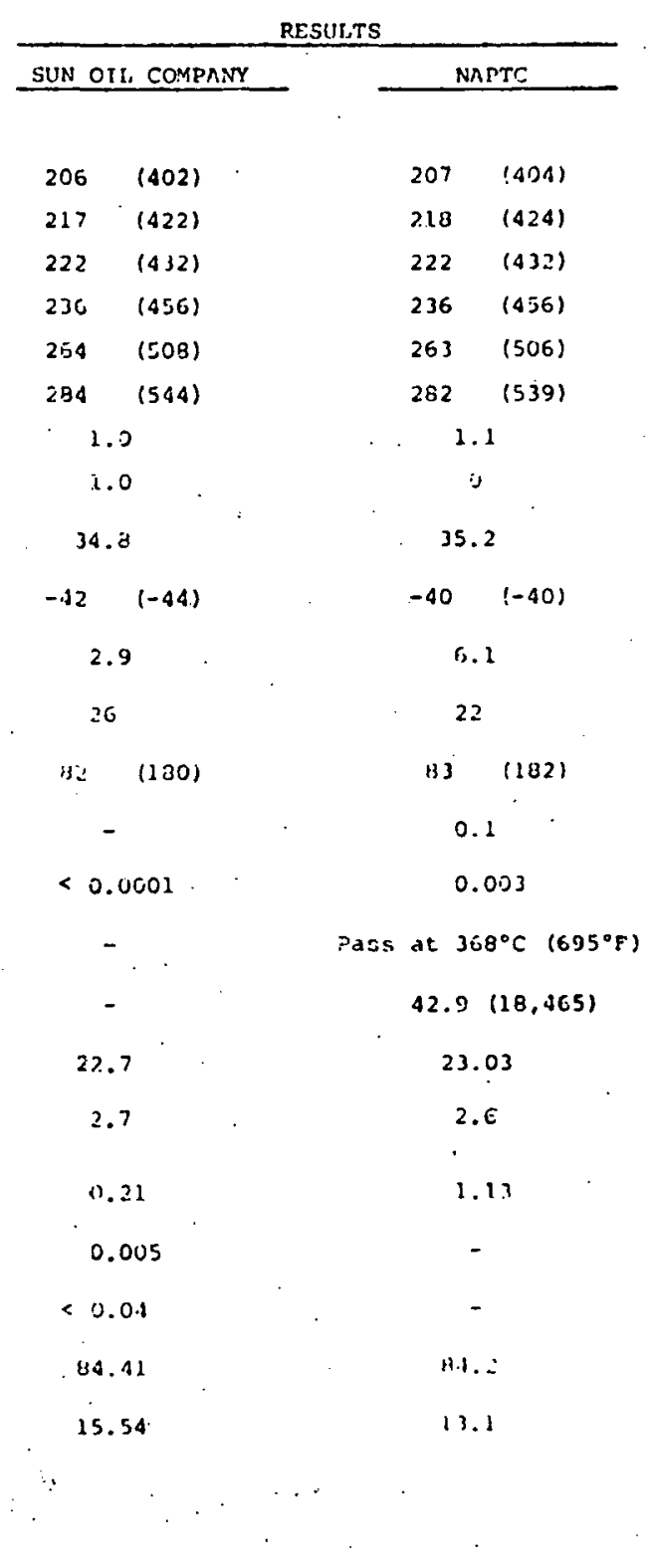




\section{FIGURE $3-1$}

VARIATION IN SMOKE POINT VALUES

FOR FUEL DERIVED FROM COAL

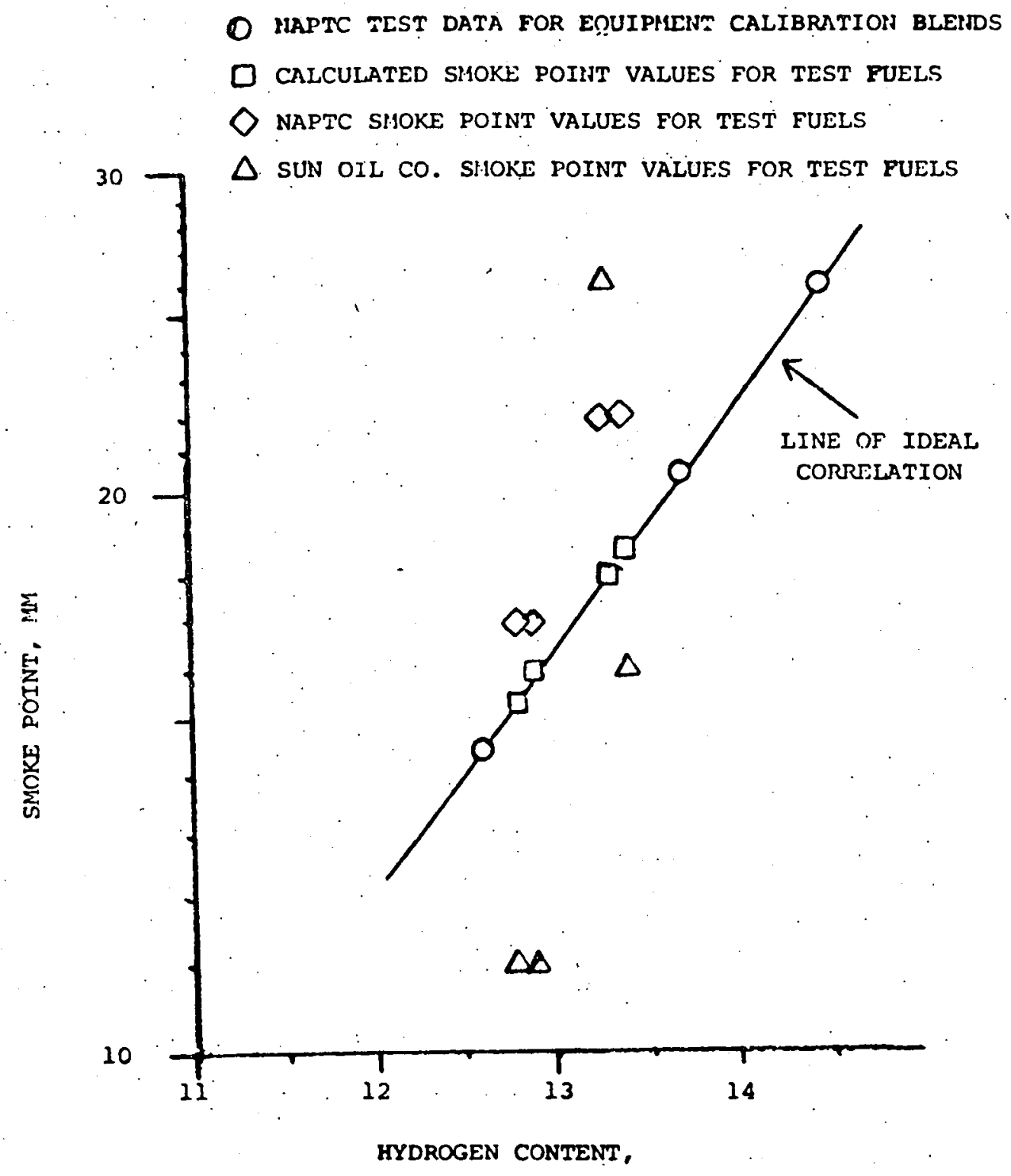

Source: Ref. 3-5 
TABLE 3-23

HYDROGENATION CONDITIONS AND PROPERTIES OF GAS TURB INE ENGINE FUEL SAMPLE PREPARED FROM COAL SYNCRUDE

\section{H.YLZOGENATION}

Feeds tock

Syncrude Codl Source

Aromatics (D1319), Vol.?

Conditions

Catalyst (American Cyanamid)

Temperature, ' $F$. (Zone Outlet: $)$

Total Pressure, pslg

Space Rate, LHSV (Vol.)

Charge Race, Gal./Hour

Gas Recycle, SCF/Bbl.

$\mathrm{H}_{2}$ Bleed Rate, SCF/bbl.
Western Kentucky

48.8

HDS - $9 A$

$630-680$

3000

0.3

0.8

4000

115

\section{PRCOUCT PROPERTIES}

Sample DesIgnation

ASTM Test

D1319 Aromatics, Vol.\%

086 Distillation, ${ }^{\circ} \mathrm{F}$ $10 \%$

End Point

093 Flash Point, ${ }^{\circ} \mathrm{F}$

D287 Gravity, ${ }^{\circ}$ API

D2386 Freeze Point, ${ }^{\circ} \mathrm{F}$

D1322 Smoke Point, m
Desired

20-25

23.4

425 max.

500

364

502

140-155

140

30-48

34.1

-51 max.

$-70$

19 min. 
TABLE 3-24

OIL DERIVED FROM CQAL

Comparison of Fuel Properties

\begin{tabular}{|c|c|c|c|}
\hline Requirement & $\begin{array}{c}\text { Boiler } \\
\text { Navy Distillate } \\
\text { Fuel Spec } \\
\text { MIL-F-24397 }\end{array}$ & $\begin{array}{l}\text { COED } \\
\text { NSRDC } \\
\text { Full Range }\end{array}$ & $\begin{array}{l}\text { COED } \\
\text { NAVSEC PHILADIV } \\
\text { Topped }\end{array}$ \\
\hline viscosity, is at $100^{\circ} \mathrm{F}$ & $\therefore \quad 10.0 \mathrm{Max}$ & .4 .50 & 8.0 \\
\hline Ash, \% & i $0.01 \mathrm{Max}$ & 0.01 & 0.007 \\
\hline Pour point $F$ & +25 Max. & -5 & +20 \\
\hline Flash Point $F$ & $150 \operatorname{Max}$. & 58 & 160 \\
\hline Explosiveness, $q$ & $50 \mathrm{~min}$ & - & - \\
\hline $\begin{array}{l}\text { Water \& Sediment by } \\
\text { Centrifuge. \& }\end{array}$ & 0.02 & 0.30 & - \\
\hline $\begin{array}{l}\text { Sulfur, } \% \\
\text { Carbon Residue, } 10 \% \\
\text { Bottoms, } \%\end{array}$ & $\begin{array}{l}1.3 \mathrm{Max} . \\
0.4 \mathrm{Max} .\end{array}$ & 0.2 & $\begin{array}{c}0.16 \\
-\end{array}$ \\
\hline $\begin{array}{l}\text { Corrosion, Copper strip. } \\
212^{\circ} \mathrm{F} \text {. }\end{array}$ & $2 \operatorname{Max}$ & 4 & 2 \\
\hline $\begin{array}{l}\text { Emulsion Characteristics } \\
\text { Minutes. }\end{array}$ & 20 Max. & 120 & - \\
\hline Neutrality & Neutral & & \\
\hline \multicolumn{4}{|l|}{ Distillation } \\
\hline $\begin{array}{l}\text { 10\%, F } \\
50 \%, \circ \mathrm{F} \\
90 \%, \circ \mathrm{F} \\
95 \%, \circ \mathrm{F} \\
\text { End point, }{ }^{\circ} \mathrm{F} \\
\end{array}$ & $\begin{array}{l}500 \text { Max. } \\
644 \text { Max. } \\
740 \text { Max. } \\
765 \text { Max. } \\
\end{array}$ & $\begin{array}{l}292 \\
540 \\
727+ \\
- \\
- \\
\end{array}$ & $\begin{array}{c}409 \\
580 \\
780 \\
- \\
-\end{array}$ \\
\hline $\begin{array}{l}\text { Vanadium, PPM } \\
\text { Cetane Number, }\end{array}$ & $\begin{array}{r}0.5 \mathrm{Max} . \\
39 \mathrm{Min} .\end{array}$ & $\begin{array}{l}<0.1 \\
29 * \\
\end{array}$ & $\begin{array}{l}<0.1 \\
27.7^{*}\end{array}$ \\
\hline Gravitye API & $27 \mathrm{Min}$ & 23.1 & 18.4 \\
\hline $\begin{array}{l}\text { E.P. Propertics, } \\
\text { scar Dia.. mm }\end{array}$ & 0.55 & 0.392 & 0.511 \\
\hline - Getane Index & & . & \\
\hline
\end{tabular}

Source: Ref. 3-7 
JET A FUEL FROM SHALE OIL--INSPECTIONS

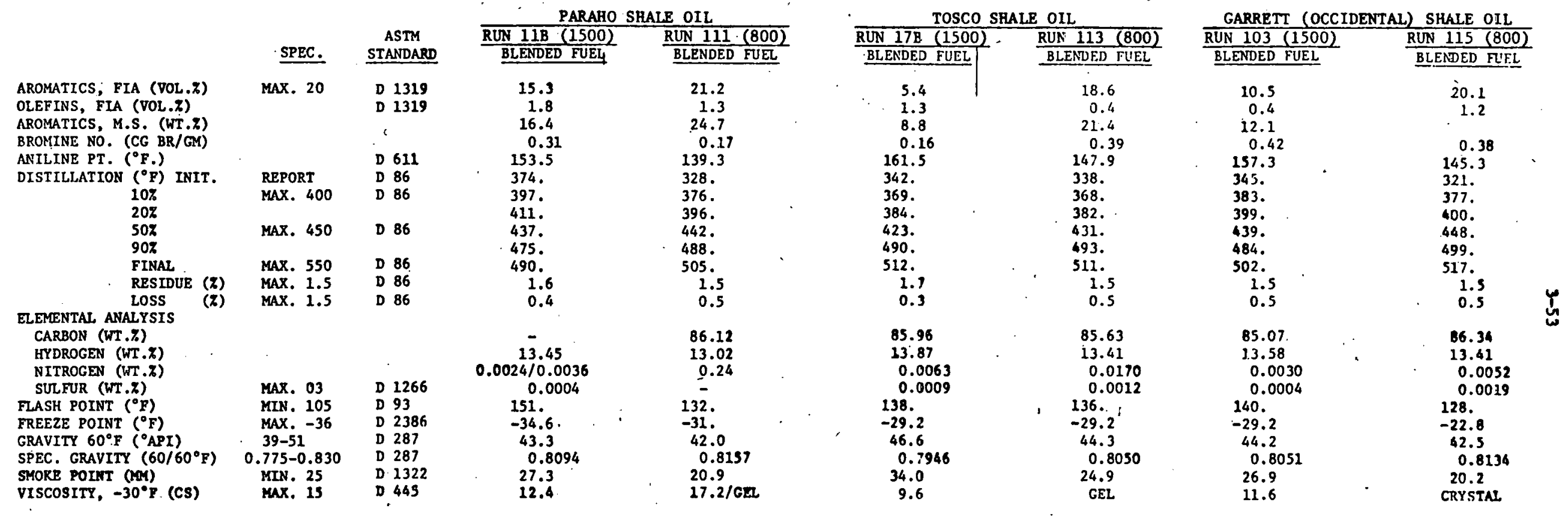

Source: Ref. 3-19 
TABLE 3-26

SYNTHETIC JP-4 (WIDE-CUT) AVIATION TURBINE FUEL BLEND FROM GARRETT (OCCIDENTAL) SHALE OIL

RUN NO.

404

Total Pressure, PSIG

2200

LHSV

0.48

ASTM Distillation

IBP

.246

5 Percent

275

10

296

20

332

30

383

40

434

50

453

60

463

70

470

80

476

90

486

95

494

EBP

500

Density, GMS/CC C $60^{\circ} \mathrm{F}$

0.7956

Mass Spectroscopy

Paraffins

49.2

Monocycloparaffins

33.8

Dicycloparaffins

9.3

Tricycloparaffins

1.7

PARAFFINS, Total

94.0

Alkylbenzenes

5.1

Indans

0.7

Indenes

0.0

Naphthalenes

$\underline{0.0}$

AROMATICS, Total

$\underline{5.8}$

Sulfur, Total Wt. Percent

0.0056

Nitrogen, Total Wt. Percent

0.0027

JFTOT, Spun Tube Deposit Rating, ${ }_{F}$

$>500$

Source: Ref. 3-19 
TABLE $3-27$

JP-4 FROM TOSCO SHALE OIL--INSPECTIONS

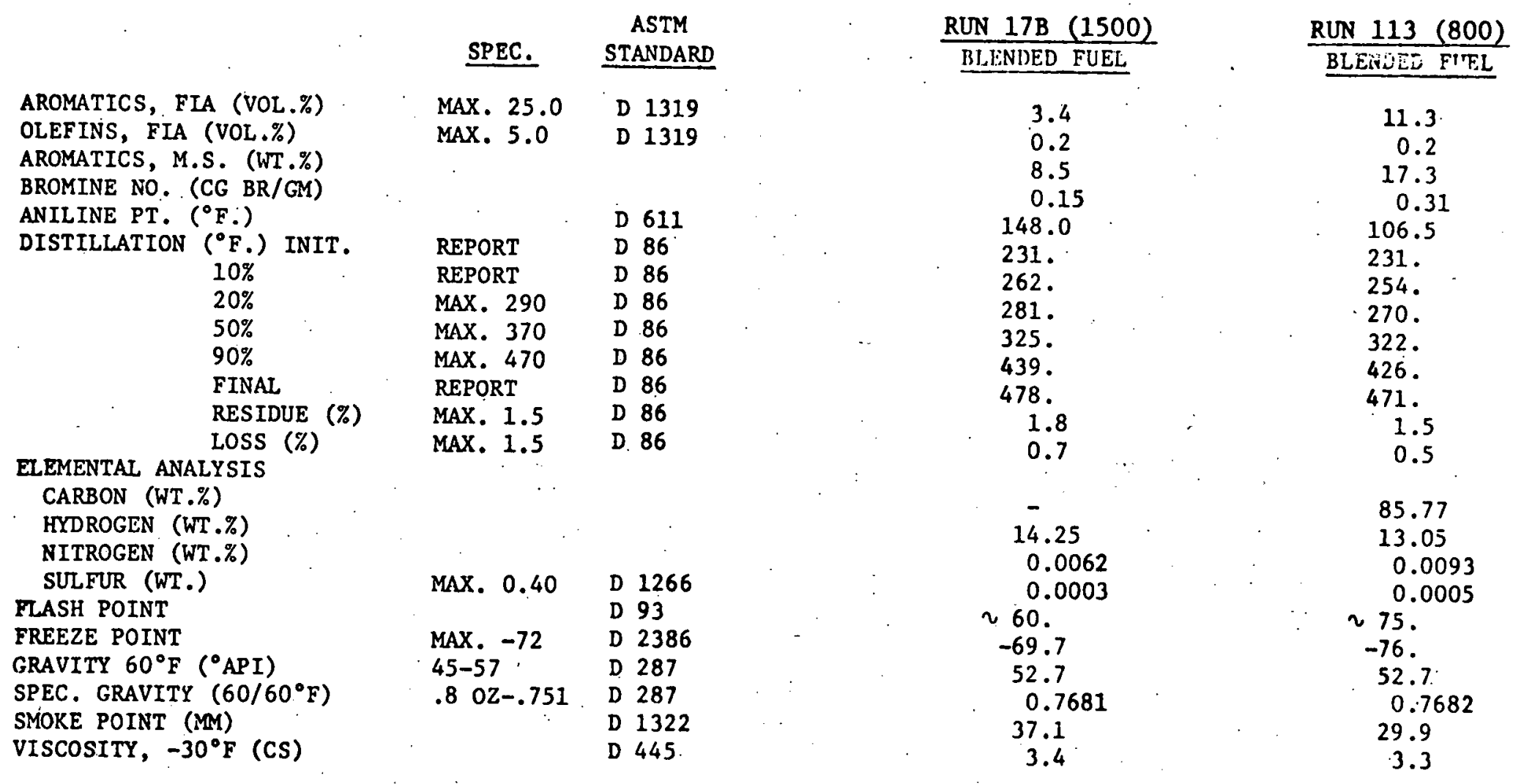

Source: Ref. 3-19 


\section{TABLE $\quad 3-28$}

JET A FROM H-COAL LIQUID--INSPECTIONS

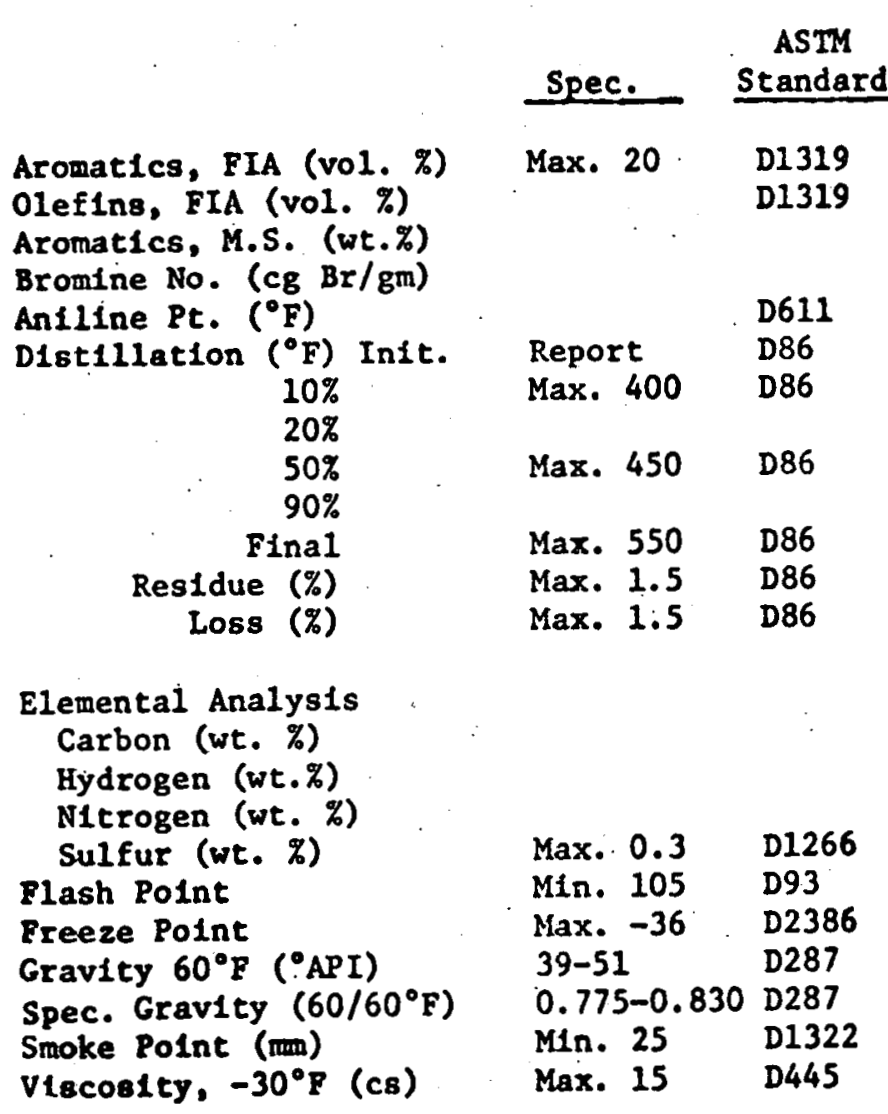

$\frac{\text { Run } 209(1500)}{\text { Blended Fue1 }}$

18.5

$$
0.8
$$$$
20.4
$$$$
0.18
$$$$
115.8
$$

340

369

381.

410

454

476

1.5

86.73

12.66

0.0047

0.0016

134

$-47$

35.7

0.8464

17.97

9.35
Run 304 (800) Blended Fuel

$$
\begin{gathered}
37.4 \\
1.6 \\
41.6 \\
0.39 \\
.76 .9 \\
347 \\
37 ? \\
384 \\
410 \\
456 \\
480 \\
2.0 \\
0.0
\end{gathered}
$$

87.91

11.70

0.0027

0.0006

138

$<-94$

30.7

0.8724

9.71

9.36 . 
JP-4 FROM H-COAL LIQUID--INSPECTIONS

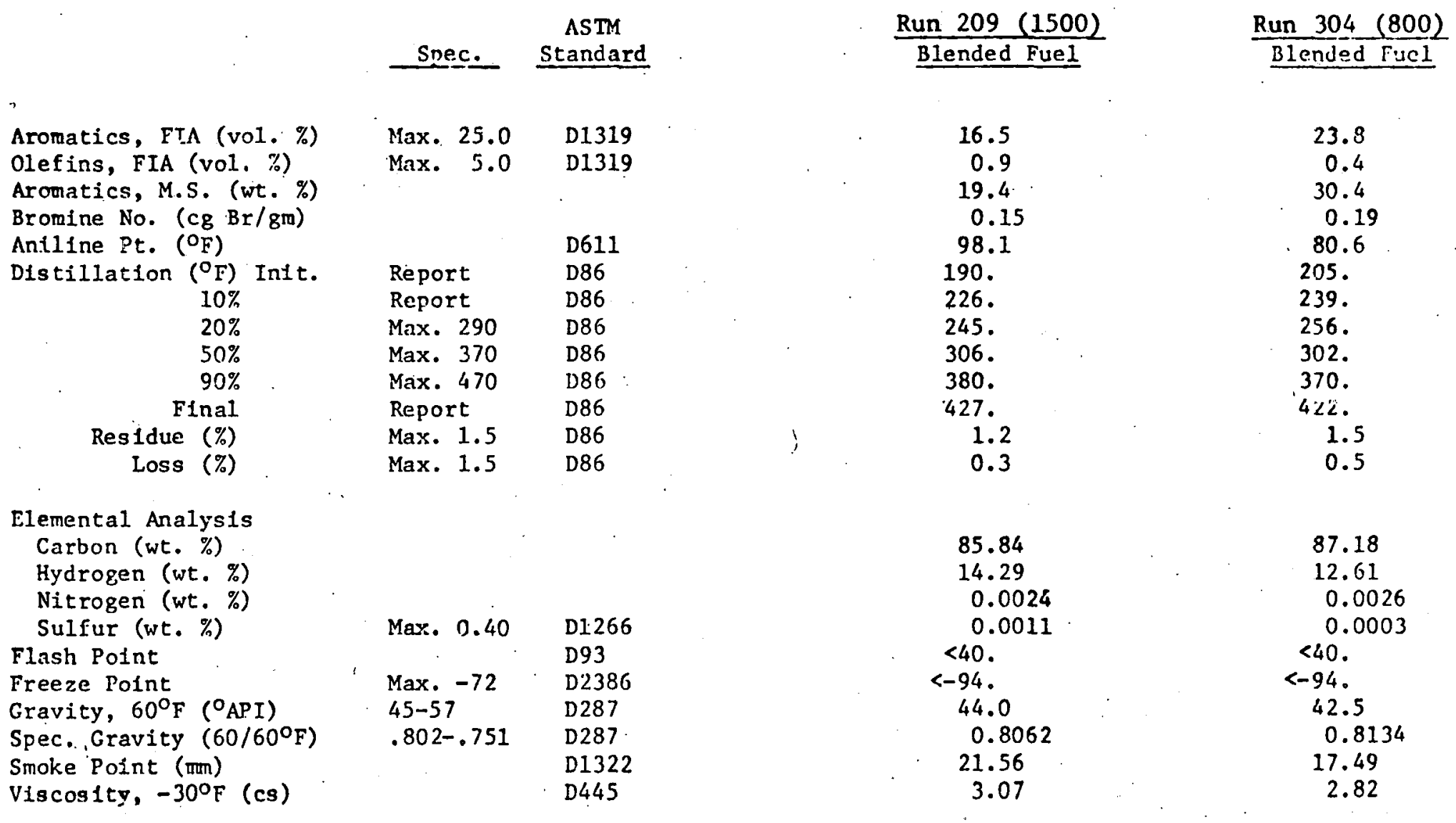


REFERENCES

3-1 Kant, F. H., et al., "Feasibility Study of Alternate Fuels for Automotive Transportation," ER\&E for EPA, Report No. EPA-460/3-74-0090, June 1974.

3-2 Affens, W. A., et al., "Flammab1l1ty and Ignition Properties of JP-5 Jet Fuel from Alternate Sources," NRL Report No. 3191 .

3-3 Lorenzi, O (editor), "Combustion Engineering." Table 2-3.

3-4 Garciä, A., "Assessment of Potential for Colloldal Fuels," Report No. $\mathrm{AD} / \mathrm{A}-022082$, June 1975.

3-5 Nowack, "Analysis and Testing of JP-5 Fuel Derived from Coal," NAPTCPE-99, Naval Alr Propulsion Test Center, January 1977.

3-6. Antoine, A. C., et al., "Jet Fuels from Synthetic Crudes," Coal Processing Technology, Vol. 3, pp. 107-114, 1977.

3-7 Belt, J. R., et al., "Proceedings of Workshop on Navy Alternate Energy. Sources Research and Development," AD-773746, January 1974.

3-8 Taylor, W. F., et al., "Evaluation of Methods to Produce Aviation Turbine Fue is from Synthetic Crude 011s--Phase 3," ER\&E for the Air Force, June 1977.

3-9 Pangborn, J., et al., "Alternate Fuels for Automotive Transportation," IGT for EPA, EPA-460/3-74-012b, July 1974.

3-10 Chowhury, D. H., "Indian Vegetable Fuel Oils for Diesel Engines," Gas and 011 Power, May 1942.

3-11 Karim, G. A., et al., J. Inst. Fuel, March 1966.

3-12 Swain, M. R., et al., SAE Paper 729217 (1972).

3-13 Adt, R. R., SAE Paper 739092 (1973).

3-14 Murray, R. G., et al., SAE Paper 700608 (1970).

3-15 Bush, A. F., et al., "On the UCLA Hydrogen Car," School of Engineering and Applied Sclence, UCLA, Los Angeles, CA.

3-16 Bartick, H., et al., "The Production and Refining of Crude Shale 0il into Milltary Fuels," Applled Systems Corp., August 1975.

3-17 Russel, J. A., et al., "Impact of Coal and 011 Shale Products on Gasoline Composition, 1976-2000," Task I Report, PB-265 478, December 1976.

3-18 Eisen, F. S., "Preparation of Gas Turbine Engine Fuel from Synthetic Crude 011 Derived from Coal," Report AD/A-007923, February 1975. 
3-19 Kalfadelis, C. D., "Evaluation of Methods to Produce Aviation Turbine Fuels from Synthetic Crude 0il, Phase 2," Report No. AFAPL-TR-75-10, Vol: 2, May 1976. 


\section{PRIME MOVER - FUEL INTERACTION}

J. Percival

This section is concerned with interrelationships between fuels and engines (prime movers). However, there are other components of any transportation system and it is the interrelationships among all of the components of the system that determine its practicality, cost, performance, and merits relative to alternative systems. Moreover, the relative importance of the constraints applying to different components of the given system vary with transportation mode. For example, a high power/weight ratio is of paramount importance to aircraft systems but relatively unimportant in large' marine vessels. Also, auxiliary equipment such as required for fuel preparation is practical aboard ship but impractical or problematic on aircraft or small ground vehicles. And, as a third example, some pipelines require pumping stations that can operate with a minimum of direct human attention and maintenance thereby placing a premium value on simple, trouble-free systems. In this section, such considerations will only be mentioned briefly. However, in some cases, this may be of controlling importance.

The role of the fuel in transportation is that it shall release its heat of combustion and that heat shall be transferred to a working fluid which can be expanded through an engine to convert a reasonably high percentage of the input heat (usually between 25 and 40\%) to work. This work is applied as reactive thrust in jet aircraft, applied to the turning of wheels or screws in the rail and marine transportation, or applied to the shaft of a pump or compressor for pipeline movements.

Both the fuel itself and its products of combustion come in contact with parts of the engine. Impurities such as ash and sulfur can cause deposits or corrosion and may shorten its working life or cause increased maintenance costs relative to operation on a cleaner fuel. Physical properties such as freezing point and viscosity can affect the movement of the fuel through filters and spray pattern of burners and injectors, and thus interfere with the completion of combustion. terized as:

Various chemical species burn in different ways which may be charac-

- speed of combustion

- temperature of self-ignition in air

- spark energy required to ignite a mixture of fuel vapor with air

- delay period between injection of fuel droplets into hot compressed air, and the commencement of ignition

- luminosity of the resulting flame. 
These properties can make a fuel very suitable for one type of engine, and yet quite unsuitable for another. The clearest example of different combustion behavior is seen between high octane number gasoline which is excellent for the spark ignited Otto cycle, and diesel fuel oil. made from petroleum distillate and characterized by a good cetane number.

The combustion properties which are looked for in these two fuels are almost diametrically opposed. In essence, the gasoline is required to mix readily with air prior to admission to the engine. It must then resist the heat generated during compression without self igniting. Up.on application of the spark it should burn in a controlled fashion, producing the required pressure rise to drive the engine but without detonation. A satisfactory diesel fuel on the other hand is one which self ignites readily and quickly upon admission (as a spray under pressure) to the hot compressed air produced by the compression stroke. The rate at which it burns is controlled thereafter, not so much by its chemical properties as by the rate of admission and duration of injection, that is by outside mechanical controls.

The various hydrocarbon species exhibit in general either good octane number properties or good cetane number properties, never both.

\begin{tabular}{ll} 
Good Octane & Good Cetane \\
Components & Components \\
\hline
\end{tabular}

Normal paraffins Iso paraffins

olefins

Aromatics

\section{$\mathrm{X}$}

$\mathrm{X}$

$\mathrm{X}$

$\mathrm{X}$

\subsection{Diese1 Engines}

The diesel engines used in non-highway transportation, notably in railraods and ships are not as critical of fuel chemistry as the smaller, higher speed truck and automobile diesel engines. That is because there is more time for fuel to ignite and burn out within a stipulated range of crank angle with the slower speed engines, than with the high speed engines.

Marine diesel engines, particularly the slow-speed engines successfully consume blends of heavy petroleum distillate with $80 \%$ or more of residual fuel oil with an asphaltic content of some $10 \%$ (4-1). Such fuels cannot be rated by the standard laboratory engine procedure which determines cetane number only down to a minimum of 38. However, the engine builders, after observing the ignition delay of such fuels in the large engine, and on comparing this with what they observe in the same large engines with clean distillate fuels, describe the behavior of the heavy fuel as equivalent to about 25 cetane 
number. A clean distillate fuel for marine service shows close to 40 cetane number, and the lighter distillates used in trucks show mostly 45 and sometimes higher. Thus, a good cetane rating, while directionally preferred, is not always mandatory for large marine diesel engines.

Similarly, railroad locomotives have been operated successfully on highly aromatic fuels made from tar sands (4-2), fuels with cetane numbers too low to be rated on the standard engine procedure, but having a probable rating in the vicinity of 30 cetane, possibly 28 .

Both the slow-speed marine engines and the locomotive engines discussed in this context owe much of their success to the fact that they are practically never called upon to start on the low cetane fuel. Ships are started, stopped and maneuvered on a separate supply of good cetane number fuel of the distillate type, and locomotives are frequently kept with engines running practically all their lives. While this may sound wasteful, the fuel consumed in 12 hours idling is only $5.5 \%$ of that which is consumed during the other 12 daily hours of working $(4-18)$. . It is therefore feasible to consider fuels of very poor cetane number for diesel engine operation, as long as some provision is made for starting and stopping on a better fuel, or for never stopping.

Cetane number is different from octane number in this respect. An otto engine requires some minimum octane number but derives no benefit if it receives fuel of higher octane number, at least not until it is tuned by spark advance to take advantage. A diesel engine needs some minimum cetane number especially at the moment of starting when conditions for autoignition (temperature and pressure of the compressed air) are least favorable.

If supplied with fuel having a higher cetane number than this minimum, engine performance may be improved particularly in terms of the engine's ability to start under cold conditions or at high altitude.

Fuels made from shale, or from coal by Fischer Tropsch synthesis may be expected to have good cetane properties and to be more fully compatible with the diesel engines used at sea and on the railroads. Other more aromatic fuels that can be expected from other coal liquefaction processes are not necessarily excluded, provided they are upgraded. The engine builders are studying, and are anxious to study such fuels further, but are hampered in their development work by a shortage of the tonnage samples which they will need.

The diesel engine, in the sizes which are applicable to off-highway transportation have shown themselves to be tolerant of metallic impurities in the fuel up to an ash content of $0.1 \%$ mass, though special features such as water cooled valves have been employed to withstand aggressive attack from vanadium compounds which are a frequent constituent of residual petroleum fuels. A primary requirement of the diesel engine is that the fuel shall pass the close tolerances of the fuel handling equipment, pump and injectors, without producing too rapid wear, and shall be well atomized as it passes from the injector into the combustion chamber. With "dirty" fuels the clean-up is accomplished usually by centrifuging enroute to the engine, and viscosity control at the injectors is obtained by preheat. Both of these features may be considered state of the art. 
The expressions "clean" and "dirty" fuels as used here are those which are common to the petroleum industry, namely a "clean" fuel is one which has been completely distilled whereas a "dirty" fuel is one which contains a proportion of undistilled residue and therefore has a content of asphaltic material plus ash. It is of course possible for a "clean" fuel to become contaminated with water, sand, rust, etc., but in general these can be relied upon to settle out of a distillate fuel by gravity alone.

\subsection{Gas Turbines}

Gas turbines are much more demanding of fuel quality, and as a general rule, the more efficient the gas turbine is made, the cleaner the fuel has to be. Cleanliness in particular means an absence or near absence of sodium and potassium contaminants, and a control of the amount and nature of other ash forming constitutents such as vanadium, nickel, lead, calcium, rust and silicates. The points of principal vulnerability in the gas turbine are the first row stators (nozzles) and the first row blades (buckets). In this area, hot combustion gas at turbine inlet temperature encounters metal (often specially coated) which must resist oxidation, sulfidation (from alkali metal sulfates) and deleterious effects by corrosion, erosion and deposition from other ash forming impurities.

The ongoing development of the gas turbine, which is aimed to permit an increase in turbine inlet temperature from the current $2000-2200^{\circ} \mathrm{F}$ to ultimately $3000^{\circ} \mathrm{F}$ or $3500^{\circ} \mathrm{F}$, is very largely concerned with furnishing these vulnerable blades with enough cooling and surface protection to permit them reasonable life within the high temperature environment. It is not envisaged that these developments toward high temperature and high efficiency will permit the use of fuels with more than a trace of ash.

Accordingly, synthetics like liquid hydrogen, the alcohols, methane and low contaminant distillate fuels could be used for high efficiency gas turbines. Among these methane and clean distillate fuels are well proven at today's inlet temperatures and sufficient testing has been done with hydrogen and methanol to show their suitability. Ammonia has likewise been demonstrated successfully $(4-3)$.

Modifications of the fuel handling equipment, pumps and flow dividers are needed to accommodate fuels of low viscosity, and preheating together with the use of air blast nozzles will be required to obtain a 20 centistoke (or lower) atomizable fuel at the burners when high viscosity fuels are used.

These modifications, or at least similar ones, are supplied routinely today, because gas turbines are handling a range of liquid fuels from a light gasoline type (naphtha) with viscosity about $0.6 \mathrm{cs} / 100^{\circ} \mathrm{F}$, up to heavy waxy gas oils which need preheat up to $170^{\circ} \mathrm{F}$. Even more highly viscous fuels have been used, including some residual petroleum fuels with considerable ash (4-4) content. In this latter case the fuel has to be desalted by a water wash and inhibited with magnesium additive in the ratio $3 \mathrm{Mg} / 1$ vanadium by mass to prevent corrosion and deposits on the critical blades. Even with this fuel 
treatment it is customary not to fire with turbine inlet temperature any higher than $1750^{\circ} \mathrm{F}$, which corresponds to an efficiency about $27 \%$ on net heat content of fuel, and peak power about $10 \%$ less than would be obtained from the same engine on clean fuel with turbine inlet temperature at $1850^{\circ} \mathrm{F}$. Because of the total ash which remains in the fuel after washing, and which is of course increased in mass by the magnesium additive (though thereby rendered much less corrosive), turbines fired on residual fuels are normally shut down for one day every two weeks to have deposits washed from the blades.

It must be pointed out that the experience which has been gained with gas turbines on these relatively dirty fuels is for applications in the $25,000 \mathrm{HP}$ and higher range. Although the use of such fuels in gas turbines restricts the efficiency obtainable from the gas turbine itself, such units can be combined with waste heat boilers and steam turbines to bring the total efficiency to over $40 \%$. Thus, if the size is suitable', a combined cycle residual fuel burning gas turbine installation could match an alternative diesel plant in efficiency, fuel costs and maintenance costs (4-5). However, applications of these principles to date have been to large stationary plants mostly above $100,000 \mathrm{HP}$.

Low viscosity liquid fuels which lack lubricity could cause wear problems with the fuel divider. The fuel divider is a device which meters equal rates of fuel to each combustor in a multicombustor array, to insure that the turbine inlet temperature is even around the whole circumference of the first blading.

A special problem that has to be overcome with liquid hydrogen if used in aircraft turbines, is the development of a reliable pump that will be light enough and small enough in physical size to be incorporated into the aircraft. This has been identified as the only real remaining technical requirement associated with hydrogen as a fuel for aircraft, and one which should be fairly easily developed (4-6).

The ultra-clean liquid fuels which have a high latent heat of evaporation like methanol or are supplied refrigerated like hydrogen can help provide some of the blade cooling and may permit turbine inlet temperatures (and thus efficiency) to be raised higher than would be possible with more conventional fuels.

An important warning (4-7) has been voiced in connection with methanol, concerning its possible contamination with salt water. Sodium contamination even at a concentration of one part per million of fuel can be very damaging in causing sulfidation of blade material. Operators pay great respect to sodium contamination whatever the fuel; contamination by sea water is avoided wherever possible, and when it does occur, adequate centrifuging, washing or settling time is provided to remove it. The particular fear with methanol is that it would dissolve the aqueous part of the seawater and leave the salts in a very finely divided solid state which might be impossible to settle, and which could not be washed out because of the complete miscibility of methanol with water. Ethanol would have this same potential hazard. 
However, if these alcohols are transported by pipeline or other land-based means of transportation this concern should not arise. Tanker or barge movements over salt water would call for special care to avoid sea-water contamination.

\subsection{Free Piston Engine}

The free piston engine converts its fuel to combustion gas in what is essentially a diesel cycle and then presents this gas to a gas turbine for expansion and conversion to useful work. The highest temperatures occur in a wa Eer cooled cylinder between opposed pistons and thus the free piston engine is tolerant of dirty fuels to about the same extent that the diesel is, namely up to $0.1 \%$ of ash and possibly higher with modification.

The companion gas turbine $(4-8)$ is not as vulnerable to blade corrosion, oxidation or deposit formation as is a gas turbine fired directly with fuel. That is because the inlet temperature at $900-1000^{\circ} \mathrm{F}$ is much lower than the $1800^{\circ} \mathrm{F}$ and upward temperatures employed with open cycle gas turbines. Thus the combination of a diesel cycle gasifier and companion gas turbine has the capability of burning many kinds of fuels. It appears to be more widely omniverous than the diesel engine itself in that the combustion characteristics of the fuel, particularly cetane number are much less important. This is because the work developed in the free piston diesel cycle is stored (albeit very temporarily) as potential energy in a hot compressed gas. It is not taken out mechanically by linkage to the moving pistons. Very high compression ratios are possible and ignition delay and time of burning are not critical provided only that the fuel can ignite and can burn out substantially within the combustion cycle. Free piston engines are providing electric power in some of.the Caribbean islands and parts of Africa.

A $5000 \mathrm{HP}$ installation was tested extensively in the ship "William Patterson" in 1962 (4-9). An efficiency of $27 \%$ was found which could have been improved in several ways by use of exhaust heat. The principal finding was that "the maintenance hours required were materially greater than those for a steam turbine installation of the same size and somewhat higher than those for a residual fuel burning diesel installation." Much of the difficulty was associated with lubrication problems and broken rings. This particular engine consisted of half a dozen gasifiers producing about $1250 \mathrm{HP}$ each feeding to a common turbine. The author of the reference (4-9) concluded that if a higher horsepower unit were required, it would be provided by increasing the number of gasifiers, rather than their size which would increase the labor costscosts further above those for alternative plants, steam or diesel. That is to say the labor costs of the latter two would not escalate much with size, whereas the free piston case would.

This observation was made at a time when ship's fuel was much lower in price than it is today. There is some cross-over point at which the relatively expensive maintenance would be justified in terms of monetary saving on the fuel, if such a fuel saving could really be made. Stated more precisely, the differential in costs between a fuel which is satisfactory for diesel oepration and some lower quality fuel which would satisfy the free piston engine, would have to cover both the expected higher maintenance and the lower efficiency of the latter. 
Up to now diesel engines, at least in the marine transportation size and speed, have shown themselves capable of running on the lowest cost liquid fuels available. For this reason the free piston engine has not been able to show erough edge over a diesel engine to enable it to grow in market size. If lower cost fuels become available which cannot be employed by diesels, the $f$ :ee piston could become a more serious contender than it has been to date. The principal idea here is that if certain liquids derived from coal, having perhaps very low cetane numbers, burn out to be poor in diesel operation the possibility remains that they might be used in free piston engines.

\subsection{Otto Cycle Engines}

Ot to cycle engines, either spark ignited or pilot ignited (dual fuel diesel/gas engine) have to date been restricted to pipeline pumping in the nonhighway transportation sector, and methane has been the principal fuel employed. To achieve efficiency, these engines are of high compression ration, about 13:1 and fuel of high octane number is essential to their use under that condition. Methanol, ethanol and hydrogen are clearly candidates, requiring very little modification of existing designs. However; in the case of hydrogen unless it is intended to run on a very lean mixture, there are problems of pre-ignition or flash-back to be overcome $(4-10)$. This tendency comes not from octane number deficiency per se, but from the remarkably small spark energy needed to fire a near-stoichiometric hydrogen/air mixture. Very careful containment of the lube oil by multiple oil rings has been found effective. The purpose of this approach is to minimize formation of pyrolytic carbon deposits on piston and cylinder walls which can act as uncleation centers for pre-ignition. Water injection has been used to control the problem, and spark plugs are generally of the colder type with smaller spark gaps, with well shielded leads to prevent spurious induced electrical discharge across the gap. Exhaust gas recycle suppresses pre-ignition and back-flash by slowing the movement of the flame front, but at the expense of efficiency.

Alternative ways of using hydrogen in compression ignition engines (diesel cycles) have been studied. However, none has really been successful and the modifications which have been introduced have actually converted the diesel cycle into an 0tto cycle. Reference (4-11) studied a dual-fuel operation in which a very small amount of pilot fuel (diesel oil) representing less than $5 \%$ of the fuel rate needed for full power was used to ignite a compressed air hydrogen mixture. Knock-free operation could be obrained only between narrow limits of hydrogen/air mixture. Ignition failure occurred if the hydrogen were less than $22 \%$ of stoichiometric, and knock set in at mixture strengths above about $50 \%$ of stoichiometric.

Reference (4-12) describes a hybrid engine called CFI (cylinder fuel injection). This proposed engine is not a true compression ignition engine, since it requires a source of ignition. The hydrogen would be injected as a gas under pressure after the air intake valve had closed with a view to avoiding backfiring. Furthermore the low charge density limitation which is an inherent property of hydrogen/air mixtures when fed pre-mixed to the intake, and which is in part responsible for the lower volumetric power output of hydrogen relative 
to gasoline, would be overcome. In short, the authors consider this approach to be the one most likely to yield high efficiency and high power together, in other words to allow hydrogen to approximate the role of a diesel engine fuel. It is not considered possible for hydrogen to be used without an external source of ignition since such operation would require a compression ratio of about $80: 1$.

\subsection{Externally Fired Enyines}

The only point of interaction of fuels with externally fired engines such as steam turbines, Stirling engines and closed cycle gas turbines is at the boiler or fired heat exchanger where the heat of the combustion gases is transferred through tubing to boiler water, air, hydrogen or helium, whatever the working fluid may be.

Accordingly, there is a wealth of useful experience among the boiler manufacturers, as to the materials which are required and the geometrical spacings permitted in the several parts of the equipment. These include the combustion chamber, superheater, steam generating tubes, economizers and air preheaters. Maximum and minimum metal temperatures have to be controlled, and arrangements made to blow deposits off the surfaces. The most vulnerable metal is usually that in the superheater where heat transfer from one gas (the combustion gas) is made to another (the dry superheated steam). The designers are concerned with the amount of ash in the fuel, and with the chemical properties of the ash which determine how badly it is likely to foul surfaces, and to what extent it may be corrosive to metal. Inasmuch as boilers have not been ,produced with outstanding success to burn all types of coal and lignite, the heaviest types of petroleum fuel and all kinds of waste products, the use of some fuels which could be contemplated for these externally fired engines, will have to be studied carefully. There is still much research going on in the area of understanding slagging and fouling. Mine wastes and fines with $50 \%$ ash and high moisture are examples of troublesome fuels. Closed cycle gas turbines have operated for many years successfully on lignite (4-13).

Design differences for different fuels revolve generally around the combustion volume which is needed for complete burn out and the relative areas receiving heat transfer by radiation and by convection. The coals and heavy petroleum fuels transmit more heat by radiation than does natural gas for example. Ultra clean fuels like hydrogen and methanol which burn with flames of low luminosity would require the most heat transfer be accomplished by convection. The design principles are not well understood which would permit adequate design for any fuel. Most design data are based on empirical data and new fuels sometimes create problems. In addition to slagging problems created by some coals, the properties of fly ash which could affect resistivity, and thus particulate removal capability, are not completely understood. There is a limit to the range of fuels which any single boller of given design can accept. Power station boilers are generally designed to operate on at least two fuels, e.g., coal or oil, oil or gas, but their design efficiency is highest on the principal fuel, and suffers slightly when operated on the secondary stand-by fuel. On the other hand, if a boiler has to be made to accept a range of fuels, it may have to be designed at some sacrifice of efficiency, and may suffer from control problems if the feeds are quite different. Examples, however, can be found in the steel industry where coal, 
coal tar, petroleum, coke oven gas and blast furnace gas are fired to the same boiler, usually two at a time, sometimes all together. As with the design of heat exchange surface, the design of burners for any available fuel can be considered state-of-the-art.

\subsection{Fuel Cells}

The only fuels which are seriously contemplated for use in fuel cells in the near and medium term, are hydrogen and methanol. of all fuel cell systems the most highly developed are those employing aqueous phosphoric acid electrolyte and supported noble metal catalysts. The hydrogen can be contaminated with $\mathrm{CO}_{2}$ but $\mathrm{CO}$ must be held at less than 0.3 percent.

Cells with aqueous base electrolyte require fuel which is free of $\mathrm{CO}_{2}$, at least down to a few parts per million.

Cells with molten carbonate electrolyte operating at temperatures above $1100^{\circ} \mathrm{F}$ can consume $\mathrm{CO}$ and therefore would be tolerant to hydrogen fuel made on-site, for example from a carbonaceous source such as coal.

Solid oxide cells operate at temperatures near $1800^{\circ} \mathrm{F}$ and are usable In principle with a wide variety of feedstock. However, their development is very slow due to their being several basic problems with materials.

It would appear then, that near-term application of hydrogen to nonhighway transportation, using fuel cells and DC motors, will require very. pure hydrogen $(4-14)$.

\subsection{Unconventional Fuel-Prime Mover-Combinations}

This review has not touched all the possible combinations of fuels and prime movers, and the interactions which could occur. Some combinations are clearly not necessary to consider. For example; coal/oil slurry is entirely incompatible with the fuel cell and with spark ignited Otto engines. Among the unconventional combinations which have been tried, the literature shows the following.

\begin{tabular}{llll}
\multicolumn{1}{c}{ Fuel } & Prime Mover & Reference \\
\cline { 1 - 2 } $\begin{array}{l}\text { Powdered coal and } \\
\text { coal/oil slurry }\end{array}$ & Diesel engine & $\begin{array}{c}4-15 \\
4-16\end{array}$ \\
Ammonia & Gas turbine & $4-3$ \\
Coal & Gas turbine & $4-17$ \\
& & & $4-13$
\end{tabular}

The coal fired gas turbine shows good promise if the coal is burned in a fluidized bed, because the particles emitted from such beds are soft and friable, rather than vitreous like the ash particles which come from coal fired directly into a refractory lined combustor. Strimbeck (4-17) indicates that the particle content of gas going to the turbine inlet must be less than 
$20 \mathrm{ppm}$ by weight, a figure which could not be approached in that work with centrifugal separators following the combustor. Frass (4-13) indicates less than $1 \mathrm{ppm}$ solids to be desirable and calls for a maximum particle size of 6 micrometers. It is recognized that blades are more tolerant of particles when wheel tip speed is reduced (e.g. from $1100 \mathrm{ieet} / \mathrm{second}$ to $800 \mathrm{feet} / \mathrm{second}$ ). However such a modification calls for a larger machine with twice as many turbine stages as are used at the higher tip speed.

Alkali metal contamination would probably limit the turbine inlet temperature to below $1600^{\circ} \mathrm{F}$ and the author concludes that the closed cycle gas turbine is a better proposition for use with coal.

The ammonia fired gas turbine is reported to need a larger combustor than one fired with natural gas. There is a power increase available (reported as $10-20 \%$ ). The efficiency remains practically identical with that obtained on other fuels.

The two references (4-15), (4-16) may be said to have proved that the diesel engine can be made to run on coal, but in both cases there was a significant loss of efficiency and operating problems. Marshall (4-16) employed a fairly dilute slurry, $15 \%$ of solvent refined coal ground to 2 micrometers. Even with that careful preparation, the conventional fuel injection system plugged in short time.

\subsection{Fuel and Maintenance Costs}

In closing this section, a few words might be said about the relative costs of fuel and maintenance based on published experience with various types of conventional fuels. Generally, engine maintenance costs are much lower than fucl costs, so that an economical case might frequently be made to live with the costs of increased maintenance, if this permits the use of a lower cost fuel.

This point has been made in the discussion of the free piston engine versus the diesel. Such considerations must be tempered by the need for reliability. Maintenance takes time and calls for scheduling, as well as money.

An interesting example in which an extra maintenance burden is accepted in order to enjoy lower fuel costs comes from the adaptation of a stationary gas turbine to burn a residual bunker fuel.

This involves:

1. washing the fuel and inhibiting against vanadium (fuel oil treatment)

2. acceptance of somewhat increased maintenance of the gas turbine itself.

Reference (4-5) indicates a cost equivalent to $30 \mathrm{c} / \mathrm{mill}$ ion Btu for the total ownership; operation and maintenance of the fuel oil treatment equipment, with a high vanadium content in the fuel (200 ppm), a fixed charge rate of $18 \%$ and 4000 operating hours per year on the gas turbine. With more operating hours and/or less contamination in the fuel this cost would drop in 


\section{$4-11$}

proportion, for example to $10 \mathrm{c} / \mathrm{million} \mathrm{Btu}$ at $100 \mathrm{ppm}$ vanadium and $7000 \mathrm{~h} / \mathrm{yr}$ operation.

Incremental turbine maintenance is also about $10 \mathrm{c} / \mathrm{m} 11$ lion Btu maximum, for a total maintenance cost of $20-40 \mathrm{c} / \mathrm{milli}$ in $\mathrm{Btil}$ of fuel above that which would be incurred if the turbine were operated on a ilean fuel like natural gas or petroleum distillate.

Thus a price differential of the order $25 \mathrm{c} / \mathrm{million}$ Btu between the two classes of fuel, clean and dirty would make this relatively complicated maintenance procedure commercially viable. 


\section{REFERENCES}

4-1 Fenenia, J. "Alternate Energy Sources for Marine Power Plants" Report No. COM 75-11474 (1975).

4-2 Canadian Research Council report to Quadripartite Navy Meeting, Ottawa (1973).

4-3 Bull, M. G. "Development of an Ammonia Burning Gas Turbine Engine". DA-44-009-AMC-824(T), April 1968.

4-4 Winkler, M. F. "Management of Residual Fuel Systems for Gas Turbines", Gas Turbine International, pp. 16-18 (May 1977).

4-5 General Electric brochure No. STAG-12-77 "Combined Cycle Power Systems."

4-6 Esgar, J. D. "State of Technology on Hydrogen Fueled Gas Turbine Engines", Report No. NASA TMX-71561. (May 1974).

4-7 Jarvis, P. M. "Methanol as a Gas Turbine Fuel", Engineering Foundation Conference (July 8, 1974).

4-8 London, A. L. "The Free Piston and Turbine Compound Engine -Status of the Development", SAE Preprint No. 252 (January 1954).

4-9 Specht, H. "Evaluation of Free Piston Gas Turbine Marine Propulsion Machinery in GTs William Patterson", SAE Paper No. 604A (October 1962).

4-10 Simpson, F. B. "Modification Techniques and Performance Characteristics of Hydrogen Powered I-C Engines, State of the Art 1975", Report No. ANCR-1302 (September 1976).

4-11 Karim, G. A., et al. "Hydrogen as a Fuel in Compression Ignition Engines" Mechanical Engineering, pp. 34-39 (April 1976).

4-12 McAlevy, R. S. "The Performance of Hydrogen Injected Reciprocating Engines", SAE Paper No. 77-795 (September 1977).

4-13 Frass, A. P. "Survey of Turbine Bucket Erosion, Deposits and Corrosion", ASME Paper No. 75-GT-123 (March 1975).

4-14 Ackerman, J. P. "Assessment Study of Devices for the Generation of Electricity from Stored Hydrogen", Report No. ANL-75-71, (December 1975).

4-15 Anonymous, "Pulverized Coal-Burning Diesel Engine", Howard University, U.S. Office of Coal Research Report No. 46 (1969).

4-16 Marsha11, H. P. "An Experimental Investigation of a Coal-Slurry Fueled Diesel Engine", SAE Paper No. 770795, (September 1977). 
4-17 Strimbeck, D. C. "Bureau of Mines Coal-Fired Gas Turbine Research Project", Bu. of Mines Report, RI 7295. (September 1969).

4-18 Cetinfch, J. M. "Fuel Efficlency Improvement in Rafl Frelght Transportation", Report No. PB 250673 (December 1975). 


\section{REVIEW OF POTENTIAL FOR ALTERNATE ENERGY}

FORMS FOR NON-HIGHWAY TRANSPORTATION-

E. W. Nicholson

E. N. Cart, Jr.

In consldering the varlous energy forms that may have a potential use in non-highway transportation, there are three forms which are considered in this section. First, is the possible applications of fuel cells in all four modes. Second, is the use of nuclear power, and third, a brief discussion on the use of solar-thermal and solar-electric forms.

\subsection{Possible Applications of Fuel Cells (E. W. Nicholson)}

In considering alternate fuels for non-highway transportation uses in the future, it is appropriate to assess the possibilities of utilizing fuel cells in these applications. Synthetic fuels are necessarily going to be more expensive than petroleum and natural gas fuels have been in the past, and therefore the fuel costs will be a higher percentage of the total annualized costs of the propulsion systems. Since fuel cells are not subject to Carnot cycle efficiency ifmitations, they theoretically can be operated at higher thermal efflclencles than can heat engines, such as combustion turbines and diesel englnes. Thus it may be that fuel cell systems could be operated at lower annual costs, including fuel, than other types of prime movers.

A great deal has been written about the prospects for fuel cells in many applications, including vehicles, small and moderate sized power generation and utility power generation. $(5-1,2,3,4,5,6)$ The potential for high thermal efflciencies has been especially emphasized. Other advantages of fuel cells stated are:

- They are clean, quiet and have little effect on the environment.

- They have very flat efflciency/load curves over the full range of operation and follow changes in load readily.

- The fuel cells themselves are modular in nature, so that there is a relatively small effect of capacity on cost down to small system capacities; systems can readily be enlarged in capacity by adding modules, and individual modules can easily be replaced when failures occur without shutting down the entire system.

- The systems could potentially be low cost when mass production of modules to meet high demand rates becomes possible. 
Originally demonstrated by Grove in 1839, using hydrogen and oxygen, little was done with fuel cells until F. T. Bacon In England developed a high-current-density cell operating on hydrogen and oxygen in 1932. A large amount of work was carried out by industrial concerns in the $1950^{\prime} \mathrm{s}$ and $60^{\prime} \mathrm{s}$, including Union Carbide, General Electric, United Technologies, Allis-Chalmers, Exxon, Leesona-Moos, Westinghouse and others.(5-7) Many of the organizations discontinued work when the difficult technical problems encountered resisted solution.

The first practical use of fuel cells occurred in connection with the space program in the U.S. In the $1960^{\prime}$ 's utilizing fuel cells produced by GE and UTC which operated on pure hydrogen and oxygen. These, however, were too expensive to consider for normal terrestrial applications. In 1967, serious interest developed among gas utflities and, in 1972, among electric utilities in possible application of fuel cells in their systems. UTC and Exxon carried out work on such systems, $(5-8,5-9)$ and the UTC phosphoric acid system has been carried to the point of construction of a 4.8 megawatt demonstration unit $(5-35)$ which will be installed in the Consolidated Edison system in New York City. UTC has also built 12-40 kW units, originally for the gas utilities and designed to operate on natural gas. $(5-5)$

\subsubsection{The Fuel Cell System}

In a fuel cell, 1llustrated in Figure 5-1, a fuel and an oxidant are fed continuously to the cell and the oxidation of the fuel is carried out electrochemically, so that the heat of oxidation is released as electrical energy. This electrical energy is in the form of low-voltage direct current. A number of cells ordinarily are connected in series internally (bipolar construction of the cells) or externally (monopolar cells) to provide up to 3000 volts DC from a system. (5-35) This power output can be inverted to alternating current and transformed to higher voltages in a power conditioning stage. However, in applications of fuel cells to non-highway transportation, the direct-current output of the fuel cell stacks or modules can be utilized without inversion to drive direct-current motors. This would save a significant amount of investment cost and some loss of efficiency otherwise encountered in power conditioning.

At the present time, the only practical fuel cells known require hydrogen or $\mathrm{H}_{2} / \mathrm{CO}$ mixtures as fuel feed to the cell itself. Direct feeding of methanol to a fuel cell has been demonstrated, $(5-10)$ and 1 t has been shown that a fuel cell can be run on direct feeding of 1ight hydrocarbons, (5-11) but such cells so far have required uneconomically large amounts of platinum catalysts on the anodes. Hence, all fuel cells of commerclal interest incorporate a fuel preparation and conditioning section preceding the fuel cell modules, unless pure hydrogen can be used as the feed. This fuel preparation and conditioning section will normally include a steam reformer to convert the original fuel (hydrocarbon distillate, methane, methanol, ethanol, etc.) to hydrogen and $\mathrm{Co}$, followed by a shift converter to convert $\mathrm{CO}$ to $\mathrm{H}_{2}$ and $\mathrm{CO}_{2}$, and, when necessary, equipment to remove the $\mathrm{CO}_{2}$. With hydrocarbons the steam reformer would operate at $1400-1800^{\circ} \mathrm{F}$, while for methanol the reforming temperature would be between $350-400^{\circ} \mathrm{F}$. 
FIGURE 5-1

SCHEMATIC DIAGRAM OF A FUEL

CELL WITH ACID ELECTROLYTE

$$
\mathrm{H}_{2}+\frac{1}{2} \mathrm{O}_{2} \rightarrow \mathrm{H}_{2} \mathrm{O}
$$

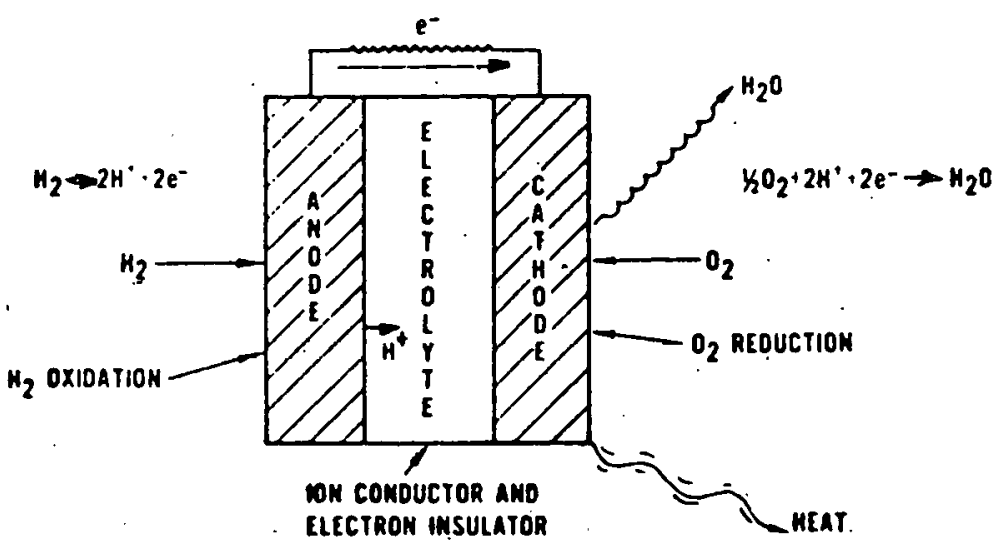

Source: $\quad 5-17$ 
Furthermore, it is important to note that sulfur level in fuel cell fuels is a very important factor. Sulfur poisons the catalysts used in the fuel processing operations, and sulfur content of the feed to the steam reformer must be kept below 0.1 part per million (ppm). Th1s is normally accomplished by including a hydrodesulfurization unit followed by a zinc oxide bed to remove the $\mathrm{H}_{2} \mathrm{~S}$ formed before the ateam reformer. Such equipment will handle sulfur contents in feeds of up to about $1000 \mathrm{ppm}$; light distillates from coal liquefaction may be avallable with oulfur contents below this. Methanol would not be a problem, in this respect. It is desirable, however, to be able to use heavier and higher-sulfur feeds for fuel cells, in order to provide greater fuel flexibility. UTC has been carrying out some promising development work on "autothermal" reforming, (5-37) involving introduction of alr along with the feed and steam to the reformer. With this process, they have been able to reform No. 2 fuel o1l containing 2500 ppm of sulfur; the resultant $\mathrm{H}_{2} \mathrm{~S}$ in the gas stream from the reformer must be reduced by scrubbing to the level that can be tolerated by the fuel cells. Depending on the type of fuel cell employed, sulfur content of the hydrogen actually entering the fuel cell may have to be in the range of 1 to $200 \mathrm{ppm}$.

In addition, facilities for maintaining water balance, temperature control, electrolyte quality and control of electrical output may be necessary.

Thus, a total fuel cell system may include the various sections shown in Figure 5-2. The cost of the fuel cell modules themselves is not necessarily the major item in the total cost.

\subsubsection{Types of Fuel Cells}

A number of different types of fuel cells have been investigated, and these can generally be classified on the basis of the types of electrolytes utilized.

In general, the higher the $\mathrm{pH}$ of the electrolyte, the higher will be the net voltage obtained from the cell and, therefore, the higher the power efficiency of the cell. Voltage and efficlency also increase with temperature.

Concentrated solutions of alkalis, such as $\mathrm{KOH}$, are the most desirable electrolytes, and fuel cells of this type were used on satelites with pure $\mathrm{H}_{2}$ and $\mathrm{O}_{2}$ feeds. With more practical feeds, however, such as hydrocarbon distillates, methanol or coal, and using air as the oxidant, $\mathrm{CO}_{2}$ will get through to the electrolyte and precipitate carbonates. Therefore, extraordinary efforts must be made to exclude $\mathrm{CO}_{2}$ from the feed streams into the fuel cell, or the electrolyte must be reconditioned on a regular basis; both of these expedients add cost.

As a result, major efforts have gone into developing systems that refect $\mathrm{CO}_{2}$ continuously by their nature. Exxon investigated alkaline electrolytes buffered with bicarbonates 80 that they would reject $\mathrm{CO}_{2}$, but efficiencles were lower than desirable. $(5-12)$ The most promising systems so far are the aqueous phosphoric acid $(5-8,5-36)$ and the molten carbonate 
GENERALIZED FUEL CELL SYSTEM

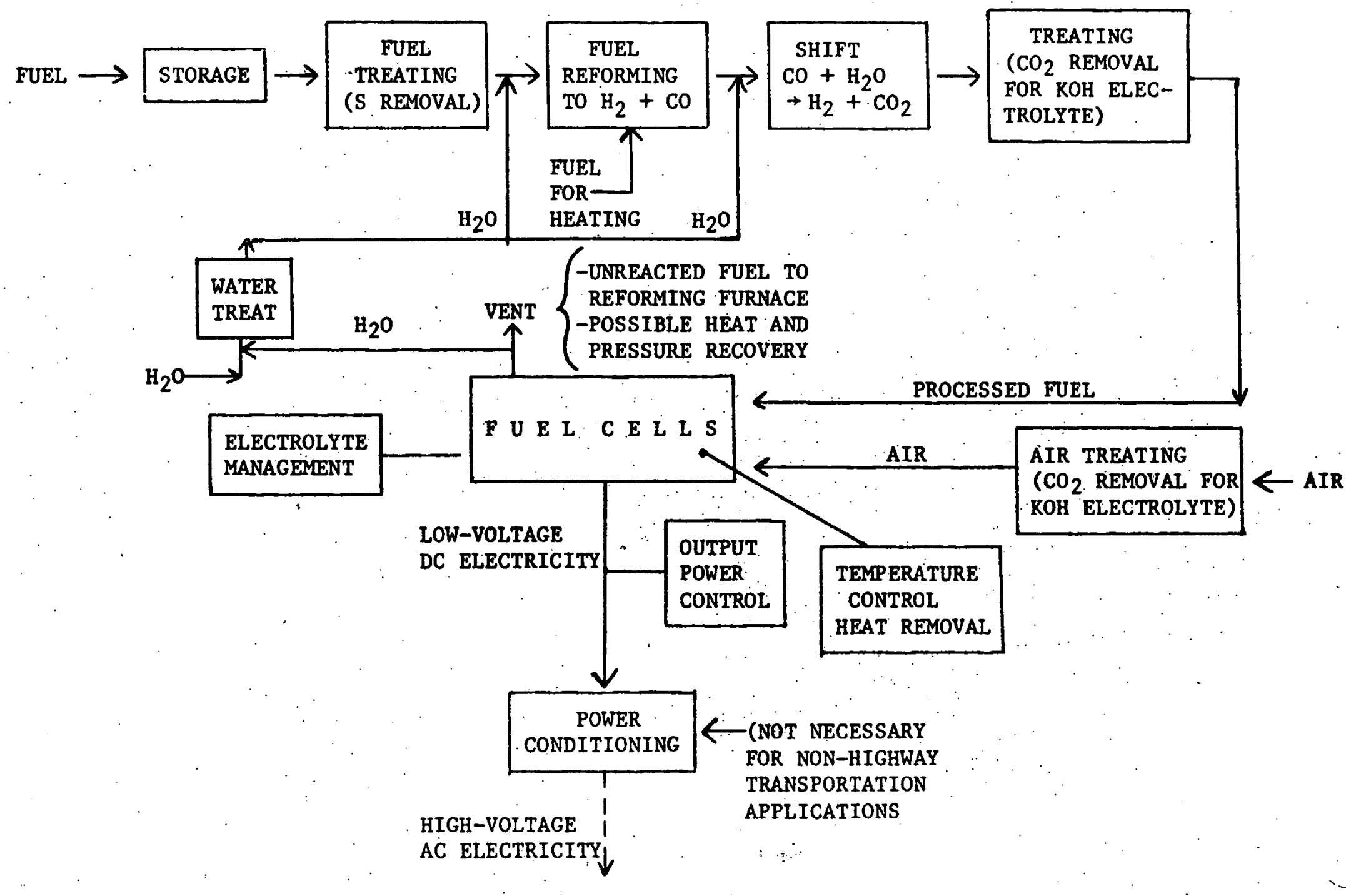


electrolyte(5-13,5-37) systems under development by Un1ted Technologies Corp. (UTC). Exxon studied the economic possibilities of large fuel cell systems for utilitfes based on $\mathrm{KOH}$ electrolytes in which $\mathrm{CO}_{2}$ in the fuel and air feeds was completely removed by treating, but concluded that more research was needed to achieve the target fuel cell performance level before development work on such a system was justifled.(5-9) Westinghouse has worked on a system utilizing a solid electrolyte (doped zirconia) operated at around $1800^{\circ} \mathrm{F}$ which can handle mixtures of $\mathrm{H}_{2}, \mathrm{CO}$ and $\mathrm{CO}_{2}$, but the difficult material.s problems involved have not yet been resolved. (5-14) General Electric developed a fuel cell based on a solid polymer electrolyte which was successfully used in the Gemini spacecraft with pure hydrogen and oxygen, but costs of solid electrolyte, catalysts, and other critical components so far are too high fpr this cell to be potentially competitive in commercial applications. $(5-15)$ The Department of Energy has an active program seeking practical advanced fuel cell systems.(5-16)

\subsubsection{Fuel Cells to Consider for Non-Highway Transporation Applications}

\subsubsection{1978-1985 Period}

The only fuel cell that can be considered in the 1978-85 time period for use in non-highway transporation applications is the phosphoric acld electrolyte system being developed by UTC. $(5-8,5-36)$ None of the others is far enough along in development to achieve commercialization by 1985 . A 4.8 MW phosphoric acid based unit, $(5-35)$ however, is currently being prepared for a demonstration in the Consolidated Edison system in New. York City under a program jointly sponsored by UTC, Consolidated Edison, the Department of Energy and EPRI. This demonstration unit is expected to be in operation in the last half of 1979.

The phosphoric acid fuel cell operates at $375^{\circ} \mathrm{F}$ and can convert hydrogen produced from hydrocarbon distillates or methane feeds to direct current electricity with an overall efficiency of about $41 \%$ (lower heating value basis).* The Consolidated Edison demonstration unit will be operated Initially on a naphtha feed with a maximum of $500 \mathrm{ppm}$ of sulfur. Other fuels, such as hydrogen, methanol or ethanol can be used with easier operations in the fuel processing section and higher overall efficiencies. On pure hydrogen feed, UTC estimates $50 \%$ efficiency currently, with $55 \%$ avallable from future systems.(5-17) If the "autothermal" reforming system being developed by UTC(5-37) proves successful, heavier and higher-sulfur hydrocarbon distillates may be usable as fuels. Sulfur in the feed to the fuel cell 1tself may be as high as $200 \mathrm{ppm}$, but co must be below $1 \%$. Life of the fuel cell modules of over 10,000 hours has been demonstrated, and it hoped that 40,000 hours can be obtalned longer range. The fuel processing section and other auxiliary facilities should be operable over a nominal 20 years or more life.

* All thermal efficlencies in this section are on the lower heating value basis. 
The welght and volumetric energy densities of fuel cell systems have not been well established yet because most of the intensive efforts so far have been in connection with utility-type installations where these considerations are not particularly significant. For moblle applications, it will be necessary to under zake careful and innovative design studies directed toward packaging the entire fuel system with minimum weight and volume. During a workshop at Los Alamos Scientific Laboratory in August, 1977 directed toward potent1al applications of fuel cells in vehicles, It was estimated that phosphoric acid fuel cells operating on methanol feed (relatively easy processing requirements) and producing $P C$ power (no inverter) might reach 30 pounds/kW and $1 \mathrm{cu} . \mathrm{ft} . / \mathrm{kW} .(5-18)$ The fuel cells being considered, however, were of about $10 \mathrm{~kW}$ size, and units in the 2 to 60 megawatt size range which would be applicable to locomotives, ships and pipelines should have better energy densities.

\section{$5.1 .2 .2 \quad \underline{1985-2000 \text { Period }}$}

It is possible that elther or both of the molten carbonate and the $\mathrm{KOH}$ electrolyte system with clean-up of feed streams could be commerclally available in the 1985-2000 time perfod. This assumes there are applications in which these fuel cells would have competitive advantages large enough to justify spending the considerable amounts of money that would be required to complete the research and development work still remaining to be done.

The molten carbonate fuel cell utilizes a mixture of alkali metal carbonates as the electrolyte and operates between 1100 and $1300^{\circ} \mathrm{F}$, and at 150 psia pressure. $(5-13 *, 5-37)$ No noble metal catalysts are required on the electrodes. This fuel cell can achleve overall thermal efficiencies on methane, methanol, or hydrocarbon distillates to $\mathrm{DC}$ power of about $50 \%$ at full load or $53 \%$ at part 1oad. The molten carbonate fuel cell cannot operate on a pure hydrogen feed or hydrazine because $\mathrm{CO}_{2}$ is required for reaction at the cathode; if pure hydrogen or hydrazine were fed, an extraneous $\mathrm{CO}_{2}$ feed to the cathode would have to be.provided. Sulfur in the feed to the fuel cell itself probably will have to be below $10 \mathrm{ppm} .(5-38)$ High Co concentration is acceptable.

The alkaline (KOH) electrolyte fuel cell would be the preferred system if hydrogen or hydrazine are useable as fuels. The air, of course, would have to scrubbed free of $\mathrm{CO}_{2}$. With hydrogen and air, a $\mathrm{KOH}$ fuel cell should achieve $60 \%$ efficiency. On pure hydrogen and oxygen, UTC projects $75 \%$ efficifency with alkaline fuel cells based on their satellite-type units, $(5-17)$ but these are uneconomic for commercial use. With hydrocarbon distillates, methanol or methane, which would have to be reformed, shifted and treated intensively for removal of essentially all $\mathrm{CO}_{2}$ and $\mathrm{H}_{2} \mathrm{~S}$, overall thermal efficlencies should be around 55\%. The development of process equipment which could be incorporated into mobile fuel cell systems and which would adequately remove $\mathrm{CO}_{2}$ within economic constraints will be a dificult job. The energy densities of Exxon thin-cell fuel cells with KOH electrolytes

* This report is concerned with operation of molten carbonate fuel cells in conjunction with coal gasification to produce the feed, but the fuel cell sections would be comparable. 
are estimated to be $6.3 \mathrm{lb} . / \mathrm{kW}$ and $0.44 \mathrm{cu}$. ft. $/ \mathrm{kW}$ for a $10 \mathrm{MW}$ module, not including the fuel or afr processing equipment or power conditioning (Inversion, etc.).(5-9) This fuel cell operates at $195^{\circ} \mathrm{F}$ and 1 s constructed using light-weight and low-cost plastlc elements.

None of the other fuel cell systems that have been under investigation appears worthwile considering in this study. The high-temperature $\left(1800^{\circ} \mathrm{F}\right)$ solid electrolyte (doped zirconia) oystem, even if it were commerclalized, would not be practical in non-h1ghway transportation applications. As pointed out earlier, the solid polymer electrolyte system still has serious cost problems, and $1 t$ is not being actively developed at the present time.

Of course, an advanced system of superior characteristics might be developed by 2000 or af ter as a result of the research programs being sponsored by the Department of Defense and EPRI. S1nce these systems are not yet specifically defined, it "1s not possible to consider them in this. study.

In all cases of applications of fuel cells to moblle operations, questions of the resistance of the systems to vibration, tilting, shock, etc. will have to be investigated. None of these problems seems insurmountable. Fuel cells did. withstand the shocks of launching of satelites for space applications.

\subsubsection{Applicability of Fuel Cells to Non-H1ghway Transportat1on Systems}

\section{1 .3 .1 Alrcraft}

Fuel cells will probably always have much too high a weight-topower ratio for application to aircraft. For example, the following tabulation compares welghts for the engines and fuel required for a Lockheed Electra turboprop with the welghts that would be involved in a comparable airplane powered by fuel cells and DC motors. The Electra requires 15,000 HP at takeoff and 11.,800 HP for crulse. In the tabulation, it is assumed that fuel cells and motor installed power need be only that for cruise, and that the extra power for takeoff can be provided by short-time overloads.

$\begin{array}{lcr}\text { Weights, pounds } & \begin{array}{c}\text { Turbol Cells } \\ \text { t Motors }\end{array} \\ \text { Engines } & 7,300 & \\ \text { Fuel Cells } & & 52,200 \\ \text { DC Motors } & & 153,000 \\ \text { Fuel } & \frac{32,500}{18,000} \\ \quad \text { TOTAL } & 39,800 & \frac{223,200}{}\end{array}$


Thus 1 t is seen that the weights of the fuel cells and motors alone are more than five times the weight of the turboprop engines and fuel in the case of the Electra, even though the fuel efficiency of the Electra is only $23 \%$ and the fuel cell efficlency might be twice that. The weight shown for the fuel cells is based on the I1ght-weight construction assumed for the Exxon $\mathrm{KOH}$ electrolyte system (5-9) and includes only the cell module weight, excluding the weights of fuel processing and conditioning equipment. Indeed, even this weight of the cell modules alone, without considering the weight of motors, fuel and other equipment, is shown to be greater than the weights of turboprop englnes and their fuel.

In view of the above comparisons, no further consideration will be given to the use of fuel cells in aircraft.

\subsubsection{Railroad Locomotives}

Diesel-electrics predominate the locomotive market in the United States. At the beginning of $1978,99.3 \%$ of the 27,669 locomotives owned by Class I railroads were diesel-electrics, and the rest were straight electric locomotives operated off catenarfes.*(5-19) The following tabulation shows a breakdown of locomotives by services for 1974 , the latest year for which such data are available: $(5-20)$.

\begin{tabular}{|c|c|c|c|}
\hline \multirow[b]{2}{*}{ Service } & \multicolumn{2}{|c|}{$\begin{array}{c}\text { Locomotives in } \\
\text { Each Service }\end{array}$} & \multirow{2}{*}{$\begin{array}{l}\text { Percent } \\
\text { of Total } \\
\text { of Type }\end{array}$} \\
\hline & Number & Percent & \\
\hline \multicolumn{4}{|l|}{ Freight } \\
\hline Dlesel-electric & 22,374 & 99.3 & 80 \\
\hline Electric & 162 & 0.7 & 75 \\
\hline \multicolumn{4}{|l|}{ Passenger } \\
\hline $\begin{array}{l}\text { Diesel-electric } \\
\text { Electric }\end{array}$ & $\begin{array}{r}657 \\
. \quad 46\end{array}$ & $\begin{array}{r}93.5 \\
6.5\end{array}$ & $\begin{array}{r}2 \\
21\end{array}$ \\
\hline \multicolumn{4}{|l|}{ Switching } \\
\hline Diesel-electric & 4,894 & 99.9 & 18 \\
\hline Electric & 7. & 0.1 & 4 \\
\hline \multicolumn{4}{|l|}{ Totals } \\
\hline Diesel-electric & 27,925 & 99.2 & 99.2 \\
\hline Electric & 215 & 0.8 & 0.8 \\
\hline
\end{tabular}

Diesel-electrics also account for the bulk of the energy consumed by locomotives: $\star \star(5-21)$.

* Actually, there were 11 steam locomotives owned by Class I railroads as of $1 / 1 / 78$, but these were in only nominal service. There were 225 "slave" units in service in conjunction with diesel-electrics in 1974. These are separate units with motor-driven wheels the power for which comes from the diesel-electric locomotive; they provide extra tractive force. 


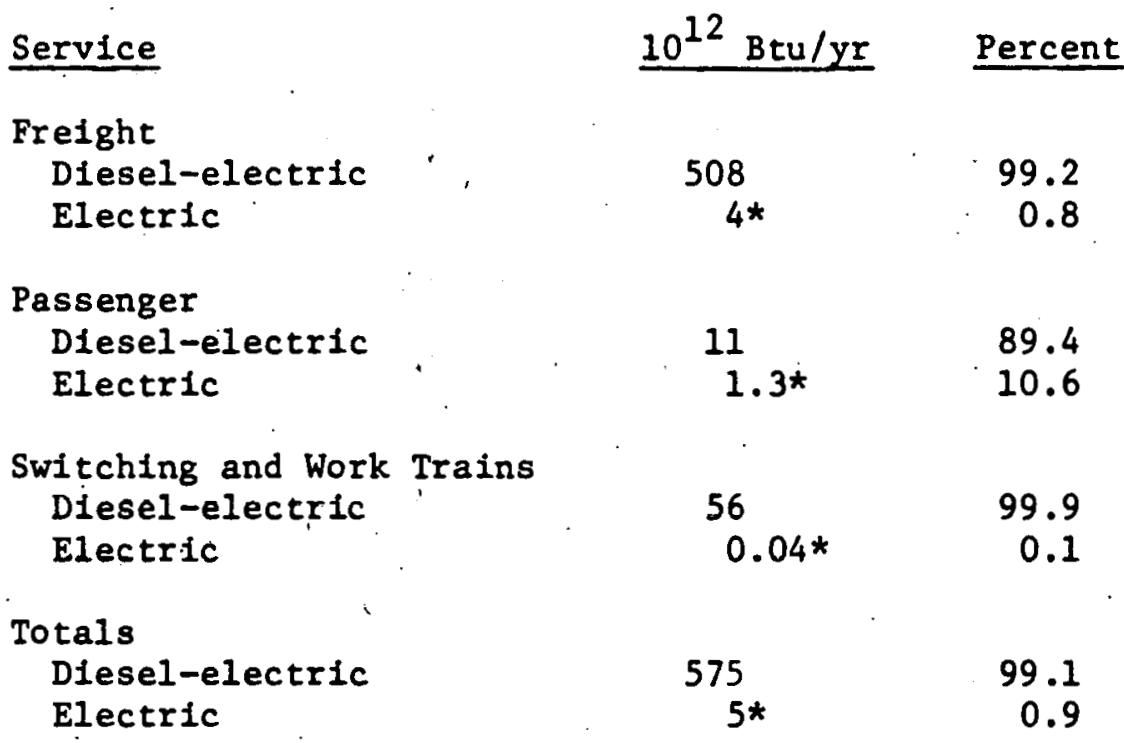

* In terms of primary energy utilized in generating electricity ( $33 \%$ efficlency) and allowing for distribution losses (15\%).

It can also be seen from the above tabulation that freight services require $89 \%$ of the total energy consumed by the railroads, and switching operations take almost $10 \%$. Passenger services (long-line) consume only $2 \%$. This does not include local and commuter passenger services, which consume another $10.2 \times 10^{12} \mathrm{Btu} /$ year; $95 \%$ of which $1 \mathrm{~s}$ in the form of electricity to operate electric-powered cars.

In view of the above information, primary consideration of the possible use of fuel cells in railroad locomotives will be based on a comparison with diesel-electrics in frelght service, although some consideration will be given to diesel-electrics used for switching.

A summary of the horse-power ranges of all locomotives currently in operation is as follows: $(5-21)$

Horse-Power Range

$700-1400$

$1500-1850$

2000-2800

$3000-3600$

4000-5000

\section{$\underline{\text { Percent }}$}

20

35

24

20 
For long-line freight operations, the predominant sizes of locomotives being used are in the 3000-3600 HP range, and most of the locomotives in switching service are 1000 to $1400 \mathrm{HP} .(5-21)$ The bulk of the orders from railroads for frelght locomotives currently are for $3000 \mathrm{HP}$ units, although $3600 \mathrm{HP}$ untts are avallable.

\subsection{Characteristics of Diesel-Electrics}

A diesel-electric locomotive consists basically of a large diesel engine with 16 to 20 cylinders which drives a generator to produce direct.current power. This DC power is distributed to series-wound DC traction motors at each wheel. In newer models, however, AC generators, or alternator: are being used in order to overcome the maintenance problems associated with the comutators and brushes required in DC generators. The AC current produced is rectified by solid-state units to provide the DC power for the traction motors. $(5-21)$

A $3300 \mathrm{HP}$ (at the wheels) diesel-electric locomotive weighs 390,000 pounds, including 4000 gallons of fuel. The engine and alternator for this locomotive weigh 59,500 pounds. Based on an $85 \%$ efficiency from the engine output to the wheels, this represents a weight to power ratio of $15 \mathrm{lb} . / \mathrm{HP}$ or $20 \mathrm{lb} . / \mathrm{kW}$. The corresponding volumetric ratios are about $0.3 \mathrm{cu}$. ft. $/ \mathrm{HP}$ or $0.4 \mathrm{cu}$. ft. $/ \mathrm{kW}$.

\subsection{Possibilities for Fuel Cells}

It is not inconceivable that the above ratios could be achieved with fuel cells. As pointed out earlier, the Fuel Cell Powered Vehicle Workshop at Los Alamos in August, 1977 concluded that fuel cells Including fuel processing equipment but with no power inversion facilities should be possible with $30 \mathrm{lb} . / \mathrm{kW}$ and $1 \mathrm{cu}$. ft. $/ \mathrm{kW}$ ratios. $(5-18)$ But, in this case, small units of only about $10 \mathrm{~kW}$ were being considered; the $2900 \mathrm{~kW}$ units required for a locomotive of this type should have much better power densities. For exampie, the power densitles of the $10 \mathrm{MW}$ fuel cell trafler in the design study on $\mathrm{KOH}$ electrolyte fuel cells Exxon Enterprises did for EPRI (5-9) were $6.3 \mathrm{lb} . / \mathrm{kW}$ and $0.44 \mathrm{cu}$. $\mathrm{ft.} / \mathrm{kW}$. These values do not include the weight and volume required for the fuel processing section. Further study will be needed in order to reach a more definitive conclusion regarding the technical feasibility of substituting fuel cells for the diesel enginealternator-rectifier system in present-day diesel-electric locomotives.

A fuel cell system probably cannot be appreciably larger in volum than the present diesel-electric power equipment for the same horsepower rating because the overall dimensions of existing large diesel-electric locomotives are near the limits as constrained by tunnel and bridge cleara. radius of curvature of tracks, etc. on existing railroads. Space within t existing locomotive envelopes is already well utilized by required equipme: and facllities. Improved fuel efficiency in a fuel cell powered unit cou? make additional volume avallable for the fuel cell by reducing the size 0 the fuel tank. 
The allowable weight of a fuel cell system for the required power output needs to be studied further because a number of factors are involved which are assoclated with the design of the locomotive. One of these factors is "adhesion" between the drive wheels and the rails. Some locomotives are provided with ballast over some of the axles to improve adhesion. It seems possible that, in a modular fuel cell system, some of the fuel cell weight could be distributed to take the place of ballast, thus providing more allowable weight for the fuel cells.

In present locomotive design, the total load-pulling capacity, or tractive effort, is limited by the current-handling capability of the traction motors. More horsepower on board a given locomotive could, however, be used to operate the train at a higher speed. This could have a net economic advantage to the railroad.(5-2I) Even though the average daily speed of frelght trains is only about $20 \mathrm{miles} / \mathrm{hour}$ (allowing for idle time waiting for reassembling of trains, switching, etc.),(5-22) the railroads seem to have ilttle inclination to go to higher horsepower locomotives, as stated earlier.

Another aspect relating to adhesion could prove to be beneficlal for fuel cell systems. In a diesel-electric locomotive, when slippage between wheels and track occurs for the limiting axle, power to all the axles must be reduced until the slippage stops. On electric locomotives with power from catenaries, control systems are possible so that power needs to be reduced only to that axle where slippage is occurring. It seems possible that a similar control system could be provided with fuel cells; since the system is modular in nature, separate power takeoffs could be arranged for various groupings of modules.

Fuel cells could have a significant advantage in fuel efficiency. The overall fuel efficlency of a diesel-electric when operating on productive load over an average load cycle is about $37 \%$.(5-21) But, diesel engines are most susceptible to damage, and thus increased maintenance costs and downtime, when they are being started up, as temperatures equalize; during this time, coolant and lubricant flows must be carefully monitored. In addition, the coolant is subject to freezing in cold weather. For these reasons, diesel-electric locomotives are generally kept running at idle continuously when they are not in load service, or in the shop for service. Road engines generally operate at 1dle $45-55 \%$ of the time, and switch engines $77 \%$. For the road engines, the fuel consumed during idling amounts to about $6 \%$ of the total consumption, and reduces the overall fuel efficiency to about $33 \%$. It is possible, however, that diesel efficiencies could be increased in the future through incorporation of bottoming cycles.

Fuel cell systems have been demonstrated to be easily and quickly started up and shut down, so continuing to run them at idle would not be necessary.* Assuming a $40 \%$ fuel efficiency can be obtained with phosphoric

* The fuel reforming section would probably be maintained at temperature except for idling perlods of greater than about 4 hours. 
acld fuel cell system, and naphthe can be used as fuel, as shown in Table 5-1, this would reduce the fuel requirement on board the $3300 \mathrm{HP}$ locomotive being considered from 4000 gallons to 3670 gallons, or a saving about 5400 pounds of welght and $45 \mathrm{cu}$. ft. of volume on board the locomotive, as well as reducing the operating costs for, fuel.

Of course, the critical question is whether or not a fuel cell system could be economically competitive with diesel-electrics in railroad service. This is discussed in another section. It appears wor thwhile to consider both the phosphoric acid fuel cell system for the 197.8-85 period, and the molten carbonate system for later application. It is also conceivable that a $\mathrm{KOH}$ electrolyte system could be utilized if a feasible means can be devised to remove $\mathrm{CO}_{2}$ from the fuel and air streams to the fuel cell.

\subsubsection{Marine}

The marine Industry serving United States trade is very diverse, consisting of a number of different types of vessels to handle the various: requirements. The marine industry may be characterized as follows $(5-23)$ :

- Foreign Trade

IIners (comon carriers providing scheduled service; includes break-bulk, containerships, ships providing for roll-on/roll-off of cargo, and barge carriers.)

Tramps (irregular service and charters)

Dry Bulk Carriers (bulk cargoes such as grains and ores)

Tankers (IIquid bulk cargoes such as crude petroleum, refined petroleum products, chemicals, edible olls)

Passenger (cruises and trans-ocean service)

- Great Lakes

Dry Bulk Carrlers (ore, coal, etc.)

Tankers

Tugs, Package Freighters, Car Ferries

- Coastal

Tankers (mostly clean petroleum products between East, West and Gulf Coast Ports)

Tugs and Barges ( 011 and dry bulk commodities) 
TABLE 5-1

FUEL CELL POWER FOR A LOCOMOTIVE

\section{Power Source}

Fuel

Vol. Power Density-f $\mathrm{t}^{3} / \mathrm{kW}$

Weight Power Density-1bs/kW

Efficiency - $\%(a)$

Fuel on Board ( 3300 HP Locomotive)

Gallons

Cubic Feet

Pounds
Diesel

Electric

Distillate

0.4

20

33

4000

535

28000

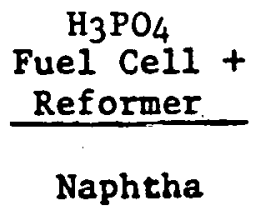

1

30

40

3670

490

22600

(a) Based on output of prime mover, less requirement for locomotive auxiliaries. 
- Inland Waterways

Towboats and tugboats (pushing or pulling barges loaded with bulk liquid or dry cargoes (petroleum products, chemicals, coal, ore, etc.)

- Offshore

(Vessels engaged in the discovery and recovery of petroleum in offshore areas; includes drilling rigs, exploration craft, tugs, supply craft, construction and pipelaying vessels)

- Pleasure Craft (Inboard and outboard motor driven)

- Flshing and Miscellaneous

(Commercial fishing boats and miscellaneous harbor service craft)

Booz-Allen Hamilton carrled out extensive studies for the Department of Energy on the marine transportation industry.(5-23,5-24,5-25) They developed information on the types of vessels and the power sources for the various sectors of the industry, and estimated the fuel consumed in each service for 1974, the latest year for which such information was avallable. They also estimated the increases in power levels that will probably occur. in each type of vessel by the year 2000, and the probable fuel consumptions in that year. A summary of this information is given in. Table 5-2.

It will be seen from the table that the forelgn trade sector consumes by far the largest fraction of all fuel utilized by the marine industry: $80 \%$. In 1974 and an estimated $84 \%$ in 2000 . However, the bulk of the fuel consumed by this sector is purchased outside the United States. Only $7 \%$ of nearly 4800 vessels engaged in U. S. foreign trade are American flag ships. The fuel purchased by this sector in 1974 is shown below:(5-23)

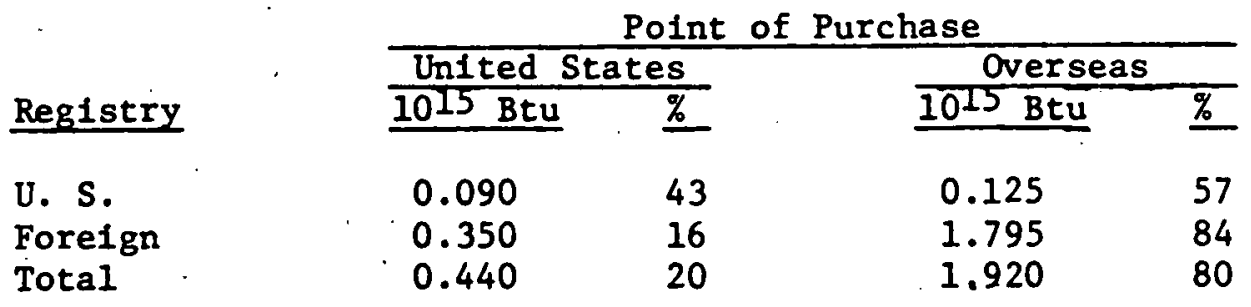

In addition to the $0.44 \times 1015 \mathrm{Btu}$ of marine fuels purchased in the U. S. in 1974 by the vessels engaged in foreign trade, another $0.37 \times 1015$ BTU of fuel was purchased in the U. S. by the other sectors of the marine industry. This was a total of $0.81 \times 1015 \mathrm{Btu}$ out of the $2.9 \times 1015 \mathrm{Btu}$ for the Industry, or $28 \%$. Of the fuel purchased in the U. S., $72 \%$ was residual fuel, $17 \%$ diesel and $11 \%$ gasoline. Of the fuel purchased outside the U. S., $91 \%$ was diesel and the rest resid. (5-23) 


\section{TABLE 5-2}

ENGINES AND FUEL CONSUMPTION IN VARIOUS SECTORS OF U. S. MARINE INDUSTRY

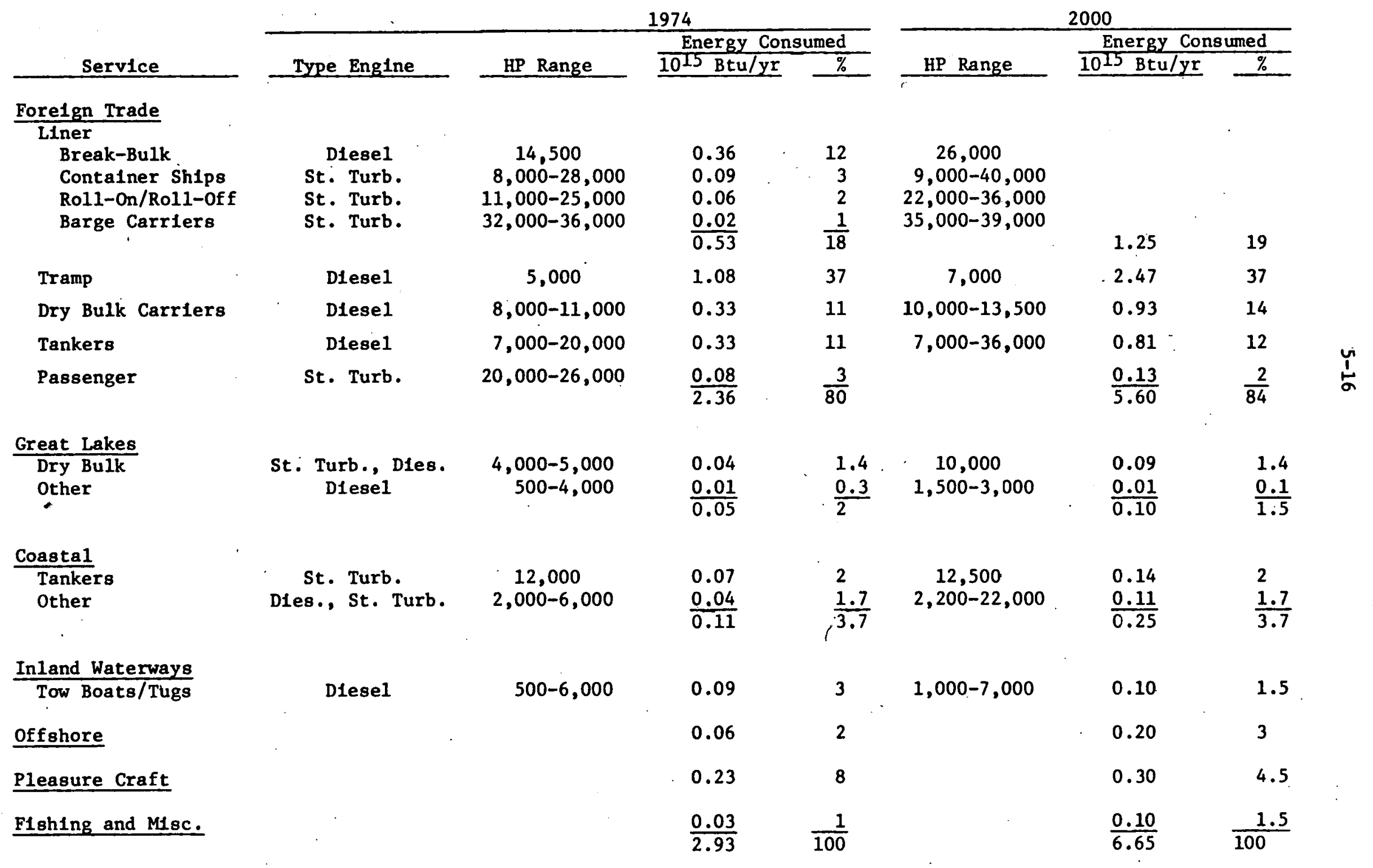


Above 20,000 shaft horsepower (SHP), most of the vessels are powered by steam turbines with residual fuel fired to the bollers. Diesel engines are generally used for lower horsepowers; the smaller SHP engines have been fueled with distillate, but currently, especially overseas, the predominant choice is low-speed diesel engines utilizing the same residual fuel fired to steam boilers. These low-speed diesels get good efficiency and operate on the cheaper, more avallable restdual fuel. They can be built up to 45,000 SHP, but delivery times are so long for such sizes that usually diesel installations are below 30,000 sHP. If the quallty of the residual fuals avallable for marlne use continues to deterforate, ship operators may go back to the use of steam turblnes for vessels above 20,000 SHP.

The Booz-Allen \& Hamilton study also included Information on power plants that could be avallable for the marine industry by 2000 , including the projected fuel efficiencles, and this is sumarized below: (5-24)

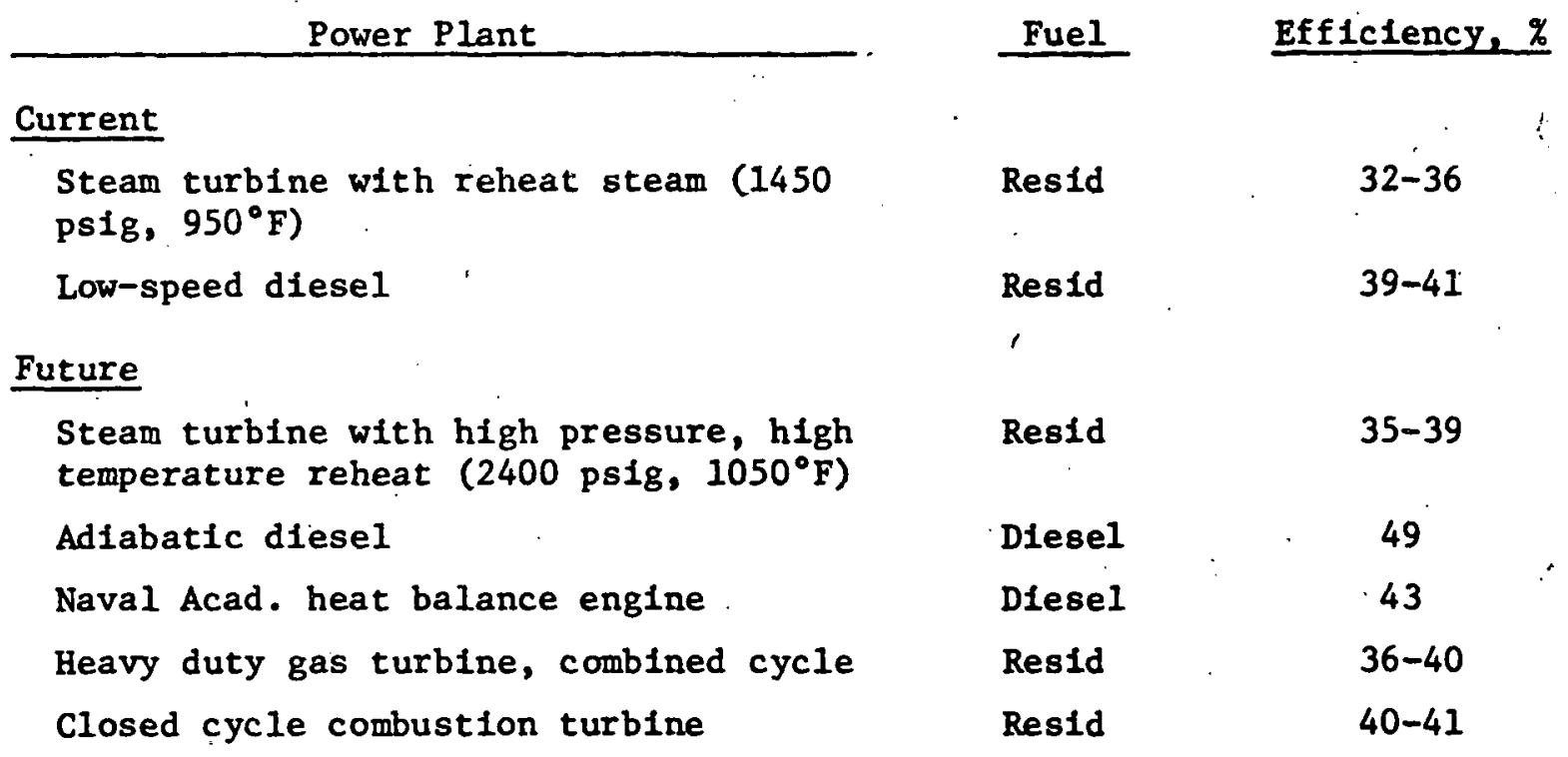

Combustion turbines for powering ships have not been used significantly so far. Deterrents have included the need for clean distillate fuels and the inherent drop-off of efficiency at part load. Efficlencles of simple-cycle combustion turbines are not high (around $30 \%$ ), but incorporation of a steam/turbine bottoming cycle (combined cycle) can increase efficiencies to $40 \%$ or more. Combustion turbines do have an advantage in providing low welght/SHP.

Work is being carried out to overcome the shortcomings of combustion turbines. Heavy-duty combined cycle units that can operate on residual fuel are being developed, as indicated in the tabulation above. Detroit Diesel Allison is developing a 7000 SHP simple-cycle combustion turbine for marine use which maintains essentially constant $30 \%$ fuel efficlency over the top $70 \%$ of its load curve. (5-26) United Technologles Corp, has been carrying out desIgn studies for the Office of Naval Research to Identify light-weight propulsion systems for high performance naval ships in the 20,000 to 200,000 
SHP range. They have studied simple-cycle combustion turbines operating at higher gas inlet temperatures to achieve higher effictencies, and closedcycle turbines for which the heat is provided by an external heater fired with a hydrocarbon fuel or a nuclear reactor. They find that, with fossil fuels, the total engine-plus-fuel weight would be smaller for the simplecycle case for short-endurance missions, and the closed-cycle would be lighter for long-endurance missions. The use of a light-weight nuclear heat source could make that case with a closed-cycle better than either of the fossil fuel cases for all missions. (5-27)

\subsection{Possibllities for Fuel Cells}

The only fuel cell system that could be commercially avallable before 1985 is the phosphoric acid system, and the overall efficiency of this system from fuel to DC electriclty is projected to be about $40 \%$. This would not have any advantage on a fuel consumption basis over the low-speed diesels already available, especially since the fuel cells would require a low-bolling, clean distillate fuel whereas the diesels can run on resid. As noted in the above tabulation, advanced diesel engines running on diesel fuel may be able to achleve efficlencies above $40 \%$. Studies also have been made on the possibilities of utilizing a secondary, or bottoming cycle to produce additional useful energy from the hot exhaust gases liberated from the diesel engine. It is estimated (5-24) that $15-18 \%$ of the energy in the exhaust gases can be recovered in this way. This could provide at least part of the power required for ship services, and would result in an overall improvement in the efficiency. of the diesel engine system.

On ships, especially tankers, that require steam for operations such as heating cargo or cleaning holds, there is an advantage for employing steam turbines and boilers. A fuel-cell-powered ship would have to have an auxiliary-fired boiler. In a diesel-powered ship, the heat in the exhaust can be used to generate steam for some of these needs. The fuel cells would directly provide the electricity needed aboard ship, whereas auxiliary generators are needed with diesels or steam turbines.

Because of maintenance problems with diesel engines, diesel-powered ships generally are equipped with a spare engine. Extra power is always needed in port to handle the loading/unloading operations, and extra engines are always provided for these purposes. On a small ship, there may be three -engines: one for normal at-sea operation, another to be put on line for in-port duty, and one spare. A fuel cell power plant, being made up of a number of smaller modules, would not have as large a percentage of spare capacity.

With fuel cells, direct current motors would be necessary to drive the shafts, whereas only gear trains are required for diesels or steam turbines.

In the 1985-2000 period, molten carbonate fuel cells may be commercially available, and they could be feasible on large ships. With a potential effictency of about $50 \%$, such fuel cells might be economically 
competitive. The use of fuel cells employing hydrogen or hydrazine as fuels have been suggested for marine use. $(5-28,5-29,5-30)$ As shown in Table 6-1, the cost of hydrazine is expected to be at least six times that of liquid fuels from coal per million Btu's, so that it does not seem possible that a hydrazine-based fuel cell could ever compete economically with other prime mover systems. Liquid hydrogen cost from Table 6-1 is more than twice that of coal liquids. With hydrogen fuel, an alkaline electrolyte fuel cell could be used, which would be cheaper and of higher efficiency than those utilizing hydrocarbon fuels. No fuel processing equipment would be needed, but the air feed would have to be scrubbed to remove $\mathrm{CO}_{2}$, and 11quid hydrogen storage would be expensive and require additional volume compared with liquid hydrocarbon fuels, even with higher fuel efficiency. Use of gaseous hydrogen stored in metal hydrides is an alternative; gaseous hydrogen is about \$5/MBTU cheaper than liquid, but the cost of a metal hydride storage system is significant. An economic analysis of this situation would be necessary.

In view of the information presented in Table 5-2 and the tabulation of current and future efficiencies as well as the factors considered in the above discussion, a detailed investigation has been made on the economic feasibilities for fuel cells in marine applications. Two cases are covered: (1) a medium-sized vessel of about 7000 SHP normally powered by diesel engines, such as a small tanker or a tramp ship; and (2) a large vessel normally utilizing a steam turbine drive of around 40,000 SHP, such as an ultra-large tanker.

\subsubsection{Plpelines}

In the United States in 1975, there were 263,000 miles of natura1 gas transmission lines and $130,000 \mathrm{miles}$ of trunk lines for long-distance movement of crude petroleum and petroleum products. (5-31) Assuming there is a pumping station about every 150 miles for the gas 11nes and every 40 miles for the ofl lines, there would be about 5000 such stations in the Unfted States. In 1970, which was about the peak period for gas and oil production in the U. S., $740 \times 1012 \mathrm{Btu} / \mathrm{yr}$ were consumed in pumping natural gas, and $390 \times 1012 \mathrm{Btu} / \mathrm{yr}$ for pumping crude and petroleum products. (5-32) These values were about $600 \times 10^{12}$ and $235 \times 10^{12} \mathrm{Btu} / \mathrm{yr}$ in 1976 .

In the U. S., almost all the ofl pipeline pumping is accomplished with AC electric motors fed from local electric utility grids. In the past, the plpelines obtained special low prices from the utilities for their power requirements because they provided an assured, steady load. Recently, however, the utilities have been increasing their prices to closer to the average residentlal rates. Even at these higher cost levels, it is unlikely that fuel cells could provide pumping power at lower cost than that available from the utility grids. Banks and Horton (5-33) describe as a major advantage of fuel cells for ilquid pipeline pumping operations the fact that the speed of the DC motor drives could be easily varied as liquid throughput requirements varied by adjusting the output of the fuel cells. In current operations with constant-speed AC motors, throttling of the liquid flow is sometimes 
necessary to control throughput, and this results in significant wastage of energy. However, AC motors are now becoming available that provide for controlled phase changing so that power, and therefore throughput, can be adjusted as desired. Also, variable-speed 11nkages can be provided between the motor and the centrifugal pump. On the other hand, some extra costs would be involved in using DC motors; because of the arcing inherent in commutated motors, which would be quite hazardous in the pump houses, some kind of protection would have to be provided around the motors. In view of the above factors, further consideration of fuel cells for use on oil pipelines is probably not justified.

For gas pipelines, at least $93 \%$ of the compression energy is supplied by gas taken from the pipeline.(5-32) otto cycle, reciprocating engines are used to drive the compressors in about half the compressor stations today. These range in capactty from 1000 to $13,500 \mathrm{HP}$; about $70 \%$ are in the 1000-2000 HP range. (5-33) High efficlency is obtainable with such engines because of the high octane number of methane and the high compression ratios therefore usable. Prior to the Arab oil embargo, combustion turbines had been purchased for this service in increasing numbers because their lower maintenance requirements were able to offset the higher efficiency of the reciprocating engines, and their cost was less (average of $\$ 219 /$ installed HP vs $\$ 295$ for reciprocating machines). As gas prices increased in recent years, the combustion turbines were the first to be taken out of service in those lines where throughput declined. In an effort to reverse this trend, combustion turbine manufacturers have undertaken research and development programs to improve turbine efficiencies. (5-33)

Efficiencles of existing and possible future prime movers which can be utilized on gas pipelines are summarized below. $(5-33,5-34)$

Prime Mover

Combustion Turbines

Older simple-cycle

Newer simple-cycle

Simple-cycle with heat recuperation

Combined-cycle with steam bottoming

(Existing)

(Future)

Combined-cycle with organic bottoming

Same with heat recuperation

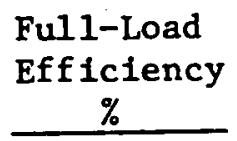

$20-25$

30-39

$34-35$

39

42

43

$47+$
Part-Load Efficlency $\%$

Otto Cycle Reciprocating Engines

Existing, new

31-39

Combined-cycle with steam bottoming*

$38-43$

Combined-cycle with organic bottoming*

$39-45$

*Retrofit of bottoming cycles appears possible on existing machines.

(Continued) 
Prime Mover

Diesel Reciprocating Englnes
(Using Diesel Fuel)

Existing

Combined-cycles with organic bottoming

\begin{tabular}{cc}
$\begin{array}{c}\text { Ful1-Load } \\
\text { Effictency } \\
\%\end{array}$ & $\begin{array}{c}\text { Part-Load } \\
\text { Efficiency } \\
\%\end{array}$ \\
\hline
\end{tabular}

It is seen from the above information that equipment already exists which is about as efficient as the phosphoric acid electrolyte fuel cells are expected to be, and improvements to existing equipment are being studied which could bring efficiencies to the range anticipated for molten carbonate fuel cells. Fuel cells would have an advantage at part-load conditions, because their efficiency improves as load decreases, whereas combustion turbine efficiencies drop of $\mathrm{f}$ sharply at part load. The Banks and Horton study(5-33) concludes, based on generalized considerations, that fuel cells are very promising devices for applications on pipelines. Their study, however, does not assess some of the limitations to fuel cells brought out in the earlier part of this section.

\section{1 .4 Conclusions}

From the considerations discussed in this section, it may be concluded that there are some possibilities for applications of fuel cells in non-highway transportation, but more detailed studies and economic comparisons with probable improvements on existing systems on a total systems basis will have to be made to determine whether fuel cells could be practically viable and economically competitive in the future. The various fuels that will be avallable in the future will have to be considered for each type of prime mover. Undoubtedly, research and development efforts will be necessary on fuel cell systems, and the studies proposed will indicate where those. efforts could best be directed.

The areas that seem most worthwhile studying in more detall are listed below. In general, comparisons of applications at the lower levels of power requirements will probably be more favorable to fuel cells because there is a larger reduction in cost per horsepower with increasing power level for the various heat engines than there is for fuel cells.

- Railroad locomotives

Comparison of fuel cells with diesel-electric drives for 3000-3600 HP road engine and $1500 \mathrm{HP}$ switch engine.

- Marine

Comparison of fuel cells with $7000 \mathrm{HP}$ diesel engine and with 30-40,000 HP steam turblne drives. 
- Pipelines

Comparison of fuel cells with advanced combustion turbine combined-cycle systems and advanced reciprocating engines of about $5000 \mathrm{HP}$.

\subsection{Nuclear}

In addition to using nuclear energy to generate electricity or hydrogen,' which can serve as energy carriers, nuclear energy is being used directly in marine transportation and has been seriously considered for aircraft application. The nuclear reactor is used to generate steam to drive a steam turbine in one case, and to preheat the air to high temperatures to drive a gas turbine in the other case. Theoretically, it is possible to use nuclear energy in railroads and pipelines, but the institutional problems would be greater than for the marine or aircraft application. The following sections will address the status and problems of direct use of nuclear power in each of the four modes of non-highway transportation.

\section{2 .1 Marine}

Currently there are in excess of 200 operating nuclear-powered ships, with some of these having been in service for more than 20 years. (5-39) Almost all these are naval ships, but there have been two nuclear merchant ships built--the "Savannah" In the United States and the "Otto Hahn" in the Federal Republic of Germany. Also, a third non-military nuclear ship, the "Mutsu" has been built in Japan for use in government assignments. (5-39)

The "Savannah" was a 9830 deadweight ton vessel powered by a pressurized water reactor nuclear power plant. The vessel operated from 1962 to 1970. The service record of the nuclear propulsion system was nearly flawless ( $99.88 \%$ availability record) during its 500,000 miles of operation. $(5-39)$

The "Otto Hahn" Is a 15,000 deadweight ton vessel that Incorporates a more advanced nuclear propulsion system than the "Savannah." The "Otto Hahn" has been in service since 1968 and its nuclear plant has had one of the best operating records of any nuclear plant constructed in Europe. (5-39)

Based on the operating record of the "Savannah" and "Otto Hahn," together with the more than 200 nuclear naval vessels, it is clear that the technology exists today to produce nuclear-powered commercial vessels.

There are three major problem areas that have retarded the progress of nuclear-powered ships:

1. Economics

2. Indemnification and liability

3. Port entry and international clearances 


\subsubsection{Economics}

As the situation exists now, the economic competitiveness of nuclear vessels over conventional vessels cannot be demonstrated with any real degree of confidence. Construction costs of a nuclear-powered ship are considerably higher than those for a conventional vessel, so that the economic incentive must come from the lower unit fuel cost of nuclear versus fossil fuel, to offset the carrying charges assoclated with the higher investment. Nuclear power plants, with lower unit operating costs, are generally more economically attractive than conventional power plants if the size and output of the unit is raised to a sufficiently high level. Thus, nuclear power would have the best opportunity to be economical in very large ship sizes. Huskisson of Lloyd's Register states, "The cost of nuclear propulsion seems to rise at almost the same rate as o11." $(5-40)$ Thus, it is not clear when in the future nuclear-powered ships may be economical.

\subsubsection{Indemification and Liability}

Lability coverage is also one of the major problems deterring commercial nuclear ship development. At present, sufficient liability coverage is not obtainable in the U.S. through the commerclal underwriting markets to protect owners against claims by persons who may be injured or sustain property loss or casualty as a result of radioactive damage from a nucPear ship accident. (5-39)

The Price-Anderson bill, which provides U, S. government indemnity for land-based reactors does not apply to merchant vessels. The "Savannah" was covered by the Price-Anderson b111, but in 1974, the proposal to grant the same provisions to all merchant ships was dropped for legislative reasons. The "Otto Hahn" and the "Mutsu" are covered by combined commercial and government insurance. $(5-39)$

\subsubsection{Port Entry and International Clearance}

The third major obstacle to nuclear-powered marine vessels is obtaining clearance to dock in the U. S. and forelgn ports. For the "Savannah" and the "Otto Hahn," port entry was obtalned through governmentto-government negotiation of bilaterial agreements. (5-39) This is a timeconsuming practice and impractical on a commercial basis.

Acceptance of nuclear-power vessels by a government does not necessarily mean that the ship could call at its ports. Pressure groups within a country could easily bar admittance. Considering the recent protest over land-based reactors which have occurred in the U. S. and other nations of the world, it seems reasonable to assume that mobile reactors in ships would be treated similarly.

In sumary, the technology exists to build nuclear-powered merchant ships. However, it is not clear when nuclear-powered ships will become economical to fossil-fueled vessels. In addition, there are substantial non-economic problems to be solved before a nuclear merchant fleet becomes a reality. 


\subsubsection{Aircraft}

Nuclear-powered aircraft have been explored in considerable detail since the $1950^{\prime} \mathrm{s}$. A schematic drawing of a nuclear alrcraft power plant is shown in the figure below.

\section{SCHEMATIC OF A NUCLEAR AIRCRAFT POWER PLANT}

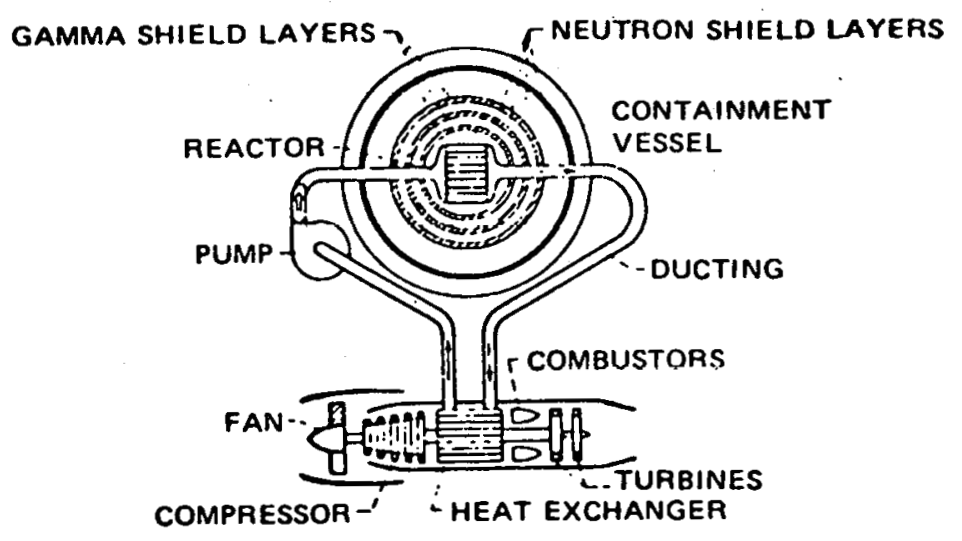

$\mathbf{6}$

Source: Ref. 5-41

A major problem with nuclear-powered aircraft is the weight penalty assoclated with the reactor shielding to protect the crew and passengers. It appears that a nuclear-powered aircraft would require a take-off weight of perhaps 1.5 million pounds to carry a practical payload. $(5-41)$ Because of the total power plant weight, it seems that the payload carrying ability would be comparatively small even though the large fuel weight requirement of conventional turbine engines has been eliminated.(5-42) The increased price of fossil fuels is a factor that should help the relative economics of a nuclear-powered aircraft. However, the cost of the nuclear power plant and fuel, and the cost of the airframe to carry the heavy power plant are such that it is not clear that there would be any economic gain. On the basis of avallable data, the high investment costs appear to outweigh the fuel cost savings. (5-42)

A recent study by Rand for the Air Force on very large military airplanes (VLA's) gives an indication of the cost of a military nuclearpowered aircraft compared to fossil-fueled planes with the same design payload (350,000 pounds). The fossil-fuel planes were limited to a range of around 6,500 nautical miles, while the nuclear plane would have essentially unlimited range. The following table compares the life-cycle cost estimate 
for 112 unit equipment (U.E) aircraft (which could be interpreted as providing "equal capability" on the design-point mission) and Include a representative peacetime utilization rate.

LIFE-CYCLE COST ESTIMATES

(BILLIONS OF 1975 DOLIARS)

\begin{tabular}{|c|c|c|c|c|}
\hline Alternative & $\begin{array}{l}\text { Acquisition } \\
\text { Cost } \\
\end{array}$ & $\begin{array}{l}20 \text { Year Operating } \\
\text { and Support Cost }\end{array}$ & $\begin{array}{c}\text { Total } \\
\text { Life-Cycle } \\
\text { Costs } \\
\end{array}$ & $\begin{array}{l}\text { Ratio to } \\
\text { VLA-Syn JP }\end{array}$ \\
\hline VLA-Syn. Jet Fuel & 15.5 & 16.4 & 31.9 & 1.0 \\
\hline VLA-Liquid $\mathrm{CH}_{4}$ & 16.5 & 18.8 & 35.3 & 1.11 \\
\hline VLA-Liquid $\mathrm{H}_{2}$ & 13.6 & 21.3 & 34.9 & 1.09 \\
\hline VLA-Nuclear & 32.1 & 24.6 & 56.7 & 1.78 \\
\hline
\end{tabular}

Source: $5-43$

The absolute cost figures are not as meaningful as the ratio of the cost, which clearly show that a nuclear-powered aircraft is not economically attractive.

One of the conclusions from the Air Force study was that nuclear propulsion for aircraft was only attractive for station-keeping missions requiring large station radil (greater than 4,000 nautical miles). Thus it would appear that from a commerclal standpoint, nuclear-power afrcraft would not be economically attractive.

In addition to the economic factors, the environment and safety concerns of carrying a nuclear plant in an alrplane, which might crash in populated areas, would seem to be almost an insurmountable problem to overcome. It would seem to be a safe guess that nuclear aircraft for commercial transport purposes will not be seen until sometime well after the year 2000 , if at all.

\subsection{3 - Railroad and Pipeline}

While it should be technically feasible to use nuclear power to generate electric power that could be used on board a rallroad engine or at a remote pipeline pumping station, it would seem to be extremely unlikely that it would be elther economical or practical. In general, nuclear power is potentially economical only for very large-size plants. On the scale envisioned for railroad or pipeline application, it would seem to be unlikely that nuclear power could compete with any of the other alternate fuels being considered. 
The institutional problems to be overcome on using a nuclear reactor on board a railroad engine, that may derail in a populated area, would seem to be insurmountable.

\subsection{Direct Solar Radiation}

Direct solar radiation may be used to heat a working fluid that may be used to develop power in a heat engine. Thermal conversion may be divided into three levels: low temperature $\left(225-250^{\circ} \mathrm{F}\right)$ used for solar heating, high temperatures (producing steam temperatures of up to $600^{\circ} \mathrm{F}$ by concentrating the sun's rays by use of reflecting surfaces), and ultrahightemperature (approaching $5000^{\circ} \mathrm{F}$ through the use of precisely controlled parabolic reflectors). Only the latter two areas would generate steam temperatures high enough to be considered for non-highway transportation. However, both'systems require the use of reflectors which require a large area.

Another direct radiation method is the application of photovoltalc cells to convert sunlight directly to electric power. The amount of area of solar cells required for typical rail, marine, and pipeline applications are discussed in the following sections. The use of solar photovoltaic is not possible to even consider for aircraft application because of weight limitations and the impact of the solar cells on the aerodynamic behavior of the plane.

\subsubsection{Marine}

The average amount of solar power that falls on the earth during a 24-hour day at an average location is about 18.6 continuous watts/ft ${ }^{2}$ (200 watts $/ \mathrm{m}^{2}$ ). In some parts of the world, the rate will be considerably greater. The intermittant peak solar power falling on the earth is around 93 watts/ft ${ }^{2}$ (1000 watts $/ \mathrm{m}^{2}$ ), but due to the nature of solar energy, storage batterles must be used to store the electrical energy generated during peak hours. Thus, the annual average amount considered for this screening study is 18.6 watts/ft ${ }^{2}$ (200 watts/m ${ }^{2}$ ). Since current photovoltalc collectors have efficlencies of around $10 \%$, this means that the power collected is 1.9 watts $/ \mathrm{ft}^{2}$ (20 watts $/ \mathrm{m}^{2}$ ) of collector area. The theoretical maximum efficiency is limited to about $20 \%$.

To generate 10,000 SHP (continuously for 24 hours) would require about $4.2 \times 106 \mathrm{ft}^{2}$ of collector surface if the photovoltalc efficiency is $10 \%$. For a 485,000 deadweight ton tanker, the approximate deck area is only $0.24 \times 106 \mathrm{ft}^{2} .(5-40)$ Thus, it is clear to see the impracticability of using solar photovoltaics as an alternate energy form. for marine application. Even at a $20 \%$ photovoltaic cell efficiency, it is still impractical.

\subsubsection{Ra1lroad}

For a $3300 \mathrm{hp}$ locomotive, a solar photovoltaic collector surface of $1.3 \times 10^{6} \mathrm{ft}^{2}$ would be required, assuming the average of 18.6 continuous watts/ $\mathrm{ft}^{2}$ (200 watts $/ \mathrm{m}^{2}$ ) of solar power and a $10 \%$ collector efficlency. If one assumes the collector could be attached to the top of each locomotive and 
freight car, then a 50-car train would be able to carry only $0.025 \times 10^{6} \mathrm{ft}^{2}$ of collector area. Thus, it is not necessary to consider further the use of solar photovoltaics for rall use.

\subsubsection{Pipeline}

The size of pumps vary widely in the pipeline industry, but for illustrative purposes, it will be assumed that a $500 \mathrm{hp}$ driver is required. The amount of collector area required assuming 18.6 watts $/ \mathrm{ft}^{2}$ (200 watts $/ \mathrm{m}^{2}$ ) and $10 \%$ efficiency) is about $0.2 \times 106 \mathrm{ft}^{2}$. Th1s would require an area of about 5 acres for this 500 hp case. Again, in most cases this would be an impractical solution to the alternate fuel problem. In some isolated cases, the use of photovoltaic cells may be useful if the pumping station is very remote and the material being pumped cannot be used as a fuel in either a diesel or gas turbine. 


\section{REFERENCES}

5-1 Llebhafsky, H. A. and E. J. Cairns, Fuel Cells and Fuel Batteries, Wiley, New York, 1968.

5-2 Kordesch, K. V., "Fuel Cells for Electric Vehicles," International Society of. Eledtrochemistry, 28th Meeting, 9/18-23/77.

5-3 Lueckel, W. J., L. G. Eklund, S. H. Iaw, "Fuel Cells for Dispersed Power Generation," IEEC PEC Winter Meeting, New York C1ty, 1/30/72$2 / 4 / 72$.

5-4 Fickett, A. P., "An Electric Utility Fuel Cell: Dream or Reality," American Power Conference, Chicago, Illinois, Apr11 1975.

5-5 Lueckel, W. J., "Fuel Cells for Ut1l1ty Service," United Technologies Corp., April 1976.

5-6 Noyes, R., editor, Fuel Cells for Public Utility and Industrial Power, Noyes Data Corp., Park R1dge, N. J., 197.

5-7 Adams, D. R., et al., "Fuel Cells: Power for the Future," Harvard Business School, October 1960.

5-8 Lueckel, W. J., P. Faris, "The FCG-1 Fuel Cell Powerplant for Electric Utility Use," IEEE PEC, July 15, 1974.

5-9 Elzinga, E. R., et al., "Application of the Alsthom/Exxon Alkaline Fuel Cell System to Utility Power Generation," January 1977, EPRI EM-384 (Research Project 584-1).

5-10 Ciprios, G., "The Methanol-Air Fuel Cell Battery," Intersociety Energy Conversion Engineering Conference, Los Angeles, California, September 26-28, 1966.

5-11 Okrent, E. H. and C. E. Heath, "A LIquid Hydrocarbon Fuel Cell Battery," chapter in Fuel Cell Systems - II, B. S. Baker, editor, Advances in Chemistry Series 9.0 , American Chemical Soctety, Washington, D. C., 1969, page 328 .

5-12 Bono, P., et al., "Methanol-Air Fuel Cells with Buffer Electrolyte," Rev. Gen. Elec. (France) 86 (1) 31, January 1977.

5-13 King, J. M., "Energy Conversion Alternatives Study - United Technologies Phase II Final Report," October 19, 1976, NASA CR 134955 FCR-0237.

5-14 Warde, C. J., A. 0. Isenberg, "A Hydrogen-Fueled Power System Based on the Westinghouse OCR High-Temperature Solid-Electrolyte Fuel Cell," presented at Argonne National Laboratory meeting, April 1975. 
5-15 Harrison, J. W., "The Potential of Fuel Cells for Generation of Electricity from Hydrogen," presented at Argonne National Laboratories meeting, April 1975.

5-16 Lawrence, L. R., "The ERDA Fuel Cell Program," IEEE PES Summer meeting, Mexico City, Mexico, July 17-22, 1977 :

5-17 "Use of Fuels to Generate Electricity from Hydrogen," United Technologies Power Systems Division, presented at Argonne National Laboratories meeting, April 1975.

5-18 "Proceedings of the Fuei Cell Powered Vehicle' Workshop," Los Alamos Scientific Laboratory, Los Alamos, N. M., August 15-17, 1977.

5-19 1977 Annual Report of the Association of American Railroads.

5-20 ICC Transport Statistics in the United States.

5-21 "Railroad Energy Study: Description of Rall Transportation in the United States; Volume I: Freight Raliroading," Stanford Research Institute, ERDA Contract E4-76-C-03-1176, January 1977.

5-22 Dellacanonica, O. G., "Electric Locomotives to Meet Today's Needs," Mechanical Engineering; October 1972.

5-23 "Energy Use in the Marine Transportation Industry; Task I - Industry Summary, Booz-Allen \& Hamilton, January 11, 1977, ERDA Contract No. $E(04-3)-1175$.

5-24 "Energy Use in the Marine Transportation Industry, Task IV - Industry Future," Booz-Allen \& Hamilton, August 18, 1977, ERDA Contract No. EY-76-C-03-1175.

5-25 "Evaluation of the Alternatives for Contingency Fuels in the Commercial Marine Transportation Industry," Booz-Allen \& Hamilton, December 1977, Department of Energy Contract No. EY-76-C-03-1175.

5-26 Strother, J. R., "Description and Performance of a 7000 SHP Marine Gas Turbine Engine," ASME, Gas Turbine Conference, London, England, Apr11 9-13, 1978.

5-27 Kuo, S. C., T. L. O. Horton, H. T. Shu and W. R. Seng, "The Prospects for Lightwelght Ship Propulsion Systems," ASME, Gas Turbine Conference, London, England, April 9-13, 1978.

5-28 Carhart, H. W., et al., "Hydrogen as a Navy Fuel," Neval Research Laboratory, Washington, D. C., NRL Report 7754, June 1974.

5-29 Belt, J. R. and H. V. Nutt, "Proceedings of Workshop on Navy Alternate Energy Sources Research and Development," Naval ShIp Research and Development Cènter, Annapolis, Maryland, Report No. 4195, January 1974. 
5-30 Femenia, J., "Alternate Energy Sources for Marine Power Plants," National Maritime Research Center, Kings Point, N. Y., September 1975.

5-31 "Statistical Abstract of the Unfted States, 1977," U. S. Department of Commerce.

5-32 Shonka, D. B., A. S. Loebl, P. D. Patterson, "Transportation Energy Conservation Data Book," Edịtion 2, Oak Ridge National Laboratory, Oak Ridge, Tennessee, October 1977.

5-33 Banks, W. F. and J. F. Horton, "Efficiency Improvements in Pipeline Transportation Systems," Technical Report -: Task 3, SSS-R-77-3025, ERDA Contract EY-76-C-03-1171, September 9, 1977.

5-34 Hajnal, T. E., "Economic Evaluation Technique of Selecting Turbines for Natural Gas Pipelines," ASMA, Gas Turbine Conference, London, England, April 9-13, 1978.

5-35 Handley, L. M., L. J. Rogers, E. Gillis, "4.8 Megawatt Fuel Cell Module Demonstrator," August 1977, ERDA/EPRI/UTC Contract No. EX-76-C-01-2102.

5-36 Handley, L. M., P. E. Grevstad, D. R. McVay, "Improvement in Phosphoric Acid Fuel Cell Powerplant Technology," United Technologies Corp., August 1977.

5-37 King, J. M., "Advanced Technology Fuel Cell Program," Interim Report, September 1977, United Technologies Corp., EPRI Research Project 114-2.

5-38 "Fuel Ce11 Research on Second Generation Molten Carbonate Systems," Project 8984, Special Report; "The Influence of Sulfur Compounds in the Fuel on the Performance and Components of Molten Carbonate Fuel Cells," Institute of Gas Technology, November 1977.

5-39 "The Future of Nuclear Propulsion in Merchant Ship," The Motor Ship, October 1977, pp. 112-116.

5-40 "Lloyd's Pushes for Coal-Fired Sh1p,". news article, New Sclentist, Apri1 13, 1978.

5-41 Rom, F. E., "Status of the Nuclear-Powered Alrplane," Journal of Aircraft, Vol. 8, No. 1., January 1971.

5-42. "Technology Assessment of Future Intercity Passenger Transportation Systems," Vol. 3., March 1976.

5-43 Milkolowsky, W. T., et al., "An Evaluation of Very Large Alrplanes and Alternate Fuels," R-1889-AF, December 1976.

5-44 Femenia, J., "Alternate Energy Sources for Marine Power Plants," COM-75-11474, September 1975. 


\begin{tabular}{|c|c|}
\hline \begin{tabular}{l|l|l|l|} 
BIBLIOGRAPHIC DATA & 1. REPOON NO. & 2. \\
SHEET
\end{tabular} & 3. Recipient's Accession No. \\
\hline \multirow{2}{*}{$\begin{array}{l}\text { Ailternative Energy Sources for Non-Highway Transportation } \\
\text { - Volume IIIA - - Appendices }\end{array}$} & 5. Reporr Dase 1979 \\
\hline & \\
\hline E. N. Cart, Jr., W. Herbst, J. Percival, E. W. Nicholson & $\begin{array}{l}\text { 8. Performing Organization Repr. } \\
\text { No. Exxon/GRU.3T.79 }\end{array}$ \\
\hline 9. Perlorming Organizarion Nane and Address & 10. Project/Task/tiork Unis No. \\
\hline $\begin{array}{l}\text { Government Research Laboratories } \\
\text { Exxon Research and Engineering Company } \\
\text { P.0.Box } 8 \\
\text { Linden, New Jersey } 07036\end{array}$ & $\begin{array}{l}\text { 11. Contract/Grant No. } \\
\text { DE-AC05-77CS05438 }\end{array}$ \\
\hline \multirow{2}{*}{$\begin{array}{l}12 \text { Sponsoginz Oresaizasion Nage and Addract } \\
\text { Non-Highway Systems Branch } \\
\text { Transportation - Energy Conservation Division } \\
\text { Office of Conservation and Solar Applications } \\
\text { Department of Energy, Washington, D.C. }\end{array}$} & $\begin{array}{l}\text { 13. Type of Regoor: Pesiod } \\
\text { Covered FINAL } \\
\text { Sept. 1977-June } 1979\end{array}$ \\
\hline & 14. \\
\hline
\end{tabular}

15. Supple mentary Notes

16. Abstrects

A planning study has been made for $D O E$ on alternate fuels for non-highway transportation (aircraft, rail, marine and pipeline). The purpose of the study was to provide DOE with a recommendation of what alternate fuels may be of interest to nonhighway transportation users from now through 2025 and to recommend R\&D needed to allow non-petroleum derived fuels to be used in non-highway transportation.

In the near term (present 1985), there is unlikely to be any major change in the fuels used in any of the four modes of transportation except that the average quality of the marine fuel is likely to get worse. In the mid-term period (1985-2000), there will be a transition to non-petroleum fuels, based primarily on shale oil derived liquids assuming a shale oil industry is started during this time.

(over)

17. Key Words and Doçument Analysis. 17a. Descriptors

Alternate Fuels

Marine

Aircraft

Pipel ine

Railroad

Prime Movers

Diesel Engines

Gas Turbines
Free Piston Engine

Stirling Engine

Closed Cycle Gas Turbine

Physical Properties of Alternate Fuels

Otto Cycle Engines

Fuel Cells

Nuclear Power

Direct Solar Radiation

17b. Identifiers/Open-Ended Terms

17e. COSATI FieId/Group

18. Availability Statement

APPROVED FOR PUBLIC RELEASE; DISTRIBUT ION UNL IY!ITED

\begin{tabular}{|c|c|}
\hline $\begin{array}{l}\text { 19. Security C.Iass (This } \\
\text { Pepurt) UNCLASS IF IED }\end{array}$ & $\begin{array}{l}\text { 21. No. of Hafes } \\
167\end{array}$ \\
\hline $\begin{array}{l}\text { 20. Security C.Tass This } \\
\text { Page UNCLASSIFIED }\end{array}$ & 22. \\
\hline
\end{tabular}




\section{Abstracts (cont.)}

The future outlook for possible prime movers and potential fuel sources for the long term $(2000+)$ is as follows. In the marine area, steam engines burning coal or diesel engines with unrefined shale oil or coal slurries are the prime candidates. With the aircraft gas turbine, either synthetic liquids from shale or coal would appear to be the most desirable fuels. Railroads will probably remain with the diesel/ electric prime mover using shale oil as a source of distillate. Pipelines will - probably use electric motors as the major type of prime mover.

This Appendix covers the background information on the various prime movers, the physical property data, the fuel-prime mover interaction and a review of some alternate energy forms. . 
A. R. Cunningham

D. A. Carter

\subsection{Introduction and Overall Summary}

The United States faces a serious energy problem with regard to petroleum and natural gas. These two fuels presently sipply essentially all of the energy needs for non-highway transportation systems. One major consideration in evaluating alternative energy sources is fuel cost. Th1s section deals with the economics of fuel manufacture. Analysis of alternative production routes for any particular fuel is performed when the information is avallable. Total costs excluding distribution are calculated as the sum of three factors:
- Recovery of capital
- Cost of feedstocks
- Operating costs.

The economic basis for these calculations is explained in Section 6.2 .

The following alternate fuels are investigated:
1) Shale gasoline
2) Shale distillate
3) Coal gasoline
4) Coal distillate
5) Coal-1n-011 Slurry
6) Methanol
7) Hydrogen
8) Ammonia
9) Ethanol
10) Methane or Substitute Natural Gas
11) Oil from Organic Waste
12) Hydrazine
13) Acetylene
14) Methylamine
15) Low BTU Gas
16) Electricity

Fuel costs are developed from published 11terature. One problem with 11terature data is differences in economic bases, rates of return, plant sizes, etc. A common bases is needed for realistic comparison; the details of this basis are presented in section 6.2. A list of references is included as an attachment to this section. 
The costs for the varlous fuels are shown in Figure 6-1 on the basis of dollars per million BTU (lower heating value*) with cost increasing from left to right. The shaded bar In Figure 6-1 represents the range of costs obtained from the literature. In some cases a single line is shown simply because only one estil:ate was located in the literature. Even with these fuels, there is uncertilinty about the cost. For the purpose of this study, the relative cost, on a consistent basis, is more important than the absolute cost. The absolute cost will be uncertain until some of these plants are actually built and operating experience is obtained.

The same information is shown in Table 6-1 grouped into three cost categories, less than 10 \$/MBTU, 10-20 \$/MBTU, and greater than $20 \$ / M B T U$. Thirteen different fuels/energy carriers are projected to cost less than 10 \$/MBTU in terms of 1980 dollars. It must be stressed that this cost excludes distribution cost, and in the case of both hydrogen and methane, which will best find application in liquid form, the liquefaction cost. These costs are discussed in Section 7.

Another way to consider the same data is to look at the cost of fuels/energy source through the resource base used to produce the fuel. Information on this basis is shown in Figure 6-2. The shale resource base fuels fall in the 4-5 \$/MBTU range. Coal dertved fuels cover a broad range, from 0.5 to $45 \$ / M B T U$. For the solar (biomass) resource most of the fuels are in the 8-16 \$/MBTU range.

Also, this information is examined by fuel produced. Costs on this basis are presented in Table 6-2. In the case of methanol, for example, coal appears to be the most economical resource base. Where a given fuel can be produced from either coal or biomass, the most economical resource base is coal.

* Lower heating value because the latent heat of vaporization of water is not generally recoverable with transportation fuels. 
FIGURE 6-1

ALTERNATE FUELS COSTS

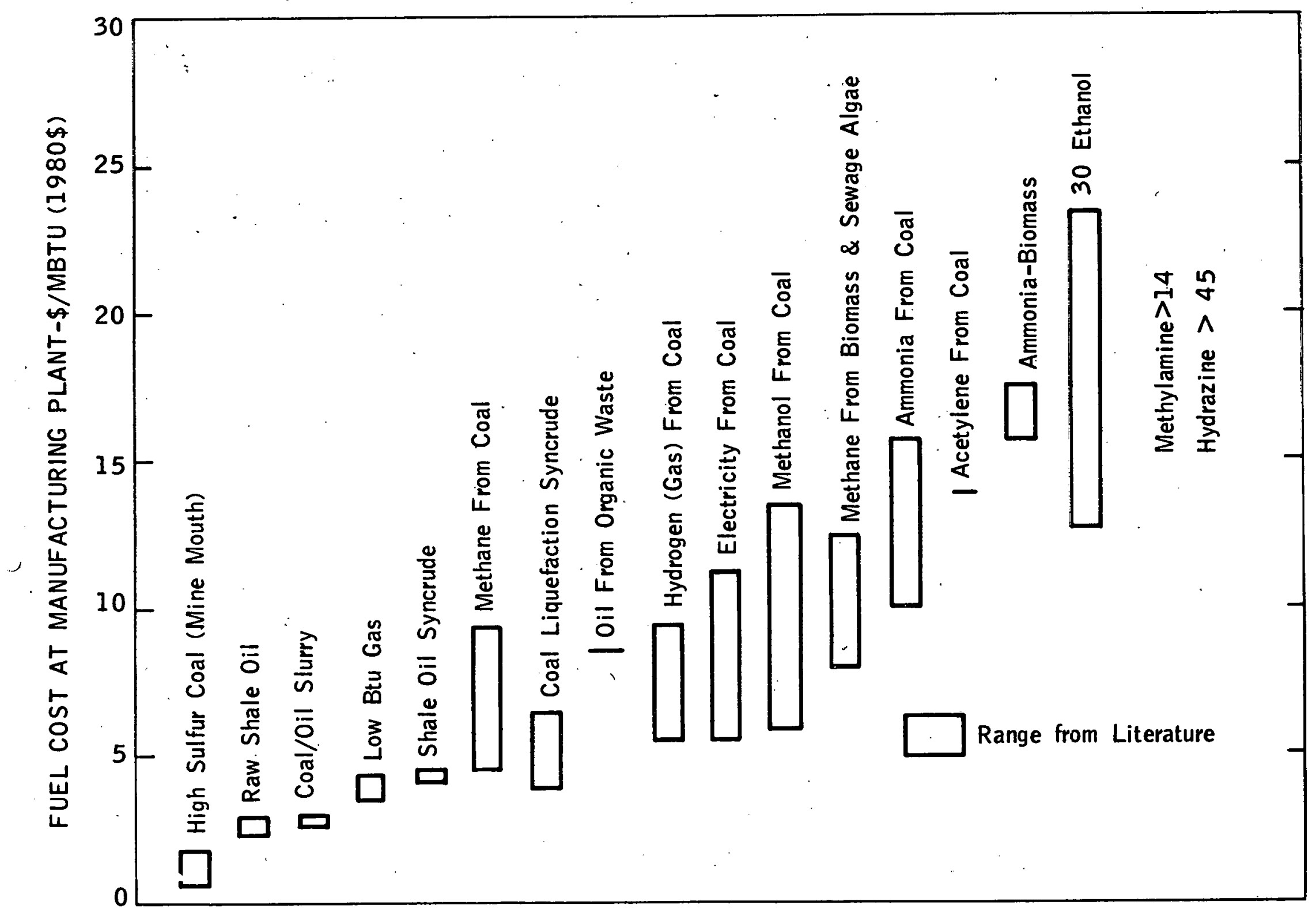


TABLE $6-1$

\section{COST OF ALTERNATE FUELS}

$\leq 10 \$ / \mathrm{MBTU}$ $\underline{10-20 \$ / M B T U}$

$\geq 20 \$ / \mathrm{MBTU}$

'Coal

Raw shale oil slurry

Coal-1n-oil slurry

Low BTU gas

Shale syncrude

Shale distillate

Shale gasoline

Coal 1iquids

(syncrude)

Methane from coal

6.10-8.75

4.90-5. 20

$3.75-6.30$

Acetylene from coal

Methane from sewage

algae

12.50

Amonita from coal

$\cdot 12.30-12.90$

14.00

coa1*
Hydrazine

Methylamine-

20.75

Solid waste

Ethanol by fermentation

21.20

29.70

$>45$

$>14$

Methanol by OTEC
Methanol from blomass 14.80

Ammonia from biomass. $\quad 17.55$ :

Direct coal gasoline $\quad 4.85-8.40$

Direct coal distillate

011 from organic

waste

Hydrogen from coal

$7.90-9.60$

5.35-9.00 Hydrogen by electrol- 19.65 ysis

$$
8.60
$$


FIGURE 6-2

COST OF ALTERNATÉ FUELS BY RESOURCE BASE

\$/MILLION BTU (1980\$)

FUEL/ENERGY SOURCE

Shale

Raw Shale Oil

Shale Syncrude

Shale Distillate

Shale Gasoline

Coal

III. High Sulfur (Mine)

Wyoming Low Sulfur

Coal/Oil Slurry

Low Btu Gas

Methane (Gas)

Distillate-Coal Liquids

Gasoline-Coal Liquids

Electricity

Hydrogen (gas)

Methanol

Ammonia

Acetylene

Methylamine

Hydrazine

Solar

Ethanol/

Fermentation

Oil From Organic Waste

Methane

Ammonia

Methanol

$\begin{array}{lllllllllll}0 & 2 & 4 & 6 & 8 & 10 & 12 & 14 & 16 & 18 & 20\end{array}$

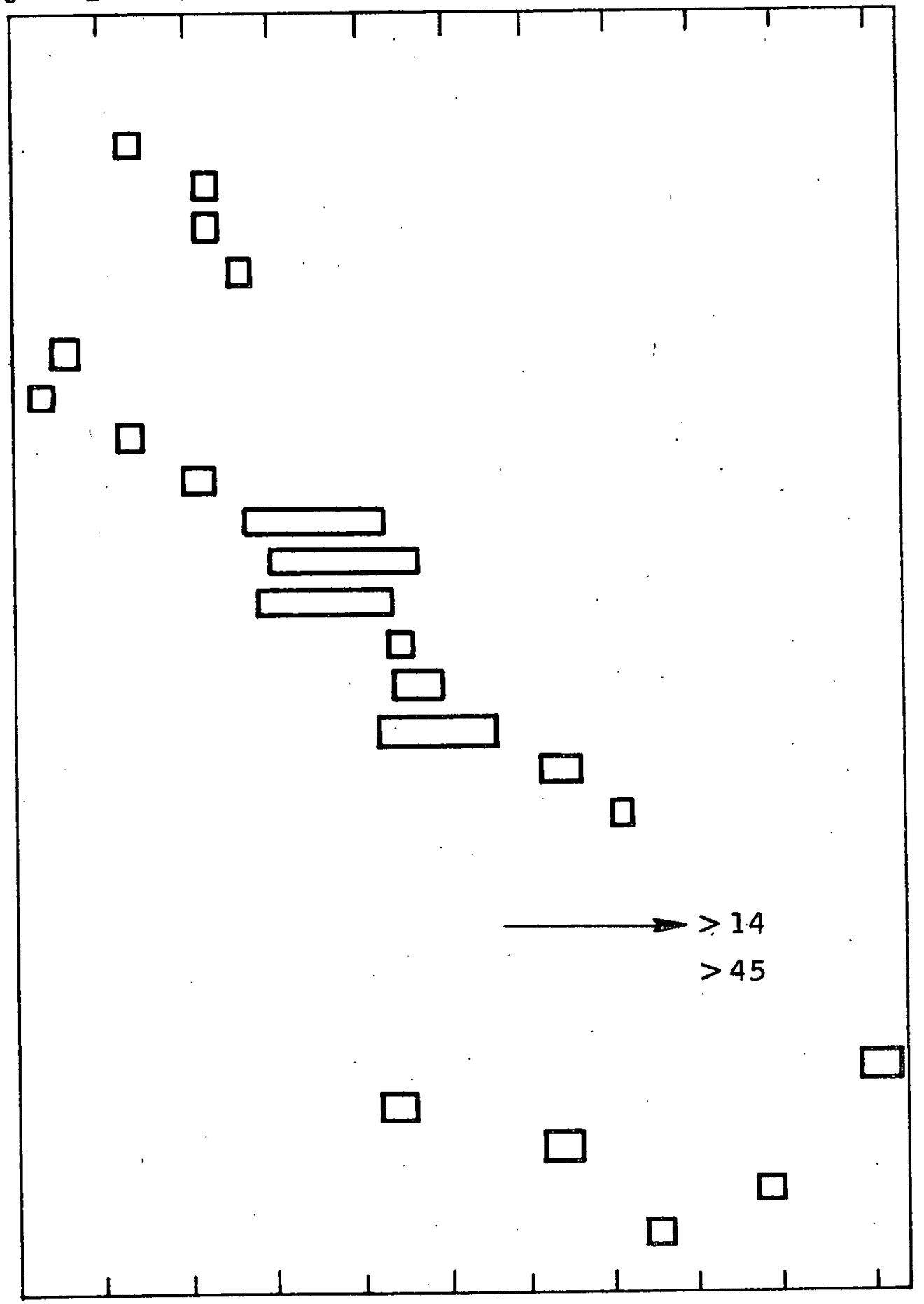




\section{Cost S/MBTU (1980\$)}

Shale gasoline(1)

Shale distillate(1)

Coal gasoline(2)

Coal distillate(2)

Coal (3)-in-011 Slurry

Methanol
- Coal (2)
- Biomass (4)
- Solid Waste Pyrolysis(4)
- OTEC(5)

Hydrogen

- Coal (2)

- Electrolysis (6)

Ammonta

- Coal (2)

o Blomass (4)

Ethanol

- Fermentation (7)

Methane

$$
\begin{aligned}
& \text { - Coal (2) } \\
& \text { - Sewage Algae(4) }
\end{aligned}
$$

$$
4.90-5.20
$$

$4.20-4.40$

$4.85-8.40$

$5.35-9.00$

$2.55+$

$6.65-11.15$

14.80

20.75

29.70

$7.90-9.60$

19.65

$12.30-12.90$

17.55

$16.75-21.20$

5.45-7.95

12.50 
Table 6-2 (Cont.)

Cost, \$/MBTU (1980\$)

Oil from Organic Wastes (4)

Acetylene (8)

Me thylamine (9)

Hydrazine (9)

Low BTU gas (10)

\&/kwh (1980\$)
8.60

14.00

$>14.00$

$>45$

4.25

Electricity

- Coal (11)/Nuclear (12)

3.00

- Solar (13)

10.90

\section{Notes: For Table 6-2}

(1) Produced by aboveground retorting .

(2) Coal at 21 \$/Ton.

(3) Coal at 8 \$/Ton.

(4) Includes waste collection cost of 20 \$/Ton.

(5) Ocean thermal energy conversion.

(6) Current potassium hydroxide technology; about 13 \$/MBTU for developmental SPE process..

(7) Corn at $3.75 \$ /$ Bushel

(8) Cost about the same for.calclum carbide or coal arcing technology.

(9) Current raw material costs only; higher with addition of processing and investment costs.

(10) Coal technology; coal at 21 \$/Ton.

(11) Steam-electric cycle; coal at 21 \$/Ton.

(12) Light water reactor process.

(13) Steam-electric cycle 


\subsection{Basis for Econom1c Evaluation}

Realistic comparison of fuel costs requires a common basis. This is especially true when the information source is published literature whi:h contains a large number of different bases. The bases chosen in this study are presented in Table 6-3.

The dollar basis year is 1980. Investments and operating costs obtained from the literature are escalated at $7 \%$ /year for the years preceding 1980. $100 \%$ equity financing is assumed and a capital recovery factor (CRF) of 0.2 $\$$ /year per dollar of investment is chosen.

A CRF of 0.2 roughly corresponds to a $10 \%$ discounted cash flow (DCF) return. This return rate may be lower than the minimum acceptable to many companies today. Assumptions of project 11fe, depreciation period, depreciation schedule, investment schedule and production rate all affect the CRF and Table 6-4 1llustrates how changes in these varlables affect CRF. CRF is also a function of DCF return level as illustrated in Table 6-5, which shows the CRF for DCF levels of $5 \%, 10 \%$, and $15 \%$ using the assumptions of Case F, Table 6-4. A sample DCF calculation is shown in Table 6-6, using the assumptions presented for Case F, Table 6-4.

An alternative to $100 \%$ equity financing method is utility financing where a substantial portion of the investment is debt financed. This financing scheme generally permlts a somewhat lower capltal recovery factor because of the low equity fraction. Typlcal utility financing CRF's range from 0.155 to 0.17 based on the following:

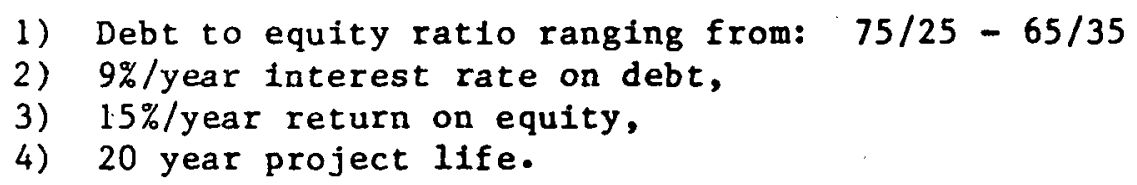

Thus, a CRF of 0.2 represents the lower end of the acceptable industry return levels and is somewhat higher than typical utility recovery levels. 
Table 6-3

\section{Beses For Economic Evaluationg - Task 2}

- Money on 1980 dollar basis

- Assume $100 \%$ equity financing for fuel manufacturing

- Assume capital recovery factor of 0.2 ( $\$ / y r$ per dollar Investment)

- Th18 corresponds roughly to a $10 \%$ DCF return

- Assume cost escalation of $7 \% / y r$ prior to $1980,5 \% / y r$ after 1980

- Investments based on U.S. Gulf location except for facllities which must be located in other regions.

- Investments include a $25 \%$ contingency factor.

- Plant esze

SNG

Ilquids

Bydrogen

Low Btu Gas

Methanol

Ethanol

- Byproduct Prices

\section{Sulfur}

Amonon la

- Electricity Cost

$3 \mathrm{clkowh}$

$$
\begin{array}{rl}
250 & \mathrm{MSCF} / \mathrm{D} \\
50 \mathrm{kB} / \mathrm{D} \\
880 \mathrm{MSCF} / \mathrm{D} \\
1350 \mathrm{MSCF} / \mathrm{D} \\
2000 \mathrm{Ton} / \mathrm{D} \\
1500 \mathrm{Ton} / \mathrm{D}
\end{array}
$$

- Mne-Mouth Coal Cost

B1gh Sulfur (Eastern - underground mine) - 21 \$/Ton

Low Sulfur (Western - surface mine) - 8 \$/Ton 
Table 6-4

CAPITAL RECOVERY FOR 10\% DCF

EFFECTS OF SOME FACTORS

\begin{tabular}{|c|c|c|c|c|c|c|}
\hline Case & $\mathbf{A}$ & $\mathbf{B}$ & C & $\mathbf{D}$ & $\mathbf{B}$ & $\boldsymbol{F}$ \\
\hline Project I1fe, Years & 16 & 16 & 20. & 20 & 20 & 20 \\
\hline Depreclation Period, Years & 16 & 16 & 16 & 16 & 16 & 16 \\
\hline Depreclation Type* & sL & SYD & SYD & SYD & SYO & SYD \\
\hline WorkIng Capital, $z$ on Inv. & 0 & $\mathbf{0}$ & $\mathbf{0}$ & $\mathbf{0}$ & 7.5 & 7.5 \\
\hline $\begin{array}{l}\text { Startup Cost, } Z \text { on Inv. } \\
\text { Production Rate, } Z\end{array}$ & $\mathbf{0}$ & $\mathbf{0}$ & $\mathbf{0}$ & 0 & 0 & 5 \\
\hline $\begin{array}{l}\text { Year } 1 \\
\text { Year } 2 \\
\text { Year } 3 \text { to End }\end{array}$ & $\begin{array}{l}100 \\
100 \\
100\end{array}$ & $\begin{array}{l}100 \\
100 \\
100\end{array}$ & $\begin{array}{l}100 \\
100 \\
100\end{array}$ & $\begin{array}{l}100 \\
100 \\
100\end{array}$ & $\begin{array}{l}100 \\
100 \\
100\end{array}$ & $\begin{array}{r}50 \\
87.5 \\
100\end{array}$ \\
\hline $\begin{array}{l}\text { Investment Schedule } \\
Z \text { In Year }\end{array}$ & & & & & & \\
\hline 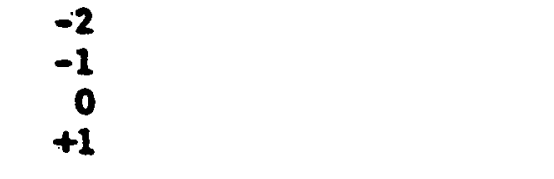 & $\begin{array}{r}0 \\
0 \\
100 \\
0\end{array}$ & $\begin{array}{r}0 \\
0 \\
100 \\
0\end{array}$ & $\begin{array}{r}0 \\
0 \\
100 \\
0\end{array}$ & $\begin{array}{l}15 \\
45 \\
30 \\
10\end{array}$ & $\begin{array}{l}15 \\
45 \\
30 \\
10\end{array}$ & $\begin{array}{r}15 \\
45 \\
30 \\
-10\end{array}$ \\
\hline Capital Recovery Factor & 0.193. & 0.179 & 0.164 & 0.181 & 0.196 & 0.215 \\
\hline
\end{tabular}

- Code

SL - Straight Line Depreciation

SYD - Sum of Yearly Digits 


$$
\begin{array}{r}
6-11 \\
\text { Table 6-5 }
\end{array}
$$

CAPITAL RECOVERY COST FACTORS

\begin{tabular}{cc} 
DCF Return & Capital Recovery Factor \\
\hline $5 \%$ & 0.122 \\
$10 \%$ & 0.215 \\
$15 \%$ & 0.322
\end{tabular}

Bases - Same as Case F Table 6-3 except for return rate. 
(A)

(B)

(C)

(D)

(E)

(F)

(G)

(H)

(I)

Taxable

Year Revenue
End Minus Cos

Cost Depreciation

$-2$

$-1$

0

1

2

3

5

7
8

9
10

10

11

13

14

15

16

17

18

19

20

roteis.

$\begin{array}{rr}(100)(2) & - \\ (4,500)(2) & - \\ 10,350(2) & 11,800 \\ 18,800 & 11,000 \\ 21,500 & 10,300 \\ 21,500 & 9,600 \\ 21,500 & 8,800 \\ 21,500 & 8,100 \\ 21,500 & 7,400 \\ 21,500 & 6,600 \\ 21,500 & 5,900 \\ 21,500 & 5,100 \\ 21,500 & 4,400 \\ 21,500 & 3,700 \\ 21,500 & 2,900 \\ 21,500 & 2,200 \\ 21,500 & 1,500 \\ 21,500 & 700 \\ 21,500 & 0 \\ 21,500 & 0 \\ 21,500 & 0 \\ 21,500 & 0 \\ & . \\ & 100,000\end{array}$

Incoine

(A) - (B)

Net A/T

$$
\text { (100) }
$$

$(4,500)$

$(1,450)$

7,800

11,200

11,900

12,700

$1.3,400$

14,100

14,900

15,600

16,400

17,100

17,800

18,600

19,300

20,000

20,800

21,500

C. 21,500

21,500

21,500
(A) $-50 \%$ (C)

(A) $-50 \%$ (C)

Investment

$$
\begin{aligned}
& 15,000 \\
& 45,000 \\
& 30,000
\end{aligned}
$$

$(2,250)$

11,100

14,900

15,900

15,500

15,100

14,800

14,500

14,100

13,700

13,300

12,900

12,600

12,200

11,800

11,500

11,100

10,800

10,700

10,800

10,700
Working Cash Flow

Capital (D)-(E)-(F)

$7,400(3)$

$(45,000)$

$(39,600)$

1,100

14,900

15,900

15,500

15,100

14,800

14,500

14,100

13,700

13,300

12,900

12,600

12,200

11,800

11,500

11,100

10,800

10,700

10,800

18,100
Discount

Factor

1.21

1.10

1.0

0.909

0.826

0.751

0.683

0.621

0.564

0.513

0.467

0.424

0.386

0.350

0.319

0. 290

0.263

0.239

0.218

0.198

0.180

0.164

0.149
0
Discounted

Cash Flow

(G) $\times(H)$

$(18,150)$

$(49,500)$

$(39,600)$

1,000

12,300

11,900

10,600

9,400

8,300

7,440

6,600

5,810

5,130

4.520

4,020

3,540

3,100

2,750

2,420

2,140

1,930

1,770

2,700

120

Note8:

(1) Units - thousand dollars/year.

(2) Includes startup costs: Year $1,100 \mathrm{MB}$

$+1 \quad 400$

Total $\quad \overline{5000}$

(3) Ass-.-d to be $7.4 \%$ of Investment. 


\subsection{Shale 011}

A potentially important source of non-highway transportation fuels is shale oil. Incentives for developing the large domestic shate resource will increase as the cost of crude oil, especially imported crude ofl, rises.

\subsubsection{Shale 0il Process Description}

The steps required for production of raw shale oil are: mining, crushing, and aboveground retorting. Another alternative currently being developed is referred to as in-situ retorting. In this process retorting occurs underground, in place, followed by product recovery. A further discussion of this process follows later in this section. It is possible to mine shale efther using surface or underground methods. The major underground mining method involves the room-and-pillar technique, in which underground "rooms" are excavated, leaving pillars of unmined shale to support the structure. This operation has been demonstrated in prototype mines. Surface minting is a well developed technique for a variety of ores. It requires removal and disposal of existing overburden, followed by a quarrylike mining operation of the underlying shale. Thus far, this technique has not been applied to shale mining. For economic purposes the room-andpillar technique has been selected in this study.

Oil shale has resiliency and abrasive properties which can lead to difficulties in the crushing operation. In addition, the retorting operation impacts on the shale particle size requirements. The recycled hot solids retort, such as the TOSCO retort, requires particles of $1 / 2$ inch or less. The Gas Combustion Retort (GCR) of the Bureau of Mines has size requirements of 3 inches or smaller. However, the fines of $1 / 2$ inch and less wich are produced in crushing are unacceptable to the GCR and briquetting is required to use them. Altematively, these fines could be used in an assoclated recycled hot solids retort.

Retorting is the process for recovering ofl from the shale bearing rock. In the recycled hot solids retort direct contact heating of small sized shale particles with heated ceramic balls is used to pyrolyze the kerogen*, converting 1t to raw shale oil. Indications are that this retort is best suited for richer shales (30-35 gal/ton). In the Gas Combustion Retort (GCR) air is introduced in the middle of the retort where a combustion $z o n e$ is created to generate the heat required for pyrolysis of the kerogen. The particle size required for this operation is larger than for the TOSCO retort, thereby reducing crushing requirements. However, flow problems occur with particles smaller than $1 / 2$ inch and, as previously mentioned, briquetting or combination with a recycled hot solids retort will be required. Additionally, clinkering and flow problems result with shales of oil content in the 30-35 gal/ton range, thus this retort will find application with the somewhat leane $r$ shales.

* Kerogen is the bituminous material occurring in oil shale that yields oil when heated. 
Environmental concerns assoclated with aboveground retorting operations mainly involve the surface disposal of spent shale and, in view of these concerns, there is increasing interest in developing an underground, in-situ, retorting technique. Basic research indicates that fracturing of the impermeable rock is very difficult and it is cruclal that an efficlent method be developed to generate this permeability, so that heat for the retorting can be introduced and products withdrawn efficiently. It is conceivable that in-situ retorting can lead to environmental problems: such as subsidence and underground water contamination, which will requirt investigation. In general, it is too early to tell whether this technique will provide an effective means for recovering shale oll. The process economics section will be concerned with the recycled hot solids type of retort and $30 \mathrm{gal} / \mathrm{ton}$ shale richness. 


\subsubsection{Shale 011 Properties}

When compared with conventional petroleum raw materials, raw shale oll has a high pour point, as well as high nitrogen and sulfur content. Sulfur and nitrogen must be removed either at the shale oil mining site or at the refinery where the shale oil is to be processed. The scheme investigated here is that the raw shale oil will be upgraded at the mining site to synthetic crude quality. A comparison of typical raw shale oll and syncrude properties is shown in Table 6-7. The upgrading consumes approximately 2000 SCF of hydrogen per barrel of raw oll feed. This syncrude is of high quality with about a quarter of its volume in the naphtha bolling range. As produced the syncrude fractions are useable as turbine fuels without further treating.

\subsubsection{Production Economics for Raw Shale 011 and Syncrude}

Raw shale oil can be produced for about $2.50 \$ / M B T U$ (13 $\$ / B b 1)$. The total cost and components is shown in Table 6-8 for a production rate of 100,000 barrels per day of raw shale o1l. The total cost includes a feedstock cost equivalent to a 1 \$ per barrel bonus bid payment, mining, retorting, and spent shale disposai.

\section{Table 6-8}

RAW** SHALE OIL COST

$\begin{array}{llll}\text { Investment } & -\$ / M B T U / Y r & 9.45 & \\ \text { Capital Recovery } & -\$ / M B T U & & 1.90 \\ \text { Operating Cost } & -\$ / M B T U & 0.40 \\ \text { Peedstock Cost } & -\$ M B T U & & 0.20 \\ \text { Total Cost } & -\$ / M B T U & & 2.5 \alpha^{*}\end{array}$

It is clear that capital recovery is the highest contributor (75\%) to the total cost of raw shale oil. It is important to note that feedstock cost, $1 . e .$, resource value, will vary from project to project because of differences in bonus bid payments and will directly influence the total cost. A value of $\$ 1$ per barrel was assumed in this investigation.

The total cost for mining, disposal, retorting and upgrading the raw shale oil to syncrude is estimated to be $4.30 \$$ MBTO $(23 \$ / B b 1)$. It is difficult to compare the raw shale production cost and syncrude production cost because no single reference addressess these issues separately. Therefore, caution should be used when trylng to determine incremental costs for. upgrading raw shale ofl. An illustration of the total cost and its breakdown is shown in Table 6-9 for a 50,000 barrel per day operation (reference: 6-10).

*A single value does not imply that this is a precise value, but rather that only one literature reference was found for raw shale oil. This value probably would have a range of about $2.5-3$ \$ $/$ MBTU. $* *$ Also referred to in the Executive Summary as unrefined shale oil. 
Table 6-7

TYPICAL PROPERTIES FOR RAW SHALE

OIL AND SYNTHETIC CRUDE

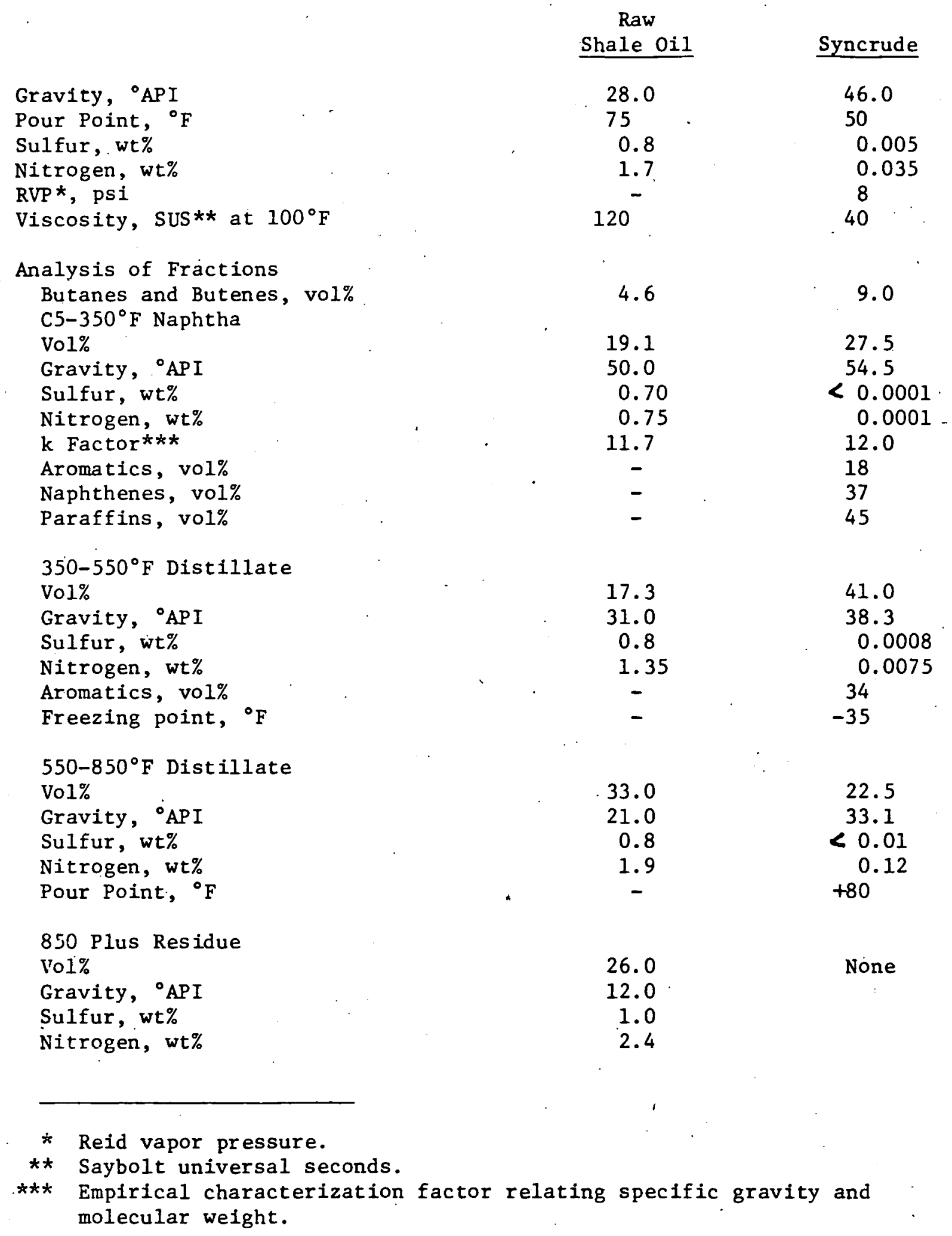

Reference: 6-11 
Table 6-9

COST OF SYNCRUDE (UPGRADED SHALE OIL)

about $75 \%$.

Again, it is capital recovery which is the mafor contributor,

\subsubsection{Syncrude Upgrading/Refining}

Having produced syncrude this must be converted to fuels products in operations similar to those in conventional petroleum refining. This section will deal with economics of producing gasoline, and turbine and diesel fuels from shale synthetic crude.

A simplified flow sheet for a shale syncrude refinery is shown in Figure 6-3. Some key areas concerning shale syncrude are as follows:

I. Shale syncrude, as indicated by the properties shown in Table 6-7 is quite different from conventional petroleum crude in that it contains no "bottoms", 1.e., material bolling above 850-9750F. Conse-. quently, the refining sequence does not employ any bottoms conversion.

II. Syncrude contains very 1ittle sulfur and nitrogen, which reduces the need for hydrotreating during refining.

The simple upgrading sequence involves the following steps:

1. The syncrude is distilled into various fractions:

- Initial $/ 375^{\circ} \mathrm{F}$, which goes into gasoline production.

- $375 / 650+0 \mathrm{~F}$, which is aimed primarily at distillate production.

2a. When maximum gasoline is required, all the $375+^{\circ} \mathrm{F}$ material 18 fed to the conversion process which is hydrocracking.

$2 \mathrm{~b}$. For distillate and gasoline coproduction* the $375 / 650^{\circ} \mathrm{F}$ material is sent to the distillate pool and hydrocracking is replaced with catalytic cracking, a milder process, and the $650+^{\circ} \mathrm{F}$ material is cat cracked.

* Gasoline/Distillate ratio: $2.4 / 1$ for prudent refining operations. See reference 6-11 for more information on this subject. 
Figure 6-3

SIMPLIFIED SHALE SYNCRUDE REFINERY

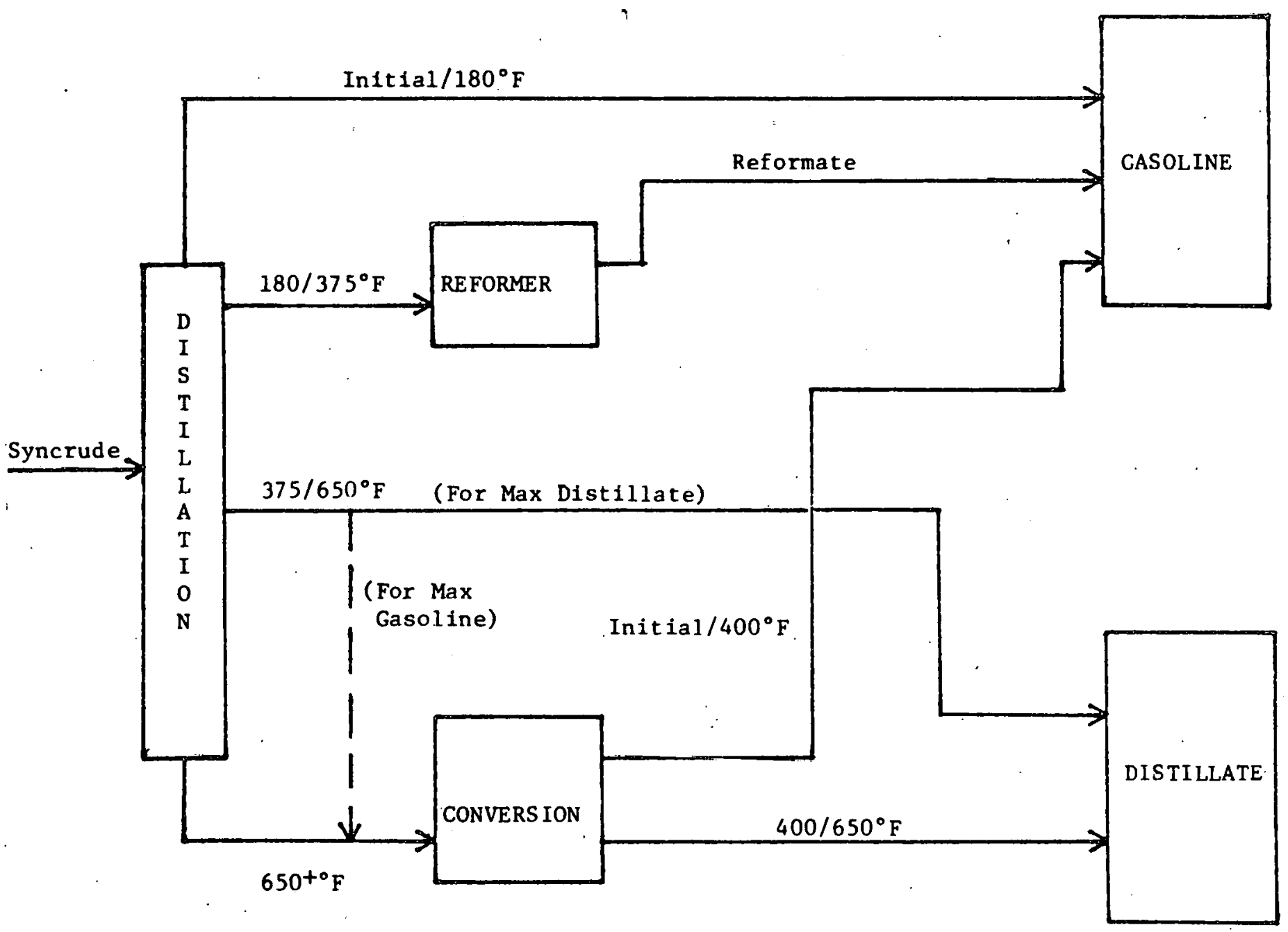


The refining cost for upgrading shale syncrude to gasoline via the hydrocracking conversion route is about 0.7-0.8 \$/MBTU. When distillate is made by substituting cat cracking for hydrocracking and running more syncrude, the added operating costs are essentially zero since the savings for substituting a less costly conversion step offset the costs of running more feed. Thus, the cost of this dist1llate are the same as the cost of syncrude. It should be emphasized that it would be much more costly to make additional distillate beyond this increment. A summary of these costs is presented in Table 6-10.

Table 6-10

Shale Finished Product Costs

\begin{tabular}{lcc}
\hline Fuel Product & $\begin{array}{c}\text { Gasoline } \\
\text { \$/MBTU }\end{array}$ & $\begin{array}{c}\text { Dist11late } \\
\text { \$/MBTU }\end{array}$ \\
\hline $\begin{array}{l}\text { Syncrude Cost } \\
\text { Refining }\end{array}$ & $\begin{array}{c}4.2-4.4 \\
0.7-0.8\end{array}$ & $\begin{array}{c}4.2-4.4 \\
0\end{array}$ \\
\hline Total Cost & $4.9-5.2$ & $4.2-4.4$ \\
\hline $\begin{array}{c}\text { Lower Heating Value, MBTU } \\
\text { per barrel }\end{array}$ & 4.95 & 5.40 \\
\hline
\end{tabular}

Product qualities: the gasoline is 91 research octane number clear (RONC) and the distillate cetane number is 50.

As indicated in Table 6-10, gasoline can be co-produced for about 4.9-5.2 \$/MBTU (25-26\$/barre1) and distillate: fuel for 4.2-4.4 \$/MBTU (23-2.4 \$(barre1). 


\section{$6.4 \quad$ Coal Cost}

It is obvious that the cost of coal impacts on the cost of alternaive fuels derived from coal. For the fuels derived from coal in this study $\therefore$ t has been assumed that mine-mouth cost for a high sulfur/high BTU coal, such as Illinols No. 6 , is 21 \$/Ton and for low sulfur/low BTU coal, such as Wyoming coal, 8 \$/Ton. Mine-mouth coal prices reflect mining costs plus resource value. Delivered coal prices, which vary from one geographic location to another, are the sum of mine-mouth plus transportation costs. Transportation costs are a function of distance and are covered in section 7.2. The total delivered cost of coal will include a transportation cost.

The literature* indicates coal prices which cover a broad range. A summary of variations in mine-mouth costs for different types of coal is shown in Table 6-11.

Table 6-11

Mine Mouth Coal Costs - 1980 Dollars

Mine location

Type of coal

Mine Mouth Cost, \$/Ton
Illinois

High Sulfur
Wyoming

Low Sulfur
Minimum

Most 11kely

Maximum

Heating Value

MBTU/Ton
14.00

21.00

30.00

22.80
5.30

8.00

12.00

16.50

* The main source of information in this study: Reference 6-8; other references: 6-18 and 6-19. 


\subsection{Coal Liquids}

One of the major fossil energy resources in the United. States is coal. Coal cin be used dfrectly as a fuel in non-hlghway transportation (rail and martne), to generate steam to power a steam engine or turbine. However, to $\mathrm{k}$ : used in all forms of non-highway transportation, coal will need to be ccinverted to a liquid form. To obtain reasonable ylelds of liquid fuels from coal, it will be necessary to break the large condensed ring compounds into smaller molecules and to add large amounts of hydrogen to increase :he hydrogen-to-carbon ratio. Coal has a hydrogen-to-carbon weight ratio of around 0.07 , compared to a hydrogen-to-carbon weight ratio of around $0.14-0.17$ for petroleum products. The bydrogenation of coal also assists in removing the sulfur and nitrogen impurities.

\subsubsection{General Process Classiftcation}

The various processes for producing liquid fuels from coal can be grouped into three general levels of processing severity. Table 6-12 shows the three general levels of processing severity. (pyrolysis, liquefaction and indirect liquefaction) and several sub-levels of classification, along with some of the various processes that are being developed in each category.

Many articles have been written comparing the various processes: It is not the purpose of this study to make an in-depth analysis of the various coal liquefaction processes. The following sections will briefly describe each type of general processing method.

\subsubsection{Pyrolysis}

Pyrolysis is the least severe approach to producing liquids from coal. In direct pyrolysis, heat is used to distill the volatile portions of the coal without adding hydrogen. A general flow plan of coal pyrolysis is shown in Figure 6r4. Feed coal, crushed to the proper particle size, is heated to an elevated temperature $\left(600-1500^{\circ} \mathrm{F}\right)$ to produce gas, oil and char. The ofl is recovered and hydrogenated for upgrading to either a fuel oil or synthetic crude. The gases are recovered, purified, and used as plant fuel, hydrogen plant feedstock or sold as a by-product. The char is available for sale as a high BTU solid fuel or it can be gasified to produce a synthesis gas (primarily hydrogen and carbon monoxide). This synthesis gas can be used to produce SNG, methanol, ammonia, or liquids via the FischerTropsch process.

In hydropyrolysis, the pulverized coal is heated in the presence of hydrogen to increase the yield of lighter products (gases and liquids).

\subsubsection{Liquefaction}

The second level of severity involves both heat and pressure and is usually referred to as coal liquefaction. The broad range of conditions at which liquefaction has been tested runs from $750^{\circ} \mathrm{F}$ and $300 \mathrm{psig}$ up to $900^{\circ} \mathrm{F}$ and $10,000 \mathrm{psig}$. Hydrogen chemlcally reacts with some of the carbon to form hydrocarbons with molecular welghts lower than the original coal molecules. A generalized coal liquefaction process scheme is shown in Figure 6-5. 
TABLE 6-12

\section{COAL LIO JEFACTION PROCESS CLASSIFICATION}

Classification

1. Pyrolysis

- Direct

- Hydropyrolysis

2. Liquefaction

- Direct Hydrogenation

- Non-Catalytic

- Pseudocatalytịc

- Catalytic

- $\mathrm{H}_{2}$. Donor Solvent

3. Indirect Liquefaction
Example

COED, Garrett, TOSCOAL

Lurgi-Ruhrgas

Clean Coke

Hydrocarbonization

Solvent-Refined Coal (SRC-I) Clean Coke

SRC II, Oil/Gas

Synthoil, H-Coal, Catalytic Coal Gasification (Gulf)

CSF (CRESAP), Exxon EDS

Fischer-Tropsch, Methanol

Source: Adapted from article, "Coal-Liquefaction--State-of-the-Art," J. B. O'Hara, Hydrocarbon Processing, November 1976. 
Figure $6-4$

SCHEMATIC FLOW PLAN OF COAL PYROLYSIS

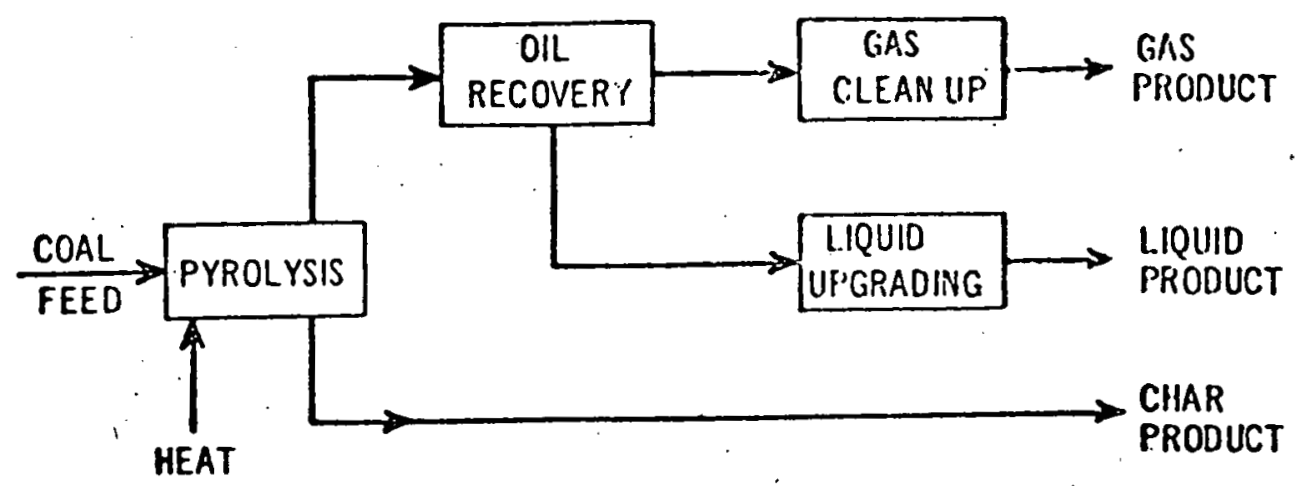

Source: "Status of Coal Liquefaction Technology," W. R. Epperly and H. M. Siegel. Presented at Ninth Intersociety Energy Conversion Engineering Conference, August 29, 1974.

Figure $v-z$

COAL LIQUEFACTION PঙOCESS SCHEME

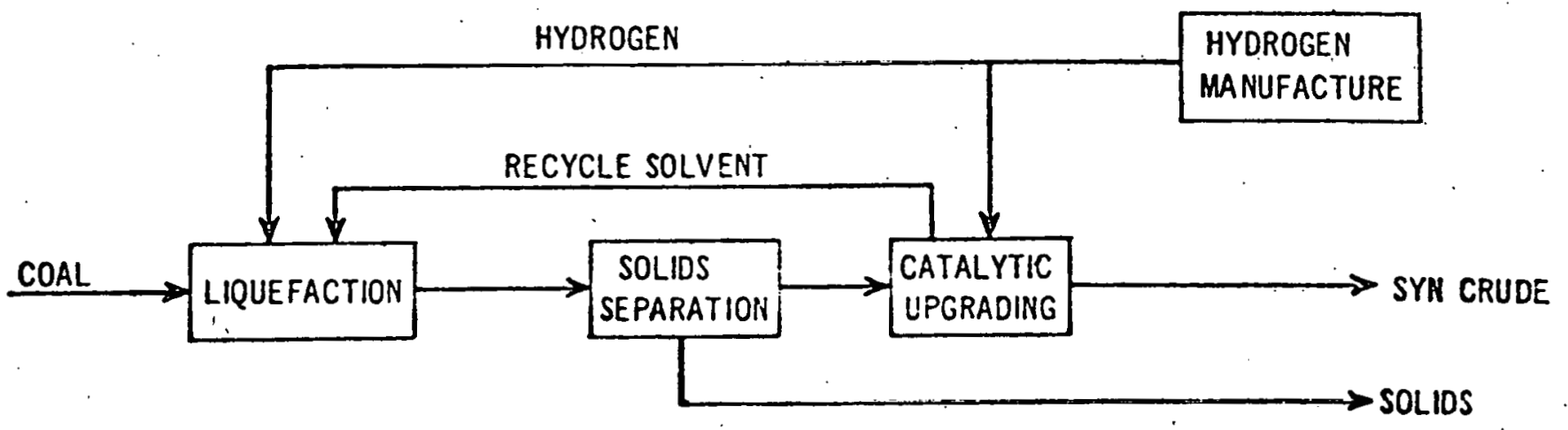

Source: "Status of Coal Liquefaction," Ib1d. 
With direct hydrogenation, ground coal is slurried in a recycle coal-derived solvent, mixed with a hydrogen-containing gas and reacted at elevated temperatures and pressures. In the non-catalytic processes, no external catalyst is used. In the pseudocatalytic processes; a portion of the reaction product is recycled to the feed s].urry to increase the ash content, which apparently acts as a catalyst. In the catalytic version, a catalyst is used to speed up the reaction. In the hydrogen donor-solvent process, the hydrogen is added as a hydrogener ated recycle coal-derived liquid and directly as $\mathrm{H}_{2}$ to the reaction.

Varlous methods have been tested for separating the solids from the liquids, including distillation, coking, hydroclones, filters and centrifuges. The liquids are upgraded in either fixed or ebullating beds to remove sulfur and nitrogen and to increase the product hydrogen content. The hydrogen used in the process is manufactured from coal or liquefaction by-products via gasification of coal or char or by reforming of product gas.

\subsubsection{Indirect Liquefaction}

The most severe approach to liquid fuels from coal is the combination of coal gasification to produce a synthesis gas followed by catalytic synthesis of hydrocarbons. Fischer-Tropsch is one example of indirect liquefaction technology. Production of methanol from coal is another example. This methanol can be used directly as a fuel or catalytically converted to gasoline via the Mobil 0il Corp. process.* A general process sequence is shown in Figure 6-6.

\section{F1gure 6-i}

INDIRECT COAL LIQUEFACTION SCHEME

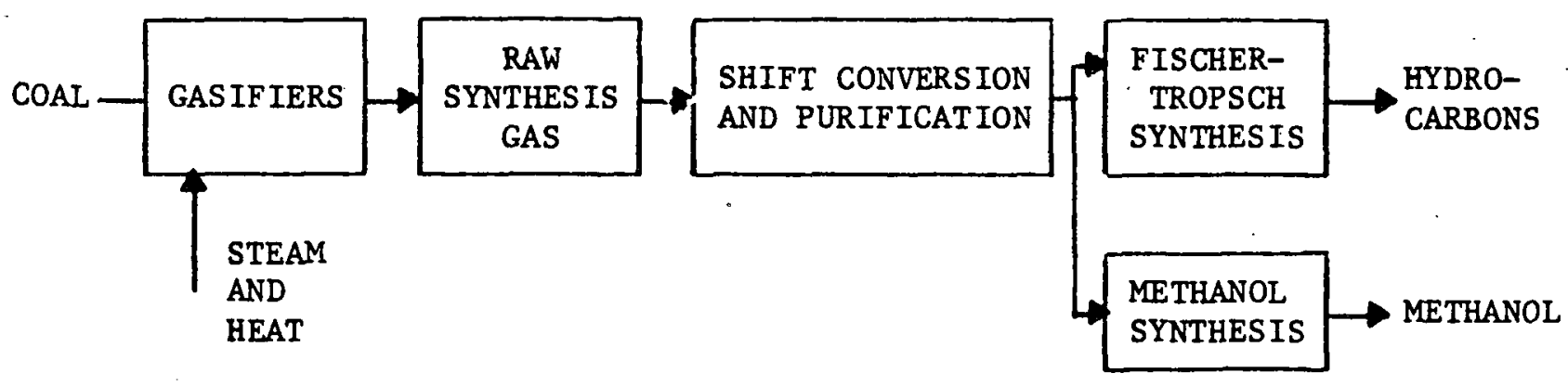

The steps include gasification of feed coal to produce a synthesis gas, purification of the syn gas and conversion to liquids.

In the Fischer-Tropsch synthesis, the hydrogen and carbon oxides are catalytically converted into liquld hydrocarbons. This process is in commercial use in South. Africa by SASOL.

* Chemical and Engineering News, January 30, 1978. 
With the large number of coal liquefaction processes being developed, it is beyond the scope of this study to include all of these processes in the economic comparison or to cover the physical properties of the products from the various processes. Therefore, the information will be presented for the three basic processing methods: pyrolysis, liquefaction and indirect 11quefaction. Also, since the economics of pyrolysis are sensitive to coal type and the economics for both pyrolysis and indirect. Iiquefaction are very sensitive to the values assigned to the byproducts produced, the costs of liquids from these process types can range widely among applications and projects. Therefore, in developing 1llustrative coal liquids costs the costs for direct liquefaction are used due to this process' relative Insensitivity to byproduct values. Sections 6.5 .3 and 6.5.4 show how these are derived. Thus, these costs represent a median cost of coal liquids within the range of costs which could be derived for the various liquefaction processes.

The following sections will cover the process yields from each of the general categorles and the properties of the liquids produced. 


\subsubsection{Product Yields - General}

Each of the three general types of coal processing (pyrolysis, liquefaction, and Indirect liquefaction) produces a different type of product mix. For example, pyrolysis produces primarily a char while liquefaction maximizes liquid products, and the indirect liquefactio: produces a large amount of SNG as a by-product. A comparison of typical yields from the three general types of processes is shown in Table 6-13. As can be noted, direct liquefaction produces the highest yields of 11quid fuels, which are of interest in non-highway transportation. However, it may be possible to utilize the char as a fuel for marine or rall transportation. The SNG is also a potential fuel that could be used in gas turbines. In addition the pyrolysis char and methane could be used to generate synthesis gas to feed an indirect liquefaction plant, but this would be more costly. Also, the process energy requirements would be higher than if the products were used directly as fuels.

Comparisons between the three general types of processes are complicated by the variation in yields between the various processes within each group, operating conditions, type of coal used, etc. In the following sections, product yields and properties of the various liquid fractions are described for a typical process within a given group. The aim is to point out the general characteristics of the liquid products as they apply to non-highway transportation fuels. It is not the purpose of this study to make an in-depth comparison between the various processes.

\subsubsection{Pyrolysis Products: Yields and Properties}

Typical product yields for pyrolysis of Illinois No. 6 coal are shown in Table 6-14. Note the large char yield about 62 wt\% of the total product yield. Typical pyrolysis ofl properties appear in Table 6-15. These properties are for the oil directly from the pyrolysis unit before any upgrading. ASTM distillation indicates a very low naphtha content, about a quarter of the material is in the middle distillate boiling range $\left(325 / 650^{\circ} \mathrm{F}\right)$. While $75 \%$ boils above $650^{\circ} \mathrm{F}$. In addition, the ofl is low in hydrogen and high in oxygen, nitrogen and sulfur. Table 6-16 shows typical product syncrude properties. The upgrading of the raw pyrolysis oll consumes approximately 4300 SCF of hydrogen per barrel of raw o1l. As the table shows the hydrogen to carbon ratio has been substantially increased while the nitrogen, sulfur and oxygen levels have been reduced. Additional treating will be required to further reduce the sulfur and nitrogen level.

Properties of the naphtha component of this syncrude are shown in Table 6-17. This naphtha contains a high percentage of naphthenes which are an excellent catalytic reformer feedstock once the Impurities, such as sulfur, are removed. The naphtha is low in aromatics content and, therefore, has a low research octane number (RON) of 70 . It is 
Table 6-13

A COMPARISON OF TYPICAL PRODUCT YIELDS FOR COAL PROCESSES*

\section{Process}

Coal Input, Tons/Day:

Product Output:

$L P G, B / D$

Naphtha, B/D

Diesel Fuel, B/D

Fuel Oil, B/D

Pipeline Gas, MSCF/D

Sulfur, LT/D**

Ammonia, ST/D

Char, Tons/D

\section{Pyrolysis}

24,000

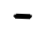

$$
1,300
$$

-

12,250

37

305

114

10,730
Indirect

Liquefaction

24,000

Iiquefaction

24,000

2,800

16,000

12,800

4,000

210

800

700

124

-

* Values have been normalized to 24,000 Tons/day basis for comparison; following tables present yields as found in specific reference.

** Comnercial practice in the sulfur industry is to use long tons (LT) of 2400 lbs. The other tons above are short tons of 2000 lbs. 
Table 6-14

TYPICAL PRODUCT YIELDS FROM A DIRECT PYROLYSIS PROCESS

Input :

coal

40,665 Tons/Day (Dry)

Output:

Char

18,178 Tons/Day

Naptha

2,200 Barrels/Day

Fuel oil

20,756 Barrels/Day

Plpeline Gas

$63 \mathrm{MSCF} / \mathrm{D}$

Sulfur

519 LT/Day*

Ammonia

193 Tons/Day

* $\quad$ LT $=$ long tons of 2400 lbs.; other tons equal $20001 \mathrm{bs}$.

Reference: 6-5 
Table 6-15

PYROLYSIS OIL* PROPERTIES

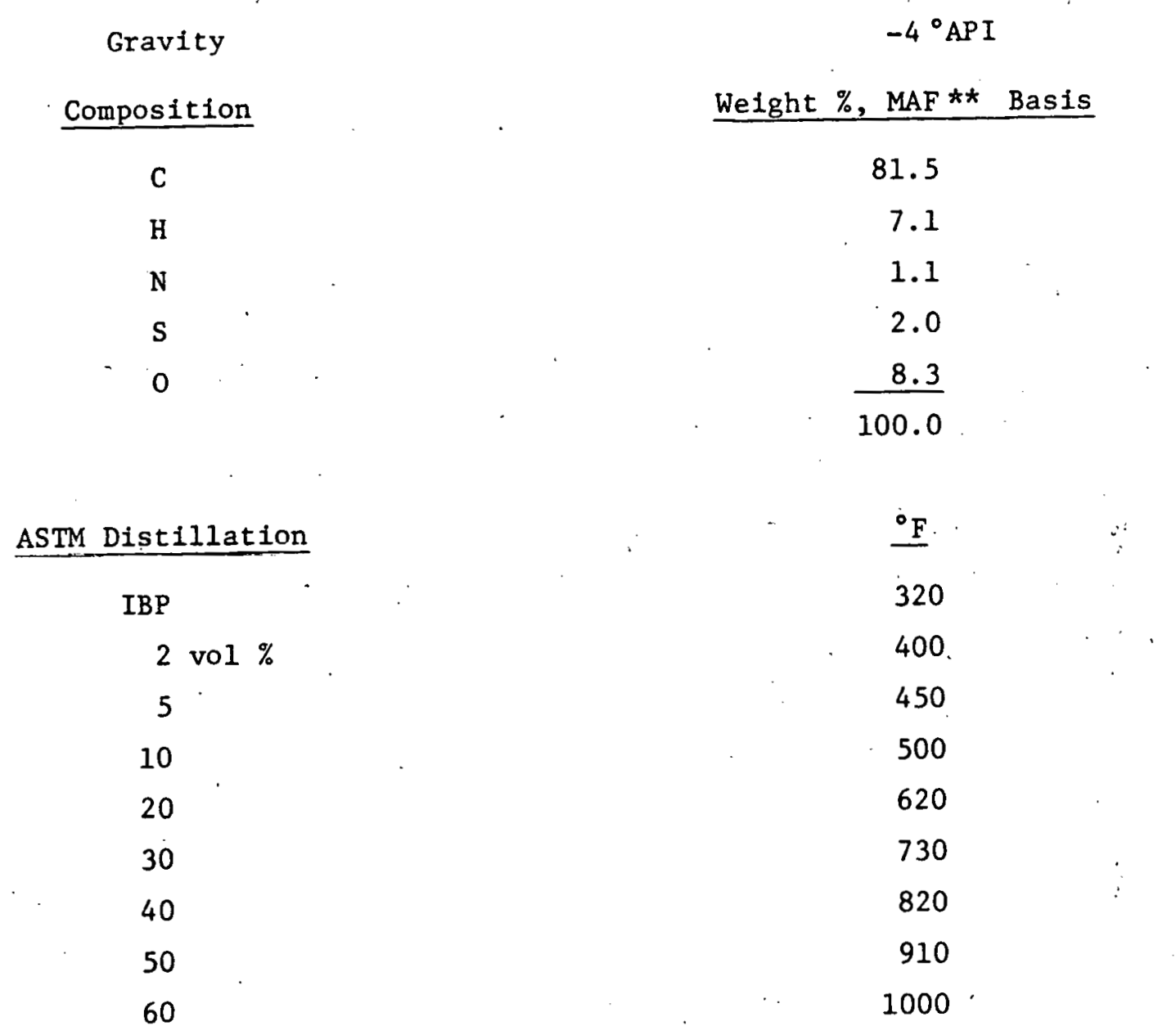

* Raw product before upgrading to syncrude.

** Moisture and ash free.

Reference: $6-1$ 
Table 6-16

SYNCRUDE* PROPERTIES FROM PYROLYSIS TYPE PROCESS

$$
\text { Gravity }
$$

Composition

$\mathrm{C}$
$\mathrm{H}$
$\mathrm{N}$
$\mathrm{S}$
$\mathrm{O}$

$25^{\circ} \mathrm{API}$
Weight \%, MAF $\star \star$ Basis
86.4
$\begin{gathered}12.4 \\ 0.1 \\ 0.05 \\ 1.05\end{gathered}$

* Upgraded pyrolysis liquids, Hydrogen addition - $4300 \mathrm{SCF} / \mathrm{Bbl}$. ** Moisture and ash free.

Reference: $6-1$ 
Table 6-17

SYNCRUDE NAPHTHA* PROPERTIES FROM PYROLYSIS TYPE PROCESS

\begin{tabular}{lc}
$\begin{array}{l}\text { Hydrocarbon Type Analysis } \\
\text { Liquid Volume \% }\end{array}$ & Naphtha \\
\hline Paraffins. & 7.0 \\
Naphthenes & 71.2 \\
Aromatics & 21.8 \\
Olefins & nil \\
& 100.0 \\
Gravity, $60^{\circ} \mathrm{F}$ & $44^{\circ} \mathrm{API}$ \\
Sulfur, PPM & 93 \\
Research Octane No. clear & 70
\end{tabular}

* Naphtha derived from upgraded pyrolysis oil.

Reference: 6-2 
expected that this clear* RON can be substantially increased to $99-100$ by processing, such as catalytic reforming.

Characteristics of various syncrude fractions are shown in Table 6-18. The $390 / 650^{\circ} \mathrm{F}$ bolling component is high in aromatics content ${ }^{* t}$ and conseyuently would be unsultable for current turbo-jet or diesel engines. Severe hydroprocessing is required to meet current jet and diesel fuel specifications. The $350^{\circ} \mathrm{F}+$ fraction, or any portion of $1 \mathrm{t}$, could be used as a low sulfur fuel ofl without further hydrotreating. The $650^{\circ} \mathrm{F}+$ material might be suitable for hydrocracking, but the high density (low API gravity) would indicate that it would be very refractory for catalytic cracking. It would be necessary to add a lot of hydrogen to make products approaching conventional specifications.

\subsubsection{Liquefaction Products: Yields and Properties}

Typical product ylelds for liquefaction of Illinols No. 6 coal are.shown in Table 6-19. It should be noted that the liquid yield from this type of process is twice that from pyrolysis processes.

Table 6-20 shows the composition of 11quefaction naphtha, both raw and hydrofined. As with pyrolysis naphtha, liquefaction naphtha is high in naphthenes which can readily be converted to aromatics by reforming.

The $350 / 650^{\circ} \mathrm{F}$ fraction properties are presented in Table 6-21. The high aromatic content ${ }^{\star \star \star}$ of the syncrude would prohibit use in current turbine and diesel engines without additional treating. Severe hydroprocessing of this fraction w111 be required for application in these areas: This fraction can be utilized as a fuel ofl without further treating.

The $400^{\circ} \mathrm{F}+$ product properties are summarized in Table 6-22. This product can also be used as a low sulfur fuel oil without further treating - Hydrotreatment for nitrogen and oxygen removal will be needed prior to hydrocracking or catalytic cracking this material to make naphtha or distillate products. Considerable hydrogen uptake would be needed to approach the hydrogen/carbon ratios typical of conventional products.

* Lead-free

** The 390-5250F bolling range derived from Illinols No. 6 contains 60 liquid volume percent aromatics.

** $*$ Upwards. of 80 welght $\%$ of the $350 / 650^{\circ} \mathrm{F}$ fraction. 
Table $6 \cdot 18$

SYNCRUDE COMPONENT CHARACTERISTICS FROM PYROLYSIS TYPE PROCESS

$350+$ Fraction $\quad 390-650^{\circ} \mathrm{F}$ Fraction $\quad 650+$ Fraction

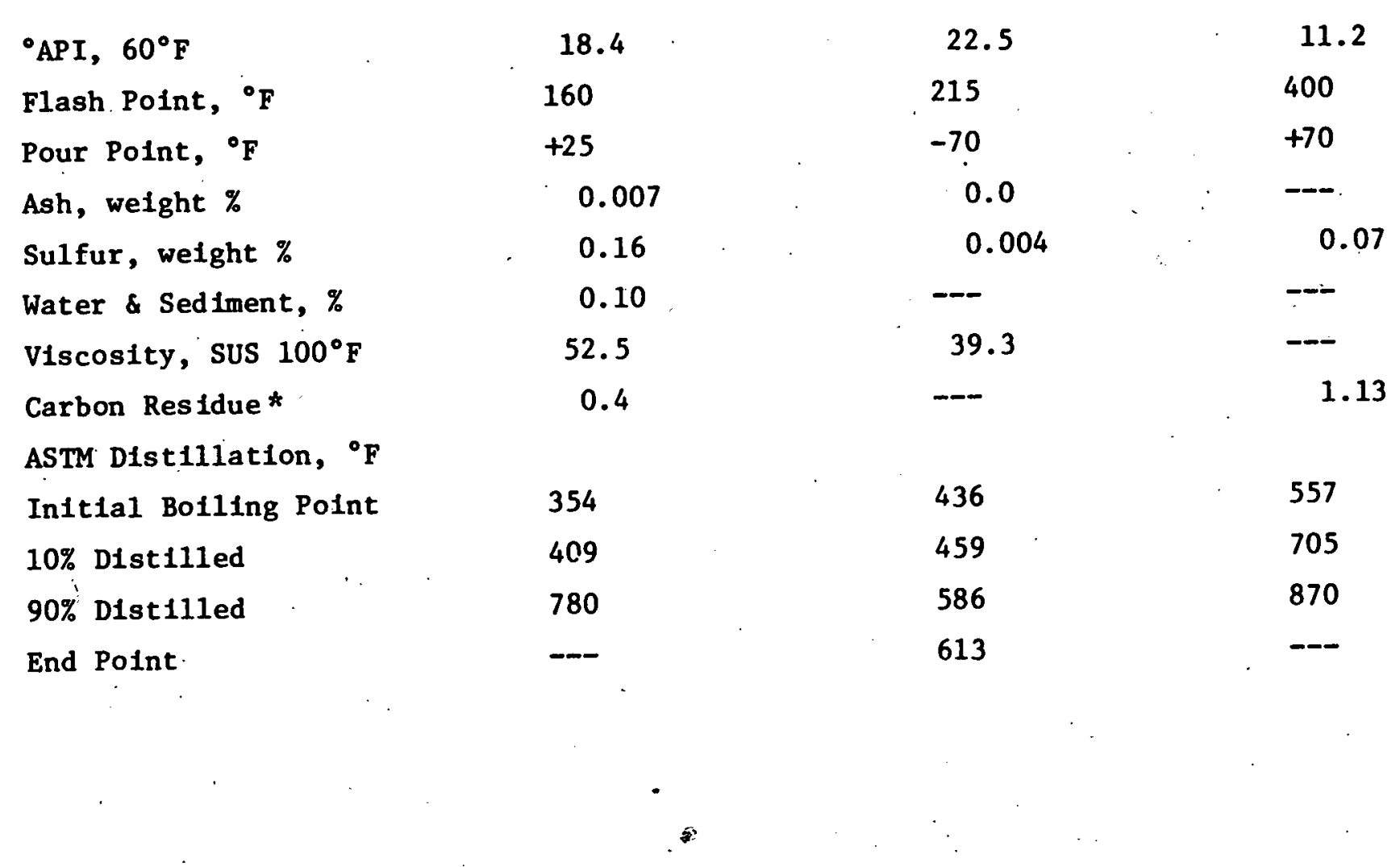

* Conradson Carbon Residue Test.

Reference: 6-2 
Table 6-19

TYPICAL PRODUCT YIELDS FROM A LIQUEFACTION TYPE PROCESS

Input :

Coa L

24,000 Tons/Day (Dry)

Outputs:

$\mathrm{C}_{3}$ and $\mathrm{C}_{4}$ LPG

8,000 Barrels/Day

$\mathrm{C}_{5} / 400^{\circ} \mathrm{F}$ Naphtha

22,000 Barrels/Day

LSFO

29,000 Barrels/Day

Sulfur

700. LT/Day *

Ammonia

124 Tons/Day

* LT $=$ long tons of $2400 \mathrm{lbs}$; other tons equal $2000 \mathrm{lbs}$.

Reference: 6-3

\lrcorner 
Table $\quad 6-20$

NAPHTHA PROPERTIES FROM A TYPICAL LIQUEFACTION PROCESS

RAW

\begin{tabular}{c} 
Gravity \\
Composition \\
\hline C \\
H \\
O \\
N \\
S \\
\\
Composition \\
\hline C \\
H \\
O \\
N \\
S
\end{tabular}

$$
41^{\circ} \mathrm{API}
$$

Weight \%

84.1

12.2

2.5

0.2

1.0

100.0

\section{Hydrofined*}

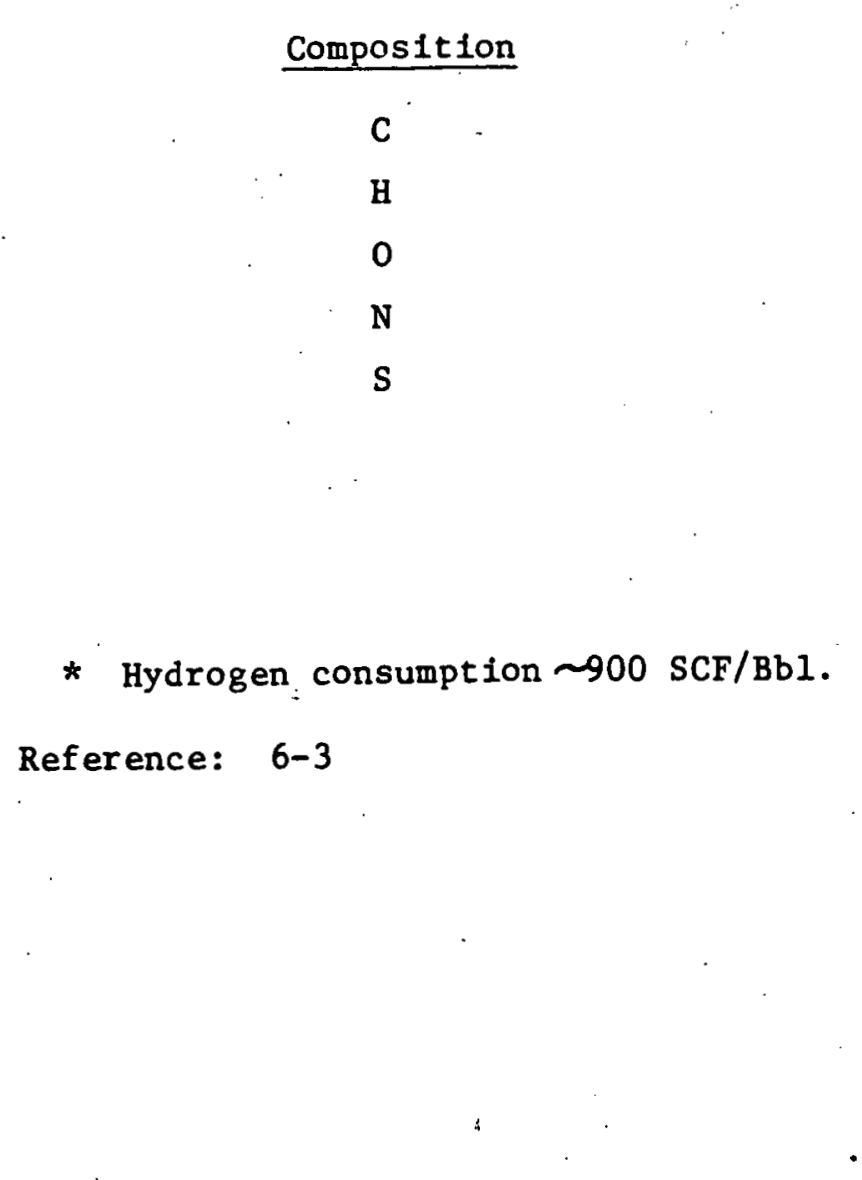

\section{Weight $\%$}

87.4

12.6

$<0.01$

0.0007

0.0025 
Table 6-21

PROPERTIES OF THE $350 / 650^{\circ} \mathrm{F}$ FRACTION FROM

A TYPICAL LIQUEFACTION PROCESS

$$
\text { Gravity }
$$

Composition

C

H

S

0

N $15^{\prime \prime} \mathrm{API}$

Weight \%

89.66

8.97

0.03

1.22

0.12

100.00

146

$-70$

2.1

Reference: 6-3 
Table 6-22

FUEL OIL PRODUCT PROPERTIES

$\left(400^{\circ} \mathrm{F}+\right)$ FROM A TYPICAL LIQUEFACTION PROCESS

Gravity

Composition

C

$\mathrm{H}$

$\mathrm{S}$

0

$\mathrm{N}$

Flash Point, ${ }^{\circ} \mathrm{F}$

Pour Point, ${ }^{\circ} \mathrm{F}$

Viscosity, SSF at $122^{\circ} \mathrm{F}$

$$
-1^{\circ} \mathrm{API}
$$

Weight \%

87.9

7.0

0.8

3.2

1.1

100.0

196

40

158

Reference: 6-3 


\subsubsection{Indirect Liquefaction: Yields and Properties}

Indirect 11quefaction processes produce substantial amounts of substitute natural gas (SNG). Typical produrt yields for 1ndirect liquefaction are shown in Table 6-23. Note the iarge yields of SNG and the relatively small yields of liquids. These liquid products, however, are essentlally in a useable form, 1.e., naphtha, diesel fuel and fuel oll, without additional treatment.

The properties of the naphtha component are summarized in. Table 6-24. The naphtha is mainly composed of straight chain saturated and monounsaturated hydrocarbons; thus, these naphthas may have a high potential as a feedstock for ethylene production. In addition, the naphtha contalns nil sulfur and near nil aromatics. This low aromatics content results in a low octane number. Extensive processing involving catalytic reforming would be required to raise the octane number. Part of the heavy naphtha product could possibly find application as a turbine fuel.

The propertles of the diesel fuel product appear in Table 6-25. This product contains nil sulfur, has a high cetane number and a high heating value. It is considered as a marketable diesel fuel or alternatively a low sulfur boller fuel or a home heating oil. As with the naphtha, this product can also be used as a turbine fuel.

Indirect liquefaction fuel ofl could be marketed as a high-pour fuel for use in the industrial or marine sectors for turbine or diesel drivers or as boller fuel. The properties of this product are summarized in Table 6-26. The nil sulfur, metals and nitrogen content should provide an advantage. With only trace quantities of aromatics projected, the luminosity usually associated with other coal derived fuels should not exist. 


$$
\begin{gathered}
6-39 \\
\text { Table } 6-23 \\
\text { TYPICAL PRODUCT YIELDS FROM AN } \\
\text { INDIRECT LIQUEFACTION TYPE PROCESS } \\
\hline
\end{gathered}
$$

$\begin{array}{lr}\text { Input: } & 30,000 \mathrm{Ton} / \text { Day (dry) } \\ \text { Outputs: } & 260 \mathrm{MSCF} / \mathrm{Day} \\ \text { SNG } & 3,500 \mathrm{Barrels} / \mathrm{Day} \\ \mathrm{C}_{4} \text { 's } & 20,000 \mathrm{Barrels} / \mathrm{Day} \\ \text { Naphtha } & 16,000 \mathrm{Barrels} / \mathrm{Day} \\ \text { Diesel Fuel } & 5,000 \mathrm{Barrels} / \text { Day } \\ \text { Fuel Oil } & 1,000 \mathrm{LT} / \text { Day } \\ \text { Sulfur } & 1.40 \mathrm{MW} \\ \text { Electricity } & \end{array}$

* LT $=$ long ton of $2400 \mathrm{lbs.;}$ other tons equal $2000 \mathrm{lbs}$.

Reference: 6-4 
Table 6-24

NAPHTHA PROPERTIES FROM AN

INDIRECT LIQUEFACTION TYPE PROCESS

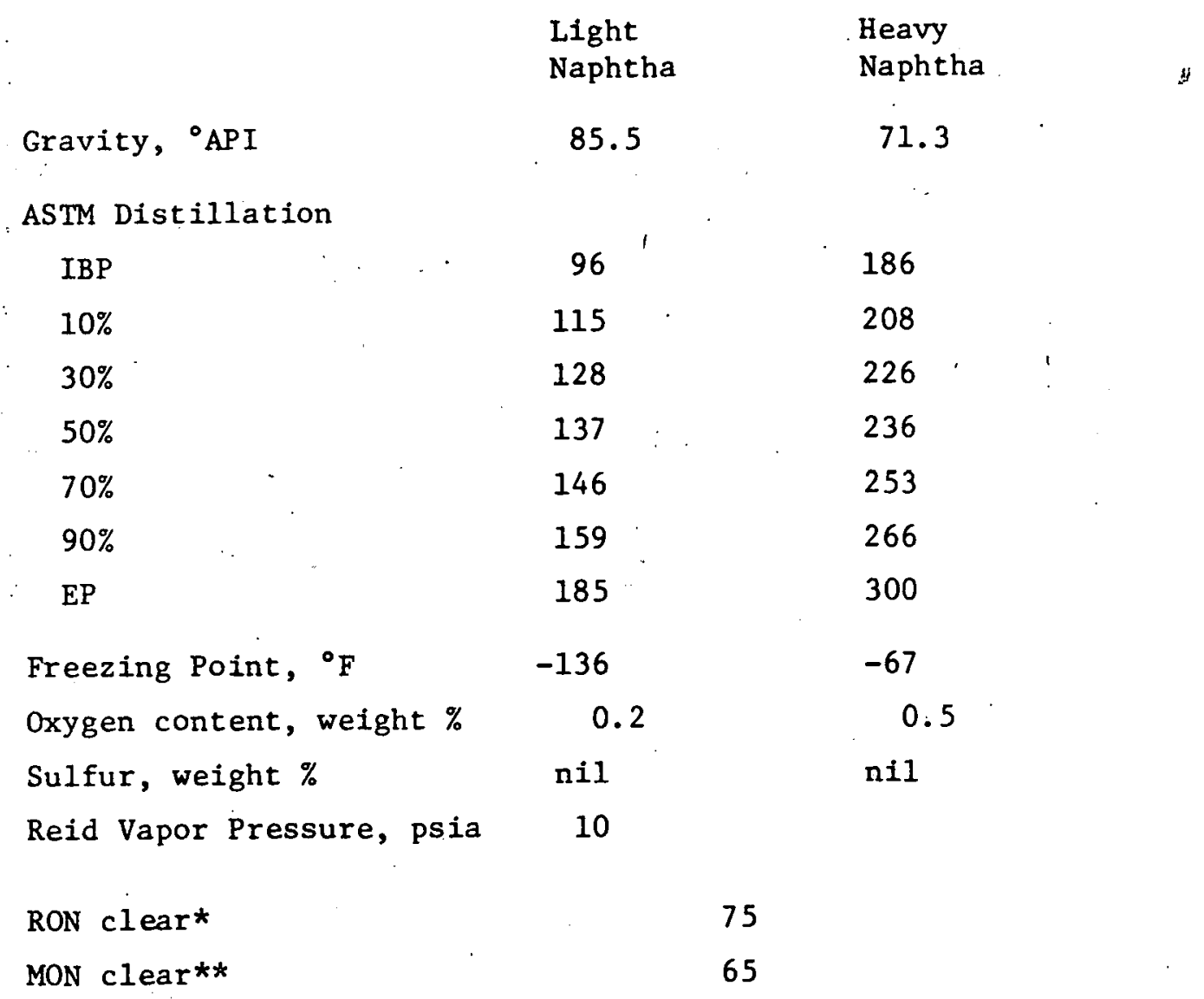

* Research octane number for the total naphtha after treating.

** Motor octane number for the total naphtha after treating.

Reference: $6-4$ 
Table 6-25

DIESEL FUEL PROPERTIES

FROM AN INDIRECT LIQUEFACTION TYPE PROCESS

Gravity

\begin{abstract}
ASTM Distillation
\end{abstract}
IBP

$10 \%$

$30 \%$

$50 \%$

$70 \%$

$90 \%$

EP

Flash Point, ${ }^{\circ} \mathrm{F}$

Pour Point, ${ }^{\circ} \mathrm{F}$

Oxygen, weight \%

Sulfur, weight \%

Ash, weight \%

Cetane No.

IP smoke point, mm $57^{\circ} \mathrm{API}$

301

327

351

372

421

539

637

$-100$

$+10$

0.5

n11

0.01

$60+$

25

Reference: 6-4 
Table 6-26

FUEL OIL INSPECTIONS FROM AN INDIRECT LIQUEFACTION TYPE PROCESS

Gravity

$41^{\circ} \mathrm{API}$

ASTM Distillation

IBP

572

$5 \%$

642

$10 \%$

665

$30 \%$

715

$50 \%$

759

$70 \%$

811

$90 \%$

873

$95 \%$

886

Viscosity, SSU at $100^{\circ} \mathrm{F}$

155

Flash Point, ${ }^{\circ} \mathrm{F}$

200

Pour Point, ${ }^{\circ} \mathrm{F}$

150

Oxygen, weight \%

0.5

Sulfur

nil

Reference: 6-4 


\section{5 .3 Economics of Producing Coal Liquids}

Numerous estimates of the capital investment and operating costs of the vartous liquefaction processes are available in the literature. Most of the processes are st1ll being developed, so the data necessary for a detailed equipment design and economic analysis are not avallable.

One must be extremely cautious when comparing estimated costs of conceptual coal conversion processes and projects. Information used in many estimates is preliminary and frequently optimistic. Additionally, even for a particular process, results can differ depending on plant size, coal source and cost, product slate and location.

The following sections are designed to cover:

1) Total cost and its components

+ Capital investment

+ Operating cost and co-product credit

+ Feedstock cost

2) Variation of total cost with plant size

3) Variation of total cost with coal type

4) Selection of the representative cost.

This total cost will be expressed in dollars per million BTU of liquid product and dollars per equivalent barrel (Eq B) * of liquid product. Co-product gas and char which contain substantial heating value are not included in the divisor. These co-products have been credited against the operating costs at thelr most likely values. These same untes ( $\$ / M B T U$ of liquid product) will apply to the operating cost and feedstock costs as well. The total cost in \$/MBTU of liquid product is equal to [(Feedstock Cost + Capltal Recovery + Operating Cost, all in $\$ / \mathrm{Yr}_{\bullet}$ ) divided by (Liquid BTU production, in MBTU/Yr•)].

* I equivalent barrel $=5.8 \mathrm{MBTU}$ Lower Heat Valve. 
Variations in coproduct value will have a major impact on the economics of producing liquids by pyrolysis and Indirect converaton. These impacts will be discussed in later sections.

\subsubsection{Total Costs of Coal L1quids from D1rect Liquefaction}

The range of costs for direct coal liquefaction are shown in Table 6-27. The costs are for syncrude only, and if these products are to be used as motor gasoline or alrcraft jet fuel, upgrading costs must be added to these costs. Upgrading costs are discussed in Section 6.5.4.

TABLE 6-27

TOTAL COST OF COAL LIQUIDS FROM DIRECT LIQUEFACTION

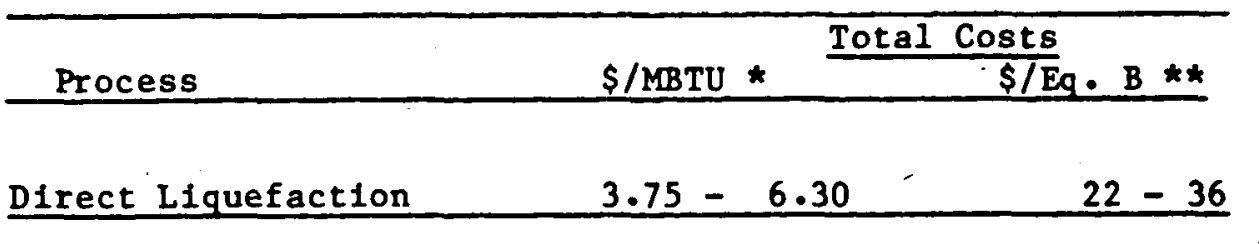

The factors that contribute to these manufacturing costs are:

1) Capital Investment

2) Operating Costs less credit for by-products

3) Feedstock Costs

* Dollars per Milion BTU of Product, Lower Heating Value (LHV).

* Dollars per barrel, 5.8 Million BTU per Barrel (LHV). 


$$
6-45
$$

6.5.3.2 - Capital Investment for Direct Coal Liquefaction Processes

The varlation of the capital investment for direct coal liquefaction is shown in Table 6-28. Investments have been charged against liquids alone.

Table 6-28

INVESTMENT LEVELS FOR DIRECT COAL LIQUEFACTION

\begin{tabular}{crr}
\hline Process & $\begin{array}{c}\text { Cap1tal } \\
\text { \$/MBTU/Yr.* }\end{array}$ & $\begin{array}{c}\text { Investment } \\
\$ / \mathrm{Bb} 1 / \mathrm{Yr}_{\star} \star \star\end{array}$ \\
\hline Direct Liquefaction & $9.00-18.00$ & $52-104$ \\
\hline
\end{tabular}

\subsubsection{Operating Cost/Co-product Credits}

The breakdown for Total Cost is shown in Table 6-29. Obviously, these processes will be extremely sensitive to market values assigned to the co-products. For direct liquefaction the by-products are sulfur and ammonia and if these had zero value the total cost would increase by approximately $0.30 \$ / \mathrm{MBTU}(5-8 \%)$. Direct 11quefaction costs are not too sensitive to co-product values due to the high yield of liquid products.

* Dollars per Million BTU of product, Lower Heating Value, liquid products only.

* Dollars per Barrel, 5.8 Million BTU per Barrel, llquid products only. 
Table 6-29*

TOTAL COST BREAKDOWN FOR DIRECT LIQUEFACTION COAL LIQUIDS

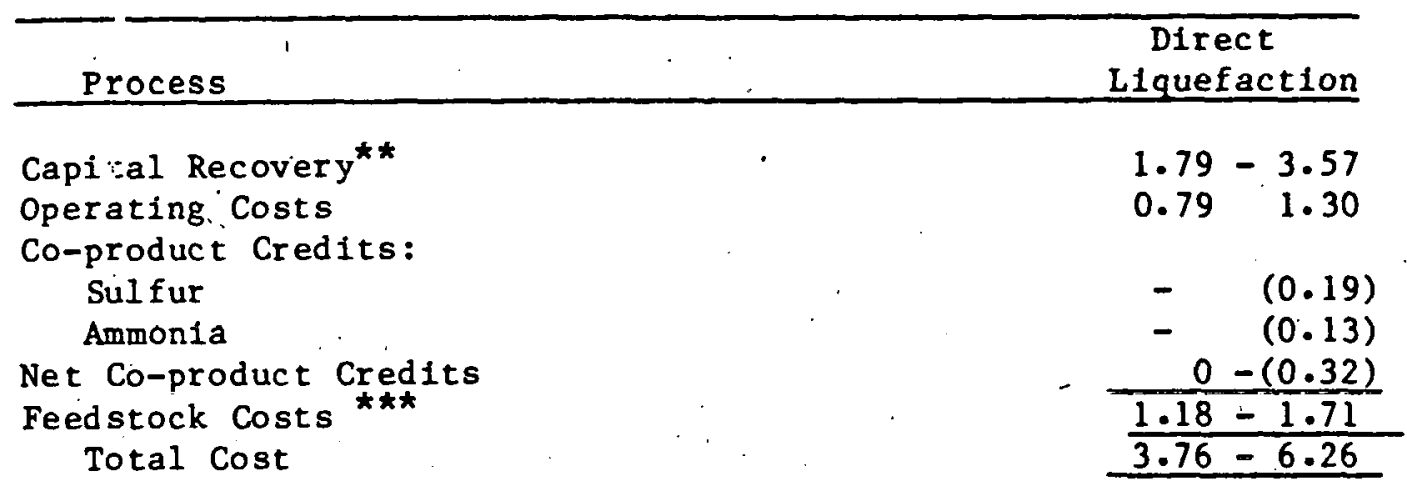

* All figures are $\$ / M B T U$ of liquid products.

$\star * 0.20$ times the capital investment.

$\star \star \star$ Coal is priced at 21 \$/Ton.

\subsubsection{Feedstock Cost}

The range of feedstock costs for direct coal liquefaction is. shown in Table 6-29. Direct liquefaction has a feedstock cost of about $1.70 \$ / M B T U$ for a high sulfur coal.

\subsubsection{Variation of Total Cost with Plant Size}

The analysis up to this point has been for plants that produce the equivalent of 50,000 barrels per stream day of liquid product. This section will discuss the effect of plant size on manufacturing cost.

Doubling the size of these process plants will effectively reduce the unit cost of manufacture by about 7\%. Table 6-30 compares the manufacturing cost for direct liquefaction with equivalent production of 100,000 , barrels per stream day versus 50,000 barrels per stream day.

The major reason for this somewhat small reduction of production cost is that increasing production rate will entall multiples of equipment with limited economy of scale effects. These changes in plant size can be characterized by a proration factor of 0.9 . 
$\underline{\text { Table } \cdot 6-30}$

COMPARISON OF TOTAL COST FOR $100 \mathrm{kB} / \mathrm{D}$ AND

$50 \mathrm{kB} / \mathrm{D}$ PRODUCTION

\begin{tabular}{lcc}
\hline Process & $\begin{array}{c}\text { Total Cost, } \\
100 \mathrm{kB} / \mathrm{D}\end{array}$ & $50 \mathrm{kB} / \mathrm{D}$ \\
\hline Direct Liquefaction & $3.50-5.80$ & $3.75-6.25$ \\
\hline
\end{tabular}

\subsubsection{Variation of Total Cost with Coal Type}

Varfous references $(6-6,6-7)$ have shown that for production of similar product slates using a lower sulfur/lower heat content coal (relative to Illinois No. 6) will result in an approximate $10 \%$ reduction in manufacturing cost directly traceable to feedstock cost reduction. A comparison of the reduction in cost of the liquid products from two types of coal is presented in Table 6-31.

Table 6-31

Feedstock Cost and Manufacturing Cost with Wyodak, Wyoming* Coal Compared with Illinois No. $6 \star \star *$ coal.

\begin{tabular}{|c|c|c|c|c|}
\hline Process & $\frac{\text { Feedstock }}{\text { Wyodak }}$ & $\begin{array}{r}\text { Cost, } \$ / \mathrm{MBTU} \\
\mathrm{I11 \text {nois }}\end{array}$ & $\frac{\text { Total Cost }}{\text { Wyodak }}$ & $\frac{\text { S/MBTU }}{\text { Il11nols }}$. \\
\hline irect Lique & $0.70-1.20$ & $1.20-1.70$ & $3.25-5.75$ & $3.75-6.25$ \\
\hline
\end{tabular}

These feedstock cost savings are diluted by increased investment and operating costs due to the Wyodak's higher molsture content. Additionally, there are examples in the literature (6-8) which show that the transportation of Wyodak, Wyoming coal can reduce and even eliminate the feedstock cost advantage for this coal type. A summary of the properties for these coal types is presented in Table 6-32. Note the relatively higher moisture and oxygen, but lower carbon content of the Wyoming coal.

* Priced at $8 \$ /$ Ton

** Priced at $21 \$ /$ Ton 
Table $6-32$

COAL PROPERTIES

Illinois No. 6

\section{Analysis, wt\% (Dry Basis)}

\begin{tabular}{lr}
$\mathrm{C}$ & 70.15 \\
$\mathrm{H}$ & 5.07 \\
$\mathrm{O}$ & 10.24 \\
$\mathrm{~N}$ & 1.19 \\
$\mathrm{~S}$ & 4.14 \\
$\mathrm{C} 1$ & 0.11 \\
Ash & 9.10 \\
\hline & 100.00
\end{tabular}

Moisture (as received), wt\%:

16.5

30.0 


\subsubsection{Coal Liquids Upgrading}

Section 6.5 .3 covered the economics of producing synthet1c crudes from coal. These "crudes" must be converted to fuel products in operations analogous to petroleum refining. This section deals with the economics of producing gasolines, turbine fuels, etc., from direct liquefaction 11quids. The literature Indicates that most of the government sponsored research and development work on coal liquids has centered on I1quefaction, and there has been little work on producing fuels such as gasoline, turbo fuels and diesel from the coal liquids. This section will be addressed to the economics of producing fuels from coal liquids.

Coal liquids boiling above $350-400^{\circ} \mathrm{F}$ may be suitable for boller fuels providing that the sulfur levels do not exceed mandated levels. It is conceivable that $400^{\circ} \mathrm{F}+11$ quids could be shipped direct to industrial and marlne consumers bypassing refinerles. For these outlets further upgrading costs are unnecessary. It may be necessary to segregate coal-based boller fuels from petroleum-based boller fuels to avold formation of solid precipitates which can occur when fuel components are not completely miscible.

The coal liquids must be refined to produce other fuels such as gasoline, and turbo and diesel fuels. The principal characteristics of coal liquids are their low hydrogen content and the high levels of oxygen and nitrogen and sulfur.

For satisfactory engine performance it is assumed that spark Ignition fuels must have a minimum hydrogen content of $12.5 \mathrm{wt} \%{ }^{*}$ and turbine and diesel fuels a minimum hydrogen content of 13.5 wt $\%^{\star \star}$. To achieve these levels, severe treating will be needed. Such hydrotreatment would also convert the oxygen, nitrogen, and sulfur in the feed to water, ammonia, and hydrogen sufide. Removal of these impurities is probably necessary for satisfactory engine performance.

As mentioned above, consistent technical and economic data on the refining of coal liquids are not avallable. A system was developed for roughing out comparative economics for upgrading syncrude to gasoline, diesel, and turbine fuels.

The cost of hydrogenating coal liquids is assumed to be proportional to hydrogen consumption, and would be the sum of the cost of hydrogen itself and the cost of running the hydrogenation units. It is assumed that hydrogenation costs would be about the same per unit of hydrogen consumption as petroleum vacuum gas oil hydrocracking units. To these costs were added typical refinery costs for recelving crude, shipping products and primary distillation. These costs are shown in Table 6-33.

* Corresponds to a mixture of hydrocarbons with $50 \%$ aromatics.

** "Synthetic Petroleum for Department of Defense Use," SRI, Menlo Park, Cal1f., November 1974, P.47. 
Table 6-33

UPGRADING COST COMPONENTS

$\begin{aligned} & \text { Hydrogenation Costs } \\ & \text { - Equipment }\end{aligned}$
$\begin{aligned} & \text { Hydrogen } \\ & \text { - . }\end{aligned}$
$\begin{aligned} & \text { Primary Distillation, } \\ & \text { and feed \& product } \\ & \text { handling }\end{aligned}$

As the table indicates approximately two thirds of the total hydrogenation cost is the hydrogen 1tself; the balance belong ing to the equipment operation. The cost of distillation, feed and product handling is assumed the same as for a conventional petroleum atmospheric pipestill of 150,000 barrels per stream day.

The cost of producing syncrude, with the added cost of dist111ation, feed and product handling are presented in Table 6-34.

\section{Table 6-34}

Cost of Coal Liquids including Primary Distillation, Shipping and Receiving

\begin{tabular}{lll}
\hline Process & \multicolumn{2}{c}{ Cost } \\
& $\$ / \mathrm{MBTU}$ & $\$ / \mathrm{Bb} 1$ \\
\hline Direct Liquefaction & $3.95-6.50$ & $23-38$ \\
\hline
\end{tabular}

\subsubsection{Coal Liquids Upgrading Costs}

The costs for upgrading the products of direct liquefaction are shown in Table 6-35. Due to the limited available information and the roughness of the estimates, it is recommended that the higher end of the range be used for comparison purposes.

\subsubsection{Coal Liquids Overall Cost}

Using the information now developed, it is possible to determine the cost of producing, distilling, upgrading and handiling the products from direct liquefaction. This cost appears in Table 6-36. 


\subsubsection{Hydro Pyrolys is Liquids Costs}

As was previously mentioned, the cost of pyrolysis liquids is very sensitive to the type of coal used and the value placed on the relatively large volumes of char and gas produced. Using the same economlc basis and evaluation approach for pyrolysis as for direct liquefaction, and valuing the char on a heat content parity with coal and the SNG at about $6 \$ / \mathrm{MBTU}^{*}$, the costs shown in Table 6-37. can be derived. As the table shows, the cost of pyro ysis liquids, 8.85 . $\$ / M B T U$, is higher than that for direct liquefaction liquids. It should be noted that these costs are based on Illinois coal feed and that lower cost coals which provide higher ylelds of pyrolysis liquids would, naturally, provide lower cost pyrolysis liquids.

* See section 6.11 for more information on substitute natural gas.

Table 6-35

UPGRADING COSTS FOR DIRECT LIQUEFACTION

Product

\begin{tabular}{cc|cc}
\hline \multicolumn{2}{c|}{ Gasoline $^{\star}$} & \multicolumn{2}{c}{ Distillate } \\
\hline S/MBTU & \$/Bb1 & \$/MBTU & $\$ /$ Bb1 \\
\hline $0.90-1.90$ & $5.20-11.00$ & $1.40-2.50$ & $7.10-14.50$ \\
\hline
\end{tabular}

Table 6-36

PRODUCT COSTS*** FOR DIRECT LIQUEFACTION

Product

\begin{tabular}{|c|c|c|c|}
\hline \multicolumn{2}{|c|}{ Gasoline } & \multicolumn{2}{|c|}{ Distillate } \\
\hline \$/MBTU & $\$ / \mathrm{BbI}$ & S/MBTU & $\$ / B b 1$ \\
\hline $4.85-8.40$ & $28-49$ & $5.35-9$ & $31-52$ \\
\hline
\end{tabular}

*. $\quad \$ / M B T U$ and $\$ / B b l$ of liquid product.

$\star * \quad \$ / M B T U$ and $\$ / B b 1$ of liquid product boiling above $350-400^{\circ} \mathrm{F}$.

$\star * *$ Includes: cost of pröduction, distillation, upgrading and handling. 
Some investigators have reported that hydro pyrolysis such as the "Clean Coke" process might provide transportation liquids at costs comparable to upgraded direct liquefaction 11quids. It is concelvable that pyrolysis could be a preferred process under certain conditions and where lower quality liquids could be used, e.g., when building new coal based power facilities, it may be economical to build larger coal recelving and preparation facilities, recover pyrolysis liquids, and burn char, rather than coal, directly in the new facility and burn the pyrolysis liquid in the older boiler.

Table 6-37

TOTAL COST BREAKDOWN FOR HYDRO PYROLYSIS LIQUIDS*

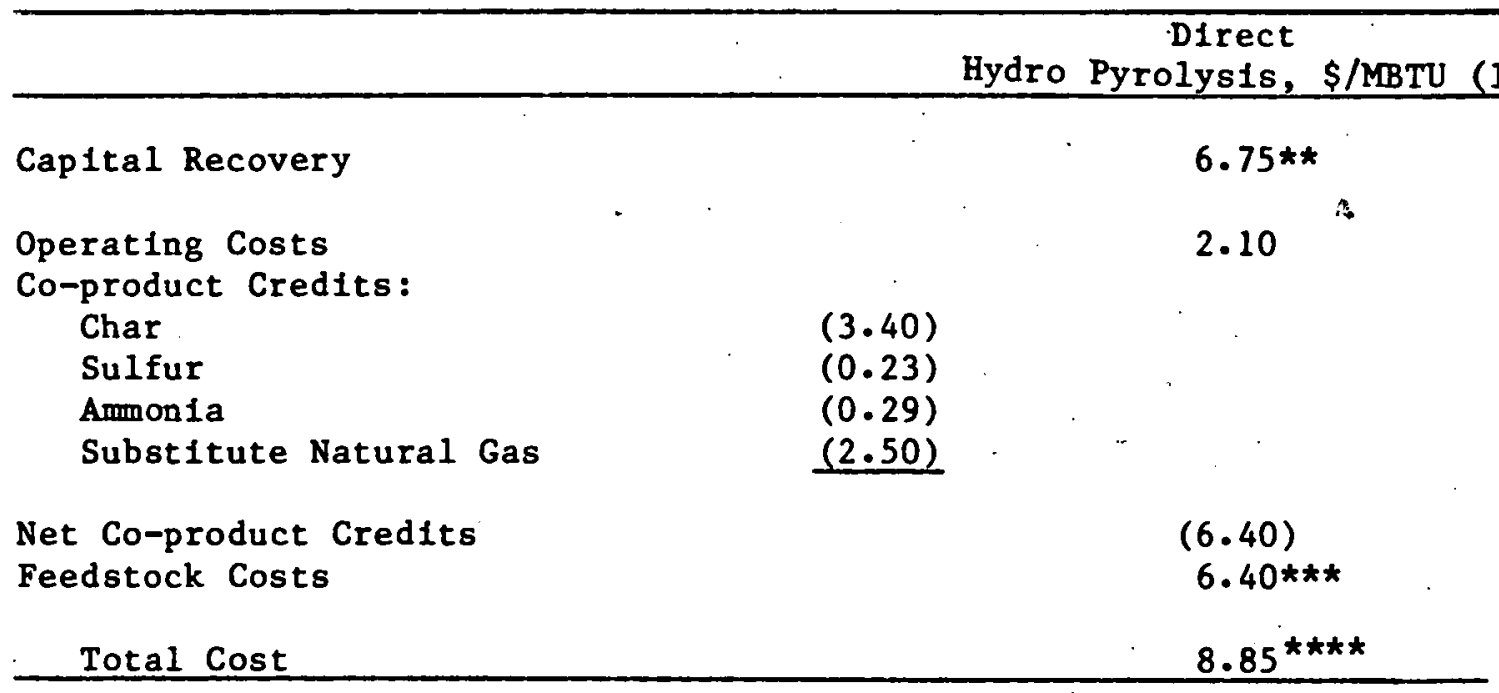

The upgrading costs for pyrolysis liquids, on the same basis as for direct coal liquids, are shown in Table 6-39. The upgrading costs for pyrolysis liquids are somewhat lower than for direct liquefaction liquids.

* All figures are $\$ / M B T U$ of liquild products.

** Corresponds to investment level of about $34.00 \$ / M B T U / Y r$.

$\star \star \star$ Coal at 21 \$/TON.

**** Single value not meant to imply precision in number -- rather that only one reference was available. 
Table $6-38$

UPGRADING COSTS

Product

\begin{tabular}{|c|c|c|c|c|}
\hline & \multicolumn{2}{|c|}{ Gasoline** } & \multicolumn{2}{|c|}{ Dist1llate*** } \\
\hline & S/MBTU & $\mathrm{S} / \mathrm{Bb} \mathrm{B}$ & S/MBTU & $\$ / \mathrm{Bbl}$ \\
\hline Pyrolysis & $0.40-1.60$ & $2 \cdot 30-9 \cdot 30$ & $0.80-2.15$ & $4 \cdot 60-12 \cdot 50$ \\
\hline
\end{tabular}

Representative total costs for fuel products including primary distillation, shipping and receiving are shown in Table 6-39.

Table 6-39

REPRESENTATIVE COSTS OF FUEL PRODUCTS* FROM PYROLYSIS

Product

\begin{tabular}{|c|c|c|c|c|}
\hline & \multicolumn{2}{|c|}{ Gasoline** } & \multicolumn{2}{|c|}{ Dist1llate*** } \\
\hline & \$/MBTU & $\$ / \mathrm{Bbl}$ & $\$ / \mathrm{MBTU}$ & $\mathrm{S} / \mathrm{Bbl}$ \\
\hline Pyrolysis & $9.45-10.65$ & $5.5-62$ & $9.85-11.2$ & $57-65$ \\
\hline
\end{tabular}

* Includes cost of production, distillation, upgrading and handling .

$* * \$ / M B T U$ and $\$ / B b 1$ of liquid product.

$\star * \star \$ / \mathrm{MBTU}$ and $\$ / \mathrm{Bbl}$ of liquid product boiling above $350-400^{\circ} \mathrm{F}$. 
These total costs are higher than those for direct liquefaction based on the information avallable. It is worth re-emphasizing that for a specific profect pyrolysis may be the preferred alternative.

\subsubsection{Indirect Liquefaction Product Cost}

The economics of producing fuel products via the indirect liquefaction mode, e.g., Fischer-Tropsch, is extremely sensitive to the value assigned to substitute natural gas. Using the same econmic basis and evaluation approach as for direct liquefaction, and valuing the SNG at about 6 \$/MBTU*, the cost shown in Table 6-40 can be developed.

Table $6-40$.

TOTAL COST BREAKDOWN FOR INDIRECT LIQUEFACTION PRODUCTS**

Indirect Liquefaction, S/MBTU (1980\$)

\begin{tabular}{|c|c|c|}
\hline $\begin{array}{l}\text { Capital Recovery } \\
\text { Operating Costs } \\
\text { Co-product Credits: } \\
\text { Sulfur } \\
\text { Electricity } \\
\text { Substitute Natural Gas }\end{array}$ & $\begin{array}{l}(0.20) \\
(0.20) \\
(6.20) \\
\end{array}$ & $\begin{array}{l}7 \cdot 10 * * * \\
2 \cdot 50\end{array}$ \\
\hline $\begin{array}{l}\text { Net Co-product Credits } \\
\text { Feedstock Costs }\end{array}$ & & $\begin{array}{l}(6.60) \\
2.85 * \star \star \star\end{array}$ \\
\hline Total Cost & & $5.85^{\star \star \star * \star * *}$ \\
\hline
\end{tabular}

The total cost for indirect liquefaction products, 5.85 \$/MBTU, shown in Table $6-40$ is a true total cost. The liquids as produced are saleable as distillate fuels, 1.e., for turbine application and the facilities

* Refer to Section 6.11 for more Information on substitute natural gas.

* All figures are $\$ / M B T U$ of liquid product.

$\star \star \star$ Corresponds to an investment level of about $36 \$ / M B T U / Y r$.

$\star * \star *$ Coal at 21 \$/TON.

$\star \star \star \star *$ A single value is not meant to imply precision but rather that only one reference was available with enough detail to allow the cost to be adjusted to a common basis. The cost is very sensitive to the coproduct credits. 
provided include product storage and handling. Thus, this is the total cost and no additional costs will be added. Indirect liquefaction does not produce a liquid suitable for spark ignition engines; therefore, the total Iiquid product is treated as a distillate* and as such shows a substantial advantage over the distillates produced via direct liquefaction or pyrolysis. The advantage over direct liquefaction is about $2.55 \$ / M B T U$ and the advantage over pyrolysis, even higher. It is important to realize the tremendous impact of the SNG credit**. If, for example, the credit was reduced by about 1 \$/MBTU, the gap separating indirect and direct liquefaction is reduced to about 1.40 \$MBTU. If the credit is reduced by 2 $\$ / M B T U$ the gap reduces to only $0.25 \$$ MBTU. If the credit is halved, the distillates from direct liquefaction are now cheaper.

\subsection{Coal-1n-0il Slurry}

A coal-in-oil slurry, referred to as colliodal fuel, is a combination of residual fuel oils*** and coal in particulate form. Colloidal fuel received considerable attention during World War I and II as potential fuel substitutes in case the petroleum supply was interrupted. Colloidal fuel could be a means of using coal reserves to extend limited petroleum resouces and at least could provide a means of reducing residual fuel requirements. Colloidal fuels would also be made using shale or coal liquids.

\subsubsection{Process Description}

Coal is received at the facility and pulvertzed to produce coal powder. This coal powder is blended with residual fuel oil to produce the colloidal fuel. The blending operation is assumed to be similar to a convent1onal refinery process unit of minimum complexity (reference 6-17). For this study, it has been assumed that coal will be 40 weight \% of the mixture. This appears to be the maximum allowable, coal content due to pumping considerations.

* The conventional naphtha fraction is expected to have a sufficient hydrogen content to allow such treatment.

** Government regulation or similar forces could affect the value of this credit substantially.

*** The economics are based on using a conventional petroleum residual oil. However, use of a shale or coal derived oil should be possible but the oil cost would be higher than the value used in this study. 


$$
6-56
$$

\subsubsection{Costs of Collo1dal Fuel}

Using the low cost western coal at $8 \$ /$ ton, colloldal fuel can be produced at a cost of $87 \$ /$ ton $(2.55 \$ / M B T U)$ well under the cost of fuel ofl - 3.30 \$/MBTU. The higher cost Illinols coal will add approximately $5 \$ /$ ton to the above cost, however due to its h1gher heat content the cost per MBTU remains relatively unchanged.

Table 6-41

Cost of Collo1da1 Fuel

\begin{tabular}{cccc}
\hline $\begin{array}{l}\text { Operating plus } \\
\text { Capital Recovery Cost } \\
\text { \$/MBTU }\end{array}$ & $\begin{array}{l}\text { Feedstock } \\
\text { Cost } \\
\text { \$/MBTU* }\end{array}$ & $\begin{array}{c}\text { Total Cost } \\
\text { S/MBTU }\end{array}$ \\
\hline 0.35 & 2.20 & 2.55 & 87 \\
\hline
\end{tabular}

\subsection{Methanol}

Today essentially all methanol manufacturered in the U.S. is produced by catalytic steam reforming of natural gas or some other light hydrocarbon feed stock. However, future shortages of natural gas and other hydrocarbons will encourage consideration of alternative routes to methanol. Routes which w1ll be considered in this study include:
1) Coal
2) Blomass
3) Solid Waste Pyrolysis
4) Ocean Thermal Energy Conversion

* Coal at 8 \$/ton, fuel ofl $119 \$ / T$ (20 $\$ /$ Barrel). ** Based on 40 wt\% coal in blend, 33.94 MBTU per ton. 


\section{$6.7: 1.1$ Coal}

The first step in converting coal to methanol involves the production of a synthesis gas. Gasifier operating conditions vary from 1 to 40 atm and $1000-3300 \%$. The synthesis gas is fed to a conversion unit where hydrogen reacts with carbon monoxide or carbon dioxide at 750-1500 psi and at 400-600 $\mathrm{F}$ over a catalyst to produce the methanol The reactions involved are:

$$
\begin{aligned}
& 2 \mathrm{H}_{2}+\mathrm{CO}_{2} \mathrm{CH}_{3} \mathrm{OH} \\
& 3 \mathrm{H}_{2}+\mathrm{CO}_{2} \rightarrow \mathrm{CH}_{3} \mathrm{OH}+\mathrm{H}_{2} \mathrm{O}
\end{aligned}
$$

Figure $6-7$ presents a simple schematic for the production of methanol from coal.

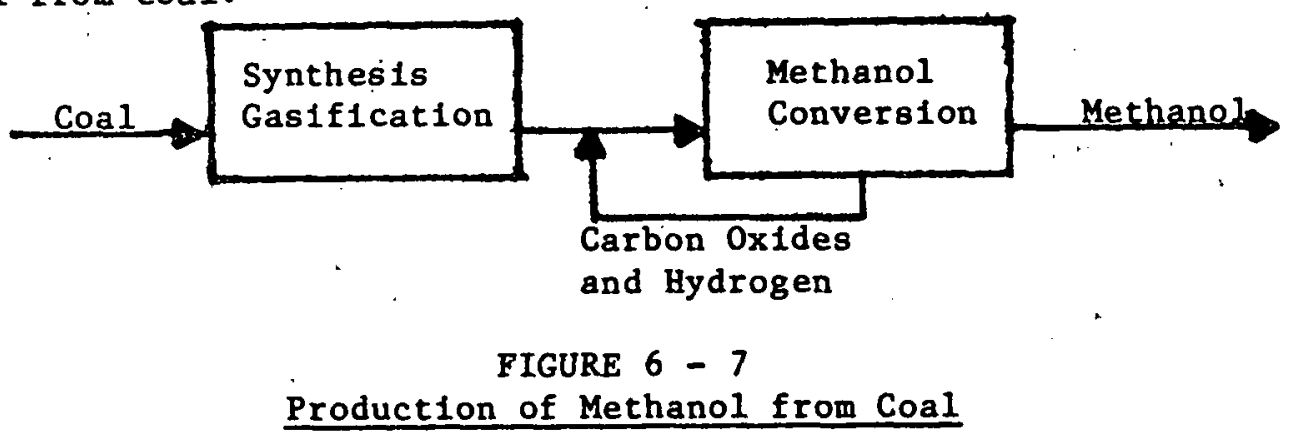

Since conversion per pass is low, unreacted carbon oxides and hydrogen are recycled to the conversion unit. The ICI. (100 atm) methanol technology is used in the conversion step. The production of 2000 tons per day of methanol requires 3500 tons per day of Illinols coal. Currently the largest plant produces 2000 tons per day via light hydrocarbon reforming. This was chosen as the economic basis.

\subsubsection{Economics of Methanol Manufacture from Coal}

The cost of methanol from coal is presented in Table 6-42 Investment levels are of the same order of magnitude as pyrolysis processes for coal liquids and the feedstock cost is also of the same order. However, the operating cost is higher, and the total cost is about $6.65-11.15 / \mathrm{MBTU}$ $(113-190 \$ /$ ton $)$.

TABLE 6-42

Cost of Methanol from Coal

\begin{tabular}{lll}
\hline Investment & - \$MBTU/Yr. & $15-34$ \\
Capital Recovery & - \$MBTU & $3.00-6.80$ \\
Operat1ng Cost & - \$/MBTU & $2.00-2.25$ \\
Feedstock Cost & - \$MBTU* & $1.65-2.10$ \\
Total Cost & - \$/MBTU (\$/Ton) & $6.65-11.15(113-190)$ \\
\hline
\end{tabular}

* Coal is priced at $21 \$ / t o n$ and plant s1ze is 2000 tons/day. 
A high operating cost is attributable to the inherent low yields per pass and resultant large recycle rates. The use of a coproduct system may lower the cost.

\subsection{Effect of Coal Type on Methanol Cost}

For a 2000 TPD plant fed on low sulfur/low BTU western coal priced at $8 \$ / T$ the total cost is reduced by $0.45 \$ / M B T U$. Table $6-43$ compares the total cost and its components for the two coal types. The cost for elther type of coal is essentially equivalent.

TABLE 6-43

Methanol Costs from Different Coals

\begin{tabular}{|c|c|c|c|}
\hline Coal & & Illinols & Wyoming \\
\hline $\begin{array}{l}\text { Investment } \\
\text { Capital Recovery } \\
\text { Operating Cost } \\
\text { Feedstock Cost } \\
\text { Total Cost }\end{array}$ & $\begin{array}{ll}- & \$ / M B T U / Y r \\
- & \$ / M B T U \\
- & \$ / M B T U \\
- & \$ / M B T U \\
- & \$ / M B T U \\
& \text { s/Ton } \\
\end{array}$ & $34 \begin{array}{r}6.80 \\
2.25 \\
2.10 \\
11.15 \\
190 \\
\end{array}$ & $\begin{array}{r}76.20 \\
2.60 \\
0.90 \\
10.70 \\
184 \\
\end{array}$ \\
\hline
\end{tabular}

As the table indicates, the feedstock costs are substantially lower for the Wyoming coal. However, these savings are diluted due to increased capital and operating costs because of the higher moisture content of the western coal. If the mines for this type of coal are remote from the synthesis plant any additional transportation costs will most likely eliminate the advantage for western coals.

\subsubsection{Methanol from Biomass}

Many investigations have recently been made into the feasibility of using blomass to supply energy. In general, the term biomass has been used to describe municipal solid wastes, agricultural wastes, and crops grown specifically as energy feedstocks. This section will consider a crop, sugarcane, grown specifically as an energy feedstock and the process sequence to methanol.

\subsubsection{Process Route}

The production of methanol from sugarcane 1nvolves: the generation of a synthesis gas from sugarcane fiber (bagasse) via the Purox Process or a similar gasification process, and the conversion of this synthesis gas to methanol. The bagasse is obtainable as a byproduct in the production of sugar from sugarcane or in the recovery of fermentable juice in an ethanol operation (see section 6.10). Reference 6-9 has established the price of bagasse at one dollar per MBTU of bagasse* (1976\$). Th1s cost has been escalated and used in this study. 
A simple depiction of the conversion of sugarcane fiber to methanol is presented in Figure 6-8..

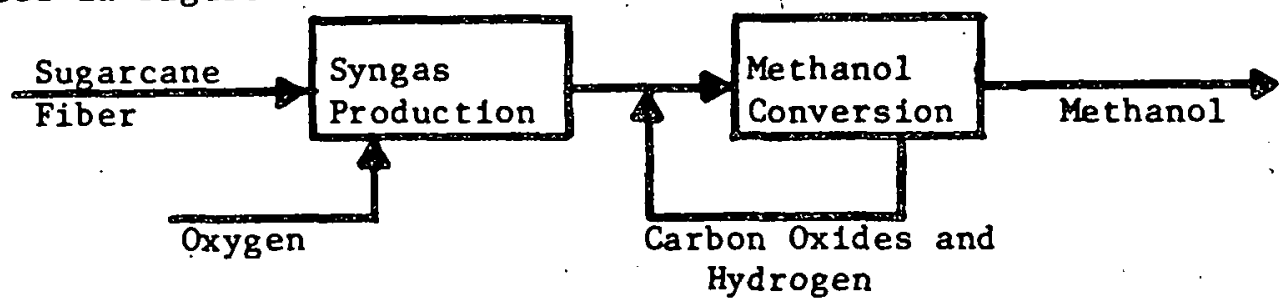

Figure 6-8

Methanol Production from Sugarcane

The prepared ftber is sent to a Syngas unit where oxygen from an air separation plant is added. This syngas is then sent to a shift reactor where the required $\mathrm{H}_{2}$ to $\mathrm{CO}$ ratio is generated. Once this is accomplished the gas is sent to the conversion reactor where steps as previously described for syngas derived from coal are carried out. Approximately 10,000 tons/day of sugarcane is required to make 1700 tons/day of fiber (dry) which in turn makes 430 tons/day of methanol.

\subsubsection{Methanol from Biomass: Process Economics}

It is estimated that methanol from blomass will cost approximately $14.80 \$ / M B T U$ or approximately $253 \$ /$ ton. This is about $60 \$ /$ ton more than methanol from coal. The total cost and its components is shown in Table 6-44.

TABLE 6-44

Cost of Methanol from Sugarcane Fiber

\begin{tabular}{|c|c|c|c|c|c|}
\hline Component & $\begin{array}{l}\text { Investment } \\
\$ / \mathrm{MBTU} / \mathrm{Yr} \text {. }\end{array}$ & $\begin{array}{l}\text { Capital } \\
\text { Recovery } \\
\text { \$/MBTU } \\
\end{array}$ & $\begin{array}{l}\text { Operating } \\
\text { Cost } \\
\text { \$/MBTU }\end{array}$ & $\begin{array}{l}\text { Feedstock } \\
\text { Cost } \\
\text { \$/MBTU } \\
\end{array}$ & $\begin{array}{l}\text { Total } \\
\text { Cost } \\
\text { \$/MBTU } \\
\end{array}$ \\
\hline $\begin{array}{l}\text { Syngas } \\
\text { Generation }\end{array}$ & 10.10 & 2.00 & 1.20 & 2.55 & 5.75 \\
\hline $\begin{array}{l}\text { Methanol } \\
\text { Synthesis }\end{array}$ & 7.00 & 1.40 & 0.65 & $7: 00$ & 9.05 \\
\hline TOTAL & 17.10 & 3.40 & 1.85 & 9.55 & 14.80 \\
\hline
\end{tabular}


The synthesis gas generation contributes $60 \%$ of the total investment required, therefore, it also contributes the most to capital recovery costs. From an operating cost standpoint syngas generation 1s almost twice as expensive as the methanol synthesis and the total operating cost contributes $12.5 \%$ of the total cost. The table clearly indicates that feedstock cost 18 the major contributor to the total cost, $65 \%$, and that the feed cost for the synthesis step, $1 . e$. , the syngas, is the largest single item in the total cost, almost $50 \%$. The fiber itself comprises only $17 \%$ of the total cost and this fiber, as previously mentioned, has been priced at $1 \$ / M B T U$ as set out in reference 6-9.

\subsubsection{Methanol from Other Sources}

There are two other sources for producing methanol which have been considered:

1) Solid Waste Pyrolysis

2) Ocean Thermal Energy Conversion (OTEC)

\subsubsection{Sol1d Waste Pyrolysis}

Recently interest has been shown in investigating the utilization of municipal trash as an energy source. These waste materials can be pyrolyzed to gaseous products: methane, hydrogen, carbon monoxide, carbon dloxide, and water. This gaseous product can then be converted to methanol. The basic requirements for a synthesis gas are produced in the pyrolysis of waste and this. is converted as described in the preceding sections. Apprcximately 3400 tons per day of municlpal wastes are required to produce 400 tons per day of methanol. The cost of this waste to the producer has been assumed as 20 \$/ton.

\subsubsection{Ocean Thermal Energy Conversion (OTEC)}

This process takes hydrogen, made avallable by water electrolysis onboard an OTEC plant, and combines it with purchased carbon dioxide which is transported from an onshore facility to form methanol via the following reaction:

$$
\mathrm{CO}_{2}+3 \mathrm{H}_{2} \longrightarrow \mathrm{CH}_{3} \mathrm{OH}+\mathrm{H}_{2} \mathrm{O}
$$

Approximately 1900 ton/day of carbon dloxide are required to produce 1245 ton/day of methanol.

The production costs of these alternate sources are discussed In the following section. 


\subsubsection{Cost of Methanol Production from Other Sources}

The costs of producing methanol from solid waste and OTEC are summarized in Table 6-45. As the table indicates, both solld waste pyrolysis and OTEC are expensive processes. Relative to coal they are some 9 to 19 \$/MBTU (150-320 \$/ton) more expensive. The total cost for solid waste pyrolysis is $355 \$ / t o n$ and for OTEC about 509 \$/ton.

TABLE $6-45$

Cost of Methanol* Via Solid Waste Pyrolysis and OTEC

\begin{tabular}{|c|c|c|c|c|}
\hline Process & & $\begin{array}{c}\text { Solid Waste } \\
\text { Pyrolysis }\end{array}$ & OTEC & \\
\hline $\begin{array}{l}\text { Investment } \\
\text { Capital Recovery } \\
\text { Operating Cost } \\
\text { Feedstock Cost } \\
\text { Total Cost }\end{array}$ & $\begin{array}{ll}- & \$ / \mathrm{MBTU} / \mathrm{Yr} \\
- & \$ / \mathrm{MBTU} \\
- & \$ / \mathrm{MBTU} \\
- & \$ / \mathrm{MBTU} \\
- & \text { \$/MBTU }\end{array}$ & $\begin{array}{r}11.00 \\
1.45 \\
8.30 \\
20.75\end{array}$ & 39 & $\begin{array}{l}7.90 \\
16.55 \\
5.25 * \star \\
29.70\end{array}$ \\
\hline
\end{tabular}

* All figures are based on lower heating value of methanol ** $\mathrm{CO}_{2}$ at $63 \$ /$ ton

\subsubsection{Summary of Methanol Cost From Different Sources}

Methanol costs vary over a wide range. A summary of methanol costs on a lower heating value basis for a 2000 ton per day production rate is presented in Table 6-46.

The table Indicates that methanol can be manufctured from coal at a cost of about 113-190 \$/Ton, from sugarcane about 250 \$/Ton, from municipal waste at $355 \$ / T o n$ and by ocean thermal energy conver- , sion at $509 \$ / T$. Capltal investments vary from $15 \$ / M B T U / Y r$ - 55 $\$ / M B T U / Y r$. (290 \$/Ton/Yr. - 943\$/Ton/Yr.) with biomass being the least capital intensive followed by coal, OTEC and soldd waste. Solid waste is the least costly to operate and coal has the lowest feedstock cost. Essentially all the processes involve the production of a synthesis gas and the conversion of this gas using conventional technology. It is the route to this synthesis gas which varies from process to process. 
TABLE $6-46$

COMPARISON OF METHANOL COSTS FROM VARIOUS PROCESS

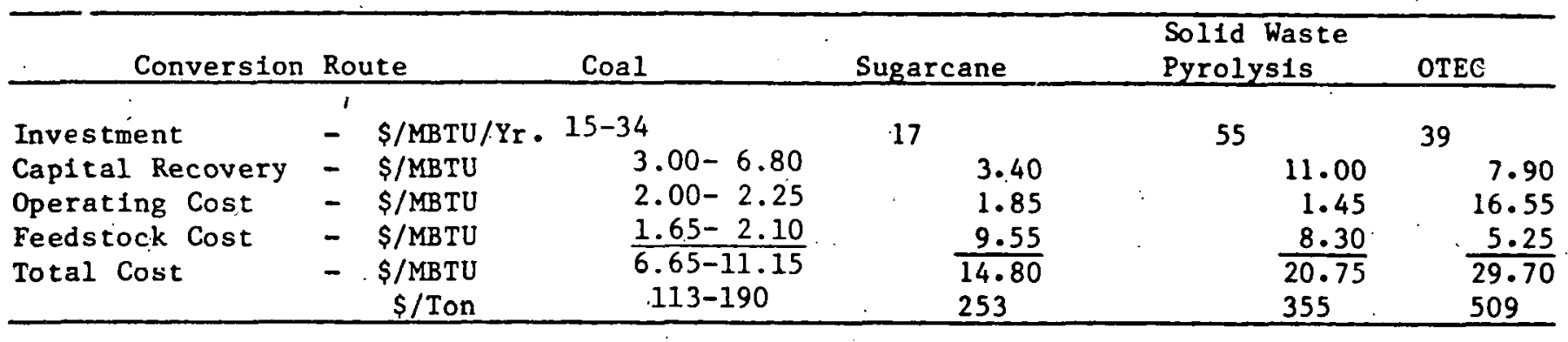

Alternatively, methanol costs can be compared on an index basis. Using the figures in Table 6-46 the indices shown in Table 6-47 can be calculated. This representation better 1llustrates the relative differences in total costs (note that each column is a separate comparison and that only the specific numbers in a particular column can be compared, columns cannot).

\section{TABLE $6-47$}

RELATIVE VALUES OF METHANOL COST FROM VARIOUS PROCESSES

\begin{tabular}{lccccc}
\hline & Investment & $\begin{array}{c}\text { Cap1tal } \\
\text { Recovery }\end{array}$ & $\begin{array}{c}\text { Operating } \\
\text { Costs }\end{array}$ & $\begin{array}{c}\text { Feedstock } \\
\text { Cost }\end{array}$ & $\begin{array}{c}\text { Total } \\
\text { Costs }\end{array}$ \\
\hline Coal (upper range) & 200 & 200 & 155 & 1100 & [100 \\
Sugarcane & 100 & 000 & 128 & 455 & 133 \\
Sol1d Waste Pyrolysis & 320 & 320 & 1100 & 395 & 187 \\
OTEC & 230 & 230 & 1140 & 250 & 267 \\
\hline
\end{tabular}




\subsection{Hydrogen}

Nearly all 1ndustrial hydrogen currently produced in the U. S. Is manufactured by the catalytic steam reforming of natural gas or some other light hydrocarbon feed stock. The increasing cost and decreasing supplits of natural gas and light hydrocarbons provide a definite incentive for developing new processes for hydrogen manufacture. Coal gasification or electrolysis, are frontrunners in this regard.

\subsubsection{Coal Gasification}

Manufacturing hydrogen from coal involves several steps. First, finely ground coal is gasified with steam and oxygen at a temperature of about $2700^{\circ} \mathrm{F}$ to form hydrogen and carbon oxides as shown in Figure 6-9. Reaction temperature is controlled by adjusting the oxygen/steam ratio. Ash is withdrawn from the reactor as slag. Hydrogen yleld is increased by the "shift" reaction in which carbon monoxide reacts with steam to make hydrogen and carbon dioxide. In the next step, carbon dioxide and hydrogen sulfide are removed with calcium oxide or other bases. Residual carbon. oxides are removed by methanation. The Koppers-Totzek process, which has been widely used in Europe, employs these steps.

Other processes, such as Lurg1, employ a different type of gasifler. which produces pyrolysis products such as tars, phenols, and methane as well as hydrogen and carbon oxides. The alternative technology requires less energy and may be preferable for making methane. However, the KoppersTotzek gasification is probably better for making hydrogen. 'It avoids the problems of removing the methane, o1ls, etc., from the hydrogen.

The Koppers-Totzek gasifier operates at about atmospheric pressure. The gases are compressed to about 300 psig for shift and purification. There is substantial incentive for modifylng the gasifier for higher pressure operation.

\subsubsection{Process Economics For Coal Gasification}

Hydrogen can be produced via coal gasification for 7.9-9.6 \$/MBTU. Table 6-48 shows the cost breakdown for this process. As the table indicates this route to hydrogen is capital intensive with capital recovery comprising $50 \%$ of the total cost. 
Figure $6-9$

CONVERSION OF COAL TO HYDROGEN

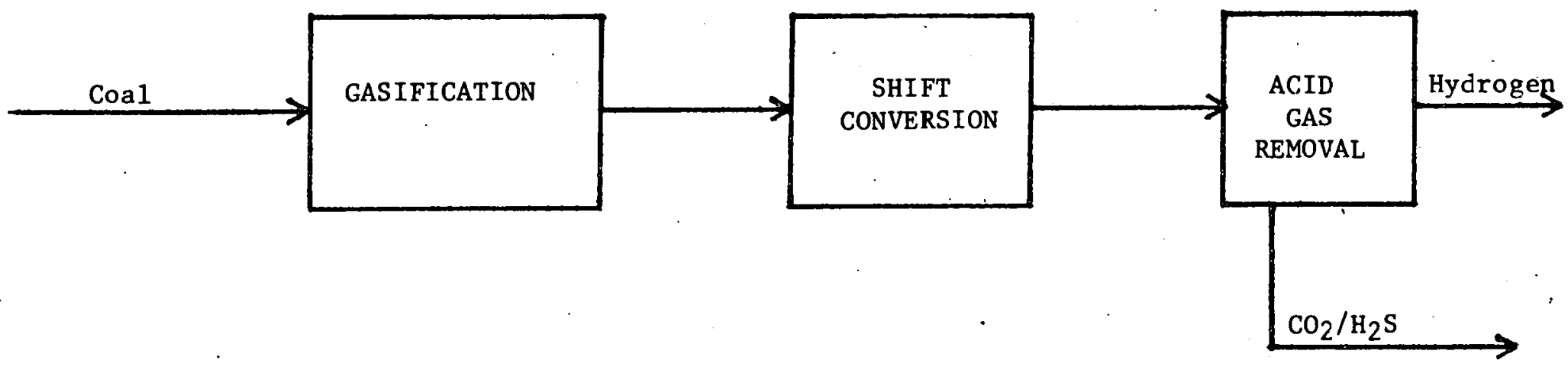


TABLE 6-48

COST BREAKDOWN FOR HYDROGEN VIA COAL GASIFICATION*

\begin{tabular}{llc}
\hline & & Hydrogen from Coal \\
\hline & & \\
Investment & - \$MBTU/Yr. & $23-29.5$ \\
Cap1tal Recovery & - \$/MBTU & $4.6-5.9$ \\
Operating Cost & - \$MBTU & $1.6-1.9$ \\
Feedstock Cost & - \$/MBTU & $1.7-1.8$ \\
Total Cost & - \$MBTU & $7.9-9.6$ \\
\hline
\end{tabular}

\subsubsection{Effect of Coal Cost on Hydrogen Cost}

The use of low sulfur, lower priced ( $8 \$ /$ Ton) western coals to produce hydrogen by gasification apparently reduces the cost by $0.50-0.60 \$ /$ MBTU. These cost reductions are mainly in raw material cost savings, however increased costs for coal handling and drying of the higher molsture western coal dilute these savings considerably.

The $8 \$ /$ Ton cost referred to above is at the mine mouth. If the mine were remote from the hydrogen plant the addition of transportation charges required to move the coal would offset the raw material cost savings. Thus, it might be more economical to use local coal for making hydrogen in the mid-west or east.

\subsubsection{Hydrogen via Electrolysis}

A simplified scheme for generating hydrogen via water electrolysis 18 presented in figure 6-10. The heart of the process is the medium with ion exchange properties that, with the addition of liquid water allows hydrogen lons to flow. Hydrogen lons are converted to hydrogen gas at the cathode. Current technology uses an aqueous potassium hydroxide (KOH) solution. An alternative which shows considerable promise, but which requires substantial development is the solid polymer electrolyte (SPE) which 1s currently being developed by General Electric. The following section presents a comparison of hydrogen costs via these alternatives.

\subsubsection{Hydrogen Costs via Electrolysis}

A comparison of costs for hydrogen via SPE and $\mathrm{KOH}$ electrolys is is presented in Table 6-49. Hydrogen can be produced for $19.65 \$ / \mathrm{MBTU}$ by $\mathrm{KOH}$ technology and for about 13\$/MBTU via SPE technology. As the table indicates it is the considerable improvements in investment and operating costs which

* Basis: Coal at 21\$/Ton, Plant S1ze: $880 \mathrm{MSCF} / \mathrm{D}$. This plant size $1 \mathrm{~s}$ equivalent in BTU output, lower heating value, to a $250 \mathrm{MSCF} / \mathrm{D}$ natural gas plant. Basic investment is based on a $100 \mathrm{MSCF} / \mathrm{D} \mathrm{H}_{2}$ plant and a scaling factor of 1 . 
Figure $6-10$

SIMPLIFIED FLOW SCHEME FOR HYDROGEN VIA ELECTROLYSIS

Electrical Power

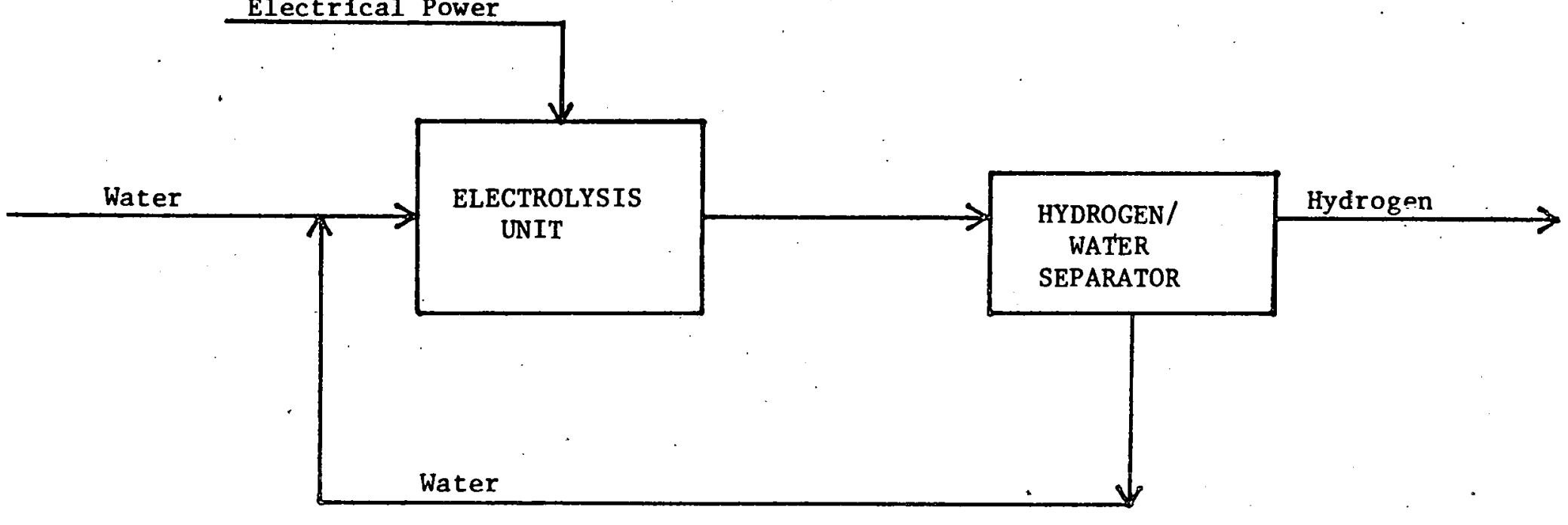


provide the incentive for developing the advanced SPE process. It is projected that SPE will lower investment by a factor of 4 and reduce operation cost by about $1.50 \$$ MBTU relative to the aqueous KOH technology.

The single factor which has the largest impact on the cost of hydrogen via this route is the cost of electricity. The estimates of production costs are based on an electricity cost $0.03 \$ / \mathrm{kwin}$. If this cost increased to $0.035 \$ / \mathrm{kwh}$ the cost of hydrogen v1a $\mathrm{KOH}$ would increase to about $22 \$ / \mathrm{MBTU}$ and for SPE to about 15\$/MBTU. Thus, a $17 \%$ increase in electric1ty cost causes a $12 \%$ increase in the cost of hydrogen using current technology, while the advanced SPE process 1ncreases by $15 \%$.

Table $6-49$

Hydrogen Costs From Electrolysis Processes*

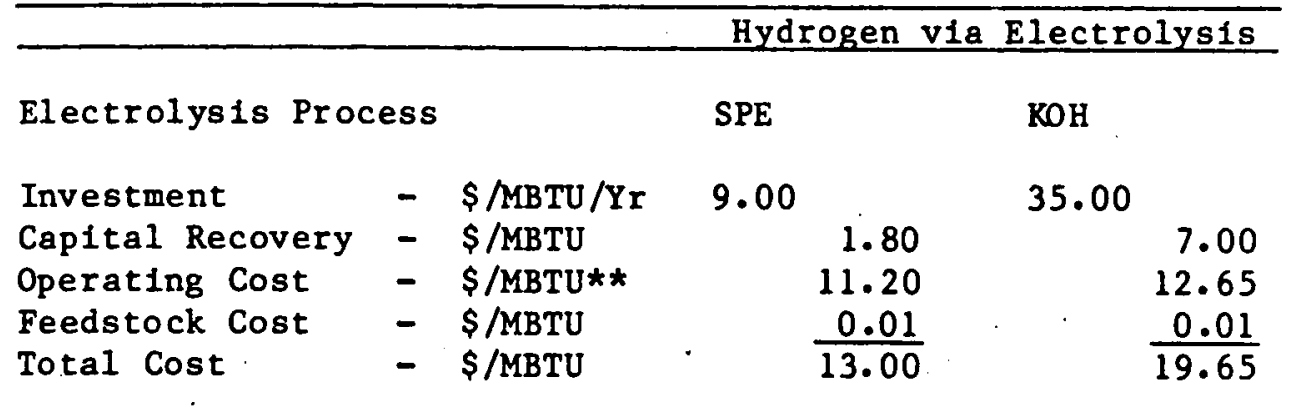

* Plant size: $880 \mathrm{MSCF} / \mathrm{D}$; approximately equivalent to $250 \mathrm{MSCF} / \mathrm{D}$ Natural Gas Plant. ** Electricity: $3 k / k w h$

\subsubsection{Comparison of Alternat1ve Hydrogen Processes}

Coal gasification shows a considerable advantage over both electrolysis routes. Relative to current potassium hydroxide (KOH) technology the advantage is about $10 \$$ MBTU. While comparison with the solid polymer electrolyte (SPE) technology, which is currently under development, shows a smaller advantage of $3.50 \$$ MBTU. A comparison of the total cost and component contributions is presented in Table 6-50 for the three technologies.

In addition, typical process inputs and outputs are shown in Table 6-51. Coal gasification requires 2400 Tons/day to produce $100 \mathrm{MSCF} /$ Day of hydrogen. The potassium hydroxide technology requires $520,000 \mathrm{kwh}$ and 1100 thousand gallons of water per day to produce $100 \mathrm{MSCF} /$ Day while SPE electrolysis requires $510,000 \mathrm{kwh}$ and 575 thousand gallons of water per day for the same quantity of hydrogen. 
Table $6-50$

Comparison of Production Costs for Different Hydrogen Technologies

\begin{tabular}{|c|c|c|c|c|c|c|}
\hline & \multirow{2}{*}{$\begin{array}{c}\text { Coal } \\
\text { Gasification } \\
\end{array}$} & \multicolumn{4}{|c|}{ Electrolysis } \\
\hline & & & SPE & & $\mathrm{KOH}$ & \\
\hline $\begin{array}{l}\text { Investment } \\
\text { Capital Recovery } \\
\text { Operating Cost } \\
\text { Feedstock Cost } \\
\text { Total Cost }\end{array}$ & $\begin{array}{ll}- & \$ / M B T U / Y r \\
- & \$ / M B T U \\
- & \$ / M B T U \\
- & \$ / M B T U \\
- & \$ / M B T U\end{array}$ & $\begin{array}{r}23-29.5 \\
: 4.60-5.9 \\
1.60-1.9 \\
1.70-1.8 \\
\frac{7.90-9.6}{1}\end{array}$ & 9 & $\begin{array}{r}1.80 \\
11.13 \\
0.01 \\
13.00\end{array}$ & 35 & $\begin{array}{r}7.00 \\
12.64 \\
0.01 \\
19.65\end{array}$ \\
\hline
\end{tabular}

Table 6-51

Typical Process Inputs and Outputs for Hydrogen Production

\begin{tabular}{|c|c|c|c|}
\hline Process & $\begin{array}{c}\text { Coal } \\
\text { Gasification } \\
\end{array}$ & $\begin{array}{c}\text { SPE } \\
\text { Electrolysis } \\
\end{array}$ & $\begin{array}{c}\mathrm{KOH} \\
\text { Electrolysis } \\
\end{array}$ \\
\hline \multicolumn{4}{|l|}{ Inputs: } \\
\hline Coal, Tons/Day & 2400 & - & - \\
\hline Electricity, $\mathrm{KW}$ & 1450 & 510,000 & 520,000 \\
\hline \multicolumn{4}{|l|}{ Process } \\
\hline Water, kgal/Day & 7600 & 575 & 1,100 \\
\hline Outputs: & ' & & \\
\hline - & • & & \\
\hline Hydrogen, MSCF/D & 100 & 100 & 100 \\
\hline Sulfur, Tons/Day & 80 & - & - \\
\hline
\end{tabular}




\subsection{Ammonia}

Currently ammonia provides the largest single requirement for Industrial hydrogen. In the U.S. essentially all ammonla curretity produced is made by catalyt ic steam reforming of natural gas or some other light hydrocarbon feed stock. Future shortages of these feed stocks and increas $a s$ in their prices will provide the incentive for considering alternative feeds for ammonia manufacture. The alternative routes considered here are:

1) Coal

2) Biomass

\subsubsection{Ammonia From Coal}

As in hydrogen or methanol manufacture, the first step in ammonia manufacture is the production of synthesis gas. The gasifier products are cooled and then shifted to convert $C O$ to additional hydrogen. The $\mathrm{CO}_{2}$ is then removed and high purity nitrogen from alr separation is added.

The ammonia synthesis gas is compressed to 2000-4500 psig and sent to the synthesis reactor where ammonia is formed at about $900^{\circ} \mathrm{F}$ over a promoted iron catalyst. Figure 6-11 illustrates a possible flow diagram for the conversion of coal to ammonia. The synthesis reaction is:

$$
\mathrm{N}_{2}+3 \mathrm{H}_{2} \rightarrow 2 \mathrm{NH}_{3}
$$

of coal.

The production of 1500 ton/day of ammonia requires 2600 ton/day.

\subsubsection{Ammonia from Coal: Process Economics}

Ammonia can be produced from coal at a cost of 208 \$/T (13 \$/MBTU). As with other coal conversion processes it is the required capital investment which contributes heavily to the total cost. In the case of ammonia capital recovery is $50 \%$ of the total. 
Figure $6-11$

CONVERS ION OF COAL TO AMMONIA

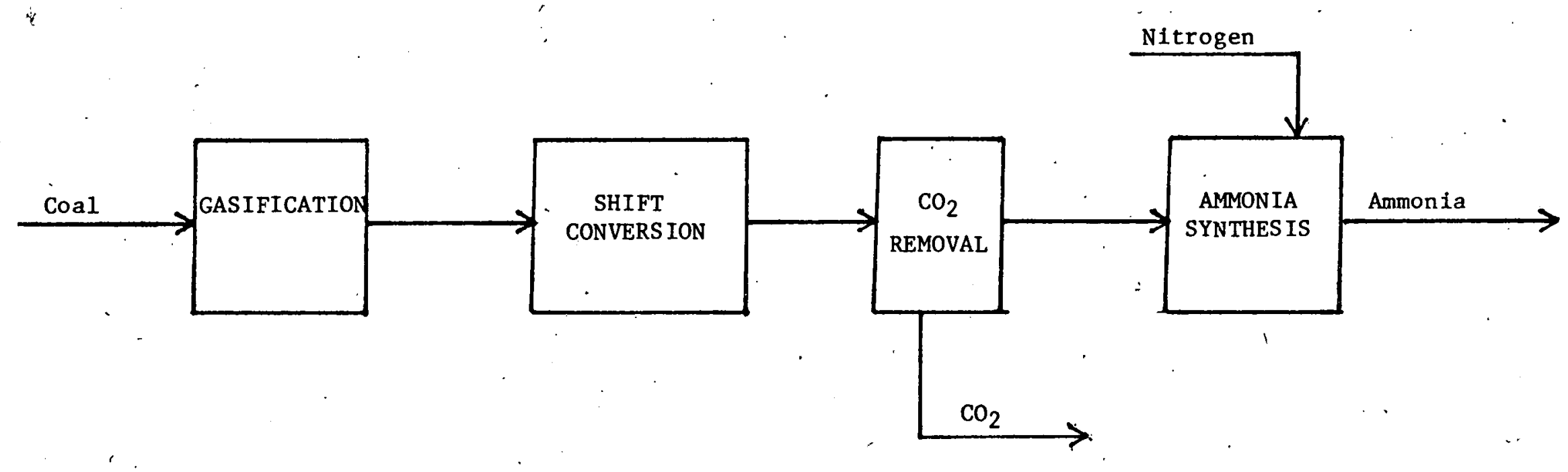


Table 6-52 summarizes the component costs of this process. Operating costs contribute $36 \%$ of the total; and the remainder is the cost of the coal (feedstock).

Table 6-52

COST OF AMMONIA FROM COAL

(2000 Ton per day plant; Coal at 21 per Ton)

\begin{tabular}{lllr}
\hline Investment & $-\$ / M B T U / Y r$ & 39 \\
Capital Recovery & $-\$ / M B T U$ & -7.90 \\
Operating Cost & $-\$ / M B T U$ & $2.2-2.70$ \\
Feedstock Cost & $-\$ / M B T U$ & $2.2-2.30$ \\
Total Cost & $-\$ / M B T U$ & $12.3-12.90$ \\
& & \$/Ton & $198-208$ \\
\hline
\end{tabular}

\subsubsection{Ammonia From Sugarcane}

The generation of synthesis gas from sugarcane has been discussed previously, in section 6.7 .2 .1 , in the manufacture of methanol. This same synthesis gas can be converted to ammonia. The production steps required to produce ammonta from the Purox syngas are the same as those already discussed for the conversion of syngas derived from coal. Production of 568 ton/day of ammonia consumes 1700 ton/day of dry fiber, which consumes 10,000 ton/day of sugarcane.

\subsubsection{Ammonta from B1omass: Process Economics}

Ammonia can be produced from biomass by the Purox syngas process at a cost of approximately $283 \$ / T O N(17.55 \$ / M B T U)$. Th1s process alternative is less capital intensive with capital recovery contributing $27 \%$ of the total cost. The feedstock cost is about $50 \%$ of the total and this is the major difference between the biomass versus coal routes. The total cost breakdown appears in Table 6-53. 
Table 6-53

COST OF AMMONIA FROM BIOMASS

(2000 Ton per day plant)

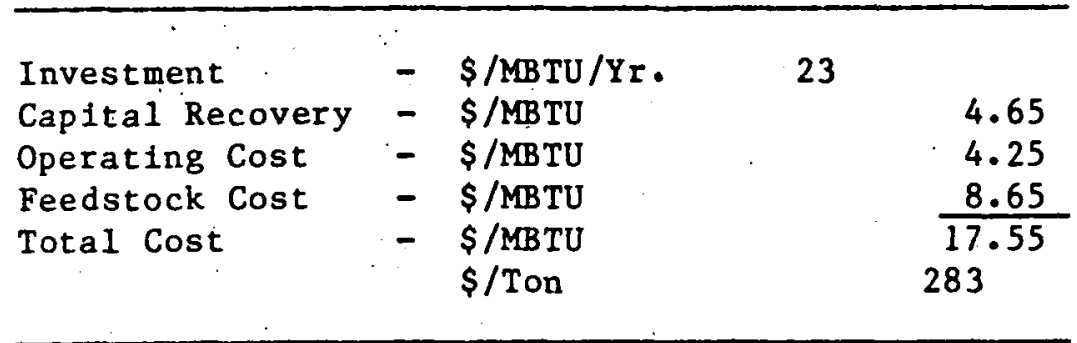

A further breakdown which illustrates the contributions of Syngas generation and ammonia synthesis to the total is shown in Table 6-54.

Table 6-54

COST BREAKDOWN FOR AMMONIA FROM BIOMASS

\begin{tabular}{lccccc}
\hline Component & $\begin{array}{l}\text { Investment } \\
\text { \$/MBTU/Yr. }\end{array}$ & $\begin{array}{c}\text { Capital } \\
\text { Recovery } \\
\text { \$/MBTU }\end{array}$ & $\begin{array}{c}\text { Operating } \\
\text { Cost } \\
\text { \$/MBTU }\end{array}$ & $\begin{array}{c}\text { Feedstock } \\
\text { Cost } \\
\text { \$/MBTU }\end{array}$ & $\begin{array}{c}\text { Total } \\
\text { \$/MBTU }\end{array}$ \\
\hline $\begin{array}{l}\text { Syngas } \\
\text { Generation }\end{array}$ & 9.65 & 1.90 & 1.70 & 2.30 & 5.90 \\
$\begin{array}{l}\text { Ammonia } \\
\text { Synthesis }\end{array}$ & 13.70 & 2.75 & 2.55 & 6.35 & 11.65 \\
\hline $\begin{array}{l}\text { Total } \\
\text { Sym }\end{array}$ & 23.35 & 4.65 & 4.25 & 8.65 & 17.55 \\
\hline
\end{tabular}

The synthesis step in the production of ammonia contributes $60 \%$ of the total investment required, therefore it also contributes the most to capital recovery. Both the syngas generation and ammonia synthesis steps are expensive to operate. Again, synthesis contributes a higher percentage. Clearly the most expensive portion of the total cost is the feedstock cost; $50 \%$ of the total cost. The feed to the synthesis step is the syngas generated the step previousiy and this contributes about $75 \%$ of the total feedstock cost and is the largest single 1tem in the total cost (more than 35\%). The feedstock cost for the syngas generation step is bagasse, reference 6-9, the source of this information, has set the price of bagasse at one dollar per MBTU of bagasse* (1976\$). Th1s cost was subsequently escalated and used in this study.

* Approximately $3600 \mathrm{BTU} / \mathrm{lb}$. 


\subsubsection{Comparison of Ammonia from Coal and from Sugarcane}

Ammonia from coal can be made cheaper than from sugarcane by about $75 \$ / T o n$. The cap1tal investment for coal, is higher at $39.45 \mathrm{\$} / \mathrm{MBTU} / \mathrm{Yr}$. versus 23.35 \$/MBTU/Yr. Both the feedstock and operating costs for the sugarcane alternative are considerably higher than for coal. The net difference between these factors provides the advantage for coal. Table 6-55 compares all of these factors and the total cost.

Table 6-55

\section{COMPARISON OF AMMONIA COST FROM COAL AND BIOMASS}

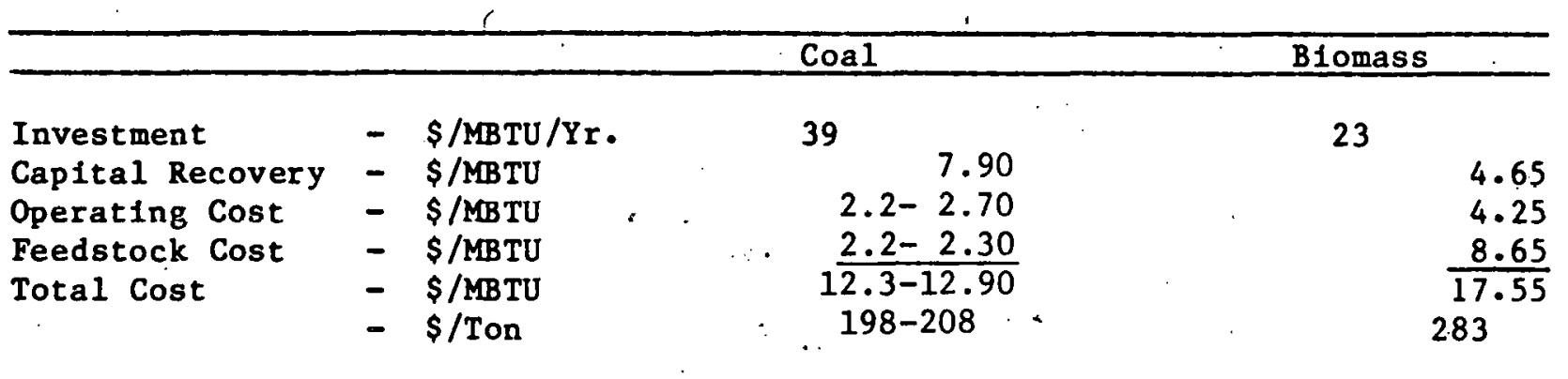

\subsection{Ethanol}

Ethyl alcohol (ethanol) was extensively used in Europe as a motor fuel in the pre-World War II period. In the United States there has been minor use of ethanol as a fuel at any time. The low cost and availability of petroleum products have made extensive use of alcohols impractical. Currently ethylene, a petroleum product, is hydrated to produce industrial ethanol. As the cost of ethylene increases and availability decreases, incentives for developing alternative routes will grow. w111 be discussed:

The following alternative routes for producing ethanol

1) Fermentation of corn

2) Hydrolysis of wood followed by fermentation

3) Blomass Conversion. 


\subsubsection{Alternat1ve Methods for Producing Ethanol}

- Fermentation

Ethanol has been produced for centuries through the fermentation of fruits and grains. Essentially, fermentation is a decomposition process in which enzymes behave as catalysts. Fisedstocks can be any material which contaln or can be converted 1.to hexose sugars. Such materials include: sugar beets, potatoes, rice, corn, molasses, and wheat. The general chemistry is 11lustrated below:

$\mathrm{C}_{12} \mathrm{H}_{22} \mathrm{O}_{11} \mathrm{H}_{20}$ Invertase $2 \mathrm{C}_{6} \mathrm{H}_{12} \mathrm{O}_{6}$ Sucrose Invert Sugar

$\mathrm{C}_{6} \mathrm{H}_{12} \mathrm{O}_{6} \stackrel{\text { Zymase }}{\longrightarrow} \underset{\text { Ethanol }}{2} \mathrm{C}_{2} \mathrm{H}_{5} \mathrm{OH}+2 \mathrm{CO}_{2}$

The product is a fluid containing ethanol and unconverted reactant. The ethanol is recovered by distillation. Wood can also be included as a feedstock because it contains cellulose which can be converted by hydrolysis. into glucose.

- Hydrolysis of Wood (Cellulose)

Cellulose in wood can be converted into glucose by hydrolysis. This glucose is fermented and distilled into ethanol as previously described. There are two techniques for the conversion of cellulose:

+ acid hyrolysis

+ enzymatic hydrolysis

In acid hydrolysis weak acid solutions are added to wood chips and the mixture is "cooked" to generate the glucose. As its name infers, enzymatic hydrolysis involves enzyme attack for the conversion of cellulose to glucose. The concept of acid hydrolysis 18 not new; this technique is used commercially today to convert wood wastes to glucose. Enzymat1c hydrolys is is a newer concept. A critical step in this process is the growth of a particular culture whose enzymes are required for conversion. In addition, the rate of hydrolysis is very sensitive to the form of the cellulose. The cellulose must be thoroughly milled. for acceptable conversion by enzyme attack. Ac1d hydrolys 18 conversion requires only minutes while enzymatic hydrolysis requires hours.

The economics presented in the following section are based on the fermentation process. 


\section{- Biomass (Sugarcane) Conversion}

Agricultural crops, such as the sugarcane, can be used as a source of ethanol. After shredding and mill extraction the sugarcane juice is recovered. This juice is directly fermentable and the fermentation step as previously described can be used for conversion of the fuice to ethanol. Approximately 12,200 tons per day of fuice contalning 11.5 wt\% fermentable sugars is required to produce 690 tons per day of 95 vol\% ethanol.

\subsubsection{The Cost of Producing Ethanol}

The cost for 1500 Tons/day of ethanol by the fermentation of corn is $485 \$ / t o n$. While the 1iterature provides some preliminary information on ethanol costs via acid hydrolysis and fermentation of wood and conversion of biomass, the investments quoted appear inconsistent with well established information on grain fermentation.

A cost buildup for ethanol via grain fermentation appears in Table 6-56.

Table $6-56$

Cost of Ethanol from Corn*

\begin{tabular}{lc}
\hline Investment $-\$ / \mathrm{MBTU} / \mathrm{yr}$ & 18 \\
Capital Recovery $-\$ / \mathrm{MBTU}$ & 3.50 \\
Operating Cost $-\$ / \mathrm{MBTO}$ & 4.20 \\
Net Feedstock Cost $-\$ / \mathrm{MBTU}$ & $\frac{13.50}{21.20}$ \\
Total Cost $-\$ / \mathrm{MBTU}$ & 485 \\
$\quad-\$ /$ Ton & \\
\hline
\end{tabular}

* Source - Reference 6-20.

$\star *$ Corn at $\$ 3.75 /$ Bushel.

The net feedstock cost, which contributes over $60 \%$ of the total cost of ethanol, is the cost of corn at $\$ 3.75 /$ bushel less a credit for the by-product dry grain, as high protein animal feed, selling at $\$ 130 /$ ton. Ethanol cost is quite sensitive to the cost of grain as 1llustrated in Table 6-57. 
Table 6-57

Sensitivity of Ethanol Costs to Grain Price

\begin{tabular}{lrrr}
\hline Corn Cost $-\$ /$ Bus iel & 1.75 & 3.75 & 5.75 \\
Net Feedstock Cost - \$/MBTU* & 4.60 & 13.50 & 22.30 \\
Total Cost - \$/MBTU & 12.30 & 21.20 & 30.00 \\
\hline
\end{tabular}

*Includes credits for by-product dry grain priced at 100, 130, and $160 \$ /$ ton when corn costs $1.75,3.75$, and $5.75 \$ / b u s h e 1$.

Production of ethanol from wood or biomass may prove less costly than ethanol from grain. HIgher investments and operating costs may be more than offset by lower feedstock costs.

\subsection{Methane}

In the past natural gas, $i . e .$, methane has found application in the residential, commercial, industrial and power generating sectors due to its low cost, via government regulation, and clean burning properties. Recently, shortfalls in supply have been backing out natural gas from both the industrial and power generating sectors. A few years ago anticipated shortfalls triggered the production of a substitute natural gas (SNG). from hydrocarbon feedstocks, such as naphtha, especially in response to winter peak demands. The choice of hydrocarbons is due to the ease in producing SNG via steam reforming. Obviously, as the supply of natural gas and hydrocarbons continues to decline alternative sources of a natural gas type product, 1.e., SNG, will have to be found. 'Probably the leading contender to augment gas supplies is coal. Biomass and sewage algae also represent potential sources of SNG.' SNG can be used as a turbine fuel and may find application, in liquid form, as an aircraft fuel, and it could be used as a (gas) pipeline fuel. 
6.11.1.1 Methane (SNG) from Coal

There are a larg: number of processes to convert coal to SNG under study; they irvolve the following steps:

1) Coal preparation

2) Gasification

3) Shift and Purification

4) Methanation

5). Compression

Some of the posstble contenders are:

a) Lurgi: 300 psig gasification

b) Bituminous Coal Research, Inc. (Bi-Gas): 2 stage gasifier at $1000-1500$ psig

c) Institute of Gas Technology (Hygas): 2 stage gasifier at $1000-1500$ psig

d) Bureau of Mines (Synthane): fluid bed gasifier at 1000 psig

e) Consolidation Coal $\mathrm{Co} \cdot\left(\mathrm{CO}_{2}\right.$ Acceptor $)$

In the gasification step, the products of 1mportance are $\mathrm{CO}$ and $\mathrm{H}_{2}, \mathrm{CO}_{2}$ is also generated. The gasification products undergo shift reaction ( $\left.\mathrm{CO}+\mathrm{H}_{2} \mathrm{O} \longrightarrow \mathrm{H}_{2}+\mathrm{CO}_{2}\right)$ to adjust the $\mathrm{H}_{2}$ to $\mathrm{CO}$ ratio to about $3 / 1$ to allow for subsequent methanation. The acid gases produced in this step $\left(\mathrm{CO}_{2}\right.$ and $\left.\mathrm{H}_{2} \mathrm{~S}\right)$ are subsequently scrubbed out. In the methanator, $\mathrm{CO}$ and the small amount of remaining $\mathrm{CO}_{2}$ are converted over a catalyst to $\mathrm{CH}_{4}$ and $\mathrm{H}_{2} \mathrm{O}$ with the release of large quantities of heat. The product SNG is dried and compressed.

\subsection{1 .1 .2 SNG Production Economics}

As previously mentioned there exists a large number of processes for SNG production all in various stages of study and commercialization. They all differ somewhat in particular gasifier design and by-products made, however, the production steps are the same for all and it is beyond the scope of this study to critically analyze each process. Thus, a range of costs for SNG from coal is presented in Table 6-58 for a plant size of $250 \mathrm{MSCF} / \mathrm{D}$ and $870 \mathrm{BTU} / \mathrm{SCF}$ (LHV), and coal at 21 \$/Ton (information derived from reference 6-12). 
Table 6-58

TOTAL COST OF SNG FROM COAL

\begin{tabular}{llr}
\hline Investment & - \$MBTU/Yr. $17-22$ & \\
Cap1tal Recovery & - \$MBTU & $3.40-4.40$ \\
Operat1ng Cost & - \$MBTU & $.80-1.65$ \\
Feedstock Cost & - \$MBTU & $1.90-2.70$ \\
Total Cost & - \$MBTU & $6.10-8.75$ \\
\hline
\end{tabular}

\subsubsection{SNG from Blomass and Sewage Algae}

At this point in time the conversion processes for blomass and materials such as algae are conceptual and will require a great deal of development for significant impact on SNG production. It is percelved that the conversion of blomass will involve anerobic fermentation or an advanced pyrolysis or gasification system. The fermentation scheme w111 most likely yield methane and $\mathrm{CO}_{2}$ directly, while the pyrolysis and gasification schemes will yleld primarily $\mathrm{CO}$ and $\mathrm{H}_{2}$ which will have to be converted to methane in a manner similar to that described in the section on Methane from Coal $(6.11 .1,1)$.

The production of algae for SNG production will Involve these steps: growth of the algae in open ponds followed by harvesting, conversion of the algae by anerobic digestion to produce methane and $\mathrm{CO}_{2}$ by fermentation. The problems which. must be solved before implementation include:

- finding adequate water and $\mathrm{CO}_{2}$ supplies (sewage waste is one possibllity),

- maximlzing algae growth,

- developing inexpensive harvesting methods,

- achleving rellable aneroblc digestion.

The 11terature data (ref. 6-14) used to estimate the cost of methane (SNG) is based on assumed advances in these areas. 


\subsubsection{SNG V1a Blomass and Algae Conversion}

Indications are that conversion of bionass to SNG by a conceptual advanced process will yleld SNG at abcist 8.00\$/MBTU and that algae conversion using an advanced process I lelds SNG at about 12.50 \$MBTU. These total costs and cost components are compared with that of coal in Table 6-59 for a 250 MSCF/D plant size and product heating value of $870 \mathrm{BTU} / \mathrm{SCF}$ (LHV).

TABLE 6-59

COMPARISON OF TOTAI COSTS FOR SNG VIA DIFFERENT ROUTES

\begin{tabular}{|c|c|c|c|c|c|c|}
\hline Conversion Route & & Coal & Biomass & & Algae* & \\
\hline $\begin{array}{l}\text { Investment } \\
\text { Capital Recovery } \\
\text { Operating Cost } \\
\text { Feedstock Cost } \\
\text { Total Cost }\end{array}$ & $\begin{aligned} & \text { \$/MBTU/Yr } \\
- & \$ / M B T U \\
- & \$ / M B T U \\
- & \$ / M B T U \\
- & \$ / M B T U\end{aligned}$ & $\begin{array}{l}17-22 \\
3.40-4.40 \\
0.80-1.65 \\
1.90-2.70 * * \\
\\
\frac{6.10-8.75}{}\end{array}$ & 12.00 & $\begin{array}{l}2.40 \\
1.00 \\
4.60 * * * \\
8.00\end{array}$ & 12.00 & $\begin{array}{l}2.40 \\
4.35 \\
5.75 \star \star \star \\
12.50\end{array}$ \\
\hline
\end{tabular}

* Prorations from smaller plants (60 MSCF/D) for comparison with coal based process; factor: 0.9 .

* Coal at 21 \$/Ton.

$\star \star \star$ Includes collection cost of 20 \$/Ton.

As Table 6-59 indicates, coal has an advantage over the biomass and algae routes. The feedstock cost difference between coal and biomass provides the basic advantage for coal, while it is a combination of operating and feedstock cost which provides the advantage for coal over algae processing. It is worth re-emphasizing that the costs for biomass and algae are based on the assumption of significant improvement over today's technology and will require demonstration. The coal based process 18 .much further along in development and the estimate used is better substantlated. 


\subsection{Other Alternate Fuels}

Th1s section will deal with alternate fuels which have not been covered in previous sections. These fuels are:

Fue1

Synthetic 0il from Organic Waste

Hydrazine

Acetylene

Methylamine

Low BTU gas

Electricity
Section Number
6.12 .1
6.12 .2
6.12 .3
6.12 .4
6.12 .5
6.12 .6

\subsubsection{Synthetic 011 from Organic Waste}

A process is being developed for the conversion of solid organic wastes to a low sulfur synthetic ofl which may have potential use in power plants or for conversion to petroleum type products. The production of this oil is achieved by reacting carbon monoxide, water and the organic waste at temperatures of $350-400^{\circ} \mathrm{C}$ and at pressures near 4000 psig in the prescence of various catalysts and solvents. This oil is expected to cost about 8.60 \$MBTU. A breakdown of this total cost is shown in Table 6-61. It should be noted that this is the cost of liquids as produced, without upgrading, and is far more expensive than the cost of elther coal liquids or shale liquids (sections 6.5 and 6.3 respectively). A comparison of costs from these sources is also shown in Table 6-60.

Table 6-60

COMPARISON OF SYNTHETICS LIQUIDS COSTS*

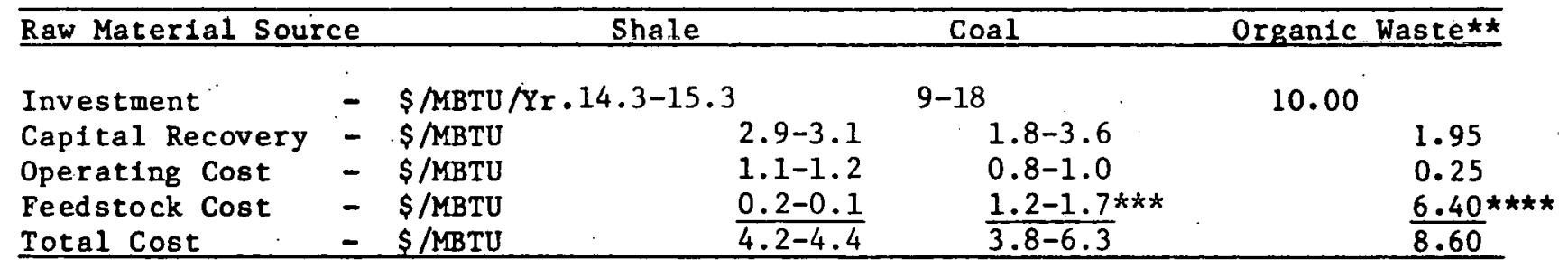

* Production of 50,000 barrels per day without upgrading.

** Reference: 6-14.

$\star \star \star$ Coal at 21 \$ per ton.

$\star \star \star \star \star *$ Includes waste collection cost of 20 \$/Ton. 


\subsection{2 .2 Hydrazine}

Hydrazine has a fairly high electrochemical reactivity and, therefore, may be attractive for use in fuel cells. Hydrazine can be produced by the Raschig process by the reactions shown below:

$$
\begin{aligned}
& \mathrm{NaOH}+\mathrm{Cl}_{2} \rightarrow \mathrm{NaOCl}+\mathrm{HCl} \\
& \mathrm{NH}_{3}+\mathrm{Na} \mathrm{OC} 1 \rightarrow \mathrm{NH}_{2} \mathrm{Cl}+\mathrm{Na} \mathrm{OH} \\
& \mathrm{NH}_{3}+\mathrm{NH}_{2} \mathrm{Cl} \rightarrow \mathrm{NH}_{2} \mathrm{NH}_{2}+\mathrm{HCl}
\end{aligned}
$$

Process and investment Information were not avallable, so the study approach has been to use the most recent costs avallable (as published in Chemical Marketing Reporter, * for the main raw materials: chlorine (135\$/ ton) and, ammonia (120 \$/ton) and using the reaction stoichiometry above determine the lower limit of the cost of hydrazine. With this approach no capital recovery costs or operating costs are taken into account so this represents the lower limit. This estimate showed that the hydrazine cost is about 37 \$MBTU**. If the ammonia cost developed in this study is used, then the hydrazine cost is about 45 \$MBTU**. The cost, as developed, is the bare minimum unless an alternative synthesis route is found. Chemical Marketing Reporter indicates current prices at $1.60 \$ / 1 \mathrm{~b}$ or more than 200 \$/MBTU. Clearly, hydrazine is a very expensive material.

\subsubsection{Acetylene}

Acetylene can be produced by reacting calcium carbide and water or through the electric arc processing of coal at high temperatures. The literature (ref. 6-15, 6-16) Indicates that acetylene can be produced for about 14 \$MBTU. A summary of the total cost and 1 ts components is presented in Table 6-61.

Table 6-61

Total Cost of Acetylene

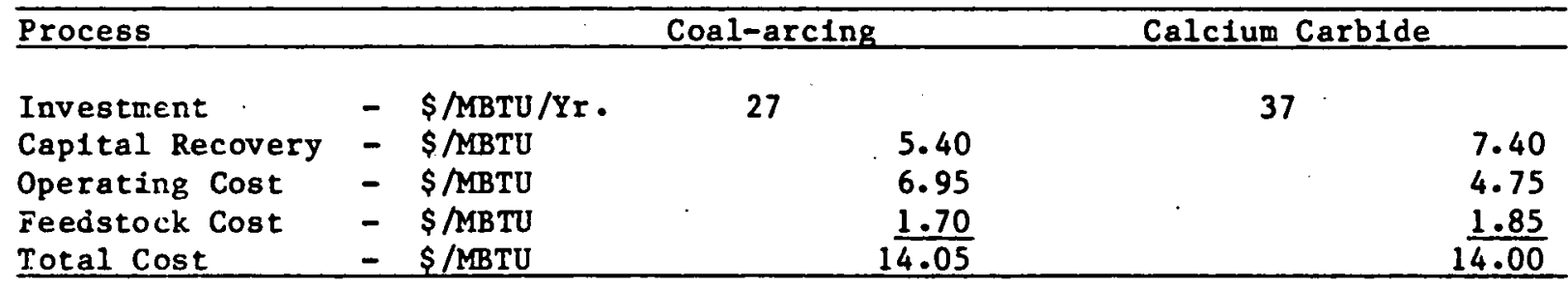

As a fuel.acetylene has a high heating value $(20,730 \mathrm{BTO} / 1 \mathrm{~b})$

but because it is unstable, plpelining or bulk transportation is highly improbaile. The transportation cost for acetylene is covered in section 7.11 .1 .

* January 30,$1978 ; 1977$ \$ are assumed.

$\star \star 1980 \$$. 


\subsubsection{Methylamine}

Methylamines are produced by the reaction of ammonia and methanol over dehydrating catalysts at temperatures ranging from $300^{\circ} \mathrm{C} t 0^{\circ} 500^{\circ} \mathrm{C}$. The reaction product is a mixture of amines, unconverted reactant and water. Water is condensed out and the amines are separated by a serfes of distillations. The reaction chemistry 18 illustrated below:

$$
\mathrm{NH}_{3}+\mathrm{CH}_{3} \mathrm{OH} \longrightarrow \mathrm{CH}_{3} \mathrm{NH}_{2}+\mathrm{H}_{2} \mathrm{O}
$$

Current selling prices* are about $0.33 \$ / 1 \mathrm{~b}$ or about 25 \$MBTU (1977\$). Using the costs of Ammonia (255 $\$ / T$ ) and methanol (232 $\$ / T)$ developed In this study plus the reaction stolchlometry above, the lower limit of the cost for methylamine will be about 14 \$/MBTU (1980\$).

\section{$6.12 .5 \quad$ Low BTU Gas}

W1th curtallment of natural gas supplies or the exclusion of direct coal utilization, an alternate energy supply might be low BTU gas (LBG). LBG may find application in utility power generation, as an industrial fuel, or perhaps as a synthesis gas for chemical feedstock.

The source of LBG studied here is coal. Coal gasification technologies described for producing SNG (section 6.11) can be applied in the production of LBG with the substitution of alr for oxygen in the gasifier. The product gases contain carbon oxides, hydrogen and nitrogen. The expected product heating value is about $180 \mathrm{BTU} / \mathrm{SCF}$. However, after. gasification and purification, the shift and methanation steps required for SNG are not used in making LBG, thus cost savings are realized. Using the data in reference 6-6, the cost for LBG is estimated to be 4.25 \$/MBTU. Additional charges for developing a gas distribution system may add considerably to this cost. A summary of the total cost is shown in Table 6-62 for a $1350 \mathrm{MSCF} / \mathrm{D}$ plant. This is equivalent to a $250 \mathrm{MSCF} / \mathrm{D}$ natural gas plant, since the low BTU gas has a lower heating value of about $180 \mathrm{BTU} / \mathrm{SCF}$. The coal feedstock is assumed to cost $21 \$ /$ Ton.

Table 6-62

Cost of Low BTU Gas

\begin{tabular}{llrr}
\hline & & \multicolumn{1}{c}{ Coal } \\
\hline Investment & - \$MBTU/Yr & $8.4-11$ & \\
Cap1tal Recovery - \$MBTU & & $1.7-2.20$ \\
Operating Cost & - \$MBTU & & $0.7-0.80$ \\
Feedstock Cost & - \$MBTU & & 1.25 \\
Total Cost & - S/MBTU & $3.65-\frac{1.25}{4.25}$ \\
\hline
\end{tabular}

* As reported In the March 13, 1978 18sue of Chem1cal Marketing Reporter. 


\subsubsection{Electricity .}

- Electricity may find application in non-highway transportation

In two modes: motor drives in pipeline operation and rallroad electrification. In addition, the cost of electricity has a significant impact on the operating costs for most alternate fuel production schemes. Various routes for producing electricity have been reviewed (the information presented has been abstracted from reference $6-6$ ). These are:

- Steam - electric cycle

+ low sulfur coal

+ high sulfur coal

- Nuclear

+ light water reactor

- Solar

Electricity costs range from 2 /KWH for low sulfur coal to almost $11 \mathrm{t} / \mathrm{KWH}$ for solar. A cost of $3 \mathrm{k} / \mathrm{KWH}$ is chosen for use in this study. This cost is equivalent to that for electricity from high sulfur coal. A summary of electricity cost and cost components is shown in Table 6-63.

TABLE $6-63$

Electricity Costs

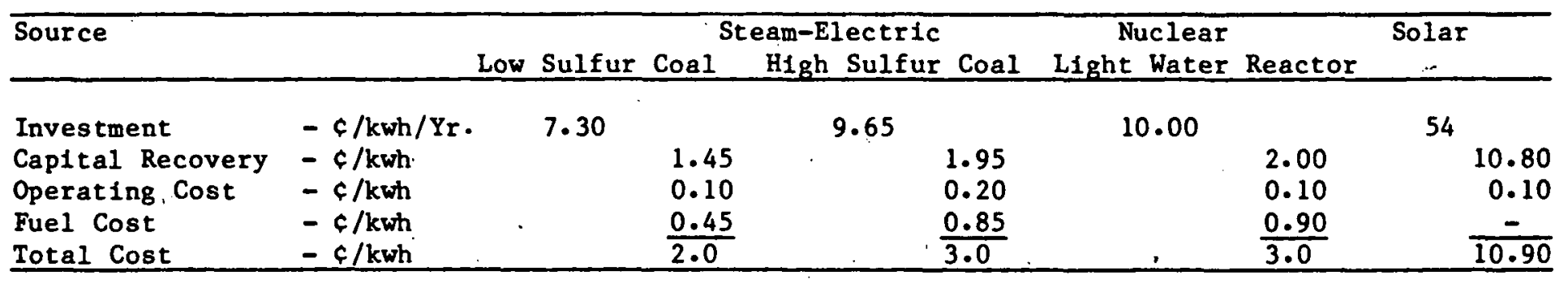




\subsection{The Cost of Fuels: Variation With Time}

All of the cost estimates have been shown in terms of 1980 constant dollars; even so, it is necessary to consider whether the relative cost estimates (1.e., the ranking of estimated fuel costs) will remain valid over the period 1980 to 2000 . Th1s is considered to be a good baseline assumption, but it is not the only possibility. The technologies are at different stages of development and there can be variation in cost due to differences in estimating techniques, etc.

Experfence with large commercial ventures lnvolving complex technology indicates a pattern of cost-estimating and actual cost behavior that may be divided into two parts with "first commerialization" as the dividing line:

(1) before first commercialization: significant cost escalation between "first concept" and pilot plant demonstration, and later between large pilot plant and first commercial plant. The range of the cost estimates is rather wide at first with the width decreasing as the time of first commercialization approaches.

(2) after first commercialization: the cost of additional plants usually declines because experience permits many improvements to be made on an incremental basis; this experience is of ten termed the "learning curve".

This variation of capital cost with time for a new technology is illustrated in the following figure.

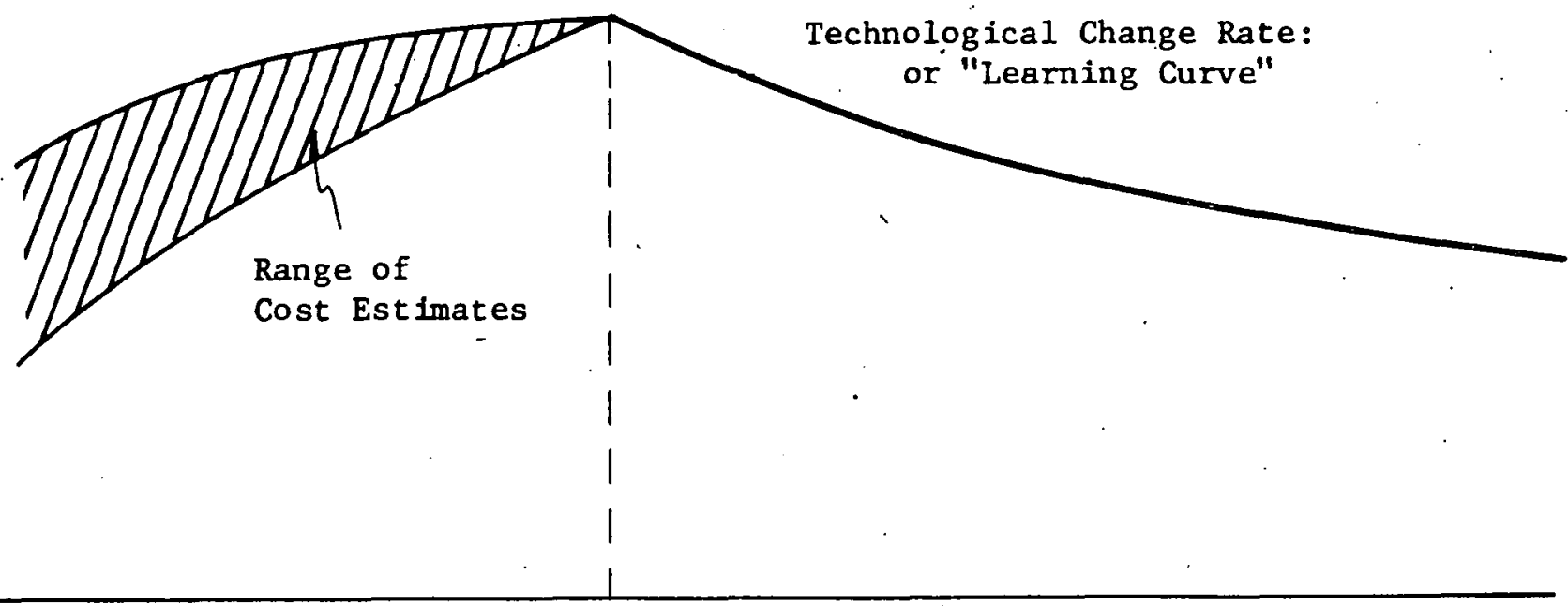

First

Commercialization 
SRI (6-21) has also quantified the effects of technological changes on capital costs (calling this "technological change on capital"): For all of the processes examined, the rate of decline in cost was similar, $1 . e$. , the cost at the "Initial level" approached the "technological change limit" at about the same rate. If this finding is applicable to the alternate fuels in this study, then their relative cost rankings would not change significantly. Our baseline assumption is that this will be the case. However, a definitional and conceptual issue arises: what exactly is meant by "technological limit"? In a different form the question concerns the distinction between (a) technological improvements to identified technology, particularly those accomplished by engineering changes and "know how", and (b) advantages that may be achlevable by radically different technology. For example, chemical and biochemical processes, such as are conceivable for biomass utilization, may be susceptible to radical rather than incremental improvement. An important research corollary follows:

- learning curve improvements are unlikely to change the economically competitive position of the high cost fuels; radically improved technology is needed for this purpose.

Constant dollars are an excellent device for comparing what has already occurred. In part, this is because the past has only one "scenario", 1.e., what has actually occurred. Th1s means that the different lead times, the different stages of development, and the different institutional problems associated with past technological developments not only are all known but the vector of their interactions is also known. This is not so when the future is addressed, except for a hypothetical baseline or reference case. Judgmental problems arise if technologies to be compared are not yet commercial and are at different, but not precisely known, positions (in time) on the upward part of the hypothesized cost curve. It is also possible for two competing technologies to "shift" in relative position after commerclalization. This concept can best be illustrated by a hypothetical comparison between two new technologies "A" and "B". Figure 6-13 shows a series of frames, with each frame representing a different "real" time in. the future. This is a dynamic simulation using a static format. The situation represented by each could be as follows:

Frame 1 Both $A$ and $B$ are new technologies that are under development.

Frame 2 A has moved into large pilot plant stage while B is still at the lab pilot plant stage because some problems, such as with metallurgy, have occured.

Frame 3 A has checked out in the large pllot plant and moves to first commercial plant. Lab pilot plant difficulties with B are overcome and it moves to large scale pilot plant.

Frame 4 A starts down the learning curve when the second commercial plant is built. B checks out in the large scale pilot plant and first commercial plant is bullt. 
Frame 5 First commerclal plant for B works well and shows better reliability. than $A$ (or some other advantage not established until both full scale plants are operating). Hence the 2nd commercial plant for $B$ is bullt and $B$ starts down the learning curve. Another A plant is not built because B looks $11 \mathrm{ke}$ the better technology. Therefore A does not move down the learning curve any more.

Frame 6 A is an -obsolete technology that can' $t$ benefit from the learning curve, even though some improvements are possible, because no one 1s bullding A plants. B, however, continues down the learning curve.

One of the critical assumptions in the above scenarlo comes between Frame 2 and 3. If $A$ is working as the large pllot plant, why would anyone continue to work on $B$, especially if $A$ has moved to the commercial stage and $B$ is still in the lab pilot plant stage? It has been assumed that some precelved institutional factor is able to keep $B$ active past Frame 3 .

Another, but quite different, difficulty arises if the technological comparison involves differences in capital intensity and/or project implementation time under conditions of general inflation. Constant dollars pertain to the GNP deflator, which is not necessarily an adequate indicator of how different sectors of the economy or different goods will experience cost inflation (1.e., "escalation"). In principle, labor costs, raw materials cost, and capltal equipment costs will not experience the same degrees or patterns of cost inflation. Pragmatically, however, much of this difficulty disappears when comparisons are made within a given technological and raw materlals subset, e.g., coal conversion. Many of the alternate fuels are derivable from coal, hence the economic rank-ordering of these fuels is mich less susceptible to differential cost escalation than is potentially the case for such fuels versus those derived from a quite different resource such as blomass. However, there are factors that can cause a change in the technology to be used to produce the fuels; such as plant location restriction, difference in reactions with different types of coals, etc.

Still another kind of difficulty exists in relation to assumptions made about the pattern of future oil price changes in an economy that for many years is expected to be substantially dependent on o1l. For example, the response to steady price changes may differ from what might be triggered by sudden sharp changes. Assuming technological readiness at the time of a sharp price increase, it is belleved that quickly implemented technologies would be favored over those with long lead times, thereby permitting the learning curve of the quickly implemented technologies to begin sooner than those with long lead times. Put differently, Figure6-12 is a static representation of learning curve behavior which does not necessarily capture the dynamics of technological choice.

Two further sets of observations may be made with respect to shale-derived and coal-derived fuels: 
(1) It is expected that shale derlved fuels will be lower in cost than coal derived fuels. However, the development of shale fuels will not be governed only by economics. The environmental and water limltations of a lirge (multi-milition barrel-per-day) shale industry are expected to be controlling.* The impact of such an industry will have to be istudied and the economics of manufacture adjusted for any limfing factors which may be determined. In fact, the impact of an Industry for any of these fuels supplying the non-highway transportation sector will require study and the impacts quantifled. It is also 1mportant to realize that none of these fuels w111 be developed strictly for non-highway applications. Highway and industrial demands will play an 1mportant role as to which alternate fuels are developed. It is possible that the timing of the development will be controlled, or strongly influenced, by factors or purposes outside the NHT sector, and also that the timing may vary from purpose to purpose.

(2) Operating experience plus ongoing research of potential process - improvements can translate itself into lower investment requirements for a particular plant. Investments may even be reduced by $25-40 \%$ (on a constant $\$$ basis).* Coal liquids plants of the direct I1quefaction process group have shown investment levels of approximately \$9-18 per MBTU per year. For discussion a level of $\$ 15 / \mathrm{MBTU} / \mathrm{Yr}$ is assumed; if this was reduced by 25 to $40 \%$, the cost of coal liquids could be reduced by about 13 to $20 \%$. These figures have been determined via a simplistic sensitivity calculation. In reality the actual cost and potential cost reductions will only be determined when commerclal plants are built and operating experience is obtalned.

* See reference $6-22$ for more information on this subject. ** Reference 6-23. 
SIMULATION OF WAY TWO NEW TECHNOLOGIES

MAY CHANGE RELATIVE POSITION WITH TIME
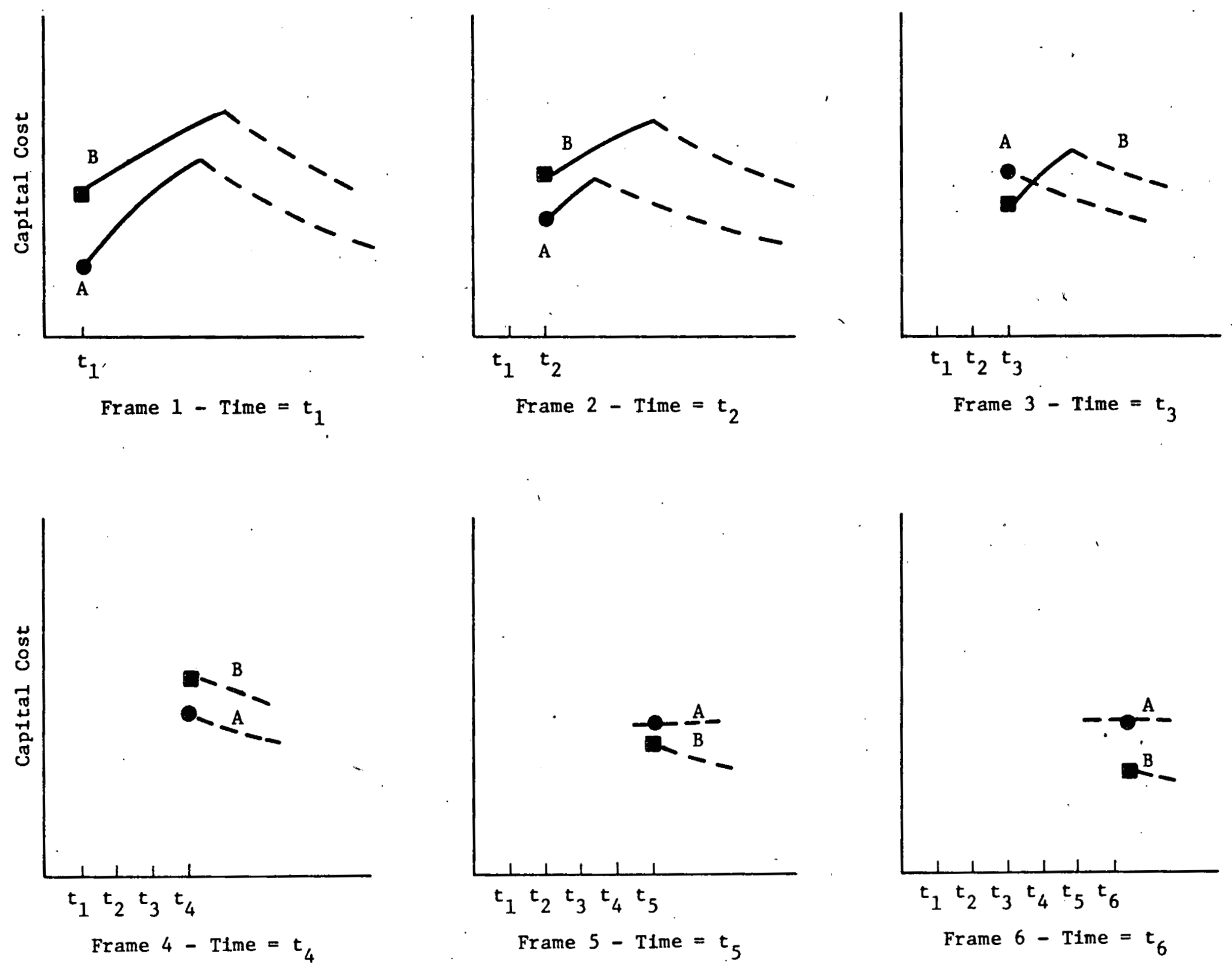


\section{Cost of Upgrading Cosl Liquids}

Coal liquids are unsultable for today's diesels and turbines because they contain larger amounts of impurities (especially sulfur and nitrogen) and contain more aromatics (therefore, less hydrogen) than current fuels. To find application in current engines the carbon to hydrogen ratio of the coal liquids will have to be reduced, $1 . e .$, hydrogen will have to be added, or the engines will require modifications, or perhaps both.

Proper evaluation of which alternative to choose requires the examination of relative costs. The intent here is to examine the cost* of

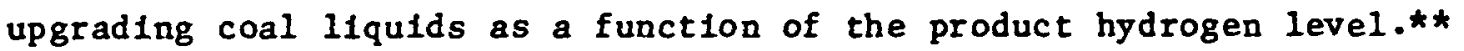

\subsubsection{Upgrading Cost and We1ght Percent Bydrogen}

In the mechanism used for approximating upgrading costs, this cost is assumed to be directly proportional to hydrogen consumption. The cost is composed of the following:

a) The cost of hydroprocessing equipment (simulated by a conventional petroleum vacuum gas oll hydrocracker)

b) The cost of producing the hydrogen

c) The cost for handling crude and products plus primary distillation (as approximated by a conventional petroleum atmospheric pipestill of 150,000-barrels-per-day capacity)

A summary of these cost components follows:

Table 6-64

COAL LIQUIDS UPGRADING COST COMPONENTS (1980 \$)

Hydroprocessing

- Equipment

- Hydrogen

Cost of handling crude, product and primary

distillation
$0.28 \$$ per pound of hydrogen

$0.50 \$$ per pound

* Upgrading cost is defined as the sum of the cost for receiving, and handling crude and products plus primary distillation and hydroprocessing.

** Assumes that hydrogen content is a measure of fuel quality. 
Hydrogenative upgrading is used not only to increase the hydrogen content of coal liquids, but also to reduce sulfur, oxygen, and nttrogen levels which are undesirable in synthetfc crude o1ls. Hydrogen requirements are a function of coal liquids composition, which can vary significantly with both coal source and liquefaction process employed. To illustrate, the costs of upgrading two coal liquids of widely different compositions are shown in Figures $6-14$ and $6-15 . *$ The coal liquid composition 18 shown on each figure. The figures 1llustrate that upgrading costs increase with increasing levels of feed sulfur, nitrogen, and oxygen, decrease with higher feed hydrogen, and rise with increasing hydrogen content of the upgraded product. The $10 \mathrm{wt} . \%$ case will serve for purposes of discussion. The upgradiag cost for current turbo engines, requiring 13.5 wt.\% hydrogen, 18 about 1.80 \$/MBTU. If this requirement is reduced to $11.5 \mathrm{wt} . \%$ hydrogen, the corregponding upgrading cost is 0.95 \$MBTU. Further reduction to $10 \mathrm{wt} . \%$ lowers the upgrading cost to 0.30 \$/MBTU.

The foregoing shows that definite incentives do exist for reducing engine fuel quality requirements; however, this must be balanced against the cost of the required engine modifications.

* The Intersection of the 10 wt\% hydrogen line with the cost axis at 0.30 \$/MBTU represents the minimum cost for producing a fuel at this hydrogen level, 1.e., the cost for handling and primary distillation and impurity removal. 
FIGURE 6-14

COAL LIQUIDS UPGRADING COST VS.

PRODUCT WEIGHT PERCENT HYDROGEN

(Base Content: $7 \mathrm{Wt} \%$ )

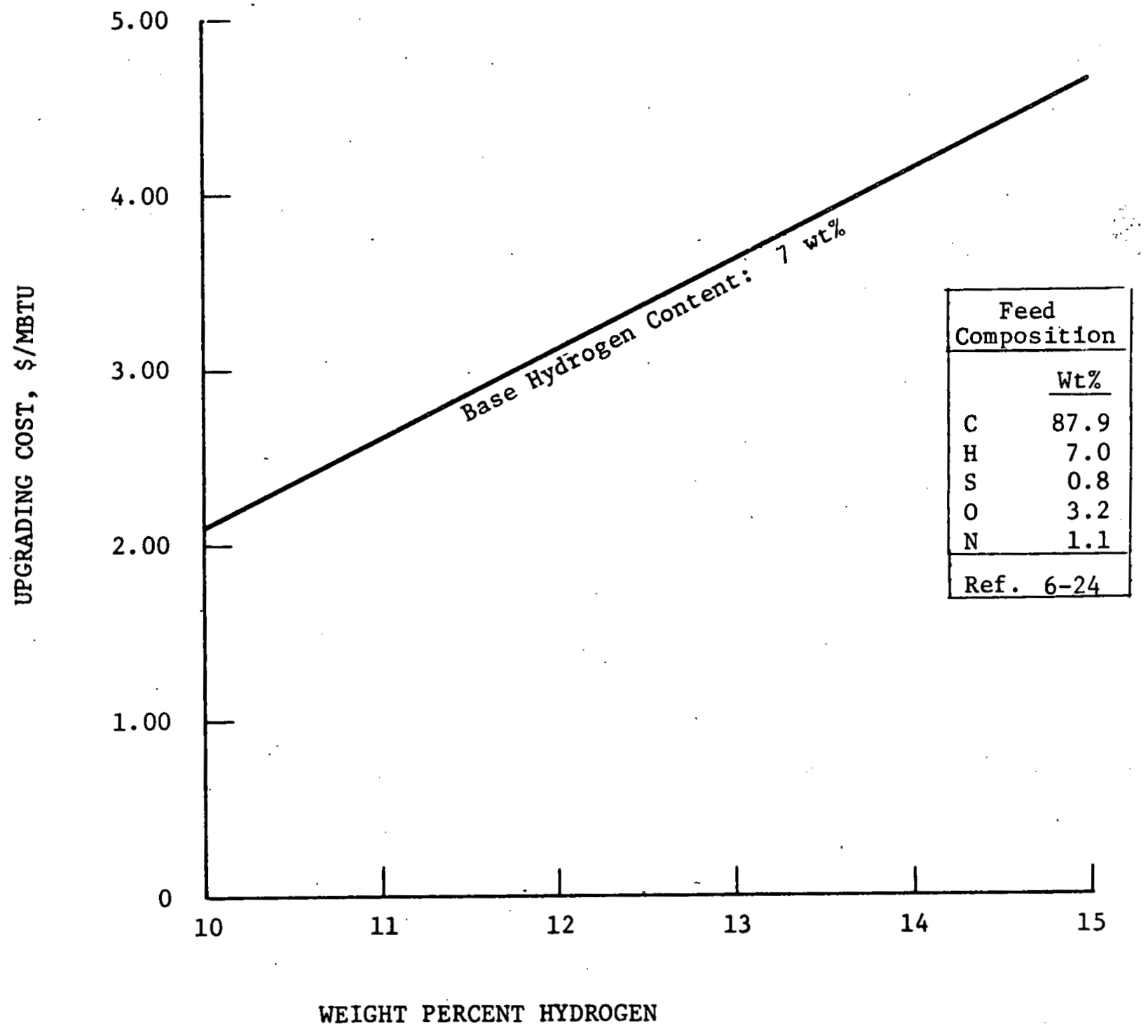




$$
\text { 6-92 }
$$

\section{FIGURE $\quad 6-15$}

COAL ĹIQUIDS UPGRADING COST VS.

PRODUCT WEIGHT PERCENT HYDROGEN

(Base Content: 10 wt\%)

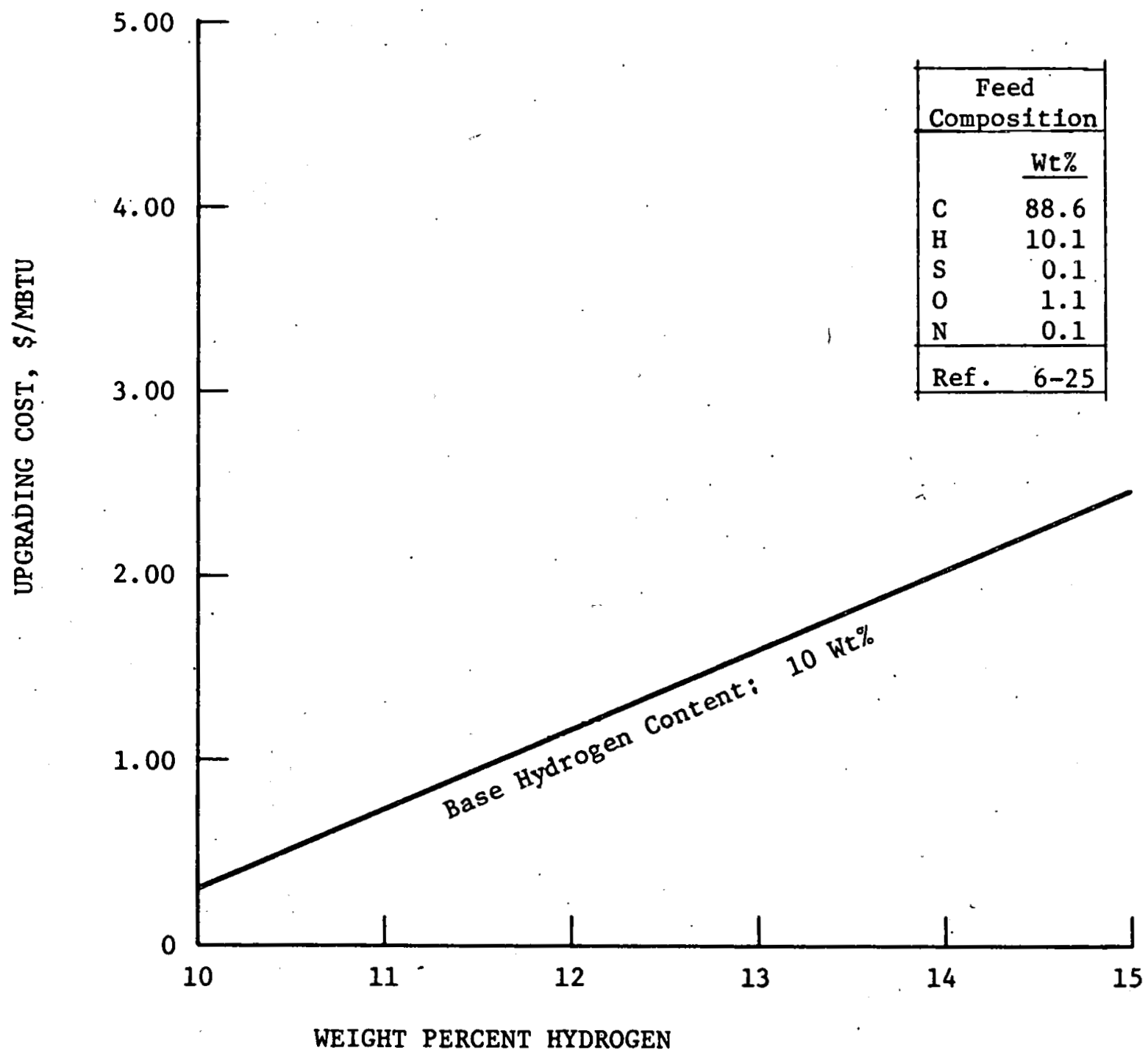




\subsection{Raw Shale 011 Upgrading Cost}

Raw shale ofl is much higher in nitrogen than typical petroleum crudes. For shale ofl to be used as a conventional transportation fuel nearly all of this nitrogen must be remived 80 as to minimize $\mathrm{NO}_{\mathrm{x}}$ emissions and avold fuel instability. In additicn, nitrogen acts as an inhibitor for conversion catalysts. Further, the refiner has the option of upgrading at the retort site to synthetic crude quality or to restrict field processing to the minimum required to make it sultable for pipelining (as produced the raw shale oil requires some pour point reduction for pipeline transportation). Weight percent nitrogen in the product provides a measure of the degree of upgrading. Stangeland and Sullivan (Ref, -26 ) have reported on hydroprocessing of shale to various product nitrogen levels. As one might expect, decreasing nitrogen level requires increasing hydrogen consumption as shown In Figure 6-16. In order to calculate the cost of upgrading to different product nitrogen levels, a system for estimating the cost has been developed. The cost of upgrading of raw shale liquids is assumed to be proportional to the hydrogen consumption. There are two components to this upgrading cost: the cost of hydrogen and the necessary hydrotreating equipment (as simulated by a conventional vacuum gas oil hydrocracking unit). The cost components follow in Table 6-66.

Table 6-65

SHALE LIQUID UPGRADING COST COMPONENTS (1980 \$)

\begin{tabular}{ll}
\hline Equipment & 0.28 ser pound of hydrogen \\
Hydrogen & 0.50 \$ per pound
\end{tabular}

Combining the information of Figure 6-16 and Table 6-66 a plot of upgrading cost versus product nitrogen level can be developed and is shown in Figure 6.17. The relationshlp between cost and nitrogen level follows a relatively smooth curve until about the 0.5 wt\% level. Beyond this point the cost takes a very sharp upturn, so that upgrading below this level is incrementally more expensive than above $0.5 \mathrm{wt} \%$.

Again, this is an approximate technique and true upgrading costs will be determined only when commercial plants are designed, built and operating experience obtained. 
FIGURE - 6-16

HYDROGEN CONSUMPTION VERSUS

PRODUCT NITROGEN

HYDROFINING OF WHOLE SHALE OIL WITH ICR 106

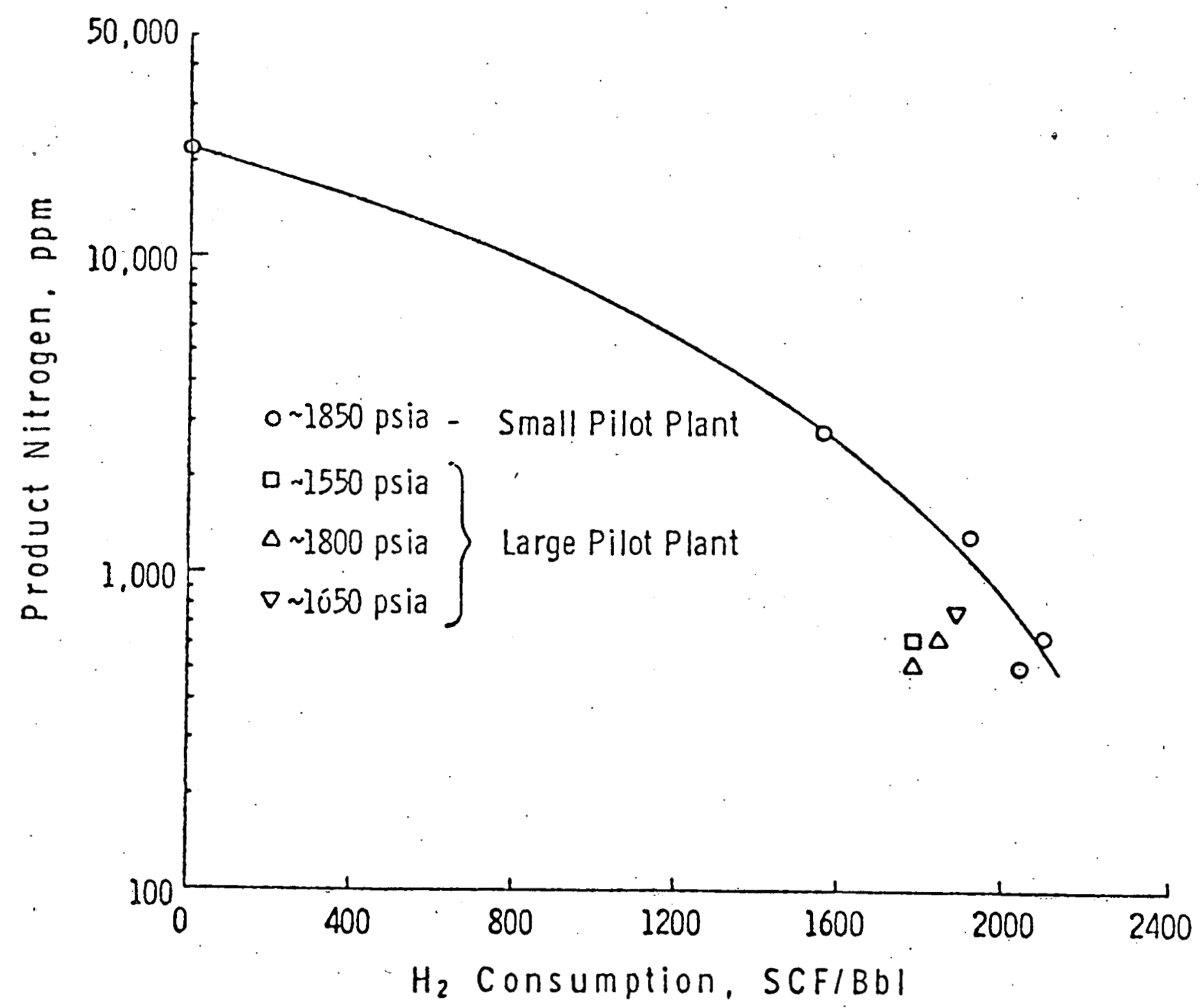

Reference $6-26$ 


$$
\text { 6-95 }
$$

FIGURE 6-17

SHALE UPGRADING COST VS. PRODUCT

NITROGEN LEVEL

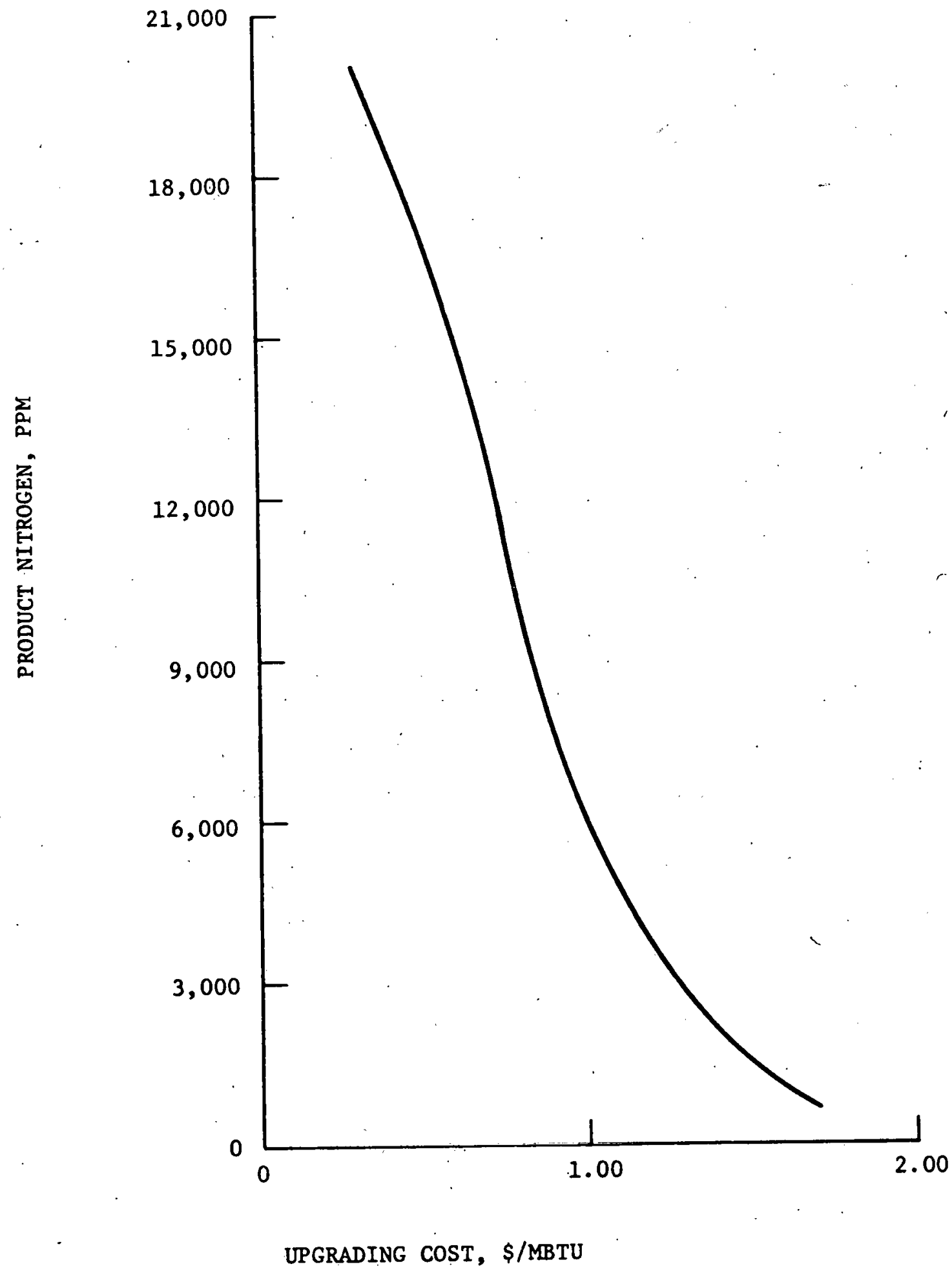




\subsection{Possible Impact of Process Improvement on Cost of Hydrogen}

With the cost to manufacture hydrogen from coal being falrly expensive, and the cost to produce hydrogen via electrolysis even higher, the question could be asked--does new electrolytic technology have the potential to reduce the cost of hydrogen substantlally. As was pointed cut In an earlier section a developmental process called Solid Polymer Electrolyte (SPE) electrolysis has the potential to reduce the cost from about \$20/MBTU w1th ROH electrolys1s to \$13/MBTU with the SPE process. If the SPE process is proven viable, then the electricity cost required for hydrogen via this route to be competitive with coal derived hydrogen, would have to be $1.6 \mathrm{k} / \mathrm{kwh}$ or approximately $50 \%$ of the value used in this study. This figure $(1.6 \mathrm{k} / \mathrm{kwh})$ represents the rough equivalent to the sum of fuel plus operating costs in generating electriclty without provigion for capital recovery. Electricity at this cost level is not foreseen, at this time, to be avallable in the 1980-2000 time frame. Therefore, Improvements in coal based technology would be needed to reduce the cost of hydrogen.

\section{1.it Broadcut Petroleum Jet Fue1}

One area that is receiving attention as a means for increasing the availability of jet fuel from petroleum is the use of a broadcut fuel increasing the final boiling point and reducing the initial cut point. A broadcut fuel does not increase petroleum supply, it increases jet fuel supply at the expense of something else - such as diesel fuel, chemical feedstocks, or home heating oil. Thus as petroleum resources diminish, it will be necessary to establish end use priorities (by market or nonmarket mechanisms). The purpose of this section is to give an idea of what changes in fuel properties and yields are possible if the fuel specifications are relaxed. While the examples apply to petroleum based fuels, similar changes would apply to a coal derived liquid or a shale oil based jet fuel.

Current Jet $A$ and two possible alternative specifications (derived from the minutes of the "Jet Afrcraft Hydrocarbon Fuels Technology Workshop") are compared with representative virgin crude fractions from South Loulsiana and Prudhoe Bay in Tables 6-67 - 6-69.

The volume and quality of the jet fuel is directly related to the specific crude being processed. This examination is made without regard for competing non-aviation demands for the middle of the crude barrel. The alm is to 1llustrate theoretical yield and processing differences if jet fuel specifications. are relaxed. Demands for diesel fuel, chemical feedstocks, and heating oil affect fuel avallability. Thus, even though yleld increases may be significant, the additional yleld may not be readily avallable to the avlation Industry. 


\subsection{7 .1 Y1elds and Qual1ties}

The yields and qualities shown in Tables 6-66-6-68 represent straight run plpestill product without consideration of downstream processing. For example hydrofining or aromatics extraction, which would alter chemical propert1es, such as sulfur, aromat1cs, etc. 1s not considered. These processes are assumed to have little effect on the volume of the kerosene or distillate cut. One important factor which 18 taken into account is that a refinery pipest111 will not produce a perfectly fractionated cut. A normal sidestream is lower in fractionation quality when compared with a True Bolling Point distillation and so an illustration of the impact that improved fractionation has on the pield of specification fuel is also shown in Table 6-66 which compares a typical sidestream cut with $15 / 5$ distillation.*

\subsubsection{Effect of Improved Distillation}

Improving fraction is one way to improve yleld of a given product. Better fractionation can be achieved, for example, by increasing the reflux ratio, adding additional tower trays or increasing the stripping steam rate. In existing towers some of these methods of increasing yield are clearly impracticable. Even if technically possible, the suggested changes all represent increased energy consumption and thus increased cost, and have not been applied in actual practice due to economic limitations. The purpose in describing the effect of improved distillation is to illustrate the changes possible if the economics would favor this change.

The reference case in this study is shown in Table 6-66. The two crudes are fractionated into boiling ranges that meet most current Jet $A$ specifications while maximizing yield. The final boiling point specification is slightly exceeded for the normal cut of South Louisiana. In addition, the Prudhoe Bay fraction would require treating to reduce aromatics content. For South Louisiana, the yield increases 34\% (23.5 vol \% to 31.5 vol \%) and the final boiling point specification is also met. The Prudhoe Bay yleld increases by $41 \%$ ( 17.1 vol \% to 24.1 vol \%), but still requires treating for aromatics reduction. A summary of key qualities follows.

\begin{tabular}{|c|c|c|c|c|c|c|c|}
\hline & Current & & & & & & \\
\hline & Spec. & So & 1 Lou 1818 & & & 1dhoe Bay & \\
\hline $\begin{array}{l}\text { Nominal Bolling } \\
\text { Range, OF }\end{array}$ & & $\begin{array}{l}320 / 510 \\
\text { (Norma1) }\end{array}$ & $\begin{array}{l}300 / 550 \\
15 / 5 *\end{array}$ & $\begin{array}{l}\text { Percent } \\
\text { Increase }\end{array}$ & $\begin{array}{l}330 / 508 \\
\text { (Norma 1) }\end{array}$ & $\begin{array}{c}300 / 550 \\
15 / 5 *\end{array}$ & $\begin{array}{l}\text { Percent } \\
\text { Increase }\end{array}$ \\
\hline $\begin{array}{l}\text { Yeld, LV\% } \\
\text { on Crude }\end{array}$ & - & 23.5 & 31.5 & 34 & 17.1 & 24.1 & 41 \\
\hline $\begin{array}{l}\text { Aromatics, } \\
\text { vol\% (max) }\end{array}$ & 20 & 15.1 & 15.3 & & $23.9 * \star$ & $25.1^{\star \star}$ & \\
\hline $\begin{array}{l}\text { Final Bolling } \\
\text { Polnt oF (max) }\end{array}$ & 550 & $553 * *$ & 550 & & 550 & 550 & \\
\hline
\end{tabular}

$\star \star$ Does not meet specification

*This is a laboratory distillation technique which provides fractionation equivalent to a column with 15 theoretical trays and a 5:1 reflux ratio. 
Although the yield credits for improving fractionation are large, individual case evaluation of the cost for improving fractionation is required. The methods for better fractionation outlined above each carry assoclated costs. In addition, physical and economic constraints may Inhtbit their implementation. Existing units may not have capacity enough for increasing the number of trays and the additional expense for steam generation or more reflux may heavily debit the yleld improvement. Grass roots design does present more opportunities for tightrr fractionation, but the economic factors of additional investment and operating cost may outwelgh the advantage of added product volume. Generalizations concerning fractionation improvement would be misleading. Suffice it to say that there is theoretical scope for higher yields of specification product, but practical limitations may prevent these ylelds from being realized.

\subsubsection{Broadcut Implications on Yleld and Quality}

The first broad specification examined is shown in Table 6-67. Comparison with current specifications shows that the aromatics content will be higher, the boilling range wider, the gravity specification has increased and the viscosity is now measured at $100^{\circ} \mathrm{F}$ instead of $-30^{\circ} \mathrm{F}$. These changes result in increased yield. The normal South Louisiana recovery has increased by $50 \%$ over the normal cut for current specifications. The ylelds for Prudhoe Bay have also increased - the normal cut shows a $58 \%$ Increase over the reference cut. However, as the table indicates, the relaxation of the aromatics content spec. ellminates the need for further treatment because the Prudhoe Bay quality now falls below the maximum. A key quality summary follows:

\begin{tabular}{|c|c|c|c|c|c|c|c|}
\hline \multirow[b]{2}{*}{$\begin{array}{l}\text { Nom Inal Bolling } \\
\text { Range, }{ }^{\circ} \mathrm{F}\end{array}$} & \multirow[t]{2}{*}{$\begin{array}{l}\text { Broad } \\
\text { Spec. }\end{array}$} & \multicolumn{3}{|c|}{ South Louisiana } & \multicolumn{3}{|c|}{ Prudhoe Bay } \\
\hline & & $290 / 570$ & $320 / 510$ & $\begin{array}{l}\text { Percent } \\
\text { Increase }\end{array}$ & $290 / 570$ & $330 / 508$ & $\begin{array}{l}\text { Percent } \\
\text { Increase }\end{array}$ \\
\hline $\begin{array}{l}\text { Yield, LV\% } \\
\text { on Crude }\end{array}$ & - & 35.2 & 23.5 & 50. & 27.1 & 17.1 & 58 \\
\hline $\begin{array}{l}\text { Aromatics, } \\
\text { vol\% (max) } \\
\text { Final Bo1ling } \\
\text { Point of (max) }\end{array}$ & 600 & 603 & $\begin{array}{r}15 \\
553 \\
\end{array}$ & & $\begin{array}{r}25 \\
606 \\
\end{array}$ & $\begin{array}{r}24 \\
550 \\
\end{array}$ & $\cdot$ \\
\hline
\end{tabular}




\subsection{Additional Broadcut Spectfication}

A further relaxation in specification will increase the theoretical yield even more, as shown in Jiable 6-68. Here the allowable aromatics content is 40 vol\%, the final bollir:8 point $650^{\circ} \mathrm{F}$, minimum flash $90^{\circ} \mathrm{F}$, maximum flash $200^{\circ} \mathrm{F}$, and the maximum viscosity at $100^{\circ} \mathrm{F}$ is $4 \mathrm{CS}$. The South Loulsiana (normal fractionation) yield 1843.1 vol\% - and $83 \%$ increase over the reference cut. The Prudhoe Bay yield 1833.4 vol\% (normal) an Increase of $95 \%$ over the reference normal cut. Unlike the reference cut, these Prudhoe Bay fractions do not require treating to meet the aromatics content specification. The following table summarizes important qualities.

\begin{tabular}{|c|c|c|c|c|c|c|c|}
\hline \multirow[b]{2}{*}{$\begin{array}{l}\text { Nominal Botling } \\
\text { Range, }{ }^{\circ} F\end{array}$} & \multirow[t]{2}{*}{$\begin{array}{l}\text { Broad } \\
\text { Spec. }\end{array}$} & \multicolumn{3}{|c|}{ South Lou1slana } & \multicolumn{3}{|c|}{ Prudhoe Bay } \\
\hline & & $280 / 620$ & $320 / 510$ & $\begin{array}{l}\text { Percent } \\
\text { Increase }\end{array}$ & $280 / 620$ & $330 / 508$ & $\begin{array}{l}\text { Percent } \\
\text { Increase }\end{array}$ \\
\hline $\begin{array}{l}\text { Yield, LV\% } \\
\text { on Crude }\end{array}$ & - & 43.1 & 23.5 & 83 & 33.4 & 17.1 & 95 \\
\hline $\begin{array}{l}\text { Aromatics, } \\
\text { vol\% (max) }\end{array}$ & 40 & 15 & 15 & & 26 & 24 & · \\
\hline $\begin{array}{l}\text { Final Boiling } \\
\text { Point of (max) }\end{array}$ & 650 & 648 & 553 & & 650 & 550 & \\
\hline
\end{tabular}

In sumiary, relaxation of jet fuel specifications will lead to higher yields of this product. Competing demands for the middle of the crude barrel will have to be evaluated in order to determine the total impact of maximizing jet fuel yleld. In addition, broader specifications may eliminate the need for some downstream processing, thereby reducing cost.

In addition, the production of broad cut fuels can impact directly on both refinery and end-use energy consumption. Anderson (Ref. 6-27) in studying highway transportation has reported that process energy savings of 1 to 3 percentage points can be attained when producing a broad cut fuel roughly equivalent to equal parts of gasoline and diesel fuel. Also, Anderson indicates increased engine efficiency for the broadcut fuel. Thus, there is scope for increasing the composite production/use fuel system in the broadcut option. However, he points out that these data are very preliminary and require further atudy for confirmation.

Even though yield increases may be significant, the additional yield may not be avallable to the aviation industry, because of competing demands for liquid fuels. 


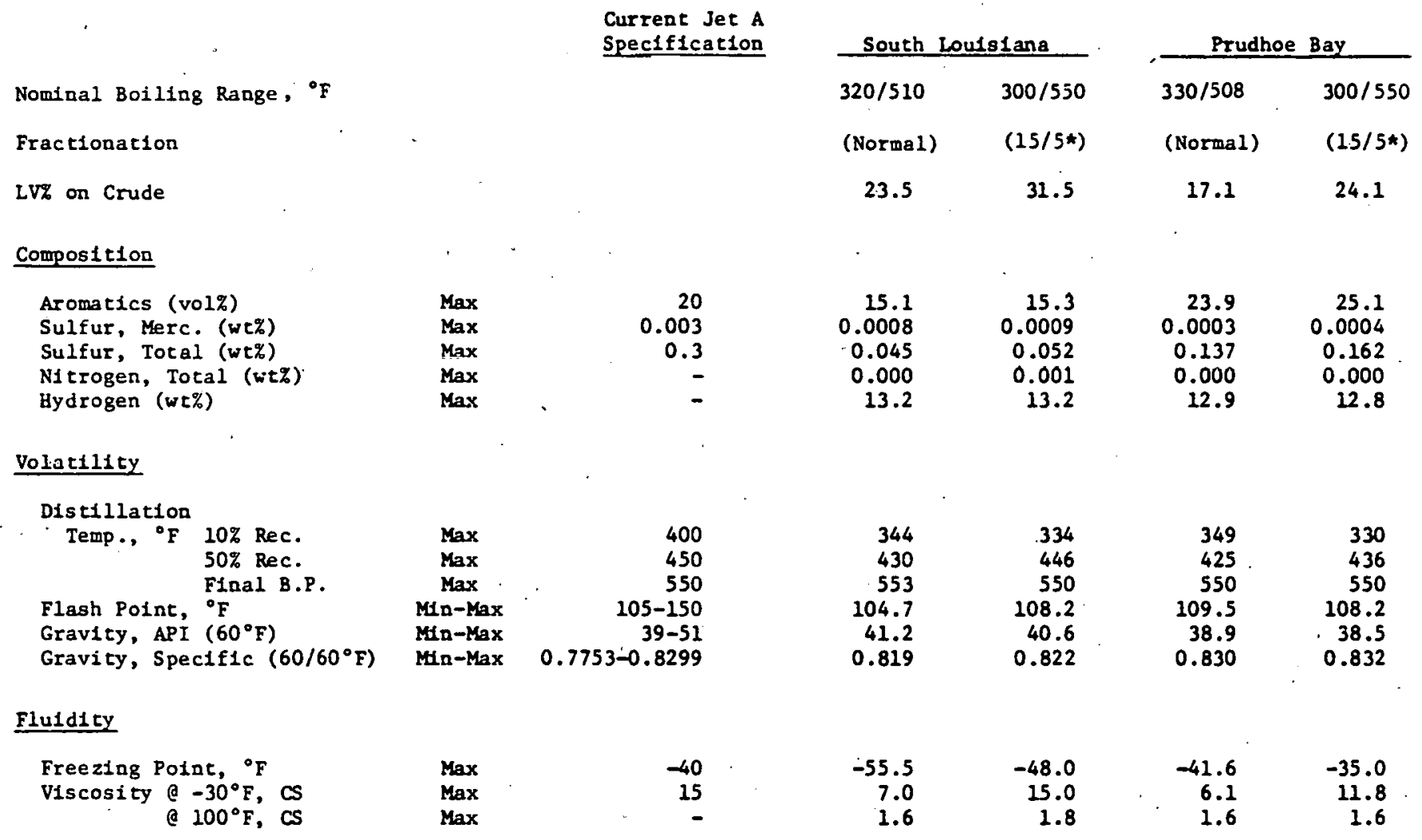

Thermal Stab1l1ty o $300 / 400^{\circ} \mathrm{F}$

$\begin{array}{llr}\text { Coker } \Delta P \text { in } \mathrm{Hg} & \operatorname{Max} & 12 \\ \text { Coker Tube Color Code } & \operatorname{Max} & 3\end{array}$

Combustion
Net Heat, Btu/1b
Min
18,400
18,500
18,500
18,500
18,500

* A laboratory distillation technique which provides fractionation equivalent to a column with 15 trays and 5:1 reflux ratio. 
TABLE $6-67$

COMPARISON OF A POSSIBLE BROAD JET FUEL SPECIFICATION WITH VIRGIN CUTS OF SOUTH LOUISIANA AND PRUDHOE BAY CRUDES

.. $\quad$\begin{tabular}{l}
$\begin{array}{l}\text { Possible Broad } \\
\text { Specification }\end{array}$ \\
\hline
\end{tabular}

Nominal Bolling Range, ${ }^{\circ} \mathrm{F}$

LVyz on Crude

Composition

Aromatics (Vo1\%)

Sulfur, Merc. (wt\%)

Sulfur, Total (wt\%)

N1 trogen, Total (wt\%)

Hydrogen (wt\%)

Volatility

$\begin{array}{lr}\operatorname{Max} & 35 \\ \operatorname{Max} & 0.003 \\ \operatorname{Max} & 0.3 \\ \operatorname{Max} & 0.005 \\ \operatorname{Min} & 13.0\end{array}$

South Loulsiana

$290 / 570$

35.2

15.0

0.0009

0.056

0.001

13.3
Prudhoe Bay

$290 / 570$

27.1

24.8 0.0004

0.195

0.002

13.0

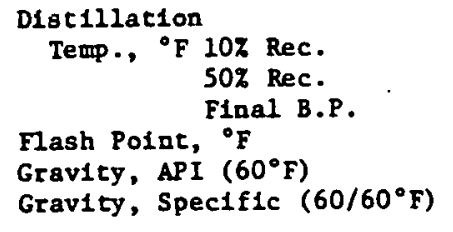

$\begin{array}{lr}\operatorname{Max} & 420 \\ \operatorname{Max} & 470 \\ \operatorname{Max} & 600 \\ \text { Min-Max } & 90-170 \\ \text { Min-Max } & 36-51 \\ \text { Min-Max } & 0.7753-0.8448\end{array}$

Flutd15y
$\operatorname{Max}$

$\operatorname{Max}$
$-20$

3

Thermal Stability e $250 / 350^{\circ} \mathrm{F}$

Coker $\triangle \mathrm{P}$ in $\mathrm{Hg}$.

Coker Tube Color code

\section{Combustion}

Net Heat, Btu/1b

Max

$\operatorname{Max}$

12

3

$\min$

18,300
18,500

18,450 
COMPARISON OF A POSSIBLE BROAD SPECIFICATION WITH VIRGIN CUTS OF SOUTH LOUIS IANA AND PRUDHOE BAY CRUDES

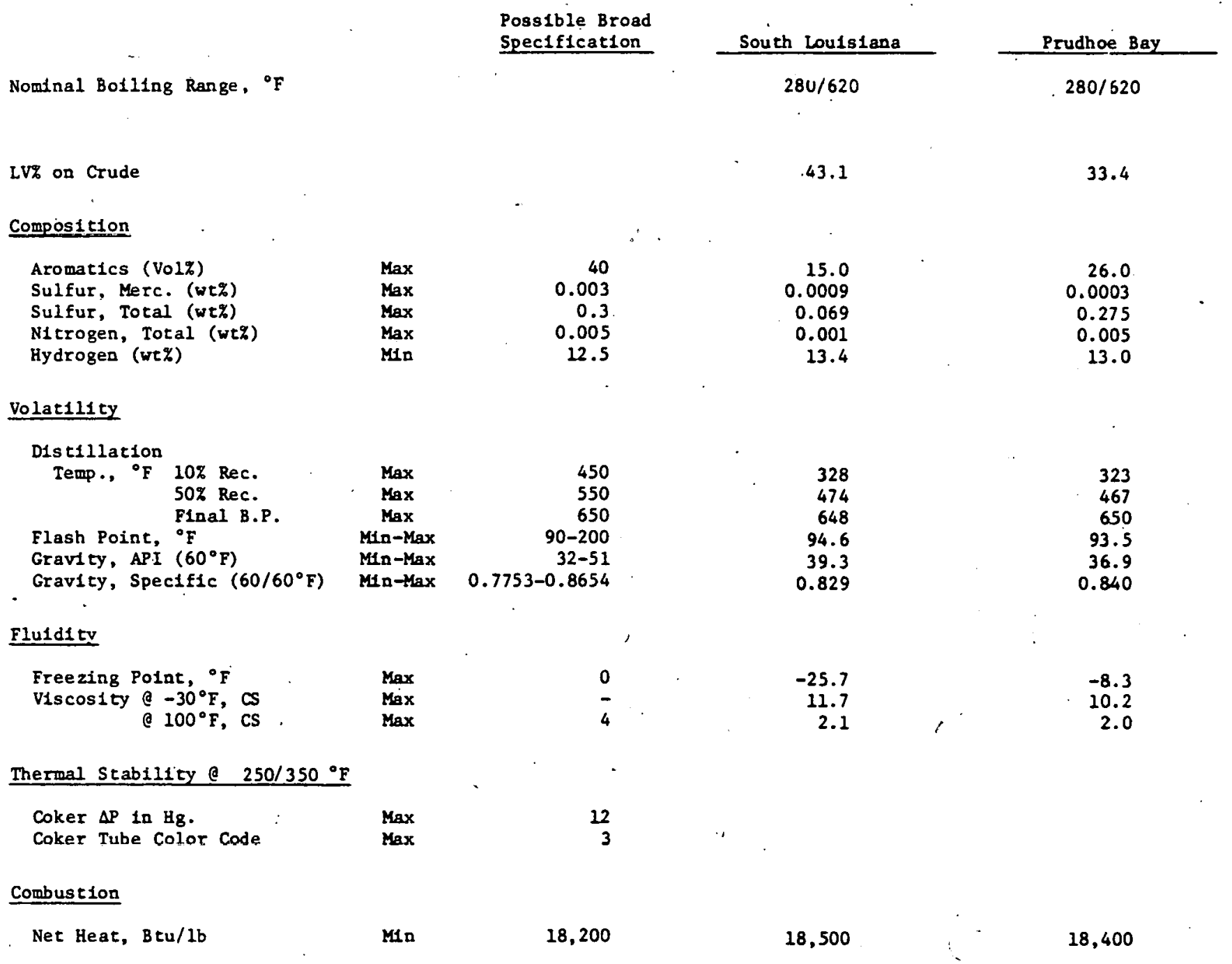




\subsection{Processing of Shale 0il and Coal Liquids in a Petroleum Refinery}

When shale oil and coal liquids are produced they could be refined in a separate facility or used as feedstocks in existing refineries. The latter case is thi: most likely situation. In this case, it is important for this study to know if the coal or shale oil liquids will end up in jet or diesel fuel or will the synthetics displace petroleum fractions from heavier products and thus only petroleum fractions will end up in these two particular products. It is also important to have an idea of how much coal or shale oil liquids can be run in existing refineries with existing conversion equipment. Two engineering planning studies have been made previously, by Exxon Research \& Engineering that addressed these questions. The conclusions from these studies are covered in the following sections.

\subsection{8 .1 Processing of Shale 011 Liquids}

An engineering planning study was made of the effect of processing shale oil in a refinery processing both shale oil and petroleum to a full product slate including jet fuel (Ref.6-28). The study which involved a number of arbitrary but well-defined assumptions, was done in the context of a grass roots refinery processing raw shale oil and petroleum in segregated operations. Shale oil processing was restricted to distillation and hydrotreating of the kerosene and gas oil fractions, whereas petroleum processing involved a full spectrum of refinery processes with a relatively high level of conversion of heavier fractions to lighter fractions to meet a high motor gasoline demand. Conversion processing options for shale oil fractions were specifically excluded due to a lack of such data available to the program. The hydrotreated shale kerosene was blended to jet fuel product and the hydrotreated shale vacuum gas oil and untreated vacuum resid were blended into fuel oil or liquid plant fuel displacing petroleum fractions which are in turn converted to lighter products. Shale oil was incrementally introduced into the refinery which was initially processing $100 \mathrm{kB} / \mathrm{CD}$ of petroleum crude while the refinery was constrained to produce the same volume of prime products.

\subsubsection{Conclusions}

The major conclusions of the study are as follows:

- Shale oil may be used to replace or supplement petroleum crude and still meet historical jet fuel demands.

- Jet fuel yield per barrel of shale oil is low. The principal mechanism for producing incremental jet fuel from shale oil is to have shale fuel oil and distillate fractions replace petroleum fractions as fuel oil flux, thereby freeing heavier petroleum fractions for use as conversion process feed. 
- The volume of shale oil that may be run is limited by the availability of fuel oil outlets and the unavailability of conversion outlets for shale oil.

- A program of developing data on conversion of shale fuel oil fractions should be pursued.

\subsection{8 .1 .2 Discussion}

It is likely that as shale oil comes into significant commercial production, it will be processed in conventional petroleum refineries along with petroleum crudes rather than in refineries designed specifically for shale oil refining. This approach will minimize the processing required to produce salable products from shale ofl as well as reduce the performance and quality risk normally associated with the introduction of new products. Shale oil production will most likely reduce foreign crude imports otherwise needed to meet increasing product demand in the U.S.

The study wo done with the aid of a refinery, linear programming, computer model. Linear programing (LP) is a mathematical technique for finding the optimum configuration of a complex system. LP is widely used throughout the petroleum industry as well as other industries. As applied to this situation LP was used to define the optimum refinery processing sequence for both petroleum and shale oil consistent with product demand, crude availability, product quality, heat and material balance constraints.

The Base Case for the study was a grass roots refinery producing $100 \mathrm{kB} / \mathrm{CD}$ of 1 iquid product $(97.5 \mathrm{kB} / \mathrm{CD}$ of prime product - 1.e. ex LPG) according to the base demand pattern of PAD II by processing a $100 \%$ petroleum crude slate (67/33 So. Louisiana/Arabian Light) in refining facilities typical of PAD II.* The product yield is shown below:

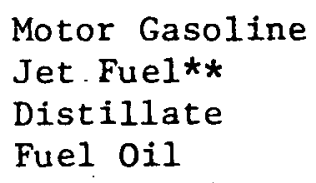

Total Prime Product
$58.0 \mathrm{kB} / \mathrm{CD}$

$5.0 \mathrm{kB} / \mathrm{CD}$

$23.5 \mathrm{kB} / \mathrm{CD}$

$11.0 \mathrm{kB} / \mathrm{CD}$

$97.5 \mathrm{kB} / \mathrm{CD}$

* Selection of petroleum crude slate and PAD II refining facilities was arbitrary. While the results may not therefore be generalized, they do illustrate how shale oil liquids may be refined in existing facilities. ** "Jet Fuel" represents a 4/1 combination of Jet A/JP-4". 
Increments of raw shale oil were brought into the crude slate, replacing Arabian Light crude, while the refinery was forced to meet the same prime product demand as the Base Case. Production c.f LPG and refinery fuel gas, both relatively low volume products, was allowed to vary. This resulted in a series of cases with an ever increasing volume of shale ofl in the crude slate. Since, in this study, shale oll fractions boiling above $500^{\circ} \mathrm{F}$ cannot be converted to lighter products, there is a practical limit as to how much shale ofl may be introduced into the crude slate. This limit was reached when virtually all of the fuel oil ard plant fuel demand had been satisfied by shale oil derived fuel oil. The limit was approximately $16 \mathrm{kB} / \mathrm{CD}$ (per $100 \mathrm{kB} / \mathrm{CD}$ of product).

The study does not assess the possibility of making diesel fuel from fractions boiling in the distillate range of shale oil, which contain substantial amounts of oxygen, nitrogen, and sulfur. It should be possible to select hydrotreating conditions for making a stable product meeting current cetane number specifications. The yield may be restricted by pour point.

\subsubsection{Processing Coal Liquids}

Economic studies have been made at Exxon Research and Engineering on the preferred route for converting coal liquids to lighter products and to evaluate coal liquids as a refinery feedstock in comparison to Arabian Light crude. The selection of a particular crude and refinery configuration will vary from company to company. The cases covered here were of specific interest to Exxon, but the conclusions are included because they may be helpful, fully realizing that the results may not be of a general nature.

The studies indicated that up to $25 \%$ petroleum can be replaced by coal liquids in a typical refinery. Only the naphtha fraction of the coal liquids will be used in transportation fuel blends, and the $350^{\circ} \mathrm{Ft}$ fractions are incorporated in heating oil and low sulfur fuel oil. The study assumed that the pipestill fractions from coal liquids would be segregated from petroleum fractions either by using separate distillation facilities or by blocked operations. They study suggests that a coal liquefaction plant may sell its $400^{\circ} \mathrm{F}$ - product to a refinery for upgrading to gasoline and heating oil and sell $400^{\circ} \mathrm{F}+$ product directly to consumers in the utility and industrial sectors.

Using a proprietary linear program model two coal liquids from the EDS coal liquefaction process were evaluated in $100 \mathrm{kB} / \mathrm{D}$ grass roots refineries running mixtures of EDS coal liquids and Arabian Light petroleum crude. The overall conclusion of the study was that the most economical way to ut1lize coal liquids is by blending them directly into heating oil and fuel oil products and to increase the conversion of heavy petroleum fractions to maintain gasoline and distillate production. Specific conclusions are as follows:

- Coal liquids are worth up to $2 \$ / B b 1$ more than the Arabian Light crude (a $12.50 \$ / \mathrm{Bbl}$ ) they displace when they constitute $25 \%$ or less of total crude input. 
- Upgrading the $450^{\circ} \mathrm{F}+$ fraction by hydrotreating in the 11quefaction plant did not increase the value of coal liquids.

- Catalytic reforming of the $350^{\circ} \mathrm{F}^{-}$naphtha provided high yields of hydrogen and high octane gasoline.

- Coal liquid fractions boiling above $350^{\circ} \mathrm{F}$ had a high values as $0.7 \%$ sulfur fuel oil due to their low sulfur content and high volumetric heat content.

- There are substantial disincentives for converting $350^{\circ} \mathrm{F}+$ coal liquids by efther catalytic cracking or hydrocracking.

- The $350^{\circ} \mathrm{F}+$ coal liquids should be utilized as low sulfur fuel oil or heating oil, displacing petroleum fractions to catalytic cracking feed. 


\section{BIBLIOGRAPHY}

Reference Number

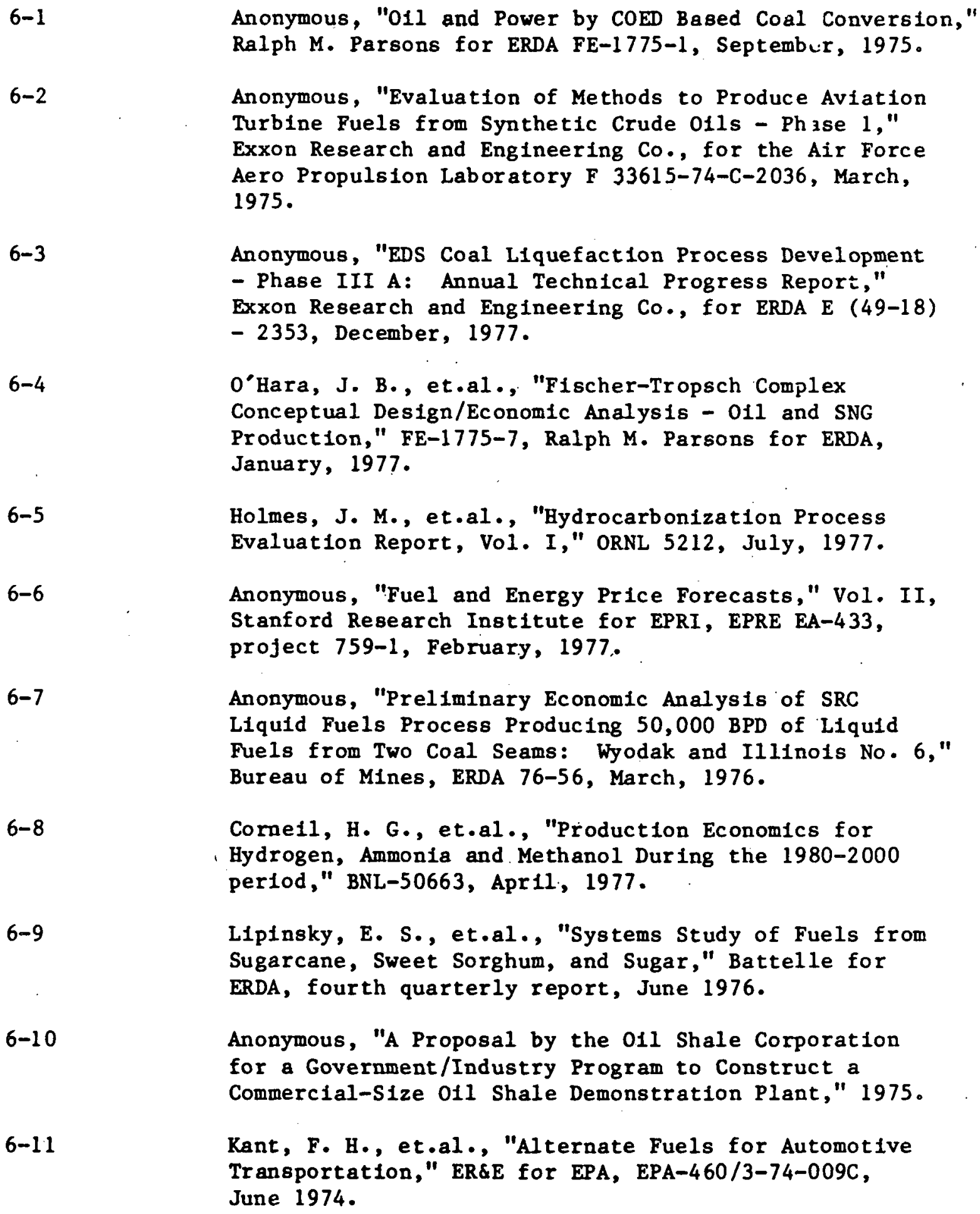

6-11 Kant, F. H., et.al., "Alternate Fuels for Automotive Transportation," ER\&E for EPA, EPA-460/3-74-009C, June 1974. 
$6-12$

6-13

$6-14$

6-15

$6-16$

6-17

$6-18$

6-19

$6-20$

$6-21$

$6-22$

$6-23$

Detman, R., "Factored Estimate for Western Coal Commerclal Concepts, "C. F. Braun for ERDA-AGA Coal Gasification Program, FE-2240-5, October 1976.

Jeffries, T. W., et.al., "Biosolar Production of Fuels," UCRL-52177, November 1976.

Alexander, A. D., "United States Transportation Fuel Economics (1975-1995)," Ames Research Center, N75-21154, Apr 111975.

Kirpatrick, D. M., "Acetylene from Calcium Carb1de is an Alternate Feedstock Route," 011 and Gas Journal, June 7, 1976.

Anonymous, "Review and Evaluation of $300 \mathrm{M} \mathrm{1bs/yr}$ Acetylene Plant Avco Arc-Coal Process," Blaw-Knox Chemical Plants, Inc, for DOI, OCR 14-32-0001-1215, November 1971.

Carcia, A., "Assessment of Potential for Colliodal Fue1s," TT-A-642-75-170, T etra Tech, Inc. for Department fo Navy, June 1975 .

Anonymous, "National Energy-Outlook," Federal Energy Adminstration, February 1976.

Anonymous, "A Study of Coal Prices," Executive Office of the President - Council on Wage and Price Stability, March 1976.

David, M. L., et.al., "Gasahol Economic Feasibility Study," prepared for Energy Research and Development Center, University of Nebraska at Lincoln, July 1978 .

Anonymous, "Fuel and Energy Price Forecasts," Vol. II, Stanford Research Institute for EPRI, EPRI EA-433, project 759-1, February 1977.

Kant, F. H., et al, "Alternate Fuels for Automotive Transportation," ER\&E for EPA, EPA-460/3-74-009C, June 1974.

Anonymous, "EDS Coal Liquefaction Process Development Phase IIIA: Interim Report," Exxon Research and Engineering Co. for ERDA, E(49-18)-2353. 
Anonymous, "EDS Coal Liquefaction Process Development Phase IIIA: Annual Technical Progress Report," Exxon Research and Engineering Co. for ERDA E(49-18)-2353, December 1977.

Anonymous," "O11 and Power by COED Based Coal Conversion," Ralph M. Parsons for ERDA FE-1775-1, September 1975.

Stangeland, B. E. and Sullivan R. F., "Catalytic Hydroprocessing of Shale Oil to Produce Distillate Fuels," Chevron Research Co: for ERDA, EF-76-C-01-2315, August 1977.

Anderson, C. J., "Alternative Fuels for Transportation: Implications of the Broadcut Option", Lawrence Livermore Laboratory for ERDA, W-7405-Eng-48, July 1977.

Taylor, W. F., et al, "Evaluation of Methods to Produce. Aviation Jet Fuels from Synthetic Crude Oils, Phase 3", Exxon Research and Engineering Co. Technical Report AF HP2-TR-75-10, Volume 3, September 1977. 
Table 6-69

LOWER HEATING, VAIUES OF FUELS

Fuel Oll
Shale Liquids
Coal Liquids
Oll from Organic Waste
Ammonia!
Ethanol:
Methanol
Coal/Oil Slurry
Acetylene
Hydrazine
Methylamine
Coal
High Sulfur
Low' Sulfur
SNG
LBG

$\begin{array}{rc}6.05 & \text { MBTU/Barrel } \\ 5.3 & " \\ 5.8 & " \\ 5.8 & \text { " } \\ 16.1 & \text { MBTU/Ton } \\ 23.0 & " \\ 17.1 & " \\ 33.9 & \text { " } \\ 20,730 & " \\ 7,294 & \\ 13,285 & \text { " } \\ 11,975 & \text { BTU/Pound } \\ 8,050 & \text { " } \\ 870 & \\ 180 & \end{array}$




\section{TRANSPORTATION, DISTRIBUTION AND STORAGE COST OF ALTERNATE FUELS}

E. N. Cart, Jr.

\subsection{Introduction and Summary}

In addition to considering the economics of manufacture of the various alternate fuels, it is also necessary to consider the cost of transportation, storage, and distribution associated with moving the fuels to the customer. In most cases, the raw material resources are not located near the markets, so a large transportation network is required to move the resource to the conversion site and ultimately to the customer.

There are two basic types of energy movement considered-transportation and distribution. Transportation refers to movement of energy over long distances, generally between a single source and a single destination, usually interregional. Transportation also generally refers to large scale energy transmission with high load factors. Distribution describes how energy is delivered from a large terminal to the customer. Typically, the distance will be short (intraregional), there will be many destinations, and the load factor will be low, designed for peak demands. Typically, also, there are storage facilities at distribution terminals.

A typical transportation system for petroleum from the oil well to the refinery is shown in Figure 7-1. The transportation/distribution system for petroleum products for alrcraft, marine, and rail are shown in Figure 7-2. The products move from the refinery by either pipeline, tanker/ barge, or rail car to a marketing storage terminal. Most of these storage facilities have a capacity of more than 2 million gallons. In the case of aircraft fuels, the products move by tank truck, rail, or pipeline to tankage at the airport. From tankage, the fuel moves either by truck or through a hydrant system to the aircraft. For marine fuels, the products move to the vessel via a barge that services the ships in a harbor or by trucks that service the vessels at the dock. The products can also move by various means to smaller bulk plants that are used to supply small scale operations, such as pleasure crafts. The railroads generally pick up their fuel from major marketing terminals and move the products by rail to their own tankage.

The method of selecting how the products move from refinery to bulk terminal to the customer's tankage depends on a number of factors. The method of transporting refined petroleum products in 1974 was fairly equally divided among pipelines, water carriers, and trucks, as shown below:

Transporting Refined (7-23)
Petroleum Products (wt. \%)

Water Carriers Pipelines Trucks $\operatorname{Ra} 11$
$25.8 \%$

33.5

38.5

2.2 
EIGURE 7-1

MAIN ELEMENTS OF TRANSPORTATION, STORAGE AND DISTRIBUTION

\section{Conventional Petroleum}

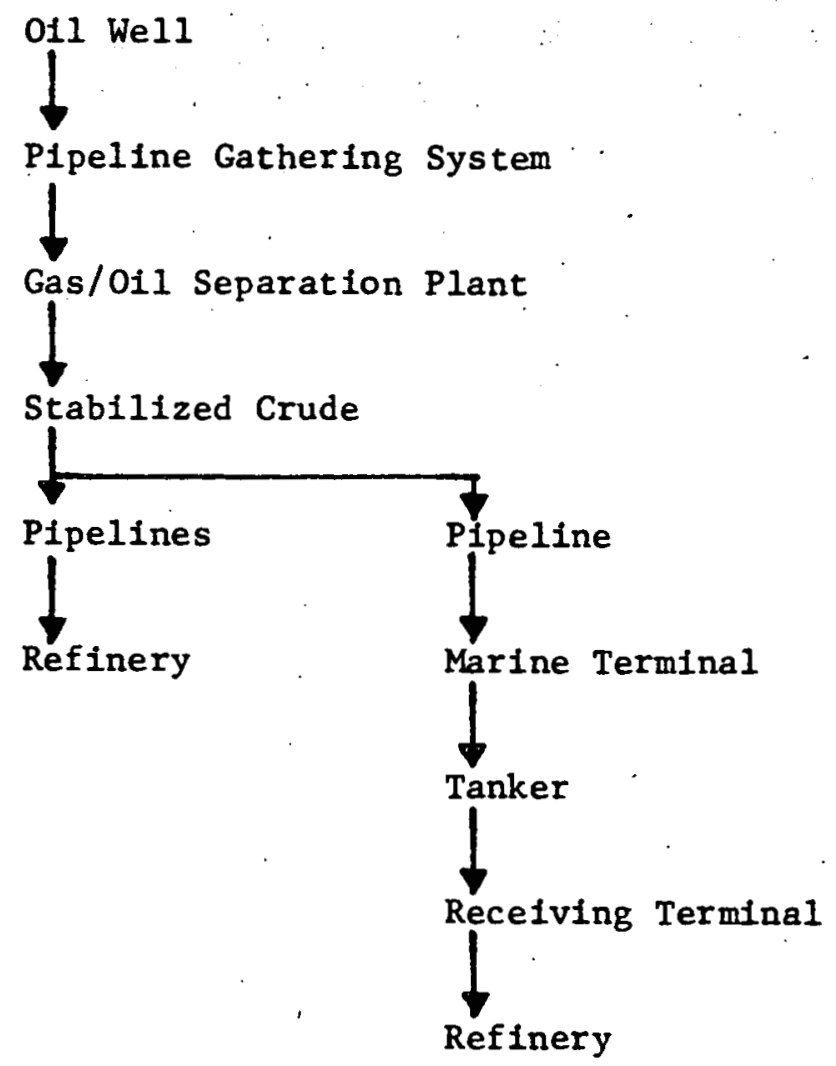




\section{FIGURE 7-2}

\section{TYPICAL TRANSPORTATION/DISTRIBUTION SYSTEMS FOR PETROLEUM PRODUCTS}

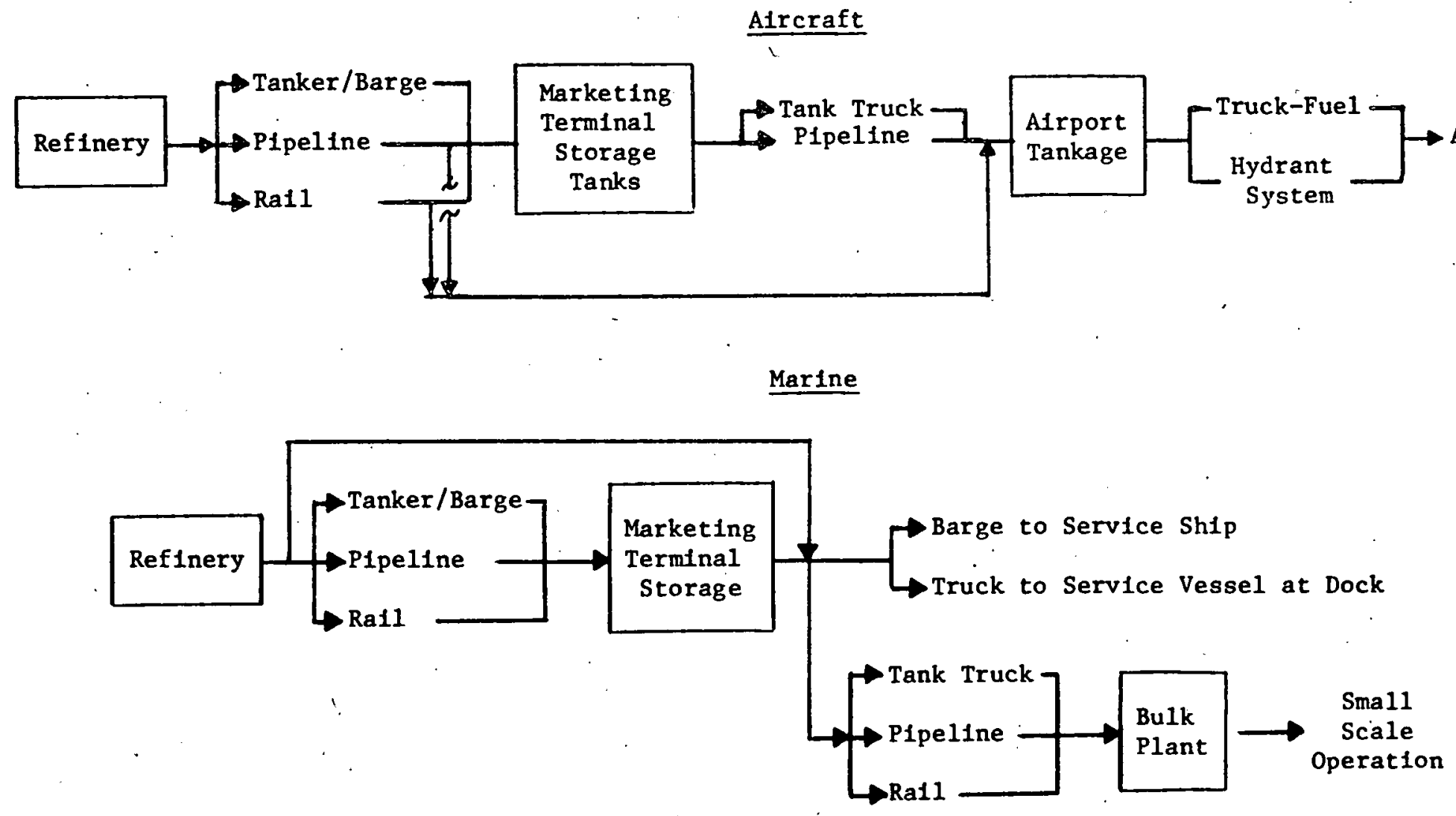

$\underline{\text { Ra11 }}$

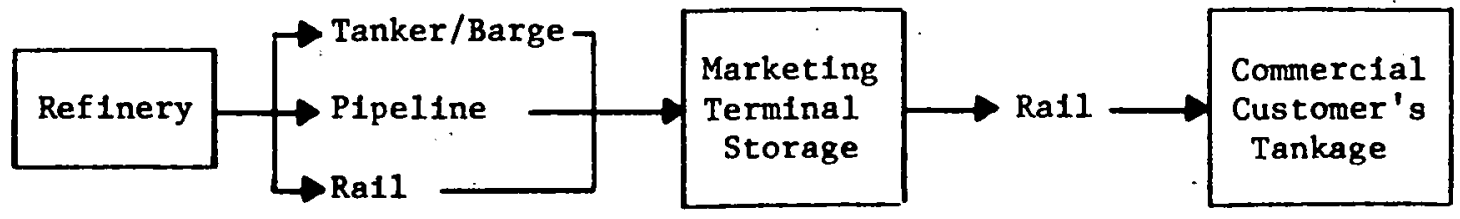


While rail accounts for only a small percentage of the movement of refined products, it is an important method of supplying fuel within the railroad industry.

In the following sections, the transportation costs for the different alternate fuels and for various modes of transmission (pipeline, rail, barge, truck) are summarized and put on a common basis. The costs are expressed on a dollars per million BTU per $1000 \mathrm{mile}$ basis. The storage and distribution costs are also covered for the major fuels of interest. To arrive at the estimated cost of the fuei delivered to the customer, it is necessary to make some assumptions on representative distances. Actual transportation and distribution costs can vary from the values shown, depending on shipping distance, terrain, tariff rates, etc. The transportation distance assumed for this comparison has been arbitrarily set at 1000 mfles in most cases. The coal and shale ofl liquids have an additional 500 mile product pipeline cost added to move the product from a refinery to a bulk terminal. For some of the unconventional fuels, the processing plants may be smaller and located nearer to the point of use. Sufficient information is given in later sections to permit adjustments to a different basis. Table 7-1 summarizes the total delivered cost for some of the various alternate fuels. The costs are divided into four major areas--feedstock or raw material costs, manufacturing costs, upgrading costs (includes liquefaction cost for hydrogen and methane), and transportation and distribution costs. The costs have been rounded to the nearest $\$ 0.05 / 10^{6}$ BTU which accounts for some of the numbers being slightly different from that number shown in other sections. The detailed basis for each fuel is described in the following sections. Several interesting facts are apparent from Table 7-1 from the standpoint of the transportation and distribution costs.

- Transportation costs can be a significant cost in using coal as a fuel directly or in contributing to the total feedstock cost of a coal-based alternative fuel.

- Transportation and distribution costs represent around 7-8\% of the total delivered cost of coal liquids.

- Transportation and distribution costs represent $5-22 \%$ of the total delivered cost for shale oil, methanol, and ethanol.

- Transportation and distribution costs for hydrogen, methane, ammonia and acetylene represent $10-26 \%$ of the total delivered cost.

- The transmission and distribution costs for electricity represent around $35 \%$ of the total cost for large commercial users.

This type of ranking indicates where additional research and development may be useful in reducing the overall cost of delivery of some of these fuels to the consumer.

\subsection{Coal Transportation Costs}

Coal can be transported by rall (unit train or conventional), slurry pipeline, or barge. For short hauls, trucks or conveyors could also 


\section{TABLE 7-1}

SUMMARY OF TOTAL DELIVERED COST OF ALTERNATE FUELS

$\$ / 10^{6}$ BTU (1980 Cost)

\begin{tabular}{|c|c|c|c|c|c|c|c|}
\hline Fue1 & $\begin{array}{l}\text { Feedstock } \\
\text { or Raw } \\
\text { Material } \\
\end{array}$ & $\begin{array}{l}\text { Manufacturing } \\
\text { Cost } \\
\end{array}$ & $\begin{array}{l}\text { Upgrading } \\
\text { Costs } \\
\end{array}$ & $\begin{array}{c}\text { Fuel } \\
\text { Transportation } \\
\text { and D1stribution }\end{array}$ & Total Cost & $\begin{array}{c}\text { Transportation/ } \\
\text { Distribution-- } \\
\% \text { of Tota1 } \\
\end{array}$ & $\begin{array}{c}\text { Detalls } \\
\text { In Figure } \\
\end{array}$ \\
\hline $\begin{array}{r}\text { Coal--Eastern } \\
\text {--Western }\end{array}$ & $\begin{array}{l}0.60-1.30 \\
0.30-0.70\end{array}$ & -- & $=$ & $\begin{array}{l}0.30(1) \\
0.75(1)\end{array}$ & $\begin{array}{l}0.90-1.60 \\
1.05-1.45\end{array}$ & $\begin{array}{l}19-33 \\
52-71\end{array}$ & \\
\hline Coal/O11 slurry & 2.45 & 0.35 & -- & (2) & 2.80 & - & $7-3$ \\
\hline Coal Liquids & $1.20-1.70$ & $2.60-4.60$ & I. $60-2.70$ & $0.50-0.65$ & $5.90-9.90$ & $7-8$ & $7-5$ \\
\hline Shale ofl Liquids & 2.50 & $1.70-1.90$ & $0.00(7)$ & $0.50-0.70$ & $4.70-5.10$ & $11-14$ & $7-6$ \\
\hline Methanol & $1.70-2.15$ & $5.00-9.05$ & - & $1.10-3.20$ & $7.80-14.40$ & $14-22$ & $7-8$ \\
\hline Ethanol & $9.00-13.50$ & $7.70^{(5)}$ & -- & $0.85-2.40$ & $17.55-23.60$ & $5-10$ & $7-9$ \\
\hline Hydrogen & $1.70-1.80^{(4)}$ & $6.20-7.90$ & $4.90(6)$ & $3.80-4.80$ & $16.10-18.90$ & $23-25$ & $7-11$ \\
\hline Methane & $1.90-2.70^{(4)}$ & $4.20-6.05$ & $2.00(6)$ & $1.6-1.8$ & $9.70-12.55$ & $13-19$ & $7-13$ \\
\hline Ammonia & $2.20-2.30^{(4)}$ & $10.10-10.60$ & -- & $3.80-4.20$ & $16.10-17.10$ & $24-25$ & $7-15$ \\
\hline Acetylene & $1.85^{(4)}$ & 12.15 & - & $>4.60$ & $>18.65$ & $n_{25}$ & $7-16$ \\
\hline Hydrazine & $>37$ & $?$ & - & $>3.25$ & $>>40$ & & $7-17$ \\
\hline Electricity & 3.4 & 6.20 & - & 5.3 & 14.9 & 36 & $7-18$ \\
\hline $\begin{array}{l}\text { (1) } 500 \text { mfles for } \\
\text { (2) Included In } f \\
\text { (3) Upgraded to } \\
\text { (4) Eastern coal }\end{array}$ & $\begin{array}{l}\text { Eastern coal } \\
\text { eedstock In ra } \\
13.5 \% \text { hydrogen } \\
\text { based product } 1\end{array}$ & $\begin{array}{l}\text { and } 1000 \text { miles } \\
\text { aw material cos } \\
\text { a In distillate } \\
\text { lon. Plant at }\end{array}$ & $\begin{array}{l}\text { for Western } \\
\text { ts. } \\
\text { ine mouth. }\end{array}$ & $\begin{array}{l}(5) \\
(6) \\
(7)\end{array}$ & $\begin{array}{l}\text { Corn resource b } \\
\text { Liquefaction co } \\
\text { Covered in mamu }\end{array}$ & turing cost. & \\
\hline
\end{tabular}


be used. The relative economics of the various modes of transporting coal vary depending on utilization of the facllities, the distance the coal is to be moved, terrain, coal density; car and train size in the case of unit trains, and train speed. A study by Nagarvala(7-20) shows how the unit rate can vary with transportation distance.

A summary of coal transportation costs for a unit tra1n, a water slurry pipeline, and barge movements is shown in Table 7-2. All data have been adjusted to 1980 dollars, using the same economic basis described in Table 6-4. The costs are shown as dollars per million BTU per 1000 miles. Since most of the literature reported the costs on a cents/ton-mile basis, It was necessary to assume an average heating value of Western and Eastern coals to convert this to a cents/million BTU basis. The values assumed are $24.0 \times 106 \mathrm{BTU} / \mathrm{short}$ ton for high sulfur coal (assumed to be Eastern coal) and $16.1 \times 10^{6} \mathrm{BTU} /$ short ton for low sulfur coal (assumed to be Western coal). As shown in Table 7-2, there is a range of coal transportation costs. The values that will be used in this study are shown at the bottom of the table.

Since coal can be a basic resource for several alternate fuels, there are several ways to move the coal from the mine to the conversion plant, with some of the methods depending on whether the conversion plant is located at the mine mouth or near the demand center. From an economic standpoint, mine mouth conversion plants are usually favored since the cost of pipeline transportation of the liquid products usually are lower than the cost of moving the coal long distances. However, the environmental and socioeconomic Impacts of locating several large coal conversion plants in the arid and rural West may force the conversion plants nearer the demand center. The question of rall versus slurry pipeline is beyond the scope of this study. Rieber, et al (7-10) have made a detalled comparison on the future of coal transportation, looking at unit trains, slurry pipeline and high pressure pneumatic plpeline. That study concluded that slurry pipelines and unit trains are competitive. $(7-10)$

\subsection{Coal/0i1 Slurry Transportation}

One of the alternate fuels being considered for a non-highway transportation fuel is a colloldal blend of coal and oll. The overall production, transportation and distribution system is shown in Figure 7-3. It is assumed that the coal and ofl would be delivered separately to the customer and a $25 \mathrm{KT} / \mathrm{D}$ grinding and blending facllity would be used to blend the two components.

Eastern coal at $\$ 21 /$ ton at the mine is moved 1,000 miles by unit train to the grinding and blending plant. Other combinations of coal type and distances could apply as well. The oll cost at the point of blending is assumed at around $\$ 20 / \mathrm{B}$. A blend of $40 \%$ by welght coal and $60 \%$ by weight oil is assumed. Grinding and blending costs add $\$ 0.35 / 10^{6}$ BTU to the total fuel cost of $\$ 2.80 / 106$ BTU. 


$$
7-7
$$

TABLE 7-2

SUMMARY OF COAL TRANSPORTATION COST

1980 Dollars

$\$ / 10^{6}$ BTU per 1000 miles

$24.0 \times 10^{6} \mathrm{BTU} / \mathrm{St}$ - Eastern Coal

$16.1 \times 10^{6} \mathrm{BTU} / \mathrm{St}$ - Western Coal

\begin{tabular}{|c|c|c|c|c|c|}
\hline & Unit & Train & Slurry & peline & Barge \\
\hline Ref. & Western & Eastern & Wester $n$ & Eastern & Eastern \\
\hline $7-1$ & 0.75 & 0.65 & 1.31 & 0.87 & 0.27 \\
\hline $7-6$ & $0.69-0.86$ & $0.46-0.57$ & $0.43-0.60$ & $0.29-0.40$ & \\
\hline $7-7$ & 0.86 & 0.91 & 0.82 & 0.54 & 0.49 \\
\hline $7-8$ & $0.47-0.64$ & $0.30=0.41$ & & & : \\
\hline $7-9$ & 0.64 & 0.64 & & & 0.18 \\
\hline $7-10$ & 0.58 & 0.37 & & & \\
\hline $7-11$ & 1.23 & 0.79 & & & \\
\hline $7-20$ & 0.90 & 0.58 & $0.64-1.01$ & $0.41-0.65$ & $0.22-0.34$ \\
\hline $7-22$ & 0.78 & 0.50 & 0.67 & 0.43 & $0.21-0.33$ \\
\hline . $7-34$ & $0.60-1.00$ & $0.4-0.7$ & $0.6-1.2^{\prime}$ & $0.4-0.8$ & $0.1-0.3$ \\
\hline $\begin{array}{l}\text { Used in } \\
\text { this study }\end{array}$ & 0.75 & 0.65 & 0.75 & 0.65 & 0.27 \\
\hline
\end{tabular}


FIGURE 7-3

COAL/OIL SLURRY PRODUCTION, TRANSPORTATION AND DISTRIBUTION SYSTEM

$\$ / 10^{6} \mathrm{BTU}$

Coal

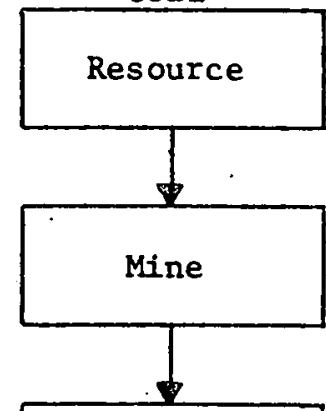

011

0.88

Railroad

or Pipeline

1.53

( $40 \%$ by Weight)

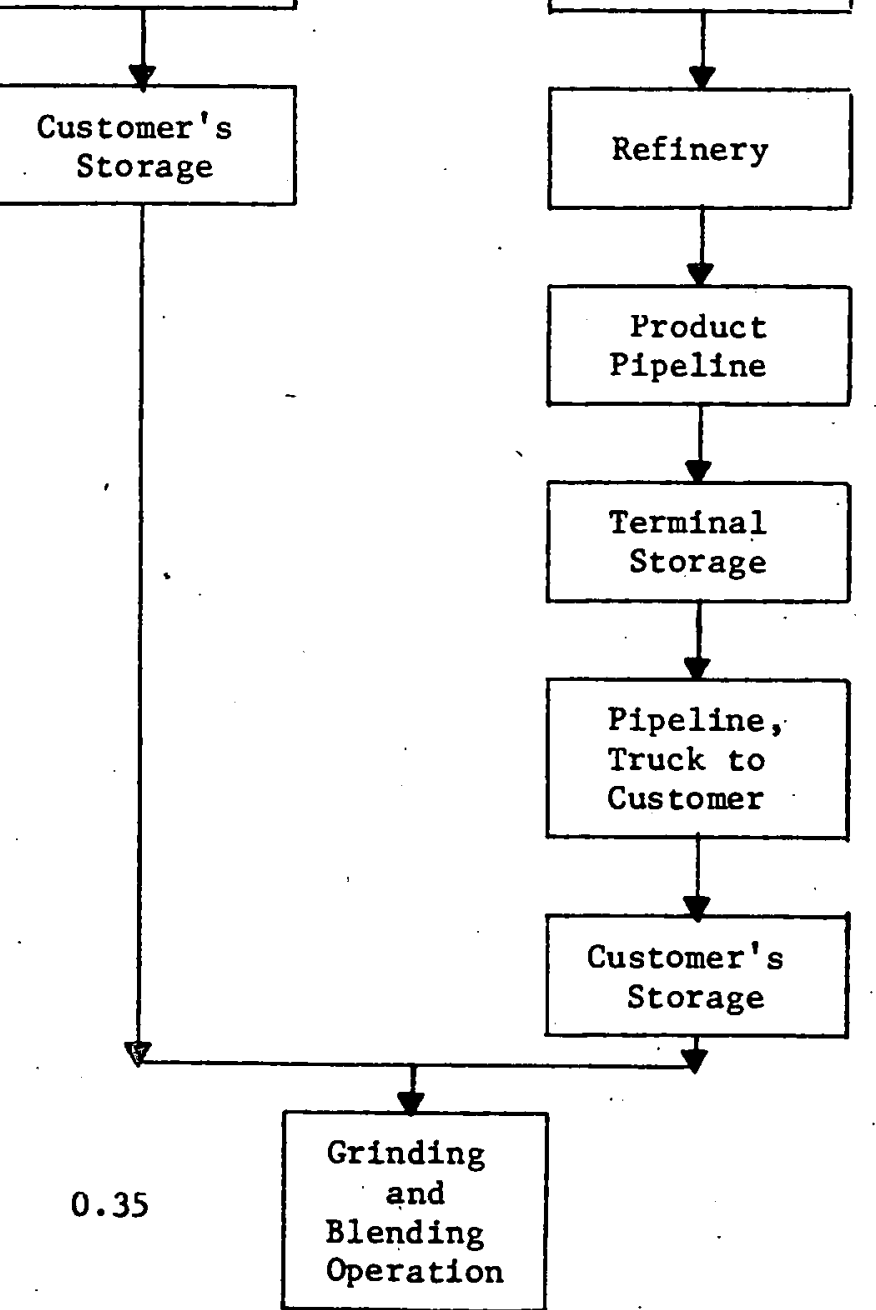

3.08

(60\% by Weight)

2.81 


\subsection{Coal Liquids}

\subsubsection{Transportation Costs}

It is assumed that any coal liquids would move by plpeifne from the liquefaction facilities to a refining center. The cost of moving Ilquids by plpeline will depend on the shipping distance, volume pumped, type and number of products handled, liquid viscosity, rerrain to be crossed, size of line, etc. Table 7-3 summarizes the literature data on the cost of moving crude and distillate by pipeline. The 11terature data have been converted to 1980 dollars using a $7 \%$ per year inflation rate. In some cases, a capital recovery factor of $15 \%$ from the 11terature has been retained rather than adjust to the higher recovery rate used for the liquefaction plant.

A study by Nagarvala, et al (7-20) derived the cost of interregional pipeline transportation costs for crude oil pipeline and product pipelined, as a function of pipeline carrying capacity (pipeline size). The cost of moving liquids in a crude pipeline as a function of pipeline capacity is shown in Figure 7-4, calculated from the equation in Reference 7-20. A $15 \%$ capital recovery factor is assumed in the cost shown in Figure 7-4. The other data are shown for comparison, and are in general agreement. It would appear the cost calculated from Reference 7-40 may be about 15-20\% lower than the other data. For this study, it has been decided to use the higher cost, as shown in Figure 7-4.

One of the major questions that will need to be answered is: Can or will coal liquids be added to existing crude supply lines or will it be necessary to build separate pipelines to move the coal syncrude to a refinery for processing? If a separate line is built, the size would be much smaller, and result in a higher transportation cost, than if the existing crude distribution system with $600-800,000 \mathrm{~B} / \mathrm{D}$ capacities were used.

\subsubsection{Storage and Distribution Costs}

It 1 s assumed that after the coal syncrude is upgraded, the dist1llate and fuel oil product would be handled in the same manner as petroleum products are currently distributed. Thus, the products would move from the refinery by a product pipeline to a large terminal and from the terminal by tank truck, rall or barge or smaller pipeline to the customer's tankage. It is difficult, to arrive at a good estimate of the cost of distribution of products due to the wide variation in distances, flow rates and mode of cransportation involved.

For the product pipeline costs, the data reported by Nagarvala, et al., shown in Figure 7-4, will be used. An average flow rate of $100 \times 10^{3}$ $\mathrm{B} / \mathrm{D}$ will be assumed, which is typical for a 14-inch diameter pipeline. An average distance of $500 \mathrm{miles}$ will be assumed between the refinery and the bulk terminal. The actual distance can vary considerably, but this average value w1ll be assumed for this study. With these assumptions, the pipeline cost would be around $\$ 0.10 / 106$ BTU in terms of 1980 dollars. This is in line with the cost reported by Grigsby, et al (7-21) for the cost to move products by pipeline from a refinery to a terminal. 
TABLE 7-3

SUMMARY OF COAL LIQUIDS PIPELINE COST

$\begin{array}{lc}\text { ief. } & \begin{array}{c}\text { Cost }-1980 \text { Dollars } \\ \text { \$-1 }\end{array} \\ & 0.095 \\ 7-6 & 0.12 \\ & \\ & \\ 7-9 & 0.07-0.09 \\ 7-11 & 0.16 \\ 7-19 & 0.24 \\ 7-20 & 0.09 \\ & 0.08 \\ 7 & 0.22\end{array}$

14-1nch diameter--100,000 B/D 10-inch diameter-- 50,000 B/D

30-inch diameter line, 600,000 $B / D$ for crude and distillate.

Assumes coal liquid of $5.8 \mathrm{x}$ $10^{6} \mathrm{BTU} / \mathrm{B}$ and $15^{\circ} \mathrm{API}$ to convert from cents per ton mile

to $\$ / 10^{6}$ BTU/mile.

\section{Comments}

36-inch diameter--800,000 B/D 12-inch diameter--product pipeline 


\section{FIGURE 7-4}

COST OF MOVING CRUDE BY PIPELINE

(CRUDE, COAL LIQUIDS OR SHALE OIL SYNCRUDE)

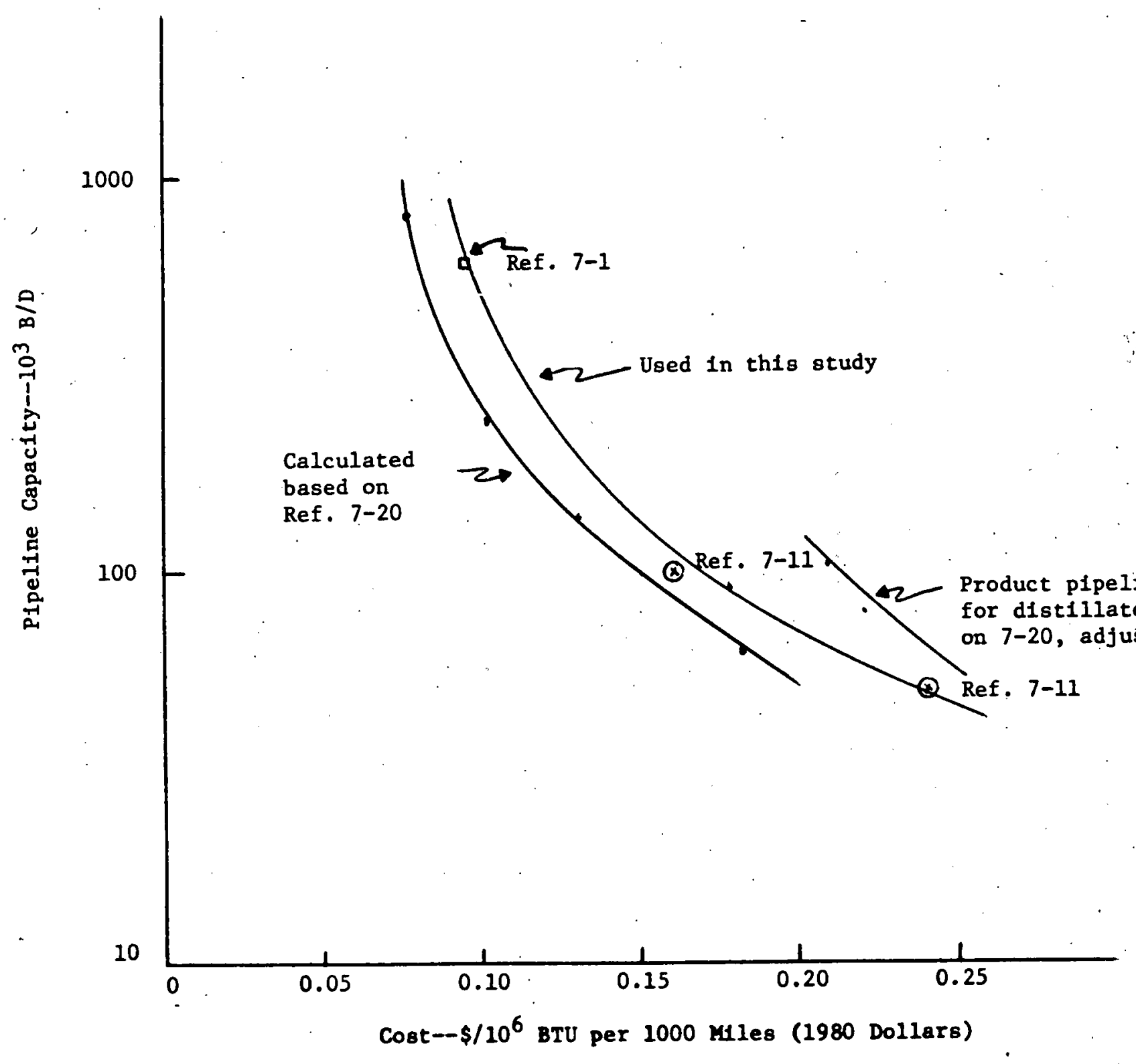


The distribution cost for petroleum products has been reported by Grigsby, et al.(7-21) The cost for distribution of petroleum products in terms of 1980 dollars is shown below. For this study, the same average cost used by Grigsby w1ll be used, but the range is also shown.

$\begin{array}{lccc} & \$ / B(1980 \text { Dollars) } & & \text { Range } \$ / B \\ \text { Terminal Operating Cost } & 0.19 & 0.04-0.37 \\ \text { Marketing Cost } & 0.78 & 0.32-1.56 \\ \text { Truck to Customer } & 0.63 & 0.31-1.56 \\ \text { Capital Recovery at 35\% } & \underline{0.14} & 0.14 \\ \text { (Terminal and Truck) } & 1.74 & 0.81-3.63\end{array}$

On a BTU basis, the average cost is $\$ 0.31 / 10^{6}$ BTU for coal-derived distillates. This cost is lower than 1 would be for gasoline, since the operating cost of the service station and capital recovery would add another $\$ 1.28 / 10^{6}$ BTU to the cost of distributing gasoline in a retall operation.

\subsubsection{Total Delivered Cost to Customer}

A total production, transportation and distribution system for coal liquids is shown in Figure 7-5. The costs shown are for an Illinols coal, with the liquefaction plant located at the mine with coal movement 10 miles by truck or conveyor. It is also possible that the liquefaction facilities could be located several hundred miles from the mine, in which case the coal transportation would be by unit train or slurry pipeline and could add about $\$ 0.5 / 106$ BTU to the total cost if the distance was 500 miles. Another alternate would be for the coal syncrude to be from Western coal, with the liquefaction plant either in the mine site or located in the Midwest. If the Western coal is transported 1000 miles, the coal transportation cost could be in the $\$ 0.7-1 / 106$ BTU range.

Estimates of liquefaction cost vary considerably, depending on the type of product produced, the process used and degree of detall information available for the cost estimates. Section 6.5 describes the various types of processes and the range of cost for a syncrude from coal. A typical liquefaction process has been used in Figure 7-5 to show the cost of producing distillates from coal. The coal liquefaction cost of $\$ 2.55-4.60 / 106 \mathrm{BTU}$ is in the range of several of the processes under consideration for further development (H-coal, Exxon EDS, SRC-II).

The cost to move the syncrude to a refinery will not be a significant cost; around $\$ 0.10 / 106$ BTU if a large size pipeline $(500 \mathrm{~KB} / \mathrm{D})$ can be used and $\$ 0.24 / 106$ BTU if the flow rate is only around $50 \mathrm{~KB} / \mathrm{D}$. The assumed distance in both cases is 1000 miles.

The refinery upgrading cost of $\$ 1.60-2.70 / 10^{6} \mathrm{BTU}$ is a rough estimate of the cost to provide distillate from coal liquids. The distillate has been upgraded to $13.5 \%$ hydrogen. 


\section{FIGURE $7-5$}

COAL LIQUIDS PRODUCTION,

TRANSPORTATICN AND DISTRIBUTION SYSTEM

Coal

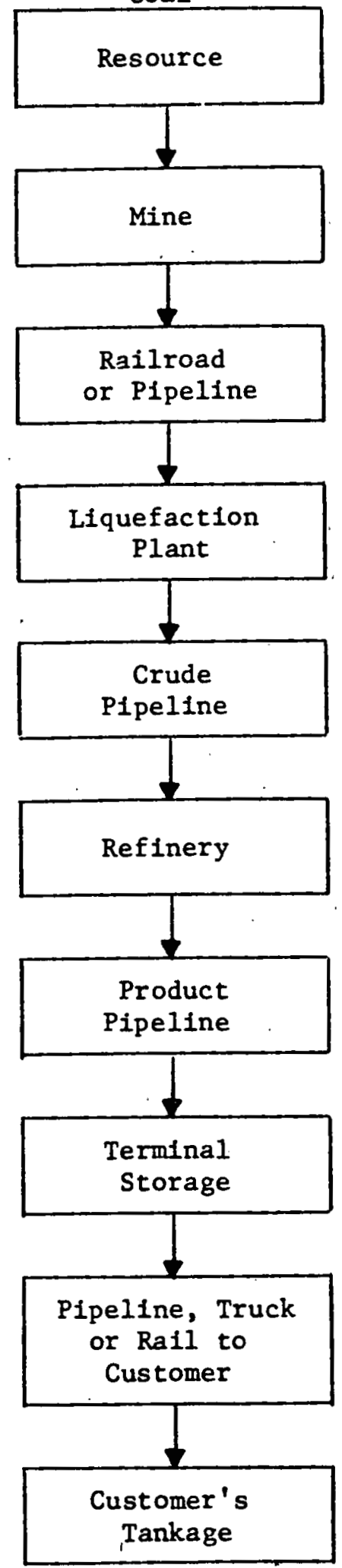

\$/106 BTU (1980 Dollars)

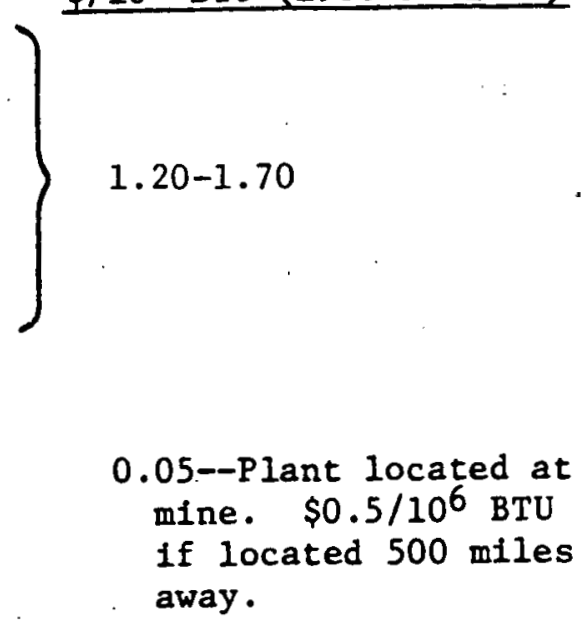

$2.55-4.60$

$0.10-0.25$

1.60-2.70--Upgrade to distillate-$13.5 \%$ hydrogen content.

0.11

0.31 
The basis for the product pipeline and distribution costs are described in Section 7.4.2. As can be seen, the overall transportation and distribution costs represent only about $7 \%$ of the total costs of coal liquids delivered to the customer.

\subsection{Shale 011 Liquids}

\subsubsection{Transportation Costs}

The most economical method for moving shale ofl liquids would be by pipeline. However, crude shale olls have a high viscosity and pour point, which will require some pretreatment before the product can be moved in conventional, unheated pipelines. Rallroad tank cars and tank trucks with heating coils could be used to move the crude shale oil, but the cost would probably be excessive. For this study, it is assumed that the raw shale ofl will be partially refined at the retort to decrease the pour point. The cost of moving liquids shown in Figure 7-4 will be used for this study. Difference in gravity and heating value of the shale oil compared to coal liquids are neglected since the difference is on the order of $\$ 0.01 / 106$ BTU per $1000 \mathrm{miles}$.

\subsubsection{Storage and Distribution Costs}

It 1s assumed that after the shale syncrude is upgraded, the distillate and fuel ofl products would be handled in the same manner as petroleum products are currently distributed. Thus the products would move from the refinery by a product pipeline to a large terminal and from the terminal by tank truck, rall or barge or smaller pipeline to the customer's tankage. It is difficult to arrive at a good estimate of the cost of distribution of products due to the wide variation in distances, flow rates and modes of transportation involved.

For the product plpeline cost, the data reported by Nagarvala, et a1 shown in Figure 7-4 w1:11 be used. An average flow rate of $100 \times 10^{3} \mathrm{~B} / \mathrm{D}$ will be assumed, which is typical for a 14-inch diameter pipeline. An average distance of 500 miles will be assumed between the refinery and the bulk terminal. The actual distance can vary conslderably, but this average value will be assumed for this study. With these assumptions, the pipeline cost would be around $\$ 0.10 / 106$ in terms of 1980 dollars. This is in line with the cost reported by Grigsby, et al (7-21) for the cost to move products by pipeline from a refinery to a terminal.

The distribution cost for 11quid products was covered in Section 7.4.2 for coal liquids. The cost for distributing shale oil derived liquids would be about the same cost-\$0.3/106 BTU.

\subsubsection{Total Dellvered Cost to Customer}

The total production, transportation and distribution costs for shale oil liquids is summarized in Figure 7-6. The resource cost is based on $\$ 0.2 / 10^{6}$ BTU for lease cost, but could be higher. The product upgrading, which would occur at the production site, would produce a syncrude that could be pumped in a conventional crude pipeline. For purposes of this 
FIGURE 7-6

SHALE OIL LIQUIDS PRODUCTION, TRANSPORTATION AND DISTRIBUTION SYSTEM

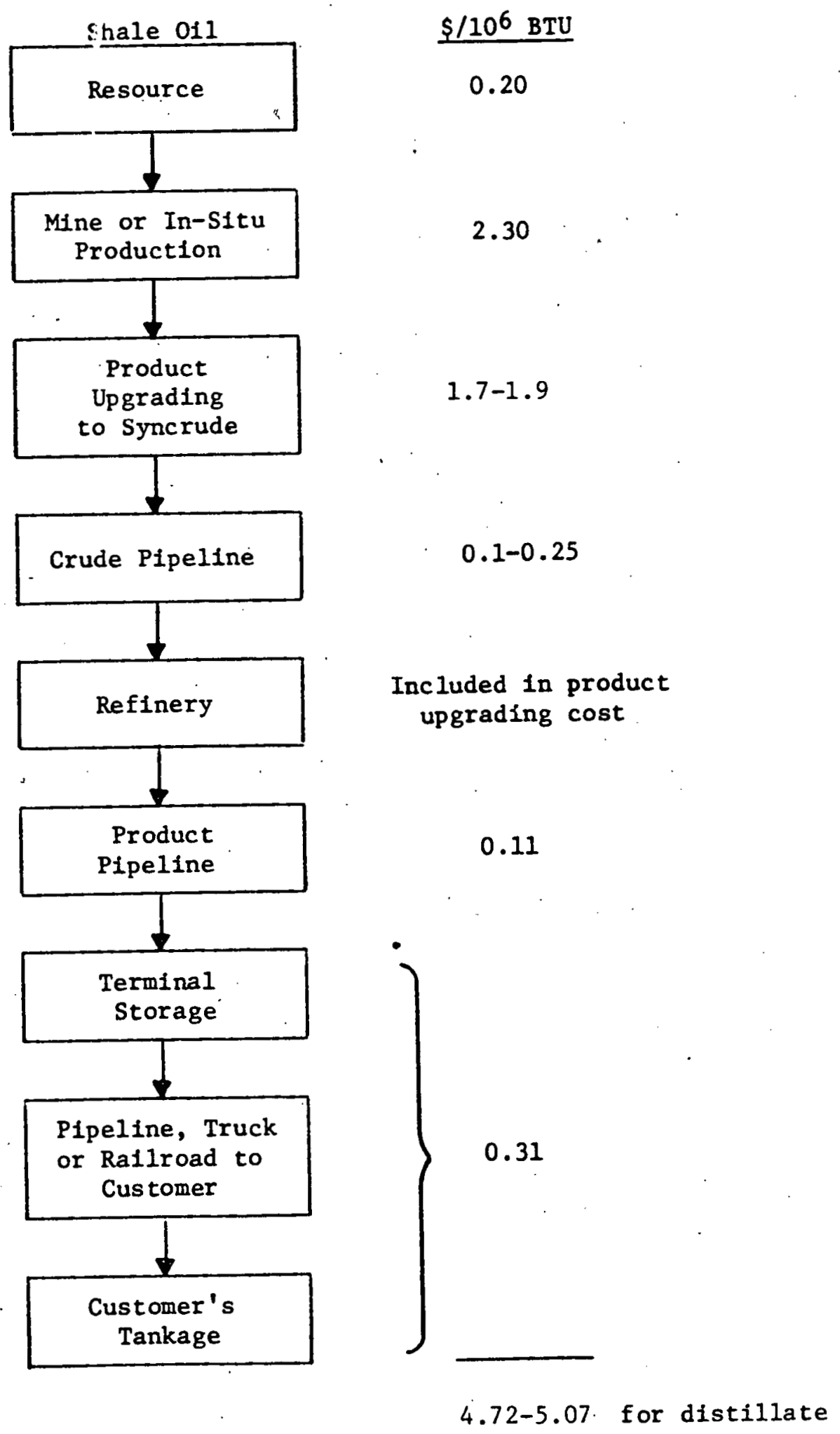


study, it is assumed that the crude would move 1000 miles to a refinery for further upgrading. The range of $\$ 0.1-0.25 / 10^{6}$ BTU reflects a pipeline capacity of $500 \mathrm{~KB} / \mathrm{D}$ to $50 \mathrm{~KB} / \mathrm{D}$.

The refining cost for shale oll derlved distillate was discussed In Section 6.3.3. In this particular example, distillate is made by substituting cat cracking for hydrocraking and running more syncrude. In this case, the added operating costs are essentially zero since the savings for substituting a less costly conversion step offsets the cost of running more feed. Also, the addition of hydrogen to remove sulfur and nitrogen was done in the product upgrading step.

The product pipeline cost is based on moving the product in a 14-inch diameter pipeline, an average distance of $500 \mathrm{miles}$ to a bulk terminal. The total distribution cost is based on the study by Grigsby(7-21) for petroleum products.

The total cost of any shale oll-derived distillate is about $90 \%$ assoclated with mining, product upgrading and refining, and 10-15\% associated with transportation and distribution.

\subsection{Methanol}

\subsubsection{Transportation Costs}

Methanol has long been a basic, tonnage petrochemical and distribution by all means has been fully developed. Due to the lower specific energy of methanol, compared to petroleum products, the transportation cost per MBTU for methanol will be approximately double that for transporting petroleum products. A summary of the costs associated with the various methods of transporting methanol are given in Table 7-4. The lowest cost way to transport large volumes of methanol would be by pipeline. The estimated relationship between pipeline costs and capacity for methanol is shown in Figure 7-7, based on the curve shown in Figure 7-4, adjusted for the net heating value difference between petroleum products and methanol.

The location and number of plants near the pipeline would determine the size and capacity of the system. For example, it would take eight (8) $2000 \mathrm{~T} / \mathrm{D}$ methanol plants to feed a plpeline with a $100,000 \mathrm{~B} / \mathrm{D}$ capacity. Since it seems unlikely that this many plants would be in one location, a pipeline transportation cost of $\$ 0.8-1.00 / 10^{6}$ BTU-1000 miles seems like a more likely range (1-2 plants).

The transportation cost by tanker is for moving methanol from the Gulf Coast to the East Coast. Another alternative would be to convert natural gas in the Middle East to methanol for use in the U. S. Since this study is concerned with domestic supplies of energy, this alternate is not being considered.

The methanol could also be transported by rail. Rates are shown for a unit train and a conventional train, based on rail rates given in 
TABLE 7-4

SUMMARY OF METHANOL TRANSPORTATION COST

Cost - 1980 Dollars

Ref. $\$ 1 / 106$ BTU per 1000 Miles

$7-1$

0.18

$7-1$

0.63

$7-2$

0.93

$7-3$

0.78

7-19

$7-1$

0.27

ò. 26

$7-19$

1.18

7-7

1.21

2.43

7-7

$7-7$
Mode

Pipeline

Alaska

Pipeline

Pipeline

Pipeline

Pipeline

Tanker

Unit Tra1n

Unit Train

Conventional Train

Barge
Comments

$600,000 \mathrm{~B} / \mathrm{D}$ rate, 30-1nch diameter line

48-inch diameter line

$210,000 \mathrm{~B} / \mathrm{D}$ rate, $20 \%$ capital recovery factor

Same as Ref. 7-2 except 15\% capital recovery facțor

35 MDWT U. S. built and flag tanker, moving 888, 300 long tons per year over a trading distance of 2000 miles

Details not given on train size

Based on $1.5 \mathrm{c} /$ ton mile in 1975 dollars for $1000 \mathrm{miles}$ and 25 million tons per year

Based on 3q/ton-mile in 1975 dollars

Based on $\$ 0.85 /$ ton-mile 


$$
7-18
$$

\section{FIGURE 7-7}

COST OF MOVING ALCOHOLS BY PIPELINE

(BASED ON FIGURE 7-4, ADJUSTED FOR HEATING VAIUE)

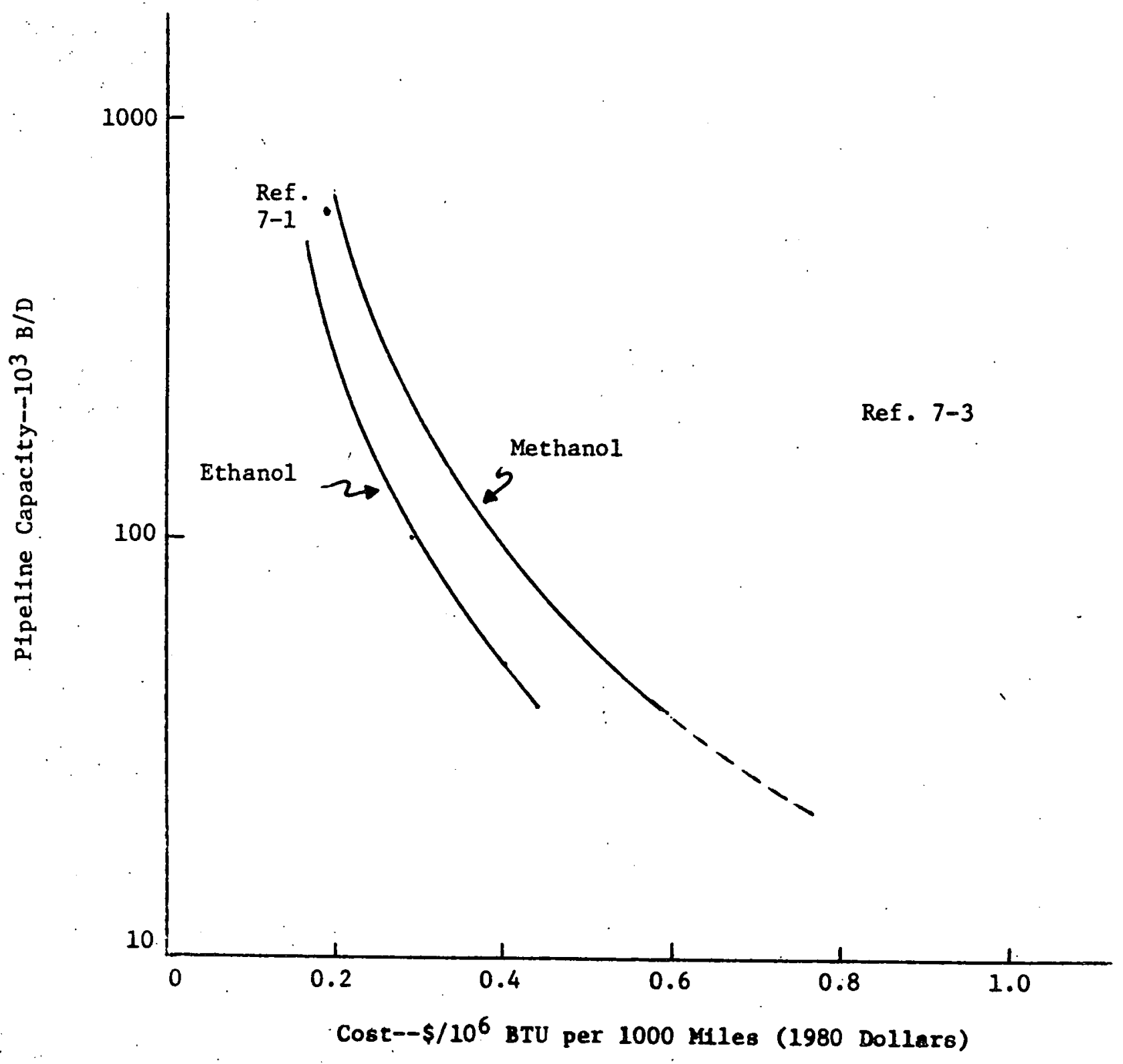


Reference 7-7 of 1.5 and $3 c /$ ton-mile in 1975 dollars for coal. The rates shown in the table have been adjusted to 1980 dollars and to reflect the difference in welght and heating value between coal and methanol. Another mode of transportation would be to move the methanol by barge. This rate Is estimated based on Information in Reference 7-7 for coal.

\subsubsection{Storage and Distribution Cost--Methanol}

The distribution system for methanol will be somewhat different than the shale or coal liquids system described in previous sections since. the methanol does not require refining and can go directly from the synthesis. plant to the bulk terminal. The lower energy density of methanol relative to hydrocarbon will mean that roughly twice the amount of methanol has to be distributed for the same energy output as coal or shale liquids. In addition, the initial distribution system will likely involve movement of methanol by rallroad tank cars to bulk terminals. When market demand has Increased substantially, plpelines can be constructed between the synthesis plant and the bulk terminals.

The cost of transporting the methanol from the synthesis plant to the bulk terminal is covered in Table 7-4 and Figure 7-7. Movement by conventional train, would cost around $\$ 2.44 / 106$ BTU. Movement by pipeline would be around $\$ 0.4 / 106$ BTU. A pipeline capacity of $100 \mathrm{kB} / \mathrm{D}$ represents about elght large plants supplylng the system. If only one or two plants are served by a plpeline, the cost could be around $\$ 0.8 / 106$ BTU.

The storage and distribution costs have been estimated at $\$ 0.73 / 10^{6}$ BTU, based on the cost of storing and distributing petroleum products and adjusting the difference in heating value of the methanol compared to petroleum products. The study by Johnson(7-2) gives the storage cost of methanol, on a cents/gallon basis, as being the same as for distillates.

\subsubsection{Total Delivered Cost to Customer}

The total production, transportation and distribution cost for methanol, produced from elther coal or biomass, is summarized in Figure 7-8. The coal resource based methanol is based on an Illinois coal ( $\$ 2.10 / 106$ BTU). The gasification and methanol synthesis plant could be located 500 miles from the mine with movement of the coal by unit train $(\$ 0.69 / 106$ BTU) or the methanol synthesis plant could be located at the mine site, in which case the coal transportation cost would be on the order of $\$ 0.05 / 106 \mathrm{BTU}$ (coal moved 10 miles by pneumatic line or truck). Another alternate would be to use Western coal, with the gasification and synthesis plant either at the mine site or located in the Midwest. The economics in Section 6.7.1 give the cost of using Western coal to produce methanol.

One possible method of producing methanol from biomass is to use sugarcane and generate a synthesis gas using the Purox process. Collection and transporting the material to the gasification and synthesis 


\section{FIGURE 7-8}

METHANOL PRODUCTION, TRANSPORTATION AND DISTRIBUTION SYSTEM

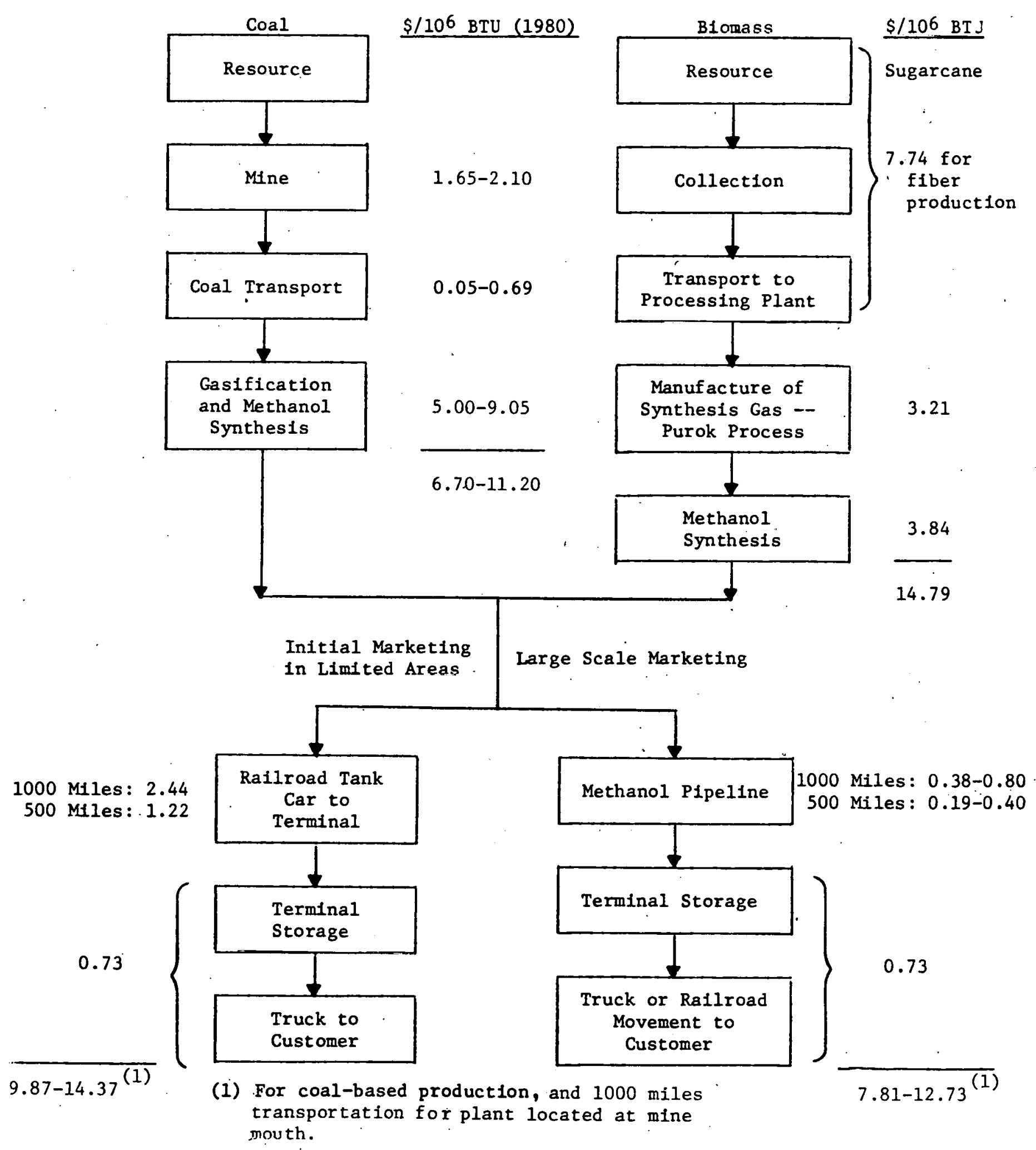


plant could cost $\$ 7.74 / 106$ BTU. The cost of manufacture of the oyngas would be $\$ 3.20 / 106 \mathrm{BTU}$, while the methanol oynthesis cost would be $\$ 3.84 / 106 \mathrm{BTU}$. The total cost of methanol from a $2000 \mathrm{~T} / \mathrm{D}$ plant would be $\$ 14.79 / 106$ BTU. Other methods of producing methanol from blomass are discussed in Section 6.7.2.

The distribution of methanol for non-highway transportation purposes is shown for two different scales of marketing. The initial marketing would most likely be in a few limlted areas and transportation would be by raflroad tank car. It is assumed the terminal would be located $500 \mathrm{mlles}$ from the synthesis plant. Once a large scale marketing system is established, the methanol could move by pipeline to a terminal. The assumed distance is 1000 miles. This could reduce the total cost of the methanol by 8 much as $\$ 1 / 106$ BTU. Distribution and storage costs represent about $16-22 \%$ of the total cost of the delivered methanol.

\subsection{Oxygenated Compound - Ethanol}

\subsubsection{Transportation Costs}

One of the oxygenated compounds of potential interest as a transportation fuel is ethanol. If produced in very large quantities, the fuel could be moved by pipeline. The estimated relationship between pipeline cost and capacity for ethanol is shown in Figure 7-7. The cost of moving ethanol on a BTU/mile basis is slightly less than the cost of transportating methanol, since the heating value of ethanol is intermediate between methanol and petroleum liquids. As was the case with methanol, it will require about $101500 \mathrm{~T} / \mathrm{D}$ ethanol plants to support a $100,000 \mathrm{~B} / \mathrm{D}$ plpeline. For a biomass resource base, it is unlikely that this many plants would be in a given area and near a large pipeline.

If the ethanol were moved by rall, the transportation cost would be about $75 \%$ of that shown in Table 7-4 for methanol, or about $\$ 0.90 / 106$ BTU per 1000 miles for a unit train and $\$ 1.82 / 106$ BTU per 1000 miles for a conventional train, based on the basic rates given by Foster Associates. (7-7)

\subsubsection{Storage and Distribution Costs}

The distribution system for ethanol would probably be similar to that for methanol, except that the ethanol may be produced from grair or waste products. In that case, the distances involved would probably be shorter since it 18 expected that the production facilities will be smaller and more dispersed than a coal-based methanol system. The cost of transporting the ethanol from the synthesis plant to the bulk terminal is covered 1n Table 7-4 and Figure 7-7. If the ethanol moves by conventional rail car, the cost would be around $\$ 1.80 / 106$ per 1000 miles. The distribution cost from the terminal to the user is est1mated at $\$ 0.55 / 10^{6} \mathrm{BTU}$, based on the cost for petroleum products adjusted for differences in heating value.

\subsubsection{Total Dellvered Cost to Customer}

The total production, transportation, and distribution cost for ethanol produced from a corn resource base is shown in Figure ?-9. 
FIGURE 7-9

ETHANOL PRODUCTION, TRANSPORTATION AND DISTRIBUTION SYSTEM

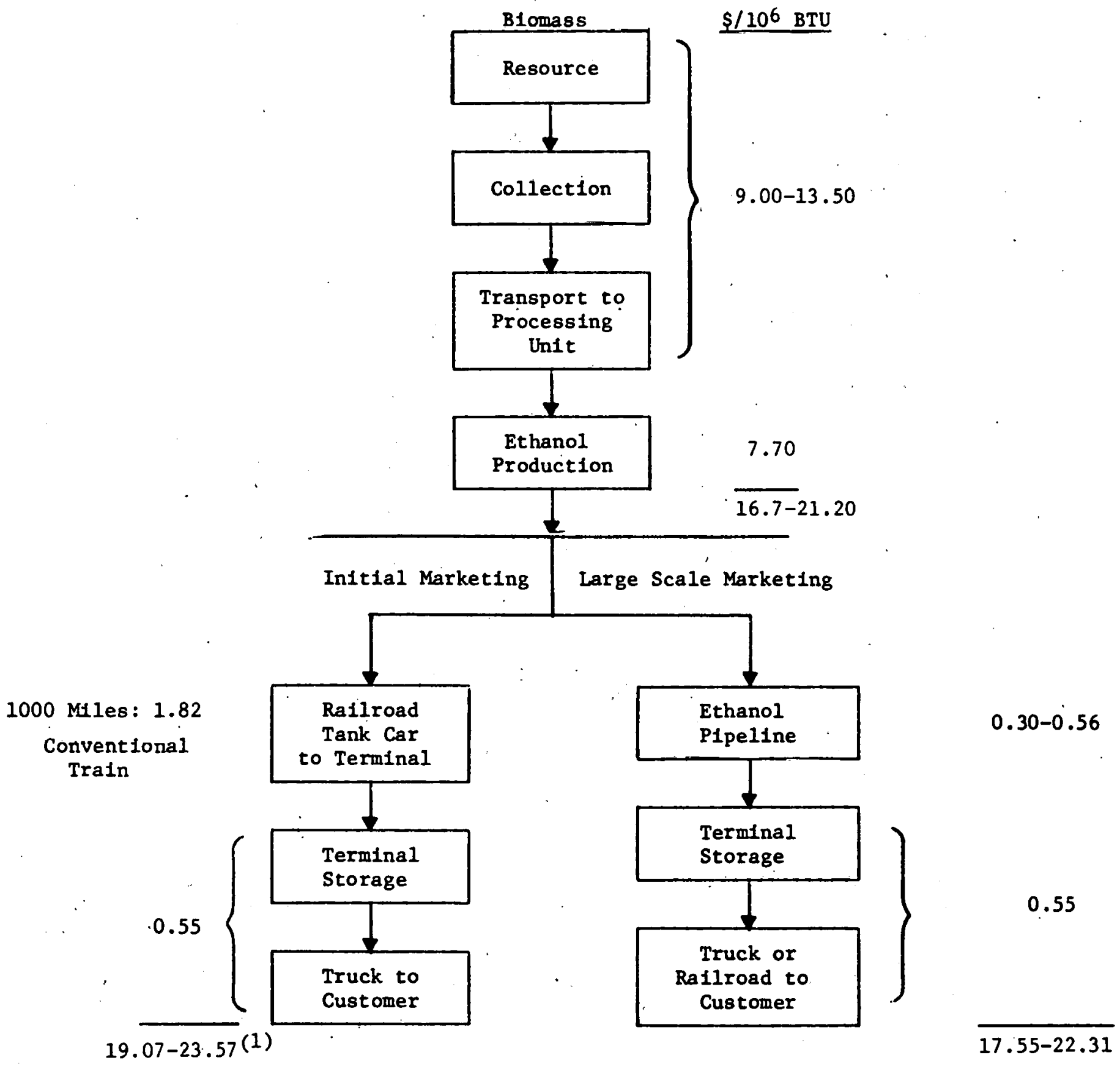

(1) Range reflects different cost of corn $\$ 2.75 /$ bushel to $\$ 3.75 /$ bushel 
In the corn-based system, corn is purchased at an assumed price of $\$ 3.75 /$ bushel or $\$ 13.50 / \mathrm{MBTU}$. The fermentation step raises the total to $\$ 21.20 / 106$ BTU.

The distribution system for ethanol for non-h1ghway transportation is shown for two different scales of marketing. The initial marketing would most likely be in a few limiled areas and the movement of the fuel would be by railroad tank car. It is assumed the production plant is located 1000 miles from the terminal. If a large scale operation were established where a pipeline system could be used, the distribution cost would drop to $\$ 0.30-0.56 / 10^{6}$ BTU. However, with a biomass resource base, it is unlikely that a large scale system would develop. The reduction in cost would be $\$ 1.26-1.52 / 106$ BTU or about a $10 \%$ reduction in cost.

\subsection{Hydrogen}

\subsubsection{Transportation Costs}

Hydrogen can be transported as a gas, as a liquid, or it could be distributed in metal hydride form. However, due to the weight of the metal hydride beds, this particular form is impractical and too costly to be considered for large volume transmission of hydrogen. Table 7-5 summarizes the literature data on the cost of transporting hydrogen by the various modes for both a gaseous and liquid form. The data from the various sources have been adjusted to 1980 dollars and put on a consistent unit basis.

\subsubsection{Gas Pipeline}

It is generally agreed that the most economical and convenient way to move large amounts of hydrogen in the future will be by gas pipeline. (7-15) There is some commercial experience on pipelining hydrogen. Air Products has an 8-inch line, 12 miles long, operating at a pressure of 200 psi in the Houston area. (7-14) A 130-mile pipeline (diameter of 6 to 12 inches) has been distributing hydrogen in Germany for nearly 30 years, at a pressure of about 150 psi.(7-15) Another hydrogen pipeline is 150 miles long and is located in Johannesburg. $(7-14)$ 
TABLE 7-5

SUMMARY OF $\mathrm{H}_{2}$ TRANSPORTATION COSTS

\begin{tabular}{|c|c|c|c|c|c|}
\hline Ref. & $\begin{array}{r}\text { Cost } \\
\$ / 106 \\
\end{array}$ & $\begin{array}{l}-1980 \text { jolla } \\
\text { BTU per } 1000\end{array}$ & $\begin{array}{l}\text { ars } \\
\text { Miles }\end{array}$ & Mode & Comments \\
\hline $7-1$ & - & 0.71 & & Gas Pipeline & $\begin{array}{l}\text { 36-inch diameter--2 billion } \\
\text { SCF/day input }\end{array}$ \\
\hline $7-2$ & & 1.06 & & Gas Pipeline & $\begin{array}{l}1.55 \text { billion SCF/day, 36-inch } \\
\text { diameter pipellne, } 15 \% \text { capital } \\
\text { recovery factor }\end{array}$ \\
\hline $7-20$ & & 1.49 & & Gas Pipeline & $\begin{array}{l}\text { 36-inch diameter pipeline, } \\
0.87 \times 109 \mathrm{SCF} / \text { day }\end{array}$ \\
\hline $7-14$ & & 0.92 & & Gas Pipeline & $\begin{array}{l}36-\text { Inch diameter, } 3.2 \times 109 \\
\text { SCF/D. Hydrogen fuel at } \\
\$ 7.6 / 106 \text { BTU }\end{array}$ \\
\hline $7-24$ & . & 1.12 & & Gas Pipeline & $\begin{array}{l}36-1 \text { nch diameter pipeline, } \\
100 \times 10^{12} \mathrm{BTU} / \mathrm{yr} \text {. Adjusted } \\
\text { for fuel cost to } \$ 7.6 / 10^{6} \mathrm{BTU}\end{array}$ \\
\hline $7-25$ & & 2.91 & & Gas Pipeline & $\begin{array}{l}12 \times 1012 \mathrm{BTU} / \mathrm{yr} \text {. Assumes } \\
\text { electric motor for com- } \\
\text { pression at } 2 \mathrm{c} / \mathrm{kwhr} \text {. }\end{array}$ \\
\hline $7-26$ & & 0.69 & & Gas Pipeline & $\begin{array}{l}\text { Assumes gas is at } 440 \text { psia at } \\
\text { Inlet }\end{array}$ \\
\hline $7-2$ & & 46.7 & & Liquid Pipeline & $\begin{array}{l}\text { 3-Inch diameter pipeline, } \\
550 \times 10^{6} \mathrm{BTU} / \mathrm{hr}\end{array}$ \\
\hline $7-13$ & & 40.15 & & Liquid Plpeline & $\begin{array}{l}\text { Based on } 1000 \text { miles. For } 50 \\
\text { miles, cost would be only } \\
\$ 15.95 / 10^{6} \text { BTU per } 1000 \text { miles }\end{array}$ \\
\hline $7-13$ & & 2.91 & & Railroad & $9165 \mathrm{~kg}$ load ( $\left.34 \times 10^{3} \mathrm{gals}\right)$ \\
\hline $7-15$ & & 8.40 & & Railroad & $\begin{array}{l}\text { Rate for } 100 \text { miles based on a } \\
500 \text { mile trip and freight } \\
\text { rate of } 1 \mathrm{f} \text { per ton miles }\end{array}$ \\
\hline $7-25$ & & 5.82 & & Railroad & $\begin{array}{l}\text { Rate for } 50 \text { to } 200 \text { mile range. } \\
\text { Specific basis in reference }\end{array}$ \\
\hline $7-2$ & & 1.28 & - & Barge & $\begin{array}{l}1800 \times 10^{6} \mathrm{BTU} / \mathrm{hr}, 1.1 \times 10^{6} \\
\text { gal barge }\end{array}$ \\
\hline $7-15$ & & 1.33 & & Barge & \\
\hline
\end{tabular}


$7-25$

Cost - 1980 Dollars

Ref. $\$ / 10^{6}$ BTU per 1000 Miles

7-2

6.34

$7-13$

6.44

$7-15$

7.00

7-25
Mode

Truck

Truck

Truck

Truck
Comments

$62 \times 10^{6} \mathrm{BTU} / \mathrm{hr}, 13 \times 10^{3} \mathrm{gal}$ trailer

11,442 gal tra1ler

13,000 gal trailer. Range depends on cost, inflation (base year not given) 
There have been several studies on converting the existing natural gas system to carry hydrogen. $(7-14,15)$ A study by Gregory(7-14) showed that an unmodified natural gas line would be severely reduced in capacity, to $26 \%$ of its original value, if hydrogen we:re to be substituted without modification; as shown in Table 7-6 below.

TABLE 7-6

RELATIVE CAPACITY OF TRANSMISSION LINE ON HYDROGEN AND NATURAL GAS AT 750 PSIA

\begin{tabular}{|c|c|c|c|}
\hline Gas & $\begin{array}{c}\text { Compressor } \\
\text { Capacity }\end{array}$ & $\begin{array}{l}\text { Compressor } \\
\text { Horsepower }\end{array}$ & $\begin{array}{c}\text { Energy } \\
\text { Delivery Rate }\end{array}$ \\
\hline Natura 1 & 1.0 & 1.0 & 1.0 \\
\hline Hydrogen & $\begin{array}{l}1.0 \\
2.1 \\
3.8\end{array}$ & $\begin{array}{l}0.1 \\
1.0 \\
5.5\end{array}$ & $\begin{array}{l}0.26 \\
0.56 \\
1.0\end{array}$ \\
\hline
\end{tabular}

Source: Ref. 7-14.

This assumes that the compressor efficiency would be unchanged, which is valid only for reciprocating compressors. As shown above, modifications in both the compressor and the engines must be made to recover the original capacity of the line. Turbocompressors would be replaced with customdesigned equipment intended for hydrogen service.

Several in-depth studies have also been made on the cost of a dedicated gaseous hydrogen'pipeline. $(7-14 ; 24,25,26)$ The Institute of Gas Technology (IGT) has made a very complete study on the optimum overall transmission cost for a 1000-mile gaseous hydrogen pipeline.(7-24,7-14) The study by IGT was based on radial turbocompressors designed for hydrogen service, with gas turbine drives, using hydrogen for fuel. Pipeline sizes from 24 to 48 inches were investigated. Operating pressure levels of 750 to 2000 psi were evaluated. The study by IGT considered $\mathrm{H}_{2}$ costs $\$ 2,3$ and $4 / 10^{6}$ BTU, and used a capital recovery factor of $13 \%$. The results presented by IGT were extrapolated to a hydrogen fuel cost of $\$ 10 / 106$ BTU and the investment data adjusted to 1980 dollars and a $15 \%$ capital recovery factor. The original study by IGT optimized the capacity of the system with fuel costs, so an extrapolation to a $\$ 10 / 106$ BTU fuel cost represents a large deviation from the original study. Thus, the cost of transmitting hydrogen as a function of capacity, shown in Figure 7-10, is at best an estimate of the cost to transmit hydrogen under these conditions. The other data on gaseous pipeline costs from Table 7-5 are plotted in Figure 7-10 for comparison. There is general agreement, with two studies showing higher cost. Increasing operating pressure to $2000 \mathrm{psig}$ would reduce the cost, but this is quite an extension from the 150-200 psia operating pressure of current hydrogen pipeline systems. 
FIGURE 7-10

$\underline{\mathrm{H}}_{2}$ GAS TRANSMISSION COST

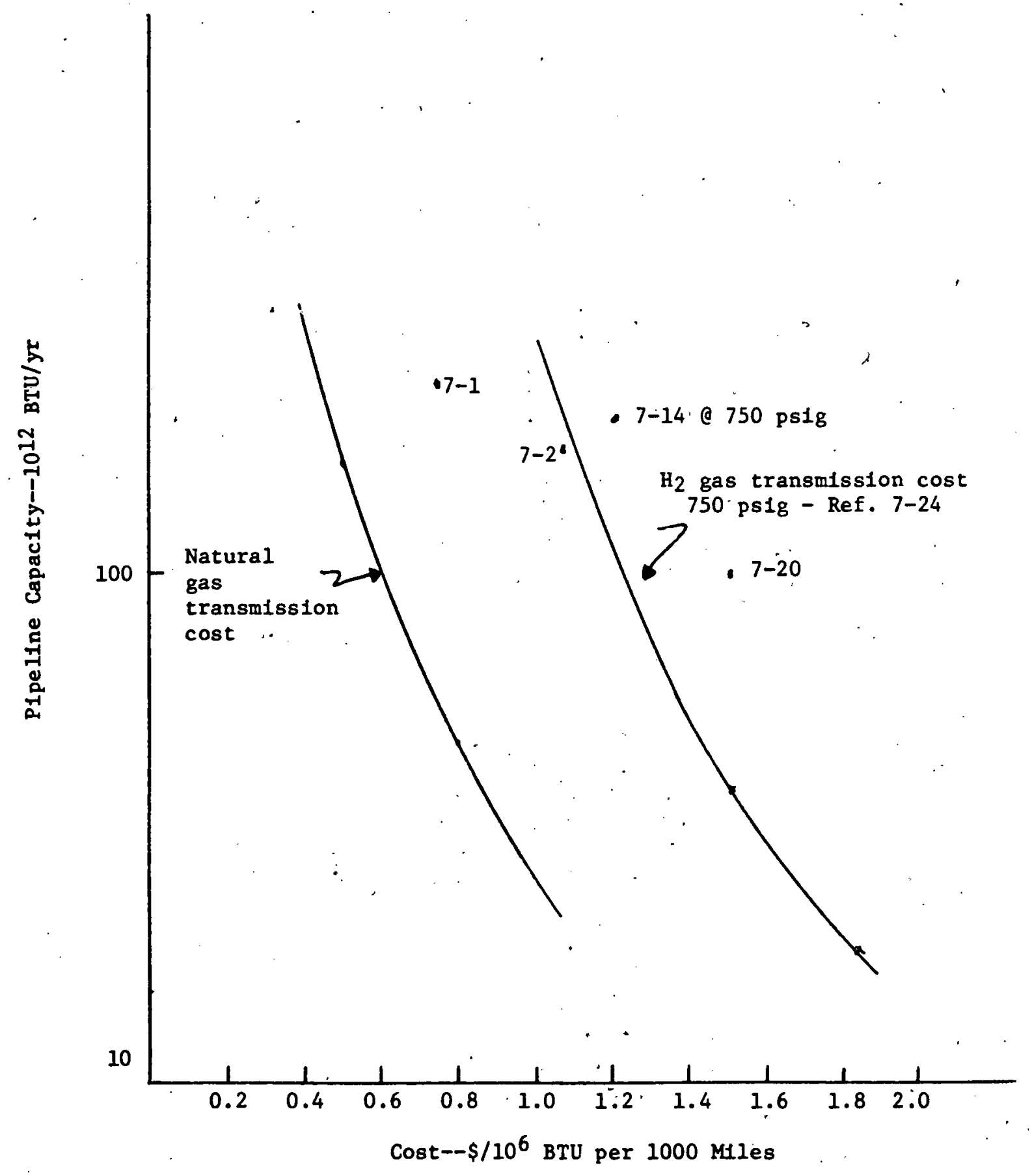


The cost of transmitting natural gas is shown in Figure 7-10 for comparison. The cost of transmitting hydrogen is estimated to cost 2-3 times more than today's natural cost transmission costs. (7-24) For this study the data from Reference 7-24 will be used.

It is interesting to consider the number of hydrogel plants required to support a large plpeline. About elght plants wou d be required to supply $100 \times 1012 \mathrm{BTU} /$ year hydrogen compared to about a single $250 \mathrm{x}$ $106 \mathrm{SCF} / \mathrm{D}$ SNG plant. A single large hydrogen plant (100 x $106 \mathrm{SCF} / \mathrm{D})$ would supply around $12 \times 1012$ BTU, which according to Reference 7-25; would involve a transportation cost of $\$ 2.91 / 10^{6}$ BTU per 1000 miles.

In the economics of transporting gaseous hydrogen, it is assumed that the hydrogen gas is at the initial pipeline pressure. Thus, it is necessary to Insure that the initial cost of compressing the gas to pipeline pressure is included. The gaseous hydrogen produced from coal in Reference 2-45 is at a pressure of $450 \mathrm{psig}$. Therefore, a cost for compressing this from 450 to plpeline pressure of 750 psia must be included in the total cost analysis. A study by IGT(7-25) conteins some information on the cost to compress hydrogen. Adjusting to 1980 dollars and to an electricity cost of $3 \mathrm{c} / \mathrm{kwhr}$, it is estimated that the compression cost would be around $\$ 0.5 / 106$ BTU.

\section{8:1.2 Liquid Hydrogen}

Over one billion gallons of liquid hydrogen has been produced and distributed in support of the space program. (7-2) This 11quid hydrogen has been moved by tank truck and rail. Transport of liquid hydrogen is more difficult and therefore more costly than transport of petroleum fuels because of the necessity of cryogenic facilities.

It is technically possible to distribute liquid hydrogen through. an extremely well insulated cryogenic pipeline. However, as shown in Table 7-5, the costs are very high, in the range of $\$ 40-47 / 10^{6}$ BTU per $1000 \mathrm{mfles}$. Such pipelines would be economical for only very short distances and for very high hydrogen flow rates. For example, in alrcraft application, it may be necessary to move liquid hydrogen underground a mile or $s 0$ from the liquefaction plant to the aircraft fueling station.

The cost to transport liquid hydrogen by railroad, barge and by truck are shown in Table $7-5$. The rail cost reported in Reference 7-13 appears low and the rate given in Reference $7-15$ will be used in this study for rall movement of liquid hydrogen. The cost of barge shipment is comparable to the cost of a gaseous hydrogen pipeline. The cost of truck transport is in the same range as rall--the $\$ 7-8 / 10^{6}$ BTU per $1000 \mathrm{mile}$ range. Reference 7-25 gives additional detalls on the basis for the cost of both rail and truck transportation and how they vary with trip distance.

\subsubsection{Ifterature Studies on Systems Optimižation}

Several studies have dealt with the most economical method to transmit hydrogen. Johnson(7-27) Investigated the supply of liquid hydrogen 
for air transportation. He concluded that gas plpelining was cheaper than barging and that the liquefier should be located at the airport. Sindt $(7-13)$ looked at seven different systems for supplying liquid hydrogen with the hydrogen being produced from water in an electrolyzer. He concluded that the most practical means of supplying liquid hydrogen to users within aboti 50-75 miles of the power plant is probably by truck. If the use is at a single installation, gas pipeline is probably the best choice. If the transmission distance is long, around 1000 miles, he concluded ratlroad delivery is attractive. However, the rall rates used in his study appear to be very low. If the use is by a single consumer, the gas pipeline was the most efficient and practical since the boil-off gas from and 11quid transfer could be reliquefied. Dickson, et al.(7-15) concluded that the most economical and convenient way to distribute large quantities of hydrogen would be by gas pipeline.

\subsubsection{Liquefaction Costs}

For hydrogen to be used as a transportation fuel, it will be necessary to convert the gaseous hydrogen to a liquid form. The major steps in liquefaction of hydrogen are purification, fefrigeration, and conversion/liquefaction. Table 7-7 summarizes the various cost estimates from the literature, after adjusting to a consistent basis. The estimates are for a 250 ton/day size plant. The largest liquid hydrogen plant which has been built and operated had a capacity of 60 tons/day, but this was not strictly a single train plant.(7-28) Accepting a considerable amount of paralleling of equipment, it should be possible to build a 250-TPD plant with a single cold box. Thus, a 2500 TPD liquefaction complex would consist of ten 250 TPD modules. (7-28)

The various cost estimates are fairly consistent, except the costs based on data in Reference 7-25. For this study, the cost given by Union Carbide(7-28) will be used since this 1 s the most recent, detailed study on the economics of hydrogen liquefaction and sufficient information Is provided to allow adjustments to be made.

The power requirements for producing $97 \%$ para hydrogen as a saturated 11quid, starting with gaseous hydrogen at 200 psig was reported at $5.67 \mathrm{kwh} /$ pound. $(7-28)$ This value was adjusted to reflect a feed hydrogen pressure of $700 \mathrm{psig}$, using a correlation presented in the Union Carbide report. The electrical requirements at $700 \mathrm{psig}$, including that required for the ortho-para conversion, would be $4.95 \mathrm{kwh} /$ pound. The 1974 investments were adjusted to a 1980 dollar basis using a chemical equipment index of 1.18 to adjust to 1975 cost and an inflation factor of $7 \%$ per year from 1975 to 1980. Operating cost and maintenance was also adjusted to 1980 costs using the same factors. A $20 \%$ capital recovery factor was assumed, and an electricity cost of $3 \mathrm{c} / \mathrm{kwh}$ was used. This gives a cost of liquefaction of $\$ 4.40 / 106$ BTU. The effect of different assumptions on capital recovery rates is 111 ustrated below:

Capital Recovery

$20 \% \mathrm{CRF}$

$12 \%$ DCF

Ut1lity financing
Cost of LIquefaction-- $\$ / 10^{6} \mathrm{BTU}$

4.40

4.80

4.10 


\section{TABLE 7-7}

SUMMARY OF HYDROGEN LIQUEFACTION COST

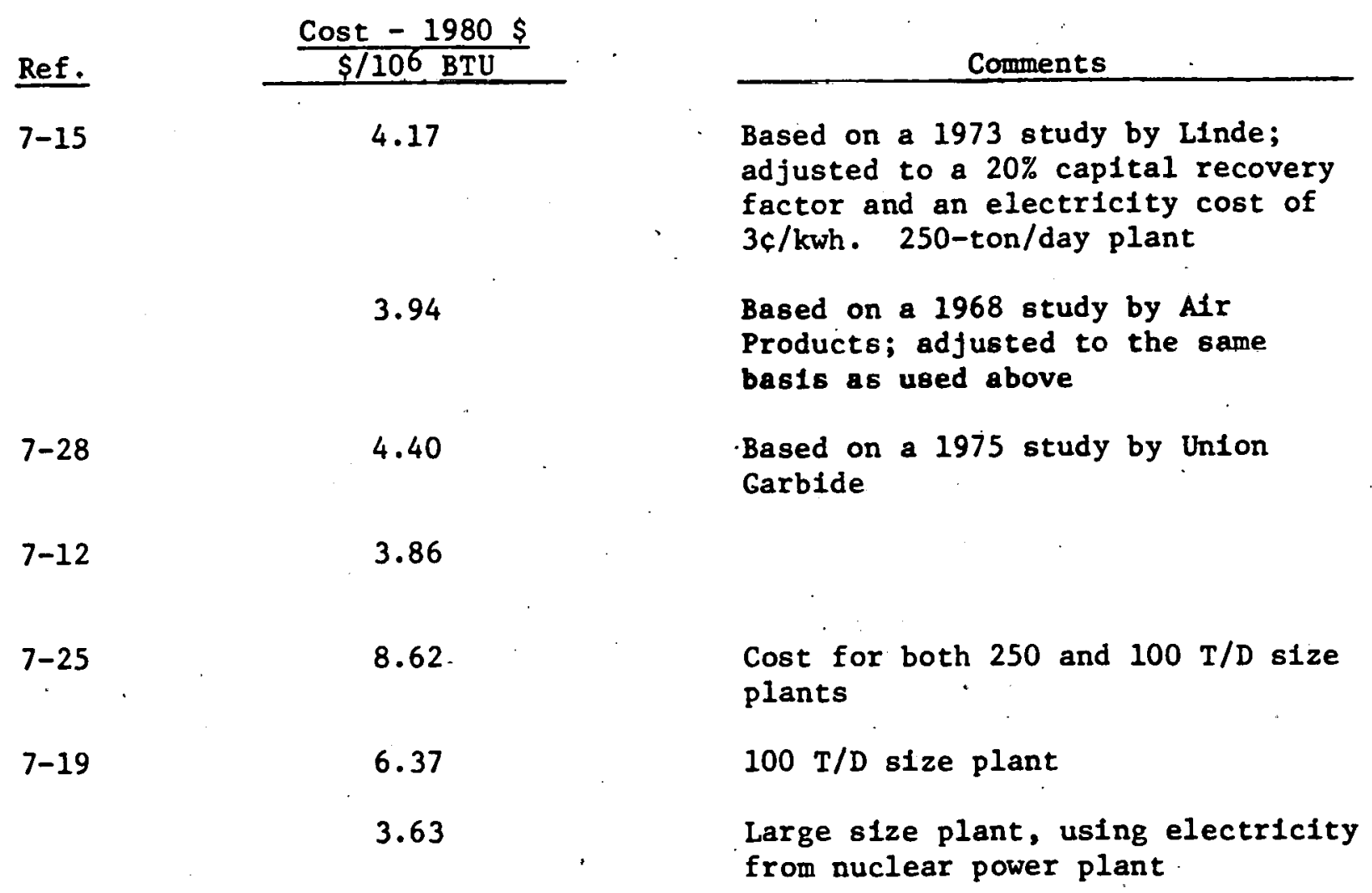




\subsubsection{Distribution Costs for Hydrogen at Major Alrport Fac1lities}

Studies have been made by Lockheed (7-16) and by Boeing Alrplane Company (7-17) on the cost of distributing liquid hydrogen to a hydrogenfueled alrcraft. In the Lockheed study, the San Francisco International Atrport was used as a basis for the analyais and a complete facility was conceptually designed. The facility includes the liquefaction plant, LH2 storage, and LH2 fuel handIIng system. Also, the requirements for ground support and maintenance for the $\mathrm{LH}_{2}$-fueled aircraft were analyzed. Based on the reported investment cost, an estimate of the IIquefaction cost, storage cost, and distribution cost can be obtained. The investment for a $250 \mathrm{~T} / \mathrm{D}$ 11quefaction plant (ex interest during construction, start-up cost and working capital) was $\$ 76.7 \times 10^{6}$ (1980 dollars) in the Lockheed study, compared to $\$ 81.3 \times 10^{6}$ (1980 dollars) for the same size plant reported by Union Carbide in Reference 7-28. The storage cost of around $\$ 5.60 /$ gal is considerably higher than reported in other references. $(7-2,3)$ The storage cost and distribution cost on a $\$ / 106$ BTU basis is 0.27 and 0.07 , respectively. However, in comparing this to the Boeing study, it will be shown that these values appear low.

Boeing evaluated the cost of instaling a liquid-hydrogen ( $\left.\mathrm{LH}_{2}\right)$ supply system at the Chicago $0^{\prime}$ Hare International Alrport. (7-17) The study looked at the cost of installing a hydrogen liquefaction and storage system, as well as the fuel distribution system. The study assumed a dual fueling system ( $\mathrm{LH}_{2}$ or JP fuel) but also considered only a $\mathrm{LH}_{2}$ system. Table 7-8 shows the comparison between the two studies and attempts to put them on a common bas1s. All costs have been adjusted to a 1980 dollar basis. As can be seen, there is a large difference between the two studies on basis and on economics. The Iiquefaction investment was provided by Air Products and is approximately $\$ 100 \times 106$ for a $250 \mathrm{~T} / \mathrm{D}$ size plane. This is a rough estimate since sufficient data are not reported to make an exact comparison. Part of the difference could be due to differences in construction costs in Chicago, compared to San Francisco. Also, Boeing has Included storage $\left(265,000 \mathrm{ft}^{3}\right)$ for gaseous hydrogen in an underground accumulator that will increase the cost. In addition, Dickson(7-15) has reported that the investment for liquefaction plants quoted by Linde (Union Carblde) are usually lower than that quoted by Air Products, but the final cost of liquefaction tends to converge because Air Products assumes a slightly lower electricity consumption rate than Linde.(7-15)

The storage cost, reported by Boelng on a dollar per gallon basis, is also greater than the Lockheed study. The major difference, however, is in the distribution cost, with Boeing reporting a distribution cost over three times greater than Lockheed. For this study, the values reported by Boeing will be used.

\subsubsection{Total Delivered Cost to Customer}

The total production, transportation, and distribution costs for liquid hydrogen produced from coal as the resource base and with hydrogen produced from electricity, with elther coal or uranium as the base resource, is shown in Figure 7-11. 
TABLE 7-8

COMPARISON OF TWO STUDIES ON COST TO

DISTRIBUTE LIQUID HYDROGEN AT MAJOR AIRPORTS

Ref.

Hydrogen Delivery State

Fueling Concept

LH2 Capacity - tons/day

Annual Average Fuel Required - tons/day

Storage Capacity - tons

Capital Required $-\$ 10^{6}(1980 \$)$

Liquefaction \& Pumping - $\$ 106 / T / D$ capacity $(1)$

Storage System(1) - $\$ 106 / T / D(2)$

- \$/gal

- $\$ 110^{6}$ BTU handled(3) (Avg)

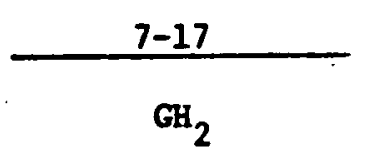

Dual

800

600

1600

0.53

0.077

8.54

0.50

Distribution System

- Hydrogen System Only - $\$ 10^{6} / \mathrm{T} / \mathrm{D}(2)$

- Alrport and Ground

- Total
0.53

0.077

8.54

0.50
1600

$$
\text { - } \$ 10^{6} / \mathrm{T} / \mathrm{D}
$$$$
\text { - } \$ 106 / T / D(2)
$$$$
\text { - } \$ / 10^{6} \text { BTU(3) }
$$

0.24

$\underline{0.08}$

0.32

2.02
$7-16$

$\mathrm{GH}_{2}$

Separate

1000

636

1680

0.40

0.044

5.6

0.27

(1) Includes interest during construction, start-up cost and working capital. Based on $\mathrm{LH}_{2}$ capacity shown.

(2) Based on annual average fuel required.

(3) Based on LHV for hydrogen; $20 \%$ capltal. recovery 'factor and $4 \%$ for operating and maintenance cost. 
FIGURE 7-11

HYDROGEN PRODUCTION, TRANSPORTATION AND DISTRIBUTION SYSTEM

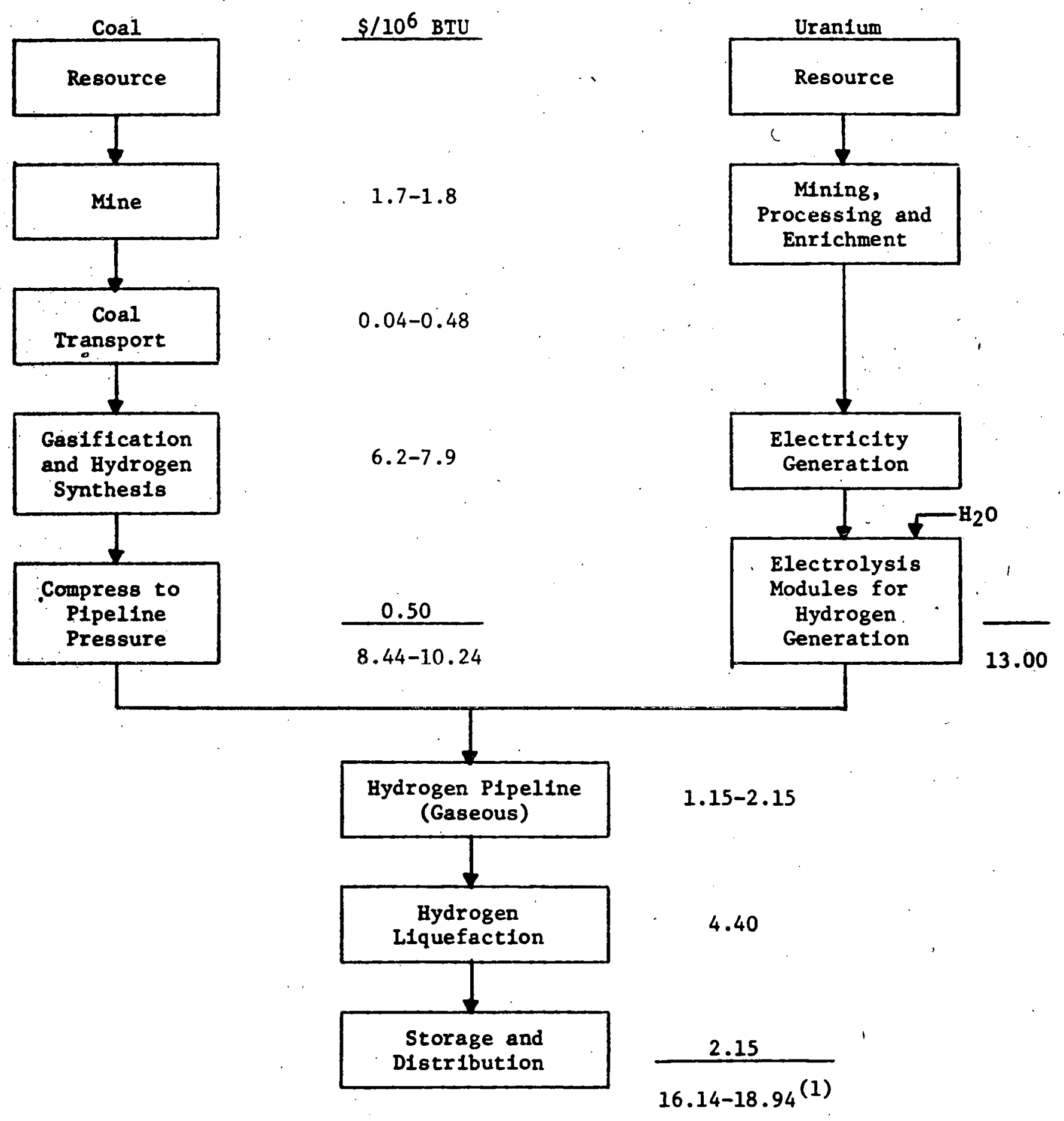

(1) Based on coal resource base. 
As discussed in Section 6.8 .1 , the cost to produce hydrogen from coal via the gasification route $18 \$ 6.2-7.9 / 106$ BTU using $K-T$ coal gasification technology. Th1s cost is based on using Eastern coal, with a coal transportation cost of $\$ 0.04-0.48 / 106 \mathrm{BTU}$, depending on the distance of the plant from the coal mine. Other options are possible, such as mine mouth location of the hydrogen production facilities or the use of Western coal (mine mouth or midwest location).

Hydrogen can also be produced by electrolysis of water, as described in Section 6.8.2. The electricity can be generated from coal or nuclear energy or any of the other advanced technologies being considered. The projected cost is higher, at around $\$ 13 / 106$ BTU. These costs Include compressing the product to $450 \mathrm{psig}$. The cost to increase the pressure to the assumed pipeline pressure of 750 psia is estimated to be $\$ 0.5 / 106$ BTU."

It is assumed that the hydrogen will be transported as a gas in a 1000 mile long pipeline. If the capacity of the line is about $100 \times 1012$ BTU/year (about elght plants of $880 \times 106 \mathrm{SCF} / \mathrm{D}$ capacity each), the transportation cost would be around $\$ 1.15 / 106$ BTU. If the line was supplied by a single large plant $(100 \times 106 \mathrm{SCF} / \mathrm{D})$, the transportation cost would increase to around $\$ 2.20 / 106 \mathrm{BTU}$. For the alrport requirements described in Table $7-8$, two $100 \times 10^{6} \mathrm{SCF} / \mathrm{D}$ size plants would be required, which would mean a pipeline cost of around $\$ 1.70 / 106$ BTU.

It is assumed that to be usable as a transportation fuel, it will be necessary to liquefy the hydrogen for storage on board a vehicle of some type. This will add $\$ 4.40 / 10^{6}$ BTU to the cost of the hydrogen. Storage and distribution cost for an afrcraft type application would add around $\$ 2.15 / 106 \mathrm{BTU}$, bringing the total dellvered cost to about $\$ 18-19 / 106$ BTU for hydrogen from coal. Hydrogen from electrolysis of water would be even more expensive.

In the case of liquid hydrogen, non-production costs are around half of the total cost of the delfvered product to the customer. This is considerably greater than for coal or shale-derived liquids.

\subsection{Methane}

\subsubsection{Transportation Costs}

Methane would be transported to a liquefaction plant via pipeline. Methane could also be Imported as ING by tanker, but the aim of this study is to concentrate on domestic supplies. The cost of transmitting gases by pipeline will depend on the distance, volume moved, pressure of the pipeline system, terrain to be crossed, acceptable rate of return, etc. Gas pipelines are highly capital intensive, with about $90 \%$ of the costs fixed and $10 \%$ operating and maintenance cost, partlally constant and partlally variable depending on throughput. $(7-22)$ The cost of pipeline transmission is very sensitive to the load factor. Table 7-9 summarizes the literature data on gas transmission cost for a gas with a heating value of $1000 \mathrm{BTU} / \mathrm{SCF}$. The 1iterature data were adjusted to a 1980 dollar basis. 
TABLE 7-9

SUMMARY OF METHANE TRANSMISSION COST

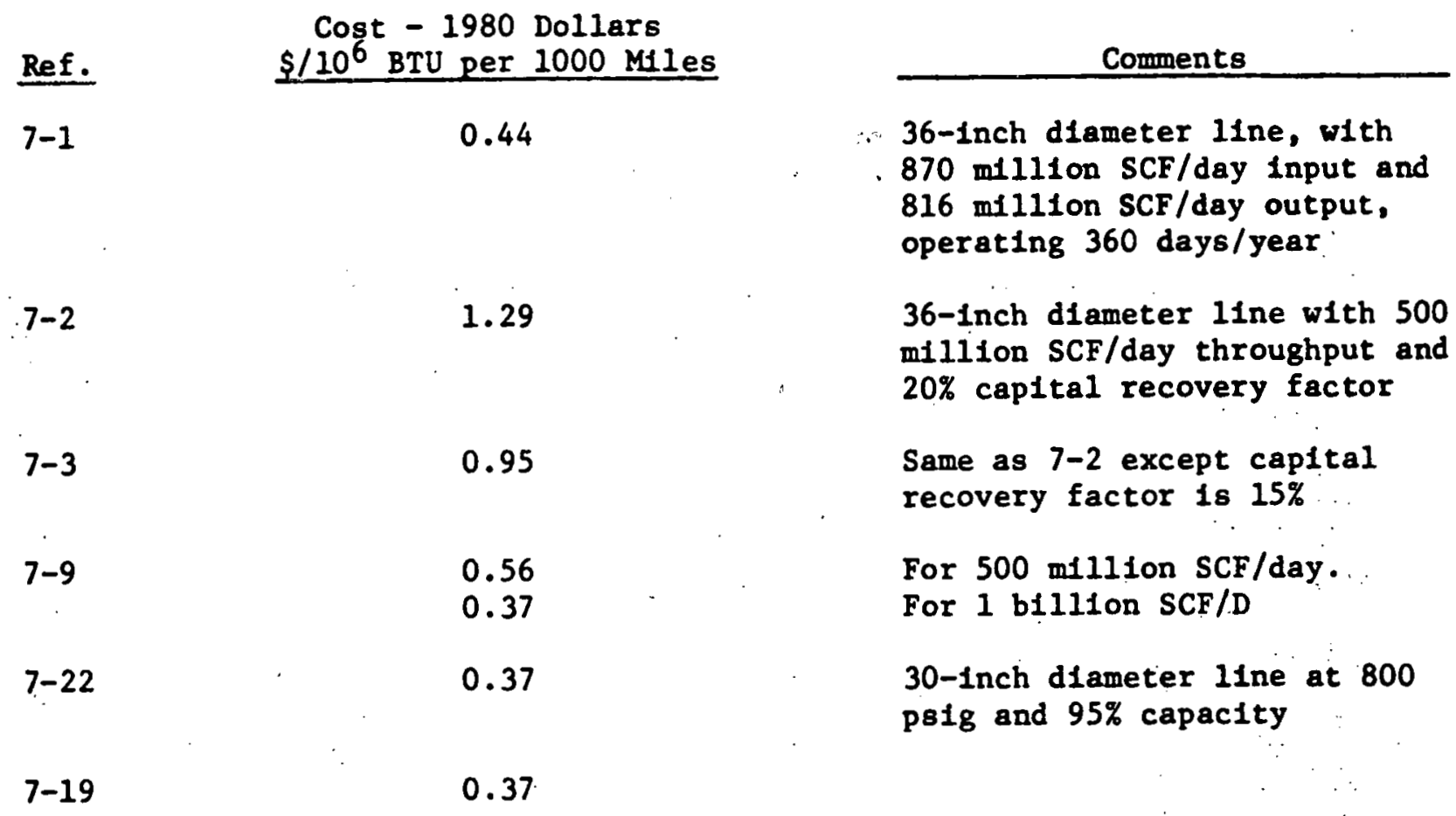


A study by Nagarvala, et al. (7-20) derived the cost of an interreglonal pipeline transmission cost for gas pipelines--as a function of pipeline capacity. Figure 7-12 shows how the cost of transmitting methane by pipeline varies with throughput. A $15 \%$ capital recovery factor is assumed in this figure. The other literature data points are in general agreement with the curve calculated from Reference 7-20, except for Reference 7-3.

\subsubsection{L1quefaction Costs}

To use methane as a transportation fuel for any mode where the fuel must be carried on board the vehicle, the methane will need to be liquified. Table 7-10 sumnarizes the cost of ilquefying methane, based on literature data, and adjusted to a common basis.

TABLE $7-10$

METHANE LIQUEFACTION COST

\begin{tabular}{|c|c|c|}
\hline Ref. & $\begin{array}{c}\text { Cost--1980 Dollars } \\
\$ / 10^{6} \mathrm{BTU}\end{array}$ & Comments \\
\hline $\begin{array}{l}7-29 \\
7-12 \\
7-19\end{array}$ & $\begin{array}{l}2.03 \\
1.83 \\
3.02\end{array}$ & $\begin{array}{l}250 \times 106 \mathrm{SCF} / \mathrm{D} \text { plant } \\
10 \times 106 \mathrm{SCF} / \mathrm{D} \text { plant }\end{array}$ \\
\hline
\end{tabular}

The basic cost of liquefaction used in this study is based on the article by DiNapoli.(7-29) The direct capital cost items include the 11quefaction and utilities section, but exclude any storage facilities. Based on the data from DINapoli, (7-29) the Indirect costs were taken at $41 \%$ of the direct cost and a $15 \%$ contingency was used. Owners' costs of $35 \%$ of the total erected costs were also included. Other bases used in arriving at the $\$ 1.91 / 106$. BTU were:

- $20 \%$ capital recovery factor (basis for this study).

- Operation and maintenance costs at $6 \%$ of initial investment per Ref. 7-29.

- Fuel requirement of $13 \%$ of the feed volume and a feed cost of $\$ 5.15 / 10^{6}$ BTU. (7-29)

- 320 days per year operation and an $86 \%$ overall production efficlency. $(7-29)$

\subsubsection{Storage and Distribution Costs}

If methane is used as a transportation fuel, it would need to be liquefled and move as a liquid. If used as an aircraft fuel, it is assumed that the methane would be moved to the alrport as a gas and then 
FIGURE 7-12

COST OF TRANSPORTATING METHANE BY PIPELINE

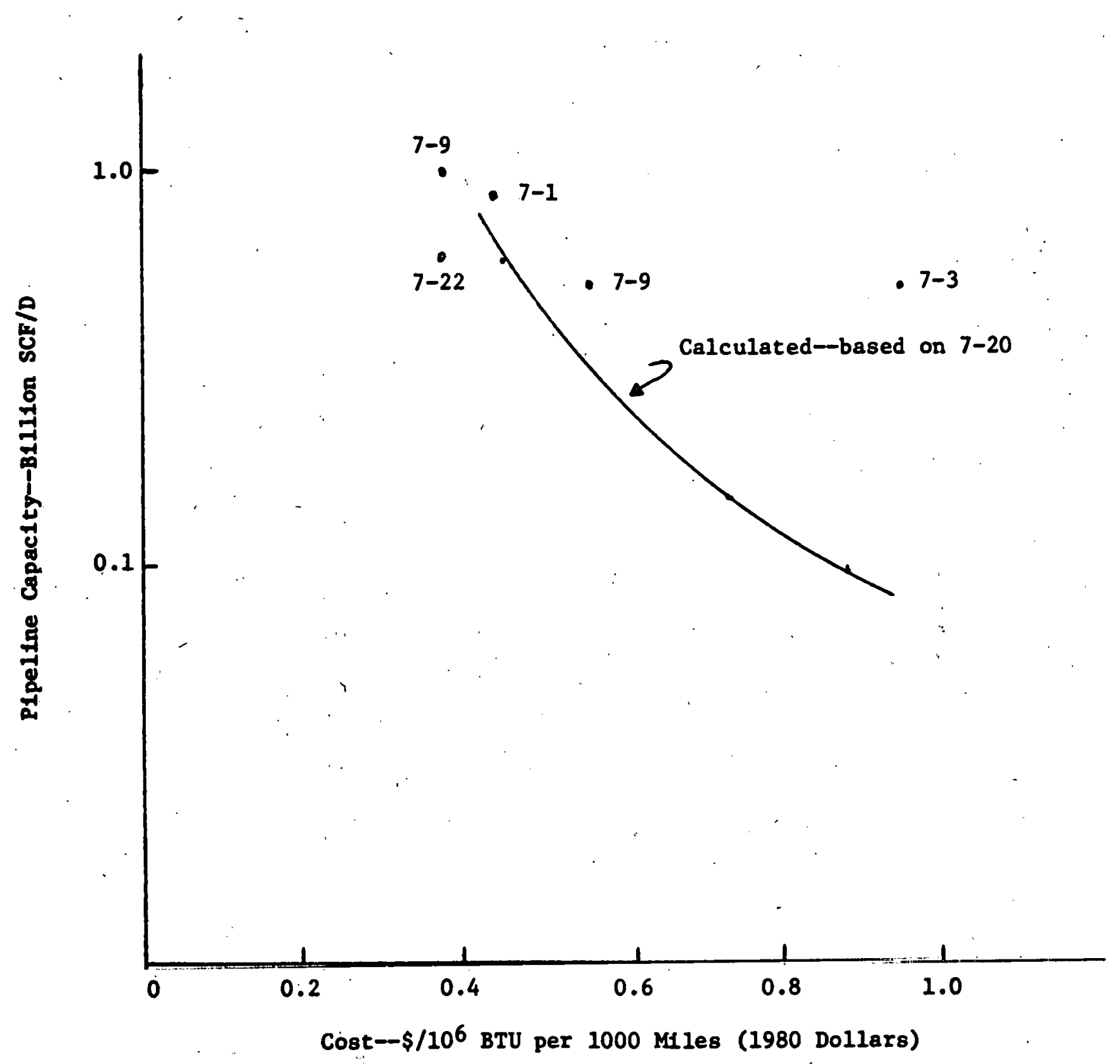


11quefied at the afrport. In thls case, the added cost of LNG storage and loading facilities would add about $\$ 0.15 / 106$ BTU to the 11quefaction cost, based on data in Reference 7-29. As a first approximation, the distribution costs within the airport will be assumed at $50 \%$ of the cost of the storage and distribution costs for liquid hydrogen or $\$ 1.10 / 106$ BTU. Information in Reference 7-33 shows this for the study Rand made for the Alr Force, comparing liquid hydrogen and liquid methane.

If IIquid methane is moved by tank truck to the customer, the distribution costs would be as follows:

$$
\$ / 10^{6} \text { BTU }(1980 \$)
$$

LNG Storage and Loading Cost 0.15

Marketing Cost 0.13

Tank Truck to Customer Over $\quad 0.84$ 250 Mile Radius

1.12

The tank truck delivery cost is based on Reference 7-19, adjusted to a 1980 dollar cost basis.

\subsubsection{Total Delivered Cost to Customer}

The total production, transportation, and distribution cost for liquid methane produced from coal as the resource base and from sewage algae 18 shown in Figure 7-13.

As discussed in Section 6.11.1, the cost to produce methane from coal via gasification is $\$ 6.20-8.80 / 106$. Th1s cost is based on using Eastern cosl at $\$ 21 /$ ton, ex. any coal transportation cost of $\$ 0.08-0.88 / 106$ BTU, depending on the distance of the gasification plant from the mine. The \$0.08/106 BTU:represents a SNG plant near the mine (10 miles), while the higher number represents moving coal by unit train 500 miles. Western coal could also be used with slightly different economics.

Methane can also be produced from biomass. Production costs from aneroblc fermentation or an advanced pyrolysis process is shown on the right-hand side of Figure 7-13. The $\$ 4.60 / 106$ feedstock costs include a transportation cost. The total cost of methane from this route is more expensive than from the coal resource base.

It 18 assumed that the SNG will move 1000 miles by pipeline at a cost of $\$ 0.4-0.6 / 106 \mathrm{BTU}$, depending on the throughput of the transportation system. Liquefaction will add $\$ 2 / 106$ BTU to the cost of the fuel. The distribution cost for liquid methane for an aircraft type application Is estimated to be an additional $\$ 1.10 / 10^{6} \mathrm{BTU}$, bringing the total delivered 
FIGURE 7-13

METHANE PRODUCTION, TRANSPORTATION AND DISTRIBUTION SYSTEM

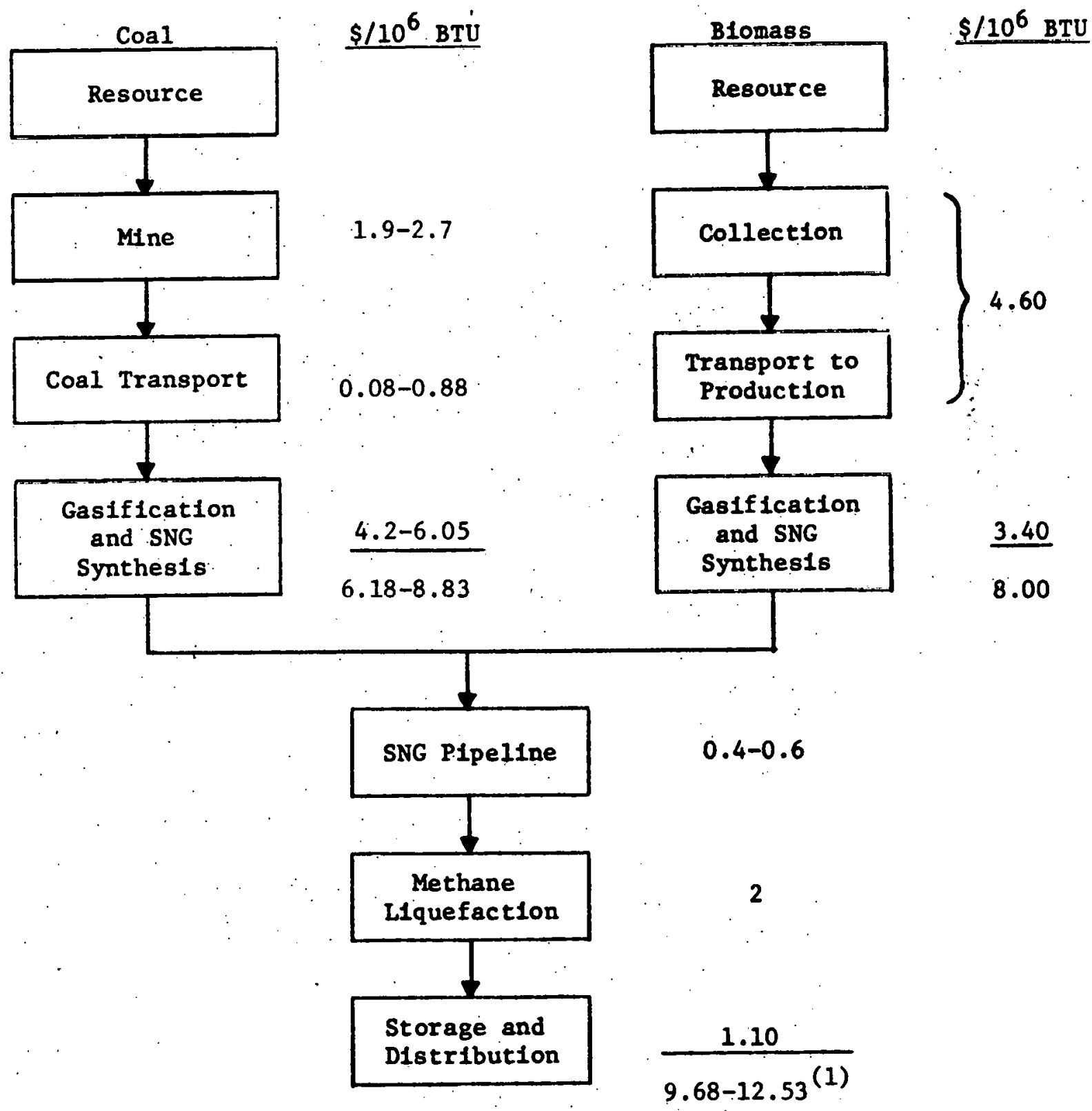

(1) Based on a cosl resource. 
cost to the customer to the $\$ 10-12.50 / 10^{6}$ BTU range. Distribution, 1iquefaction and storage costs represent around a third of the total cost, with the production of the SNG from coal representing around two-thirds of the total cost.

\subsection{Ammonia}

\subsubsection{Transportation Costs}

Production of ammonia for fertilizer has reached a scale of distribution in whiah large interstate plpelines are now operating in addition to the extensive barge, rail, and truck systems that have been built to achieve economical distribution. (7-4) A summary of the costs assoclated with several methods of transporting liquid ammonia is given in Table 7-11. The most economical way to move large volumes of ammonia would be by plpeline. The estimated relationship between pipeline cost and capacity for ammonia is shown in Figure 7-14, based on the curve shown in Figure 7-4, adjusted for the net heating value difference between petroleum distillate and ammonia. As would be the case for methanol, the location and number of plants near the pipeline would determine the size and capacity of the line. For example, it would take seven (7) $2000 \mathrm{~T} / \mathrm{D}$ ammonia plants to feed a pipeline with a 100,000 B/D capacity.

The next most economical mode of transportation for ammonia would appear to be by barge, If navigable waterways are available. The barge rate for ammonia is based on Reference $7-7$, based on $\$ 0.85 /$ ton mile for coal. Since a different type of barge would be required, the rate for ammonia would probably be greater than the $\$ 1.23 / 10^{6}$ BTU per 1000 mlles shown.

The ammonia could also be transported by rall. Rates for a unit train and a conventional train are shown in Table 7-11, based on rail rates for coal, adjusted to 1980 dollars and to reflect the difference in welght and heating value between coal and ammonia.

\subsubsection{Storage and Distribution Costs}

The cost of storing ammonia will depend on whether the amonia is stored with full refrigeration, partial or if stored under full pressure. Reference 7-2 reports an ammonia storage cost that is 2.85 times more expensive than the basic cost for distillates and fuel ofl. It is assumed that this cost is for full refrigeration, but the cost of refrigeration would have to be added to this value. This cost would depend on evaporation loss and geographical location. Storage under full pressure conditions could cost up to 6.3 times more than full refrigeration costs. The estimated storage and distribution cost is as shown on page 7-43.

If the storage was under full pressure conditions, the total cost would Increase to around $\$ 5 / 106$ BTU. 
TABLE 7-11

SUMMARY OF AMMONIA TRANSPORTATION COST

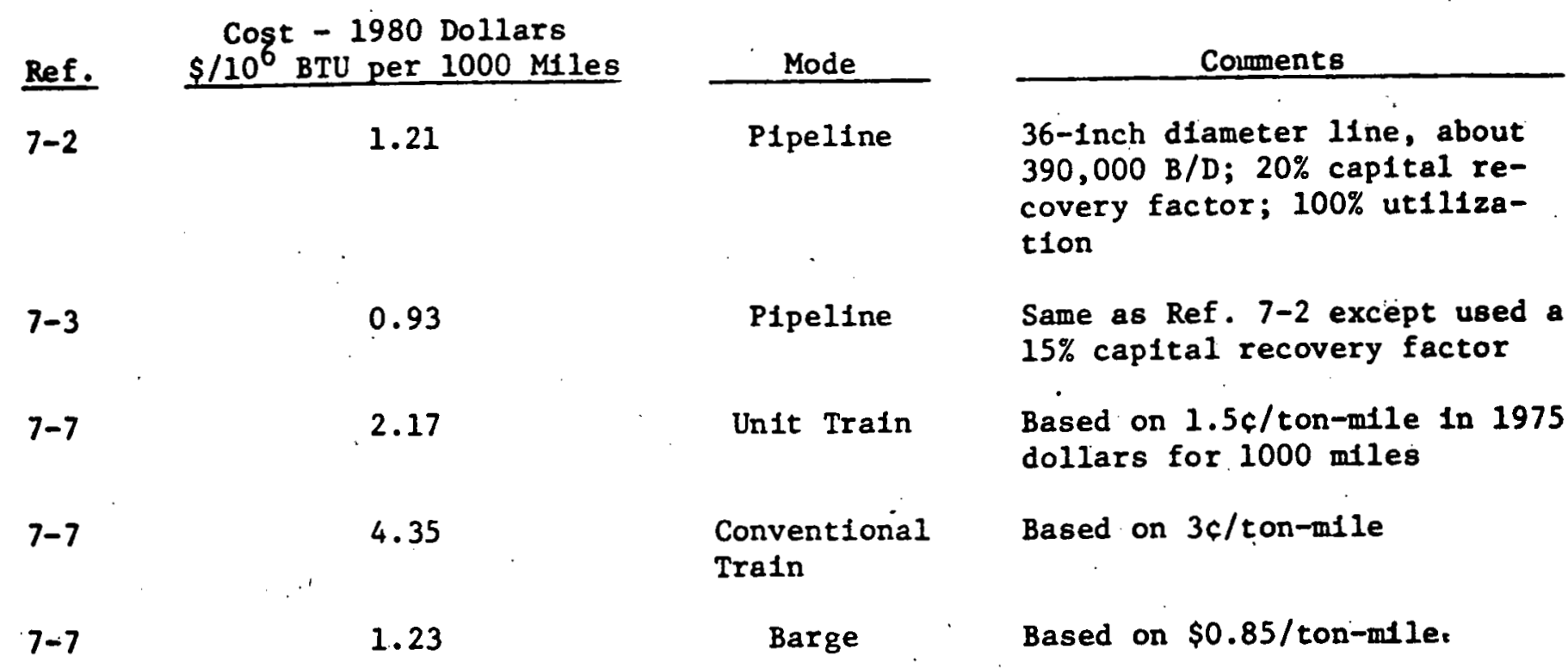




\section{FIGURE 7-14}

COST OF MOVING LIQUID AMMONIA BY PIPELINE

(BASED ON FIGURE 7-4, ADJUSTED POR HEATING VALUE)

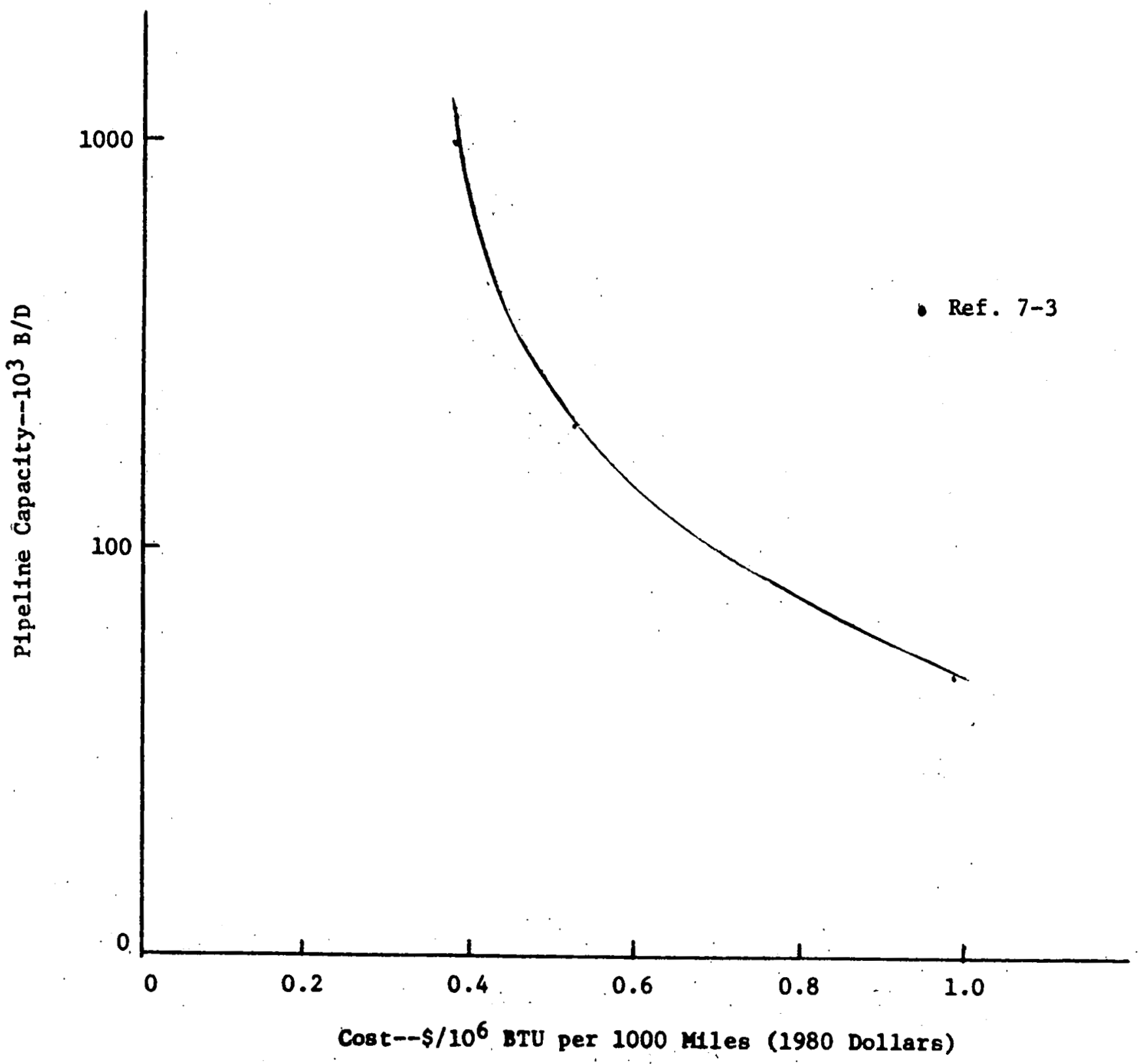




\section{$\$ / 10^{6}$ BTU (1980 Dollars)}

Terminal Operating Cost

Marketing Cost (assumed same as for petroleum on a dollar/barrel basis)

Movement to Customer by Conventional Train (500 miles)

Capital Recovery on Storage
0.29

0.60

2.18

$\underline{0.30}$

\subsubsection{Total Dellvered Cost to Customer}

The total production, transportation and distribution cost for ammonia produced from coal or biomass is shown in Figure 7-15.

As discussed in Section 6.9.1, the cost to produce amonia from coal gasification is around $\$ 12-13 / 10^{6} \mathrm{BTU}$. This cost is based on using Eastern coal at $\$ 21 /$ ton, with a coal transportation cost of $\$ 0.07-0.767$ $10^{6} \mathrm{BTU}$, depending on the distance of the ammonia synthesis plant from the mine. The $\$ 0.07 / 106$ BTU represents a location near the mine (10 miles), while the higher cost represents moving coal by unit train 500 miles.

Ammonia could also be produced by sugarcane via the Purox gasif 1 cation route, with the cost being higher, around $\$ 18 /$ ton.

It is assumed the ammonia would be moved by pipeline 1000 miles at a cost of $\$ 0.4-0.8 / 106$ BTU, the range representing a plpeline capacity of $600 \mathrm{~KB} / \mathrm{D}$ to $80 \mathrm{~KB} / \mathrm{D}$. Terminal storage and distribution to the customer would add about $\$ 3.40$ to the cost, bringing the total cost to around \$16-17/106 BTU for a coal-based system and $\$ 22 / 106$ BTU for a b1omass(sugarcane) based system.

\subsection{More Exot1c Fuels}

Literature information on the transportation and storage cost of the more exotic fuels, acetylene, hydrazine, and methylamine was not avallable. A rough approximation has been made for each of the fuels for the preliminary screening.

\subsubsection{Acetylene}

\subsubsection{Transportation Costs}

The cost of shipping acetylene adds considerably to 1ts costs because It cannot be transported in liquid form or as a free gas under high pressure. The normal means of transportation is in special cylinders, 
FIGURE $7-15$

AMMONIA PRODUCTION, TRANSPORTATION AND DISTRIBUTION SYSTEM

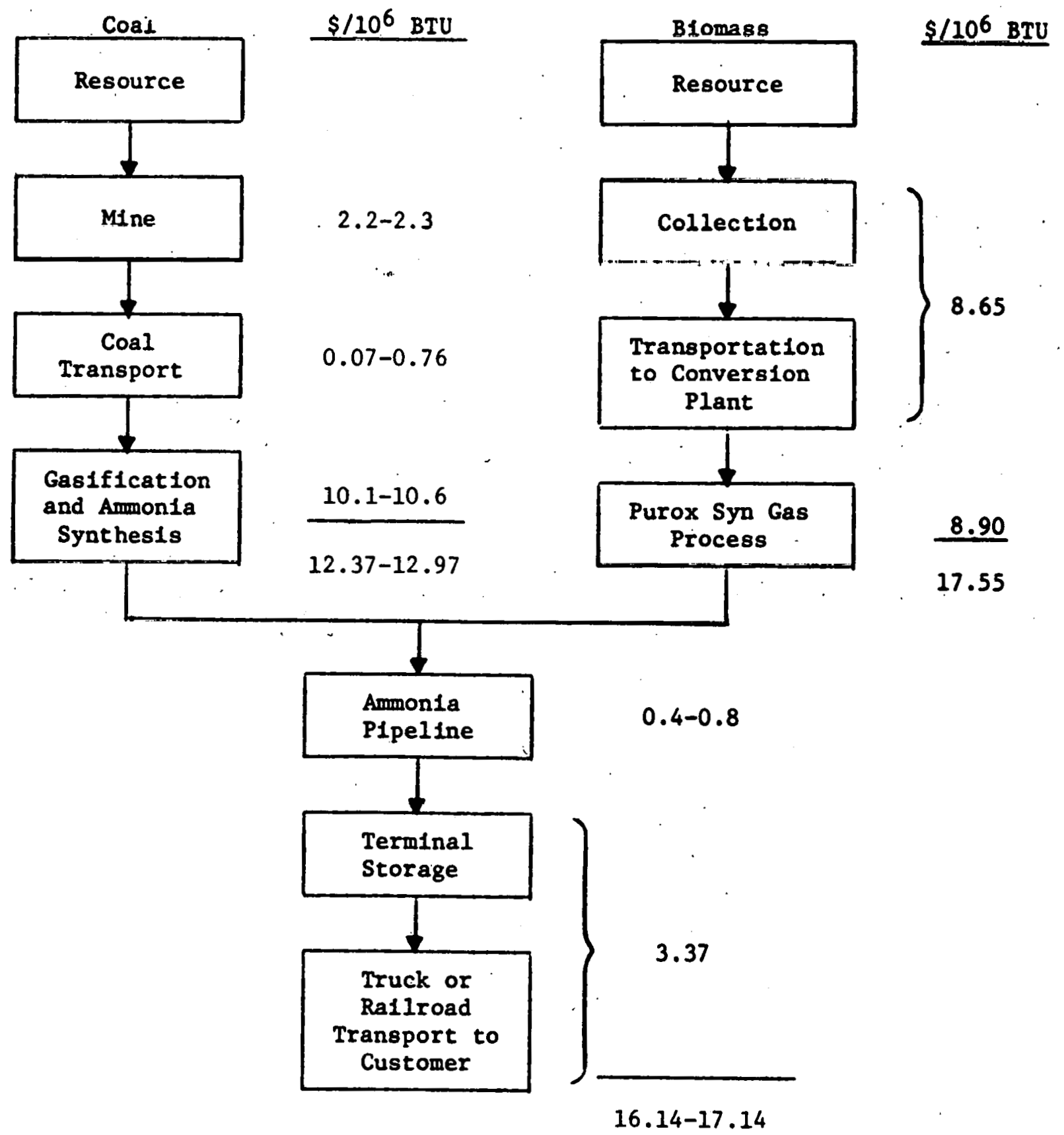

(1) Based on coal resource. 
dissolved in acetone at about 250 psi pressure. However, this is a very inefficient means of transportation since the dissolved acetylene in the acetone represents less than $10 \%$ of the total shipping weight. Considering that the empty cylinder must be returned, the net efficiency of shipping is less than $5 \%$ of the gross weight.(7-30) Assuming a rall freight rate of $4.2 \mathrm{c} /$ ton-mile (1980 dollars), the freight cost would be greater than $\$ 20 / 106$ BTU per 1000 miles. The actual rate is 11kely to be more than this, since the base freight rate used was for coal. The rate for acetylene cylinders is set by the ICC and depends on many factors. As a rough approximation, the above rate will be used.

According to Kirk-Othmer, the cheapest form of transporting acetylene by comon carrier is by shipping the calcium carbide in metal drums and then generating the acetylene onsite from the reaction between calcium carbide and water. One reference $(7-30)$ states that calcium carbide gives off acetylene equal to about $31 \%$ of its weight. Assuming a rail freight rate of $4.2 \mathrm{c} / \mathrm{ton}-\mathrm{mile}$ in 1980 dollars, the freight rate for the calcium carbide and contalner would be around $\$ 3.60 / 106$ BTU of acetylene per 1000 miles. This is probably the lowest the transportation cost will be, since the actual freight rate for calcium carbide in drums is probably higher than the assumed rate.

\subsubsection{Storage and Distribution Costs}

Lfterature data were not avallable on the storage or distribution costs for calcium carbide. For the preliminary screening, some rough approximations will be made to get an order-of-magnitude estimate for storage cost. It is assumed that the transportation will be by rail freight from the point of manufacture to a warehouse storage terminal at the rate shown above. The calcium carbide would be stored in metal drums, holding 100 or 220 pounds per can. The cost of the terminal for the solids could run up to $\$ 1 / 106$ BTU of acetylene, depending on turnover rate of the inventory, investment cost of the terminal, terminal space utilization, etc.

\subsubsection{Total Delivered Cost to the User}

The production, transportation and distribution cost for acetylene as produced from calcium carbide and water 1s. shown in Figure 7-16. The calcium carbide is produced from Eastern coal at a total cost of around $\$ 14 / 106$ BTU. It 1 s assumed that the calcium carbide is shipped by rail to a warehouse located 1000 miles away from the production facilities. Warehouse handling costs are estimated to be at least $\$ 1 / 106$ BTU and probably greater. The total delivered cost to the user. Wlll thus be in excess of $\$ 19 / 106$ BTU.

\subsection{1 .2 Hydrazine}

Hydrazine is dangerous to transport in the undiluted state and Is normally transported as a hydrate, $\mathrm{N}_{2} \mathrm{H}_{2} \cdot \mathrm{H}_{2} \mathrm{O}$, or fuming liquid that can be dissolved in water for additional safety in handing. (7-3i) Assuming a rall freight cost of $4.2 \mathrm{c} /$ ton-mile (1980 dollars) the freight cost would 
FIGURE $7-16$

ACETYLENE PRODUCTION, TRANSPORTATION AND DISTRIBUTION SYSTEM

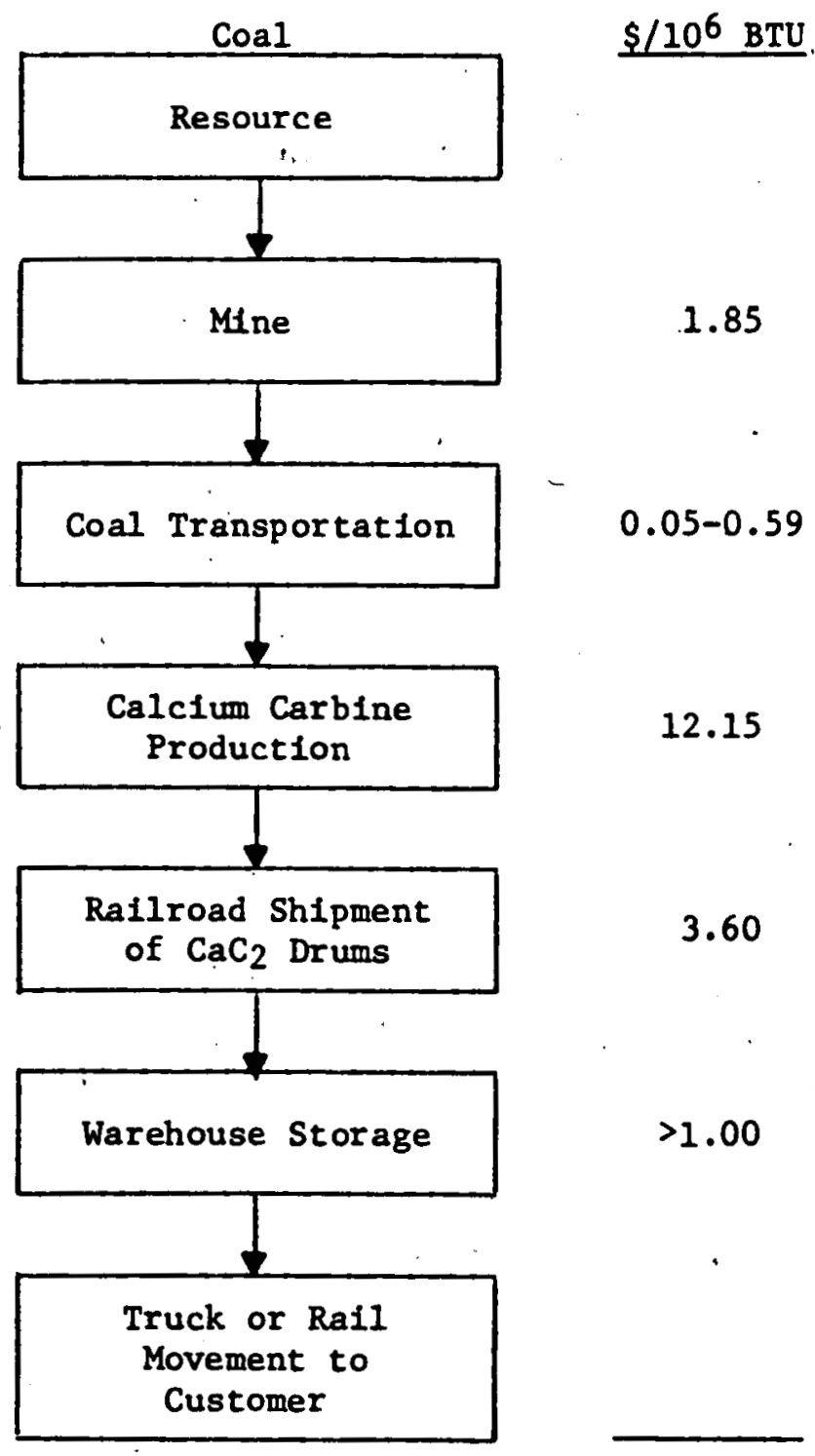

$>18.65$ 
be a minimum of $\$ 3.25 / 106$ BTU per 1000 miles, and probably much higher than this. In addition, storage and distribution costs would be added to this. If hydrazine is selected as a fuel for further study, it will be necessary to contact companies handling the material to obtain a cost of distribution and shipping.

\subsection{1 .3 Methylamine}

Methylamine is normally sold as an aqueous solution containing $25-40 \%$ amine by weight or as an anhydrous 11quid. The aqueous solution can be shipped in iron drums or tank cars and the anhydrous amine in steel cylinders or ammonia-type tank cars. Assuming a frelght rate of $4.2 \mathrm{c} / \mathrm{ton}$ mile (1980 dollars), the transportation cost for methylamine would be $\$ 1.63 / 106 \mathrm{BTU}$ per 1000 miles, assuming anhydrous material, which probably represents a minimum value. Storage and distribution costs would be additive to the above value.

The distribution, production and transportation costs are summarized in Figure 7-17. These estimates are very rough, due to the lack of detalled information on the cost of production of hydrazine. It would... appear that the major cost of producing hydrazine is associated with manufacturing, not the transportation or distribution.

\subsection{Electricity}

\subsubsection{Transmission}

Electricity is transmitted through power lines operating at various voltages typically ranging from 115 to $766 \mathrm{kV}$. The highest voltage lines are designed to handle the largest power loads and the longest transmission distances. Transmission costs refer to moving of electric power from the generating station to a major load center. It w1ll also be necessary to consider the cost of distributing the electricity to the consumer. Table 7-12 summarizes the 11terature data on electric

3 transmission costs. All data have been adfusted to a 1980 dollar basis. Transmission costs vary considerably depending on capacity, distance, and terrain. Even lines with the same nominal voltage may have widely different costs. (7-6) The following 1llustrates how transmission costs may vary with capacity.

Capac1ty - KV

138

230

345

500

765
Cost--1980 Dollars $\$ / 10^{6}$ BTU per 1000 miles-Overhead Lines

Ref. 7-6 Ref. 7-20

12.31

5.79

6.15

4.32

3.69

1.65

1.65
3.44

2.71

1.88

The data in Reference 7-20 is reported for optimum line loading and are therefore expected to be lower than actual cost ince few systems operate optimally at all times. 
FIGURE $7-17$

HYDRAZINE PRODUCTION, TRANSPORTATION AND DISTRIBUTION SYSTEM

Coa 1

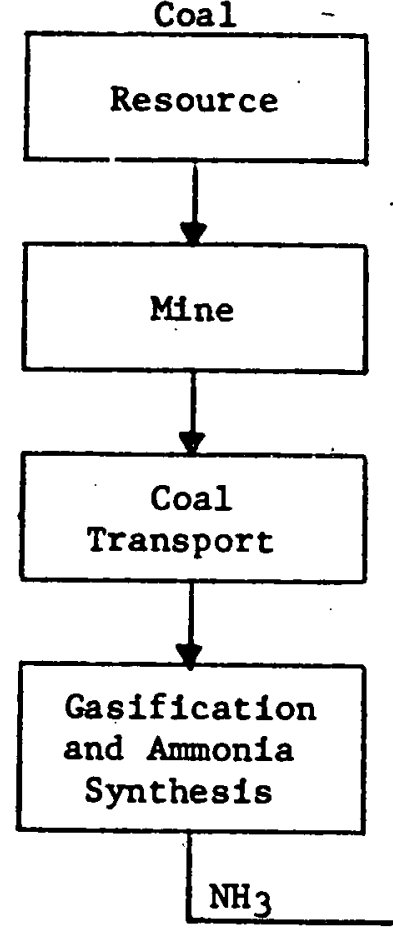

Sod1um

Hypochlorite

Manufacture

$\mathrm{NaOC1}$

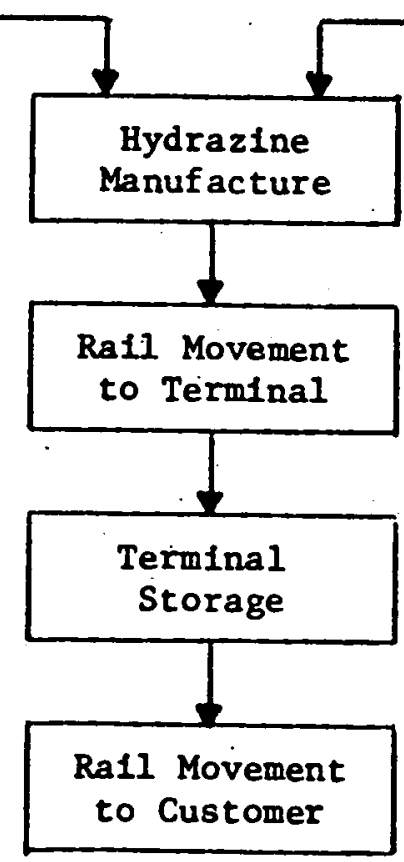

3.25

More like $\$ 200$

$\$ / 10^{6} \mathrm{BTU}$

$>>37$ 
TABLE $7-12$

SUMMARY OF ELECTRICAL TRANSMISSION COST

Ref. $\quad \$ / 106$ BTU per 1000 Miles

$\begin{array}{ll}7-1 & 4.59\end{array}$

$7-2$
7.70

$7-2 \quad 1.86-2.79$

$\begin{array}{ll}7-6 & 1.65\end{array}$

Coments

$500 \mathrm{KV}$ AC transmission line, 1000 $\mathrm{MW} /$ day Input, $85 \%$ load factor 4000 MVA superconducting 1ine; $20 \%$ capital recovery factor

Above ground $750 \mathrm{KV}, 2500 \mathrm{MVA}$ line

For $765 \mathrm{KV}$ ine. Cost increase to $\$ 12.31 / 106 \mathrm{BTU}$ per 1000 miles for a $138 \mathrm{KV}$ capacity

For $765 \mathrm{KV}$ line

For large consumers based on escalation of 1972 average cost. $\$ 3.03 / 10^{6}$ for transmission and $\$ 0.66 / 10^{6}$ BTU for distribution. Transmission distance not specified 


\subsubsection{D1stribution Cost}

The distribution cost reported in Reference 7-27 of $\$ 3,69 / 10^{6}$ BTU represents an escalation of the $1972 \mathrm{U}$. S: average cost of transmission and distribution for large light and power users.

\subsubsection{Total Delivered Cost:}

Figure 7-18 sumarizes the total delivered cost of electrical energy to a large industrial user, based on generating electricity from coal at $\$ 21 /$ ton. The transmission cost is for $1000 \mathrm{mlles}$, and the transmission and distribution cost represents about a third of the total dellvered cost. 
FIGURE 7-18

ELECTRICITY PRODUCTION, TRANSMISSION AND DISTRIBUTION

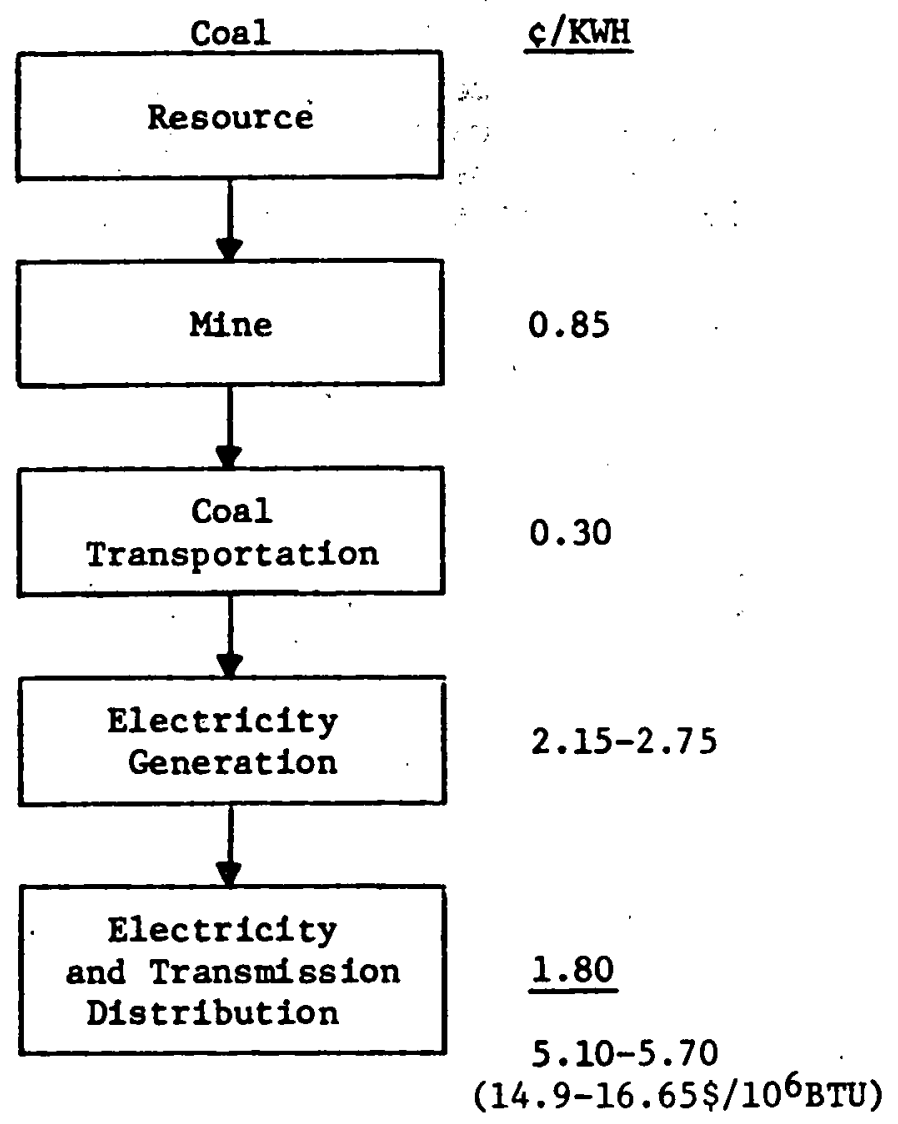


REFERENCES ON COST OF TRANSMISSION

AND DISTRIBUTION OF ALTERNATE ENERGY SOURCES

7-1 Anonymous, "Fuel and Energy Price Forecasts," Vol. [I, Stanford Research Inst1tute for EPRI, EPRI EA-433, Project 759-1, February 1977.

7-2 Johnson, J. E., "The Storage and Transportation of Synthet1c Fuels: A Report to the Synthetic Fuels Panel," ORNL-TM-4307, September 1972.

7-3 Anonymous, "Hydrogen and Other Synthet1c Fuels," a summary of the work of the Synthet1c Fuels Panel, September 1972.

7-4 Michel, J. W., "Hydrogen and Exot1c Fuels," ORNL-TM-4461, June 1973.

7-5 Beecher, D. J., et al., "Energy Conversion Alternatives Study (ECAS)," Westinghouse Phase II Final Report NASA CR-134942, November -1, 1976.

7-6 Hughes, E. E., et al., "Long Term Energy Alternatives for Automotive "Propulsion Synthetic Fuel Versus Battery/Electric Systems," SRI for NSF, PB-262 513, August 1976.

7-7 Anonymous, "Fuel and Energy Price Forecasts," Vol. I and II, Foster Associates, Inc. for EPRI, EPRI EA-411, Project 759-2, Apr11 1977.

7-8 Anderson, K. P., et al., "Long-Run Marginal Cost of Energy," NSF-RA-N-75, 225, February 1975.

7-9 Beller, M., et al., "Sourcebook for Energy Assessment," BNL 50483, December 1975.

7-10 Rleber, M., et al., "The Coal Future: Economic and Technological Analysis of Initiatives and Innovations to Secure Fuel Supply Independence;" PB-247 678, May 1975.

7-11 Goen, R. L., et a1., "Synthetic Petroleum for Department of Defense Usè," SRI for Air Force, AFAPL-TR-74-115, November 1974.

7-12 Steele, R. V., et al., "Synthetic Liquid Fuels Development: Assessment of Critical Factors," Vol. IV, SRI, ERDA 76-129/4, May 1977 .

7-13 Hord, J., et al., "Selected Topics on Hydrogen Fuel," National Bureau of Standard8, COM-75-10619, May 1975.

7-14 Gregory, D. G., "A Hydrogen-Energy System," IGT for AGA, August 1972.

7-15 Dickson, E. M., et al., "Hydrogen Economy: A Preliminary Technology Assessment," PB-266 607, SRI for National Sclence Foundation, February 1976. 
7-16 Brewer, G. D., "LH2 Alrport Requirements Study," MASA CR-2700, October 1976.

7-17 Anonymous, "An Exploratory Study to Determine the Integrated Technological Alr Transportation System Ground Requirements of Ilquid-Hydrogen-Fueled Subsonic Long-Haul Civil Air Transport8," NASA CR-2699, September 1976.

7-18 Foster, R. W., et al., "Hydrogen-Fueled Rallroad Motive Power Systems, A Feasibility Study," CONS/4707-1, September 1976.

7-19 Kant, F. H., et al., "Feaslbility Study of Alternative Fuels for Automotive Transportation," ER\&E for EPA, EPA-460/3-74-009c, June 1974.

7-20 Nagarvala, P.J., et al., "Reglonal Energy System for the Planning and Optimization of National Scenarios Response," ERDA 76-109, June 1976.

7-21 Grigsby, E. K., et al., "What W111 Future Refinerles Cost?" Hydrocarbon Processing, May 1973, pp. 133-135.

7-22 Anonymous, "Energy Alternatives--A Comparative Analys1s," May 1975.

7-23 Shonka, D. B., et al., "Transportation Energy Conservation Data Book-Edition 2," ORNL-5320, October 1977.

7-24 Konopka, A. and Wurm, "Transmission of Gaseous Hydrogen," Institute of Gas Technology. Paper presented at 9th Intersoclety Energy Conversion Engineering Conference, 1974, pages 405-412.

7-25 Blederman, N., et al., "Utilization of Off-Peak Power to Produce Industr1al Hydrogen," EPRI 320-1, August 1975.

7-26 Reynolds, R. A. and Slager, "P1peline Transportation of Hydrogen." Presented at The Hydrogen Economy Mami Energy Conference, March 1974.

7-27 Johnson, j. E., "The Economics of Liquid Hydrogen Supply for Air. Transportation," Advances in Cryogenic Engineering, Vol. 19, Plenum Press.

7-28 Anonymous, "Survey Study of the Efficlency and Economics of Hydrogen Liquefaction," Union Carbide Corp., April 1975, N75-22486.

7-29 DiNapol1, R. N., "Estimating Costs for Base-Loan LNG Plants," 011 and Gas Journal, November 17, 1975, pages 58-60.

7-30 Anonymous, "Encycloped1a of Chemical Technology," Vol, 1,. 2nd and 3rd Editions, Kirk-Othmer.

7-31 Pangborn, J., et al., "Alternate Fuels for Automotive Transportation," IGT for EPA, EPA-460/3-74-012-b, July 1974. 


\section{$7-54$}

7-32. Baughman, M. L. and Bottaro, D. J.,"Electric Power Transmission and Distribution Systems Costs and Their Allocation," IEEE Transactions on Power Apparatus and Systems, Vol. PAS-95, No. 3, May/June 1976.

7-33 Gebman, J. R., et al., "The Potentlal Role of Technological Modifications and Alternative Fuels in Alleviating Air Force Energy Problems," Rand Corp., R-1829-PR, Dec. 1976.

7-34 Rieber, M. and Soo, "Comparative Coal Transportation Costs: An Economic and Engineering Analysis of Truck, Belt, Rafl, Barge, and Coal Slurry and Pneumatic Plpelines," Vol. I, BuMines OFR 146(1)-77, August 197.7 . 


\begin{tabular}{|l|l|l|}
\hline $\begin{array}{l}\text { BIBLIOGRAPHIC DATA } \\
\text { SHEET }\end{array}$ & 1. Redor No. \\
\hline 4. Tule and Subnitle \\
Alternative Energy Sources for Non-Highway Transportation \\
- Volume III B -- Appendices \\
$\begin{array}{l}\text { 7. Aunhoi(s) } \\
\text { E. N. Cart, Jr., A. R. Cunningham, D. Carter }\end{array}$ \\
\hline
\end{tabular}

9. Petloxing Organizacion Name ad Address

Government Research Laboratories

Exxon Research and Engineering Company

P. 0. Box 8

Linden, New Jersey 07036

12 Sponsorins Orasaixasion Name and Addrees

Non-Highway Systems Branch

Transportation - Energy Conservation Division

Office of Conservation and Solar Applications

Department of Energy, Washington, D.C.

3. Recipient's Aceession Nio.

5. Regon Date

June, 1979

6.

8. Perlorming Organizalion Repr.

No. Exxon/GRU. 4T.79

10. Project/Task/Soik Unit No.

II. Cons ace/Geani Nio.

DE-AC J5-77CS05438

12 Type of Repor: \& Period

Covered FINAL

Sept. 1977-June 1979

14.

15. Supplementary Noces

16. Abstracts

A planning study has been made for DOE on alternate fuels for non-highway transportation (aircraft, rail, marine and pipeline). The purpose of the study was to provide DOE with a recommendation of what alternate fuels may be of interest to nonhighway transportation users from now through 2025 and to recommend R\&D needed to allow non-petroleum derived fuels to be used in non-highway transportation.

In the near term (present 1985), there is unlikely to be any major change in the fuels used in any of the four modes of transportation except that the average quality of the marine fuel is likely to get worse. In the mid-term period (1985-2000), there will be a transition to non-petroleum fuels, based primarily on shale oil derived liquids assuming a shale oil industry is started during this time.

(over)

17. Key Words and Document Analysis. 17a. Descriptors

Alternate Fuels

Marine

Aircraft

Shale 0 il Liquids

Pipeline

Methano]

Railroad

Hydrogen

Ammonia

Economics

Ethanol

Distribution Cost

Methane

Fuel Manufacture

Transportation Cost

Coal Liquids

Storage Cost

17b. Idensifiers/Open-Ended Terms

17e. CosATI Field/Group

18. Availability Statement

APPROVED FOR PUBLIC RELEASE; DISTRIBUTION UNLIYITED

\begin{tabular}{|l|l|}
\hline 19. Secutity C.lass (This \\
Repore) UNCLASS IF IED & $\begin{array}{c}\text { 21. No. of Pages } \\
171\end{array}$ \\
\hline $\begin{array}{l}\text { 20. Securizy C.Tass (This } \\
\text { Page UNCLASSIFIED }\end{array}$ & 22. Friee \\
\hline
\end{tabular}




\section{Abstracts (cont.)}

The future outlook for possible prime movers and potential fuel sources for the long term (2000+) is as follows. In the marine area, steam engines burning coal or diesel engines with unrefined shale oil or coal slurries are the prime candidates. With the aircraft gas turbine, either synthetic liquids from shale or coal would appear to be the most desirable fuels. Railroads will probably remain with the diesel/ electric prime mover using shale oil as a source of distillate. Pipelines will probably use electric motors as the major type of prime mover.

This Appendix covers the economics of producing, transporting and distributing the various fuels. 


\section{ENVIRONMENTAL IMPACT IN PRODUCTION}

E. M. Magee

One of the factors considered in the preliminary screening of the various alternate fuels was the environmental impact during production. Much has been written concerning the effluents to the environment on converting coal or shale to liquids, SNG, etc. (References 8-1 through 8-7). Tabulations have been made, of ten to three significant figures, of emissions of $\mathrm{SO}_{2}, \mathrm{NO}_{\mathrm{x}}$, etc. to the atmosphere; phenols, suspended solids, etc. to water; and solids to land. Quantities of effluents from processes of different developers have been compared even though commercial plants have never been built. Previous studies have pointed out (Reference 8-2, page 3) that the pollutants from a process are a function of a number of variables and thus no hard number can be assigned to any process. Four of the major factors determining qualities of effluents are plant design, location, raw material and the methods used to provide utilities.

Perhaps the plant design has the most effect on the effluents. For example, the $\mathrm{SO}_{2}$ effluent can be changed dramatically when generating steam by firing clean fuel gas rather than raw coal. Effluents in water can be reduced to zero by ponding. Even without ponding, pollutants in effluent water can be changed by changing the degree of treatment. Water effluent is also greatly affected by the type of cooling (air vs. cooling water).

The location of the plant and the source/quality of utility supplies has a great influence on elther the effluents or the treatment required for the same effluent. For example, the total dissolved solids in the raw water supply has a direct effect on the quantity of pollutants in cooling tower blow down. Ambient temperature and annual rainfall affect the quality of emlssions. In addition, local environment regulations also can have a major bearing on the amount of emissions.

The raw material has a large effect on pollutants in effluents (or, again, on the treatment required). For example, the sulfur and ash content of coal will affect effluents. Again, any adverse effects from raw materials can usually be obviated by proper design.

Publication of a table of emissions from two processes producing: simflar products can be misleading. One normally does not take the time to examine the bases for the numbers in a table and will usually assume that one process is inherently "dirtier" than another. They fail to realize that the quantities of emissions are, in large part, due to the original assumptions made in the design and that the "dirty" process can usually be made as clean or cleaner than another by changing the assumptions. One example, 'picked at random, will emphasize this point. In Reference 8-7 (page 24) various "environmental burdens" for different energy "modules" are listed. For solvent refining of coal the $\mathrm{SO}_{2}$ emissions are given as $0.0031 \mathrm{~b} / 10^{6}$ BTU whereas, for refining of domestic crude, the $\mathrm{SO}_{2}$ level was listed as $0.135 \mathrm{lb} / 10^{6}$ BTU or 45 times as much as solvent refining of coal. Since coal contains more sulfur per MBTU than crude and since the thermal efficiency of a refinery is higher than solvent refining of coal, it is obvious that a different level of sulfur removal was assumed for the coal case. Similar reasoning can be applied to the water emissions for these two cases. 
The conclusion from this is that a fuel process should not be chosen on the basis af the effluents resulting from an arbitrary design. The only logical way to compare two processes making essentially the same products would be to prepare specifications for all effluents, choose a specific location and raw materlal and prepare designs for both with the same assumptions. The cost of products from the two might then be used as a basis for comparison.. Unfortunately, most processes are in such rudimentary state of development that even this lengthy and costly procedure might not give the correct answer.

Despite the above qualification, Table 8-1 is given as an order of magnitude guide to the emissions from the production of various fuels. Table 8-2 gives a breakdown of the air pollutants. Values given in the tables are, for the most part, calculated using values given in the references. The quantity of effluents are based on BTU of fuel output. Each category of emissions is discussed below.

\subsection{Air Impacts}

Pollutants emitted to the air include $\mathrm{NO}_{\mathrm{x}}$, $\mathrm{SO}_{\mathrm{x}}$, particulates, hydrocarbons, $C O$ and others (aldehydes, etc.). Table 8-1 gives total values while Table 8-2 attempts to identify quantities of each pollutant. The values are assumed to be those after controls are applied.

\subsubsection{Coal}

Air pollutants are essentlally nil for underground mining and 7 × $10^{3}$ ibs/MBTU for surface mining (Reference 8-6). The value is per million BTU of coal produced.

\subsubsection{Coal Liquids}

The range represents data from various sources and for various processes and various coal feeds (References 8-1, 8-2, 8-4, 8-6). A value of 0.3 can be derived for the national average from Reference 8-6. Since this is roughly in the middle of the range, the breakdown in Table 8-2 uses values from Reference 8-6.

\subsubsection{Raw Shale}

Upper and lower limits are for open pit and underground mining respectively. Values given in Table 8-2 are for open pit mining.

\subsubsection{Shale Syncrude}

The low value shown corresponds to the Tosco. II operation from Reference 8-6 while the higher value is from Reference 8-1. Values in Table 8-2 are from Reference 8-6. The emissions from raw shale should be added to the shale syncrude to obtain the total emissions in producing a million BTU of shale liquid.

\subsubsection{Methanol from Coal}

The value shown is calculated from information in Reference 8-1. 


\section{ENVIRONMENTAL IMPACT IN PRODUCTION $\neq$}

Fue1

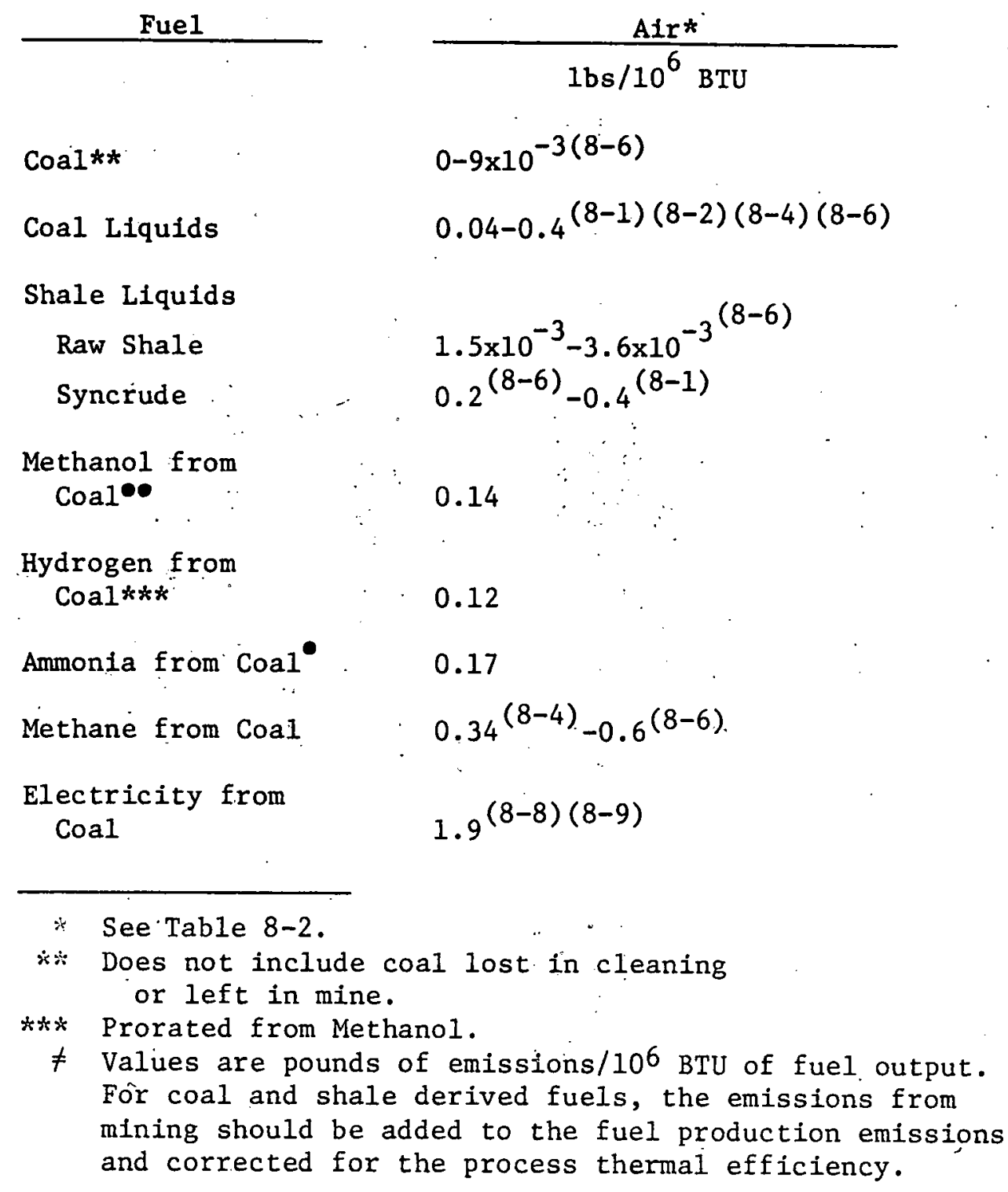

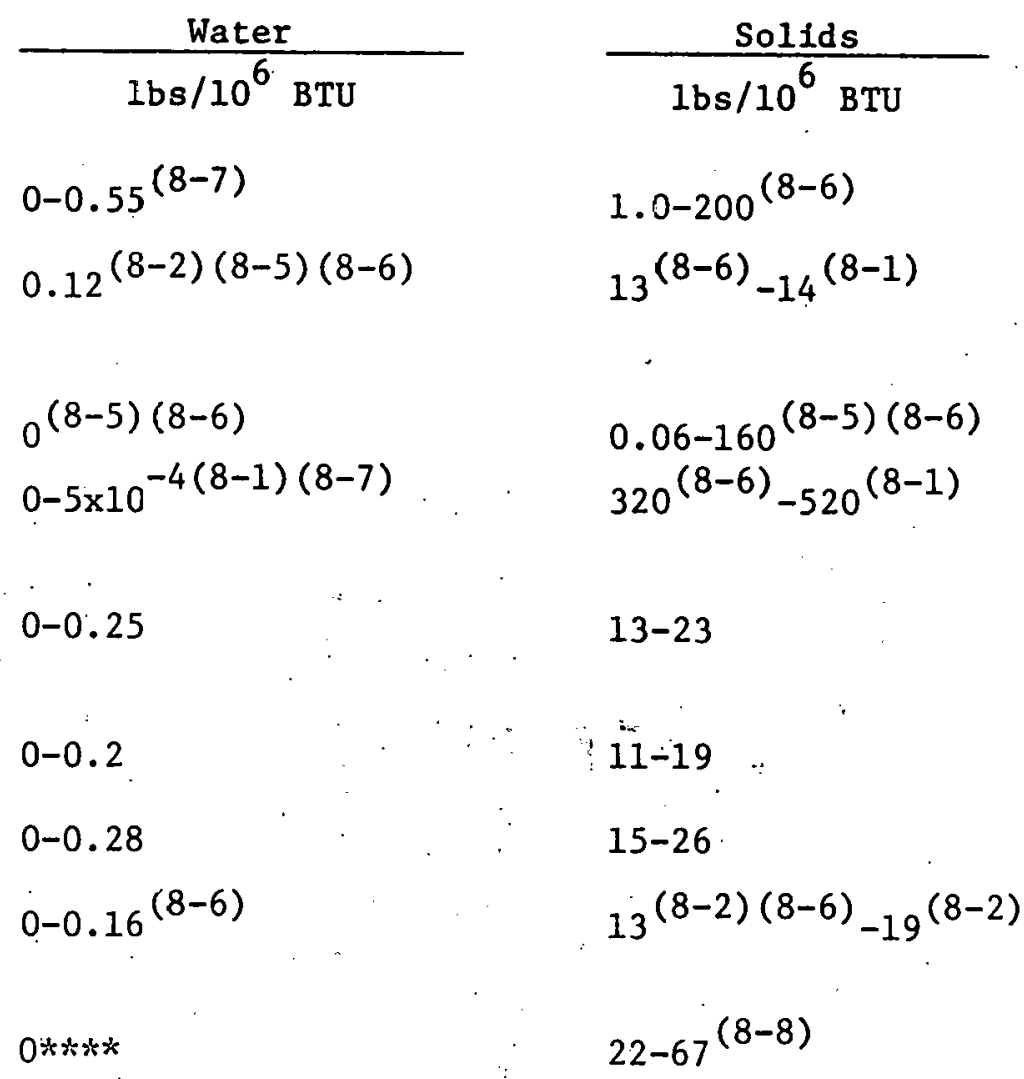

- Prorated from $\mathrm{H}_{2}$.

$\rightarrow$ Prórated from Coal Liquids.

**** Water assumed to be ponded. 


\section{DETAILS OF AIR POLLUTANTS}

LBS. OF EMISSIONS/106 BTU OF FUEL OUTPUT

\begin{tabular}{|c|c|c|c|c|c|c|}
\hline Fuel & so & No & Particulates & Hydrocarbons & $\mathrm{CO}$ & Other \\
\hline Coal $(8-6)$ & $3.6 \times 10^{-4}$ & $5 \times 10^{-3}$ & $1.7 \times 10^{-4}$ & $5 \times 10^{-5}$ & $3 \times 10^{-3}$ & $8 \times 10^{-5}$ \\
\hline Coal Liquids ${ }^{(8-6)}$ & 0.04 & 0.23 & $9 \times 10^{-3}$ & $9 \times 10^{-4}$ & $7 \times 10^{-3}$ & $8 \times 10^{-4}$ \\
\hline Raw Shale $e^{(8-6)}$ & $9 \times 10^{-5}$ & $1 \times 10^{-3}$ & $4 \times 10^{-5}$ & $1 \times 10^{-4}$ & $7 \times 10^{-4}$ & $1 \times 10^{-5}$ \\
\hline Shale Syncrude ${ }^{(8-6)}$ & 0.11 & 0.04 & $5 \times 10^{-4}$ & 0.04 & $4 \times 10^{-5}$ & $3 \times 10^{-4}$ \\
\hline $\begin{array}{l}\text { Methanol } \\
\text { From Coal }\end{array}$ & 0.05 & 0.08 & $7 \times 10^{-3}$ & $1.3 \times 10^{-3}$ & - & - \\
\hline $\begin{array}{l}\text { Hydrogen } \\
\text { From Coal }\end{array}$ & 0.04 & 0.07 & $6 \times 10^{-3}$ & $1 \times 10^{-3}$ & - & - \\
\hline $\begin{array}{l}\text { Ammonia } \\
\text { From Coal }\end{array}$ & 0.06 & 0.1 & $8 \times 10^{-3}$ & $1.4 \times 10^{-3}$ & - & - \\
\hline $\begin{array}{c}\text { Methane } \\
\text { From Coal }\end{array}$ & 0.09 & 0.4 & 0.05 & $6 \times 10^{-3}$ & 0.02 & $1 \times 10^{-3}$ \\
\hline $\begin{array}{l}\text { Electricity } \\
\text { From Coal }\end{array}$ & 1.2 & 0.7 & 0.01 & 0.01 & 0.04 & $2 \times 10^{-4}$ \\
\hline
\end{tabular}




\subsubsection{Hydrogen from Coal}

Values prorated from methanol using the ratio of the heating value of methanol to the heating value of the hydrogen that could be produced from the $\mathrm{CO}$ and $\mathrm{H}_{2}$ used to make methanol $(0.834)$.

\subsubsection{Ammonia from Coal}

The value for ammonia is obtained by multiplying the value for hydrogen from coal by 1.4 , the ratio of the thermal efficiency of $\mathrm{H}_{2}$ to that of $\mathrm{NH}_{3}$.

\subsubsection{Methane from Coal}

The higher value is the lowest value given in Reference 8-6 for the national average for several processes. The lower limit is from Reference 8-4. The process with the maximum value from Reference 8-6 is used in Table 8-2.

\subsubsection{Electricity from Coal}

Values are from References $8-8$ and $8-9$ and assume limestone scrubbing for particulate and $\mathrm{SO}_{\mathbf{x}}$ removal.

\subsection{Emissions in Water}

\subsubsection{Coal}

The maximum value for pollutants to water was taken from Reference 8-7. The solids consist essentially of silt (suspended and dissolved). Emission to natural water sources could be reduced to zero by ponding.

\subsubsection{Coal Liquefaction}

The maximum value for coal liquefaction is reported in References 3-5 and 8-6 for the national average; the minimum is from Reference 8-7. The largest component of pollutants in effluent water is total dissolved solids (TDS) and this comes mainly from cooling tower blow down. For a 91,000 B/D H-Coal liquefaction plant, the cooling tower blow down is ca $10^{6} 1 \mathrm{bs} /$ day (Reference 8-2). If this water contains $2000 \mathrm{ppm}$ dissolved solids, then the output is $0.04 \mathrm{Ibs} / 10^{6} \mathrm{BTU}$, which is the same order of magnitude as the number from Reference 8-5 and 8-6. The numbers quoted for TDS in the case of solid solvent refined coal ( $1.1 \mathrm{lb} / \mathrm{MBTU}$ ) in References 8-5 and 8-6 is believed to be too high and is not used in Table 8-1. The numbers reported in Reference 8-6 for the CSF and SRC (synthetic crude) are very close so are not listed separately. 


\subsubsection{Raw Shale}

References 8-5 and 8-6 show no pollutants to water. Any water containing dissolved solids is to be used for dust control and reclamation. It is difficult to see, however, how the disturbance of the shale will not result in run-off or seepage that could contaminate ground water.

\subsubsection{Shale Syncrude}

Reference 8-6 assumes the contaminated water from the plant will be used to moisturize spent shale and thus no water effluents are present. The upper figure of $5 \times 10^{-4} \mathrm{lbs} / \mathrm{MBTU}$ is the TDS in the contaminated water used on the spent shale (Reference 8-1).

\subsubsection{Methanol from Coal}

The values given for methanol. from coal are prorated from values for coal liquids based on the energy efficiency of conversion.

\subsubsection{Hydrogen from Coal}

The values shown in Table 8-1 for hydrogen from coal are derived. by multiplying the methanol numbers by the ratio of the heating value of methanol to the heating value of the hydrogen that could be obtained from the $\mathrm{CO}$ and $\mathrm{H}_{2}$ used to produce methanol.

\subsubsection{Ammonia from Coal}

The residuals for ammonia are prorated from hydrogen by a factor of the ratio of their thermal efficiencies (1.4).

\section{8:2.8 Methane from Coal}

The upper value in Table $8-1$ is taken as the highest value from Reference 8-4 and 8-6. The lower value of zero assumes, of course, that contaminated waste waters are impounded.

\subsubsection{Electricity from Coal}

Contaminated water is assumed to contain products from flue gas desulfurization and to be ponded.

\subsection{Solids}

The quantity of solids from coal and shale operations depends on the inorganic content of the raw materials. 


\subsubsection{Coal}

The upper figure given is the largest sum of applicable operations given in Reference 8-6 (auger mining and beneficlation) for controlled conditions on a national basis. The lower number 1s also calculated from Reference 8-6 and assumes strip mining with minimum beneficlation. Both upper and lower limits are dominated by mining.

\subsubsection{Coal Liquefaction}

The lower number in this listing is the national average from Reference 8-6. The high limit is the largest number calculated from information from Reference 8-7. In coal liquefaction, the largest source of solids is the ash and this would be essentially the same for all processes. (Some factor could be included for thermal efficiency, but this is very sensitive to design assumptions.)

\subsubsection{Shale}

The lower and upper limits in Table 8-1 are from Reference 8-6 and represent, respectively, underground versus open pit mining. The numbers áre per $10^{6}$ BTU produced.

\subsubsection{Shale Syncrude}

The lower limit is from Reference 8-6 and the higher number is from. Reference 8-7. The spent shale rock is the major solid effluent.

\subsubsection{Methanol from Coal}

Values prorated from coal liquids using thermal efficlencles.

\subsubsection{Hydrogen from Coal}

Values prorated from methanol using the ratio of the heating value of methanol to the heating value of the hydrogen that could be obtained from the $\mathrm{CO}$ and $\mathrm{H}_{2}$ used to make methanol.

\subsubsection{Ammonia from Coal}

Limits for ammonia are calculated by multiplying hydrogen from coal numbers by 1.4 , the ratio of the thermal efficiency of $\mathrm{H}_{2}$ to that of: $\mathrm{NH}_{3}$.

\subsubsection{Methane from Coal}

The lower value of the solids from high BTU coal gasification is taken from References 8-2 and 8-6 for Northwest coals. The high 1imit is from Reference 8-2 for the $\mathrm{CO}_{2}$ Acceptor Process converting 11gnite. The high number results from disposal of spent acceptor. 


\subsubsection{Electricity from Coal}

The lower limit is for a power plant without FGDS while the upper limit assumes FGDS with once-through limestone scrubbing. If the scrubber effluent is assumed to be ponded, then the solids output would be nil. 
REFERENCES

(8-1) Dickson, E.M., et al, "Synthetic Liquid Fuels Development", Vol. II, Stanford Res. Institute, 1976, ERDA 76-129/2.

(8-2) Magee, E. M., "Evaluation of Pollution Control in Fossil Fuel Conversion Processes: Final Report," EPA-600/2-76-101, 4/76.

(8-3) Corneil, H. G. et al, "Production Economics for Hydrogen, Ammonia and Methanol During The 1980-2000 Period;" BNL-50663, 4/77.

(8-4) Stone, L. K., "Emissions from Coal Conversion Processes," CEP, 12/76.

(8-5) Anonymous, "Energy Alternatives - A Comparative Analysis, University of Oklahoma, Science and Public Policy Program, for various U.S. Government Agencies," U.S. Government Printing office.

(8-6) Hittman Associates, Inc., "Environmental Impacts, Efficiency, and Cost of Energy Supply and End Use;" Vols. I and II, for CEQ, NSF, EPA, NTIS PB Nos. 238784 and 239 159, 1974-75.

(8-7) Battelle Columbus Laboratories, "Environmental Considerations in Future Energy Growth," for EPA, NTIS PB No: 239157, April 1973.

(8-8) H. Shaw, et al, "Advanced Energy Systems Pollution Assessment," Monthly Technical Report No. 14 to EPA, 6/10/77.

(8-9) Compilation of Air Pollutant Emission Factors, Second Ed., AP-42, $4 / 73$. 


\title{
9. IN-USE EMISSIONS WITH ALTERNATIVE FUELS
}

\author{
B. Kraus \\ W. Herbst
}

An evaluation of alternative fuels for non-highway transportation must take into consideration the potentlal environmental effects from the use of these fuels in the powerplants for which they were intended. While the emission impact of each fuel/powerplant combination, not ruled out by non-emission considerations, needs to be considered it is of interest to look at the contribution of non-highway transportation to the total emission burden. This gives a measure of the global impact which, even if small, would still require that the effects on local geographic regions be considered.

\section{9:1 Non-Highway Transportation Contribution to U.S. Emissions}

The pollutants of prime interest, for which ambient air quality and/or emissions standards have been legislated are particulates, sulfur oxides $\left(\mathrm{SO}_{\mathrm{x}}\right)$, nitrogen oxides $\left(\mathrm{NO}_{\mathbf{x}}\right)$; hydrocarbons $(\mathrm{HC})$, and carbon monoxide.. (CO). A non-regulated pollutant class of considerable current interest Is the polycyclic organic compounds of which benzo- $\alpha$-pyrene (BaP), a known carcinogen, is most commonly studied.

In order to ensure the best control strategy for meeting ambient air quality regulations legislated by Congress, the U. S. Environmental Protection Agency maintains a data bank of emission factors from varlous sectors of activity such as industrial, transportation, etc. This data bank, the National Emissions Data System (NEDS) gives estimates of the emissions contribution of the non-highway transportation sector. Table 9-1 contains an estimate of the emissions in the U. S. for 1973 of particulates, $\mathrm{SO}_{\mathrm{x}}, \mathrm{NO}_{\mathrm{x}}, \mathrm{HC}, \mathrm{CO}$, and $\mathrm{BaP}$ in millions of tons per year for railroads, alrcraft, and vessels. Emissions from pipeline transportation are not specifically 1dentified in the NEDS. Emissions from the Industrial sector derived from the use of natural gas have been taken as an estimate for the pipeline mode. BaP emissions in Table 9-1 have been derived from a 1972 National Science Foundation study of polycycllc organlc matter in conjunction with the fuel usage factors in the four non-highway transportation modes.

From Table 9-1, It appears that the contribution to total U. S. emissions ranges from as little as $0.1 \%$ for BaP to as much as $6 \%$ for $\mathrm{NO}_{\mathrm{x}}$ : In terms of the individual pollutants, over half of the particulates would appear to come from aircraft, while the railroads are the major emitters of sulfur oxides and nitrogen oxides. Hydrocarbon emissions are more evenly divided among three of the four modes, pipeline transportation being generally a minor emitter of all the pollutants. Marine transport is the chief contributor to both $\mathrm{CO}$ and $\mathrm{BaP}$.

A comparison of the results of Table 9-1 with those from other references, as is shown for particulates in Table 9-2, makes it clear that there is substantial uncertainty in the emissions of these sources. In 
TABLE 9-1

U. S. EMISSIONS, MILLIONS TONS/YR.

1973

\begin{tabular}{|c|c|c|c|c|c|c|}
\hline Transportation & Particulates (c) & so (c) & NO $(c)$ & $\mathrm{HC}(c)$ & $\mathrm{CO}(\mathrm{c})$ & $\operatorname{BaP}(d)$ \\
\hline Grand Total (a) & 15.9 & 32.7 & 21.7 & 23.8 & 97.0 & $900 \times 10^{-6(e)}$ \\
\hline $\begin{array}{l}\text { Railroads } \\
\text { Alrcraft } \\
\text { Marine Vessels } \\
\text { Pipelines (b) }\end{array}$ & $\begin{array}{l}0.057 \\
0.162 \\
0.025 \\
0.002\end{array}$ & $\begin{array}{l}0.130 \\
0.038 \\
0.102 \\
0.010\end{array}$ & $\begin{array}{l}0.846 \\
0.155 \\
0.194 \\
0.185\end{array}$ & $\begin{array}{l}0.215 \\
0.486 \\
0.367 \\
0.046\end{array}$ & $\begin{array}{l}0.297 \\
0.836 \\
1.084 \\
0.028\end{array}$ & $\begin{array}{l}0.32 \times 10-6 \\
0.24 \times 10^{-6} \\
0.50 \times 10-6 \\
0.10 \times 10-6\end{array}$ \\
\hline $\begin{array}{l}\text { Sub-Total } \\
\% \text { of Grand Total }\end{array}$ & $\begin{array}{l}0.246 \\
1.55\end{array}$ & $\begin{array}{l}0.280 \\
0.856\end{array}$ & $\begin{array}{r}1.380 \\
6.36\end{array}$ & $\begin{array}{l}1.114 \\
4.68\end{array}$ & $\begin{array}{l}2.245 \\
2.31\end{array}$ & $\begin{array}{c}1.16 \times 10^{-6} \\
0.12\end{array}$ \\
\hline
\end{tabular}

(a) Petroleum, coal, chem. processes, waste disposal, etc.

(b) Natural gas, industrial.

(c) Derived from May 1976 report of the National Emissions Data System.

(d) Benzo( $\alpha$ ) pyrene-estimated this study.

- Emission factors from: "Particulate Polycyclic Organic Matter"

National Academy of Science--1972

Comittee on Biological Effects of Atmospheric Pollutants

- Diesel trucks--62 $\mu \mathrm{g} / \mathrm{gal}$ (page 16)--use for railroad, pipeline and marine diesels.

- Alrcraft--100 $\mu \mathrm{g} / 10^{6} \mathrm{BTU}$ (page 23)

- 011-fired bollers--100-900 $\mu \mathrm{g} / 10^{6} \mathrm{BTU}$ (page 23)--use 100 for aircraft, 500 for marine residual

- Gas premixed burners--100 $\mathrm{g} / 106 \mathrm{BTU}$ (page 23)--use for pipeline, natural gas

- Fuel consumption from Energy Statistics: Annual Report, August 1976 and Transportation Energy Conservation Data Book, 1977.

(e) From "Preferred Standards Path Report for Polycycllc Organic Matter," October 1974, EPA page vili (includes coal refuse fires, residential furnaces, coke production, vehicle disposal, etc). 
TABLE 9-2

COMPARISON OF PARTICULATE EMISSION ESTIMATES

U. S. M1111on Tons/Year-1973

\begin{tabular}{|c|c|c|c|c|}
\hline Transportation & Ref. A & Ref. B & Ref. C & Ref. D \\
\hline Grand Total & $15.9(\mathrm{e})$ & $122(f)$ & & \\
\hline $\begin{array}{l}\text { Rallroads } \\
\text { Alrcraft } \\
\text { Fessels } \\
\text { Pipelines }\end{array}$ & $\left.\begin{array}{l}0.057 \\
0.162 \\
0.025 \\
0.002\end{array}\right\} 0.244$ & $\left.\begin{array}{l}0.22 \\
0.03 \\
0.15\end{array}\right\} 0.40$ & 0.03 & 0.055 \\
\hline
\end{tabular}

Ref. A National Emissions Data System (NEDS), May 1976.

Ref. B APCA 25(7) 699 (1975)--Primary and Secondary Particulates as Pollutants by Fennelly, P. F.

Ref. C The Effects of Smoke Suppressant and Corrosion Inhibiting Fuel Additives on the Particulate and Gaseous Emissions from a Utility Gas Turbine by Hersh, S., et al., ASMA 78-GT64.

Ref. D Unpublished data, based on heavy duty diesel truck engines; emission factor 3.4 gms particulates per kilogram of fuel.

(e) Petroleum, coal, chemical processes, waste disposal, etc.

(f) Includes natural dusts, ocean salt spray, etc. 
fact, emissions for a particular mode can vary by a factor of five when comparing different sources of data. Even the relative contribution of the several modes varles to a great extent. While the NEDS makes the aviation mode by far the major source of particulates, rallroads are the major contributor and alrcraft the least in another reference. Nevertheless, despite this variation, the literature is consistent in showing non-highway transportation to be a relatively minor contributor to the total U. S. emission burden. If this were the only emission consideration of importance, the cholce of alternate fuels would not 11kely be constrained by the emissions impact. In actuality, particular modes of non-highway transportation can impact to a far greater extent in locallzed areas than what would be imagined from a nationwide viewpoint. The airplane can be the overriding source of particulates in areas contiguous to airports. Changes In aviation fuels which would significantly increase such emission would therefore need to be considered also from that point of view. Similar arguments apply to the railroad and marine transportation and probably to a lesser extent to pipeline pump stations.

\subsection{Emissions of Various Englne/Fuel Systems}

In recent years, numerous 1nvestigators have begun to study the performance of various prime movers with non-conventional fuels. It is difficult to define in a quantitative fashion the effects on emissions from switching a particular transportation sector to alternative fuels and prime movers. Certain engine/fuel combinations have been studied from an emissions viewpoint. A good example of this is the combination of alcohols or alcohol-gasoline blends with the spark ignition engine.

\subsubsection{Alcohol Fuels}

The spark ignition engine plays only a minor role in aviation and pipeline transportation in the non-highway transportation, but it is the major consumer of fuels of any prime mover. Alcohols have been one of the alternative fuels suggested for this type of engine, either in relatively pure form or as an alcohol gasoline blend. A 1976 API study on the use of alcohol as fuels, (9-3) based on then existing literature, concluded that the somewhat leaner combustion possible with alcohols would lead to somewhat lower emisstons of carbon monoxide, hydrocarbons, and nitrogen oxides. The emlssions of aldehydes, very reactive species in photochemical oxidant formation, were however found to be higher than with gasoline. Reduction In the three primary gaseous pollutants, $\mathrm{CO}, \mathrm{HC}, \mathrm{NO}_{\mathrm{x}}$ are claimed by several authors, $(9-4,9-5,9-6)$ while others report only a lowering of $\mathrm{NO}_{\mathrm{x}} \cdot(9-7,9-8,9-9,9-10)$ Increased aldehyde emissions as well as unburnt methanol have been reported by Landman (9-6) and Lo Russo and Tabaczynsk1.(9-9) Reduced polynuclear aromatic hydrocarbon emissions both with pure methanol and methanol-gasoline blends were found in at least one study. $(9-4)$ It is obvious that differences in emissions w11l occur when alcohols replace hydrocarbons 8 fuels in spark ignition engines.

Alcohols have also been studied in stratified charge spark Ignition engines. (9-12,9-13) In these, hydrocarbons were found to increase. In this reference, (9-12) co also increased with alcohols, while all three studies claimed a reduction in nitrogen oxides. 
With the opark 1gnition engine, the use of methanol or ethanol, is likely to lead to reduced nitrogen oxide emissions. The effect of such alcohols on the emisstons. of $\mathrm{CO}$ and $\mathrm{HC}$ 1s dependent on the carburetion or tichness setting, or on the effectiveness of post engine control devices. The latter, however, are not likely for application in non-h1ghway transportation. Particulates from these engines are not a major problem with gasoline or alcohols. The absence of literature data on particulates serves to reinforce this point. Desplte the probable increase of aldehyde emissions, it is not likely that emissions considerations would have a major impact on any decisions to use alcohols as fuels.

Another powerplant in which alcohols have been recommended as alternative fuels is the gas turbine. Because of their low heat content per unit welght, alcohols would only come into consideration in stationary or surface transportatiod use. Much as with the spark Ignition engine, nitrogen oxides would appear to be lower than with conventional turbine fuels. $(9-14,9-15,9-16)$ Carbon monoxide and hydrocarbons were sald to Increase, although such emissions from the gas turbine tend to be relatively low. Smoke, an important pollutant of the gas turbine, is apparently lower with alcohols. (9-15) Emissions would not be a major factor to consider on using alcohols in gas turbines. From the behavior of alcohols in homogeneous and heterogeneous combustion systems, it is not unreasonable to generalize that their use will on the whole probably be beneficial in terms of emissions. This would be true in stationary bollers, in the Stirling engine, the diesel (9-17,9-18) and the free piston engine. The potential carcinogenicity of emissions from heterogenepus combustion systems should be considered. This problem has been recoghted with the diesel engine.(9-19) It is linked specifically to organic extracts of diesel particulates, which have shown very high activity in the Ames mutagenicity test. Since the effect of fuels on the activity of such organic extracts has not been defined, it is clear that large scale substitution of alternative fuels in combustion systems producing appreciable levels of particulates must first consider any impact in this area. Further work is needed.

\section{2 .2 Hydrogen}

Hydrogen has been considered as a potential alternative fuel in both highway and non-highway transportation. In the spark 1gnition engine, hydrogen enrichment allows significantly leaner operation which directionally leads to reduced nitrogen oxide emissions. This 18 reported by several investigators. (9-20,9-21) Increased hydrocarbon emissions were however reported in the same studies. An all hydrogen-fueled spark ignition englne would likely give the benefit of reduced $\mathrm{NO}_{\mathrm{x}}$ while also eliminating fuelderived hydrocarbons. $(9-22,9-23)$

In the gas turbine englne, whether 1t be aviation or 1ndustrial, hydrogen enrichment would reduce $\mathrm{CO}$, HC and smoke. Straight hydrogen operation would eliminate these constituents altogether. $(9-14,9-24,9-25)$ The effect on nitrogen oxides 18 not clear, though it is not likely to be higher. 
From an emissions viewpoint, hydrogen would likely lead to beneficial effects in use with any prime mover with which it is compatible, even without the consideration of the absence of $\mathrm{CO}_{2}$ emissions.

\subsubsection{Other Gaseous Fuels}

With gaseous fuels other than hydrogen, emissions effects do not reveal clear benefits or debits. $(9-14,9-26,9-27,9-18)$ The exception to this may be ammonia. Past studies $(9-28,9-29,9-30)$ are not consistent in the effect on nitrogen oxide formation. The potential problem of ammonia emissions cannot, however, be dismissed.

\subsubsection{Coal and Shale O1l Liquid Fuels}

The postulation of emissions effects derived from the use of "conventional" fuels which are derived from non-conventional sources such as coal or shale is very dependent on the assumptions made in terms of how conventional these fuels would be. It 1s, of course, possible to "refine" such fuels to be fully equivalent to those derived from petroleum. Hence, the emissions would be the same as from petroleum fuels. However, it may not be desirable to refine shale liquids and coal liquids to such an equivalent state because of cost. The emissions will depend on this degree of equivalency.

Two major factors are likely to appear with shale and coal liquid derived fuels which will impact on in-use emissions. One is the presence of relatively high fuel nitrogen levels in distillate and residual fuels which will translate directly into higher nitrogen oxide emissions. $(9-31,9-32,9-33)$ Thls would be true for gas turbines, dlesels, and stationary bollers. In at least some of these applications, certain combustion process modifications such as water injection and exhaust gas recirculation may at least partially offset the effect of the higher fuel nitrogen.

A second factor pertaining particularly to coal-derived fuels is the high aromatic content. This would in present day gas turbines lead to increased smoke emissions. $(9-34,9-35)$ The problem of carcinogenicity of particulates has already been discussed and 18 pertinent with these fuels. Directionally, the effect may well be simflar in other prime movers. The need to establish the best compromise between refining of such fuels and the adaptation of the prime mover to handle them in an environmentally acceptable fashion is apparent.

\subsubsection{Coal and Coal/Slurries}

Use of coal or coal in combination with liquid fuels is from the viewpoint of fuel avallability, an attractive option. In the nonhighway transportation sector, coal has been used in rail and marine transport as boller fuel. In powdered and slurrled form, it has even recently been considered for diesel engines. $(9-36,9-37)$ Use of coal in direct use in any prime mover would unquestionably lead to a deterioration of the emissions picture, particularly as it concerns particulates. For the immediate future, the means to handle the: in-use emfssions problems assoclated with the direct use of coal are not avallable. 


\subsection{Summary of Emtssions Effects of Fuels and Prime Movers}

A qualitative sumary of the emissions of various fuel/prime mover combinations compared to present fuels is shown in Table 9-3. The scale used is as follows:

+2 - Better in emissions of at least two pollutants

+1 -- Better in emissions of one pollutant

0 - Comparable to current fuel

-1 -- Poorer than conventional fuels

-2 -- Much poorer than conventional fuels

Since actual data on most of these is not avallable, estimates were made based on fuel propertles and their effects on emissions in certaln types of combustion systems, 1.e., heterogeneous and homogeneous. It is safe to assume certain trends that are likely to occur with the use of particular fuels. The difect combustion of coal elther straight or in liquid fuel slurries w111 lead to increased particulate emissions in any of the powerplants not normally fired with coal. Llquids produced from coal or shale w1ll directionally increase nitrogen oxide emissions because of higher fuel nitrogen and probably more particulates due to increased aromaticity. On the whole, alcohols will probably improve the in-use emlssions picture because of their beneflclal effect on $\mathrm{NO}_{\mathrm{x}}$. Hydrogen will clearly Improve emissions in-use in any prime mover because of reduced $\mathrm{CO}, \mathrm{CO}_{2}, \mathrm{HC}$, particulates and probably $\mathrm{NO}_{\mathrm{x}}$. The use of methane would also decrease inuse emissions in many prime movers. 
TABLE 9-3

EHISSTONS EFFECTS OF FUELS AND PRME MOVERS

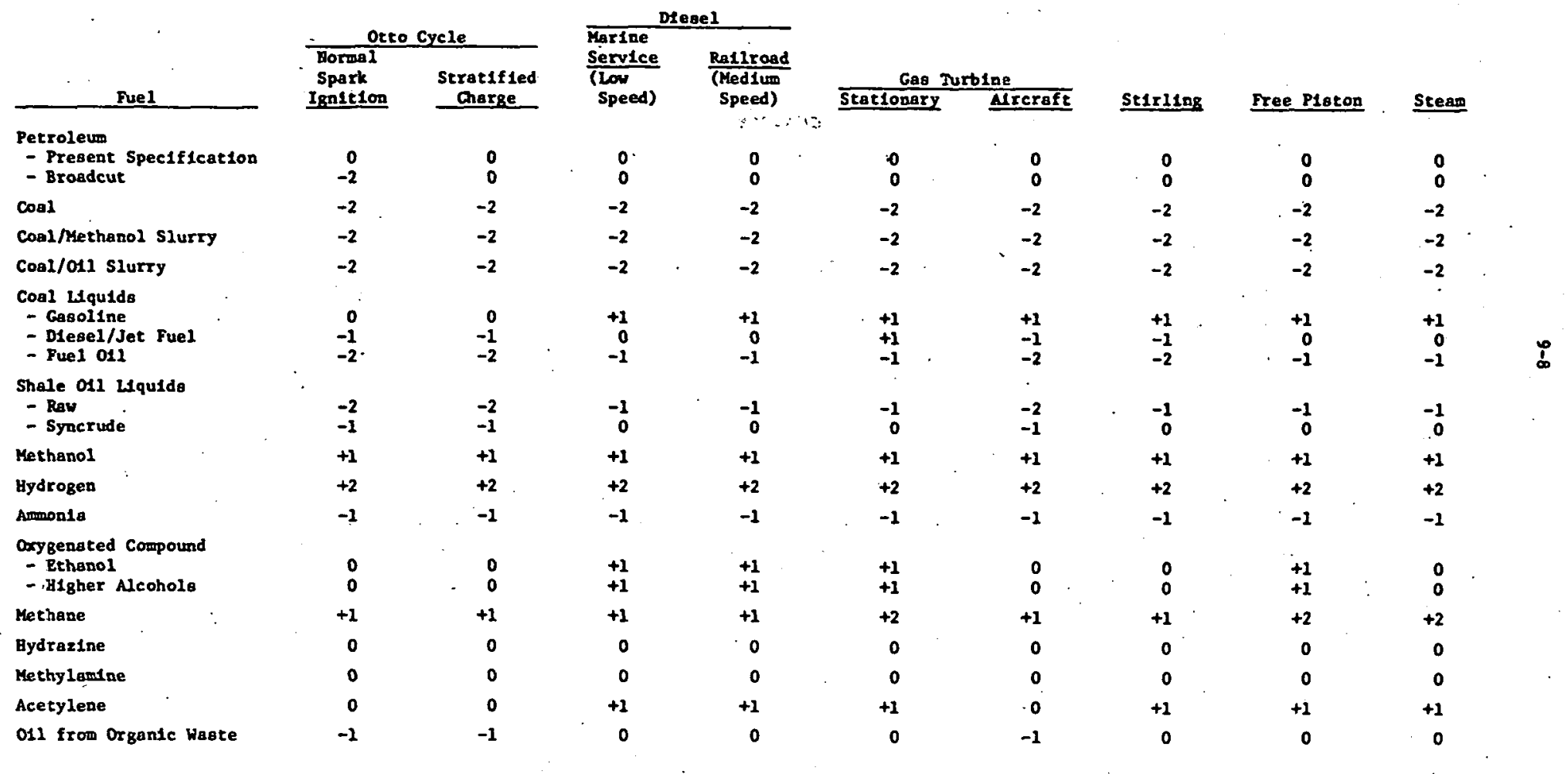




\section{REFERENCES}

9-1 Pangborn, J. and Gillis, J., "Alternative Fuels for Automotive Transportation - A Feasibility Study," EPA Report No. 460/3-74-012, July 1974.

9-2 Kant, F. H., Cahn, R. P., Cunningham, A. R., Farmer, M. H., Herbst, W. and Manny, E.'H., "Feaslbility Study of Alternative Fuels for Automotive Transportation," EPA Report No. 460/3-74-009, June 1974.

9-3 "Alcohols, A Technical Assessment of Their Application as Fuels," API Publication No. 4261, July 1976.

9-4 Lee, W. and Geffers, W., "Engine Performance and Exhaust Emission Characteristics of Spark Ignition Engines Burning Methanol and Methanol Gasoline Mixtures," AIChE Symposium Series, Vo1. 73, No. 165, pp. 328-337, 1975.

9-5 Brinkman, N. D., Gallopoulos, N. E. and Jackson, M. W., "Exhaust Emissions, Fuel Economy, and Driveability of Vehicles Fueled with Alcohol-Gasoline Blends," SAE Paper No. 750120, 1975.

9-6 Landman, A., "Methanol as an Automotive Fuel," U.S. Department of Transportation Report No. DOT-TSC-OST-77-31, Apri1 1977.

9-7 Canton, E. J., Lestz, S. S. and Meyer, W. E., "Lean Combustion of Methanol-Gasoline Blends in a Single Cylinder SI Engine," SAE Paper No. 750698, presented at SAE Fuels and Lubricants Meeting, Houston, Texas, June 3-5, 1975.

9-8 Harrington, J. A. and P1lot, R. M., "Combustion and Emission Character1stics of Methanol," SAE Paper No. 750420, January 1975.

9-9 LoRusso, J. A. and Tabaczynsk1, R. J., "Combustion and Emission Characteristics of Methano1, Methanol Water, and Gasoline-Methanol Blends in a Spark Ignition Engine," Paper. No. 769019, 11th IECEC.

9-10 Fleming, R. D. and Chamberlain, T. W., "Methanol as Automotive Fuel," U.S. Bureau of Mines Report CONF-750264-1.

9-11 Johnson, R. T. and Riley, R. K., "Single Cylinder Spark Ignition Engine Study of the Octane, Emissions, and Fuel Economy Characteristics of Methanol-Gasoline Blends," SAE Paper No. 760377, February 1976.

9-12 Branch, M. C., Wolfe, K. and Ishikawa, N., "Combustion of Methanol Blends in a Stratified Change Engine," SAE Paper No. 769021, 1976.

9-13 Johnson, R. T., Riley, R. K. and Dalen, M. D., "Performance of Methanol Gasoline Blends in a Stratifled Change Engine Vehicle," SAE Paper No. 760546, June 1976. 
9-14 Mung, W. S. Y., "The $\mathrm{NO}_{\mathrm{x}}$ Emlssion Levels of Unconventional Fuels for Gas Turb1nes," ASME Paper No. 77-GT-16, March 27-31, 1977 .

9-15 Klapatch, R. D., "Gas Turbine Emissions and Performance of Methanol Fuel," ASME Paper No. 75-PWR-22, September 1975.

9-16 Buchheim, R., "Influences on Exhaust' Emissions from Automotive Gas Turbines," ASME Paper No. 78-GT-85, presented at the Gas TurbIne Conference, London, Apr11 9-13, 1978.

9-17 Barnes, K. D., Kittelson, D. B. and Murphy, T. E., "Effect of Alcohols as Supplemental Fuel for Turbocharged Dlesel Englnes," SAE Paper No. 750469, February 1975.

9-18 Bro, K. and Pedersen, P. S.; "Alternative Dlesel Engine Fuels: An Experimental Investigation of Methanol, Ethanol, Methane and Amionia In a D.I. Diesel Engine with P1lot Injection," SAE Paper No. 770794, presented at the Passenger Car Meeting, Detroit, Michigan, September 26-30, 1977.

9-19 Lipkea, W. H., Johnson, J. H. and Vick, C. T., "The Physical and Chemfcal Character of Diesel Particulate Emissions - Measurement Techniques and Fundamental Considerations," SAE Publication No. SP-430, February 1978.

9-20 Cichanowicz, J. E. and Sawyer, R. F., "Rotary Engine Combustion w1th Hydrogen Addition," SAE Paper No. 760611; August 1976.

9-21 Stebar, R. F. and Parks, F. B., "Emission Control with Lean Operation Using Hydrogen-Supplemented Fuel," SAE Paper No. 740187, presented at Automotive Englneering Congress, February 25-March 1, 1974.

9-22 Fagelson, J. J., McLean, W. J. and deBoer, P. C. T., "Analysis of Hydrogen as a Reclprocating Engine Fuel," presented at ACS Meeting, Division of Petroleum Chem1stry, April 6-11, 1975.

9-23. Dickson, E. M., Ryan, J. W. and Smulyan, M. H., "Hydrogen Economy: A Preliminary Technology Assessment," NSF Report No. RA-760491, February 1976.

9-24 Brewer, G. D., Morr1s, R. E., Lanje, R. H. and Moore, J. W., "Study of the Application of Hydrogen Fuel to Long Range Subsonlc Transport Aircraft," NASA Report No. CR-132559, January 1975.

9-25 Clayton, R. M., "Reduction of Gaseous Pollutant Emissions from Gas Turblne Combustors Using Hydrogen-Enriched Jet Fuel - Progress Report," NASA Report No. 33-790, October 15, 1976.

9-26 Pillsbury; P. W., Cleary, E. N. G., S1ngh, P. P. and Chamberlain, R. M., "Emission Results from Coal Gas Burning in Gas Turbine Combustors," ASME Paper No. 75-GT-44, March 1975. 
9-27 Parikh, P. G., Sawyer, R. F. and London, A. L., "Pollutants from Methane Fueled Gas Turbine Combustion," ASME Paper No. 72-WA/GT-3, presented at the Winter Annual Meeting, New York, New York, November $26-30,1972$.

9-28 Graves, R. L. and Hodgson, J. W., "Emissions from an Amonia Fueled Spark Ignition Engine," ASME Paper No. 75-WA/DGP-2, November 1975.

9-29 Graves, R. L., Hodgson, J. W. and Tennant, J. S., "Ammonia as a Hydrogen Carrier and its Application in a Vehicle,". Proceedings of the Hydrogen Economy Energy, Miaml Conference, Port B, March 18, 1974.

9-30 Sawyer, R. F., Starkman, E. S., Muzio, L. and Schmidt, W. L., "Oxides of Nitrogen in the Combustion Products of an Ammonia Fueled Reciprocating Engine," SAE Paper No. 680401, May 1968.

9-31 Mosier, S. A.; Plerce, R. M. and Purvis, W. J., "Combustor Characteristics from the Burning of Petroleum Base and Shale-01l Base Diesel Fuel Marine," presentation at the Central States Section of the Combustion Institute Meeting, April 5-6, 1976.

9-32 Dilmore, J. A. and Rohrer, W., "Nitric Oxide Formation in the Combustion of Fuels Containing Nitrogen in a Gas Turbine Combustor," meeting of the Gas Turbine Division of the American Society of Mechanical Englneers, March 30-Apr11 4, 1974.

9-33 Wilkes, C. and Russell, R. C., "The Effects of Fuel Bound Nitrogen Concentration and Water Injection on $\mathrm{NO}_{x}$ Emissions from a 75-MW Gas Turbine," ASME Paper No. 78-GT-89, presented at the Gas Turbine Conference and Products Show, London, April 9-13, 1978.

9-34 Butze, H. F. and Smith, A. L., "Effect of Fuel Properties on Performance of a Single Aircraft Turbojet Combustor at Simulated Idle, Cruise, and Takeoff Conditions," NASA Technical Memorandum No. 73780, September 1977.

9-35 Robert8, R,, Peduzzi, A, and Vitt1, G. E., "Experimental Clean Combustor Program, Phase II: Alternate Fuels Addendum," NASA Report No. CR-134970, July 1976.

9-36 Anonguous, "Pulverized Coal-Burning Diesel Engine," Office of Coal Research Report No. PB 235 713, July 1970.

9-37 Marshall, H. P. and Walters, D. C., Jr., "An ExperImental Investigation of a Coa1-Slurry Fueled Diesel Engine," SAE Paper No. 770795, presented at the Passenger Car Meeting, Detroit, Michigan, September 26-30, 1977. 


\title{
10. ENERGY EFFICIENCY IN PRODUCING
}

AND TRANSPORTING ALTERNATE FUELS

\author{
E. N. Cart, Jr.
}

\subsection{Introduction and Summary}

One of the factors to consider in ranking the various alternate fuels is which fuels make the most efficient use of our national resources. To determine which fuels require the least amount of a given resource, It is necessary to estimate the thermal efficiency of the process used to produce the fuel from the resource (including the energy assoclated with liquefying a gaseous fuel, if necessary), and the energy required to transport the resource and the final fuel to the consumer. These factors are then combined in a systems approach to. Indicate the amount of a given resource that is needed to produce a certain amount of final product. The three major areas covered in this section are: (1) the thermal efficiency of the processes used to manufacture the fuels; (2) the energy required to transport the resources and fuels; and (3) the combination of items (1) and (2) In a systems analysis to indicate the amount of basic resources required.

The thermal efficiencies of the vartous processes used to manufacture alternate fuels are summarized in Table 10-1 for the non-renewable based fuels and in Table 10-2 for the blomass based fuels. Two efficiencies are shown in Table 10-1; an efficiency. which accounts for only the liquid transportation fuel $\left(\varepsilon_{1}\right)$, and the overall thermal effictency $\left(\varepsilon_{2}\right)$. Both . efficlencles are defined in Section 10.2.1. The $\varepsilon_{2}$ efficiency is the one normally reported in the literature, but "the $\varepsilon_{1}$ efficlency is also useful in indicating which fuels or processes may be best sulted to producing liquid transportation fuels.

The blomass based fuels are shown in a separate table, since it is difficult to compare a renewable resource base with a non-renewable resource base. With a renewable base, it is also worthwhile to look at the output/input ratio--an indication of how much energy is obtained per the energy required to produce the fuel. For example, with ethanol from sugarcane, the energy output is about breakeven with the energy required to produce the ethanol. Of the three fuels considered, it appears that ammonia produced from sugarcane would be the most efficient use of biomass fuels.

In an attempt to put the blomass derived fuels on a thermal efficiency basis for comparison to the coal and shale based fuels, the heating value of the biomass was assumed at $7800 \mathrm{BTU} / \mathrm{LB}$. which then allows the thermal efficiency of the process to be calculated.

The $\varepsilon_{2}$ thermal efficiencies are 1llustrated in Figure 10-0 for three different resource bases--shale, coal and blomass. As noted, there is a range of thermal efficlencles reported in the literature for each fuel. There are several reasons for the range-type of coal used (in a 
TABLE 10-1

SUMMARY OF PROCESSING THERMAL EFFICIENCIES -

NON-RENEWABLE BASED FUELS

Fuel

$$
\varepsilon_{1}-\%
$$

$\varepsilon_{2}-\%$

\section{(Liquid Fuel \\ On1y)}

(Total Thermal

Efficlency)

Coal/011 Slurry

$97-98.5$

$97-98.5$

Shale 011 - Upgraded

65

$64-72$

Coal Based Fuels

- Liquids via

+ Pyrolysis

+ Liquefaction

+ Indirect

15-28

41-63

$57-70$

30

$63-75$

50-60

- Coal Liquid Upgrading

70-92

$70-92$

$39-56$

$52-56$

$47-51$

27-29

- Ammonia

- Acetylene 46-48

- Hydrogen ( $g$ )

- Hydrogen - Liquefaction Stcp only

- Methane (g)

- Methane - Liquefaction Step only

$48-68$

$50-64$

$44-58$

$55-78$

83-91

Other Energy Carrler.s

- Hydrogen - Electrolysis

- Electricity - Coal (conventional)

30-33

$35-37$

(new technology)

- Nuclear

55-68

32

$(g)=g a s$ 
TABLE 10-2

SUMMARY OF PROCESSING THERMAL EFFICIENCIES - BIOMASS BASED FUELS

Fuel

Product Energy/

Process Energy

$\varepsilon 2$

Input (1)

Thermal Efficlency

\section{Ethanol}

- Sugar cane

1.1

27

- Corn

0.42

25-36

Methanol

- Sugar cane (pyrolysis)

2.1

$28-43$

Ammonia

- Sugar cane (pyrolysis)

4

46

(1) See Section 10.2.12 for definition. 
FIGURE 10-0

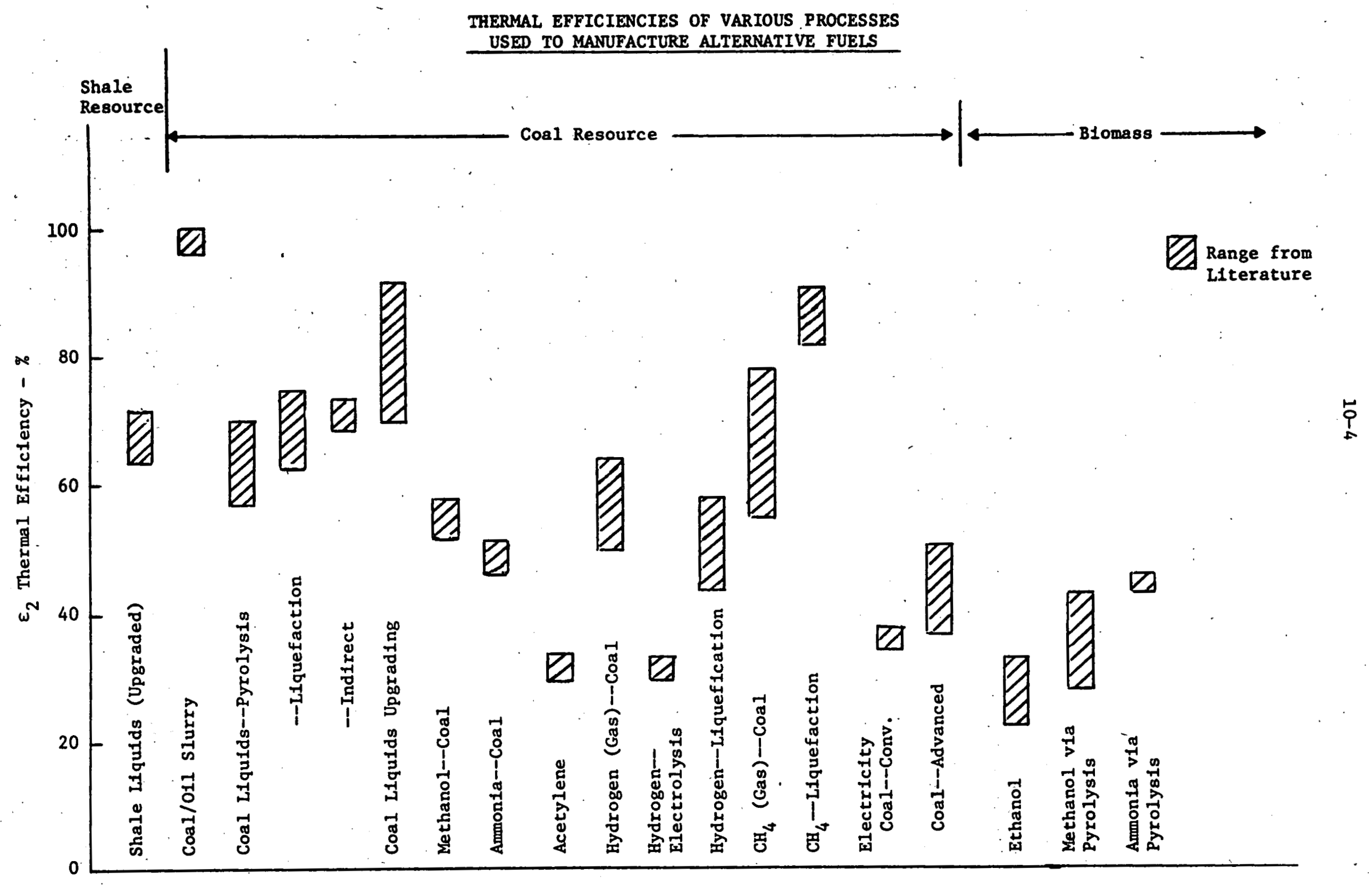


cosl based process), degree of heat Integration, whether coal or by-products are used to generate electricity, etc. Also, for processes under development, the thermal efficlency tends to be overstated, since all aspects of the problem have not been fully defined and an In-depth engineering design Is unavailable.

Also included in Figure 10-0, as a separate item, is the efficiency for upgrading of coal liquids, liquefaction of hydrogen, and IIquefaction of methane. Of course, these efficiencies must be considered In confunction with the basic process efficiency to arrive at an "overall" efficlency, which will be discussed later.

Several coments on Figure 10-0:

- In the coal liquids area, the liquefaction route was selected as representative. The pyrolysis and indirect methods have lower $\varepsilon_{1}$ efficlencles, and overall thermal efficiencles in the same range as the liquefaction route.

- The rather broad range assoclated with coal liquids upgrading reflects the range from (a) trying to upgrade coal ilquids directly to current distillate specification, to (b) mixing coal syncrude Into an existing refinery and allowing the plant to optimize the processing and feedstocks used for each product.

- Note the higher efficlency associated with methane ilquefaction (82-91\%) compared to hydrogen 11quefaction (44-58\%).

By combining the process thermal efficiencies with the energy requirement to transport the fuel, it is possible to calculate the amount of basic resource needed to supply a given amount of transportation fuel energy. Flgure 10-1 shows the coal and shale based resource required to produce a millión BTU's of final fuel. As expected; direct burning of coal is the most efficient way to use coal, if it can be accommodated in a prime mover. The next most efficient fuel, from a resource utilization standpoint, is coal/o1l slurry. Coal distillate and liquid methane are the next, most efficient, requiring about $1.88 \times 10^{6}$ BTU of coal to produce a million BTU of liquid transportation fuel. Methanol and ammonia require 2 and $2.15 \times 10^{6}$ BTU of coal to produce million BTU of liquid transportation fuel, respectively. Electricity, liquid hydrogen and acetylene require the largest amount of coal, of the alternate fuels considered.

To produce a million BTU of distillate from shale oll required $1.63 \times 106$ BTU of basic resource. Data on the blomass fuels are not included in this comparison due to the difference mentioned earlier between a renewable and a non-renewable resource. 
FIGURE 10-1

BASIC RESOURCE REQUIREMENTS FOR SEVERAL ALTERNATE FUELS
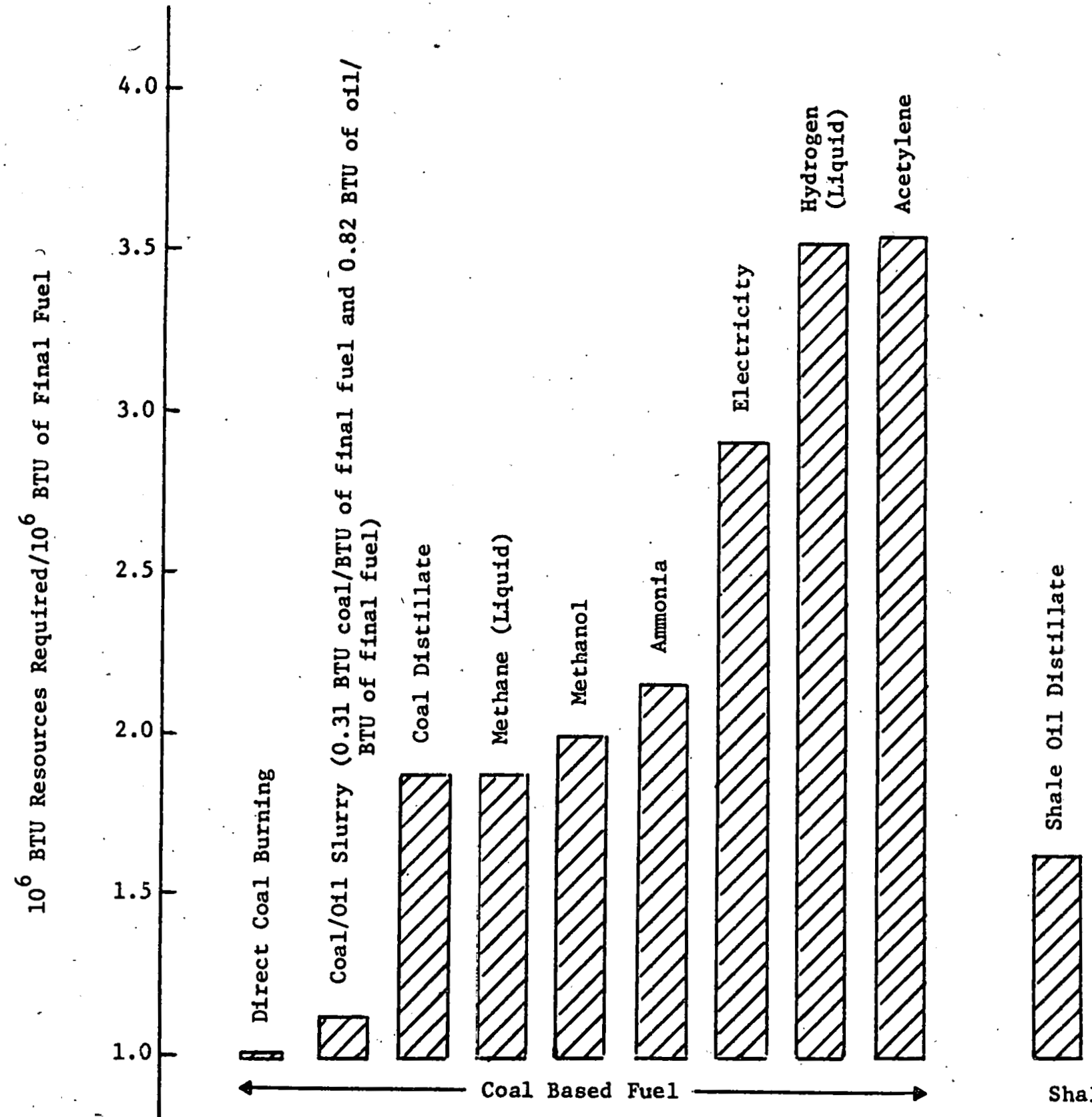
10.2 Thermal Efficlency of Manufacturing Process for Alternate Fuels

In this section, the thermal efficlency for the manufacture of the various fuels is discussed. Also included 18 the energy for liquefaction of the gaseous methane and hydrogen. One of the first areas to consider 18 the definition and basis for calculating the thermal efficiencies.

\subsubsection{Bas1s for Thermal Efficlency}

There are several ways to define thermal efficiency, all of which are valid. For example, one efficlency would indicate the amount of Initial resource that can be converted into energy. In the form of the alternate fuel of interest. Thus:

$$
\varepsilon_{1}=\frac{\text { BTU output of primary fuel }}{\text { BTU input of total resource }}
$$

F1gure 10-2 1llustrates a process to produce methanol from coal. The efficlency in this case would be:

$$
\varepsilon_{1}=\frac{272 \times 109}{692 \times 10^{9}}=39.3 \%
$$

In this particular example, there are significant quantities of combustible products produced along with the primary fuel. These products could be used as fuels themselves, so that the total efficiency would be:

$$
E_{2}=\frac{\text { BTU output of total combustible product }}{\text { BTU Input of total resource }}
$$

For the example in Figure 10-2; the efficlency would be:

$$
\varepsilon_{2}=\frac{272+110}{692}=55.2 \%
$$

It should be noted that sulfur and ammonia have been excluded, even though ammonia is one of the alternate fuels belng considered. In this particular case, the prime purpose is to produce methanol as a fuel--not ammonia.

In place of considering the by-products as a potential fuel, they could be used in some cases internally as fuel and back out part of the coal. In that case:

$$
\varepsilon_{3}=\frac{\text { BTU output of primary fuel (methanol) }}{\text { BTU Input of total resource - }}
$$

For the example in Figure 10-2:

$$
\varepsilon_{3}=\frac{272}{692-110}=46.7 \%
$$




\section{FIGURE 10-2}

\section{EXAMPLE OF ENERGY EFFICIENCY CALCULATION}

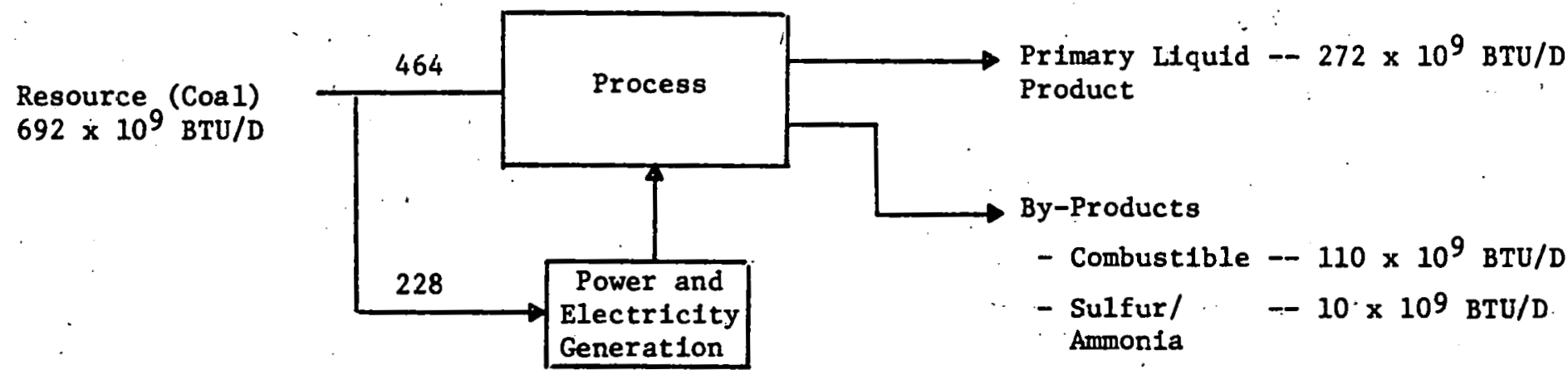

$\varepsilon_{1}=\frac{\text { BTU Output of Primary Fuel }}{\text { BTU Input of Total Resource }}=\frac{272}{692}=0.393$ or $39.3 \%$

$\varepsilon_{2}=\frac{\text { BTU Output of Total Combust1ble Product }}{- \text { BTU Input of Total Resource }}=\frac{382}{692}=0.552$ or $55.2 \%$ 
The problem with this approach is that most times, the by-products have a higher current value in non-fuel applications but incremental demand in these applications may be quite different than in fuel applications.

consider.

There are two additional accounting rules which are important to

1. Thermal efficiencies w11l be based on the gross heating values of the fuels. Elther gross or net heating values could be used but a consistent set of units must be used. When considering the amount of energy required for each prime mover, it w111 be necessary to consider the net heating value since the costs of the fuels are expressed on a net heating value basis, while the efficiencies of the prime movers are also on a net basis. Th1s final conversion will be made at the fuel/prime mover interface.

2. When electrical energy is required in a conversion process, the efficlency of the boiler-generator will be assumed to have an efficlency of $38 \%$. Thus, the amount of coal needed to produce the electricity will be included. This will insure that processes that generate their electricity internally are on the same basis where external power is purchased.

In some cases $\varepsilon_{1}, \varepsilon_{2}$ and $\varepsilon_{3}$ will be equal. For this study, $\varepsilon_{1}$ and $\varepsilon_{2}$ will be considered, assuming that sufficlent data is available in the literature to allow this calculation to be made.

\subsubsection{Coa1/O11 Slurry}

The energy requirements associated with preparation of a coal/o11 slurry are malnly due to the coal grinding energy requirements. Garcla(10-13) reports that this requirement can range from 25 to $250 \mathrm{kwh} /$ ton to reduce the coal to a 4 micron powder. Other energy requirements would be assoclated with coal handling, pumping of the fuel ofl and mixing of the coal and oil. Considering all of these factors, the overall thermal efficiency is $99-99.4 \%$ depending on the energy requirements for grinders. If the energy requirements to produce the electricity are inciuded at a $38 \%$ thermal efficlency, the overall thermal efficiency drops to $97.4-98.5 \%$. For purposes of this study, a value of $97 \%$ will be used.

\subsubsection{Coal Liquefaction}

The thermal efficiency of the various coal liquefaction processes will depend on several factors, such as type of coal used, degree of heat Integration, nature of utilities, whether coal or by-product gas is used to generate electricity and steam, the method used to generate hydrogen, etc. The thermal efficiency, $\varepsilon_{1}$ and $\varepsilon_{2}$, for the basic three types of processes described in Section 6 are summarized in Table 10-3.

Since $\varepsilon_{1}$ is a measure of the efficlency of a process to make the transportation fuel of prime interest, namely liquids in this case, the highest efficiency $(41-63 \%)$ is for the direct liquefaction route, with 
TABLE 10-3

SUMMARY OF THERMAL EFFICIENCIES

FOR COAL LIQUEFACTION PROCESSES

\begin{tabular}{|c|c|c|c|}
\hline & $\varepsilon_{1}$ & $\varepsilon_{2}$ & Source \\
\hline Pyrolysis & $15-28$ & $57-70$ & $\begin{array}{l}10-2,10-3,10-4 \\
10-5\end{array}$ \\
\hline Liquefaction & $41-63$ & $63-73$ & $\begin{array}{l}10-2,10-6,10-7 \\
10-8,10-9,10-10\end{array}$ \\
\hline Indirect & 30 & $69-73(1)$ & $10-2,10-11$ \\
\hline
\end{tabular}

(1) These values appear to be too high, since the basic coal gasification process would have a 55-65 efficiency and the Fischer-Tropsch synthesis efficiency would probably be about $90 \%$. Thus the range would be more like 0.5-0.6. 
pyrolysis and indirect liquefaction (F1scher-Tropsch) having efficiencies in the 15-30\% range. This would Indicate that if the aim is to produce primarily liquid fuels from coal, that one of the liquefaction processes would be preferred. However, it is necessary to consider the other products that are produced, such as SNG and electricity, since these can be used to displace 11quid fuels that may be used in other sectors, such as the industrial and electrical sectors. In this case, the thermal efficiency is In the 57-75\% range for all three types of processes. Part of the difference in the range of thermal effictency is due to the differences in hydrogen content of the 11quid products.

For the purpose of this study, a thermal efficiency of $63 \%$ w 111 be used for coal liquefaction, representative of the H-coal process shown in Figure 10-3. O'Hara(10-2) reported a thermal efficlency of $65 \%$; and the study by Colorado Energy Research Inst1tute(10-8) reported an efficiency of $67 \%$, If put on the same basis as used in this study. This 1llustrates the range of efficiencles that are quoted for the same process in the literature.

\subsubsection{Coal Liquids Upgrading}

The thermal effictency to upgrade coal liquids to specification products will depend on the properties of the coal syncrude (degree of hydrogen deficiency), how the hydrogen is produced, whether gasoline, diesel or jet fuel is the final product and the hydrogen content of the final product.

Tsaros(10-14) Investigated producing specification jet fuel from coal using the CSF coal liquefaction processes. In one case, shown in Figure 10-4, the jet fuel was produced by hydrocracking the heavy ofl from the CSF process. The hydrogen was generated by reforming of the high BTU product gas. In this particular process arrangement, the upgrading thermal efficlency was $70 \%$.

If instead of producing the jet fuel from coal liquid, the refinery output was increased and the aromatic material produced from coal was added to the gasoline pool and some of the petroleum components diverted from catalytic reformer feedstock, the efficiency of the upgrading step would be increased to $87 \%$. The upper 1 imit would be to add the coal liquids to an existing refinery and allow the refiner to optimize his overall system. In this case, the thermal efficiency would be the same as an existing refinery, or $88-92,(10-8)$ depending on location of refinery, product slate, complexity of processing and type of crude processed.

\subsubsection{Shale 0il Retorting and Upgrading}

The thermal efficlency of producing fuels from underground mining of shale oil from three different processes ranged from $64-70 \%,(10-8,10-1)$ a narrow range considering the wide variation in the degree of refinement 
H-COAL LIQUEFACTION PROCESS ENERGY BALANCE

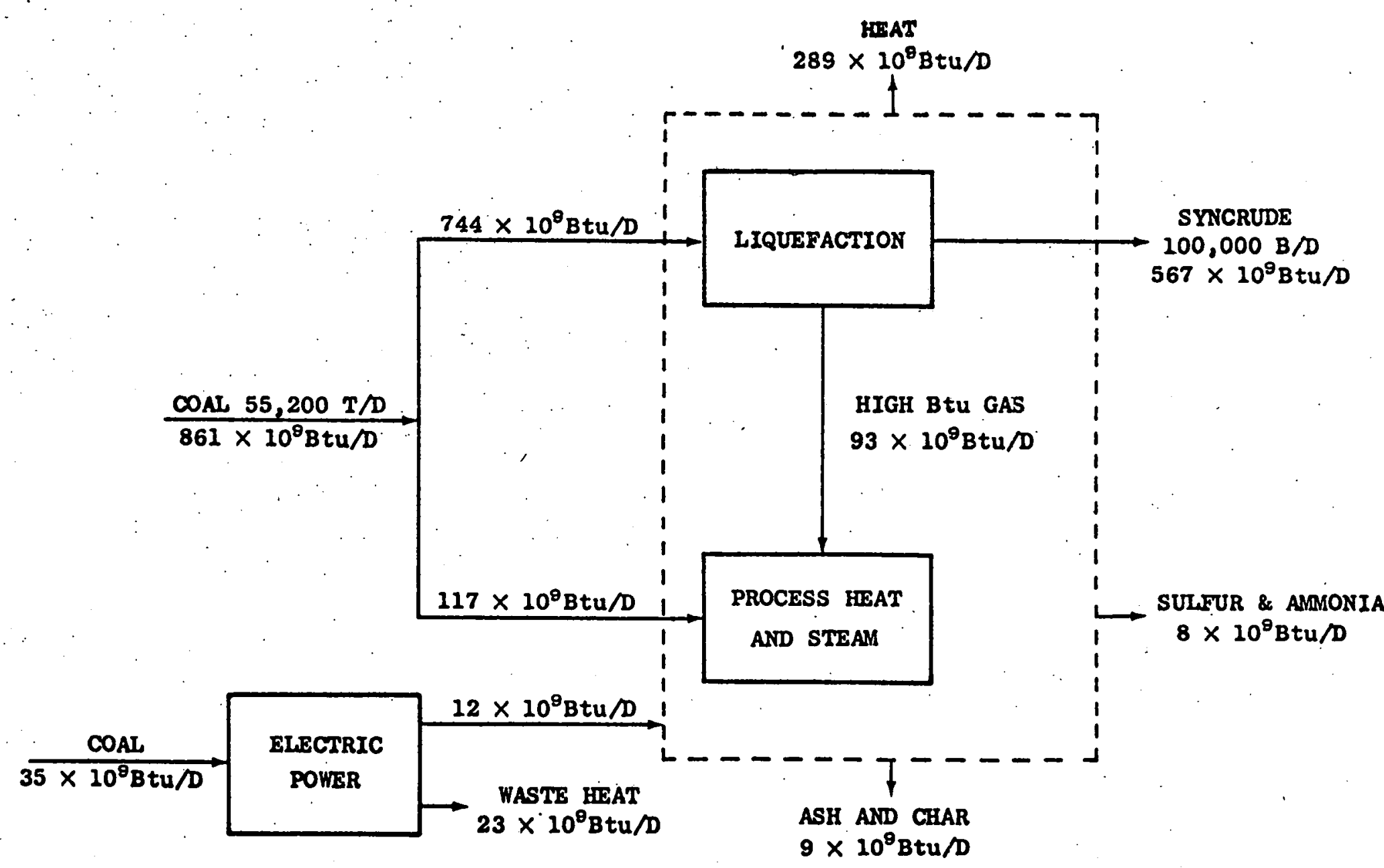




\section{FIGURE 10-4}

MANUFACTURE OF JET FUEL FROM COAL-DERIVED HEAVY FUEL OIL

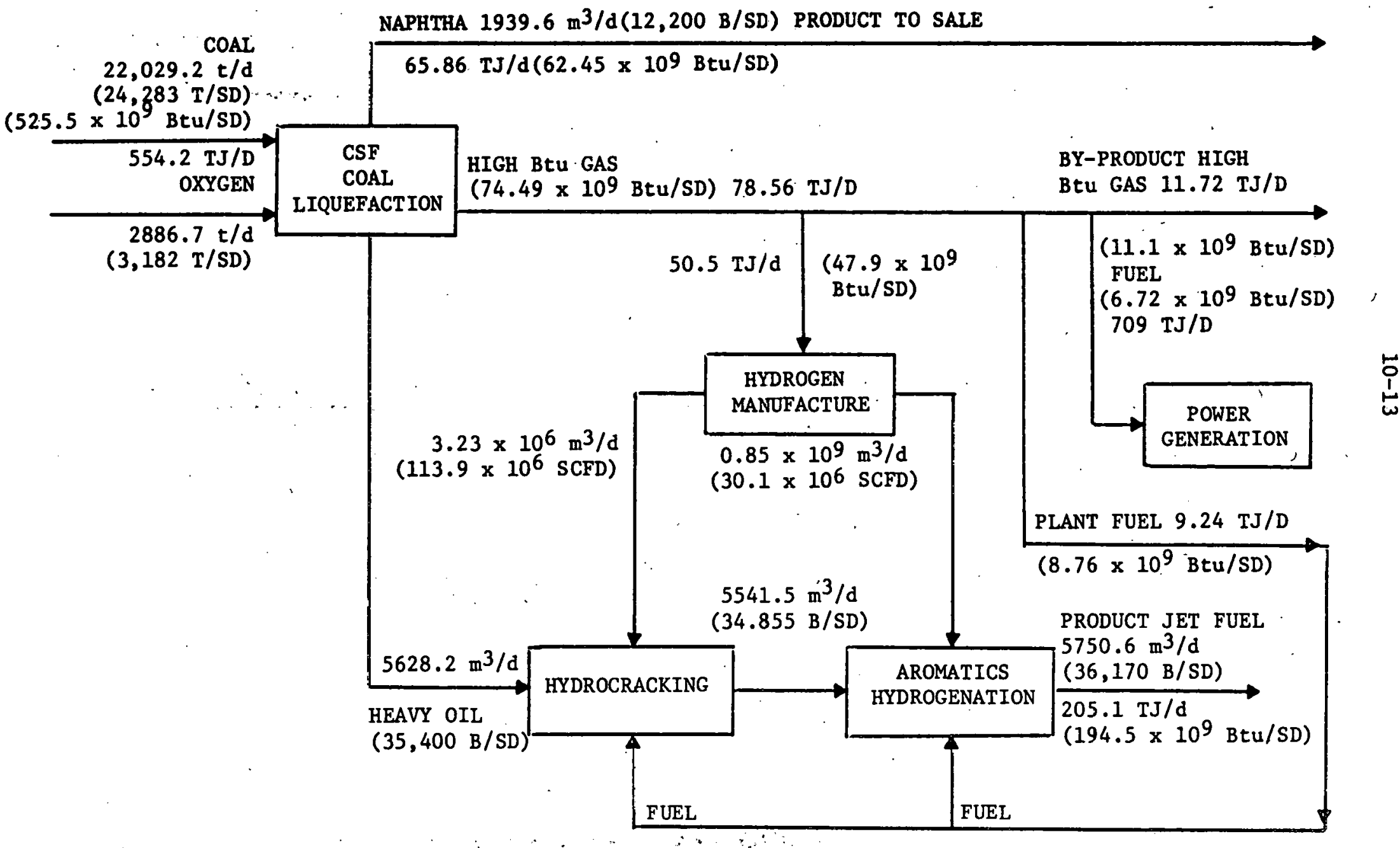


of the product from essentially no refining to almost complete refining.(10-8) For purposes of this study, the Tosco II process has been selected as typical of a mining-retort-upgrading process. The energy balance for the Tosco-II process is shown in Figure 10-5. The $\varepsilon_{1}$ efflclency (resourceto-syncrude) would be $65 \%$, while the overall thermal efficlency, $\varepsilon_{2}$, would be $72 \%$. The overall efficiency neglects the latent and sensible heat in the spent shale. The product from the Tosco II process needs to be only fractionated to obtain diesel and kerosene products, while the gasoline would need to be reformed.

\subsubsection{Methanol (Coal Derived)}

The thermal efficlency of producing methanol from coal from several different references are summarlzed in Table 10-4.

\section{TABLE 10-4}

THERMAL EFFICIENCY OF METHANOL FROM COAL

\begin{tabular}{|c|c|c|}
\hline Reference & $\underline{\varepsilon}_{1}-\%$ & $\varepsilon_{2}=z$ \\
\hline \multicolumn{3}{|l|}{$10-15$} \\
\hline $\begin{array}{l}\text { - Roppers-Totzek } \\
\text { - "New" Process }\end{array}$ & $\begin{array}{l}52 \\
56\end{array}$ & $\begin{array}{l}52 \\
56\end{array}$ \\
\hline $10-1$ & 39 & 55 \\
\hline $10-16$ & 52 & 52 \\
\hline
\end{tabular}

The data from Reference 10-1 is shown In Figure 10-6, which shows that from this particular process, tar, ofl, and naphtha are produced which accounts for the difference between $\varepsilon_{1}$ and $\varepsilon_{2}$. For this study, the $52 \%$ thermal effictency from Reference 10-15, using the Koppers-Totzek process as a developed process, w111 be used. As noted, development of a more efficient coal gasification process could increase the efficiency to $56 \%$.

\subsubsection{Ammonia (Coal Derived)}

The thermal efficiency of producing amonia from coal 1 s $47 \%$ using the Koppers-Totzek gasification process and $51 \%$ if a "new," more efficient coal gasification is developed.(10-15) For this study, the $47 \%$ efficlency w111 be used.

\subsubsection{Acetylene (Coal Based)}

The thermal efficiency of producing acetylene from calcium carbide, which 1 s produced from coal, is $27-29 \%$ for $\varepsilon_{1}$ and $46-48 \%$ for $\varepsilon_{2}$. The range reflects the uncertainty of the amount of acetylene generated from calcium 


\section{FIGURE 10-5}

TOSCO II OIL SHALE RETORTING AND UPGRADING ENERGY BALANCE

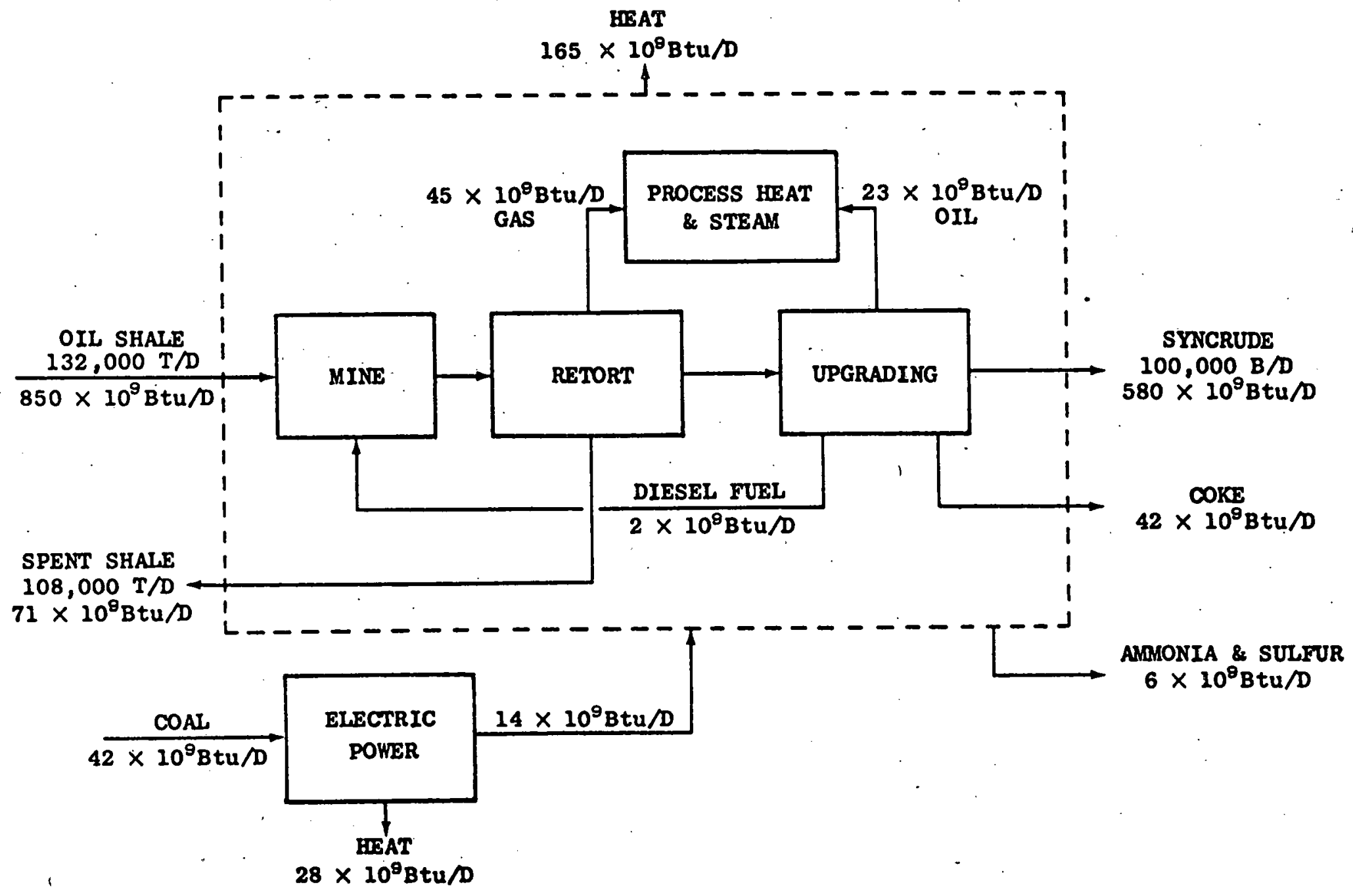

Source: Ref. 10-1 
THIS PAGE

\section{WAS INTENTIONALLY LEFT BLANK}


carbide. These efficiencles also reflect the energy required to produce the electricity. The detail energy flows are shown in Figure 10-7. As shown in FIgure 10-7, the energy balance reflects the energy used In calcining the limestone to $\mathrm{CaO}$, based on a value of 2250 BTU per pound of CaO.(10-18). Since the by-product 18 a medium BTU gas, It 18 unlikely that this energy could be ut1lized, except within the process. In that case, the efficlency would be $34 \%$ if all the by-product gas was used and $30 \%$ if only the $500 \mathrm{BTU} / \mathrm{ft}^{3} \mathrm{gas}$ was used to calclne the limestone. The $\varepsilon_{1}$ value 1s probably more representative of the overall efficlency for this particular case and will be used for this study.

\subsubsection{Hydrogen}

\subsubsection{Coal}

The thermal efficiency of producing hydrogen from coal will depend on the coal gasification process that is used, the degree of process Integration to recover waste heat and generate electricity, etc. A comparison of the thermal efficiencies reported in the literature is shown in Table 10-5. As can be seen, most of the literature results show a thermal efficlency of about $50-60 \%$ for the commerclally proven processes, with the possibility of increasing this to 64-66\% with an improved gasification process. Where external electrical energy is required, the efficlencies reflect the resources necessary to generate the electricity, assuming a $38 \%$ efficiency for the generation step. For the purpose of this study, the value quoted in Reference 10-15 of $60 \%$ will be used.

\subsubsection{Electrolysis}

Another way to produce hydrogen is by electrolysis, as described In Section 6. The thermal efficiency for the solld polymer electrolyte electrolytic cell is $30 \%$, based on data from Reference 10-15. The low efficlency is due to the large electrical energy requirements for the process with the assumed $38 \%$ thermal efficlency for electricity generation. England, et al(10-26) give a simflar efficiency. of $33 \%$ for nuclear/ electrolysis. They also estimate around 33\% process efficiency for nuclear/ thermochemical and solar/thermal/electrolysis.

\subsubsection{Liquefaction}

To use hydrogen as a transportation fuel most likely w11l require storage of the material within the vehicle as a liquid. To liquefy hydrogen for a transportation fuel requires a considerable energy penalty, particularly If one includes the resource requirements to generate electricity. For storage as a liquid, hydrogen must be cooled to $-423^{\circ} \mathrm{F}$. The thermal efficlency for liquefying hydrogen from several literature references are summarized in Table 10-6. As noted in the 11terature, the thermal efficiency of the basic liquefaction process ranges from 71 to $77 \%$. Including the efficiency of electrictty generation reduces the overall thermal efficlency to the 48-58\% range. Part of this varlation is due to differences in the estimate of actual electrical energy required compared to the theoretical work, hydrogen losses in liquefaction, degree of integration 


\section{FIGURE 10-7}

ENERGY FLOWS IN PRODUCING ACETYLENE FROM CALCIUM CARBIDE GENERATED FROM COAL

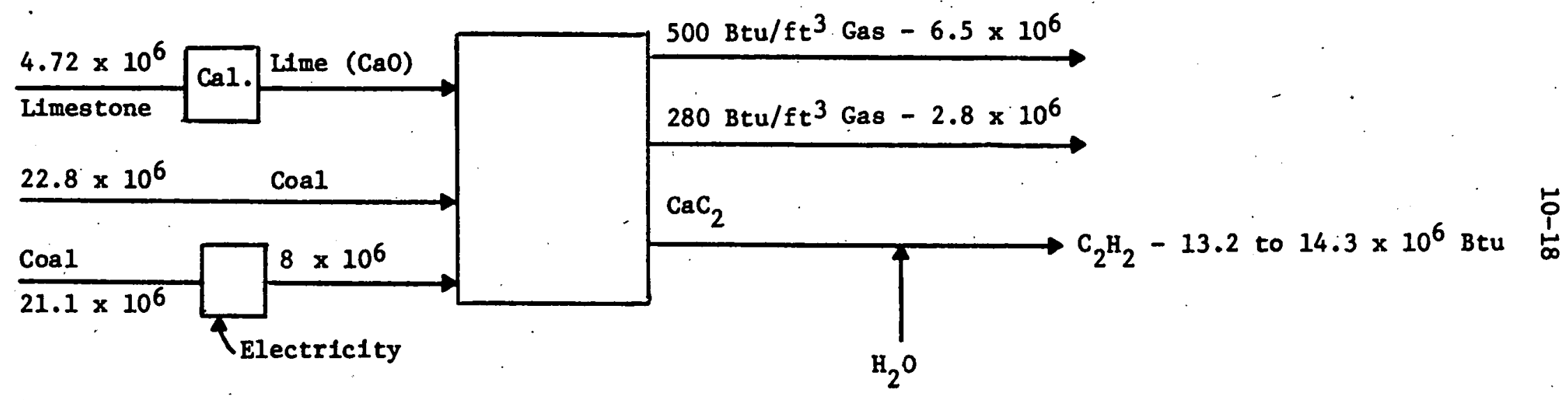

$$
\begin{aligned}
& \varepsilon_{1}=\frac{13.2}{4.72+22.8+21.1}=0.27 \\
& \varepsilon_{2}=\frac{13.2+6.5+2.8}{4.72+22.8+21.1}=0.46
\end{aligned}
$$


TABLE 10-5

COMPARISON OF THERMAL EFFICIENCIES FOR

PRODUCING GASEOUS HYDROGEN FROM COAL

\begin{tabular}{|c|c|c|c|}
\hline Reference & Process & Thermal & Efflciency \\
\hline & & & $\varepsilon_{2}$ \\
\hline $10-15$ & $\begin{array}{c}\mathrm{K}-\mathrm{T} \\
\text { "New" }\end{array}$ & & $\begin{array}{l}60 \\
64\end{array}$ \\
\hline $10-19$ & * & & 59 \\
\hline $10-20$ & $K-T$ & & 50 \\
\hline $10-21$ & $*$ & & 56 \\
\hline $10-22$ & * & & 59 \\
\hline $10-23$ & * & & 55 \\
\hline $10-7$ & * & & 59 \\
\hline $10-3$ & * & . & 58 \\
\hline $10-24$ & $\begin{array}{c}\mathrm{K}-\mathrm{T} \\
\mathrm{U}-\mathrm{GAS} \\
\text { Steam-Iron }\end{array}$ & & $\begin{array}{l}57 \\
66 \\
59(1)\end{array}$ \\
\hline $10-25$ & * & . & 58 \\
\hline
\end{tabular}

* Not Identified.

(1) Using byproduct gas to generate electricity at $38 \%$ efficiency. $\varepsilon_{1}$ for this process is $45 \%$. 
TABLE $10-6$

THERMAL EFFICIENCY FOR LIQUEFYING HYDROGEN

Thermal Efficiency

of Basic

Reference

$10-20$

$10-22$

10-23

$10-7$

10-3

$10-25$

\section{Liquefaction Process}

71

77

7.6

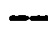

77
Thermal Effictency Including Electrical Generation Efficiency

$$
53\left(\varepsilon_{2}\right), 50\left(\varepsilon_{1}\right)
$$

55

48

$44\left(\varepsilon_{2}\right)$

58 
assumed with the gasification complex, and whether refrigerant losses are included. For example, Boggs $(10-26)$ gives the following comparison between the theoretical and actual energy required to liquefy a pound of hydrogen.

kwh/Pound

$\begin{array}{lr}\text { Theoretical work } & 1.77 \\ \text { Actual } & 4.89 \\ \text { Practical } & \ddots .5 .67\end{array}$

The practical electrical requirements include the electrical requirements for production auxiliaries such as cooling towers and thawing heaters, and the lighting, heating and alr conditioning of the plant. Hallett(10-27) reports an electrical energy requirement of $4.46 \mathrm{kwh} /$ pound of $\mathrm{H}_{2}$ liquefied. For this study, the practical electrical energy.requirements of $5.67 \mathrm{kwh} /$ pound w111 be used, In confunction with the other information from Hallett, (10-27) to arrive at an efflciency of $53 \%$. The detalls are shown In Figure 10-8. The 53\% is also in line with the value reported by Union Carbide.(10-28)

$$
10.2 .10 \text { SNG }
$$

\subsubsection{Coa1}

The thermal efficlency of producing SNG from coal will be dependent on the process used, the type of coal used, the reactivity of the coal, whether product gas or coal is used as the boiler fuel, and several other factors. The thermal efficiencies of some of the different gasification processes are summarized in Table 10-7. For the commerclally proved processes, the $\varepsilon_{1}$ efficlency 18 around $55-65 \%$, while with the advanced processes, the $\varepsilon_{1}$ efficlency could 1ncrease. The $\varepsilon_{2}$ efficlency is higher, around $65-70 \%$ for the older processes and could be higher for the newer processes. Typical energy flow rates for the Lurgi process are shown in Figure 10-9. For, this study, the older type processes such as the Lurg1 process, will be used to show the thermal efficlency.

\subsubsection{Liquefaction}

If SNG is used as a transportation fuel, the material most 1ikely w111 need to be liquefied, except for pipeline use. The energy requirements to 1iquefy methane are not as severe as to liquefy hydrogen primarily because methane requires a liquefaction temperature of $-259^{\circ} \mathrm{F}$, compared to $-423^{\circ} \mathrm{F}$ for hydrogen. The thermal efficiency of liquefying SNG reported in the 11terature ranges from 83 to $91 \%$, as shown in Table 10-8. For the purpose of this study, a value of $86 \%$ will be used (Reference 10-37) to be consistent with the cost of liquefaction given in Section 7 . 


\section{FIGURE $10-8$}

\section{THERMAL EFFICIENCY OF HYDROGEN LIQUEFACTION}

Btu/Pound of Hydrogen Produced

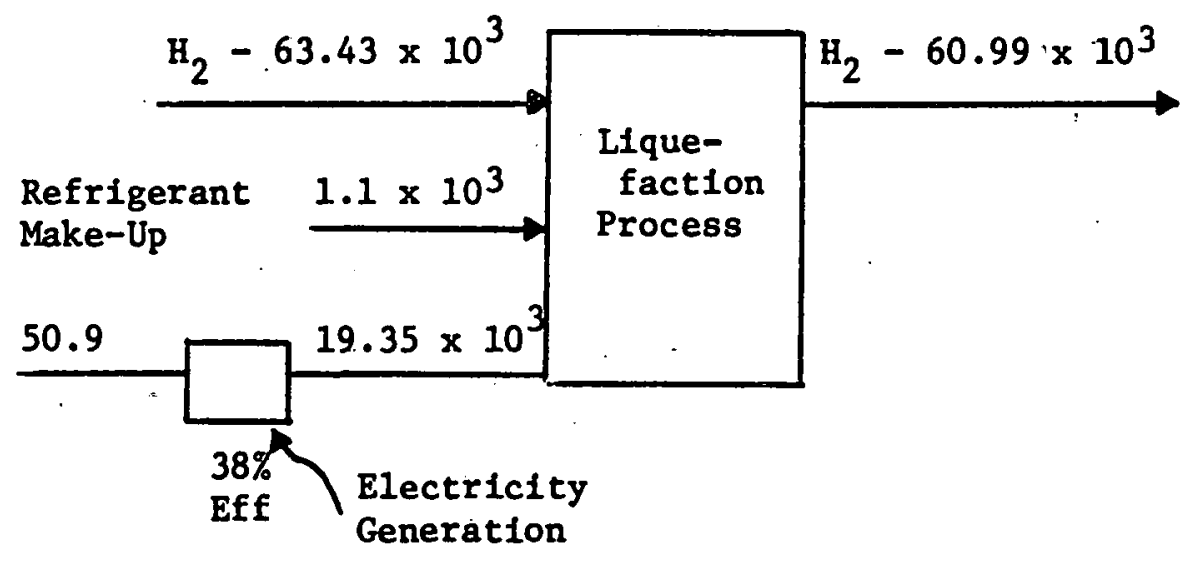

$$
\varepsilon_{2}=60.99 / 63.43+1.1+50.9=0.53
$$

If exclude electrical generation efficiency:

$$
\varepsilon_{2}=60.99 / 63.43+1.1+19.35=0.73
$$


TABLE 10-7

SUMMARY OF THERMAL EFFICIENCIES

OF COAL GASIFICATION PROCESSES (1)

Proces8

Lur $\mathbf{8} 1$

Synthane

BIGAS

HYGAS

U-GAS

Cońoco $\mathrm{CO}_{2}$

PERC-Dry Feed $\varepsilon_{1}$

$53(2)$

$55(3)$

59

54

$--$

54

59

65

60

68

66

48 $\underline{\varepsilon}_{2}$

66

66

71 (single feed)

$-$

66

67

63

65

65

68

67

55

\section{Reference}

10-29

10-29

10-30

10-31

10-8

$10-20$

$10-32$

10-33

10-34

10-35

$10-30$

$10-30$

(1) Most of these efficlencies are for a sub-bituminous type coal. With a bituminous coal, the efficiency would be lower, with $\varepsilon_{2}$ in the 50-60\% range,

(2) Based on burning fuel gas to generate electrical power.

(3) Based on a coal-fired boller to generate electrical power. 
FIGURE 10-9

THERMAL EFFICIENCIES FOR LURGI AND IGT STEAM-O 2 SNG PROCESS

$\underline{\text { Lurg1 }}$

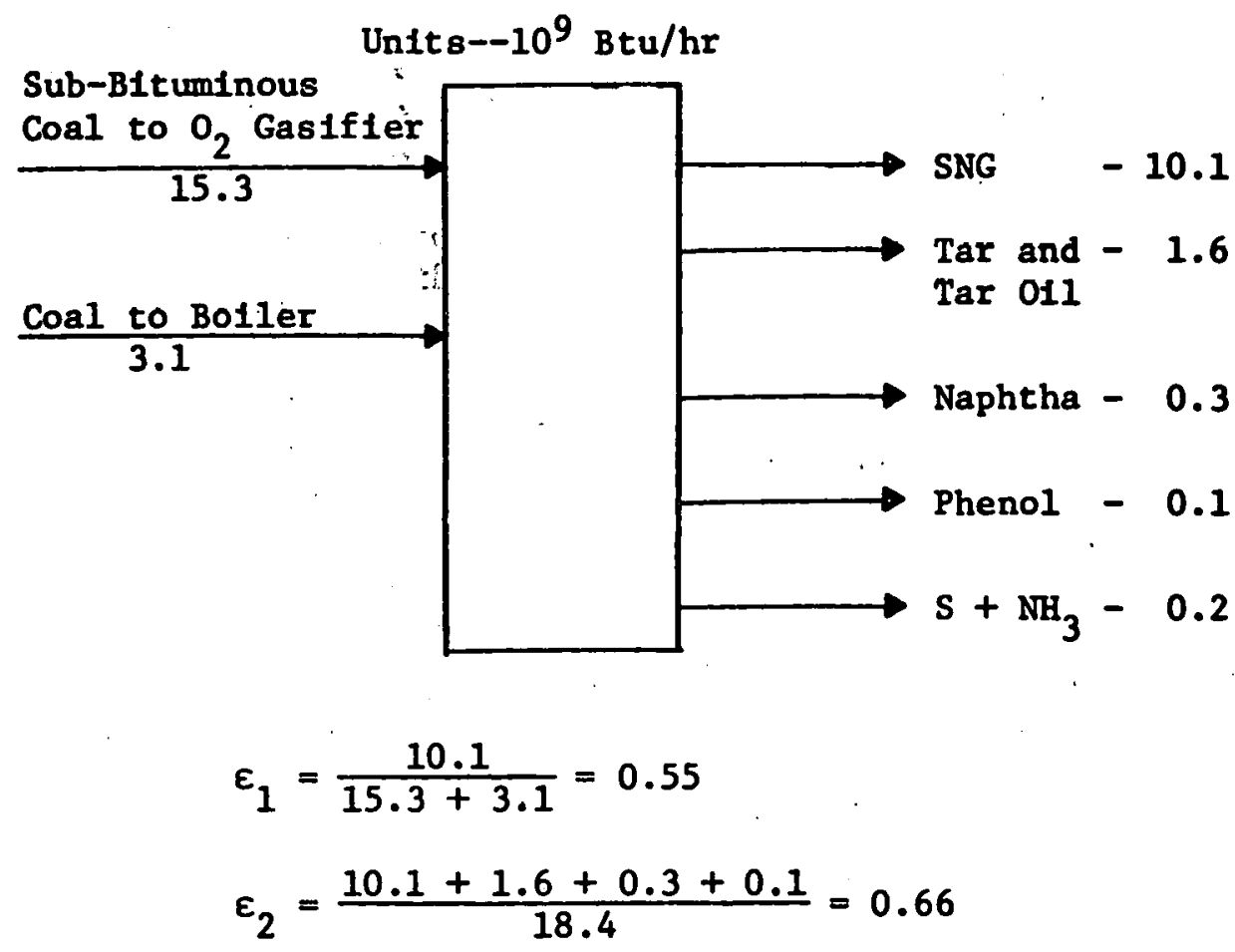

Source: Ref. 10-29 
TABLE 10-8

SUMMARY OF SNG LIQUEFACTION THERMAL EFFICIENCIES

Reference

$10-28$

$10-7$

10-3

$10-24$

10-37
Thermal Efficlency

90
83
83
91
$86-90$, ex storage losses
$83-87$, Including storage losses

\subsubsection{Electric Power Generation}

The thermal efficlencles of several different types of power plants are summarized in Table 10-9. A large, conventional, caal-fired untt will have a thermal efficlency of around 37\%. ThIs represents the net plant electrical output divided by the coal higher heating value, 1.e., "coal pile to bus bar." The efficiency of the H-coal fuel does not include the efficiency lost in preparing fuel for the power plant. If this 1088 is Included, the efficiency based on coal mined, drops to around $38 \%$.

Some of the more advanced technologles, such as a potassium topping cycle, with pressurized fluld bed combustion, and MHD are projected to have thermal efficiencies at the $50 \%$ level.

Nuclear and solar-steam electric efficlencles are shown in the bottom of this table for comparison. These efficlencles are around $33 \%$.

For this study, a thermal efficlency of $38 \%$ will be used. This Is a little higher than the value quoted for new, conventional coal-fired power plants, but lower than some of the more advanced technologies which may be developed after 1990 . The $38 \%$ is in 1 ine with the value given by Frabett1(10-39) for a coal or o1l-fired power plant, and higher than the $32 \%$ given by the Colorado Energy Research report, $(10-8)$ which is typlcal of older type units.

\subsubsection{Biomass-Derived Fuels}

The energy analysis of biomass materials is somewhat different from that for a non-renewable resource such as coal or shale oll, discussed in previous sections. With blomass materials, one value reported in the ilterature is the ratio of energy in the product to the energy consumed in the process, including the energy used in the agricultural production. It is important to consider the quality level of the various inputs and outputs as well. In this type of analysis, the ratio is generally greater than one, implying that the useful energy output exceeds the process energy input. Of course, this type of analysis does not include the energy that has come from the sun and been converted to plant materlal through photosynthesis. To put the thermal efficiencies on a similar basis with the coal and shale oil values, a heating value of the biomass material will be assumed 
TABLE 10-9

THERMAL EFFICIENCIES OF ELECTRIC

POWER GENERATION FACILITIES

\section{Power Plant \\ Thermal Efflciency-\%}

Conventional Coal Fired

0.37

AFB

0.37

PEB

0.40

Potassfum Topping - Conventional

0.45

- PFB

0.49

Combined Cycle - LHVG

$-\mathrm{H}-\mathrm{Coal}$

0.396

$0.511^{\star}$

MHD

0.50

LWR Nuclear

0.32

Solar Steam - Electric - Base Load NW

0.33

*Does not include efficiency lost in preparing the fuel. If this is Included, efficiency drops to $38 \%$.

Source: $10-38$ and $10-1.9$ 
to allow a calculation of the thermal efficiency quoted in previous sections. The following sections discuss the production of ethanol from sugarcane and corn, and the production of methanol and ammonfa from sugarcane via pyrolysis.

\subsubsection{Ethanol from Sugarcane}

Lipinsky, et al. have made an energy analysis for producing ethanol from sugarcane, (10-40) The analysis takes into account the energy used in producing the sugarcane (tractor fuel, fertilizers and pesticides). The energy analysis reported by Lipinsky is shown in Figure 10-10, with the energy values shown as million of BTU's per ton of sugarcane (dry weight basis). It is also important to consider the quality of energy involved, with the ethanol being considered high, and bagasse as a lower quality source of energy.

As shown in Figure 10-10, the bagasse that is left after the juice is extracted is used as fuel for the power plant to generate the -electricity and steam required. Assuming an $80 \%$ efficiency means that the waste product can provide $5.2 \times 10^{6}$ BTU/ton of sugarcane of the 8 milition BTU of energy required for crushing, evaporation, distillation and stillage drying. Therefore, an additional 2.8 million BTU of energy must be provided to complete the energy balance. If the same boiler efficiency of $80 \%$ applies, then 3.5 million BTU's of coal or oil would be needed. Therefore the 5.6 million BTU's of ethanol require 5.3 million BTU ( 1.8 million BTU agricultural production plus 3.5 million BTU's of coal or diesel oil) of input. Thus, the energy content of the ethanol produced from sugarcane Is slightly more than the energy consumed in the production process.

To compare the process efficiency with coal and shale o1l, it is necessary. to make an assumption on the heating value of the sugarcane. For a blomass heating value of $7800 \mathrm{BTU} /$ pound (dry), the $\varepsilon_{1}$ efficiency would be about $27 \%$. This calculation 1gnores the metabolizable energy in the st1llage, since it is a different type of energy. However, this is a very low level of energy output and would not affect the overall thermal efficiency. It is also unclear whether energy to dry the bagasse before feeding it to the power plant has been included in the literature reference. To take the bagasse from $38 \%$ molsture to a dry basis would require about 0.3 mililion BTU per ton of sugarcane and reduce the thermal efficiency to 26\%; therefore, it is not a critical uncertainty in this case.

\subsubsection{Ethanol from Corn}

There are varying opinions on the net energy balance of ethanol production from corn. Scheller has made a net energy balance which assumes that the stalks, cobs, and husks can be used to generate the process steam and electricity $(10-41)$. With this assumption, he obtains a positive energy balance. However, two other references (10-44,10-45) conclude that the energy balance is negative, mainly based on the assumption that fossil energy will be required to provide the steam and electricity since there is no commercial process that 
FIGURE 10-10

ENERGY ANALYSIS OF ETHANOL PRODUCTION FROM SUGARCANE

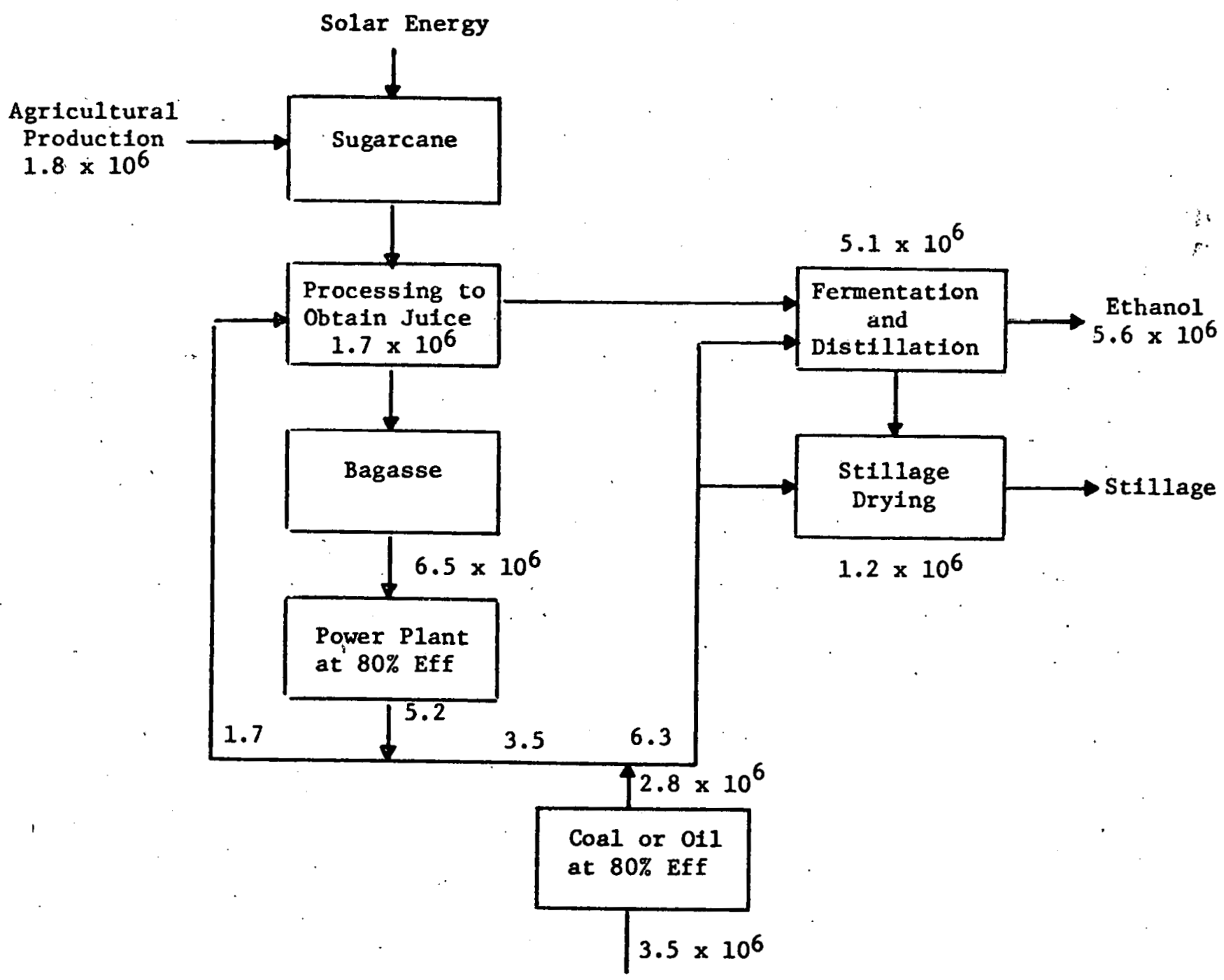

Units: Million Btu/ton Sugarcane (Dry Welght Basis)

Product Energy/Process Energy Input =

$5.6 / 1.8+3.5=5.6 / 5.3=1.06$

$\varepsilon_{1}=5.6 / 1.8+15.6^{(1)}+3.5=0.27$

(1) Based on assumed $7800 \mathrm{Btu} /$ pound (dry) heating value for biomass. 


\section{FIGURE $10-11$}

ENERGY ANALYSIS OF ETHANOL PRODUCTION FROM CORN

Agricultural Production and Transportation of Stalk, etc.

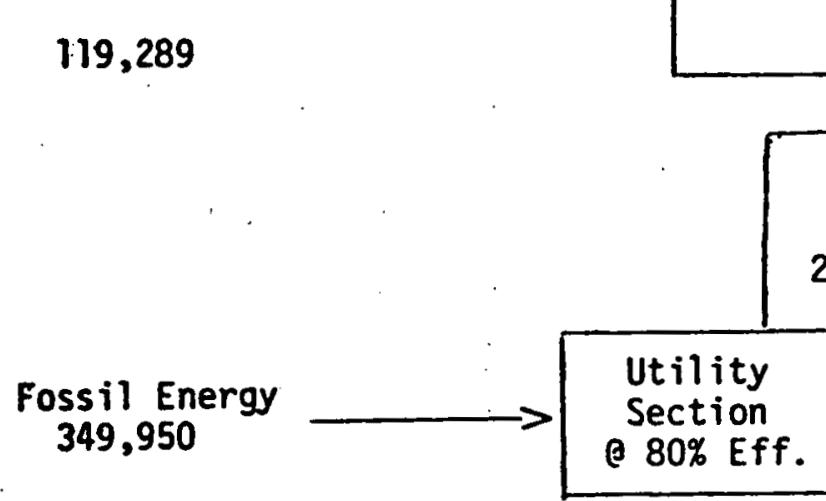

Corn Crop

Solar Energy

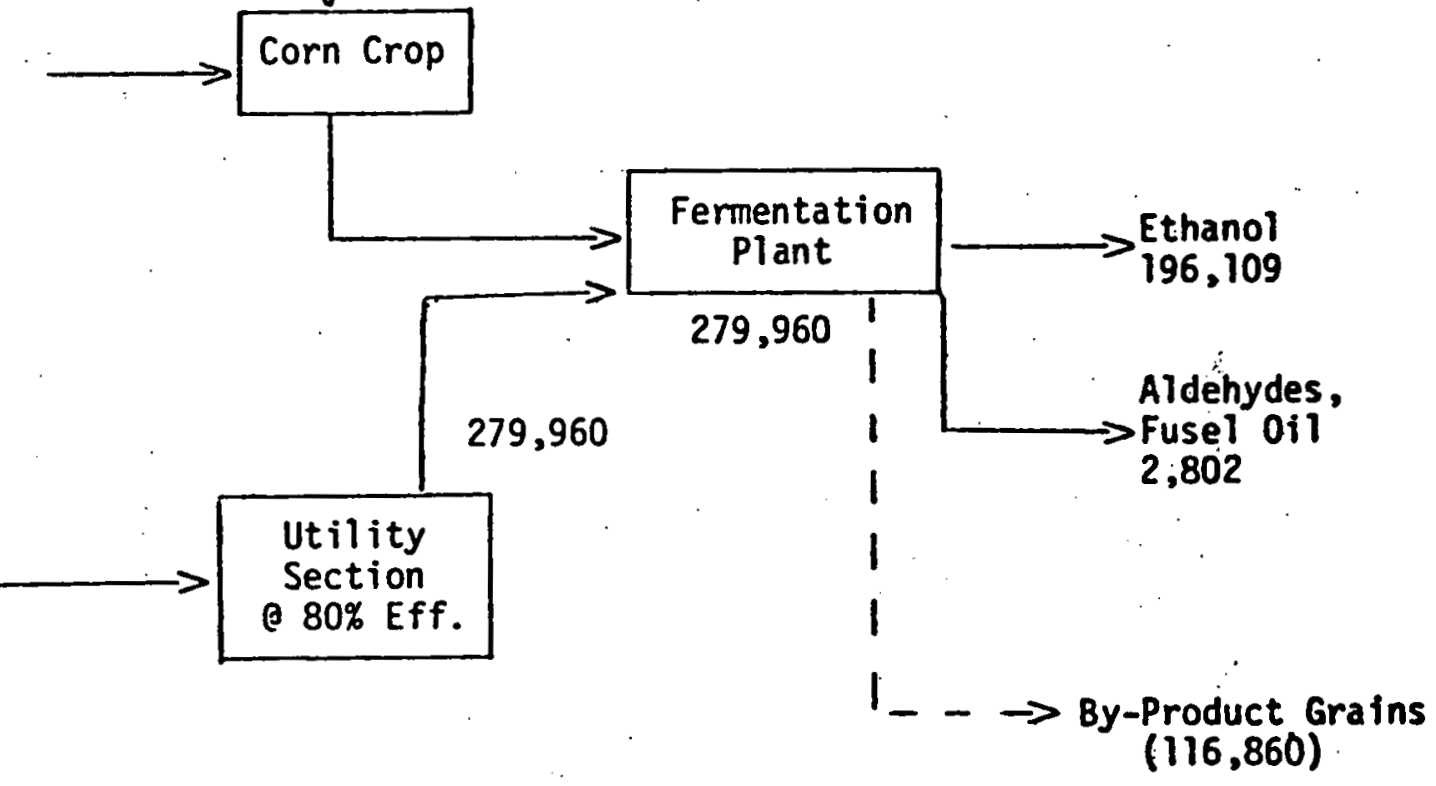

Product Energy/Process Energy $=198,911 / 119,289+349,950=0.42$

$E_{1}=196,109 / 119,289+349,950+341,750$ (Energy in Corn) $=.24$

If consider only energy in corn that produces the alcohol - which is $59 \%$ of the total.

$E_{1}=196,109 / 70,380+349,950+201,632=.32$

If include cattle feed

$$
E_{2}=\frac{196,109+2,802+116,860}{119,289+349,950+341,750+58,900}=.36
$$

Source: Adapted from Ref.- 10-40. 
ut1lizes stover as its energy source(10-45). Also, removal of the crop residues would require energy for collection and handling and also excessive removal could fead to soll degradation and additional fertilizer energy requirements $(10-44)$. A comparison of the ratio of product energy (ethanol only) to the process energy input (assuming fossil fuel for steam and electricfty) is shown below.

\begin{tabular}{cc} 
Reference & Product Energy/Process Energy \\
\hline $10-41$ & 0.42 \\
$10-44$ & 0.4 \\
$10-45$ & $0.44-0.49$
\end{tabular}

In general, there is fairly good agreement, once the results are put on a. common basis.

The energy analysis by Schellex $(10-41)$ is shown in Figure 10-11, with the energy values shown as BTU/bushel of corn. The balance is shown with fossil fuels providing the energy for steam and electricity, whereas In the reference it was assumed that corn stalks would provide the energy. The use of fossil fuels were assumed for the reasons given above. Agricultural production and transportation of the corn requires 119,289 BTU/bushe1 of corn. The energy required in the fermentation plant to produce the ethanol is $279,960 \mathrm{BTU} /$ bushel of corn. Assuming an $80 \%$ efficlency for the utility section means that $349,950 \mathrm{BTU} /$ bushel of fossil energy would be required. The products are ethanol (196,109 BTU/bushel of corn), fusel oll and aldehydes (2802 BTU/bushel of corn) and graln-by-products.

The ratio of product energy to process energy is 0.42 based on ethanol as the main product. Using the heating value for corn (341,750 BTU/ bushel) reported in the article, the thermal efficiency is $24 \%$, excluding the digestible energy content in the by-product grains. However, In the fermentation process only the starch fraction of the corn is converted to alcohol. The rest of the grain remains as a high protein feed, distillers grain. On this basis, only $59 \%$ of the energy is used to produce a bushel of corn (70,380 BTU) and $59 \%$ of the energy content of the corn $(201,632$ BTU) should be charged to alcohol production(10-45). On this bas1s; the thermal efficlency increased to $32 \%$. If the energy consumption assoclated with the production of distillers' by-product grains is included, and the digestible energy content of the by-product grains is included, the thermal efficlency Increases to $36 \%$.

\subsubsection{Methanol}

The Lipinsky study(10-40) presents information on the manufacture of methanol via gasification of the bagasse (Purox process) to produce a synthesis gas and then converting the $\mathrm{CO}$ and $\mathrm{H}_{2}$ to methanol via conventional technology. An energy balance has been developed based on information in the Lipinsky report and is shown in Figure 10-12. Several assumptions were made to arrive at the estimate shown. It was assumed that the heating value of the bagasse was $7800 \mathrm{BTU} /$ pound (dry) and that the 


$$
\text { 10-33: }
$$

agricultural requirements that could be attributed to the bagasse were proportional to the weight fraction of bagasse to the sugarcane production. It was also assumed that electricity was generated from coal with a $38 \%$ efficient power plant. The data from the Lipinsky report did not show any steam consumption so it was assumed that the steam from the turbine generators was used in the Purox process and methanol synthesis.

As shown in Figure 10-12, the production of methanol from gasification of a blomass material has a thermal efficiency of around $29 \%$ and a net energy ratio (output/input) of 2.1. Thus, the production of methanol via gasification appears to be more efficient than the production of ethanol via fermentation.

Reed (10-42) reported a thermal efficiency of producing methanol from waste of about $34 \%$ and $37 \%$ when producing methanol from dry wood. These are somewhat lower efficiencles than reported by Stanford Research Institute (10-19) of $43 \%$ for a conceptual advanced gasification system.

\subsubsection{Ammonia}

The Lipinsky study (10-40) also allows one to make an estimate on the energy requirements to produce ammonia from biomass. Figure 10-13 shows the energy analysis that has been developed using information from the Lipinsky report. It is assumed that the by-product gas will be used to provide most of the energy requirements, which greatly reduces the external energy requirements. On this basis, the output/input ratio is 4 , and the thermal efficiency $46 \%$, about the same as for producing ammonia from coal.

Thus, of the three fuels considered as belng produced from blomass (ethanol, methanol and ammonia), ammonia has the highest thermal efficlency and thus the greatest utilization of resources.

\subsection{Energy Reguirements for Transportation of Fuels}

In moving the fuel to the conversion plant and to the consumer, a certain amount of energy is required. Table 10-10 summarizes the primary efficlency, and the fuel and electricity (ancillary energy) that would be needed to move the various fuels. The energy used for construction and maintenance is not included, but generally represents only about $10 \%$ of the anclilary energy shown. Also, any losses during distribution and storage are not included since these are generally essentially zero. In some cases, data were avallable from several different references, and the range 1s shown, as well as the value that w11l be used In this study.

In the case of pipelines for liquids, the energy required to move the product is very dependent on line size, viscosity of the product, heating value of the product, and flow rate. This accounts for part of the difference between the various references.

For a natural gas pipeline, the general practice is to use some of the gas as fuel, thus the energy consumption can be expressed as a primary energy efficiency. It is assumed that hydrogen would also be used as fuel if moved by pipeline.

The transmission and distribution of electricity have an average efficlency of around 0.91 , based on national statistics. $(10-7,10-8)$ 


\section{ENERGY ANALYSIS OF METHANOL PRODUCTION FROM BIOMASS VIA GASIFICATION}

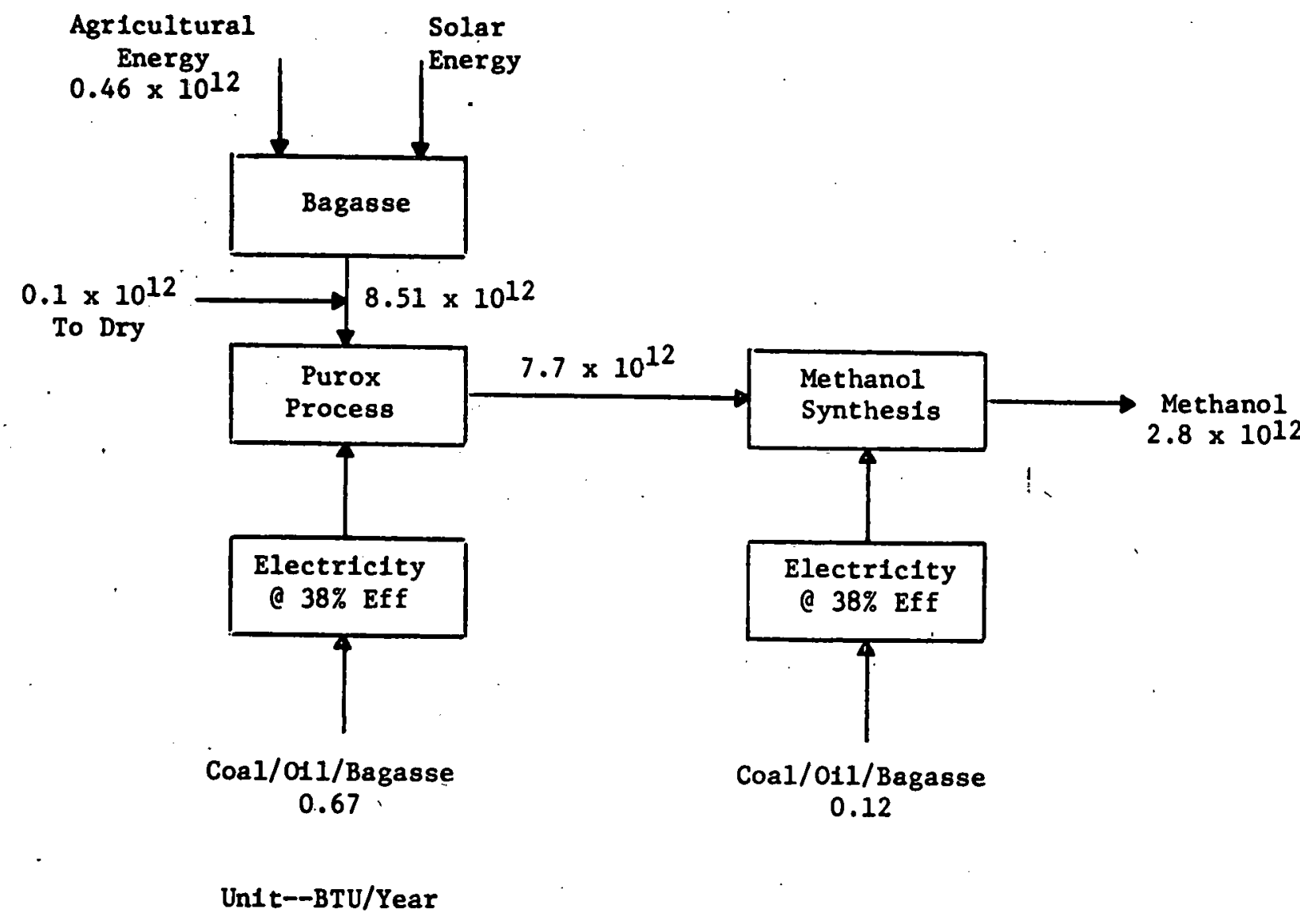

Product Energy/Process Energy $=\frac{2.8}{0.67+0.12+0.46+0.1}=2.07$

$$
\varepsilon_{1}=\frac{2.8}{8.51+0.67+0.46+0.12+0.1}=0.28
$$

Source: Adapted from Ref. 10-40 
ENERGY ANALÝSIS OF AMMONIA PRODUCTION FROM BIOMASS VIA GASIFICATION

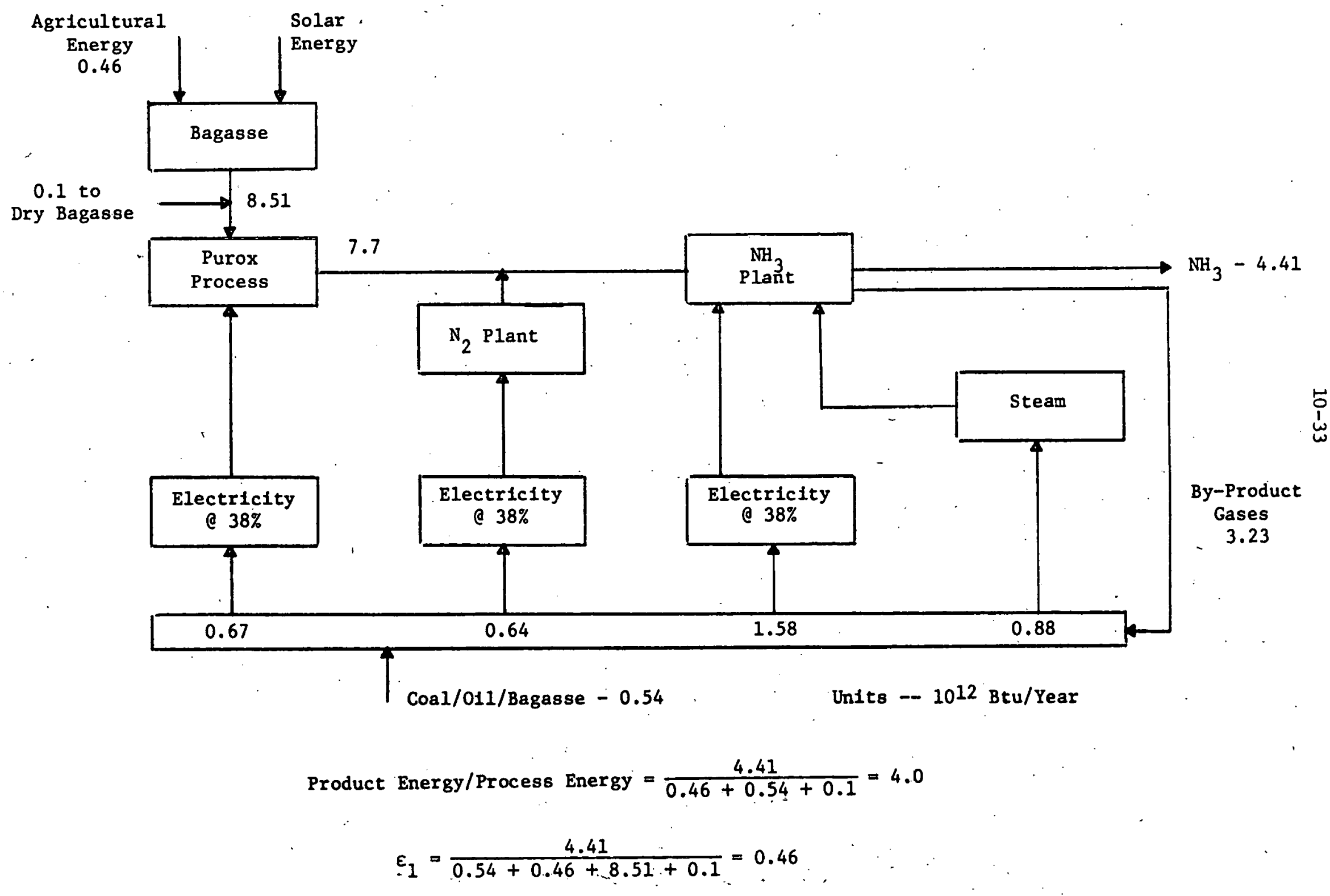


TABLE $10-10$

SUMMARY OF TRANSPORTATION ENERGY REQUIREMENTS FOR ALTERNATIVE FUELS

Fuel

\section{Coal}

- Unit train

- Siurry pipeline

- Barge

- Train

- Train

Crude Pipéline

Petroleum P1peline

(also coal or shale liquids)

Methanol P1peline

Methane

Hydrogen (gas)

Electricity transmission and distribution

\section{0}

1.0

1.0

1.0

1.0

1.0

1.0

$1-3.6 \times 10^{-5} \tau^{*}$

$1-5.2 \times 10^{-5} L^{*}$

$0.91 *$

0.92
Fuel/Electricity

Required to Move

the Product

BTU/106 BTU Output

$10-7$

10-7

$10-7$

10-7

$10-43$

$10-43$

10-8

10-7

$10-43$

$10-43$

46XI (18" $\phi-$ High Flow Rate)

10-7

10-8

$10-43$

$4 \mathrm{~L}$

4 L (25" $\phi$-High Flow)

23 I (12" $\phi-H 1 g h$ Flow)

10-7

$10-7$

10-7

$10-7$

10-8

* Value used in this study.

$I$ = transport distance in miles.

(1) 20 times the transport distance in miles. 


\subsection{Total Resolize Requirements for Varlous Alternate Fuels}

Having established the thermal efficiencies for manufacture of the varlous alternate fuels and the energy required to transport the resources and finished products, it is now possible to estimate the total resources that would be required to provide the same amount of energy for each of the fuels that could be produced from coal or shale ofl.

F1gure 10-14 shows the total resources required to produce distillate from shale oil. Two types of energy are represented--the amount of shale resource required and the ancillary (fuels and electricity) energy used to transport the fuels. The anclilary energy may likely come from a different resource base, such as crude o11, but is included in the total for completeness. In most cases, it represents less than $2-3 \%$ of the total energy required.

As shown in Figure 10-14, it takes $1.59 \times 10^{6} \mathrm{BTU}$ of shale to provide $1 \times 106 \mathrm{BTU}$ of energy in the form of distillate in the customers' tanks. In addition, $0.04 \times 10^{6} \mathrm{BTU}$ of fuels and electricity would be required to move the syncrude to a refinery, the products to terminal storage, and then to the customer tankage. The distances assumed are shown in the figure. These are rough approximations of average distances, and could vary considerably in an actual situation. The thermal efficiency assumed at each processing step is also shown in Figure 10-14.

Similar charts for the coal-based alternate fuels are shown in Figures 10-15 through 10-23. Table 10-11 summarizes the information from these figures. As shown in Table 10-11, the most efficient way to use coal would be to burn it directly, but this has some practical limitations. A coal/o1l slurry is the next most efficient way, but it does require the use of a petroleum product. Longer range, the petroleum could be replaced with a. coal or shale oil derived liquid. Coal distillate and liquid methane require the same total resources, around $1.9 \times 10^{6} \mathrm{BTU}$ of coal to provide mililion BTU of energy to the customer. LIquid hydrogen and acetylene require the most resource to provide a million BTU of fuel. 
FIGURE 10-14

SHALE OIL LIQUIDS PRODUCTION, TRANSPORTATION AND DISTRIBUTION SYSTEM

Shale 011

Resource

$1.59 \times 10^{6} \mathrm{BTU}$

Mine or In-Situ

Production $(0.98)$

$$
1.56
$$

Product

Upgrading

to Syncrude (0.70)

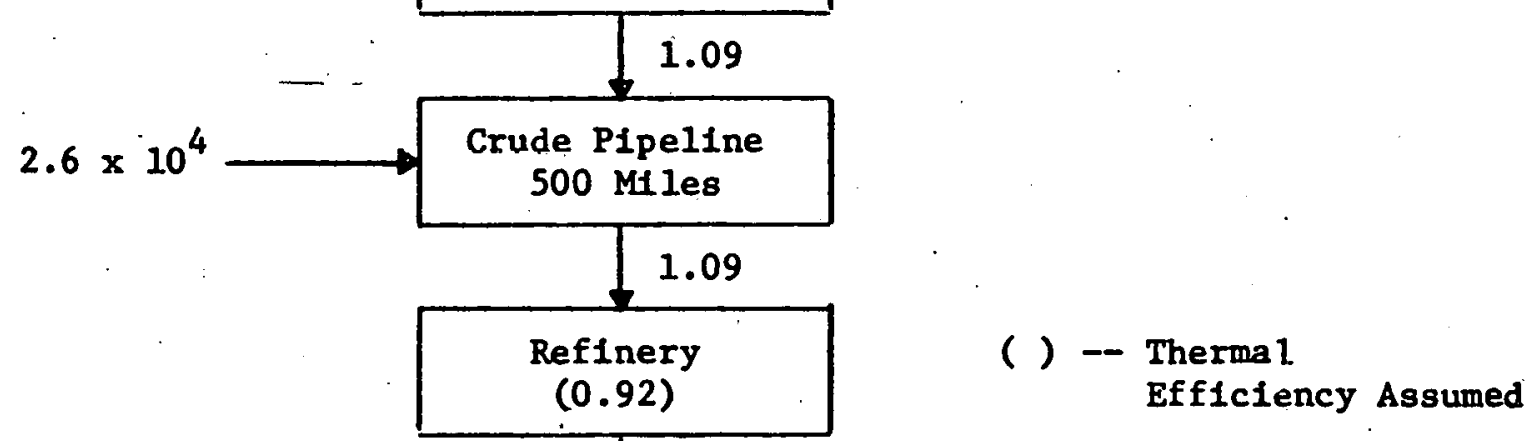

Total Resources $(1)$

Shale $\quad-1.59$

Anc1llary - 0.04

1.63

1.0

(1) MBTU Resources MBTU of Fuel

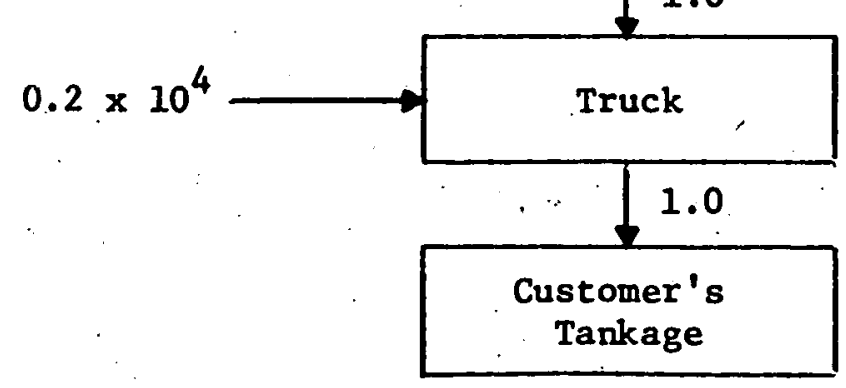

$1 \times 10^{6} \mathrm{Btu}$ 


\section{$10-37$}

FIGURE 10-15

\section{COAL-OTOTAL ENERGY UTILIZATION}

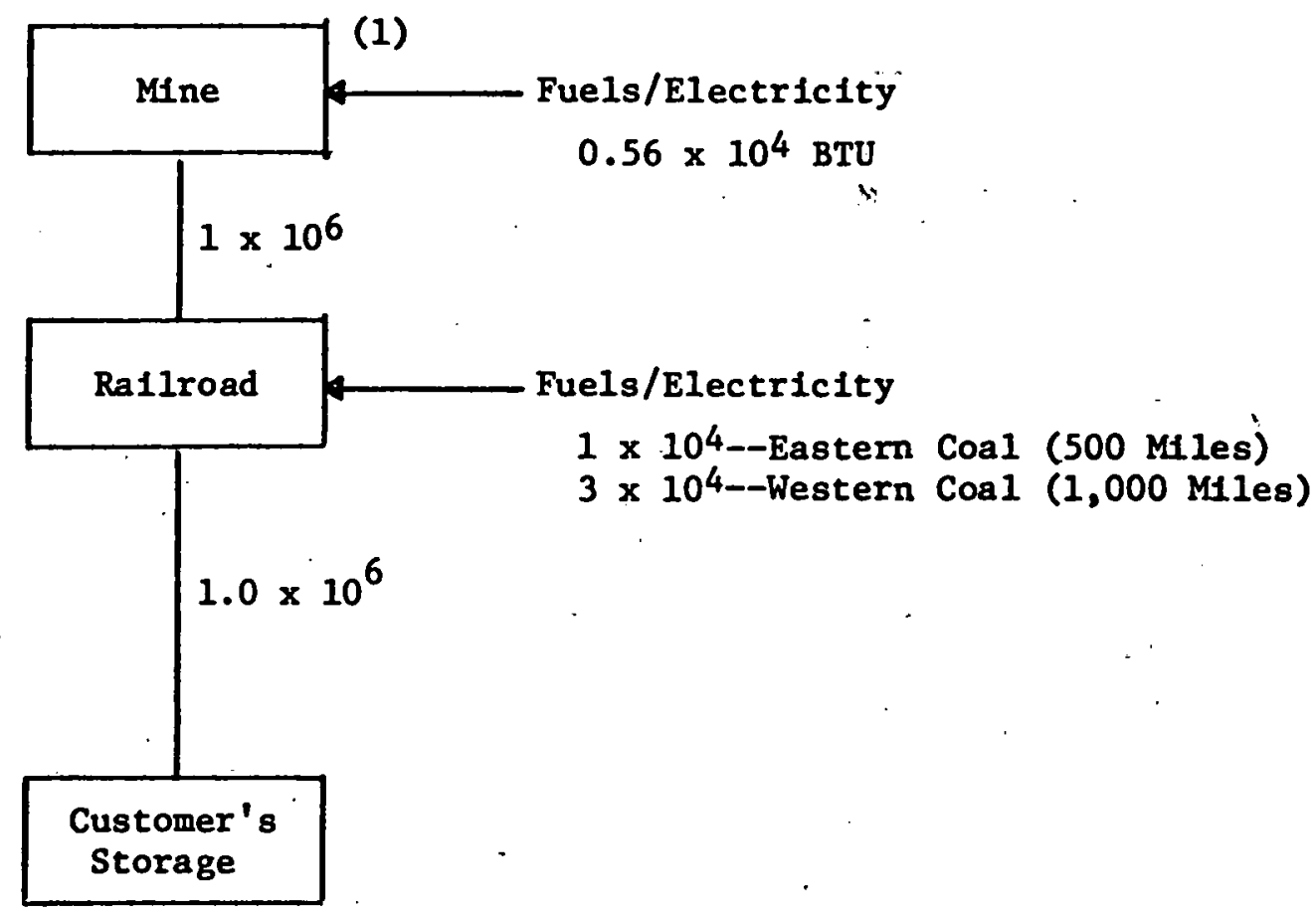

$1 \times 10^{6} \mathrm{Btu}$

Total Energy Required $-10^{6}$ BTU/106 BTU Fuel

Coal -1.0

Anc1llary- $-0.016-0.036$

Total $-1.016-1.036 \times 10^{6}$ Btu/ $/ 10^{6}$ Btu of Final Fuel

(1) Does not include any energy used in coal cleaning or 1088 of coal fines. 
FIGURE 10-16

COAL/OIL SLURRY PRODUCTION, TRANSPORTATION AND DISTRIBUTION SYSTEM

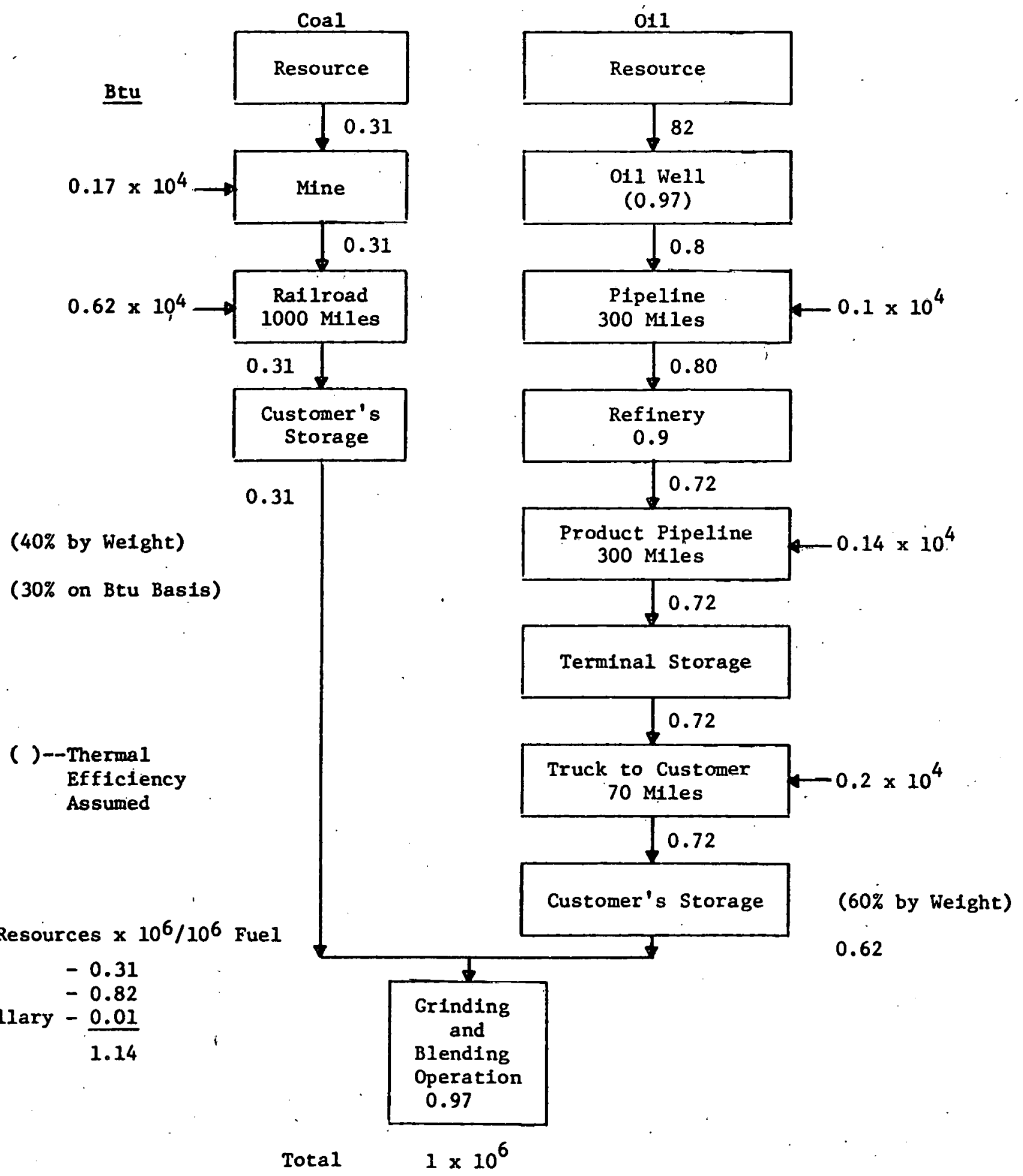


FIGURE 10-17

COAL LIQUIDS PRODUCTION, TRANSPORTATION AND DISTRIBUTION SYSTEM

Coal

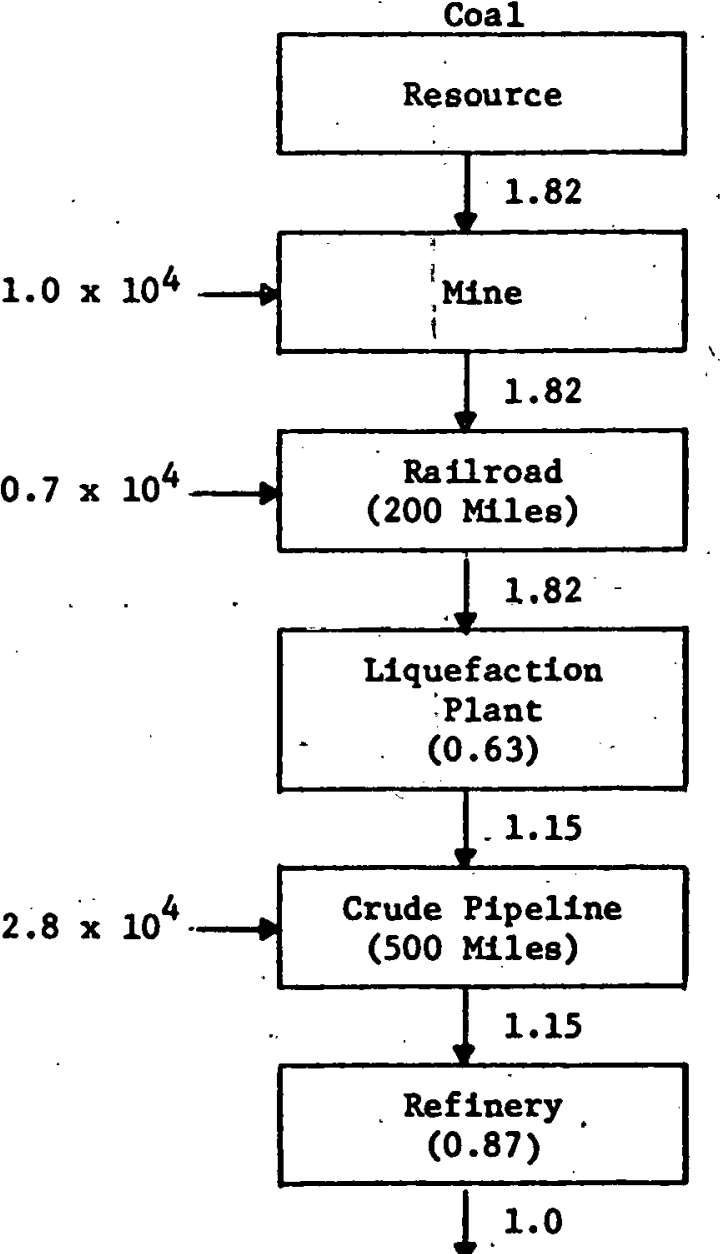

Total Resources $10^{6} \mathrm{BTU} / 10^{6} \mathrm{BTU}$ Fuel

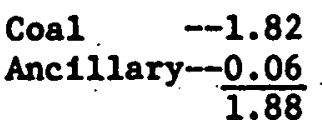

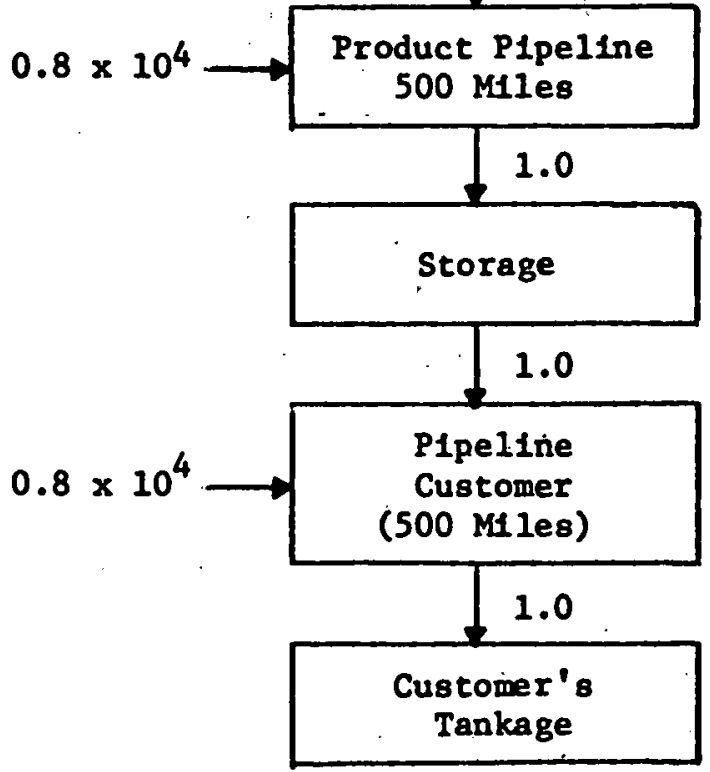

$1.0 \times 10^{6}$ 
FIGURE 10-18

METHANOL PRODUCTION (COAL), TRANSPORTATION AND DISTRIBUTION SYSTEY

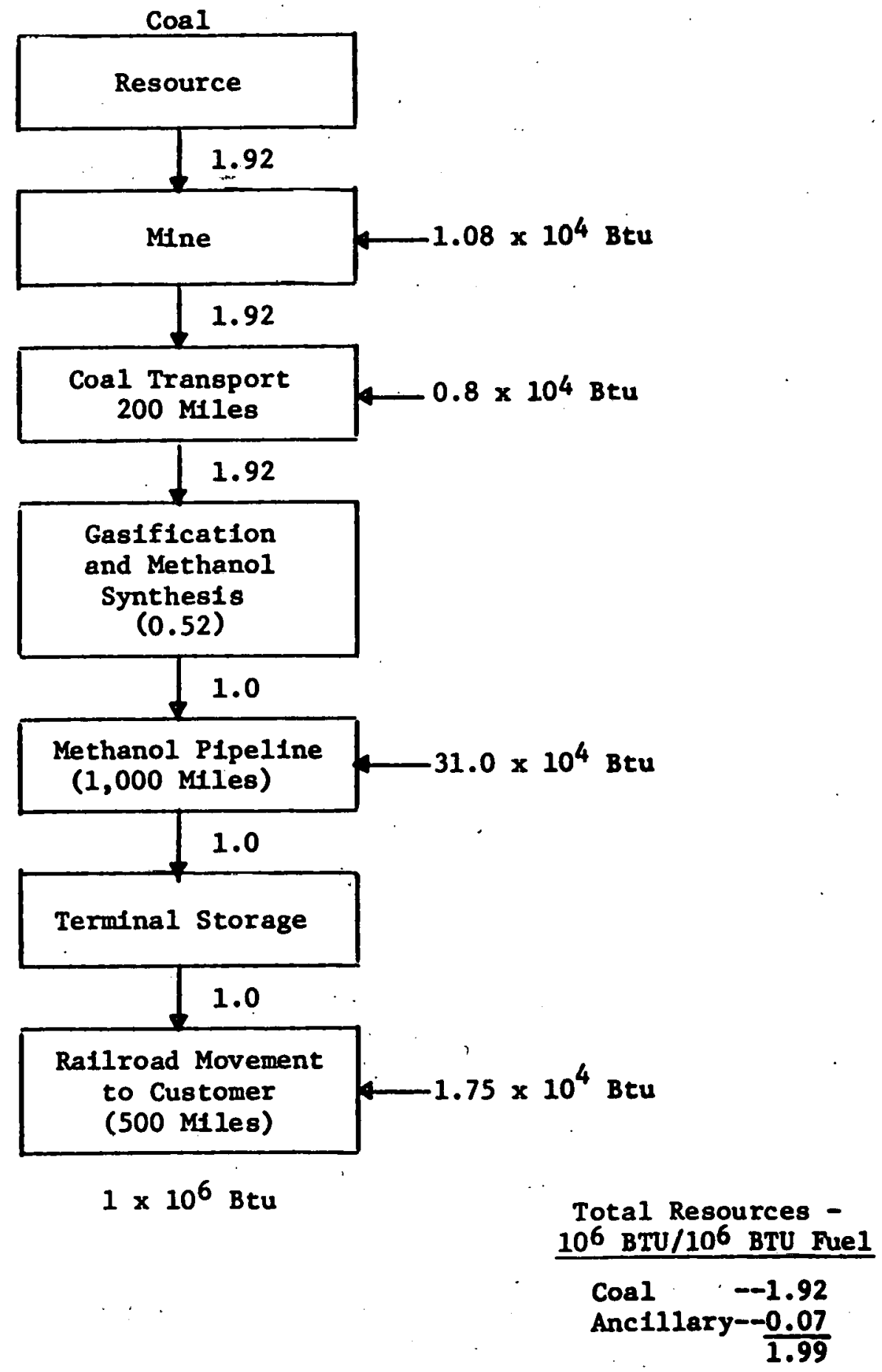


FIGURE 10-19

HYDROGEN PRODUCTION,

TRANSPORTATION AND DISTRIBUTION SYSTEY

Coal
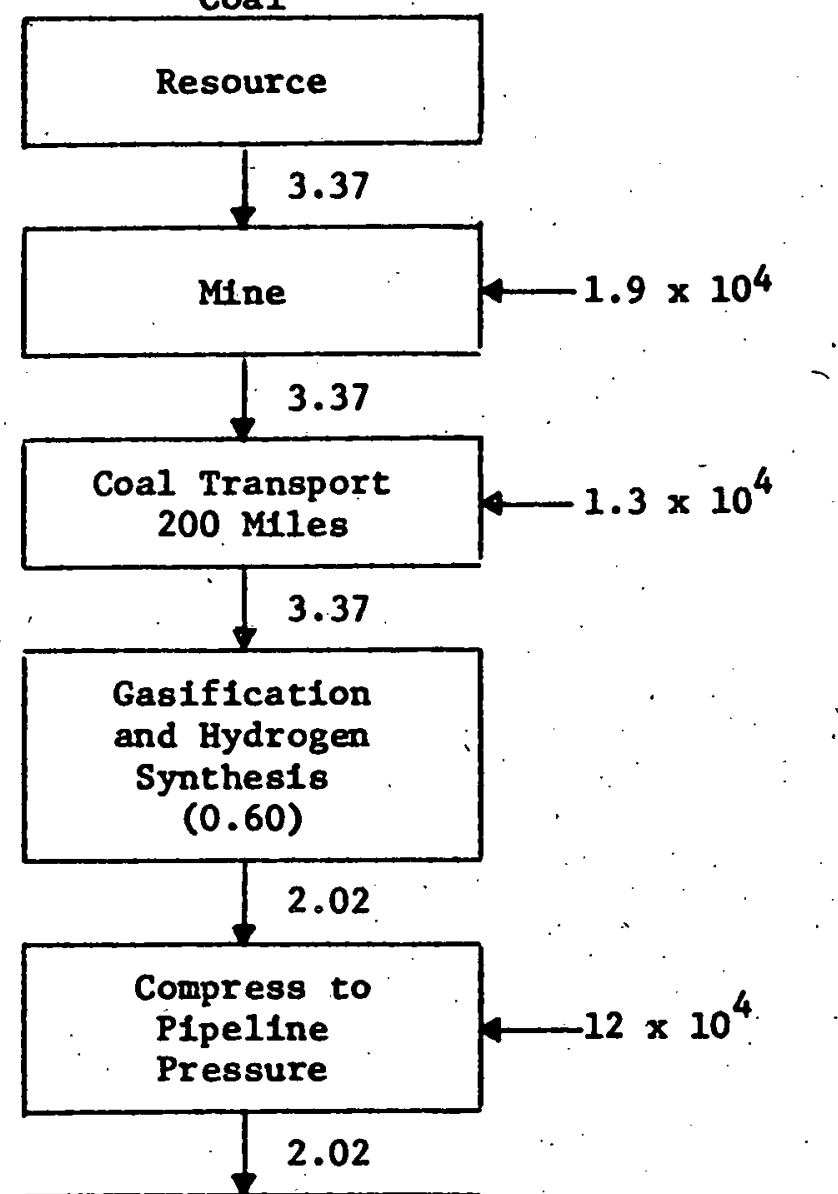
Hydrogen P1peline (Gaseous)
(1000 Mfles) $(0.95)$

$$
1.92
$$

Hydrogen

Liquefaction (0.53)

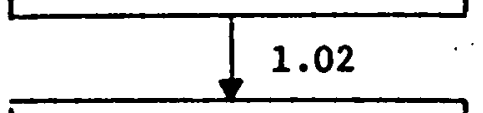

Storage and

Distribution (0.98)

$1 \times 10^{6}$

Total Resources $10^{6}$ BTU/106 BTU Fuel

Conl --3.37 Anc111ary- 0.16

3.53 
FIGURE $10-20^{-}$

METHANE PRODUCTION, TRANSPORTATION AND DISTRIBUTION SYSTEM

Coal

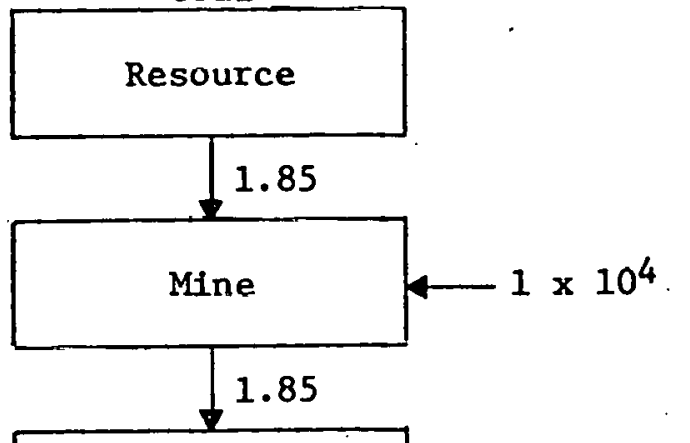

Coal Transport 200 Miles
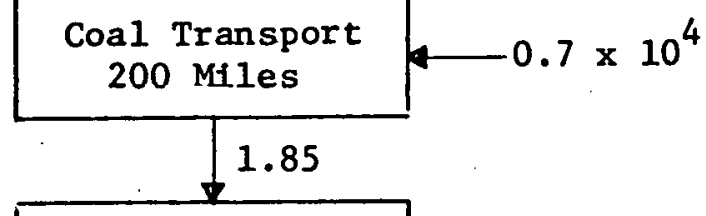

Gasification

and SNG

Synthesis

$(0.66)$

(Existing Tech.)

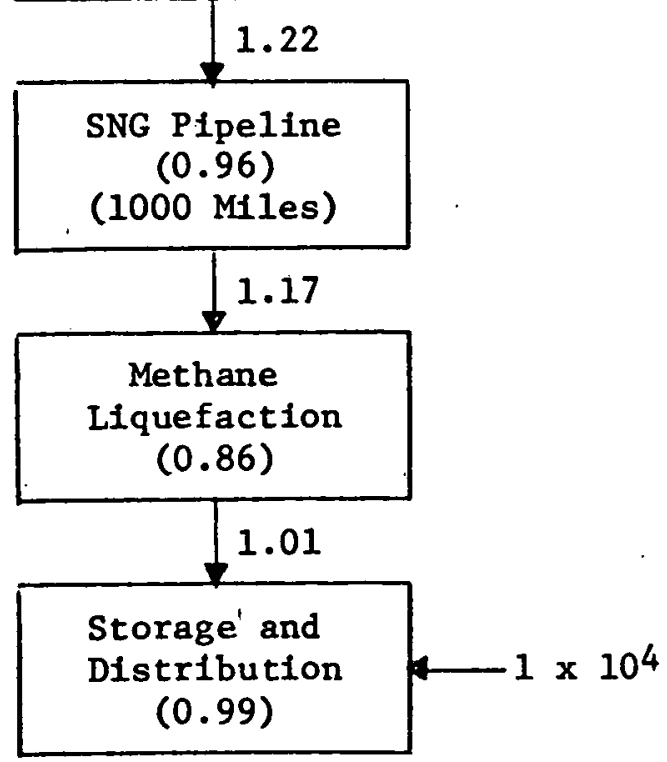

Total Resources $10^{6} \mathrm{BTU} / 10^{6} \mathrm{BTU}$ Fuel

Coal $-1.85$ Anc111ary -0.03

$1.0 \times 10^{6}$ 
FIGURE 10-21

AMMONIA PRODUCTION,

TRANSPORTATION AND DISTRIBUTION SYSTEM

Coal

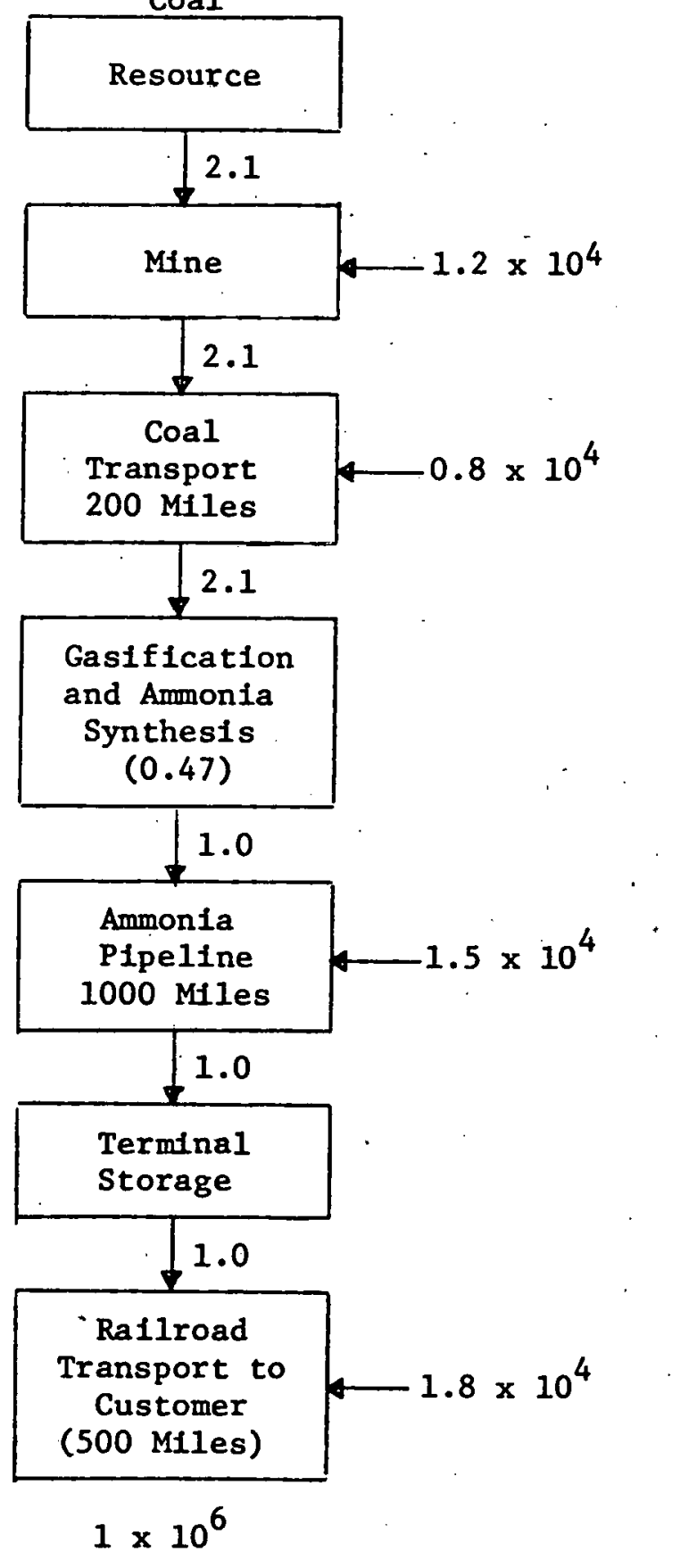

Total Resources $10^{6}$ BTU/106 BTU Fuel

Coal $\quad-2.1$

Ancillary- 0.05

2.15 


\section{$10-44$}

FIGURE 10-22

ACETYLENE PRODUCTION,

\section{TRANSPORTATION AND DISTRIBUTION SYSTEM}

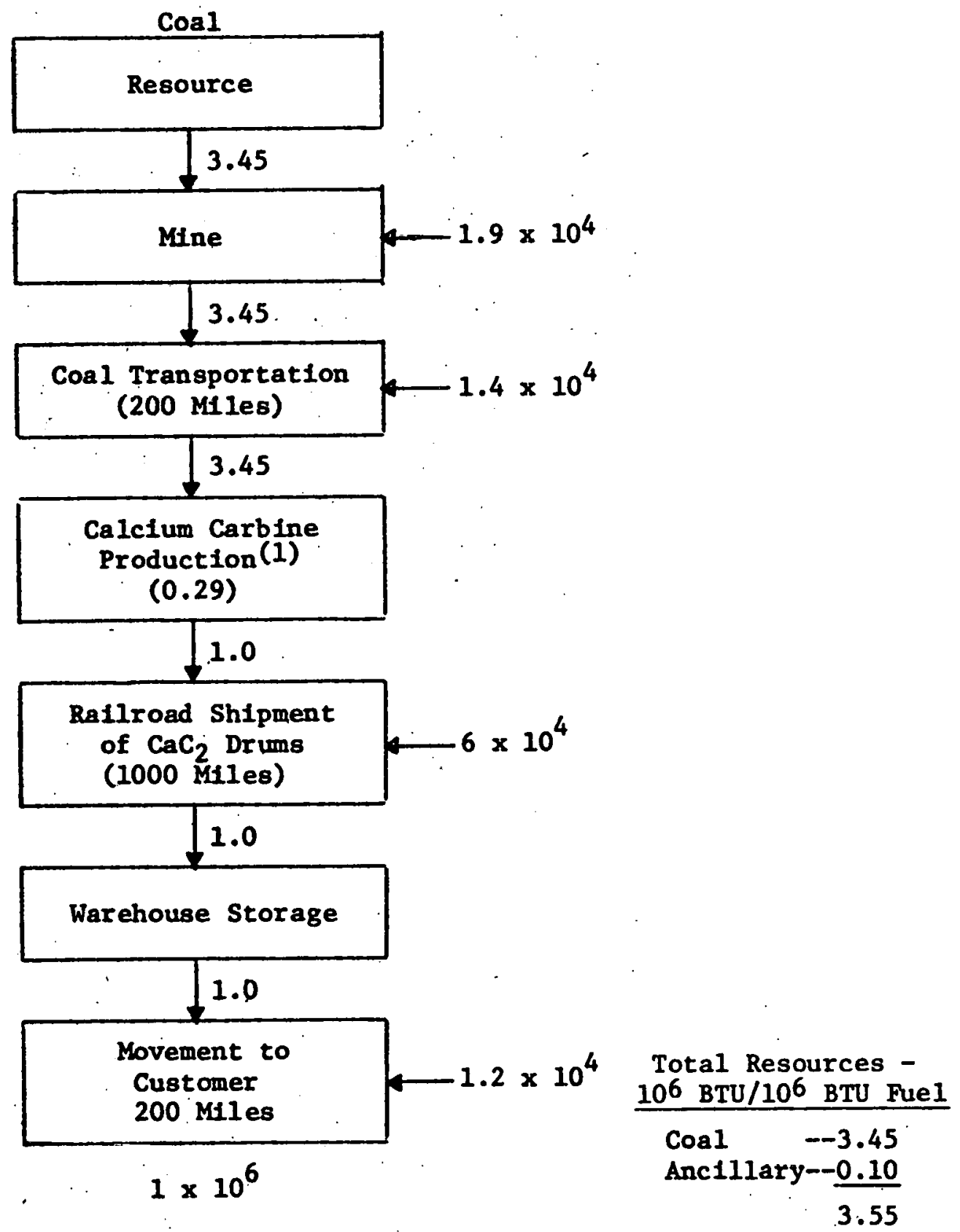

(1) Based on the $\varepsilon_{1}$ effictency. The efficiency woutd be around 30-34\% if the by-product gases were used in the process. 
FIGURE 10-23

ELECTRICITY PRODUCTION, TRANSMISSION AND DISTRIBUTION ${ }^{\circ}$

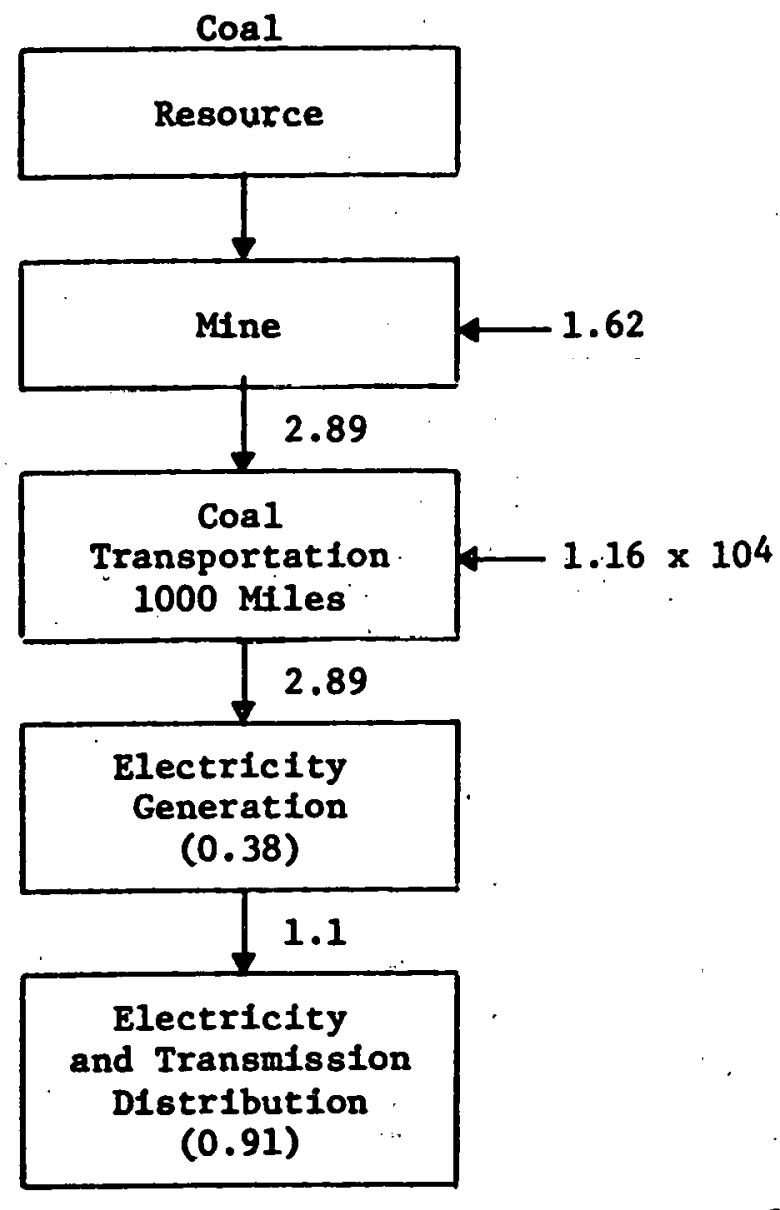

Total Resources -

$1.0 \times 10^{6}$ $10^{6}$ BTU/106 BTU Fuel

$$
\begin{array}{lr}
\text { Coal } & -2.89 \\
\text { Ancillary }-\frac{0.03}{2.92}
\end{array}
$$


TABLE 10-11

SUMMARY OF TOTAI RESOURCES REQUIREMENTS

BTU of Resource/BTU of Final Product

\begin{tabular}{c}
$\begin{array}{c}\text { Direct } \\
\text { Require- } \\
\text { ment }\end{array}$ \\
\hline
\end{tabular}

$\underline{\cos 1}$

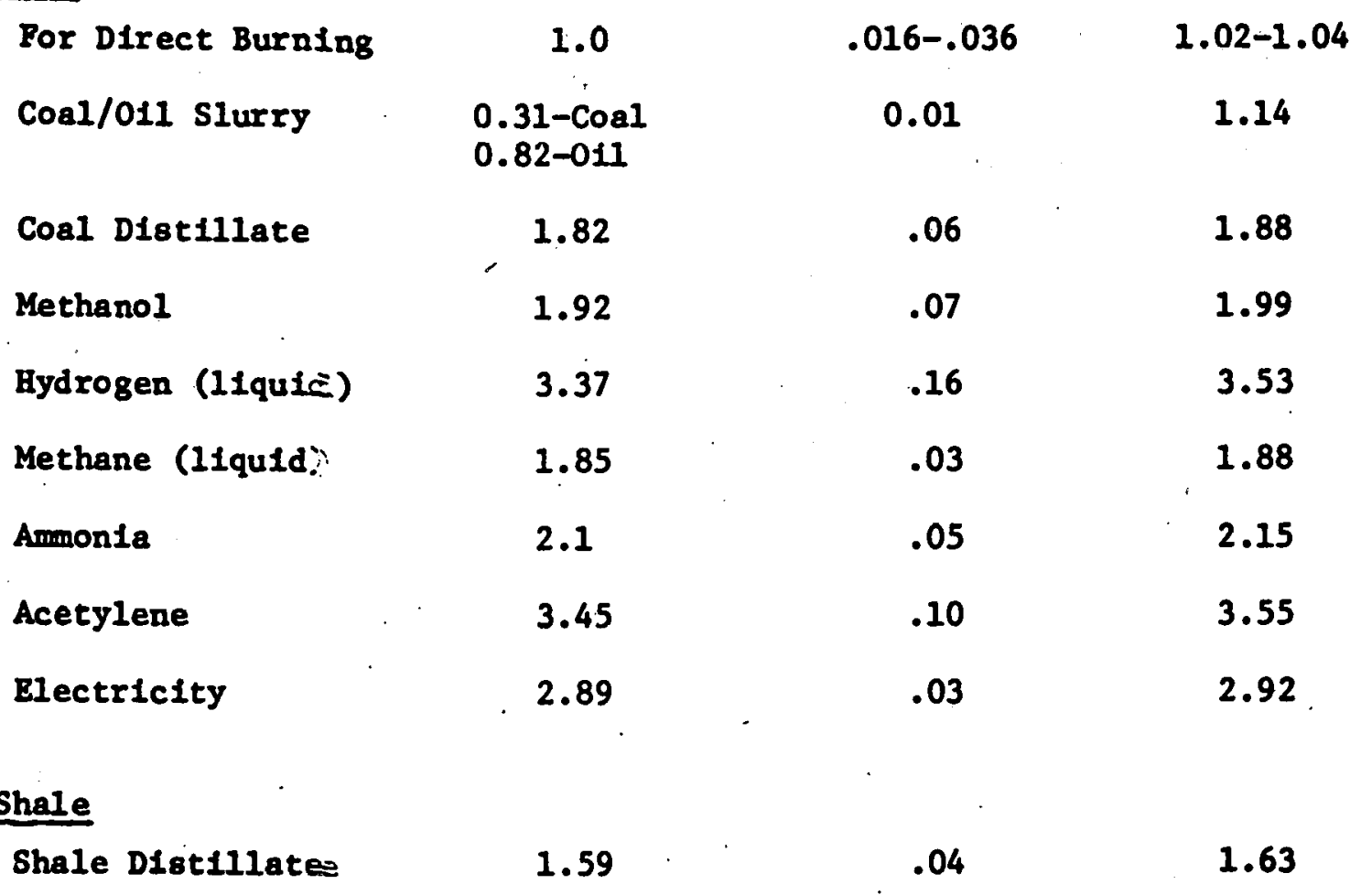




\section{REFERENCES}

10-1 Dickson, E. M., et al., "Impacts of Synthetic Liquid Fuel Development," Vo1. II, ERDA 76-129/2.

10-2 O'Hara, J. B., et al., "Project POGO: Total Coal Utilization COG Refinery Designs Criteria," November 1977.

10-3 Gebman, J. R., et al., "The Potential Role of Technological Modif1cations and Alternative Fuels in Alleviating Air Force Energy Problems," R-1829-PR, December 1976.

10-4 Anonymous, "O1l and Power by COED Based Coal Conversion," Ralph M. Parsons for ERDA, FE-1775-1, September 1975.

10-5 Holmes, J. M., "Hydrocarbonization Process Evaluation Report. Volume II--Evaluation of Process Feasibility," ORNL-5213, July 1977.

10-6 Salmon, R., et al., "Evaluation of the Synthoil Process, Vol. I, II and III," ORNL-5209, 5210, 5211, June 1977.

10-7 Steele, R. V., et al., "Synthetic Liquid Fuels Development:

Assessment of Critical Factors," Vol. IV, ERDA 76-129/4, May 1977.

10-8 Anonymous, "Net Energy Analysis: An Energy Balance Study of Fossil Fuel Resources," PB-259 158, Colorado Energy Research Institute, April 1976.

10-9 Anonymous, "Preliminary Economic Analysis of H-Coal Process Producing 50,000 BPD of LIquid Fuels from Two Coal Seams: Wyodak and Illinois No. 6," Bureau of Mines, ERDA 76-56, March 1976.

10-10 Fant, B. T., "Exxon Donor Solvent Coal LIquefaction Commercial Plant Study Design," FE-2353-13, January 1978.

10-11 0'Hara, J. B., et a1, "Fischer-Tropsch Complex Conceptual Design/ Economic Analysis--011 and SNG Production," FE-1775-7, Ralph M. Parsons for ERDA, January 1977.

10-12 Jahnig, C. E., "Evaluation of Pollution Control in Fossil Fuel Conversion Processes-Liquefaction H-Coal Process," EPA-650/2-74-009-m, October 1975.

10-13 Garcla, A., "Assessment of Potential for Colloidal Fuels," TT-A-642-75-170, Tetra Tech Inc. for Department of Navy, June 1975.

10-14 Tsaros, C. I., "A Study of the Conversion of Coal to Hydrogen, Methane, and Liquid Fuels for Alrcraft," Institute of Gas Technology, June 1976. 
10-15 Cornell, H. G., et al, "Production Economics for Hydrogen, Ammonla, and Methanol During the 1980-2000 Period," BNL-50663, April 1977.

10-16 McGeorge A., "Economic Feasibility Study Fuel Grade Methanol from Coal," E. I. duPont, TID-27156, January 1977.

10-17 Kirkpatrick, D. M., "Acetylene from Calcium Carbide is an Alternate Feedstock Route," 011 and Gas Journal, June 7, 1976, pp. 133-135,

10-18 Perry, J. H., editor, "Chemical Engineer's Handbook."

10-19 Anonymous, "Fuel and Energy Price Forecasts," Vol. II, Stanford Research Institute for EPRI, EPRI EA-433, Project 759-1, February 1977.

10-20 Anonymous, "Survey Study of the Efficlency and Economics of Hydrogen Liquefaction," Union Carbide for NASA, N75-22486, April 1975.

10-21 Soper, W. G., "International Conference on Hydrogen and 1ts Prospects," ONR, AD/A-036 936, December 1976.

10-22 Dickson, E. M., et al., "Hydrogen Economy: A Preliminary Technology Assessment," PB-266 607, SRI for National Science Foundation, February 1976 .

10-23 Kelley, J. H., "Hydrogen Tomorrow--Demands and Technology Requirements," Jet Propulsion Lab for NASA, JPL 5040-1, December 1975.

10-24 Witcofsk1, R. D., "The Thermal Efficlency and Cost of Producing Hydrogen and Other Synthetic Aircraft Fuels from Coal," paper presented at 1st World Hydrogen Energy Conference, March 1976.

10-25 Hallett, N. C., "Study, Cost and Systems Analysis of LIquid Hydrogen Production," NASA CR 73,226, June 1968.

10-26 Kelley, J. H., editor, "Hydrogen Tomorrow--Demands and Technology Requirements," Jet Propulsion Labs, December 1975.

10-27 Hallett, C., "Study, Cost and System Analysis of Liquid Hydrogen Production," NASA CR 73,226, June 1968 .

10-28 Anonymous, "Survey Study of the Efficiency and Economics of Hydrogen Liquefac' Ion," NASA CR-132631, Apri1 8, 1975.

10-29 Shaw, H., Magee, E. M., "Evaluation of Poilution Control in Fossil Fuel Conversion Processes--Gasification-Lurg1 Process," EPA-650/ 2-74-009-C.

10-30 Detman, R., "Factored Estimate for Western Coal Commercial Concepts," C. F. Braun for ERDA-AGA Coal Gasification Program, FE-2240-J, October 1976. 
10-31 Ananth, K. P., et al., "Environmental Assessment of Waste-to-Energy Processes Source Assessment Document," EPA-600/7-77-091, August 1977.

10-32 Kalfadel1s, C. D., Magee, E. M., "Evaluation of Pollution Control In Foss11 Fuel Conversion Processes--Gasification: Section 1: Synthane Process," EPA-650/2-74-009-b, June 1974.

10-33 Jahnig, C. E., "Evaluation of Pollution Control in Fossil Fuel Conversion Processes--Gasification: B1-Gas Process," EPA-650/2-74-009-g, May 1975.

10-34 Jahnig, C. E., "Evaluation of Pollution Control in Fossil Fuel Conversion Processes--Gasification Hygas Process;" EPA-650/2-74-009-h, August 1975.

10-35 Jahnig, C. E., "Evaluation of Pollution Control in Fossil Fuel. Conversion Processes--Gasification U-Gas Process," EPA-650/2-74-009-1, September 1975.

10-36 Jahnig, C. E., "Evaluation of Pollution Control in Fossil Fuel Conversion Processes--Gastification Winkler Process," EPA-650/2-74-009-f, September 1975.

10-37 DiNapol1, R. N., "Estimating Costs for Base Load LNG Plants," 011 and Gas Journal, November 17, 1975, Pp. 58-60.

10-38 Shaw, H., "Environmental Assessment of Advanced Energy Conversion. Technologies," Status Review of Project, October 1977.

10-39 Frabett1, A. J., et al., "A Study to Develop Energy Estimates of Merit for Selected Fuel Technologies," PB-249 994, September 1975.

10-40 Lipinsky, E. S., et al., "Systems Study of Fuels from Sugarcane, Sweet Sorghum, and Sugar Beets," Vol. I, II and III, BMI-1957, December 1976.

10-41 Scheller, W. A., Mohr, B. J.,; "Net Energy Analysts of Ethanol Production," ACS Preprints.

10-42 Reed, T. B., "Efficiencies of Methanol Production from Gas, Coal, Waste, or Wood," ACS Preprints.

10-43 Shonka, D. B., et al., "Transportation Energy Conservation Data Book: Edition 2," ORNL-5320, October 1977.

10-44 David, M. L, et al, "Gasohol Economic Feasibility Study", Development Planning and Research Associates, July 1978.

10-45 "Gasoho1 from Grain - The Economic Issues", U.S. Dept. of Agriculture, January 1978.

10-46 Kendrick, J. G., Murray, P. J., "Grain Alcohol in Motor Fuels - An Evaluation", Univ. of Nebraska, Report 81, Apr11 1978. 
THIS PAGE

\section{WAS INTENTIONALLY LEFT BLANK}


It is useful to note that if the same calculation were done on the gross heating value of the same diesel fuel, a lower effictency would be obtained, thus:

\section{Net Heat, Btu Gross Heat, Btu}

$11 b$ of fuel

$0.35 \mathrm{lb}$ of fuel

One HPH

Work/heat input, \%
18,500

6475
19,740

6909

of course, these two figures have exactly the same meaning, they both reflect the fact that $0.35 \mathrm{lbs}$. Of fuel was burned to produce the horsepower hour of work:

The efficiency on net BTU is greater than that on gross BTU by a factor 1.066. This factor is not the same for all fuels, it depends on the hydrogen content of the fuel.

From the point of view of final economics, it makes no difference which way the efficiency is expressed provided the price of the fuel is expressed in the same units.

Thus if the diesel fuel under consideration had a price of $6 \mathrm{c} / 1 \mathrm{~b}$. it could be quoted as:

\section{$\$ 3.24 / \mathrm{million}$ BTU net, or$$
\$ 3.04 / \mathrm{million} \text { BTU gross }
$$

The cost of producing a horsepower would calculate to exactly the same result as long as the appropriate heat content for price were employed with the appropriate efficiency.

Thus, One HPH $=2544 \mathrm{BTU}$.

Cost of one HPH:

$$
\begin{aligned}
=\$ 3.24(1) \times \frac{2544}{10^{6}} \frac{100}{39.3}(1) & =2.1 c \\
\text { or }=\$ 3.04(2) \times \frac{2544}{10^{6}} \times \frac{100}{37.0}(2) & =2.1 c \\
\text { or }=6 c / 1 b \times 0.351 \mathrm{bs} / \mathrm{HPH} & =2.1 \mathrm{c}
\end{aligned}
$$

(1) Expressions based on net heat content.

(2) Expressions based on gross heat content. 
In the literature, efficiency is expressed in various ways. Thus, a boiler/steam turbine combination is often described as $35 \%$ efficient on gross heat input to the boiler.

Alternatively it may be expressed as having a heat rate of 7270 gross BTU per HPH or 9750 gross BTU per kWh.

In this section, the efficiency figure would be translated to $37 \%$, efficiency for example, on net BTU if the fuel which had provided the data were a petroleum type. It could then be taken that the system would remain close to $37 \%$ efficiency on the net BTU content of any other fuel, because boiler efficiency varies very little from fuel to fuel when it is compared on a net BTU basis.

Data for diesel engines is frequently given in terms of fuel mass required to produce unit work, as explained in the examples above.

Data for gas turbines and for spark ignited engines is usually given in the literature directly in terms of net heat content, as it is for all prime movers in this section.

Therefore in drawing cost comparisons between various prime movers and candidate fuels the price of the fuel in terms of a million net BTU has been used in this report.

\subsection{Thermal Efficlency of Various Prime Movers}

In addressing the question, "what are the alternate fuels/energy sources for non-highway transportation?" it is perhaps useful to first list the possible prime movers in order of their currently accepted thermal efficiencies on conventional fuels. Next a series of alternate fuels for each prime mover is considered and separated into three groups:

1. those which are compatible with the prime mover as It exists;

2. those which seem capable of being made to work, after some modification;

3. those which appear to have such severe incompatibility that they cannot be considered for such service.

The list of prime movers in order of efficiency is approximately as follows: 


\section{Engine}

1. Fuel cell/D.C. electric motor

2. Diesel engine

3. Stirling engine

4. Free plston engine

5. Boiler/steam turbine

6. Spark ignited or

pilot ignited otto engine

7. Gas turbine
Thermal Efficiency, \%

of Net Heat Content of Fuel.

$$
\begin{aligned}
& 50-60 \\
& 35-40 * \\
& 30-40 \\
& 25-30 \\
& 25-35 * \\
& 22-34 * \\
& 25-32 *
\end{aligned}
$$

(Could go to 35 with inlet temperature $3000^{\circ} \mathrm{F}$ )

This tabulation of ranges has been made for plant size in the 5-50,000 HP range which is the range of most interest for non-highway transportation.

The four prime movers marked with asterisks(*) are those for which a large amount of practical experience is available, and their efficiencies are really not in doubt for any fuel which is compatible, or which can be made to be compatible by reasonable engine modification.

In Table 11-1, combinations of various fuels and prime movers have been 1 isted to show the probable efficiency that would result. Where blanks exist in this table, it is felt from a review of the literature, that there is very little hope of effecting a match. For example, although pulverized coal has been demonstrated to run in gas turbine engines $(11-3,11-4)$ and coal/oil slurry to run in diesel engines $(11-5,11-6)$ the experimental work has shown major problems. However, in the case of slow speed diesel engines, these problems may be tolerated and deserve. further consideration.

\subsubsection{Diesel Engines}

Clearly the diesel engine is favored among the time proven engines. In addition to having a hịh thermal efficiency at full load, it maintains its efficlency down through the part load and almost into the idle regime. (See Table 11-2). It is for these reasons that the diesel has come to dominate railroad and international marine propulsion. Furthermore, the proven performance of diesel engines accounts for the large amount of work which is in progress to make them work on all sorts of alternate fuels; tar sand distillates in Canada, coal derived distillates, alcohols, hydrogen, vegetable oils and even ammonia. 


\section{TABLE $11-1$}

\section{EFFICIENCIES OF PRIME MOVERS WITH VARIOUS FUELS}

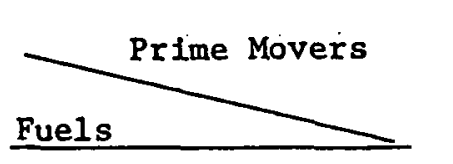

Coal/methanol slurry

Coal/oil slurry

Coal

SRC I

Coal liquids

Shale liquids

Methanol

Hydrogen

Carbon monoxide

Ammonia

Ethano1

Methane

Hydrazine

Methylamine

Acetylene

Vegetable oil

Electricity

\begin{tabular}{|c|c|c|c|c|c|c|c|c|c|}
\hline $\begin{array}{c}\text { Botler } \\
\text { Steam } \\
\text { Turbine } \\
\end{array}$ & $\begin{array}{l}\text { Stirling } \\
\text { Engine }\end{array}$ & $\begin{array}{c}\text { Closed } \\
\text { Cycle } \\
\text { Gas } \\
\text { Turbine } \\
\end{array}$ & $\begin{array}{l}\text { Spark } \\
\text { or } \\
\text { Pilot } \\
\text { Ignited } \\
\text { Otto } \\
\end{array}$ & Diese1 & $\begin{array}{c}\text { Diese1 } \\
\text { Fumigated } \\
\end{array}$ & $\begin{array}{c}\text { Gas } \\
\text { Turblne } \\
\text { Open } \\
\text { Cycle } \\
\end{array}$ & $\begin{array}{c}\text { Fuel } \\
\text { Ce11/ } \\
\text { Electric }\end{array}$ & $\begin{array}{l}\text { Electr1c } \\
\text { Motor }\end{array}$ & $\begin{array}{c}\text { Free } \\
\text { Piston } \\
\end{array}$ \\
\hline $25-35$ & $30-40$ & $25-30$ & - & -- & -- & -- & -- & -- & - \\
\hline $25-35$ & $30-40$ & $25-30$ & - & -- & -- & - & -- & -- & -- \\
\hline $25-35$ & $30-40$ & $25-30$ & - & -- & -- & -- & - & -- & -- \\
\hline $25-35$ & $30-40$ & $25-30$ & & & & & & & \\
\hline $25-35$ & $30-40$ & $25-30$ & $22-35$ & $35-40$ & -- & $25-32$ & -- & -- & $25-30$ \\
\hline $25-35$ & $30-40$ & $25-30$ & $22-34$ & $35-40$ & -- & $25-32$ & -- & -- & $25-30$ \\
\hline $27-37$ & $32-42$ & $27-32$ & $22-34$ & - & $35-40$ & $26.5-34$ & $50-60$ & -- & $25-30$ \\
\hline $25-35$ & $30-40$ & $25-30$ & $25-40$ & $35-40$ & -- & $25-36$ & $50-60$ & -- & -- \\
\hline $25-35$ & $30-40$ & $25-30$ & $22-34$ & -- & -- & $25-30$ & -- & -- & -- \\
\hline $25-35$ & $30-40$ & $25-30$ & $22-34$ & -- & $35-40$ & $25-32$ & -- & -- & -- \\
\hline $26-35$ & $31-41$ & $26-31$ & $22-34$ & -- & $35-40$ & $26-33$ & -- & -- & $25-30$ \\
\hline $25-35$ & $30-40$ & $25-30$ & $22-34$ & -- & $35-40$ & $25-32$ & -- & -- & -- \\
\hline $25-35$ & $30-40$ & $25-30$ & -- & -- & - & $25-32$ & $50-60$ & -- & -- \\
\hline $25-35$ & $30-40$ & $25-30$ & $\therefore$ & - & -- & $25-32$ & - & -- & -- \\
\hline $25-35$ & $30-40$ & $25-30$ & -- & -- & - & $25-32$ & - & -- & - \\
\hline $25-35$ & $30-40$ & $25-30$ & - & $35-40$ & -- & $25-32$ & -- & -- & $25-30$ \\
\hline $27-38^{(4)}$ & $33-44^{(4)}$ & $27-33^{(4)}$ & - & - & - & -- & -- & 95 & - \\
\hline
\end{tabular}

No'tes (1) Methanol and ethanol have been credited with higher efficiencies than other fuels in those situations where waste heat can be used regeneratively to overcome their high latent heat of vaporization.

(2) Although coal derived Iiquid fuels are shown in general as having application to both otto and Diesel cycle engines, the Otto required good octane properties whatever size the engine may be and the Diesel, good cetane at least in the smaller engines.

(3) The free piston engine is thought to be much less sensitive to the chemical nature of the fuel, than the engines in Note (2).

(4) Although electricity has been-included as a possible boller fuel in this table, it would of course be better used whth an electric motor. 
TABLE 11-2

EXAMPLE OF A TYPICAL DAILY

(1)

(3)

(4)

(5)

(6)

(7)

HPHs

Work Rate

Throttle Delivered Operation Delivered (Gals) Consumption per

Obtained

Position Horsepower

(Hours)

$(\mathrm{hp}-\mathrm{h})$

h)

(Gallons)

Ga11on

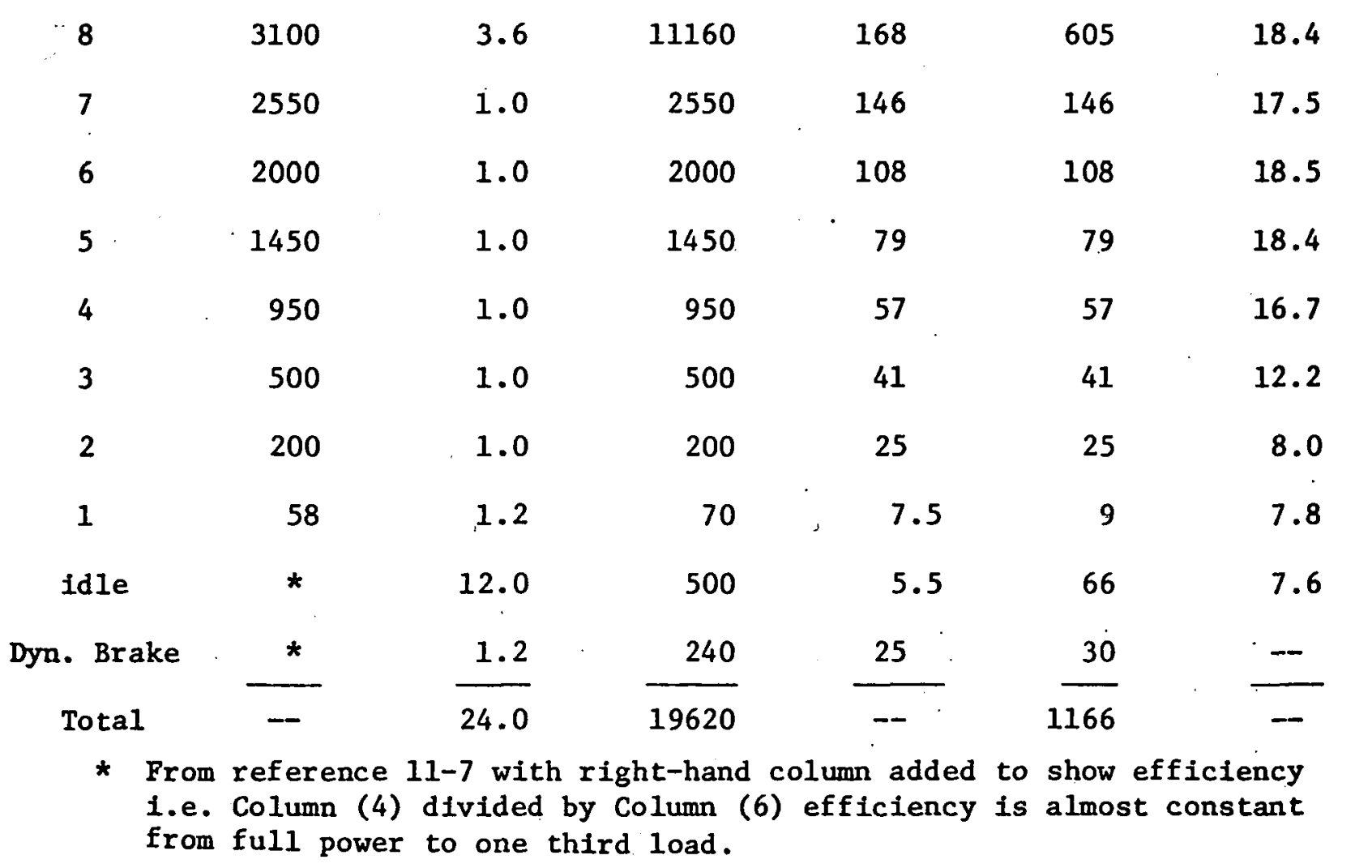

A desire to make the diesel engine omniverous, and more particularly to make it compatible with coal derived liquids has been expressed by several of the marine diesel manufacturers.

The first property which indicates likely compatibility or incompatibility of a candidate fuel with the diesel engine is its combustion performance, indicated in part by its cetane rating. Distillate fuels from petroleum and even blends of petroleum residua are proven in service, and paraffinic fuels from shale sources and distillate fuel from coal by Fischer Tropsch synthesis will be compatible with the diesel engine. 


\subsubsection{Free Piston Engines}

The free piston engine is a form of hybrid between the diesel and the gas turbine, which gives promise of thermal efficiency below the diesel itself, but a likelihood of greater flexibility toward the range of fuel candidates. It is not nearly so dependent upon good Ignition quality of the fuel and it has been stated(11-8) that it can burn anything from gasoline to bunker fuel. ofl. Ash, and the metallic impurities which are expected to be found in such candidates as coal and shale derived liquids are tolerated by this prime mover, whereas they would not be tolerable without considerable modification in an open cycle gas turbine. Therefore, on grounds of thermal efficiency and an omniverous capability, the free piston engine may deserve further consideration. Its fallure to compete on a large scale with straight diesel engines(11-9) has been largely due to its excessive maintenance requirements, a drawback which might be alleviated by further development, and which might be balanced by its ability to burn fuels which are not compatible with the diesel engine or the gas turbine.

\subsubsection{Gas Turbine}

To date, the gas turbine has lagged behind other prime movers in thermal efficiency, although it is clearly understood that its efficiency can be improved to the extent that turbine inlet temperatures can be raised, and the limit here is dependent upon the blade materials withstanding oxidation corrosion, erosion from particles in the gas stream, and possible corrosion from ash constituents in the fuel.

Gas turbines have provided invaluable service in many situations where thermal efficiency had to be made secondary to other considerations.

Thus :

1. For aircraft, because of the light weight per unit of power available.

2. For pipeline pumping, because of their low cost per horsepower, their reliability and sometimes because they need no cooling water.

3. For peak power generation, where low investment per $\mathrm{kW}$ is much more influential on the peak electricity price, than is the cost of fuel.

In the case of pipeline pumping, the efficiency of the gas turbine is frequently raised to $35 \%$ by regenerative heating of combustion air by the heat in exhaust gas, and studies have been made of the application of combined steam and gas turbine cycles which reach $40 \%$ efficiency. While the weight and complexity of either of these systems makes their use less attractive for the vehicles, aircraft, railroads and ships, they are practically for pipelines, and become more and more economically viable if fuel costs escalate more rapidly than capital costs. 
Nonetheless, the gas turbine is more limited than the diesel, the free piston, or a boller/steam turbine combination in its ability to accept poor grade fuels. With fuel washing (to remove sodium) and with inhibition of vanadium by magnesium additives(11-10), a gas turbine can be run on bunker fuel ofl with $10 \%$ reduction in power output and a small reduction in thermal efficlency of about $3 \%$ relative to operation on conventional, low ash distillate fuel.

The gas turbine is thus an engine which is capable of higher efficiencies with cleaner fuels. A wealth of experience exists with methane (natural gas), and with methane the upper limit of $32 \%$ quoted in the table can be obtained on large machines (about 100,000 HP) with inlet temperatures around $2000^{\circ} \mathrm{F}\left(1100^{\circ} \mathrm{C}\right)$. Indications are that liquid hydrogen and the alcohols (particularly methanol) could give higher efficiencies. For example an increase of $2 \%$ in thermal efficiency and $6 \%$ of power was obtained with methanol $(11-11)$.

In the case of aircraft, the gas turbine is the only prime mover under consideration by any of the workers in the field; even when nuclear energy is considered as the source of heat for the engine. The concept of efficiency for aircraft goes beyond that of comparing shaft horsepower obtained with net heat of combustion supplied.

Among these possibilities, the effect of fuel type on efficiency is a combination of engine efficiency (related to turbine inlet temperature), relative mass of fuel which has to be carried for the mission, and the effects on drag and lift which are associated with the shape, size and disposition of fuel storage tanks. The type of mission, whether it be long or short, whether subsonic or supersonic affects the ranking of cand Idate fuels under discussion, i.e. which one accomplishes the mission with least expenditure of heating value (net BTU) in fuel. Two references Indicate the following comparisons.

\begin{tabular}{|c|c|c|c|c|}
\hline & Reference & Jet Fuel & $\begin{array}{l}\text { Liquid } \\
\text { Methane }\end{array}$ & $\begin{array}{c}\text { Liquid } \\
\text { Hydrogen }\end{array}$ \\
\hline (11-12, & p. 82 , subsonic) & 1.15 & 1.22 & 1.01 \\
\hline (11-13, & subsonic) & 1.12 & - & 1.00 \\
\hline (11-13, & supersonic ) & 1.38 & - & 1.00 \\
\hline
\end{tabular}

It should be noted that engine efficiency itself as given in the reference(11-12) was essentially the same for all three fuels 11,650 to 11,850 net BTU per hour per pound of thrust, with turbine inlet temperatures at $2500^{\circ} \mathrm{F}\left(1370^{\circ} \mathrm{C}\right)$. 
Thus, the efficiency associated with the hydrogen fuel was not associated with the thermodynamic cycle, but was due to a reduction in necessary thrust with the lighter, more energy intensive fuel.

These comparisons relate to the actual net heat content of the fuels at point of receipt at the aircraft.

\subsubsection{Spark or Pilot Ignited Engines}

Apart from small aircraft and boats, spark ignited engines have had very little application in non-highway transport systems, the exception being certain pipeline applications where natural gas has been used in engines with high compression ratio. Figures given in a comparative study between electric motors and gas engines(11-14) indicate an efficiency of $34 \%$ for the latter which is about the limit that can be expected, and requires that the fuel have a high octane number. Candidate alternate fuels would therefore include hydrogen and the alcohols. The size range of these engines is generally less than $1000 \mathrm{HP}$. A marginal improvement above $34 \%$ efficiency can be anticipated if hydrogen or methanol comes into service in spark ignited engines. However, to derive the special thermal efficiency which is available from hydrogen at very lean mixtures would: entail using a large engine and derating it to about $60 \%$ of its rated power. For a stationary application like pipeline pumping, this would not necessarily be an uneconomical approach; it would be necessary that the extra capital expense of the derated engine be recovered by the fuel savings obtained by burning hydrogen in the lean mixture region. The pooled results of many workers suggests that an efficiency of $40 \%$ for hydrogen could be obtained (11-15)

Thus, in an economic comparison of methane and hydrogen in spark ignitied or pilot ignited otto engines, the principal considerations would be these.

\begin{tabular}{|c|c|c|}
\hline & $\mathrm{CH}_{4}$ & $\mathrm{H}_{2}$ \\
\hline $\begin{array}{l}\text { Size of engine to produce } \\
1000 \mathrm{HP}\end{array}$ & $1000 \mathrm{HP}$ & $1670 \mathrm{HP}$ \\
\hline $\begin{array}{l}\text { Thermal efficiency at } \\
1000 \text { HP output }\end{array}$ & $\begin{array}{l}34 \% \\
\text { (rich mixture) }\end{array}$ & $\begin{array}{c}40 \% \\
\text { (lean mixture) }\end{array}$ \\
\hline $\begin{array}{l}\text { Thermal efficiency at } \\
1670 \mathrm{HP} \text { output }\end{array}$ & - & $\begin{array}{l}\quad 34 \% \text { (rich) } \\
\text { but problems of } \\
\text { backfire and knock } \\
\text { would have to be } \\
\text { controlled }\end{array}$ \\
\hline
\end{tabular}


To explain this further, it will be noted that the larger engine $1670 \mathrm{HP}$ will cost more in capital and possibly in maintenance. As compensation, it will produce $1000 \mathrm{HP}$ of work on less net BTU of hydrogen. At the reduced output, the hydrogen will be $40 \%$ efficient, using a lean mixture. Hydrogen has this advantage over methane because it ignites well at lean mixtures whereas methane does not. Methane has to be run at a fairly rich mixture, which gives all the power the engine was built to produce, but only at $34 \%$ efficiency. If hydrogen were run at a rich mixture, it too would give'full power but its efficiency would drop to $34 \%$ and, more importantly, there would be problems of backfire and knock to be overcome, problems which do not, arise if the hydrogen is used lean in the oversized engine.

\subsubsection{Externally Fired Engines}

The efficiency of engines like steam turbines, Stirling engines and closed cycle gas turbines, for which the fuel is burned externally, is a function of three things:

1. The efficiency of the combustion equipment, (boiler in the case of a steam turbine, heat exchanger in the case of the Stirling engine or the closed cycle gas turbine).

2. The temperature range through which the working fluid (steam, hydrogen, helium, etc.) operates. Thus a steam turbine which can accept steam at $1000^{\circ} \mathrm{F}$ and which voids it to a condenser at $80^{\circ} \mathrm{F}$, can extract more work from the steam than one which accepts steam at $650^{\circ} \mathrm{F}$ and voids it to a condenser at $140^{\circ} \mathrm{F}$.

For the two cases quoted the amount of work available from the working fluid would be in the ratio $1.4: 1.0$, purely a function of the enthalpy differences between the two high and the two low temperature levels.

3. The efficiency of the turbine or engine which accepts the working fluid at high temperature and rejects it at low temperature. For a large steam turbine the figure would be close to $80 \%$. Taking the following component efficlencies as examples, the overall efficiency can be obtained.

\section{Efficiency}

1. Boiler

2. Steam cycle efficiency

3. Steam turbine efficiency
$90 \%$ on net heat of fuel

$58 \%$ available work in steam

$80 \%$ conversion of available work to actual work

Total product of (1) (2) and (3)

$=0.9 \times 0.58 \times 0.8=0.42$, i.e. $42 \%$. 
While this figure can be approached in the best large power generating steam plants, it is difficult to obtain on the smaller-scale because smaller turbines are less than $80 \%$ efficient and the steam cycles which have been available in practice aboard ships and in smaller stationary applications have not presented as much avallable work to the engine as is shown in this figure of $58 \%$ above. In addition, as discussed earlier, boiler efficiencies can vary between fuels based on differences between HHV and LHV. Also, the efficiency is a function of boiler size.

Accordingly, efficiencies in the range.25-30\% have been more common for such smaller steam plant, which accounts for specht (11-9) placing the efficiency of a free piston installation $27 \%$, as "comparable to that of a modern steam turbine installation in the same power range." The date of the reference is 1962 and the power rating under discussion was 5000 horsepower.

However, the routes whereby such a steam plant could be Improved are completely understood and depend essentially on increasing the steam conditions toward higher temperature and pressure, using lower pressure condensers and improved turbines.

The fuel for a1l externally fired cycles affects only the first component efficiency, namely that of the boiler which has been given as $90 \%$ in the discussion above. It should be noted again, that the figure is based on the net heating value of the fuel. It is common to find in the literature ranges of boiler efficiency from as low as $65 \%$ for a low BTU wet fuel like urban waste, bark or bagasse, up to $87 \%$ for a low hydrogen fuel like coal. This is largely because of the convention which has prevailed in U.S.A. of rating boilers on gross heat of combustion. Once the rating and the economic comparisons are made on net heat of combustion, most of these differences disappear and it can'be said with reasonable accuracy that any fuel among the candidates discussed in this report can be burned in equipment (be it a boiler or other type of heat exchanger) with reasonable expectation of recovering $90 \%$ of the net heat of combustion into a working fluid.

From this point of view, the steam cycles, Stirling engine and closed cycle gas turbine may be considered as omniverous, and only slightly affected as far as efficiency goes, by the quality of fuel used.

Such engines offer the possibility of using coal, coal-oil slurry, coal-water slurry and solid wastes directly. Other engines, the diesel and gas turbine for example perform poorly, if at all, on solid fuels and require in general that the solid fuel be converted first into a liquid or gas.

Thus, engines which are externally fired and which convert solld fuel to work in one step, may be more efficient overall than engines which require intermediate conversion of the solid fuel. As an example, three possible routes for the production of work from coal are given below. 


\begin{tabular}{|c|c|c|c|}
\hline $\begin{array}{l}\text { Primary } \\
\text { Fuel } \\
\text { Coal } \\
\end{array}$ & $\begin{array}{c}\text { Secondary Fuel } \\
\text { (Recovery Efficiency) }\end{array}$ & Engine (Efficiency) & $\begin{array}{c}\text { Total } \\
\text { Combined } \\
\text { Efficiency }\end{array}$ \\
\hline $100 \%$ & Coa1 (100\%) & Steam turbine (30\%) & $30 \%$ \\
\hline $100 \%$ & $\begin{array}{l}\text { Synthetic diesel (55\%) } \\
\text { fuel }\end{array}$ & Diesel engine ( $40 \%)$ & $22 \%$ \\
\hline $100 \%$ & $\begin{array}{l}\text { Synthetic methane }(g) \\
(66 \%)\end{array}$ & Gas turbine $(30 \%)$ & $20 \%$ \\
\hline
\end{tabular}

The three engines presented in this example are all well tried and well developed. Their thermodynamic limitations are known, as are the routes which might be taken toward their improvement.

The Stirling engine is untried in any of today's applications for non-highway transportation. The closed cycle gas turbine (CCGT) has been employed to date mostly in district heating operations where electric power and waste heat are used concurrently. The appeal of both the Stirling and the CCGT is that they may be capable of higher thermal efficiency than the steam cycle, in the size ranges required for non-highway transportation. be expected.

Indications are that the following range of efficiencies might

$\begin{array}{ll}\text { Steam Turbine } & 25-35 \\ \text { Stirling } & 30-40 \\ \text { Closed Cycle GT } & 25-30\end{array}$

\subsubsection{Fuel Ce11/Electric Motor}

The last class of engine to be considered is the combination fuel cell and electric motor, which lends itself particularly to a direct current electric drive. There is no doubt that a high thermal efficiency is available from fuel cells. Furthermore, that efficiency is maintained at all loads, and may even be better at part load than at full load. These are factors which could fit in well with rallroad requirements, where in a typical day the engine runs at and above $80 \%$ of full power for five hours, and averages $40 \%$ of full power for another five hours (see Table 11-2).

The diesel engine/electric generator/DC motor has. been proven very effective in railroad service, so in several ways its replacement by a fuel cell/DC motor would be a natural switch. However, in the case of fuel cells, fuel candidates are limited at least for the near and medium term to hydrogen, to fuels like hydrazine which can serve as a ready source of hydrogen, and to methanol.

Reference(11-17) indicates that fuel cells are much heavier than internal combustion engines producing equal power. 


$\begin{array}{lc} & \underline{\mathrm{kg} / \mathrm{kW}} \\ \text { Low temperature } \mathrm{H}_{2} \text { /air } & 20 \\ \mathrm{H}_{2} \text { /air solid electrolyte } & 10-15 \\ \text { Low temperature methanol } & 30-45 \\ \text { Internal Combustion Engine } & 3-4\end{array}$

\subsection{Fuel/Engine Incompatibilities - Diese1 Engine}

Obviously there are fuels, which because they do not have the desirable properties are incompatibile with the diesel engine. There are at least three levels of incompatibility.

1. The fuel may not ignite. An example of this is hydrogen, which would require a compression ratio of $80: 1$ to induce self ignition, whereas the. limit of practical design does not exceed 20:1 or perhaps $24: 1(11-17)$.

2. The fuel may ignite, but after such a delay that the conversion of heat to work cannot be optimized, and engine damage may result. Examples would be fuels of poor "cetane quality" such as gasoline, alcohols and highly aromatic liquid fuels.

3. The fuel may ignite, but take so long to burn that its heat content is either not totally released (unburned fuel in the exhaust gas) or, if released, released too late to be converted to work in an efficient manner $(11-6)$.

An example is pulverized coal, which has been used to replace part of the conventional diesel fuel oil, but at a rate of replacement of about 4 pounds of coal per pound of o1l replaced, which is indicative of an efficlency about $15 \%$ on coal compared with $40 \%$ on oil.

There are many cases in the literature in which a modification to the engine can result in a fuel becoming acceptable. Thus hydrogen and ammonia, which do not self-ignite in the diesel cycle can be fired at the right moment if a glow plug or similar source of ignition is provided. Having done that, a thermal efficiency is obtained which is very close to that obtained in an unmodified engine with its conventional fuel.

In the case of the alcohols several approaches have been explored.

1. The first is to modify the engine so that the alcohol is inducted with the air, is compressed in vapor form together with the air and ignited at the appropriate time by the injection of a reduced amount of regular diesel fuel oll. 
This process is often referred to as fumigation $(11-18)$ and has been employed with propane.

2. Another is to modify the fuel, in this case alcohol, by the inclusion of a large dose of "ignition improver!" Specifically in the case of ethanol, a dose rate of about nine percent by folume of amyl nitrate or hexyl nitrate has been recommended to the government of Brazil as a means of using ethanol more efficiently within the Brazilian transportation sector $(11-2)$.

3. A third is to provide separate injection of liquid methanol after injection of the pilot fuel, which is conventional diesel fuel oil $(11-18)$.

The point to note is that having made one of these modifications, the fuel becomes usable, and the thermal efficiency which results is again close to that of the conventional engine running on its more conventional fuel.

It was said at the beginning of this section that the efficiency of a prime mover is much more a function of its design and operating conditions than of the particular fuel which is used. This does not imply that all engines can use all available fuels, indeed many are forbidden on grounds of incompatibility. But, to a reasonable approximation it appears that if a successful modification can be made to overcome the property wherein the incompatibility lies, the resulting thermal efficiency will be neither greatly enhanced, nor greatly diminshed.

\subsection{Fuel Properties that Enhance Efficiency}

Certain fuels have properties which permit modifications to conventional engines which do enhance thermal efficiency. These are properties which the conventional fuel does not have. Thus, the range of flammability of hydrogen in air mixtures is so much wider than that of gasoline, that it can be run in an unthrottled spark ignited engine with a very lean mixture. Relative to gasoline, such operation brings three improvements in efficiency: $(11-19)$

- The "pumping 1oss" associated with throttled engines is avoided. Pumping loss is the work that has to be done in abstracting mixture from a partial vacuum at the intake manifold and delivering its combustion products to the exhaust at atmospheric pressure.

- The rapid combustion of hydrogen permits the heat to be released predominantly close to the top dead center position of the piston, which brings maximum conversion of heat to work.

- The chemical nature of the combustion gases from a lean hydrogen mixture has specific heat properties which further improve the thermodynamic cycle. 
Liquid hydrogen can also act as an efficient heat sink, that is a source of refrigeration. This property has been used to cool engine parts which are vulnerable at high temperature, and which if not cooled would impose a lower thermal efficiency ceiling on the engine. In the specific case of a gas turbine, the thermal efficiency is limited by the turbine inlet temperature, which is itself governed to avoid destruction of the first row nozzle and buckets. These elements, when cooled by internal passage of air can withstand higher inlet temperatures, and thus provide better thermal efficiency.

Liquid hydrogen has been used to supercool the air which in turn cools these blade elements, such that an efficiency was obtained which was significantly above that which was available with fuels that did not have this refrigerating capabiltity $(11-20)$.

To a lesser extent, the alcohols, methanol and ethanol, exhibit. some of these special properties of hydrogen, i.e. ability to operate at leaner limits than gasoline in spark ignited engines and ability to absorb heat by virtue of their relatively high latent heats of vaporization.

The Ifterature contains numerous references to the advantageous ways in which these properties can be utilized either to obtain more power. from a spectfic engine, or a greater thermal efficiency.

The thermal efficiency of any engine which uses liquid methanol as fuel can be increased if waste engine heat is available to convert the methanol to the gaseous state $(11-21)$.

Methanol

(a) Net heat of combustion $8570 \mathrm{Btu} / 1 \mathrm{~b}$ .. (1iquid fuel/water vapor)

(b) Latent heat of vaporization $506 \mathrm{Btu} / \mathrm{1b}$

(c) Net heat of combustion (vaporized fuel/water vapor)

$9076 \mathrm{Btu} / 1 \mathrm{~b}$

(d) Increase in energy (c) $\div$ (a) . 1.06

A corresponding table for ethanol and for jet fuel follows.
(a) Net heat of combustion (liquid fuel/water vapor)
(b) Latent heat of vaporization
$\mathrm{Btu} / 1 \mathrm{~b}$

Ethano1 Jet Fue1
(c) Net heat of combustion (vaporized fuel/water vapor)
11500
18500
11896 150
(d) Increase in energy (c) $\div$ (a)
1.03
18650

. 
It will be noted that six percent more heating power is available from a unit of methanol once the latent heat of vaporization has been supplied, and since this can practically always be supplied freely from waste engine heat, methanol can be credited with a proportional advantage relative to conventional fuels like diesel fuel oil or jet fuel which do not have a comparable latent heat, and which cannot be vaporized so cleanly. On similar grounds, ethanol has a three percent potential and jet fuel about one percent.

Going one step further, it has been suggested that a further six percent improvement in the use of methanol as fuel would accrue if waste heat were employed to split the fuel into $\mathrm{H}_{2}$ and $\mathrm{Co}$ over a catalyst at low pressure. Ethanol and methanol leave very little residue upon evaporation, and produce no coking, therefore, they are expected to perform well in engines which utilize waste heat to gain the latent heat bonus. However, the technique is not completely proven for long-term operation, so some development work may be needed relative to the design and maintenance of the heat exchange equipment wherein the evaporation occurs. Jet fuel and other petroleum products would be expected to foul evaporative heat exchangers, and the very small benefit of latent heat recovery with those fuels would not be practical nor worthwhile.

It should be noted that while the special properties of $\mathrm{H}_{2}$ and the alcohols permit design changes which improve the efficiency of certain engines, these improvements have to be bought with certain tradeoffs. Hydrogen, while operating most efficiently at very lean conditions in a spark ignited engine, produces only half the power for which the engine is rated on gasoline.

In the case of alcohol use with diesel engines(11-18), the design, and more particularly the control of the dual fuel handling system, becomes extremely complicated, especially if it is desired to approach a fifty percent replacement of the conventional fuel by the alcohol over the total operating range of the engine.

Because of this apparent complexity, several workers recommend that a better approach toward the use of methanol would be the use of a spark Ignited Otto cycle engine, with high compression ratio.

\subsection{Combined Cycles}

Various combinations of cycles can be used with several of the prime movers to obtain an overall efficiency higher than that of the engine itself when operated in the conventional way $(11-22)$. Essentially, these combinations seek to convert waste heat from the conventional engine into a further supply of work at no increase in fuel rate. The subsidiary engines most often considered are steam turbines and organic Rankine engines. In these cases the working fluid for the subsidiary engine is heated in a waste heat boiler by exhaust gas, or in some cases by the heat in high temperature cooling water. 
Ackerman (11-23) provides data on efficiencies that can be expected of gas turbines fired on hydrogen, with and without a combined steam cycle. The steam can be made avallable at about $900^{\circ} \mathrm{F}$ from heat in the GT exhaust.

\begin{tabular}{ccc}
$\begin{array}{c}\text { Inlet } \\
\text { Temperature, }{ }^{\circ} \mathrm{F}\end{array}$ & & \multicolumn{2}{c}{ Thermal Efficiency; $\%$} \\
\cline { 2 - 3 } 2000 & 30 & $\begin{array}{c}\text { Combined Cycle } \\
\text { Gas Turbine }\end{array}$ \\
2300 & 34 & 42 \\
3000 & 35.5 & 46
\end{tabular}

Organic Rankine cycle engines (ORC) may find application where waste heat is available at temperatures lower than those of the gas turbine exhaust. Diesel engines and closed cycle gas turbines may lend themselves to combination with ORC with an expectation of recovering about $13 \%$ of the waste heat as work. 
REFERENCES

(11-1) Chowhury, D. H. "Indian Vegetable Fuel Oils for Diesel Engines" Gas and Oil Power, pp. 80-83 (May 1942).

(11-2) Wolfgang, Bandel, Mercedes Benz of Brazil Paper 2-3 "International Symposium on Alcohol Fuels - Wolfsburg, November 1977."

(11-3) Strimbeck, D. C. "Bureau of Mines Coal Fired Gas Turbine Research Project", Bureau of Mines Report RI 7295 (Sept. 1969).

(11-4) Fraas, A. P. "Survey of Turbine Bucket Erosion, Deposits and Corrosion", ASME Paper 75-GT-123 (March 1975).

(11-5) Marshall, H. P. "An Experimental Investigation of a Coal-Slurry Fueled Diesel Engine", SAE Paper No. 770795 (Sept. 1977).

(11-6) Anonymous, "Pulverized Coal-Burning Diesel Engine", Howard University, U.S. Office of Coal Research, Report No. 46 (1969).

(11-7) Cetinich, J. M. "Fuel Efficiency Improvement in Rail Freight Transportation", Report No. PB 250673 (Dec. 1975).

(11-8) Erwin, R. 0. "Free Piston Turbine Power for Farm Use", SAE Report No. 150A (June 1957).

(11-9) Specht, H. "Evaluation of Free Piston Gas Turbine Marine Propulsion Machinery in GTs William Patterson", SAE Paper No. 604A (Oct. 1962).

(11-10) Winkler, M. F. "Management of Residual Fuel Systems for Gas Turbines", Gas Turbine International, pp. 16-18 (May 1977).

(11-11) Jarvis, P. M. "Methanol as a Gas Turbine Fuel", Engineering Foundation Conference, July 8, 1974.

(11-12) Mikolowsky, W. T. "An Evaluation of Very Large Airplanes and Alternate Fuels", R-1889-AF (Dec. 1976).

(11-13) Brewer "Hydrogen Fueled Aircraft", July 1977.

(11-14) McMaster, A. T. "Pipeline Studies in Texas Compare Electric Motor vs. Engine Driven Compressors", 0il \& Gas Journal, pp. 65-74 (May 1977).

(11-15) Simpson, F. B. "Modification Techniques and Performance Characteristics of Hydrogen Powered I-C Engines - State of the Art - 1975" Report No. ANCR 1302 (September 1976).

(11-16) Stickles, R. T. "Assessment of Fuels for Power Generation by Electric Utility Fuel Cells", Report No. PB-247216 (October 1975). 
(11-17) Parish, W. R. "Selective Topics on Hydrogen Fuel", Report No. COM-75-10619 (May 1975).

(11-18) "International Symposium on Alcohol Fuels - Wolfsburg, Nov. 1977" Panchapakesan, N. R., et a1. Paper 2-2 Holmer, Volvo Truck Paper 2-4 Cummings, D. R. and Scott, W. M. Paper 2-5

(11-19) Fagelson, J. "Analysis of Hydrogen as a Reciprocating Engine Fuel" Symposium on Chemistry of Combustion, Division of Petroleum Chemistry, ACS (April 6, 1975).

(11-20) Esgar, J. D. "State of Technology on Hydrogen-Fueled Gas Turbine Engines", Report No. NASA TMX-71561 (May 1974).

(11-21) "Alcohols - A Technical Assessment of Their Application as Fuels", API Publication No. 4261 (July 1976).

(11-22) Heard, K. C. "Review of a Combined Steam and Gas Turbine Cycle for Pipeline Service", ASME Paper No. 75-GT-51 (March 1975):

(11-23) Ackerman, J. P. "Assessment Study of Devices for the Generation of Electricity from Stored Hydrogen", Report No. ANL 75-71 (Dec. 1975). 


\section{FUEL LOGISTICS}

M. H. Farmer

This section will discuss three different aspects of the logistics of alternative energy sources:

(1) compatibility of alternative energy resources with present fuels and with the current fuel distribution system

(2) International and military considerations

(3) resource avallability

Item number two is considered in more detall in Section 16. Each, however, has the potential for imposing important practical constraints on the development of fuels that differ radically from those already in use. The princlpal purpose of the present discussion is to indicate the essential characteristics of the compatibility, International, and military considerations and the types of constraint that may be inferred from these characteristics. This information will serve as background for the detailed discussion of items three on resource availability.

\subsection{Compatibility with Present Fuels and the Current Distribution System}

For the purposes of this discussion an incompatible (alternative) fuel is considered to be one that cannot be used effectively in the existing equipment of a particular non-highway transportation mode. The latter is a system of use that comprises fuels, the distribution of the fuels, and the eventual use of the fuels in $\mathrm{NH}$ equipment. Incompatibility of a new (alternative) fuel with any of the elements of the system of use would require the new fuel to be considered incompatible. This does not mean that the new fuel should be eliminated from further consideration in this study. Rather, 1t implies that introduction of the new fuel would be more difficult and costly than the introduction of a compatible (alternative) fuel. It is also probable that these difficulties and costs would be Institutional as well as technological.

A second point concerns the relationship between highway (HT) and non-highway (NHT) transportation systems. For example, each of the NHT modes may be considered as a subsystem, but the aggregate of NHT modes is not a system. From a fuel standpoint, there may be a greater simllarity between individual HT and NHT subsystems than there is among the different NHT modes. Air and marine modes use significantly different fuels. On the other hand, rallroad diesel fuels are quite similar to the automotive diesel fuels used by trucks; hence the avallability of, and demand for, the one type of fuel may act as a constraint on the other type of fuel. In fact, the two types of fuel are simflar and it is primarily their end-use that differs. 
A third point is that current fuels*, for both HT and NHT systems, are part of the overall system of utilizing petroleum. For example, the consumption of middle distillate as heating ofl far exceeds consumption as diesel fuel. Similarly, the demand for "land trade" industrial fuel far exceeds the demand for marine bunker fuel. The significance of the fungibility of petroleum fuels across transportation and non-transportation end-uses makes it unrealistic to consider fuels for NHT systems in isolation. Th1s is because a change anywhere in the total system of utilization of petroleum (and other energy sources) may have an impact on other parts of the system. This is a problem of Immense difficulty and complexity, and its resolution is beyond the scope of this study. However, the interrelationships are illustrated in the cross-impact analysis segment of Section 18.

\section{2:2 International and Military Considerations}

International considerations may be divided into (a) fuels and (b) equipment. Clearly, both air and marine operations may involve international fueling. Hence, any new fuel, especially an "incompatible" fuel, should be avallable wherever it is needed, including forelgn locations that are part of the international system.

Equipment considerations and constraints are more complex than those that apply to new fuels. The U.S. Is a major exporter of equipment for NHT systems: aircraft, locomotives, construction equipment, farm vehicles, etc. Hence, U.S. manufacturers of such equipment must be mindful of the difficulties, costs, and risks they would experience if they were to develop incompatibly different equipment for the U.S. and their export markets, especially if the different equipment were to create an associated demand for incompatibly different fuels.

For some years, the Department of Defense has been interested in the development and testing of "synthetic" fuels from coal, oll shale, and tar sands. The focus of DOD's work has been on the production of fuels that meet the specifications of current petroleum fuels*t. Fuel compatibility and avallability are of obvious importance, and require consideration in relation to NATO and other overseas defense responsibilities.

\subsection{Resource Availability}

It is of paramount importance to consider that the fuel demand of non-highway transportation systems is only one of a multitude of demands placed on U.S. resources, hence neither the magnitude of the resource base of a given resource, nor the physical avallability of fuels or usable energy derived from the resource, guarantees avallability of the fuels or energy to NHT systems.

\footnotetext{
*with minor exceptions.

**A Iimited amount of effort has also been applied to coal-in-oll slurries (COS) for marine applieations.
} 
The conceptual problem is 1llustrated in Figure 12-1. In the center of the diagram, there is a "box" with dashed lines that enclose the words "future 'pool' of fuels and energy supplies derived from all resources." The concepts are that at any time in the future:

- this "pool" is the total avallable supply of all fuels and forms of energy derived from all resources.

- the "pool" must be divided among all of the varlous demands for fuels and energy, i.e. there will be competing demands for what is in the "pool".

- If the sum of the various demands exceeds the supplies avallable in the "pool", then end-uses will be constrained (i.e. a supply shortage will exist, temporarily at least).

- there is no reason, a'prlori, why one end-use w1ll have prdority over another; instead the establishment of priorities will involve complex interactions between sociopolitical and economic factors. Specifically, fuels for NHT systems cannot be considered, a priori, to have a higher priority than other end-use demands.

The conceptual problem is explained further by reference to a given resource, e.g. oll shale, which is identified as Resource " $X$ " In Figure 12-1. The resource base of " " has been estimated to be very large (in the case of oil shale). The current utilization of " $X$ " is minimal, hence HT and NHT utilization of fuels derived from " $X$ " is minimal. However, because of the size of the resource base, the future production or avallability of fuels derived from " $\mathrm{X}$ " is potentially high. At this point, the potential contribution of " $X$ " to the nation's "pool" of fuel and "energy supplies should be allocated (conceptually) to the "pool" rather than be pre-empted, a priori, for use by NHT systems. Put differently, fuels and energy for NHT systems are not coupled directly with Resource "X", rather they are coupled indirectly through a supply "pool" which must satisfy the totality of competing end-uses.

The premise that underlies the development of "alternative fuels" is an anticipation that the future supply "pool" may be inadequate to meet future demands in an unconstrained way. The anticipation of constraints is also an anticipation that mechanisms will evolve (or will have to be devised) to deal with end-use priorities, presumbbly in terms of some "sharing" of the supplies. that are available. The mecharisms may be both technological and non-technological. An example of the former is that technical paths will be devised for maximizing the effectiveness of utilization of the supply "pool" in relation to the various end-use demands placed on 1t.* Non-technological mechanisms are potentially quite diverse since, theoretically, they include institutional constraints, differential taxation, rationing, etc. The non-technical mechanisms are considered in more detail in Section 17; for present purposes, however, the point is to recognize the

*For example, it may be more economical to upgrade some conventional fuels to more sophisticated end-uses and to substitute an alternative fuel in the end-use from which the conventional fuel is displaced. 
COMPETITIVE ASPECT OF RESOURCE AVAILABILITY

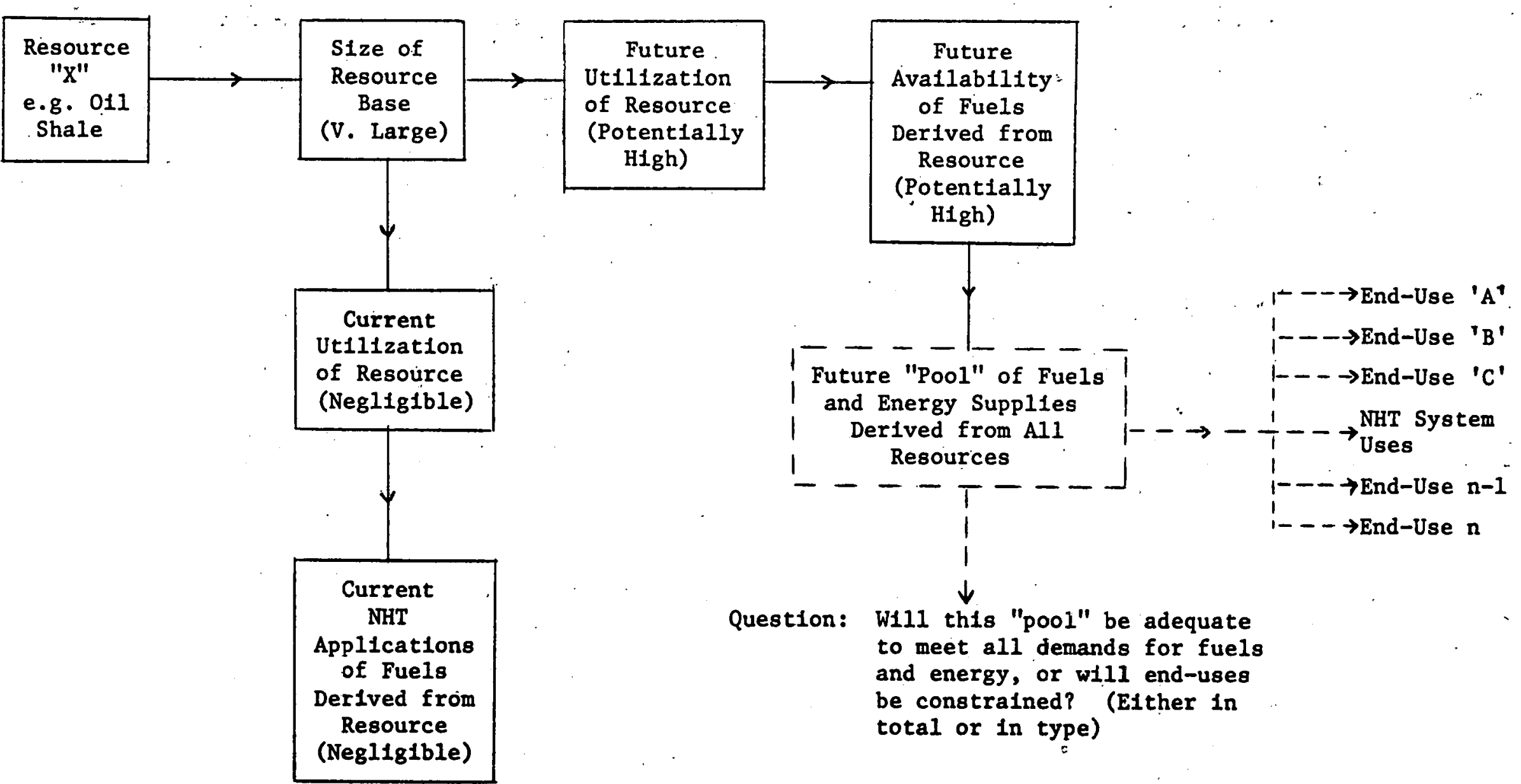


probability of their existence and importance and, hence, the difficulty or Impossibility of establishing direct, quantitative linkages between potential resources and future supplies of individual fuels or energy forms that, technologically, could be used in NHT systems.

A further point may be made about the effective utilization of the supply "pool". Substitution of one fuel or energy form for another appears much easier in statlonary applications (e.g. Industrial boller fuel, central generation of electricity) than in transportation uses. Primarily, this $1 \mathrm{~s}$ because of the greater severfty of constraints (e.g. weight, size, emission controls) that apply to mobile equipment. The same principle is applicable within the various NHT modes. For example, constraints of welght and volume are more severe for aircraft than they are for ships. Additionally, however, there are:logistical constraints that apply to certain resources. For example, wood and wood by-products are already used extensively to generate both steam and electricity by the pulp and paper industry. Indeed, this industry is moving rapidly toward self-sufficlency in satisfying its own energy demands. Hence, the blomass utilized captively by the pulp and paper industry is not avallable for conversion into fuels for NHT systems. In general, it is believed that substitution of resources across a variety of end-uses, particularly in stationary applications, will have a profound impact on the components of the supply "pool" that, in practice, become avallable to NHT systems. For example, the displacement of ofl from electricity generation has the potential for making oil avaflable for transportation uses.

Conceptual objections may be raised to the substitution hypothesis. For example, petroleum is a finite resource, and this fact will not be altered even if no o1l is used to generate electricity. On the other hand, such displacement may have Important impacts on (a) the timetable of rellance on renewable resources, and (b) the evolutionary paths towards such rellance.

\subsubsection{Primaxy Energy Resources}

The principal primary energy resources, except for petroleum (crude o1l and natural gas) are listed in the first column of Table 12.1. The next column provides a qualitative characterization of the size of the resource base of each of the primary resources. These characterizations require explanation:

- very large implies that the resource base, per se, is not expected to be a limiting factor within the next 100 years.

- large Implies that considerable further development of the resource appears possible, but that limitations to development are expected within about 50 years. In the case of nuclear energy, the reference is to reserves of fissile materials in the U.S., and does not take account of (a) imports of uranium, etc., (b) the possibility that nuclear fusion technology will become the commerctal basis of electriclty generation within the next 50 years, or (c) that breeder technology will be utilized commercially in the U.S. to greatly extend the naturally occurring resources of fissile materials.*

*The practical improbability of the combination of these three assumptions is recognized. However, the assumptions are belleved to be proper in the context of the above comparison of the U.S. resource base. 
- medium has two different implications: (a) In the case of geothermal steam that, while considerable development is possible, the ultimate potential is much smaller than for resources categorized as large or very large, and (b) In the case of hydroelectricity, while current utilization of the resource is significant, it is approaching maturity and, hence, does not represent a significant incremental resource by comparison with those categorized as large or very large.

- "other" implies that there are resources such as wind or tidal power that, currently, are not well defined in extent. Moreover, it appears that, if developed, such resources will be utilized on a local basis and, hence, are unlikely to make significant, direct contributions to the supply of transportation fuels. While electrical production of hydrogen is a possible exception to this generalization, the possibility is too indefinite to warrant a resource base rating of more than "medium".

Availability, as characterized in the third and fourth columns of Table 12-1, also requires explanation:

- high 1mplies that the resource currently supplies, or has the future potential for supplying, at least $15 \%$ of U.S. primary energy demand.

- medium Implies that the resource currently supplies, or has the future potential for supplying, about $5 \%$ of U.S. primary energy demand*

- small implies that current supply or future potential is or will be at about a $1 \%$ leve1

- negligible refers only to current level of energy supplied; it does not imply that the resource has no importance or that attempts to develop it further are misdirected

The column for "competing uses" implies that major competition for each of the resources exists now or is expected in the future. For reasons discussed earlier, the extent of this competition cannot be precisely quantified. However, "major" implies the bellef that from $15 \%$ to $100 \%$ of the available resource may be utilized for end-uses other than NHT systems.

The final columns of Table 12-1 1ist representative alternative fuel products or intermediates derivable from the primary energy resources. The term "intermediate" refers to a stage of processing, e.g. a syncrude derived from shale oil is convertible into a variety of fuel and other products as is a petroleum crude oil. The distinction between products and intermediates is fuzzy because most of the products (e.g. methane, methanol, ethanol) are convertible into other products as well as being ut1lizable directly as fuels. There is a further ambiguity in the case of electricity which is utilizable directly as an energy source for certain types of ground transportation system as well as being utilizable. indirectly in the production of fuels. Some of the special attributes of electricity are listed in Table 12-2.

*In 1978, 1t is anticipated that nuclear energy and hydro power will each supply about $4 \%$ of U.S. primary energy demand. 


\section{Primary Energy Resource}

$\operatorname{Cod1}(1),(2),(3)$

(4)

ize of U.S. Resource Base

very large

011 Shale $(5),(6)$

Peat (7)

Blomass

$\begin{cases} & \text { very large } \\ (10),(11), & \text { large }\end{cases}$
(12), (13), (14)

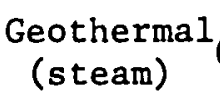

Solar (8)

$\operatorname{Nuclear}(15),(16),(18)$

Hydro $(5) ;(6)$

Other (6)

(wind, tidal, etc.)

large or
very large

large

not well

estab11shed,

\begin{tabular}{|c|c|}
\hline $\mathrm{Av}$ & \\
\hline Current & Future* \\
\hline
\end{tabular}

medium .

probably medium
hIgh

hIgh

negligible

hIgh

negligible

medium

smal1

medium

major

major

major

sma11

medium

smal1

-

Competing Lises**

major

medium

neglig1ble

smal1

major

major

major

major medium
Representative Intermediates or Alt. Fuels Derivable from Resource

coal 11quids

methanol

[ethanol]

hydrazine

methylamine

raw shale oll

shale syncrude ${ }^{\phi}$

peat liquids

methanol

ethanol

other a.lcohols.

electrictty

electricity

electricity

methane

methane

veg. o11s

electricity

electricity

mechanlcal energy

for pumping

\footnotetext{
*future avallability refers to potential, rather than implying a prediction of production.level

** competing uses imply that the resource is being currently used for purposes other than the production of non-highway transportation fuels or that there is a probability of such competing uses in the future.

] Implies an indirect synthesis route is required, thereby suggesting that ethanol production from coal is questionable.

further processing of shale syncrude would generate a range of petroleum-type transportation fuels.

) denotes references, which are 11 sted at end of section.
} 
- Electricity 1s a source of transportation energy and may become a source of transportation fuels.

- Electricity is not a primary energy resource, but depends on other resources for its generation:

- Resources currently used to generate electricity are:

- Major: fossil fuels, nuclear energy, hydro power

- Minor: blomass (primarlly wood and by-products), geothermal steam

- Additional resources that may be used to generate electricity in the future:

- Major potential: o1l shale, solar energy

- Minor potential: wind power! tidal power

- Electriclty may be applied directly as a source of power to ground transportation systems such as rallroads and monoralls.

- Electricity may be utilized as process energy in the production of fuels and hybrid energy systems Involving batteries, fuel cells, hydrides, etc.

- Hydrogen is the only transportation fuel that may be produced directly with electrical energy w1thout the need for any "feedstock" except water. 


\subsubsection{Documentation of Size of Primary Resource Base}

The purpose of the following discussion is to support the characterizations of the resource base in Table 12-1:

- coal: the quantity extractible with current technology and under existing economic conditions (1.e. "reserves") is estimated to range from 218 to 259 billion tons. However, there is geologic evidence* of the existence of 1.7 trillion tons of coal and this is the estimate of "identified resources". Total U.S. resources of coal have been estimated to be about 4 trililion tons; this figure includes both hypothetical as well as identified resources.

- oll shale: 1dentifled resources of Western ofl shales have been estimated to contain about 1.6 trillion barrels of oil. 0il shale deposits also occur in other parts of the U.S., e.g. In Michigan. While the potential recovery of oil from oil shale is very large, factors*t other than the size of the resource base are 11 kely to IImit both the pace and extent of what is recovered.

- peat: the estimated resource base for peat is equivalent to about 60 billion tons of bituminous coal. Much of this quantity is potentially recoverable because peat generally occurs at the surface in beds*** shallow enough (averaging 7 feet) to permit restoration of the stripped land to its original contour. However, peat contains several times its own weight in water and must be dried to about $35 \%$ moisture before use as a fuel. For reasons of net energy and cost, drying must be simple, effective, and performable in environmentally acceptable ways. Gasification to SNG is being investigated; this approach would yleld some hydrocarbon-type liquids (after hydrogenation) as a co-product.

- blomass: as discussed in Appendix 12A, the renewability of blomass necessitates a departure from the conventional concepts of "reserves" and "resources". In a sense, the "resource base" for biomsss depends on the amount of land**** in the U.S. that is capable of growing plants after subtraction of land utilized or reserved for other purposes (e.g. restdences, commerclal bulldings, Industrial plants, roads, etc.). Existing forests are a form of "reserves". However, forests are regenerable over a perfod of years, hence the rate of extraction and the other resources needed to accomplish this extraction are more meaningful than an estimate of reserves or of the current resource base.

- solar: as with biomass there is no precise definition of a resource base for solar energy. Moreover, the production of biomass depends directly on the utilization of solar energy. However, for the purposes of Table 12-1, only the portion of solar energy used to generate electricity or heat is considered as "solar".

tnot necessarily supported by engineering measurements.

**e.8. avallabllity of water and environmental constraints.

***because of extremely high molsture content, the "beds" are bogs. Dewatering techniques are under Investigation.

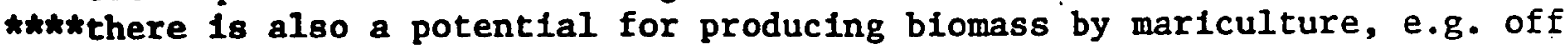
the west coast of California. 
- nuclear: In the context of Table 12-1 and 1ts footnotes, the resource base is confined to U.S. deposits of uranium ore. Approximately 780,000 tons of urantum has been estimated in the ore deposits that have been delineated by drilling. While it is clear that this is not the full extent of the resource, and It has been speculated that an additional 1.9 million tons of uranium may be recoverable, there is no consensus on the validity of this number or on how it should be interpreted. However, there is general agreement that shales and granites containing less than $100 \mathrm{ppm}$ of uranium are most unlikely to become a source of uranium. Although the extent of the U.S. uranium resource is an extremely important matter in itself, it is even more important (for the purpose of this study) to recognize that the ways in which the resource is utilized will be the eventual determinant of the quantity of useful energy produced from nuclear materials.

- domestic tar sands: It is important to distinguish between Canadian (Athabasca and Wabasca) ofl sand deposits -- which are very considerable -- and those in the U.S. -- whIch are not. The largest U.S. deposits are in Utah. It has been estimated that total production from these deposits could never exceed $500,000 \mathrm{~B} / \mathrm{D}$, and alo that anything beyond token production is unlikely before the year $2000(12-19)$.

The Utah deposits are in areas that adjoin the principal oil shale lands. In consequence, exploftation of the Utah tar sands would compete for the same natural resources (e.g. water) that are required for the far more promising oil shale production. Hence, at most, conversion of U.S. tar sands into alternate fuels may be considered as a minor peturbation of what is possible with oil shale.

\subsubsection{Logistics of the Principal Primary Energy Resources}

The purposes of this subsection are to indlcate that there are significant logistical differences among the various primary energy resources and to characterize these differences. The intent is not to make a detalled logistical analysis of the primary resources.

- coal: deposits are dispersed widely throughout much of the U.S., hence coal is potentially avallable in most locations. However, transportation costs can be a significant fraction of the delivered, cost of coal. In general, this favors the utilization of coal as close as possible to the mine or, where this is not possible, delivery of very large volumes of coal by barge, unit train, or slurry plpeline. 
- ofl shale: the richer deposits of oll shale are concentrated in a small area, primarily in Colorado and Utah but with lower grade deposits extending into Wyoming. When consideration is given to the fact that one ton of oll shale will yield only about three quarters of a barrel of shale oil, it is evident that extraction of ofl from shale must occur in a mine-mouth setting (whether by surface retorting or by an in-situ process). This suggests that shale oll will become part of the ofl supply of a Western region of the U.S. Devonfan shales exist in other parts of the U.S., e.g. Michigan, and may become a source of SNG.

- peat: slightly over half of the peat resource is In Alaska (31 billion TCE), where 1 ts early exploitation is unlikely and where dewatering and land reclamation would be more difficult than in the "Lower 48". However, there are about 16 billion TCE of peat resources in Minnesota, Michigan, and Wisconsin; SNG projects in these states may be feasible before the year 2000 . The quantity of refined liquid co-products is unlikely to exceed 0.5 quads/yr. at this time or 1 quad/yr. at any time in the future. Thus, peat liquids, per se, are unlikely to be an "alternative fuel". Instead, the liquids could be a small supplement to the "pool" of supplies available for all purposes.

- biomass: this is a class of materials, rather than a uniform resource. Both forests and crops have regional patterns that are certain to influence the ways in which different "biomasses" are utilized. A common characteristic, to the land extensive production base (as distinct from the concentration of a fossil fuel resource in a given deposit), is that utilization of biomass is likely to be in relatively small plants as close as possible to the production area. Captive utilization of byproducts by industries that produce and/or use wood is commonplace and is increasing. Certain agricultural by-products, e.g. bagasse, fit the same pattern of captive utilization.

- solar: this source of energy is inherently dispersed, thereby favoring relatively small user installations. The most probable contributions of solar energy to NHT systems are indirect, e.g. by substituting for other forms of energy thereby relleving constraints on the total pool of energy supplies.

- nuclear: while nuclear energy is, and will probably continue to be, produced in large units or groups of units ("nuclear parks"), the plants themselves may be widely dispersed throughout the U.S. Nevertheless, severe logistical constraints may apply to the production of nuclear energy because of restrictions placed on the movement and disposal of nuclear wastes. 


\subsubsection{Discussion of Representat1ve NHT Intermediates and ProductB}

The principal prtmary energy resources*, electricity and 1 ts princlpal sources*, and representative propellents of NHT systems are presented in the form of a matrix in Table 12-3. The numbers and letters in the matrix reflect judgments concerning time-frame of availability and assoclated probability. Electrifled rallroad systems are omftted from this tabulation because (a) they already exist, and (b) their further development is not ilmited by primary resources but by economics.

An asterisk has been added to several of the entrles in Table 12-3 to indicate the judgment that although the specific fuels may be avallable in a given time-frame, it is expected that they will be ut1lized in other end-uses rather than as NHT fuels. With one major exception, the electricity sources have been marked with an asterisk. The exception, nuclear energy, has been given a $3 \mathrm{~A}$ rating -- possible by the year 2000 -- because $1 t$ is possible that nuclear energy will have the practical capability both of generating electricity for conventional uses and of generating some hydrogen by the year 2000 even though a later time-frame seems more ilkely. The other electricity sources, with the exception of solar energy in a distant time-frame, are all concelved to contribute to electricity supplies in general rather than to become direct sources of transportation hydrogen. Looked at another way, the aggregate Increment of electriclty generated by minor sources is a "perturbation" of the amount of nuclear electricity available for the production of transportation hydrogen.

\subsubsection{Fuel Logistics Criteria}

Estimates made for fuel logistics criteria are listed in - Table 12-4. The second and third columns reproduce the fuels and ratings from Table 12-3. The next two columns consider the compatibility of the possible alternative fuels with the fuels used in the current system and with the system 1tself. The final column is a preliminary indication of how the various fuels may be Impacted by international considerations. The rating "variable" requires explanation. The premise is that certain other countries have substantial coal resources while most do not, and also that a few countries have ofl shale resources while the majority do not. The assoclated concept is that countries not having the pertinent coal or ofl shale resources would be unlikely to be willing to disrupt their fuel supply and transportation systems in order to accommodate U.S. technological development of the resources. However, no disruption would occur if the new fuels were completely compatible with existing fuels and transportation systems. 
TABLE 12-3

MATRIX OF PRIMARY RESOURCES AND REPRESENTATIVE

PROPELLENTS OF NHT SYSTEMS WITH INDICATION OF

TIME-FRAME OF AVAILABILITY

\begin{tabular}{|c|c|c|c|c|}
\hline & Coal & 011 Shale & B10mas8 & Electriclty \\
\hline $\begin{array}{l}\text { raw liquids } \\
\text { upgraded liquids } \\
\text { methanol } \\
\text { ethanol } \\
\text { hydrazine } \\
\text { methylamine } \\
\text { hydrogen } \\
\text { methane } \\
\text { ammonia } \\
\text { acetylene } \\
\text { oil slurry } \\
\text { methanol slurry } \\
\text { raw shale oll } \\
\text { shale syncrude } \\
\text { methanol } \\
\text { ethanol } \\
\text { other alcohols } \\
\text { methane } \\
\text { vegetable olls }\end{array}$ & $\begin{array}{l}2 A^{*}, 3 B \\
2 A^{*}, 3 B \\
2 A, 3 B \\
U \\
U \\
U \\
2 A^{*}, 3 B^{*} \\
2 A, 3 B \\
2 A^{*}, 3 B^{*} \\
U \\
1 A \\
2 A, 3 B\end{array}$ & 2B & $\begin{array}{l}1{ }^{\prime} \\
1 A^{*}, 3 B \\
1 B^{*} \\
\phi\end{array}$ & . \\
\hline $\begin{array}{l}\text { geothermal steam } \\
\text { solar } \\
\text { nuclear } \\
\text { hydro } \\
\text { other }\end{array}$ & 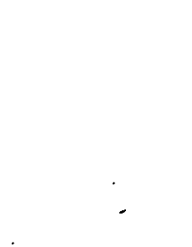 & & . & $\begin{array}{l}1 * \\
2 \star, 4 A-U \\
1 *, 3 A \\
1 * \\
1 *-3 *\end{array}$ \\
\hline
\end{tabular}

Key $1=$ now or by 1980

$2=$ by 1990

$3=$ by, 2000

$4=$ after 2000

$A=$ posstble

$B=$ probable

$U=$ unlikely or highly uncertain

*ut1lization for purposes other than NHT fuels seems probable in pertinent time-frame.

Insignificant utilization as NHT fuels expected. 


\section{FUEL LOGISTICS CRITERIA}

\begin{tabular}{|c|c|}
\hline ource & $\begin{array}{c}\text { Derivative } \\
\text { Fuel } \\
\end{array}$ \\
\hline 1 & \\
\hline & $\begin{array}{l}\text { raw 11quids } \\
\text { upgraded liquids } \\
\text { methanol } \\
\text { ethano1 } \\
\text { hydrazine } \\
\text { methylamine } \\
\text { hydrogen } \\
\text { methane } \\
\text { ammonia } \\
\text { acetylene } \\
\text { ofl slurry } \\
\text { methanol slurry }\end{array}$ \\
\hline
\end{tabular}

011 Shale

raw shale ofl

syncrude/products

methanol
ethanol
other alcohols
methane
vegetable oils

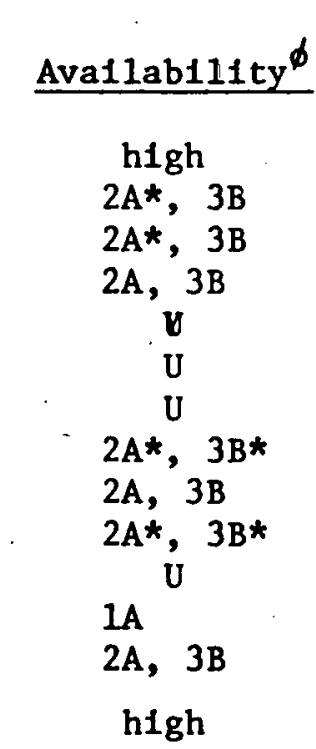

\section{B}

2B

medium

$2 A *, 3 B *$

1

Insignificant $1 \mathrm{B*}$

Insignificant

\begin{tabular}{ll} 
Compatibility with Current \\
\hline Fuels
\end{tabular}

no
some problems
yes
some problems
yes
no
no
no
some problems
no
no
some problems
some problems

no

some problems yes

no

some problems yes

-

some problems

-

\section{no}

some problems

yes

some problems

yes

no

no

no

some problems

no

no

some problems

some problems

no

some problems

yes

no

some problems yes

-

some problems
International

Considerations

\section{variable}

generally unfavorable

probably favorable

probably favorable

probably favorable

:nfavorable

unf avorable

uncertain

probably favorable generally unfavorable

generally unfavorable uncertain

generally unfavorable

variable, generally unfavorable generally unfavorable probably favorable

varlable

probably favorable probably favorable

probably favorable

\$ ratings for Individual products from Table 12-3
$1=$ now or by 1980
2 = by 1990
3 = by 2000
4 = after 2000

$A=$ possible

$B=$ probable

$U=$ unlikely or highly uncertain

* = probable ut1lization for purposes other than NHT fuels 


\section{REFERENCES}

(12-1) Paul Averitt, "Coal Resources of the United States," Geological Survey Bulletin 1412, 1974.

(12-2) N. A. Parker and B. C. Thompson, "U.S. Coal Resources and Reserves," Federal Energy Administration, Kay 1976.

(12-3) R. J. Gordon, "Economic Analysis of Coal Supply: An Assessment of Existing Studies," Pennsylvania State University, February 1976.

(12-4) Coal News, November 18, 1977, page 6. Address by Dr. Vincent E. McKelvey to the International Conference on Energy Use Management, November 1977 .

(12-5) P. K. Theobald et al., "Energy Resources of the United States," Geological Survey Circular 650, 1972.

(12-6) "U.S. Energy Outlook," National Petroleum Counc11, December 1972.

(12-7) D. V. Punwani et al., "SNG Production from Peat," International Conference on Alternative Energy Sources, Miami, December 1977.

(12-8) "Renewable Resources for Industrial Materials," National Research Council, National Academy of Sclences, Washington, D.C., 1976.

(12-9) Edward S. Lipinsky, "The Prospects for Fuels from Blomass," 12th Intersociety Energy Conversion Engineering Conference (IECED), Washington, D.C., August 1977.

(12-10) C. A. Rohrmann et al., "Methanol from Forestry, Municipal and Agrucultural Organic Residues," 1974 Engineering Foundation Conference, Henniker, N. H., July 1974.

(12-11) Robert W. Graham et al., "Preliminary Assessment of Systems for Deriving Liquid and Gaseous Fuels from Waste or Grown Organics," NASA Lewis Research Center, Cleveland, Ohio, February 1976.

(12-12) Sylvia A. Ware, "Fuel and Energy Production by Bioconversion of Waste Materials," Ebon Research Systems, Silver Springs, Maryland, August 1976.

(12-13) Robert Lowe, "Energy Conservation through Improved Solid Waste Management," U.S. EPA Report SW 125, 1974.

(12-14) Carl J. Anderson, "Biosolar Fuels for Transportation," Lawrence Livermore Laboratory, University of California, Livermore, California, January 1977.

(12-15) D. H. Rumsfeld, Department of Defense Directive No. 4140-43, December 5, 1975. 


\section{$12-16$}

(12-16) "National Energy Outlook," pages 255-257, Federal Energy Administration, 1976.

(12-17) "Statistical Data of the Uranium Industry," U.S. ERDA, Grand Junction, 1975.

(12-18) "Survey of Uranium Industry V1ews Concerning U.S. Uranium Resources and U.S. Urantum Production Activities; U.S. ERDA, April 1977.

(12-19) "U.S. Energy Outlook", National Petroleum Council, December 1972.

(12-20) Ian I. Mitroff and James R. Emshoff, "On Strateg1c Assumption Making: A Dialectical Approach to Policy Analysis and Evaluation," (forthcoming publication).

(12-21) Edward S. Lipinsky, "The Prospects for Fuels from Blomass," 12th Intersociety Energy Converstion Engineering Conference (IECEC), Washington D.C., August 1977. 


\section{Biomass Resource Availability}

Blosolar or biological resources, unlike fossil fuels, are renewable. This is the strategic characteristic that makes blomass of such interest as a source of fuels in the future. In spite of the orientation to the future, certain forms of blomass have been conventional fuels for decades and even mfllenla, although use as transportation fuels has been limfted to a few special situations. Renewab1lity, however, is not the onily characteristic that distinguishes biomass from commercial fuels such as oll, gas and coal. As discussed below, recognition of the distinguishing characteristics is important to quantitative: assessment of the future fuel potential of blomass.

Terms such as "reserves" and "resources" may be applied to biomass but, when this is done, the meaning of the terms may be different than the customary meanings and definitions that have been developed for fossil fuels. Forests, for example, might be conceptualized as "reserves" of biomass. This conception, however, would be incomplete without consideration of matters such as:

- has the use of the forest already been designated or determined? (e.g. for timber, pulp and paper, recreation, natural watershed, etc.)

- If an extractive, but non-fuel use of the forest has been predetermined would there, nevertheless, be by-products of potential use as fuels assoclated with the primary extractive use?

- If utilization of fuel by-products is possible, is it also likely that such utilization would be captive to the primary extraction endeavor? (e.g. the use of bark and other wood wastes to supply the process energy needed for a pulp plant thereby preventing the utilization of the wastes for some non-captive purpose such as the production of transportation fuels)

- how should renewabillity be defined?

- If renewability were to be related to an average annual production rate, would this rate be limited by the production rate required for the primary endeavor?

- even though the blomass itself is renewable, would the process of renewal deplete another non-renewable resource? (e.g. phosphate fertillzer)

- would the process of renewal perturb the ut1lization of what are generally considered to be renewable resources such as water?

- what will be the future impacts of possible developments in the technology of producing biomass? (e.g. plant genetics, natural fixation of nitrogen) 
Most, or all, of the above questlons would become 1mportant in the event of attempts to utilize biomass for the production of transportation fuels on a large scale. The essentlal distinctions are:

(1) the resource base of fossil fuels is fixed* and depletable

(2) the resource base of blomass is varlable, and is dependent on a large number of other variables.

Thus, the resource base of fossil fuels 1s essent1ally a "glven" (even though we may not know its precise extent), while the resource hase for biomass is essentlally a "taken" (I $\mp-1)$ ) (1.e. depends on assumptions made about the contingent variables of a complex, dynamic, interactive system).

The foregoing discussion was intended to:

- make important conceptual distinctions between fossil fuels and biomass

- explain why precise quantification of future biomass resources should not be expected.

The infeasibility of precise quantification does not imply that no quantification at all is possible. Indeed, the open literature contains a variety of estimates five of which are discussed briefly below. All of the estimates are contingent upon explicit or implicit assumptions, and should not be accepted without recognition and evaluation of these assumptions. Most of this evaluation will be undertaken later, but some background considerations are listed in Table 12A-1.

In a recent paper, $(1-i)$ Lupinsky observes that "future needs of the Unfted States for fuel are gigant1c compared with the energy that biomass can deliver." He estimates that only $1 \%$ of U.S. energy consumption in 1976 (about 74 quads inclusive of non-energy requirements, 1.e. feedstock consumption, of fossil fuels) could have been satisfied by $60 \%$ of the U.S. corn crop**. Other points made by Lipinsky are:

- "Both enzymatic hydrolysis and acid hydrolysis of lignocellulosic blomass appear to be decades from commercial utilization."

- "Both the biomass resources and the chemlcals to be used as fuels . . have alternative applications, such as chemical feedstocks, pulp for papermaking, human food; and animal feeds. The prospects for fuels from biomass are strongly affected by these alternative uses."

\footnotetext{
*except In the sense of geological time.

**the estimates are In terms of BTU equivalency and do not Imply that three fifths of the corn crop could actually have satisfled $1 \%$ of U.S. energy needs.
} 
$\underline{\text { TABLE } 12 \mathrm{~A}-1}$

SOME BIOMASS CONSIDERATIONS

(1) Wood used to be the princlpal source of fuel in the U.S. For many years, however, "fuel wood" consumption has been excluded from officlal energy otatistics.

(2) Officlal energy statistics focus on commerclal fuels, 1.e. on fuels that are sold to others.

(3) Captive consumption of by-products as fuels is not treated adequately in official energy statistics. Superficially, the latter give the impression that the consumption of by-product and "waste" materials is much lower than is actually the case.

(4) Most of the consumption of "wastes" as fuels is by a small number of Industries. "Blomass wastes" are utilized by segments of the food industry and pulp/paper industry.

(5) Utilization of "biomass wastes" In captive, stationary applications (particularly as boller fuel) has been increasing steadily (mostly in response to the higher cost of purchased fuels but also as a means of avolding waste disposal problems).

(6) When wastes are used captively, both costs and benefits can be accurately internalized. Hence, the decision-making process is stralghtforward. In contrast, schemes that envisage non-captive utilization of waste materials may involve an uneven distribution. of costs and benefits and also a complex decision-making process or chain of decisions. Important characteristics of such a "chain" are that (a) any "link" (1.e. Individual decision-maker) in the "chain" has effective veto power over the process, and (b) the corollary is that all "links" must perceive a net benefit to themselves (not a net cost).

(7) Ethanol is the only fuel derived from a biomass resource that has been used commerclally for many years as a transportation fuel blendstock. Most of such usage, however, has been outside the U.S. (Braz1l, Cuba). Relatively small percentages of synthetic methanol, ethanol, and 1sopropanol have been used in motor gasoline (as anti-icing additives rather than as fuel extenders). The state of Nebraska is considering an ethanol project.

(8) Under conditions of petroleum scarclty (or high Import cost), ethanol might have more Importance as an indirect substitute for petcoleum (e.g. as an ethylene feedstock, thereby substituting for a petroleum hydrocarbon feedstock) than as a direct substitute (e.g. as a transportation fuel blendstock).

(9) After a preparation step, such as drying or dewatering, blomass may be used directly as a stationary fuel (e.g. boller fuel). Blomass may also be converted, by varlous means, Into higher quality fuels such as methane, methanol, ethanol, and fuel o1l. 
- "The switch from nonrenewable resources to renewable resources will not occur on the basis of price for many years (personal opinton). What will motivate producers of fuels and chemical feedstocks to switch will be avallability."

In 1974, Rohrmann et al. reviewed the potent1als for converting forestry, agricultural and municipel wastes to methanol.(1-19): U.S. wastes Identified as being potentlally avallable for this purpose were:

\begin{tabular}{cc} 
Est imated Annual & Approximate Carbon \\
Quantity, $10^{6}$ tons, (any basis) & Content, wt\% \\
\hline
\end{tabular}

Sawdust, shavings, bark

and scrap from lumbering

50

Trash and garbage from municlpal residues

Agricultural residues such as corn stalks and wheat straw

The authors note that their statistics are somewhat out of date such that the waste total on a current basis (1.e. 1974) may be about 1 billion tons of $40 \%$ carbon content which they then equate to U.S. coal production ( 603 million tons of approximately $70 \%$ carbon content). The report then observes:

- "W1th some add1tional rather 'broad brush' estimations, such as a $50 \%$ conversion of the total carbon to methanol with a fuel value half that of gasoline, utilization of the total resource of these residues would yleld liquid fuel equivalent to about $2 \times 10^{9}$ barrels of gasoline. Realism, of course, requires a much more modest assessment of this potential."

- "The largest U.S. synthetic methanol plants in operation today produce over 200 million gallons per year." Approximately 420 such plants would be needed to produce the 2 bilition barrels of gasoline' equivalent referred to above.

The remainder of the report reviews various technological approaches to conversion of wastes first to synthesis gas and then to methanol. The need to collect wastes for delivery to the hypothetical methanol plants is recognized as follows:

"For the present, the delivered price of agricultural and wood wastes must include all the cost of collection, storage and hauling if these wastes are to be used for the production of methanol fuel . . . It $1 \mathrm{~s}^{\text {. }}$ estimated that agricultural wastes could be collected, stored and transported up to 33 miles to a processing plant and st111 stay at about $\$ 8.00 /$ ton. As 
environmental regulations become more stringent, the options to the generators of these wastes will become more IImited and they will have to bear a higher disposal cost which will, in turn, allow wastes to be hauled a longer distance to processing plants and still tie economical at the net delivered price of $\$ 8.00 /$ ton of waste."

No explanation is given of "still be economical," nor of who is assumed to undertake the conversion activities.

concludes that:

A study by Graham et al..$^{(12-11)}$ published in February 1976.

- "The energy contribution from a system that uses waste and grown organic feedstocks is estimated as 4 to 12 percent of our current energy consumption."

- "Economic and social issues may be as important as technology in determining the feasibility of such a proposal."

- "There is conslderable uncertainty as to how much of the total agricultural waste is collectable for use as feedstocks to conversion systems, but it is probably of the order of tens of millions of tons."

- "The development of a national program for converting organic matter to fuel requires the involvement and coordination of many sectors in the overall enterprise. Such a project organization will eventually have to interface local, state, and federal government agencies with farming, private transportation, chemfcal conversion operations, fuel storage, marketing, and public ut1lities."

The study presents a range of est1mates of fuel energy potentially avallable from (a) waste and (b) (deliberately) grown organics. Separate estimates from these two sources are:

$$
\begin{array}{lc} 
& \text { guads/yr. } \\
\text { waste (conservative estimate) } & 1.4 \\
\text { grown organics (slash plne silviculture) } & 2.0 \text { to } 3.2
\end{array}
$$

Addition of the separate estimates gives around 4 quads/yr., which is equivalent to $5 \%$ of current energy consumption.

The report has an appendix that contains rudimentary cost estimates and also the statement: "It 1s apparent from this cost analysis that the mafor influence on the cost of the fuel is the charge for biomass feedstock, regardless of the conversion process used. Thus, the economic viablilty of the system will depend mostly 
on the cost of obtaining feedstock. Organic waste, where no charge or even an income is possible, would be the most attractive feedstock for beginning this conversion enterprise." Without further critique of the estimates, the total quantity of "most attractive feedstock" is equivalent to less than $2 \%$ of current U.S. energy consumption.

In August 1976, Ware(12-12) reported that, by 1980, "an estimated 1,061 million dry tons of organic solld wastes w1ll be generated each year by munfclpalities, Industry, and agriculture." This estimate is similar to Rohrmann's, and is equivalent to about 13 quads of primary energy or almost an order of magnitude greater than the "conservative" estimate for wastes given by Graham. Most of the numerical difference between the estimates is due to reducing a "potentially avallable" to a "readily avallable" figure. However, the "ready avallabllity" of wastes does not imply any level of actual utilization. Ware, who did not make estimates of her own, cited a 1974 EPA report which contained the following numbers: $(12-13)$

Energy Potentially Recoverable from Municipal Solid Waste (MSW), 1980

$\begin{array}{lcc} & \text { guads/yr. } & \text { B/D. O.E.* } \\ \text { theoretical } & 1.44 & 680 \\ \text { avallable } & 1.085 & 512 \\ \text { projected Implementation } & 0.085 & 40\end{array}$

' If the "projected implementation" were to occur, MSW would provide about $0.1 \%$ of U.S. energy needs in 1980.

Ware's report also cites cost estimates made in seven earlier studies. A semi-quantitative pattern of costs is evident, as suggested by the approximate Index in the final column.

\begin{tabular}{lc} 
& $\begin{array}{c}\text { Index } \\
\text { combustion of MSW to produce steam }\end{array}$ \\
\cline { 2 - 2 } pipeline quality gas by anaerobic \\
digestion of MSW or manure \\
acid hydrolysis of MSW to ethanol \\
$\therefore$ conversion of MSW to methanol
\end{tabular}

Recognizing that the estimates from different sources are not on exactly the same basis, and that all of the estimates are probably low on an absolute basis, it appears that:

- using MSW to produce steam is the most economic alternative

- converting MSW to ethanol or methanol may be an order of magnitude more costly than using it to produce steam 
- conversion of MSW to pipeline quality gas is intermediate in cost between the boller fuel and alcohol cases, and is also considerably more expensive than the current range of contract prices for new intrastate natural gas in leading producing states such as Texas, Louisiana, and Oklahoma.

On an economic basis it may be expected that utilization of biomass wastes as fuel w1ll expand in boiler fuel applications before significant penetration of markets that require fuel in a converted form: either a gas or a liquid. In the latter cases, conversion to methane appears the more economic choice. Considering both the potential contribution of organic wastest to total U.S. energy supply and the potential for displacing petroleum fuels from stationary to transportation usest*, It appears that biomass is unlikely to become a significant source of U.S. transportation fuels for many years. Put differently, the conclusion in that biomass will be no more than a supplemental source of transportation fuels for many years. This conclusion is similar to those already attributed to Lipinsky. It is also supported by the work of Anderson(12-14) who concluded that "because of their costs, early implementation of biosolar conversion schemes will likely not be in the area of transportation synfuels." Anderson also presents the following estimates of the potential quantities of transportation fuels producible from various U.S. biomass resources:

Fuel

ethanol by fermentation methanol by pyrolysis methanol by pyrolysis methanol by pyrolysis methanol by pyrolysis oll by pyrolysis

\begin{tabular}{l} 
Source \\
\hline U.S. grain crop \\
agricultural waste \\
feedlot residues \\
MSW \\
forest wastes
\end{tabular}

all organic wastes

Quads/yr.
$\begin{gathered}1.6 \\ 0.18 \text { to } 1.5 \\ 0.17 \\ 0.2 \text { to } 0.3 \\ 0.3\end{gathered}$

1

Since there is no likelihood that the entire U.S. grain crop w1ll be converted to ethanol, the above estimates suggest that the maximum transportation fuel potential from U.S. organic wastes 1 s about 1 quad/yr. -as methariol, as ofl, or as some combination of the two -- assuming that these wastes are not utilized for stationary fuel purposes. As discussed previously, this is not a reasonable assumption. Hence, the overall. conclusion from this entire review may be reiterated: biomass will be no more than a supplemental source of U.S. transportation fuels for many years.

\footnotetext{
\#From an economic standpoint, it is clear that organic wastes will generally be cheaper than cultivated biomass.
}

**e.g. by changing the yleld patterns of petroleum refineries. 
E. N. Cart, Jr.

M. H. Farmer

The criteria to be used in the preliminary screening phase consists basically of four major factors: (1) fuel manufacture criteria; (2) fuel performance criteria from the designer/user viewpoint; (3) compatibility of fuels and prime movers; and (4) fuel logistics factors. The reasons for selecting these four criteria were outlined in Section 2 . The basic data on the various fuels and prime movers have been complied, critiqued, put on a consistent basis, and summarlzed, in Sections 3 through 12, to serve as a basis for rating the varfous fuels and prime movers. In the following sections, the rating scale that will be used 1 s explained and the ratings for the four major areas established.

\subsection{Rating Scale Used (LIkert Scale)}

A Likert scale was used for many of the judgmental ratings. Th1s type of scale is a standard tool of the soctal scfences when measurement is to be made by the judgment of individuals rather than by physical instruments, and especially where a physical measurement is inapplicable. For example, an Individual's preference for A over B (or vice versa) is not directly measurable except by the Individual's expression of preference. A Likert scale is a means by which preferences may be expressed in a simple numerical way. In principle, the scale may have any number of intervals. In practlce, a five-point scale is useful for "screening," 1.e., for gross differentiation of preferences. Typically, the five-point scale has the Intervals $0,1,2,3,4$ or $1,2,3,4,5$ or $-2,-1,0,+1,+2$. While these intervals are identical from a mathematical or statistical standpoint, the -2 to +2 scale has symbollc advantages in cases where $A, B, C, D$, etc., are to be compared with a "standard." There is the additional advantage that "don't know" or "uncertaln" can be rated as zero, Instead of being omitted from the comparison.

Suppose that the standard is something that already exists, while $A, B, C$, etc., are potential alternatives that could exist in the future. Then, for any given criterion of quality, A may be rated relative to the standard as:

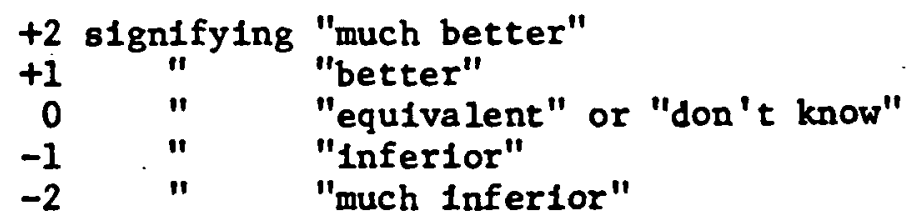

Obviously, "better" and "Inferior" may be replaced by other value pairs such as "greater difficulty" and "lesser difficulty." In each of the categorles to be rated, the scale used will be defined. 
When different criteria are rated using the same Likert scale, it is possible to sum and average the ratings across the various criteria to obtain an overall rating. Such a combination of ratings is open to challenge on the conceptual grounds that the attributes are not additfve or not properly welghted in the average (overall) rating. Such an objection is not admissible if all of the Individual ratings of $A$ are better than the standard (or all are worse), and does not appear to be of practical consequence If the majority of ratings are in one direction. However, the objection may be valid if there is a fairly even division of plus and minus ratings. It is for this reason that the overall ratings have been used for the purpose of screening only and not to establish an absolute measure of difference among the fuels or fuel systems rated. This screening, by eliminating clearly inferior hypothetical alternatives, narrows the field to a smaller number of more likely alternatives which may then be examined in greater detall that would be possible for the entire field of initial possibilities.

\subsection{Fuels Manufacture Ratings}

The three factors considered in the fuel manufacture area are: (1) cost of production, distribution and storage; (2) overall energy efficlency, up to point of use; and (3) environmental impact in production.

The rating scale used for the cost of production, distribution and storage was as follows:

\begin{tabular}{cc} 
Rating & $\begin{array}{l}\text { Cost Range }-\$ / 10^{6} \mathrm{BTU} \\
\text { (Delivered to Customer) }\end{array}$ \\
\hline & Up to 3 \\
+2 & 3 to 6 \\
0 & 6 to 10 \\
-1 & 10 to 15 \\
-2 & $>15$
\end{tabular}

It is recognized that the split into the five ranges is arbitrary. In the case of cost, the fuels can be directly rated since the costs are on a common basis. However, to be able to combine the cost ratings.with the other two ratings, it is necessary to put all the criteria on a similar rating scale. The data in Sections 6 and 7 provided the basic information for the ratings shown in the first column in Table 13-1.

was as follows:

The rating scale used for the overall energy efficlency category

Rat1ng

BTU of Resource/BTU of Fuel

$+2$

$+1$

0

$-1$

$-2$
1-1. 3

1. 31-1.7

1.71-2

2.01-2.5

$>2.51$ 
TABLE $13-1$

FUEL MANUFACTURE CRITERIA--RATINGS

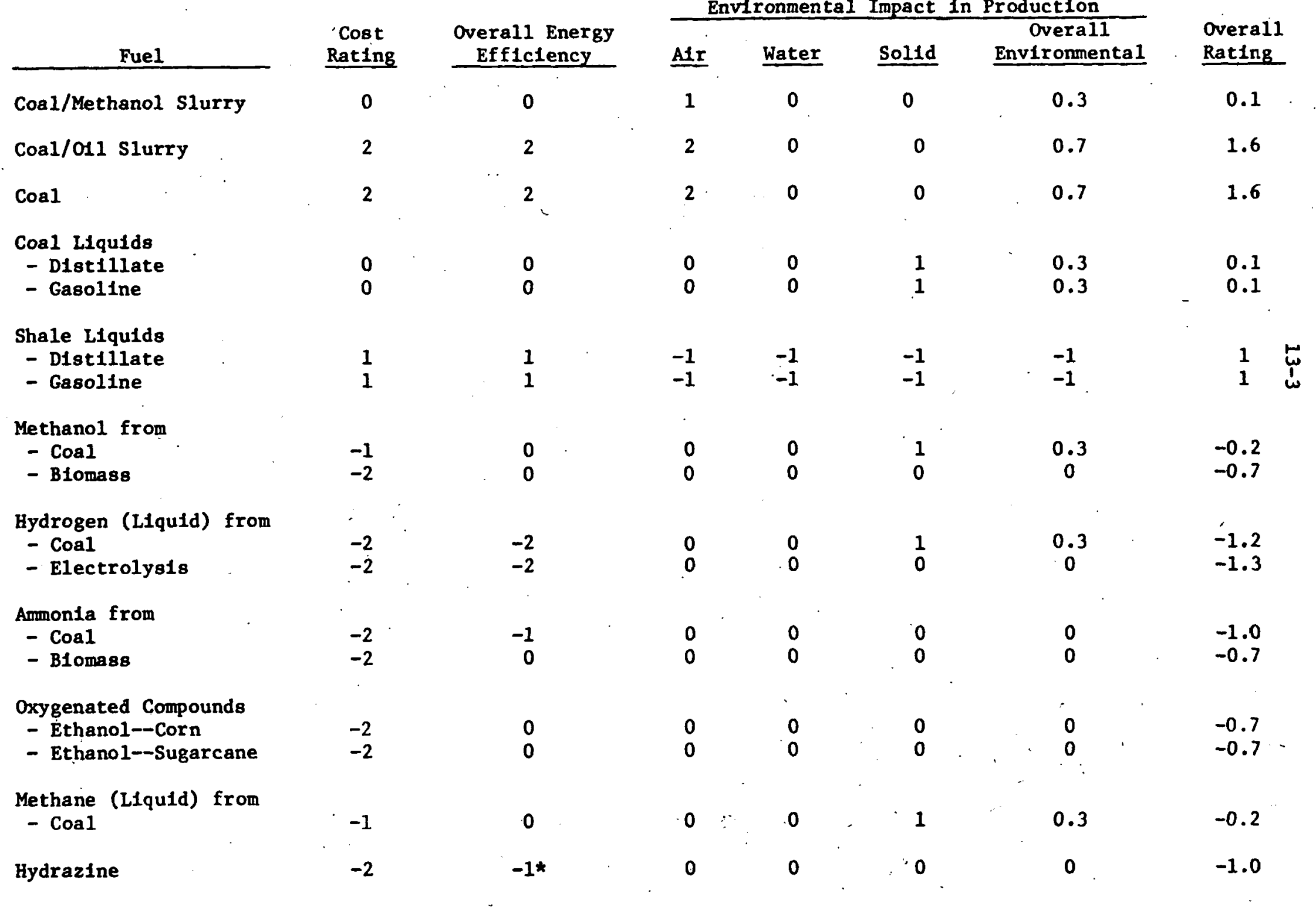


TABLE 13-1 (Cont1nued)

\begin{tabular}{|c|c|c|c|c|c|c|c|}
\hline Fuel & $\begin{array}{c}\text { Cost } \\
\text { Rat1ng }\end{array}$ & $\begin{array}{c}\text { Overall Energy } \\
\text { Efflclency }\end{array}$ & \multicolumn{4}{|c|}{ Environmental Impact in Production } & $\begin{array}{l}\text { Overall } \\
\text { Rating }\end{array}$ \\
\hline Methylamine & -2 & $-1 *$ & 0 & 0 & 0 & 0 & -1.0 \\
\hline Acetylene & -2 & -2 & 0 & 0 & 0 & 0 & -1.3 \\
\hline O11 from Organic Waste & -1 & 0 & 0 & 0 & 0 & 0 & -0.3 \\
\hline
\end{tabular}

*No direct Information avallable, but given same rating as amonla because of chemical sinilarity.

**Probably around -1 if overall energy efficiency included energy to manufacture the recovery equipment. 
For the renewable resource base, a zero was used since it is not possible to put the renewable resources on the same basis as for fuels derived from coal or shale. The data in Section 10 formed the basis for the ratings shown in the second column in Table 13-1.

follows :

The rating scale used for the environmental criterla was as

$\begin{array}{rccc}\text { Rating } & \text { Air Emissions } & \frac{\text { Water }}{\text { Lbs/106 BTU }} & \frac{\text { Solid }}{\text { Lbs/106 BTU }} \\ +2 & <0.01 & & \\ +1 & 0.01-0.1 & 0-1 & 0-20 \\ 0 & 0.1-0.5 & >1 & 20-100 \\ -1 & >0.5 & & >100 \\ -2 & & \end{array}$

In this case, the amount of information was not sufficient to allow all five "numbers" of the rating scale to be used. As was pointed out In Section 8, the source of this data, most processes can be developed to meet existing or proposed environmental standards, so that most of the fuels will. carry a zero rating, except for a few which produce more emissions than the others. Shale derived liquids and electriclty are the two fuels that fall into this category.

The ratings for air, water and solid emissions were averaged into an overall environmental rating by adding the three individual ratings and dividing by three. The overall environmental rating is then combined with the overall energy efficlency rating and the cost rating by adding all three ratings and divided by three. This means that, for screening purposes; all three categories carry equal weight in the rating system.

The fuels with a rating of zero or greater are as follows (listed in descending order of rating):

1. Coal

2. Coal/o11 slurry

3. Shale Iiquids--distillate gasoline

4. Coal 1iquids--dist1llate gasollne

5. Coal/methanol slurry 
Fuels with a rating of zero to minus 0.5 are as follows:

6. Methane (1iquid)

7. Methanol (from coal)

8. Oil from organic waste

The overall ratings do not have any absolute significance, but they do Indicate which fuels, from a manufacturing viewpoint, are most attractive and deserve further consideration. Fuels with $a$ rating of minus 0.5 or greater (on a negative scale) that would not appear to be attractive from a manufacturing standpoint are as follows:
9. Ethano1 (corn)
10. Methanol (blomass)
11. Ethano1 (sugarcane)
12. Ammonia (biomass)
13. Hydrazine
14. Methylamine
15. Electricity
16. Hydrogen (11quid)
17. Acetylene

\subsection{Fuel Performance Ratings from Designer/User Viewpoint}

In evaluating the various fuels from a performance standpoint, six different factors were considered: (1) toxic1ty, (2) safety, (3) materials compatibllity, (4) storage requirements, (5) convenience in handiling and storage, and (6) environmental impact during use. For this particular category, it is possible to use the current petroleum fuel as a reference. The particular scale that was used for each of the six factors is defined in the following sections. Section 3 is the basis for the data used for most of these ratings.

\subsubsection{Toxic1ty}

The rating scale used for the toxicity comparison is as follows:

0 -- Comparable to current petroleum based fuel

-1 -- Moderately more toxic than petroleum fuels

-2 -- Potentially much more toxic than petroleum fuels

As shown in Table 13-2 for coal 11quids, the distillate fraction (diesel/jet fuel) is shown with a zero rating. Th1s assumes that the Ilquids have been upgraded to meet the current specification. The -1 for gasoline and fuel ofl reflect the more aromatic nature of coal liquids, compared to petroleum. It is assumed that for gasoline it would be destrable to take advantage of this characteristic of coal gasolines, while for fuel 011, It would not be economical to try and upgrade the product.

\subsubsection{Safety}

The rating scale used for the safety comparison is as follows: 
TABLE 13-2

FUEL PERFORMANCE CRITERIA

\begin{tabular}{|c|c|c|c|c|c|c|c|c|c|}
\hline \multirow{2}{*}{ Fue1 } & \multirow[b]{2}{*}{ Toxictity } & \multirow[b]{2}{*}{$\underline{\text { Sefety }}$} & \multirow[b]{2}{*}{$\begin{array}{c}\text { Materials } \\
\text { Compat1b111ty }\end{array}$} & \multicolumn{3}{|c|}{ Storage Requitrements } & \multirow{2}{*}{$\begin{array}{l}\text { Conventence } \\
\text { In Handling } \\
\text { and Storage }\end{array}$} & \multirow{2}{*}{$\begin{array}{c}\text { Enviromental } \\
\text { Impact During } \\
\text { Uge } \\
\end{array}$} & \multirow[b]{2}{*}{$\begin{array}{l}\text { Overall } \\
\text { Rat1ng }\end{array}$} \\
\hline & & & & $\begin{array}{l}\text { We1ght } \\
\text { (Fuel Only) }\end{array}$ & $\begin{array}{c}\text { Volume } \\
\text { (Fue1 Only) }\end{array}$ & Avg. & & & \\
\hline $\begin{array}{l}\text { Petroleum } \\
\text { - Present Specification } \\
\text { - Broadcut }\end{array}$ & $\begin{array}{l}0 \\
0\end{array}$ & $\begin{array}{r}0 \\
+1\end{array}$ & $\begin{array}{l}0 \\
0\end{array}$ & $\begin{array}{l}0 \\
0\end{array}$ & $\begin{array}{l}0 \\
0\end{array}$ & $\begin{array}{l}0 \\
0\end{array}$ & $\begin{array}{l}0 \\
0\end{array}$ & $\begin{array}{l}0 \\
0\end{array}$ & $\begin{array}{c}0 \\
+0.2\end{array}$ \\
\hline Coal & 0 & +1 & -1 & -1 & -1 & -1 & -1 & -2 & -0.7 \\
\hline Coal/Methanol Slurry & -1 & 0 & -1 & -2 & -2 & -2 & -2 & -1 & -1.2 \\
\hline Coal/011 slurry & 0 & +1 & -1 & -1 & +1 & $\mathbf{0}$ & -2 & -1 & -0.5 \\
\hline $\begin{array}{l}\text { Coal L1quids } \\
\text { - Gasoline } \\
\text { - Diesel/Jet Fuel } \\
\text { - Fuel } 011\end{array}$ & $\begin{array}{r}-1 \\
0 \\
-1\end{array}$ & $\begin{array}{r}0 \\
+1 \\
+1\end{array}$ & $\begin{array}{l}0 \\
0 \\
0\end{array}$ & $\begin{array}{l}0 \\
0 \\
0\end{array}$ & $\begin{array}{r}0 \\
0 \\
+1\end{array}$ & $\begin{array}{l}0 \\
0 \\
0.5\end{array}$ & $\begin{array}{l}0 \\
0 \\
0\end{array}$ & $\begin{array}{l}-1 \\
-1 \\
-1\end{array}$ & $\begin{array}{c}-0.3 \\
0 \\
-0.1\end{array}$ \\
\hline $\begin{array}{l}\text { Shale 011 Liquids } \\
\text { - Raw } \\
\text { - Syncrude }\end{array}$ & $\begin{array}{l}0 \\
0\end{array}$ & $\begin{array}{l}0 \\
0\end{array}$ & $\begin{array}{r}-1 \\
0\end{array}$ & $\begin{array}{l}0 \\
0\end{array}$ & $\begin{array}{r}-1 \\
0\end{array}$ & $\begin{array}{c}-0.5 \\
0\end{array}$ & $\begin{array}{r}-2 \\
0\end{array}$ & $\begin{array}{r}-1 \\
0\end{array}$ & $\begin{array}{c}-0.7 \\
0\end{array}$ \\
\hline Methanol & -1 & 0 & -1 & -2 & -2 & -2 & -1 & +1 & -0.7 \\
\hline Bydrogen & 0 & -1 & -1 & +2 & -2 & $\mathbf{0}$ & -2 & +2 & -0.3 \\
\hline Ammonla & -2 & 0 & -2 & -2 & -2 & -2 & -1 & -1 & -1.3 \\
\hline $\begin{array}{l}\text { Oxygenated Compound } \\
\text { - Ethanol } \\
\text { - HIgher Alcohols }\end{array}$ & $\begin{array}{l}-1 \\
-1\end{array}$ & $\begin{array}{l}0 \\
0\end{array}$ & $\begin{array}{l}-1 \\
-1\end{array}$ & $\begin{array}{l}-2 \\
-2\end{array}$ & $\begin{array}{l}-2 \\
-2\end{array}$ & $\begin{array}{l}-2 \\
-2\end{array}$ & $\begin{array}{l}-1 \\
-1\end{array}$ & $\begin{array}{l}+1 \\
+1\end{array}$ & $\begin{array}{l}-0.7 \\
-0.7\end{array}$ \\
\hline Methane & 0 & -1 & 0 & +1 & -2 & -0.5 & -1 & +1 & -0.3 \\
\hline Hydrazine & -2 & 0 & -2 & -2 & -2 & -2 & -2 & $\mathbf{0}$ & -1.3 \\
\hline Methylamine & -2 & -1 & -2 & -1 & -2 & -1.5 & -2 & 0 & -1.4 \\
\hline Acetylene & 0 & -2 & 0 & -2 & -1 & -1.5 & -2 & 0 & -2.0 \\
\hline 011 from Organlc Waste & 0 & 0 & 0 & -1 & 0 & -0.5 & $\mathbf{0}$ & 0 & -0.1 \\
\hline
\end{tabular}


+1 - Safer than the current petroleum fuel

0 - As safe as the current petroleum fuel

-1 - Not as safe as the current petroleum fuel

The data from Table 3-7 were used to determine the ratings shown in rable 13-2. The broadcut fuel is rated safer than the current petroleum fuel on the basis that it will have a lower flash point.

\subsubsection{Materials Compatibility}

The materials that are considered from a fuels compatibility standpoint are those in contact with the fuel, such as various elastomers and metals in the prime movers and the distribution system. The rating scale used was as follows:

$$
\begin{aligned}
& 0 \text {-- Satisfactory. Same as the current fuel belng used } \\
& -1 \text { - Borderline when compared to the current fuels } \\
& -2 \text {-- Unsatisfactory, based on the materials currently used, Obviously } \\
& \text { a system could be designed for a given fuel that would be } \\
& \text { satisfactory. }
\end{aligned}
$$

Coal and coal/slurries would be considered a borderline fuel when compared to the current oll aystem, due to the abrasive nature of the solids. Coal liquids are rated as satisfactory, but there may be an elastomer incompatibility problem which could be easily solved. Ammonia is rated as unsatisfactory from the problem created with copper, zinc, and brass in contact with this fuel. Methylamine would be expected to resemble ammonia. Hydrazine is corrosive to cobalt, copper, pure Iron, lead, manganese, magnesium, tin, and zinc.

\subsubsection{Storage Requirements}

The storage requirements from both a welght and volume standpoint were considered. The data in Table 3-3 were used in conjunction with the following scale to rate the various fuels:

\begin{tabular}{cc} 
Rating & Ratio from Table 3-3 \\
\cline { 2 - 2 }+2 & $<0.5$ \\
+1 & $0.5-0.99$ \\
0 & Same as Petroleum \\
-1 & $(1.00-1.09)$ \\
-2 & $1.1-1.5$ \\
& $>1.5$
\end{tabular}

The ratings for welght and volume were then averaged. It is recognized that for some modes of transportation, welght is more important, such as for alrcraft. 


\subsubsection{Convenience In Handling and Storage}

Some of the characteristics related to the handling and bulk storage of the fuels are the freezing point or pour point, water solubility of the fuel, storage stability, and emulsion forming tendencles. The data from Table 3-4 were used with the following rating scale to arrive at the values shown in Table 13-2:

+1 -- Better than current fuels

0 -- Equal to current petroleum fuels

-1 - Silghtly poorer than petroleum fuels

-2 -- Much poorer than current petroleum fuels

The coal slurries (011 or methanol) are rated a -2 due to the potential problems of maintaining the coal in suspension. Methanol and the other alcohols are rated as a -1 because of the problems that may be caused if there is any water in the distribution system. Hydrogen is rated a -2 oince a cryogenic liquid would have to be handled. Hquid methane 18 rated a -1 for the same reason, but 1 t is not as severe a problem as liquid hydrogen due to the difference in temperatures involved.

\subsubsection{Environmental Impact During Use}

The rating scale used for the environmental Impact during use criterla was as follows:

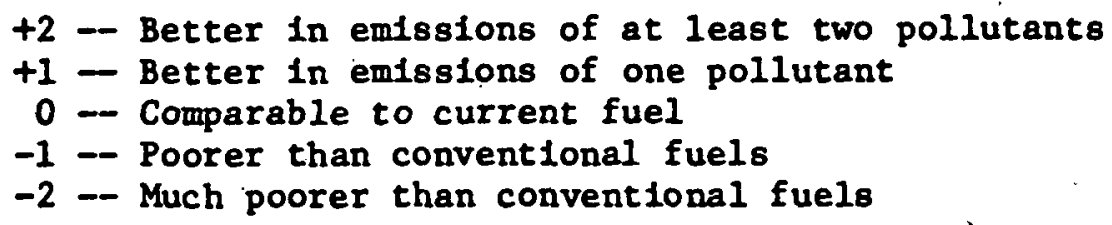

Direct use of coal 18 rated a -2 due to Increased particulate emissions as well as Increased $\mathrm{SO}_{2}$ and $\mathrm{NO}_{\mathrm{x}}$ emissions. The use of coal slurrles would reduce the emissions, elnce the fuel would contain only. $40 \%$ by welght of coal, but are st1ll expected to be poorer than conventional fuels. Coal liquids are rated a -1 due to the uncertalnty about PNA emissions. Shale liquids are assumed upgraded to the same nitrogen and sulfur levels so they would be expected to have the same emissions as conventional fuels. Ammonia would produce increased $\mathrm{NO}_{\mathrm{x}}$ emissions; this Is the reason for a -1 rating for this fuel. Hydrazine and methylamine may also cause increased emissions but since this 18 not known, a 0 rating 18 used. Hydragen is rated a +2 due to its producing less emissions than the other fuels and also no $\mathrm{CO}_{2}$.

\subsubsection{Overa11 Ratings}

The six ratings are summed and divided by $81 x$ to arrive at the overall rating shown in Table 13-2. The averages have been rounded to the nearest tenth. By definition, the current petroleum fuel would be rated 0 and any fuel that has about the same properties as petroleum would be near 0. Those fuels with a rating from -0.5 to t0.5 are as follows (1isted in descending order): 


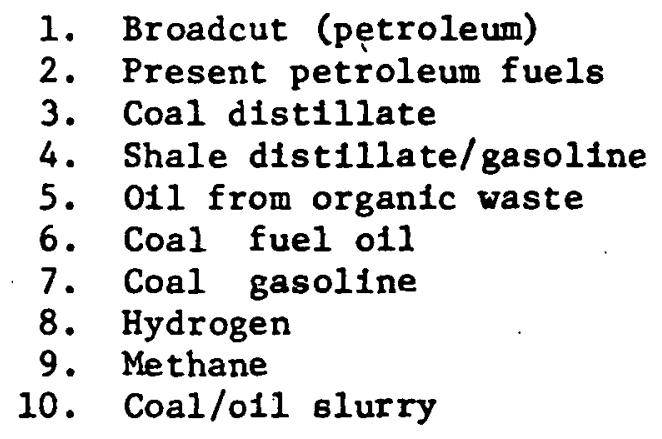

Those fuels with a rating of less than -0.5 are as follows:

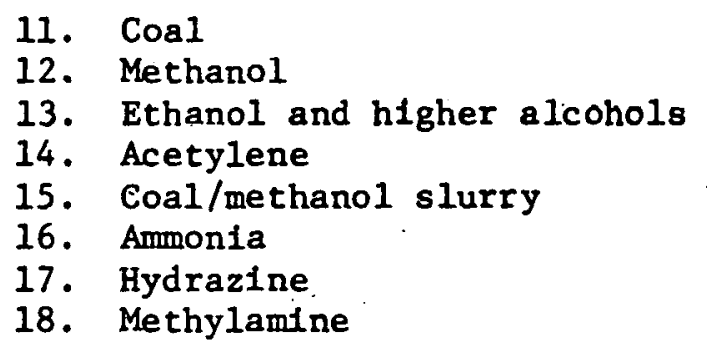

\subsection{Compatibility of Fuels and Prime Movers}

Another factor considered in evaluating the performance potential for each fuel is the compatibility of the fuels and various prime movers. Table 13-3 sumarizes how the various fuels may operate in a given type of prime mover, based on information from the literature and the combustion properties of each fuel. The rating scale used was as follows:

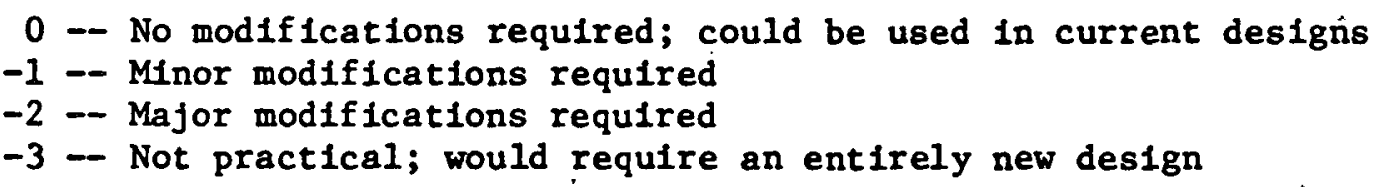

It is recognized that an entirely different type of engine could possibly be designed for the $2000+$ period, but for this preliminary screening it will be assumed that the fuels should be compatible with current designs.

In Table 13-3, several fuels/prime mover combinations are rated a -2 even though it was mentioned in Section 11 (Table $11-1$ ) that there is very little hope of effecting a match between these fuels and prime movers. In some of these cases, the problems anticipated may be tolerated and deserve further consideration if a fuel or prime mover looks attractive for other reasons. However, there are some fuels that simply are not potentially usable in certain types of engines and these are shown in Table 13-4.

As shown in Table 13-3, it is possible to sum the ratings for a given fuel and get a semi-quantitative comparison of the relative difficulty of substitution of fuels into various types of engines. Based on the totals shown, the following is a list of the relative difficulty of substitution of the fuels (1isted in order of increasing difficulty of substitution): 
TABLE 13-3

COMPATIBILITY OF FUELS AND PRIME MOVERS

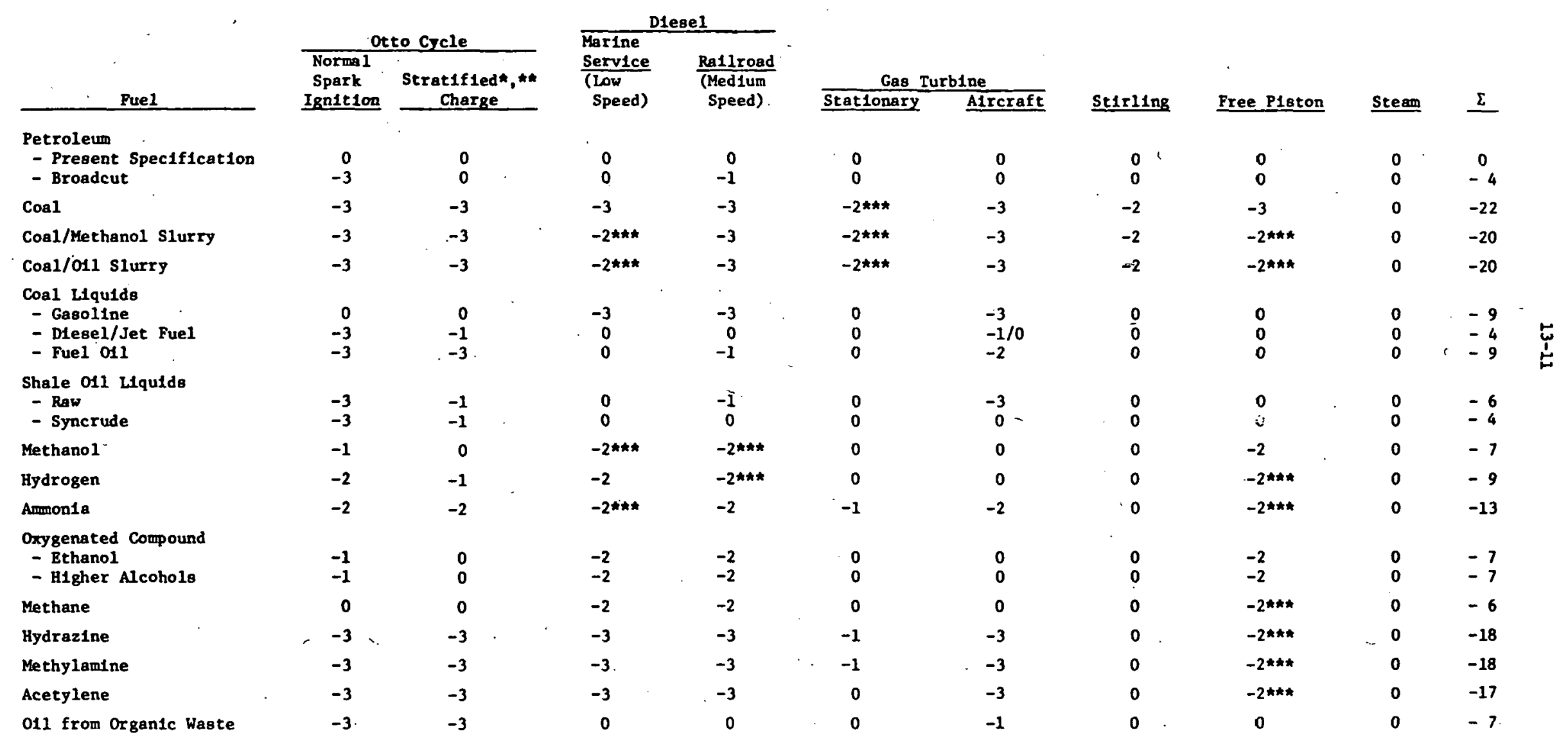

*Type under development for stationary application.

* Would not be same fuel as for normal opark 1gnited eng1ne.

**No l1terature data on these fuels/engine combinations, but worthy of further consideration. 
SUMMARY OF FUEL/ENGINES THAT SHOULD NOT BE CONSIDERED

\begin{tabular}{|c|c|c|c|c|c|c|c|c|c|}
\hline \multirow[b]{2}{*}{ Fuels } & \multicolumn{2}{|c|}{ Otto Cycle } & & & \multicolumn{2}{|c|}{ Gas Turb1ne } & \\
\hline & $\begin{array}{l}\text { Norma 1 } \\
\text { Spark }\end{array}$ & $\begin{array}{c}\text { Stratified } \\
\text { Charge } \\
\end{array}$ & $\frac{D 1}{\text { Marine }}$ & sel & $\begin{array}{l}\text { Station- } \\
\text { ary (1) }\end{array}$ & Alrcraft & Stirling & $\begin{array}{l}\text { Free } \\
\text { Piston }\end{array}$ & Steam \\
\hline $\begin{array}{l}\text { Petroleum } \\
\text { - Broadcut }\end{array}$ & $\mathrm{x}$ & & & & & & & & \\
\hline $\begin{array}{l}\text { Coal } \\
\text { Coa1/o11 slurry } \\
\text { Coal/Methanol siurry }\end{array}$ & $\begin{array}{l}\mathbf{x} \\
\dot{x} \\
\mathbf{x}\end{array}$ & $\begin{array}{l}\mathbf{X} \\
\mathbf{X} \\
\mathbf{X}\end{array}$ & $\mathrm{x}$ & $\begin{array}{l}x \\
x \\
x\end{array}$ & & $\begin{array}{l}x \\
X \\
X\end{array}$ & & $\mathrm{x}$ & \\
\hline $\begin{array}{l}\text { Coal Liquids } \\
\text { - Gasoline } \\
\text { - Diesel/Jet Fuel } \\
\text { - Fuel oll }\end{array}$ & $\begin{array}{l}\mathbf{x} \\
\mathbf{X}\end{array}$ & $\mathbf{x}$ & $\mathrm{x}$ & $\mathrm{x}$ & & $\begin{array}{l}x \\
x\end{array}$ & - & - & \\
\hline $\begin{array}{l}\text { Shale ofl LAquids } \\
\text { - Gasoline } \\
\text { - Dlesel/Jet } \\
\text { - Fuel ofl } \\
\text { Methanol } \\
\text { Ethanol/H1gher Alcohols }\end{array}$ & $\mathbf{x}$ & $\therefore$ & & . & & $\begin{array}{l}x \\
x\end{array}$ & & & \\
\hline $\begin{array}{l}\text { Methane } \\
\text { Hydrogen }\end{array}$ & 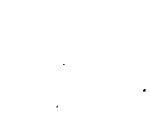 & & & & & & & & \\
\hline $\begin{array}{l}\text { Ammonia } \\
\text { Hydrazine } \\
\text { Methylanine }\end{array}$ & $\frac{x}{x}$ & $\begin{array}{l}x \\
x\end{array}$ & $\begin{array}{l}\mathbf{x} \\
\mathbf{x}\end{array}$ & $\begin{array}{l}x \\
x\end{array}$ & & $\begin{array}{l}\mathbf{x} \\
\mathbf{x}\end{array}$ & & & \\
\hline $\begin{array}{l}\text { Acetylene } \\
\text { o11 - Organic Waste }\end{array}$ & $\begin{array}{l}x \\
x\end{array}$ & $\mathbf{x}$ & $\mathrm{x}$ & $\mathbf{x}$ & & $\mathrm{x}$ & & & \\
\hline
\end{tabular}

$X$ - Indicated fuel/englne combinations that are Incompatible.

(1) For some fuels, clean-up would be ahead of the gas turbine; or In the case of coal, a FBC unit would be used. 


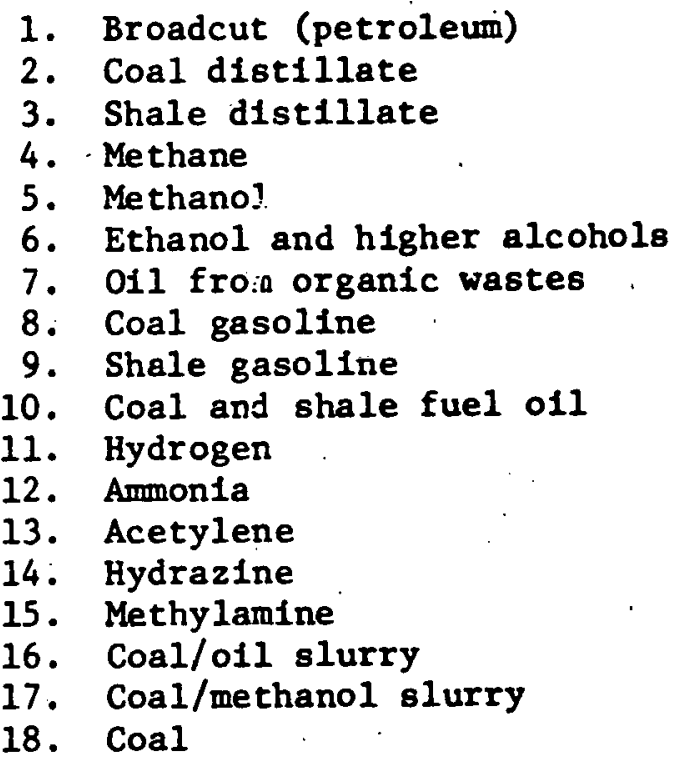

It is also possible to sum the ratings for the various types of prime movers and obtaln a semi-quantitative comparison of which types of prime movers have the greatest degree of flexibility for using different types of fuels. Based on the totals of the columns and the rows in Table 13-3, the following is a $118 t$ of the prime movers in descending order of fuel flexibility:

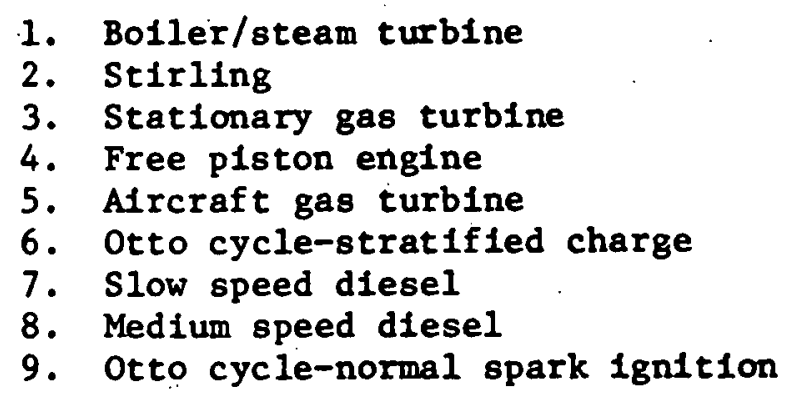

There is a large gap between. the ratings on the first three prime movers Iisted and the other $81 x$. Thus, the first three show the greatest potential for burning practically any type of fuel and are the likely candidates for fuel substitution. These are also the types of prime movers to be considered in the future since they offer greater flexibility to use poorer quality fuels.

\subsection{Fuel Loglstics Ratings}

The ratings in Table 13-5 are based on the criteria and fudgments reported in Table 12-4. The rating scale runs from -2 to +2 with the following implications:

$$
\begin{aligned}
& -2 \text { - Considerable difficulty (problem, . lower avallability) relative } \\
& \text { to current situation }
\end{aligned}
$$




\section{FUEL LOGISTICS RATINGS}

\section{Fue1}

Coal
Coal-1n-011 Slurry
Coa1-1n-Methanol Slurry
Coal Liquids (Upgraded)
Shale 011 (Raw)
Shale L1quids (Upgraded)
Methanol from Coa1
Methanol from Biomass
Hydrogen from Coa1
Hydrogen by Electrolys1s
Methane from Coal
Ammonia from Coal
Ammonia from B1omass
Hydraz1ne
Methylamine
Acetylene
Ethanol from Corn
Ethanol from Sugarcane
O11 from Organic Waste
Electric1ty from Coal
Electric1ty from Nuclear Energy
Electric1ty from Solar Energy

Fue1 Ava1lab1lity by 1990

$+2$

0

$-1$

$-1$

0

0

$-1$

$-2$

-1
-2

$-1$

$-1$

$-2$

$-2$

$-2$

$-2$

$-1$

$-1$

$-2$

0

$-2$
Compatibility with Present Fuels System

$-2$

$-1$

$-1$

$-2$

$-1$

$-1$

$-1$

-1
0

$-1$

$-1$

$-1$

$-1$

-2
-2

$-1 \quad-1$

$\begin{array}{ll}-1 & -1 \\ -2 & -2\end{array}$

$-2 \quad-2$

$-2 \quad-2$

$-2$

$-2$

$-2$

$-2$

$-1$

$-1$

0

$\begin{array}{ll}0 & 0 \\ -2 & -2 \\ -2 & -2 \\ -2 & -2\end{array}$

International

Considerations

Overall

Rating

$-0.5$

$-0.5$

$-1.0$

$-0.3$

$-0.8$

0

$-0.8$

$-1.0$

$-1.3$

$-1.5$

$-0.8$

$-1.8$

$-2$

$-2$

$-2$

$-2$

$-0.5$

$-0.5$

$-0.5$

$-1.0$

$-1.0$

$-1.8$ 
-1 -- Some difficulty (problem: lower availability) relative to current situation

0 -- Similar to present situation or unknown

+1 -- More favor:ble than current situation

+2 - Considerably more favorable than current situation

It is recognized that the logistical ratings are inherently biased against new or different types of fuels. This is realistic because of the difficulty of introducing changes into the existing logistical system (which functions smoothly). The purpose of the ratings is not to make this obvious point but rather to indicate the relative differences among the various alternative fuels.

The year 1990 has been chosen for comparison of avallability of the alternative fuels. This choice was made because: (a) an earlier date, say 1980, would eliminate many of the fuels on the basis of non-availability; (b) a substantially later date, say 2000 , would produce a hypothetical availability of most of the fuels but this "availability" would be extremely speculative, and (c) if the fuel possibilities,are to become reallties, they must pass through a transitional stage of limited avallability; 1990 appears suitable for assessment of this transitional quality because it is sufficiently far in the future to permit transitions to be underway but not so far in the future that any transition would be hypothetically possible.

The compatibility ratings are based directly on Table $12-4$, by simple conversion of "yes" into a zero rating, "some problems" into a -1 rating, and "no" into a -2 rating.

Most of the "generally unfavorable" or "probably unfavorable" ratings in the "International Considerations" column of Table 12-4 have been given a -2 rating in Table 13-5. Somewhat arbitrary exceptions have been made for coal-in-methanol slurry and raw shale oll for which the ratings are -1 . The intent here is not to penalize the possible marine applications of these fuels unnecessarily.

Alcohols other than methanol and ethanol, 1.e., "higher" alcohols, are excluded from Table 13-5 because their avallability in 1990 is considered to be insignificant.

The overall ratings in the final column of Table 13-5 are the sum of the ratings in the preceding columns divided by four. The overall ratings do not have any absolute significance; rather they are intended for screening purposes. For example, fuels with overall ratings more favorable than -1 are "screened in" from the standpoint of logistics, thereby meriting more detailed examination in other respects. Fuels with overall logistical ratings ranging from -1 to -1.5 would be difficult to introduce commercially unless their logistical disadvantages were compensated by significant advantages in other respects. Finally, it is almost inconcelvable that other advantages could offset the logistical disadvantages of the fuels with overall ratings below -1.5 ; effectively, such fuels are "screened out." 


\subsection{Overall Fuel Ratings}

To arrive at an overall ranking of the various fuels, the ratings from Table 13-1 on the manufacturing criterla, the ratings from Table 13-2 on performance, and the ratings from Table 13-5 on the logistics ratings were combined as shown in Table 13-6. For the preliminary screening, equal welght has been given to the three categories and the sum of the three Individual overail ratings 18 used to arrive at the ranking shown in Table $13-7$.

While the absolute numbers have no meaning, they do indicate that the fuels tend to fall into four groups. The first nine fuels listed are the prime candidates with ratings of 1 to -1 . The second group with ratings between -1.1 and -2 are probably of interest. The next five fuels have ratings in the -2.1 to -3.1 range and are borderline from the standpoint of attractiveness. There may be special reasons why these would look attractive. For example, electricity has a spectal application in railroads and pipelines, but no application in marine or alrcraft. In fact, it could be questioned if electricity should even be included in this comparison. The last group of five fuels, with ratings in the -4 range, are clearly not atractive and should be dropped from further consideration.

There are a couple of possible surprises in where the various fuels are ranked. These surprises are: (1) liquid methane ranked fairly high and will require more in-depth analysis; and (2) oil from organic waste also ranked fairly high, however potential availability may be limited. 


\section{TABLE 13-6}

CRITERIA IN FUEL SELECTION FOR NON-HIGHWAY TRANSPORTATION FUELS

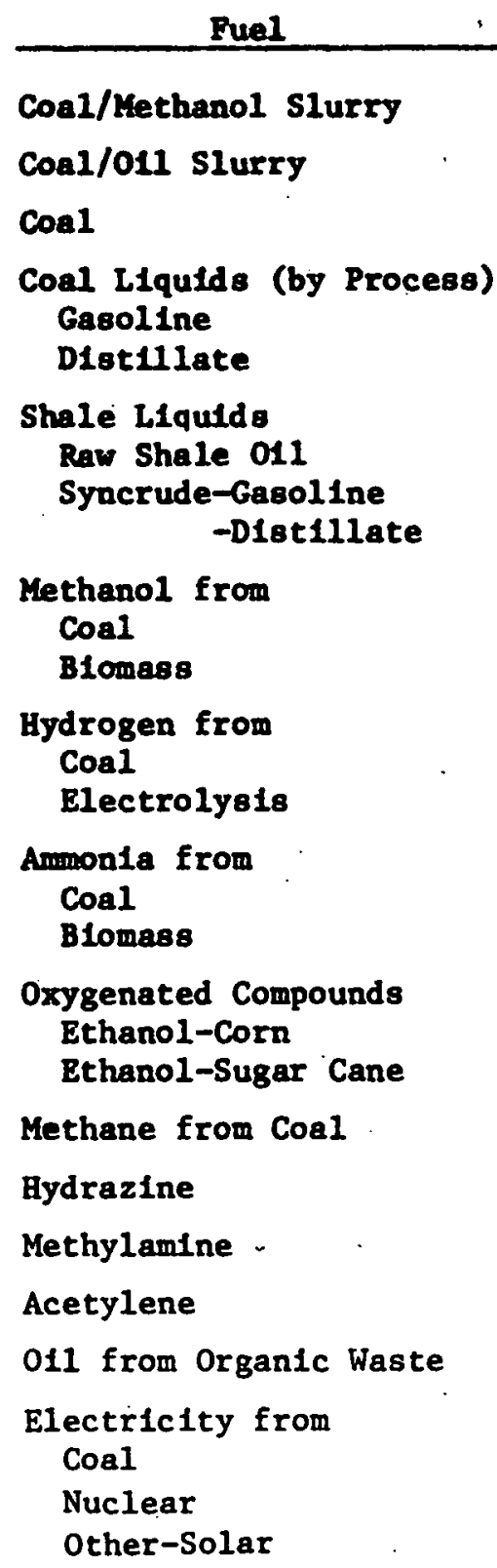

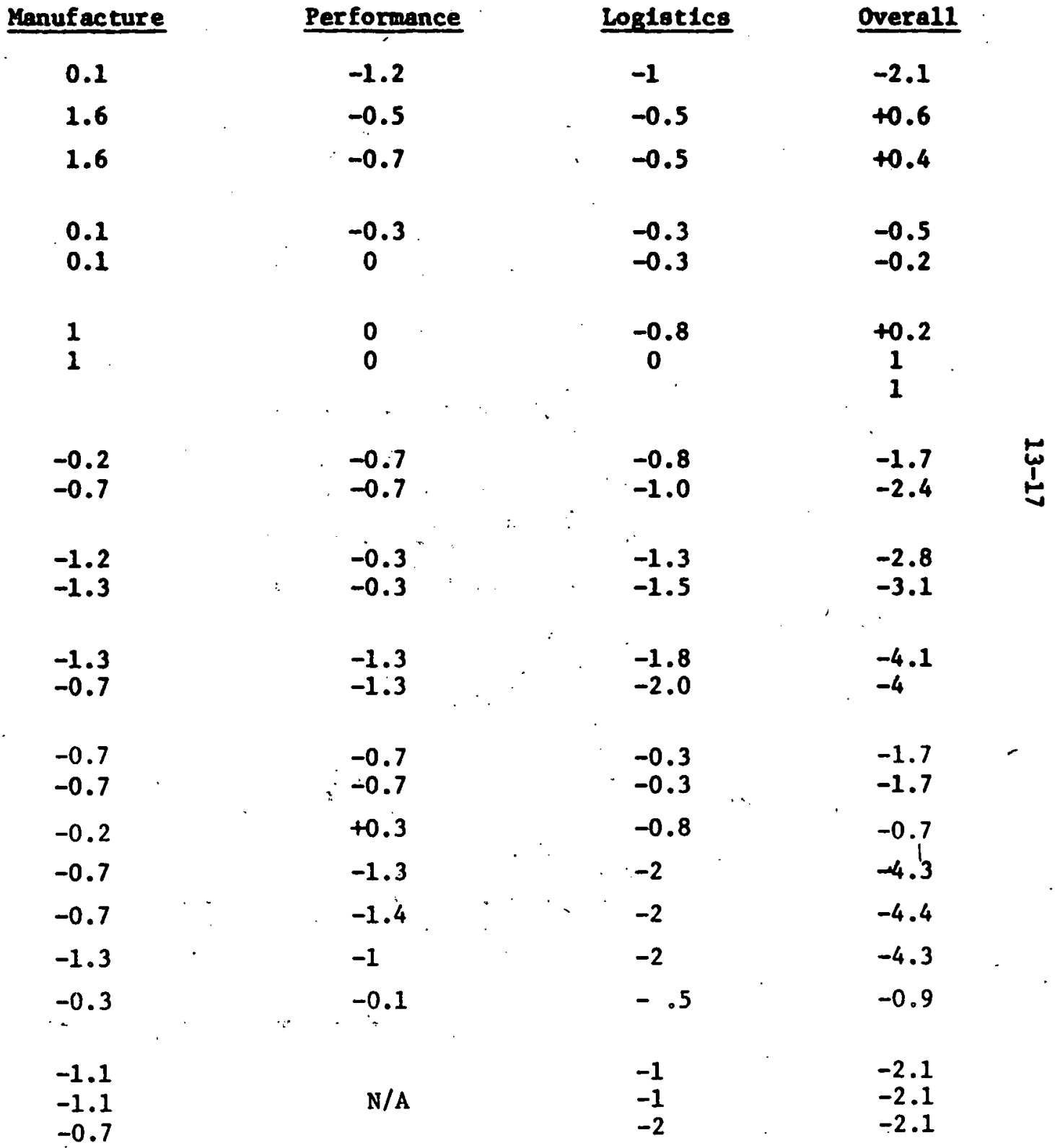


TABLE 13-7

OVERALL FUEL RANK.INGS FOR NON-HIGHWAY TRANSPORTATION

Fuels

Shale Liquids--Gasoline

Distillate

Coal/011 Slurry

Coal

Raw Shale 011

Coal Llquids--Distillate

Gasoline

Methane ( $l$ )

011--From Organic Waste

Ethano1--Corn

Sugar Cane

Methano1--Coal

Coal/Methanol slurry

Electrlcity--Coal/Nuclear

Methanol--B1omass

Hydrogen--Coal

Hydrogen--Electrolys is

1

$+0.6$

$+0.4$

$+0.2$

$-0.2$

$-0.5$

$-0.7$

$-0.9$

$-1.7$

Ammonia--Biomass

Coal

Hydrazine

Methylamine

Acetylene
$-1.7$

$-1.7$

$-2.1$

$-2.1$

$-2.4$

$-2.8$

$-3.1$

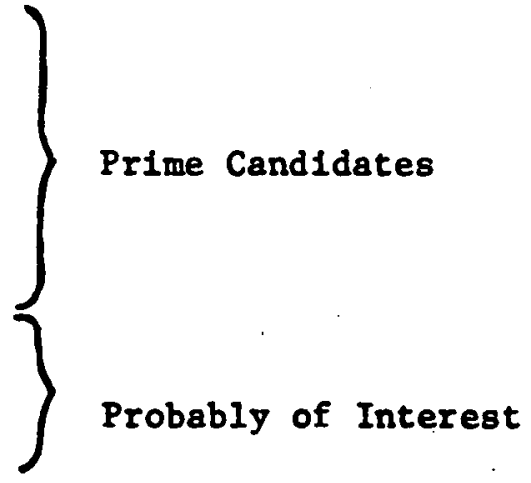

Borderline-May be

Spectal Reasons

Why These Would

Look Attractive

$-4$

4.1

$-4.3$

$-4.4$

$-4.4$ 
E. N. Cart, Jr.

One of the major objectives of the preliminary screening was to narrow cown the list of alternate fuels and prime movers for more detailed evaluation. This section covers the procedure used to select the fuels of potential interest for the various prime movers and to then recommend the fuels/pr:ime movers that will be considered for an in-depth review for each mode of transportation.

\subsection{Selection of Fuels for Each Type of Prime Mover}

The same procedure outlined in Section 13 was used to rank the fuels that would be of potential interest for each type of prime mover considered for non-highway transportation. Table 14-1 illustrates the methodology used. The overall ratings from Tables 13-1, 13-2, and 13-5 were the source of the ratings shown for manufacture, performance and logistics, respectively. The engine/fuel compatibility rating is from Table 13-3. Any engine/fuel rating of -3 means that this fuel would not be considered further for this type of engine since it would be impractical to modify this particular type of engine to use this particular fuel. The overall rating is simply the sum of the four individual ratings. Simllar tables were prepared for the other eight types of prime movers.

The ranking of the potential fuels for each of the nine prime movers is given in Tables 14-2 through 14-10. The numerical rating is included to give a rough indication of how close the ranking was or how far apart some of the fuels were. For example, in Table 14-2 the first four fuels are essentially equal in their ratings, while the last three fuels are rated considerably lower than the first group. Fuels with ratings greater than -4 are not included.

\subsection{Final Selection of Fuels and Prime Movers for Each Mode of Non-Highway Transportation}

The various prime movers of interest for each mode of nonhighway transportation are shown in Table 14-11. In the case of pipeline, rail, and marine, the number of prime movers is greater than can be included in an in-depth study. Therefore, the prime movers that will be considered for further study and the fuels that will be considered are outlined in the following sections.

\section{2 .1 Marine}

The fuels and prime movers recommended for further study in Task 3 for marine applications are shown in Table 14-12. The numbers shown indicate the relative ranking of the fuels for each type of prime mover. This is a preliminary ranking and may change in the detailed evaluation. 
TABLE 14-1

CRITERIA IN FUEL SELECTION FOR NON-HIGHWAY TRANSPORTATION FUELS

Medium Speed Diesel (Ra1lroad)

Fue1

Coal/Methanol Slurry

Coa1/011 slurry

Coal

Coal Llquids (by Process)

- Gasoline

- Dist1llate

Shale Liquids

- Raw Shale 011

- Syncrude

Methanol from

- Coal

- B1omass

Hydrogen from

- Coal

- Electrolysis

Ammonia from

- Coal

- B1omas8

Oxygenated Compounds

- Ethano1--Corn

- Ethanol--Sugar Cane

Methane from

- Coal

\begin{tabular}{|c|c|c|c|c|c|}
\hline Manufacture & Performance & Logistics & $\begin{array}{l}\text { Engine/Fuel } \\
\text { Compat1b111ty }\end{array}$ & & Overall \\
\hline 0.1 & -1.2 & -1 & $-3 *$ & & -5.1 \\
\hline 1.6 & -0.5 & -0.5 & $-3 *$ & & -2.4 \\
\hline 1.6 & -0.7 & -0.5 & $-3 *$ & ? & -2.6 \\
\hline $\begin{array}{l}0.1 \\
0.1\end{array}$ & $\begin{array}{c}-0.3 \\
0\end{array}$ & $\begin{array}{l}-0.3 \\
-0.3\end{array}$ & $\begin{array}{c}-3 \star \\
0\end{array}$ & & $\begin{array}{l}-3.5 \\
-0.2\end{array}$ \\
\hline $\begin{array}{l}1 \\
1\end{array}$ & $\begin{array}{l}0 \\
0\end{array}$ & $\begin{array}{c}-0.8 \\
0\end{array}$ & $\begin{array}{l}-1 \\
-1\end{array}$ & & $\begin{array}{c}-0.8 \\
0\end{array}$ \\
\hline $\begin{array}{l}-0.2 \\
-0.7\end{array}$ & $\begin{array}{l}-0.7 \\
-0.7\end{array}$ & $\begin{array}{l}-0.8 \\
-1.0\end{array}$ & $\begin{array}{l}-2 \\
-2\end{array}$ & & $\begin{array}{l}-3.7 \\
-4.4\end{array}$ \\
\hline $\begin{array}{l}-1.2 \\
-1.3\end{array}$ & $\begin{array}{l}-0.3 \\
-0.3\end{array}$ & $\begin{array}{l}-1.3 \\
-1.5\end{array}$ & $\begin{array}{l}-2 \\
-2\end{array}$ & & $\begin{array}{l}-4.6 \\
-5.1\end{array}$ \\
\hline $\begin{array}{l}-1.3 \\
-0.7\end{array}$ & $\begin{array}{l}-1.3 \\
-1.3\end{array}$ & $\begin{array}{l}-1.8 \\
-2.0\end{array}$ & $\begin{array}{l}-2 \\
-2\end{array}$ & & $\begin{array}{l}-6.4 \\
-6\end{array}$ \\
\hline $\begin{array}{l}-0.7 \\
-0.7\end{array}$ & $\begin{array}{l}-0.7 \\
-0.7\end{array}$ & $\begin{array}{l}-0.3 \\
-0.3\end{array}$ & $\begin{array}{l}-2 \\
-2\end{array}$ & & $\begin{array}{l}-3.7 \\
-3.7\end{array}$ \\
\hline-0.2 & +0.3 & -0.8 & -2 & & -2.7 \\
\hline
\end{tabular}


TABLE 14-1 (Continued)

\begin{tabular}{|c|c|c|c|c|c|}
\hline Fue1 & Manufacture & Performance & Log1st1c8 & $\begin{array}{c}\text { Engine/Fuel } \\
\text { Compatibllity }\end{array}$ & Overal1 \\
\hline Hydrazine & -0.7 & -1.3 & -2 & $-3 *$ & -6.7 \\
\hline Methylamine & -0.7 & -1.4 & -2 & $-3 *$ & -7.1 \\
\hline Acetylene & -1.3 & -1 & -2 & $-3 *$ & -7.3 \\
\hline 011 from Organic Waste & -0.3 & -0.1 & -0.5 & 0 & -0.9 \\
\hline
\end{tabular}

*This fuel not constdered for this engine since 1t would be Impractical to modify existing engines to use this fuel. 
TABLE 14-2

RANKING OF POTENTIAL FUELS FOR

MEDIUM SPEED DIESEL ENGINES (RAILROADS)

$\begin{array}{lc}\text { Shale Dist1llate } & 0 \\ \text { Coal Distillate } & -0.2 \\ \text { Raw Shale 011 } & -0.8 \\ \text { O11 from Organlc Waste } & -0.9 \\ \text { Methane (L)--Coal } & -2.7 \\ \text { Ethanol--Corn } & -3.7 \\ \text { Methanol--Coal } & -3.7 \\ \end{array}$


TABLE 14-3

RANKING OF POTENTIAL FUELS FOR

LOW SPEED DIESEL ENGINES (MARINE USE)

Shale Distillate

Raw Shale 011

Coal Distillate

O11 from Organic Waste

Coa1/011 Slurry

Methane (LIquid)

Ethanol--Corn

-Sugar Cane

Methano1--Coal

\section{1}

$+0.2$

$-0.2$

$-0.9$

$-1.4$

$-3.3$

$-3.7$

$-3.7$

$-3.7$ 
TABLE 14-4

RANKING OF POTENTIAL FUELS FOR

STATIONARY GAS TURBINE ENGINES

$\begin{array}{lc}\text { Shale-Distillate } & 1 \\ \text {--Raw Shale 011 } & +0.2 \\ \text { Coal Distillate } & -0.2 \\ \text { Shale Gasoline } & -0.2 \\ \text { Coal--Gasoline } & -0.5 \\ \text { Methane (Liquid)--Coal } & -0.7 \text { * } \\ \text { O1l from Organic Waste } & -0.9 \\ \text { Ethanol-Corn } & -1.7 \\ \text {--Sugar Cane } & -1.7 \\ \text { Coal/O11 Slurry } & -1.4 \\ \text { Coal } & -1.6 \\ \text { Methanol--Coal } & -1.7 \\ \text { Hydrogen (l)--Coal } & -2.4 \\ \text { (l)--Electrolysis } & -1.8 \\ \end{array}$

*Rating would be higher for gaseous methane. 
TABLE $14-5$

RANKING OF POTENTIAL FUELS FOR

AIRCRAFT GAS TURBINES

$\begin{array}{lc}\text { Shale Dist1llate } & 1 \\ \text { Coal Dist1llate } & -0.2 \\ \text { Methane (LIquid) } & -0.7 \\ 011 \text { from Organlc Waste } & -0.9 \\ \text { Ethanol } & -1.7 \\ \text { Methanol } & -1.7 / 2.4 \\ \text { Hydrogen (Liquid) } & -2.8 /-3.1 \\ & \text { (Not ranked but Included } \\ \text { Broadcut Petroleum further consideration) }\end{array}$


TABLE 14-6

RANKING OF POTENTIAL FUELS FOR OTTO CYCLE-NORMAL SPARK IGNITION

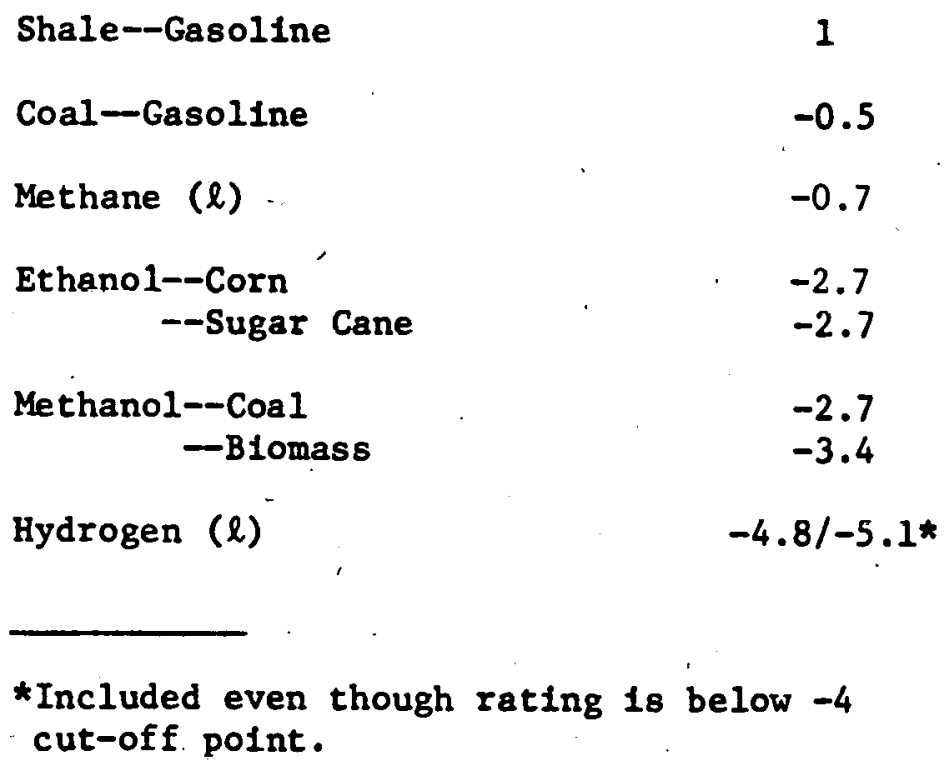


TABLE 14-7

RANKING OF POTENTIAL FUELS FOR

OTTO CYCLE-STRATIFIED CHARGE

$\begin{array}{lc}\text { Shale--Gasoline } & 0 \\ \text { Coal Gasoline } & 0 \\ \text { Raw Shale 011 } & -0.5 \\ \text { Methane (Liquid) } & -0.8 \\ \text { O1l from Organic Waste } & -0.7 \\ \text { Coal--Dist1llate } & -0.9 \\ \text { Ethanol } & -1.2 \\ \text { Methanol } & -1.7\end{array}$


TABLE 14-8

RANKING OF POTENTIAL FUELS

FOR STIRLING ENGINES

$\begin{array}{lc}\text { Shale Liqulds } & 1 \\ \text { Raw Shale 011 } & +0.2 \\ \text { Coal--D1st1llate } & -0.5 \\ \quad \text {-Gasoline } & -0.2 \\ \text { Methane (l) } & -0.7 \\ \text { O1l from Organic Waste } & -0.9 \\ \text { Coal/O11 Slurry } & -1.4 \\ \text { Coal } & -1.6 \\ \text { Methanol--Coal } & -1.7 \\ \text { Ethanol--Sugar Cane/Corn } & -1.7 \\ \text { Coal/Methanol Slurry } & -2.1 \\ \text { Methanol--Blomass } & -2.4 \\ \text { Hydrogen (l)-Coal } & -2.8 \\ & -3.1\end{array}$


TABLE 14-9

RANKING OF POTENTIAL FUELS

FOR FREE PISTON ENGINES

$\begin{array}{lc}\text { Shale--Llquids } & 1 \\ \text { Raw Shale 011 } & +0.2 \\ \text { Coal--Dist1llate } & -0.2 \\ \text {--Gasoline } & -0.5 \\ 011 \text { from Organlc Waste } & -0.9 \\ \text { Coal/011 Slurry } & -1.4 \\ \text { Methane (Liquid) } & -2.7 \\ \text { Ethanol-Corn } & -3.7 \\ \text {--Sugar Cane } & -3.7 \\ \text { Methanol--Coal } & -3.7\end{array}$


TABLE $14-10$

RANKING OF POTENTIAL FUELS

FOR STEAM BOILER/TURBINE PRIME MOVERS

$\begin{array}{lc}\text { Shale LIquids } & 1 \\ \text { Coal/O1l Slurry } & +0.6 \\ \text { Coal } & +0.4 \\ \text { Raw Shale 01I } & +0.2 \\ \text { Coal L1quids } & -0.2 /-0.5 \\ \text { Methane (l) } & -0.7 \\ \text { O1l from Organic Waste } & -0.9 \\ \text { Ethanol--Corn } & -1.7 \\ \quad-\text { Sugar Cane } & -1.7 \\ \text { Methanol--Coal } & -1.7 \\ \text { Coal/Methanol Slurry } & -2.1 \\ \text { Methanol--Blomass } & -2.4 \\ \text { Hydrogen--Coal } & -2.8 \\ & -3.1\end{array}$


TABLE $14-11$

PRIME MOVERS OF INTEREST FOR NON-HIGHWAY TRANSPORTATION

Type of Prtme Mover

DLesel Engine

Gas Turbine

- Turboprop

- Advanced Turbofan

- Supersonic Propulsion

Electric Motor

Internal Comb.

Engine (SI)

Fuel Cell

StIrling Engine

Steam Engine

Stratifled Charge

Free Piston
Mode of Transportation

\begin{tabular}{|c|c|c|c|}
\hline P1peline & Ra11 & Marlne & Arrcraft \\
\hline $\mathrm{X}$ & $Q$ & (X) & \\
\hline$\otimes$ & $\mathrm{x}$ & $\mathbf{x}$ & $\otimes$ \\
\hline${ }^{\circ}$ & & & $\begin{array}{l}\mathbf{X} \\
\mathbf{X} \\
\mathbf{X}\end{array}$ \\
\hline (X) & $x$ & & \\
\hline (X) & & $x$ & $x$ \\
\hline$\ddot{x}$ & $\mathrm{x}$ & $\mathbf{X}$ & \\
\hline & $x$ & $\mathrm{x}$ & \\
\hline$x$ & $\mathrm{x}$ & (X) & \\
\hline$x$ & $x$ & $\mathrm{x}$ & \\
\hline & $x$ & $x$ & \\
\hline
\end{tabular}

O Major Prime Mover in use Currently 
TABLE 14-12

FUELS/PRTME MOVERS SELECTED FOR IN-DEPTH STUDY FOR

\section{MARINE}

\begin{tabular}{|c|c|c|c|c|c|c|}
\hline Eue1 & Diesel & $\begin{array}{l}\text { Steam } \\
\text { Englne }\end{array}$ & $\begin{array}{c}\text { Free } \\
\text { P1ston } \\
\end{array}$ & $\begin{array}{c}\text { Gas } \\
\text { Turbine }\end{array}$ & Stirling & $\begin{array}{l}\text { Fue1 } \\
\text { Ce11 } \\
\end{array}$ \\
\hline Shale Llquids & 1 & 1 & 1 & 1 & 1 & * \\
\hline Raw Shale 011 & 2 & 4 & 2 & 2 & 2 & \\
\hline Coal Liquids & 3 & 5 & 3 & 3 & 3 & * \\
\hline 011 from Organic Waste & 4 & & 4 & 5 & 5 & \\
\hline Coal/011 Slurxy & 5 & 2 & 5 & 6 & 6 & \\
\hline Methane (l) & 6 & 6 & 6 & 4 & 4 & \\
\hline Coa1 & & 3 & & & & \\
\hline
\end{tabular}

*LIght dist1llate 
Actually, ethanol was one of the fuels that rated In the top 8 ix fuels for gas turbine and Stirling engines. However, the potential problems of handing ethanol in a marine environment, from the water miscibility and corrosion standpoint, ruled this fuel out. Fuel cells will also be considered, using a 11ght distillate from coal and/or shale as fuel to the oteam reformer.

\subsubsection{Railroads}

The fuels and prime movers recommended for further study for the railroad applications are shown in Table 14-13. Three different types of prime movers will be considered, as well as a fuel cell. An in-depth study of electrification of the railroads. Is beyond the scope of this study.

\subsubsection{P1peline}

The fuels and prime movers recomended for further study for the pipeline application are shown in Table 14-14. Four different types of prime movers will be considered in addition to electric motors and fuel cells.

\section{2 .4 Alrcraft}

The fuels and prime movers recommended for further study for the alrcraft mode of transportation are shown in Table 14-15. In this case, only the aircraft gas turbine, as a general class, will be considered. The otto-normal spark ignition type prime mover used for general availation will not be included in the in-depth study. The potential volume of fuel required is very small and does not warrant a great deal of study. The potential fuels of interest in this type of engine are shown in Table 14-15.

A broadcut petroleum fuel has been added to the list of fuels, even though it is not an alternate fuel as defined for this otudy. It has been included to 1llustrate what a change in the specification could do to Increase the volume of potential jet fuel in times of an emergency. Also, It will give an Indication of what a broadcut fuel may look like if produced from coal or shale oil. 
TABLE 14-13

FUELS/PRIME MOVERS SELECTED FOR IN-DEPTH STUDY FOR

\section{RAILROADS}

\begin{tabular}{|c|c|c|c|c|c|c|}
\hline Fue1/Energy Carrier & D1ese1 & $\begin{array}{l}\text { Steam } \\
\text { Englne }\end{array}$ & $\begin{array}{l}\text { Selrling } \\
\text { Engine }\end{array}$ & $\begin{array}{c}\text { Gas } \\
\text { Turbine }\end{array}$ & Electric (1) & Fuel Cell \\
\hline Shale D1st1llate & 1 & 1 & 1 & 1 & ${ }^{\prime}$ & * \\
\hline Coal D1st11late & 2 & 5 & 3 & 3 & & * \\
\hline Raw Shale 011 & 3 & 4 & 2 & 2 & & \\
\hline O11 from Organic Waste & 4 & · & 5 & 5 & & \\
\hline Methane & 5 & 6 & 4 & 4 & & $\therefore$ \\
\hline Ethano1 & -6 & & 6 & 6 & & \\
\hline Coal/011 slurry & & 2 & & & & \\
\hline Coal & & 3 & & & & \\
\hline
\end{tabular}

(1) Beyond scope of this atudy to make an in-depth comparison of rail electrification with other modes.

*Lght distillate as feed to a steam reformer. 
TABLE 14-14

FUELS/PRIME MOVERS SELECTED FOR IN-DEPTH STUDY FOR

\section{PIPELINE}

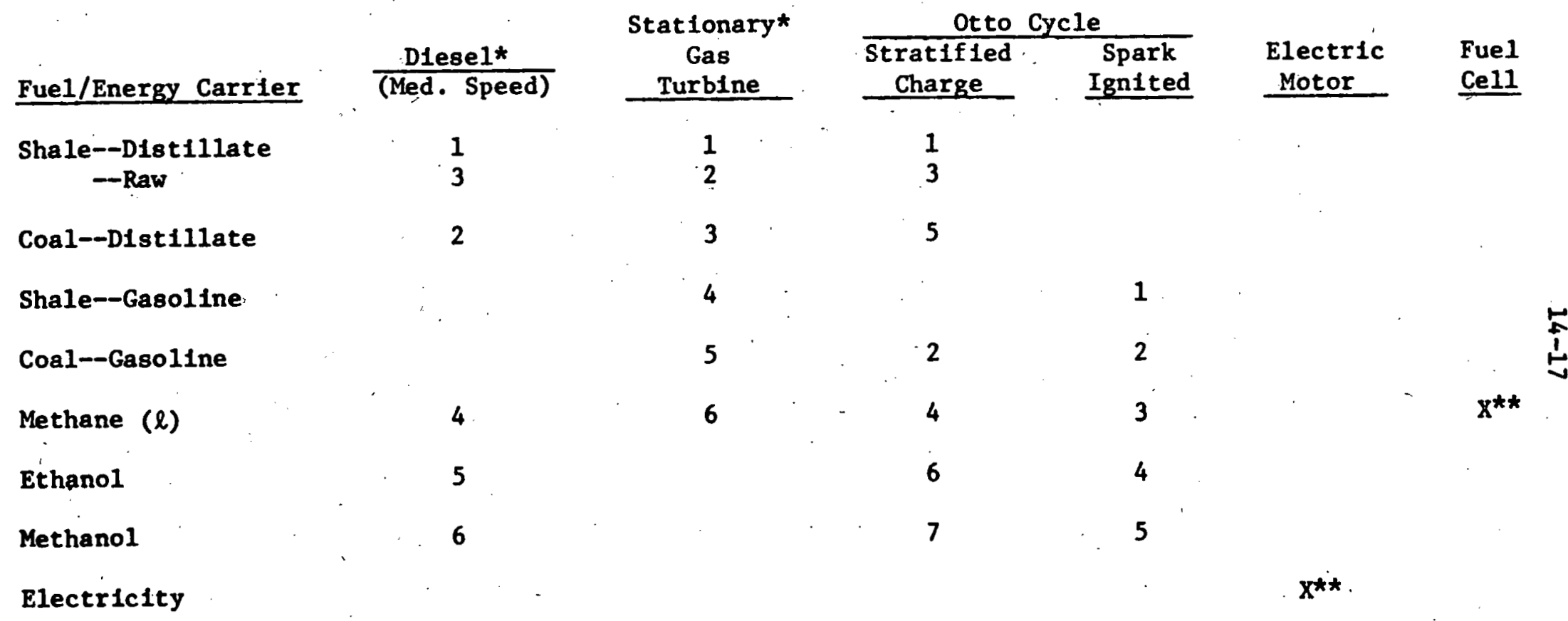

*W111 include combined cycle consideration. **W11l be included in study. 
TABLE 14-15

FUELS/PRIME MOVERS SELECTED FOR IN-DEPTH STUDY FOR

AIRCRAFT

Fue1

Gas Turbine

otto Normal

$\frac{\text { Fuel }}{\text { Shale D18t11late }}$

\section{1}

Coal Dist1llate

2

Methane (l)

3

Hydrogen ( $(\ell)$

4

Spark Ignition(1)

Broadcut Petroleum

Not Rated

(1) W111 not be covered 1n-depth 1n Task 3. Possible fuels of Interest are gasoline (from shale or coal), ethanol, methanol, and methane $(l)$. 


\begin{tabular}{|c|c|}
\hline \begin{tabular}{|l|l|} 
BIBLIOGRAPHIC DATA & I: REDON NOO. \\
SHEET & \\
\end{tabular} & 3. Recipient's Accession No. \\
\hline \multirow{2}{*}{$\begin{array}{l}\text { 4. Tule and Subtiste } \\
\text { Alternative Energy Sources for Non-Highway Transportation } \\
\text { - Volume III C -- Appendices }\end{array}$} & 5. Regon Dare 1979 \\
\hline & 6. \\
\hline $\begin{array}{l}\text { 7. Auhor(s) E. N. Cart, Jr., E. M. Magee, B. Kraus, W. Herbst, } \\
\text { J. Percival, M. H. Farmer }\end{array}$ & $\begin{array}{l}\text { 8. Performing Organizsion Repre } \\
\text { No. ExXOn/GRU.5T.79 } \\
\end{array}$ \\
\hline 9. Performing Orgenizacion Name and Address & 10. Project/Task/trotk Unit No. \\
\hline $\begin{array}{l}\text { Government Research Laboratories } \\
\text { Exxon Research and Engineering Company } \\
\text { p. B. Box } 8 \\
\text { Linden, New Jersey } 07036\end{array}$ & $\begin{array}{l}\text { 11. Contrace/Grans No. } \\
\text { DE-AC05-77,CSO5438 }\end{array}$ \\
\hline \multirow{2}{*}{$\begin{array}{l}12 \text { Sponsorinz Oresairasion Nees and Adtrece } \\
\text { Non-Highway Systems Branch } \\
\text { Transportation - Energy Conservation Division } \\
\text { Office of Conservation and Solar Applications } \\
\text { Department of Energy, Washington, D.C. }\end{array}$} & $\begin{array}{l}17 \text { Tyoe of Repa: \&i Pesiod } \\
\text { Coveied FINAL } \\
\text { Sept. 1977-June } 1979\end{array}$ \\
\hline & 14 \\
\hline
\end{tabular}

15. Supplementary Notes

16. Abstencts

A planning study has been made for DOE on alternate fuels for non-highway transportation (aircraft, rail, marine and pipeline). The purpose of the study was to provide DOE with a recommendation of what alternate fuels may be of interest to nonhighway transportation users from now through 2025 and to recomend, R\&D needed to allow non-petroleum derived fuels to be used in non-highway transportation.

In the near term (present 1985), there is unlikely to be any major change in the fuels used in any of the four modes of transportation except that the average quality of the marine fue? is likely to get worse. In the mid-term period (1985-2000), there will be a transition to non-petroleum fuels, based primarily on shale oil derived liquids assuming a shale oil industry is started during this time.

(over)

17. Key Words and Doxument Analysis. 17a Descriptors

Alternate Fuels

Marine

Aircraft

Pipeline

Railroad

Environmantal Impact

17b. Identifiess/Open-Ended Terms
Emissions (In Use)

Energy Efficiency in Production

Resource Requirements

Energy Efficiency in Use

Logistics

Likert Scale
.

17e. COSATI Field/Group

18. Arailability Statement

APPROVED FOR PUBLIC RELEASE; DISTRIBUTION UNL II!ITED

\begin{tabular}{|l|c|}
\hline $\begin{array}{l}\text { 19. Security Class (This } \\
\text { Pepust) UNCLASSIF IED }\end{array}$ & $\begin{array}{c}\text { 21. lo. of Fuge's } \\
151\end{array}$ \\
\hline $\begin{array}{l}\text { 20. Security (Tass (This } \\
\text { Page UNCLASSIFIED }\end{array}$ & 22. Frice \\
\hline
\end{tabular}




\section{Abstracts (cont.)}

The future outlook for possible prime movers and potential fuel sources for the long term $(2000+)$ is as follows. In the marine area, steam engines burning coal or diesel engines with unrefined shale oil or coal slurries are the prime candidates. With the aircraft gas turbine, either synthetic liquids from shale or coal would appear to be the most desirable fuels. Railroads will probably remain with the diesel/ electric prime mover using shale oil as a source of distillate. Pipelines will probably use electric motors as the major type of prime mover.

This Appendix is concerned with the environmental issues in production and use of the fuels, the energy efficiency in use and production, the fuel logistics considerations, and the overall ratings and selection of the fuels and prime movers for the detailed evaluation. 


\section{ENERGY SUPPLY/DEMAND PROJECTIONS}

M. H. Farmer

The Federal Energy Administration Act of 1974 and the Energy Conservation and Production Act of 1976 require that the Energy Information Administration (EIA) (as success! $r$ to FEA) prepare forecasts of energy supply and demand and consumption in the short, medium, and long term. The most recent set of forecasts, published in Apr 111978 and titied "Projections of Energy Supply and Demand and Their Impacts," constituted EIA's annual report to Congress for 1977. The stated objective of the EIA has been to "establish a neutral analytical methodology and to provide alternative energy projections based on assumptions that do not bias the results in a particular policy direction." EIA and other recent energy projections are discussed in this section.

\subsection{EIA Projections}

The various EIA projections are based on differing assumptions with regard to:

(1) Economic growth

(2) Probable levels of recoverable U.S. 011 and gas resources

(3) Changes in the real price of imported ofl

Also, to avoid predicting the future course of Government energy policy, EIA assumed "continuation of present energy policy as expressed in existing legislation and actual practice." Thus, the individual projections or "cases" may be considered as a set of "base cases." which would be affected by changes in legislation and energy policy. Put differently, the "base cases" provide a framework within which to consider alternative fuels for NHT systems in an internally consistent way. EIA has striven to achieve internal consistency and has also made the underlying assumptions explicit. It is essential that base case projections of future supply and demand be derived from a common set of assumptions, and also that the assumptions be documented. Then, if a particular assumption is varied, the impact of the change may be traced through the whole system of projection.

The Energy Information Administration's projections, which were published in April 1978, comprised the six "Series" ilsted in Table 15-1. Series $A$ through. E are a partial permutation of three demand assumptions and three supply assumptions, where each variant is combined with the assumption of a constant world oil price. Series $F$ combines an assumption of a higher world oll price with the "medium/medium" demand/supply assumptions (Series C). It is stressed that each of the Series is based on the further assumption of "continuation of present energy policy as expressed in existing legislation and actual practice."

Energy supply/demand balances for 1985 and 1990, for Series A through F, are reproduced in Tables 15-2 and 15-3. Actual statistics for 1975 are included for comparison. Price projections for transportation fuels are given at the bottom of each table. It is stressed that, with the exception of Serles F, a constant (1978 \$) world oll price is assumed. This explains 


\section{TABLE 15-1}

EIA Projection Series

\begin{tabular}{|c|c|c|c|}
\hline $\begin{array}{l}\text { Projection } \\
\text { Series } \\
\end{array}$ & $\begin{array}{l}\text { U.S. Demand } \\
\text { Assumption }\end{array}$ & $\begin{array}{l}\text { U.S. Supply } \\
\text { Assumption }\end{array}$ & $\begin{array}{l}\text { World } 011 \text { Price } \\
\text { Assumption }\end{array}$ \\
\hline $\begin{array}{l}A \\
B\end{array}$ & $\begin{array}{l}\text { High } \\
\text { High }\end{array}$ & $\begin{array}{c}\text { High } \\
\text { Low }\end{array}$ & $\begin{array}{l}\text { Cons tant } \\
\text { Constant }\end{array}$ \\
\hline $\begin{array}{l}C \\
D\end{array}$ & $\begin{array}{l}\text { Medium } \\
\text { Low }\end{array}$ & $\begin{array}{l}\text { Medium } \\
\text { High }\end{array}$ & $\begin{array}{l}\text { Constant } \\
\text { Constant }\end{array}$ \\
\hline$\cdot \frac{E}{F}$ & $\begin{array}{l}\text { Low } \\
\text { Medium }\end{array}$ & $\begin{array}{l}\text { Low } \\
\text { Medium }\end{array}$ & $\begin{array}{l}\text { Constant } \\
\text { Increasing* }\end{array}$ \\
\hline
\end{tabular}

Series Characteristic Relative to Constraint Price Assumption

Max. Consumption Max. imports and max. relative price of energy

"Mid range" Min. imports and min. relative price of energy

Minimum Consumption Important Contingency

*Assumed to increase $5 \% / \mathrm{yr}$ after 1980 , such that the 1990 price would be about $\$ 25$ per barrel in 1978 constant dollars.

Source: "Projections of Energy Supply and Demand and Their Impacts," page 14, D0E/EIA, April 1978. 
TABLE $\quad 15-2$

1985 Energy Supply/Demand Balance (Quads/yr)

Actual

1975

Domestic Production

Crude 011 + NGL

Shale 011

Natural Gas

Coal

Nuclear Energy

Hydro + Geothermal

Domestic Subtotal

Imports: Crude 011

Pet. Products

Natural Gas

Total Supply

(Less) Exports of Coal

(Less) Refinery Loss Total Domestic Consumption
20.5

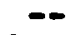

19.0

14.6

1.8

3.2

8.7

3.8

1.0

72.6

1.8

$\frac{0.2}{70.6}$

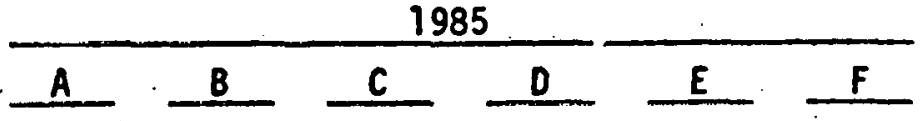

22.5

0.2

19.4

23.0

6.2

$\frac{4.2}{75.5}$

1.5 .5

6.6

$\frac{1.6}{99.2}$

19.5

0.1

16.0

21.0

22.5

19.4

0.1

21.4

0.2

19.2

$23.1 \quad 22.2$

22.2
6.2

6.2

6.2

$\frac{4.2}{69.8}$

$\frac{4.2}{71.8}$

$\frac{4.2}{74.5}$

19.3

16.5

6.9

6.7

16.0

3.2

$\frac{2.1}{98.1} \quad \frac{1.9}{96.9}$

$\frac{1.2}{94.9}$

15.6

22.8

6.2

$\frac{4.2}{68.3}$

17.5

5.7

17.0

1.9

1.9

1.9

1.9

$\frac{0.4}{96.9}$

$\frac{0.4}{95.8}$

$\frac{0.4}{94.6}$

0.4

$\frac{0.4}{92.6}$ $\frac{2.0}{93.5}$

1.9

$\frac{0.4}{91.2}$

1.9

$\frac{0.4}{93.9}$

Domestic Consumption by Sector

Industrial

Commercial

Residential

Transportation
26.0

11.3

14.7

18.6

70.8
42.0

13.8

19.3

21.8

96.9
41.5

13.5

19.0

21.8

$\frac{21.8}{95.8}$
40.7

13.5

19.0

21.4
39.9

13.4

18.9

20.4

$\frac{20.4}{92.6}$
$39.1 \quad 40.9$

$13.1 \quad 13.2$

$18.6 \quad 18.6$

$20.4 \quad 21.2$

Transportation Energy Prices* (1978 \$ per MBTU)

$\begin{array}{llllllll}\text { Gasoline } & 5.40 & 5.95 & 6.01 & 5.96 & 5.93 & 5.99 & 6.54 \\ \text { Jet Fuel } & 3.97 & 4.21 & 4.27 & 4.22 & 4.19 & 4.24 & 4.78 \\ \text { Distillate Fuel } & 4.02 & 4.80 & 4.87 & 4.82 & 4.80 & 4.84 & 5.37 \\ \text { Residual Fuel } & 2.10 & 2.98 & 3.04 & 2.99 & 3.03 & 3.03 & 3.57\end{array}$

*Prices to final consumer before excise and sales taxes.

Scurce: EIA report pages 27 and 31 (Tables 2.5 and 2.9). 
TABLE $15-3$

1990 Energy Supply/Demand Balance (Quads/yr)

Domestic Production

Crude 011 + NGL

Shale 0 il

Natural Gas

Coal

Nuclear Energy

Hydro + Geothermal

Domestic Subtotal

Imports: Crude 0il

Pet. Products

Natural Gas

Total Supply

(Less) Exports of Coal

(Less) Refinery Loss

Total Domestic Consumption
Actual

1975

20.5

19.0

14.6

1.8

$\frac{3.2}{59.1}$

8.7

3.8

$\frac{1.0}{72.6}$

1.8

$\frac{0.2}{70.6}$

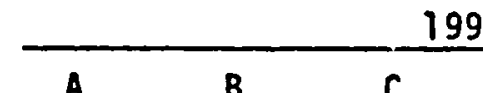

A

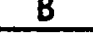

$23.5 \quad 16.0$

0.6

0.4

13.7

28.5

27.7

10.2

10.3

$\frac{5.0}{85.3}$

$\frac{5.0}{73.9}$

16.7

25.6

7.7

8.0

2.6

गा.9

T10.1

\section{1}

2.1

0.4

$\frac{0.3}{107.7}$

(1)

19.8

0.3

16.7

27.5

10.3

$\frac{5.0}{19.6}$

20.9

7.8

2.6

$\pi 0.9$

2.1

$\frac{0.3}{108.5}$

2.1

23.5

0.5

18.0

25.3

10.1

5.0

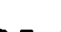

15.0

5.4

2.1

$\frac{0.4}{102.4}$

Domestic Consumption by Sector

\section{Industrial}

Commercial

Residential

Transportation
26.0

11.3

14.7

18.6
50.0

15.0

21.2

23.2
$49.1 \quad 49.0$

$14.7 \quad 15.0$

$20.9 \quad 21.2$

$\frac{23.0}{107.7} \quad \frac{23.3}{108.5}$
46.2

14.4

20.6

21.2
$45.1 \quad 48.5$

$14.2 \quad 14.3$

$20.4 \quad 20.7$

$21.0 \quad 22.7$

$2.1 \quad 2.1$

$\frac{0.3}{100.7} \frac{0.4}{106.2}$

$13.3 \quad 17: 4$

$\begin{array}{ll}26.3 & 29.4 \\ 10.1 & 10.4\end{array}$

$\begin{array}{ll}5.0 & 5.0 \\ 71.0 & 85.7\end{array}$

$21.7 \quad 15.5$

$7.8 \quad 5.0$

$2.6 \quad 2.5$

$\begin{array}{lllllll}70.6 & 109.4 & 107.7 & \frac{23}{108.5} & \frac{21.2}{102.4} & \frac{21}{100.7} & \frac{22.7}{106.2}\end{array}$

Transportation Energy Prices* (1978 \$ per MBTU)

\begin{tabular}{llllllll}
\hline Gasoline & 5.40 & 6.08 & 6.17 & 6.14 & 6.01 & 6.13 & 7.62 \\
Jet Fuel & 3.97 & 4.35 & 4.45 & 4.39 & 4.29 & 4.38 & 5.87 \\
Distillate Fuel & 4.02 & 4.94 & 5.04 & 5.00 & 4.88 & 4.98 & 6.39 \\
Residual Fuel & 2.10 & 3.11 & 3.24 & 3.16 & 3.09 & 3.17 & 4.52
\end{tabular}

ses to final consumer before excise and sales taxes.

ce: EIA report pages 28 and 32 (Tables 2.6 and 2.10 ). 
the relatively smali transportation fuel price increases in 1985 and 1990 , over actual 1975 levels. Even for Serles $F$, the projected price increases for 1985 and 1990 are not large*:

\begin{tabular}{|c|c|c|c|}
\hline & $\frac{\% 1}{985}$ & se & Over \\
\hline $\begin{array}{l}\text { gasoline } \\
\text { jet fuel } \\
\text { distillate fuel } \\
\text { residual fuel }\end{array}$ & $\begin{array}{l}21 \\
20 \\
34 \\
70\end{array}$ & $\because$ & \\
\hline
\end{tabular}

The assumption of balance between supply and demand is also an implicit assumption of no shortage on a current basis. However, the assumption of $5 \% / y r$. escalation in the constant dollar world oil price could be interpreted as a response to a perception of impending or foreseeable shortage.

The assumption of a smooth, exponential increase in the real price of a commodity is conventent for lllustrative purposes, but has almost no likel thood of occurring. An irregular, cyclical pattern is more likely, even for a non-renewable resource. For example, a sharp price increase would be expected to act as a demand constraint, at least temporarily. The consequent lower demand would be expected to bring about a surplus of supply, at least temporarlly. In thèse circumstances, further near term price increases would be unlikely and, under conditions of inflation (stimulated by the initial sharp price increase), the nominal price would probably erode on a constant dollar basis**.

Additional price information, both historical and Series $C$ projections, from the EIA report is reproduced in Table 15-4. Price erosion, on a constant dollar basis, may be noted for the 1960/72 period. In fact, the erosion began prior to 1960 and is often cited now as a factor that contributed to general lack of concern for energy conservation prior to 1973.

Comparisons of $1975 / 85$ and $1985 / 90$ projections of energy consumption and price behavior for the transportation sector and total domestic energy are given in Table 15-5. The following trends are observed:

\section{(1) energy consumption}

- projected growth rates are lower for the 1985/90 period than for $1975 / 85$

- projected growth rates are lower for the transportation sector than for total domestic energy consumption in both time periods

*By comparison with the increases that occurred in 1974.

**This is what has happened to the world price of ofl since the sharp price increases of 1973/74. It is not necessarliy a good guide to what may happen in the future. Different response patterns might be expected for (a) a production 11 mitation (Imposed by producers), and (b) a producibility ilmitation (imposed by nature, 1.e. by resource IImitations). 
TABLE 15-4

Comparison of Historical Growth Rates for Energy Prices Compared with Rates Projected for Series C

\begin{tabular}{|c|c|c|c|c|}
\hline \multirow{2}{*}{ 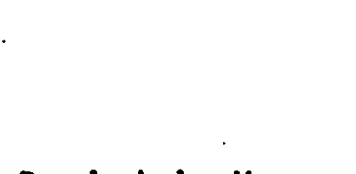 } & \multicolumn{2}{|c|}{ Annual Gr } & \multicolumn{2}{|c|}{ Constant $\$$ Basis } \\
\hline & $1960 / 72$ & $1972 / 75$ & $1975 / 85$ & $1985 / 90$ \\
\hline Period in Years & (12) & (3) & (10) & (5) \\
\hline Electricity & -2.2 & 4.7 & 2.0 & 0.6 \\
\hline Natural Gas & 0.3 & 9.2 & 5.7 & 4.1 \\
\hline $\begin{array}{l}\text { Distillate Fuel } \\
\text { Residual Fuel }\end{array}$ & $\begin{array}{l}-0.5 \\
-0.3\end{array}$ & $\begin{array}{l}14.1 \\
28.0\end{array}$ & $\begin{array}{l}2.2 \\
3.4\end{array}$ & $\begin{array}{l}0.5 \\
0.3\end{array}$ \\
\hline LPG & -1.0 & 15.2 & 3.2 & Nil \\
\hline
\end{tabular}

Source: EIA report page 90 (Table 5.1). 
TABLE $15-5$

Comparison of 1975/85 and 1985/90 Projections of Consumption and Price Behavior for Transportation Sector and Total Domestic Energy

Energy Consumption

(1) $1975 / 1985$

Transportation Sector

Total. Domestic Energy

$\begin{array}{llllll}1.6 & 1.6 & 1.4 & 0.9 & 0.9 & 1.2 \\ 2.8 & 2.7 & 2.6 & 2.3 & 2.2 & 2.4\end{array}$

(2) $1985 / 1990$

Transportation Sector

Total Domestic Energy

$\begin{array}{llllll}1.2 & 1.1 & 1.7 & 0.8 & 0.6 & 1.4 \\ 2.0 & 2.0 & 2.4 & 1.6 & 1.6 & 1.9\end{array}$

Price Change (Constant \$ Basis)

(1) $1975 / 1985$

Transportation Sector

Total Domestic Energy

$\begin{array}{rrrrrr}1.2 & 1.3 & 1.2 & 1.1 & 1.2 & 2.2 \\ 2.3 & 2.7 & 2.5 & 2.2 & 2.6 & 3.4\end{array}$

(2) $1985 / 1990$

Transportation Sector

Total Domestic Energy

$\begin{array}{lllllll}0.6 & 0.7 & 0.7 & 0.4 & 0.5 & 3.2 \\ 1.2 & 1.3 & 1.5 & 1.1 & 1.1 & 3.2\end{array}$

Source: EIA report pages 91 and 92 (Tables 5.3 and 5.5). 
(2) price change

- except for Series F, price changes are slower in the later time period

- except for Series F, price changes for the transportation sector are only about half of the corresponding changes for total domestic energy

The price change projections are questionable* on several counts:

- If petroleum resources become seriously constrained before the year 2000, it would be expected that the perception of forthcoming shortage would be stronger during the 1985/90 period than during $1975 / 85$.

- A sharpening perception of shortage is inconsistent with a declining rate of price increase.

- If the transportation sector effects were backed out of total domestic energy, the differential between the transportation sector and the other three sectors (industrial, commercial, residential) would be more marked as shown below:

\section{Annual Price Change, $\%$, for $1985 / 90$ Period}

$\begin{array}{lcccccc} & \mathrm{A} & \mathrm{B} & \mathrm{C} & \mathrm{D} & \mathrm{E} & \frac{F}{3.2} \\ \text { transportation } & 0.6 & 0.7 & 0.7 & 0.4 & 0.5 & 3.2 \\ \text { industrial } & 1.6 & 1.8 & 5.7 \star & 1.5 & 1.6 & 4.0 \\ \text { commercial } & 2.4 & 2.0 & 2.2 & 2.3 & 2.0 & 3.3 \\ \text { residential } & 2.4 & 2.2 & 2.5 & 2.3 & 2.1 & 3.4\end{array}$

- The projections of much more rapid price increases for the industrial sector than for the transportation sector have potentially negative implications for al ternate fuels, since the cost of industrial energy would be a factor in the cost of manufacturing the capital goods required for the production of al ternate fuels. The annual percentage price changes imply the following cumulative percentage changes over the 5-year period $(1985 / 90)$ :

\begin{tabular}{|c|c|c|c|c|c|c|}
\hline & \multicolumn{3}{|c|}{ Percent Change in } & \multicolumn{3}{|c|}{ Price $(1990-1985)$} \\
\hline & A & B & c & $D$ & $E$ & $\mathrm{~F}$ \\
\hline tation & 3.0 & 3.5 & 3.5 & 2.0 & $\overline{2.5}$ & 17.1 \\
\hline industrial & 8.3 & 9.3 & 31.9 & 7.7 & 8.3 & 21.7 \\
\hline
\end{tabular}

*It is recognized that the projections depend on the assumptions assoclated with EIA's "neutral analytical methodology" and do not constitute a forecast of what is expected to happen.

**This number is accurately copled from Table 5-5 of EIA's report, but seems questionable. 
The 5-year differential percentage between the transportation and industrial sectors is least for Series $F$. Thus, on a relative basis, the projections are consistent with the generally held view that higher world oil prices would improve the competitive position of alternate fuels. However, the point could be made with more conviction if the baseline transportation energy prices were increasing more rapidly than the baseline industrial energy prices.*

In addition to the reference cases (Series $A$ through $F$ ), and to the statistical projections reviewed above, EIA's study takes specific account of the impact of new and emerging technologies. Pertinent projections are reviewed in Table 15-6. The last line of this Table expresses the energy content of liquid fuels produced by the new technologies as percentages of the total energy so produced. The percentages, which range from $16-17 \%$ in 1985 to $19-24 \%$ in 1990, may be compared with the current figure of $50 \%$ of total domestic energy consumption in the form of liquid fuels. Put differently, the projected increments in liquid fuel supplies derivable from new and emerging technologies--even with "heavy government intervention" $\star \star$ -- are considerably less than required to sustain the present pattern of domestic energy usage. Hence, one inference (as drawn on page 33 of the EIA report) is that "substantial adjustments. in patterns of consumption. will take place". Such adjustments would not be limited to the transportation sector. Indeed, displacement of oil from the industrial sector $\star \star$ to transportation is a common expectation. However, shifts within the transportation sector are possible too, including shifts.within the non-highway sub-sectors. The breakdown of transportation energy use in 1976 is shown in Table 15-7.

Although EIA's own projections had a terminal year of 1990 , recent projections by others are reviewed in the report $(15-2,15-3,15-4)$. A comparison of these projections, which extend to the year 2000, is given in Table 15-8. For 11 liustrative purposes, we will assume that $20 \%$ of total domestic energy consumption is for transportation purposes in the year 2000***. In Table 15-9, this assumption leads to the inference that as much as $51 \%$ to $67 \%$ of total domestic ofl consumption could be for transportation purposes, unless fuels other than $0 i l$ were used $\star \star \star \star \star *$. Currently, transportation accounts for about $40 \%$ of U.S. oll consumption. Hence, a considerable shift in consumption patterns is implied by Table 15-9, but no obvious infeasibility is evident. A different light is cast on the matter in Table 5-10, where the assumed transportation energy consumption is related to the projected supply of domestically-produced o11. It is apparent that the postulated transportation energy needs could not be met without drastic changes in fuels used and/or very considerable imports of liquid fuels. The purpose of the final columns in Table $15-10$ is to indicate that the inferences just drawn would have been less obvious if consideration had been IImfted to non-highway transportation fuels.

*Resolution of this issue is beyond the scope of the present study. The EIA projections are derived from DOE's (formerly FEA's) Project' Independence Evaluation system computer model. Hence, resolution of the issue might be both difficult and technically complex.

$\star \star$ EIA report page 229 .

$\star \star \star$ Including electricity generation by utilities.

$\star \star \star \star * T h e ~ s t a t i s t i c$ for 1975 was $26.3 \%$. EIA's six cases range from $22.0 \%$ to $22.8 \%$ for 1985 with a mean of $22.5 \%$, and from $20.8 \%$ to $21.5 \%$ for 1990 with a mean of $21.2 \%$. Extrapolation to the year 2000 gives a value of about $20 \%$. 
TABLE $15-6$

\section{Production Projections for New and Emerging Technologies}

$\frac{1985 \text { (Quads) }}{\text { Reference* }^{\text {Upper Bound }}{ }^{* *}} \frac{1990 \text { (Quads) }}{\text { Reference* Upper Bound** }}$

Synthetic Gases

$\begin{array}{lllll}\text { High BTU. } & 0.10 & 0.15 & 0.23 & 0.45 \\ \text { LOW BTU } & N 11 & 0.05 & 0.07 & \frac{0.20}{0.65}\end{array}$

Synthetic Liquids

\begin{tabular}{|c|c|c|c|c|}
\hline $\begin{array}{l}\text { Shale } 011 \\
\text { Coal Syncrude }\end{array}$ & $\frac{0.10}{0.10}$ & $\begin{array}{l}0.20 \\
\frac{N+1}{0.20}\end{array}$ & $\begin{array}{l}0.35 \\
0.05 \\
0.40\end{array}$ & $\begin{array}{l}0.55 \\
0.15 \\
0.70\end{array}$ \\
\hline Geothermal Energy & 0.30 & 0.60 & 0.70 & 1.30 \\
\hline $\begin{array}{l}\text { Solar Heating and Cooling } \\
\text { Solar Electric Energy } \\
\text { Wind Energy }\end{array}$ & $\begin{array}{l}0.068 \\
\text { Nil } \\
0.01 \\
0.08\end{array}$ & $\begin{array}{l}0.149 \\
0.002 \\
0.09 \\
0.24\end{array}$ & $\begin{array}{l}0.144 \\
0.002 \\
0.11 \\
0.26\end{array}$ & $\begin{array}{l}0.257 \\
0.03 \\
0.66 \\
0.95\end{array}$ \\
\hline TOTAL & 0.58 & 1.24 & 1.66 & 3.60 \\
\hline Liquid Fuels as $\%$ of Total & 17 & 16 & 24 & 19 \\
\hline
\end{tabular}

*Applies to Series. A through F.

**"Assumes heavy government intervention."

Liquid fuels account for $50 \%$ of current (1978) domestic energy demand.

Source: EIA report page 229 (Table 11.1 ). 


\section{TABLE $15-7$}

\section{Breakdown of Transportation Energy Use in 1976}

Percent of Total Transportation Fuel Consumption

\section{Highway}

Automobile and Motorcycle.

53.4

Truck

23.2

Bus

$\frac{0.7}{77.3}$

Non-Highway
Air
Marine (purchased in U.S.)
8.0
Rail
Pipeline
Other
4.6
3.6
3.9
2.6
22.7

Source: EIA report page 110 (Table 5.23). 
TABLE 15-8

Comparison of Recent "Year 2000" Projections of U.S. Energy Consumption

\begin{tabular}{|c|c|c|c|c|c|c|c|}
\hline & \multirow{2}{*}{$\begin{array}{c}\text { BNL/DJA } \\
\text { Base } \\
\end{array}$} & \multicolumn{2}{|c|}{ SRI } & \multicolumn{4}{|c|}{ WAES } \\
\hline , & & Base & Low & $\mathrm{Cl}$ & $\mathrm{C2}$ & 07 & D8 \\
\hline \multicolumn{8}{|l|}{ GNP Growth, \%/yr } \\
\hline $\begin{array}{l}1975 / 1985 \\
1985 / 2000\end{array}$ & $\begin{array}{l}3.6 \\
3.0\end{array}$ & $\begin{array}{l}4.6 \\
2.9\end{array}$ & $\begin{array}{l}2.8 \\
1.7\end{array}$ & $\begin{array}{l}4.4 \\
3.5\end{array}$ & $\begin{array}{l}4.4 \\
3.5\end{array}$ & $\begin{array}{l}3.2 \\
2.5\end{array}$ & $\begin{array}{l}3.2 \\
2.5\end{array}$ \\
\hline $\begin{array}{l}\text { Technology Emphasized } \\
\text { in } 1985 / 2000 \text { Period }\end{array}$ & $\begin{array}{l}\text { Coal }+ \\
\text { Conservation }\end{array}$ & Coal & Coal & Coal & Nuclear & Coal & Nuclear \\
\hline \multicolumn{8}{|l|}{ Crude 0il, $1975 \$ / \mathrm{bbl}^{*}$} \\
\hline $\begin{array}{l}1975 / 1985 \\
1985 / 2000\end{array}$ & $\begin{array}{r}13.00 \\
\quad \quad 15.09\end{array}$ & $\begin{array}{l}14.09 \\
17.86\end{array}$ & $\begin{array}{l}12.82 \\
15.54\end{array}$ & $\begin{array}{l}13.00 \\
18.75\end{array}$ & $\begin{array}{l}13.00 \\
18.75\end{array}$ & $\begin{array}{l}13.00 \\
13.00\end{array}$ & $\begin{array}{l}13.00 \\
13.00\end{array}$ \\
\hline \multicolumn{8}{|l|}{ Domestic Consumption (Quads) } \\
\hline $\begin{array}{l}\text { Domestic } 011 \\
\text { Shale 0il } \\
\text { Imported 0il } \\
\text { 0il Subtotal } \\
\text { Domestic Gas } \\
\text { Imported Gas } \\
\text { Coal } \\
\text { Solar/Biomass } \\
\text { Other } \\
\text { Hydro/Geothermal } \\
\text { Nuclear.Energy }\end{array}$ & $\begin{array}{r}18.8 \\
3.0 \\
26.9 \\
48.7 \\
77.7 \\
1.3 \\
32.6 \\
3.9 \\
--. \\
5.8 \\
28.5 \\
\end{array}$ & $\begin{array}{r}23.5 \\
0.6 \\
14.9 \\
49.0 \\
20.1 \\
2.6 \\
43.8 \\
2.3 \\
-. \\
3.8 \\
31.6 \\
\end{array}$ & $\begin{array}{r}17.9 \\
0.2 \\
14.9 \\
33.0 \\
15.7 \\
3.1 \\
29.0 \\
1.8 \\
--. \\
3.8 \\
23.0 \\
\end{array}$ & $\begin{array}{r}14.9 \\
4.2 \\
19.9 \\
39.0 \\
14.0 \\
3.0 \\
29.8 \\
3.9 \\
1.0 \\
4.6 \\
26.0 \\
\end{array}$ & $\begin{array}{r}14.9 \\
4.2 \\
20.5 \\
39.6 \\
14.0 \\
3.6 \\
27.1 \\
3.9 \\
1.0 \\
4.6 \\
35.2 \\
\end{array}$ & $\begin{array}{c}12.7 \\
32.2 \\
32.2 \\
4.9 \\
5.0 \\
21.1 \\
1.7 \\
-. \\
3.7 \\
26.0 \\
\end{array}$ & \begin{tabular}{c}
12.7 \\
32.3 \\
$\frac{32.3}{45.0}$ \\
11.5 \\
5.0 \\
19.1 \\
1.7 \\
\hdashline-.7 \\
33.1 \\
\end{tabular} \\
\hline TOTAL & 138.5 & 143.2 & 109.4 & 124.3 & 132.0 & 115.1 & 120.3 \\
\hline O1l Subtotal as \% of Total & 35 & 34 & 30 & 31 & 30 & 39 & 37 \\
\hline
\end{tabular}

Source: EIA report pages 35 and 36 (Tables 2.11 and 2.12). 
TABLE $15-9$

Transportation Energy Implications of "Year 2000" Projections

\begin{tabular}{|c|c|c|c|c|}
\hline $\begin{array}{c}\text { Source of "Year 2000" } \\
\text { Projection }\end{array}$ & $\begin{array}{c}\text { (1) } \\
\text { Total Domestic } \\
\text { Energy Consumption } \\
1015 \text { BTU (Quads) } \\
\end{array}$ & $\begin{array}{c}\text { (2) } \\
011 \text { Consumption } \\
\text { Subtotal } \\
\text { (Quads) } \\
\end{array}$ & $\begin{array}{c}\text { (3) } \\
\text { Transportation } \\
\text { Consumption* } \\
\text { (Quads) } \\
\end{array}$ & $\begin{aligned} & \text { Column (3) }(3) \\
& \text { as \% of } \\
& \text { Column (2) }\end{aligned}$ \\
\hline BNL/OJA Base & 138.5 & 48.7 & 27.7 & 57 \\
\hline $\begin{array}{c}\text { SRI - Base } \\
\text { - Low }\end{array}$ & $\begin{array}{l}143.2 \\
109.4\end{array}$ & $\begin{array}{l}49.0 \\
33.0\end{array}$ & $\begin{array}{l}28.6 \\
27.9\end{array}$ & $\begin{array}{l}58 \\
66\end{array}$ \\
\hline $\begin{aligned} \text { WAES } & -C 1 \\
& -C 2 \\
& -D 7 \\
& -D 8\end{aligned}$ & $\begin{array}{l}124.3 \\
132.0 \\
115.1 \\
120.3\end{array}$ & $\begin{array}{l}39.0 \\
39.6 \\
44.9 \\
45.0\end{array}$ & $\begin{array}{l}24.9 \\
26.4 \\
23.0 \\
24.1\end{array}$ & $\begin{array}{l}64 \\
67 \\
51 \\
54\end{array}$ \\
\hline
\end{tabular}

*Assumed to be $20 \%$ of total domestic energy consumption.

Source: Table 15-8 and References 15-2, 15-3, and 15-4. 
TABLE 15-10

Comparison of Transportation Energy Consumption with Projected Supply of Domestically-Produced Liquid Fuels

\begin{tabular}{|c|c|c|c|c|c|}
\hline $\begin{array}{l}\text { Source of "Year } \\
2000 " \text { Projection }\end{array}$ & $\begin{array}{c}\text { (1) } \\
\text { Domesttcally-Produced } \\
\text { L1quid Fuels } \\
1015 \text { BTU (Quads) } \\
\end{array}$ & $\begin{array}{c}\text { (2) } \\
\text { Transportation } \\
\text { Consumptlon* } \\
\text { (Quads) } \\
\end{array}$ & $\begin{array}{l}\text { Column (2) } \\
\text { as } \% \text { of } \\
\text { Column (1) }\end{array}$ & $\begin{array}{c}\text { (3) } \\
\text { Non-Highway } \\
\text { Transportation } \\
\text { Consumption } \\
\text { (Quads) } \\
\end{array}$ & $\begin{array}{l}\text { Column (3) } \\
\text { as \% of } \\
\text { Column (1) }\end{array}$ \\
\hline BNL/DJA Base & 21.8 & 27.7 & 128 & 9.2 & 42 \\
\hline $\begin{array}{c}\text { SRI - Base } \\
\text { - Low }\end{array}$ & $\begin{array}{l}24.1 \\
18.1\end{array}$ & $\begin{array}{l}28.6 \\
21.9\end{array}$ & $\begin{array}{l}119 \\
121\end{array}$ & $\begin{array}{l}9.5 \\
7.3\end{array}$ & $\begin{array}{l}39 \\
40\end{array}$ \\
\hline $\begin{aligned} \text { WAES } & -C 1 \\
& -C 2 \\
& =D 7 \\
& -D 8\end{aligned}$ & $\begin{array}{l}19.1 \\
19.1 \\
12.7 \\
12.7\end{array}$ & $\begin{array}{l}24.9 \\
26.4 \\
23.0 \\
24.1\end{array}$ & $\begin{array}{l}130 \\
138 \\
181 \\
190\end{array}$ & $\begin{array}{l}8.3 \\
8.8 \\
7.7 \\
8.0\end{array}$ & $\begin{array}{l}43 \\
46 \\
61 \\
63\end{array}$ \\
\hline
\end{tabular}

*Assumed to be $20 \%$ of total domestic energy consumption.

* Assumed to be $33 \%$ of total transportation consumption.

Source: Tables 15-8 and 15-9. 
The EIA report does not provide a detalled breakdown by transportation mode and fuel type within the transportation sector. However, this has been covered in DOE's "Transportation Energy Conservation Data Book," as discussed below.

\subsection{Tranjportation Energy Conservation (TEC) Projections}

The first and second editions of the TEC Data Bpok were published, respectively, in October 1976 and October $1977(15-6,15-7)$. These extensive compilations of data include "year 2000" and other projections. Two such projections are reproduced in Tables 15-11 and 15-12. The latter table also contains projections from a 1978 up-date of the TEC Data Book*. Differences between the 1978 and 1977 projections are minor for the non-highway transportation modes. In fact, the only major change is for fuel used by automoblies. In this case, the 1978 projections for 1985 and 2000 are mid-way between those made in 1976 and in 1977. As shown in Table 15-13, the 1977 projections of future transportation energy demand were lower than those made a year earlier. In both years, separate projections were made using a variety of conservation assumptions. A comparison of the conservation cases is given in Table 15-14.

It is not surprising that there should be numerical differences between the projections published in 1976 and 1977. and the matter is mentioned in support of the view that no useful purpose is served by over-concern with precise numerical quantification of the more distant future. It is not the future (in 1985 and 2000) that has changed but "our" perceptions of this future from the vantage points of 1976, 1977 and 1978. This is true of the base cases (without conservation) and of the conservation projections. Moreover, the perception of what may be achleved by conservation also changed from 1976 to 1977, as shown below:

\% Difference between Non-Conservation and Conservation Cases of Transportation Energy Demand

Projection TEC-76 TEC-77

$\begin{array}{cc}\frac{1985}{13} & \frac{2000}{25} \\ 5 & 31\end{array}$

The pattern of the above changes is consistent with commoniy observed forecasting behavior:

- As the nearer year (1985) is approached, the perception of what may be achieved by additional changes decreases.

- As the additional potential percelved for the nearer year becomes small on an absolute basis, and if the percefved need for additional change is sustained, more drastic measures may be considered for the later year with the consequence that the revised perception is of a greater potential for change in the longer term.

\footnotetext{
ॠTEC-73 has not been printed yet. However, pertinent statistics in Table 15-12 were made available by the Non-Highway Transportation Systems Branch in the interest of making this study as current as possible.
} 


\section{TABLE $15-11$}

ERDA-48 Demand Forecast for Transportation Fuels

Automobiles

Trucks and Buses

Highway Subtotal

Air

Marine

Railroad

Pipeline

Non-Highway Subtotal

\begin{tabular}{|c|c|}
\hline \multicolumn{2}{|c|}{$10^{15}$ BTU (Quads) } \\
\hline 1985 & 2000 \\
\hline$\frac{5.49}{15.95}$ & $\begin{array}{r}12.84 \\
7.93 \\
20.77\end{array}$ \\
\hline
\end{tabular}

4.70

1.17

0.73

$\frac{1.26}{7.86}$

$\underline{23.81}$

$\underline{33.89}$

Source: TEC Data Book, 1st Edition, ORNL 5198, October 1976.

TABLE $\quad 15-12$

Baseline Transportation Energy Demand (Before ERDA Conservation Program)

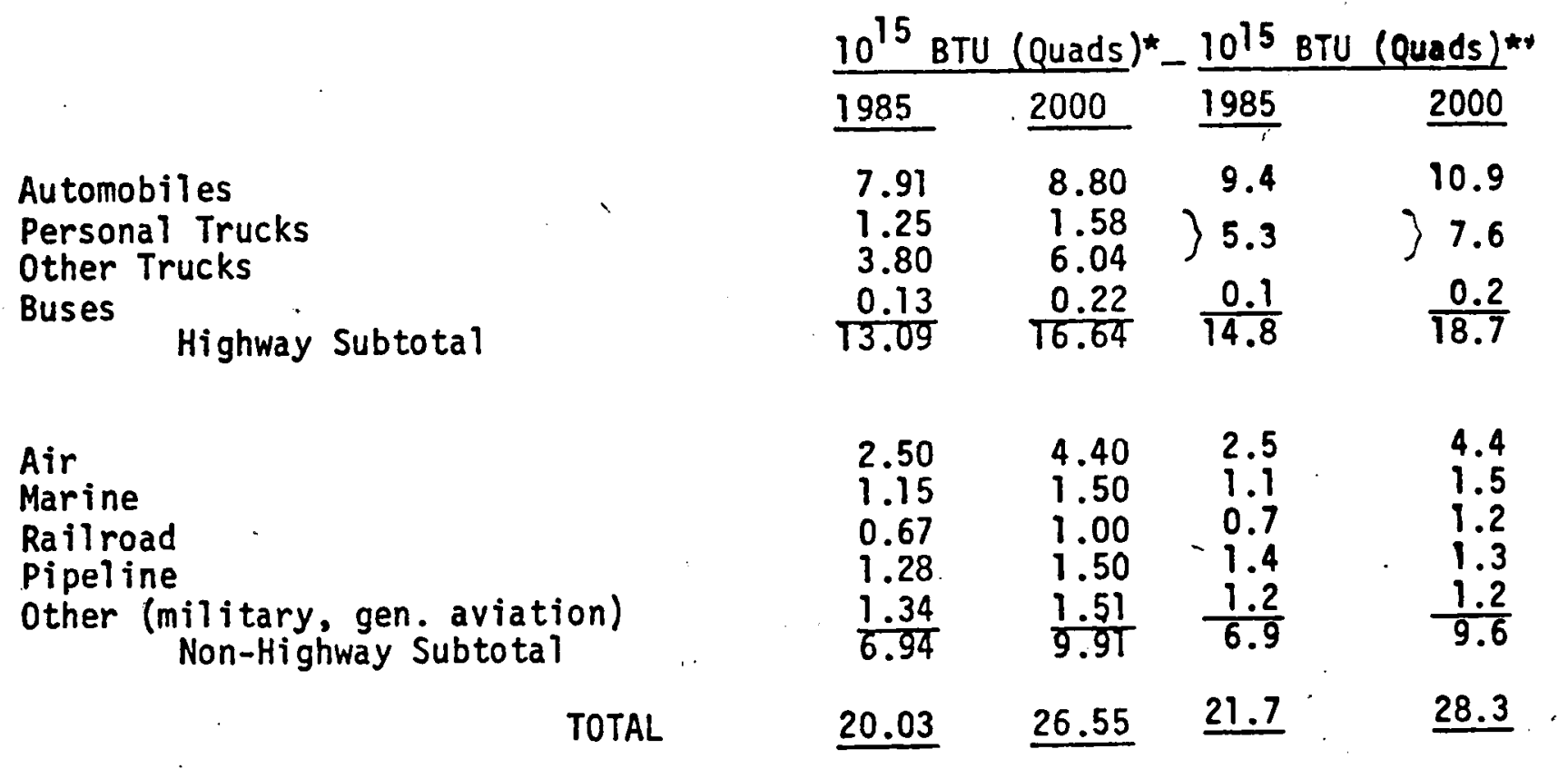

Sources: * TEC Data Book, 2nd Edition, ORNL 5320, October 1977. $\rightarrow r$ int or of November 1978, with numbers to be 


\section{TABLE $15-13$}

\section{Comparison of TEC Data Book Projections}

Published in Oct. 1976 and Oct. 1977

\begin{tabular}{|c|c|c|}
\hline $10^{1}$ & BTU (QU & ds) \\
\hline TEC-76 & TE:-77 & $37 / 76 \Delta$ \\
\hline
\end{tabular}

- $\underline{1985}$

Highway

Non-Highway

\begin{tabular}{llll}
$\begin{array}{l}15.95 \\
7.86\end{array}$ & 13.09 & -2.86 & -18 \\
\hline $23.87^{\phi}$ & $\frac{6.94}{20.03}$ & $-\frac{-0.92}{-3.78}$ & -12 \\
\hline
\end{tabular}

- 2000

Highway

Non-Highway

$$
\begin{array}{llll}
20.77 & 16.64 & -4.13 & -20 \\
\frac{13.12}{33.89^{\phi}} & \frac{9.97}{26.55} & -\frac{3.21}{-7.34} & -\frac{24}{-22}
\end{array}
$$

Adjusted ERDA-48 totals for 1985 and 2000 were 22.8 quads and 32.3 quads respectively.

TABLE $\quad 15-14$

Comparison of TEC-76 and TEC-77 Conservation Cases

Total Transportation

\begin{tabular}{|c|c|c|c|}
\hline \multicolumn{3}{|c|}{$10^{15}$ BTU (Quads) } & \multirow[b]{2}{*}{$\Delta \%$} \\
\hline TEC-76 & TEC-77 & $77 / 76 \Delta$ & \\
\hline 20.6 & 19.1 & -1.5 & -7 \\
\hline 25.3 & 18.3 & -7.0 & -28 \\
\hline
\end{tabular}
Sector Demand 
These observations concern normal forecasting behavior, which the reader is asked to keep in mind when considering the following discussion of the relationship of the TEC projections to those of EIA et al. Before beginning this discussion, two further observations will be made:

(1) Currently, non-highway iransportation accounts for about $23 \%$ of the transpirtation sector's total energy consumption. TEC-76 projected an increase to $33 \%$ in 1985 and $39 \%$ in 2000 , while TEC-77 projected $35 \%$ and $37 \%$ for the same years. The principal factors affecting this percentage are the consumption of (a) motor gasoline (highway fuel), and (b) aviation jet fuel (non-highway fuel). For example, effective conservation of motor gasoline together with expansion of air traffic would result in an increased percentage of non-highway fuel usage.

(2) TEC-77's conservation case projects a lower consumption of transportation energy in the year 2000 (18.3 quads) than in 1985 (19.1 quads). This case projects a peaking of the sector's energy consumption in 1985. Hence, the TEC-77 base and conservation cases diverge steadily.

TEC-77, TEC-78 and EIA projections for the energy consumption of the transportation sector are compared in Table 15-15. Except for TEC-77's conservation case, 11 of the projections for 1985 are clustered in the range of 20.0 to 21.8 quads. This is not particularly surprising since all of the projections are for base cases and the time untfl 1985 is insufficient for large changes to occur -- except as the consequence of the type of exogenous event that is specifically excluded by the assumptions used to generate the projections. The scatter is somewhat greater for the year 2000. Here, the TEC-77 base case (26.6 quads) is intermediate between EIA's Serles F (26.0 quads) and Series C (27.6 quads)*, while TEC-78 provides the nominally highest projection (28.3 quads). It will be recalled that both $F$ and $C$ are "medium/medium" with respect to overall supply and demand assumptions but, for $F$, the world price of crude 011 was assumed to increase by $5 \%$ per year in real terms after 1980. As modeled, this price assumption has a relatively insignificant impact (a reduction of only $6 \%$ ) on the energy consumption of the transportation sector. Except for the TEC-77 conservation case (18.3 quads), the lowest projection is for Series $E$ (22.3 quads). At first sight, this may be surprising since $E$ combines low overall demand and supply assumptions. However, the explanation, at least in part, is that "supply" refers to domestic supply and any deficit in 011 is made up with imported petroleum that is assumed to have a constant price in 1978 dollars. It may seem unreasonable to continue this price assumption from 1990 to the year 2000. If so, the inference may also be drawn that assumption of a constant world oil price until 1990 may be unreasonable. Yet, the Series $C$ and $F$ results suggest that transportation energy demand is not very sensitive to world ofl price (as modeled by PIES). This leads to the simplistically obvious conclusion that transportation energy consumption must be sensitive

*All of the EIA Serles were extrapolated from the pertinent 1985 and 1990 projections. 
TABLE 15-15

Compartson of TEC-77 Energy Consumption Projections with EIA Serles

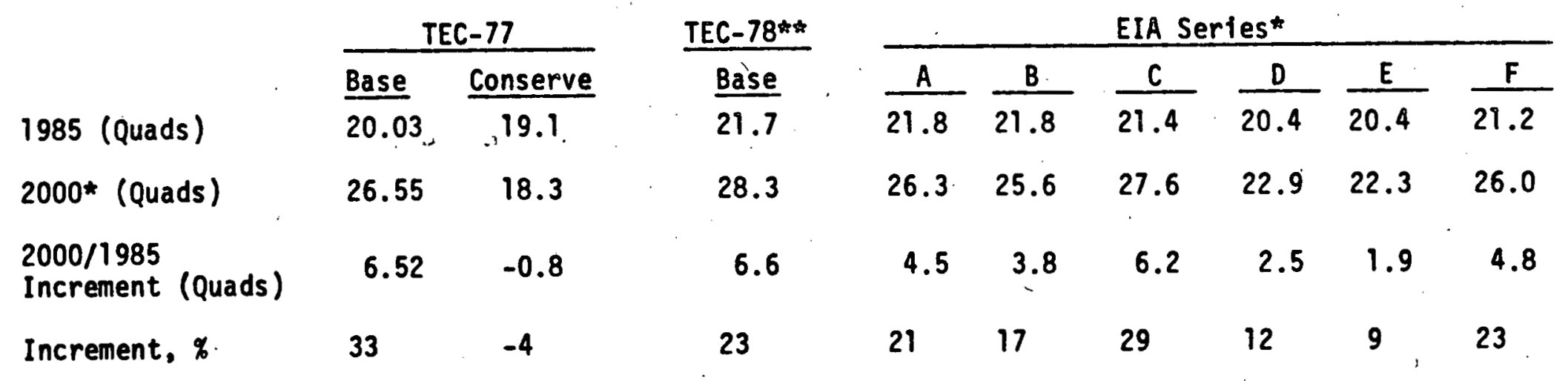

*Extrapolated from 1985 and 1990 values in Table 15-2 and 15-3.

* DOE letter of November 1978, with numbers to be included in TEC-78. 
to supply; 1.e. consumption and consumption patterns may be strongly influenced by actual shortages of supply or by perceptions of shortage in the absence of avertive actions. This is the conceptual basis of the TEC-77 conservation case.

It is also possible to compare what may be achlevable by conservation with what has been projected, on the suppiy side, for "new and emerging technologies". To do this, we took the "upper bound" numbers for shale ofl from Table 15-6 and applied the 1985/90 growth rate of $18 \% / y r$ to the 1990 synthetic liquids total of 0.70 quads to obtain a year 2000 extrapolation of 3.6 quads. This is a very optimistic (1.e. unlikely) extrapolation. The purpose is to make a comparison, on similar "maximum efforts" basis, with the 8.3 quads differential in the year 2000 projections for the TEC-77 conservation and base cases. In spite of the imprectsion of these numbers, two qualitative conclusions may be drawn:

(1) Initiatives for conservation and production of liquid fuels by new technologies both appear important.

(2) definitely in the near-term (until 1985) and probably in the mid-term (from 1985 to 2000) conservation may be quantitatively more important than what may be achieved by new supply technologies.

Intultively, we belleve that the long-term downtrend in total transportation energy demand represented by the TEC-77 conservation case is not sustainable, $i$.e. at some time in the future, absolute demand would begin to trend upward again. If so, supplies derived from new technologies would become essential. In view of the extremely long lead-time of these technologies, as manifest by an "upper bound" of 3.6 quads in year 2000 , conclusion (i) above is reinforced: It is precisely because of the long lead-time that the supply initatives seem important now, thereby complementing conservation initiatives that can produce results sooner but finitely. 


\section{REFERENCES}

(15-1) "Projections of Energy Supply and Demand and Their Inputs", Annual Report to Congress, Energy Information Administration (DOE), April 1978.

(15-2) A. Hermelee, et al. "Alternative Scenarios to Develop R\&D Strategles", Brookhaven National Laboratories, (publication pending) [BNL/DJA in Table 8].

(15-3) "Fuel and Energy Price Forecasts", Stanford Research Institute report for Electric Power Research Institute, Report EPRI EA-433, 1977. [SRI in Table 8]

(15-4) "Energy: Global Prospects, 1985-2000", Workshop on Alternative Energy Strategies (WAES), McGraw-Hill, New York, 1977. [WAES in Table 8]

(15-5) D. B. Shonka, et al., "Transportation Energy Conservation Data Book: Edition 2", Oak Ridge National Laboratory, ORNL-5320, October 1977.

(15-6) TEC Data Book, 1st Edition, ORNL 5198, October 1976.

(15-7) TEC Data Book, 2nd Edition, ORNL 5320, October 1977.

(15-8) Trade Expansion Act of 1962, Public Law 87-794, \#232, 19 USC, \#1862 (1964). 
16. MILITARY AND INTERNATIONAL CONSIDERATIONS

M. H. Farmer

Historically, the military fuel requirements of the U.S. have been procured both domestically and overseas. However, there are legislative and other provisions that make it clear that, in an emergency, military needs would have priority over many domestic civilian uses of fuel. Moreover, some level of military priority can apply even under "normal" conditions because of the need to maintain defense capabilities in the interest of national securlty. The latter has been broadly interpreted. For example, Section $232(\mathrm{c})$ of the Trade Expansion Act of $1962(8)$ recognizes "the close relation of the economic welfare of the Nation to our national security." Section $232(\mathrm{c})$ contains wording of possible applicability to all types and sources of fuel; pertinent citations follow.

"...the Director* and the President shall, in the light of requirements of national security and without excluding other relevant factors, give consideration to domestic production needed for projected national defense requirements."

"...the requirements of growth of such industries*ᄎ and such supplies and services including the investment, exploration, and development necessary to assure such growth..."

It should be pointed out that Section 232 was the statutory foundation of the former Mandatory 0il Import Program $16-1\}$. While MOIP itself has been terminated and oil import quotas have been abol ished, some. of the conditions that prompted the program still exist. Indeed, Government funding of the development of alternative fuels technology is premised by concern for the future dependability and availability of petroleum imports. Thus, while many other factors are involved, national security is a unifying issue in the military and international considerations discussed below.

\subsection{Military Considerations}

Currently, DOD's consumption of energy, including electricity, is equivalent to about $2 \%$ of U.S. energy demand. While the aggregate percentage is small, military demand is concentrated in a small number of products. About $62 \%$ of military demand is for transportation fuels and the rest for stationary sources:

\% of Total Demand

$\begin{array}{cr}\text { Transportation: } \begin{array}{cr}\text { Aircraft } \\ \text { Marine } \\ \text { Ground }\end{array} & 44 \\ & \frac{5}{62} \\ \text { Stationary Sources } & \frac{38}{100}\end{array}$

\footnotetext{
* Director of the Office of Emergency Planning (later, the Office of Emergency Preparedness). **Needed to sustain national defense requirements.
} 
At present, the transportation fuels are derived entirely from petroleum while the stationary requirements are supplied from various sources:

Energy/Fuel Source

Petroleum liquids

LNG/LPG (petroleum)

Coal

Electricity

Other

\section{\% of Total Demand}

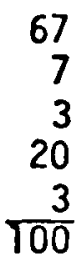

With specific exceptions (e.g. nuclear submarines and aircraft carriers), DOD's transportation fuel strategy has moved toward logistical simplicity: aircraft jet fuel and diesel fuel (which doubles as boiler fuel). The logistical practicality of this "two fuel" strategy does not imply a lack of technical interest in other types of fuel or fuel compositions, but it does mean that actual deployment of a variety of fuel types is unilikely. Put differentiy, a decision to deploy a new fuel would probably be paralleled by a decision to substitute the new fuel throughout the entire DOD system. Such a decision is unlikely unless the new fuel were to permit superior combat performance.

Only in the case of aviation jet fuels is military demand a significant fraction of total demand for aviation fuels. This fact has two important implications:

(1) Military and civilian aircraft utilize the same fraction of the "petroleum barrel."

(2) In an emergency; military jet fuel needs could be met by curtailment of civilian demand.

Potentially, there is a conflict between (1) and (2) because relief of a future supply constraint (item 1) through development of different fuels for military and civilian purposes could impair substitutability (item 2). The point may be illustrated by a technically possible, but unlikely, example. Let us hypothesize* the following:

(1) DOD sponsors the conversion of raw shale oil into jet and diesel fuels.

(2) The jet fuel derived from shale oil is not identical to conventional jet fuel.

(3) DOD equipment (i.e. aircraft) is modified to obtain optimal performance from the shale-derived jet fuel.

(4) The modified DOD equipment does not permit optimal performance on conventional jet fuel.

*The assumptions are not projections, and are made solely' for the purpose of illustrating the substitutability issue. 
The hypothetical outcome appears unsatisfactory since it implies one or more of the following consequences:

- DOD jet fuel supply becomes tied to shale oil production.

- Some DOD equipment performs suboptimally if forced to use jet fuel other than that derived from shale oil.

- Some DOD equipment uses shale-derived jet fuel while other DOD equipment uses fuel (of different quality) derived from other resources thereby violating logistical simplicity.

Another example will illustrate the hypothetical consequences of development of novel fuels for civilian aircraft. What is hypothesized is extremely unrealistic, and the purpose of the example is to illustrate why this is so. We hypothesize the following:

(1) In anticipation of an eventual shortage of conventional (paraffinic) aviation fuels, programs are undertaken to develop engines (and aircraft) capable of using blends of alcohols and aromatic hydrocarbons.

(2) The volumetric heat content of the blends is lower than that of conventional jet fuels but, technically, the new fuel/engine system is operable.

(3) Incentives are provided to induce deployment of the new fuel/engine system (thereby substituting the new fuel blends for conventional jet fuels and "saving" the latter for other uses).

(4) With the new system in place it would no longer be possible, in time of emergency, to augment supplies of military jet fuels by simple curtailment of civilian demand.

The foregoing discussion may be summarized in the form of two expectations:

- DOD may adopt a unique fuel system if this produces

a unique performance advantage.

- Most of DOD's transportation fuel needs will continue to be met with conventional types of jet and diesel fuel.

Additional information about DOD's transportation fuel activities is summarized in Table 16-1.

DOD maintains bases, personnel and equipment in many parts of the world. Some of this activity is in the form of multilateral commands such as NATO. Such overseas operations are constrained logistically. For example, supplies will be procured from a variety of sources and must be mutually compatible. In addition, changes to fuels and equipment will usually be agreed multilaterally. Moreover, equipment based in the U.S. that may be deployed overseas may also have to be 
Summary of DOD Transportation Fuel Activities

- No significant changes in fuel quality are anticipated except, eventually, greater thermal stability in fuels for high MACH Number aircraft.

- The purposes of current oil shale activities are to:

(1) provide a higher degree of assurance that fossit fuels will continue to be available in the future

(2) determine the probable characteristics of fuels derived from shale oil and what they should be to match the needs of DOD equipment (and, if necessary, how the equipment might be modified to insure a good match).

- Shale-derived fuels are being produced for testing and characterization. DOD relies on industry for the technology and capability of producing and refining the pertinent fuels.

- Emphasis on shale-derived fuels is based on the judgment that such fuels are likely to be better suited to DOD needs than coal-derived liquids.

- A cooperative project with DOE is probable. In this case, DOE would sponsor the production and refining of about 100,000 barrels of shalederived fuels while DOD would commit funds to the evaluation and testing of the fuel products.

- DOD does not intend to utilize alcohol fuels because of expected high cost and limited availability. (The alcohol fermentation unit at the Army's NATICK Laboratory is now funded by DOE.)

- No DOD effort is planned on coal-in-oil slurries, beyond monitoring of possible commercial developments.

- In non-transportation areas, DOD is making technical efforts of varying size in the use of biomass as a boiler fuel, photovoltaics, solar heating and cooling, fuel cells, geothermal energy, and wind energy.

- The breakdown of current petroleum usage is:

$\begin{array}{ll}\text { Aircraft fuels } & 65 \% \\ \text { Marine fuels } & 16 \% \\ \text { Ground " } & 8 \% \\ \text { Stationary Sources } & 11 \%\end{array}$

- The breakdown of petroleum use by service is:

$\begin{array}{lr}\text { Air Force } & 48 \% \\ \text { Navy } & 31 \% \\ \text { Army } & 18 \% \\ \text { Marine Corps } & 3 \%\end{array}$

- Long term storage stability is an important quality for DOD fuels. 
compatible with fuels available overseas. Clearly, these considerations require a high degree of standardization, i.e. the avoidance of incompatible systems. This is another reason for anticipating that changes in fuel quality are likely to be both small and incremental. With a greater margin of flexibility, similar considerations apply to commercial transportation systems.

\subsection{International Considerations}

Competition is a particularly important factor in international markets. While competition has many forms, cost, rellability, and avallability of product or service are usually parts of its cutting-edge. However, these elements may be blunted to varying degrees by regulations that, in addition to establishing international standards, tend to limit the rate at which changes can occur. This applies to changes that can not be put into effect without the approval of all parties (or, at least, a majority) to a particular international agreement. Clearly, approval is unlikely if a change would advantage one party while disadvantaging* others. The air transportation situation will be discussed first.

\subsubsection{Air Iransportation System}

The word "system" may be applied to air transportation in several different senses, e.g.:

- The component parts of a given aircraft (engines, wings, airframe, etc.).

- A family of aircraft derivable from a "basic" model.

- An airlines fleet and the incorporation of new aircraft into the fleet.

behavior, e.g.:

Each of these "systems" has characteristics that affect competitive

- The cost of developing and introducing a new system has become very large.

- The rewards for commercial success are commensurately large.

- The useful life of a given system is considerable, e.g. 20 years or more.

Thus, competition in the aircraft business is for very high stakes at relatively infrequent intervals. . The pattern of competition has been changing from along international (hence, political) lines to among transnational consortia of companies. In such cases, the different

*In the sense of comparative, or competitive, disadvantage.

**Relative, for example, to automobile and many other manufacturing activities where market share may ebb and flow on an annual basis and where competitive opportunities are always present. 
components of a new aircraft system may be manufactured by different companies in different countries, and final assembly may be in more than one country. Recent emphasis has been on the cost and performance of competing systems, and on related issues such as financing and credit terms. The only way in which fuel has figured in competitive evaluations is in terms of fuel economy. With one exception, all of the entirely new and derivative a ircraft have been designed for fuel economy. The exception, the British/ French SST, has garnered some technological and other forms of prestige but is not representative of the main thrusts of present commercial developments. The prevailing trends are to high load factor and fuel-efficient operations. New aircraft delivered in the 1980's, and probably into the 1990 's, will reflect these trends since long range purchase contracts are being negotiated and some have already been concluded. The following citation from a paper presented at a recent techntcal conference captures the essence of what one atrline (Pan Aml is trying to accomplish 16-2).

"The most rewarding way to increase fuel efficiency is to increase the seating capacity of the airplane, and then put more bodies in the seats, or more cargo in the cargo compartments. Virtually all airlines have increased seating capacities in their airplanes, either by reducing First Class seats and devoting more space to Economy seats, or by increasing the density of Economy seating. However, while this may improve fuel efficiency in terms of seat (or ton) miles per gallon, it does not necessarily decrease total gallons consumed. On the contrary, with the increase in loads resulting from the marked decrease in fares, total airline consumption undoubtedly will increase."

The conclusions of the same paper make three references to fuel quality:

(1) "Use of new fuels such as methane or hydrogen appears quite remote; the ground handling problem is of greatest concern."

(2) "If broader based specification fuels are to be used, some preference is expressed for lower volatility fuels."

(3) "The turbine engine appears reasonably tolerant to alternative fuels, but caution is expressed regarding effects on operating temperatures of hot parts."

In amplification of (1), it was pointed out that airlines would wish to refuel a given aircraft at twenty to thirty different airports--all of which would need liquid hydrogen facilities. Liquid methane would be easier to handle, and it would be easier to introduce this fuel into normal service. In relation to (2), it is recognized that a broad cut fuel would make more fuel available*, but this might be a backward step with respect

*Fuel availability would increase with respect to yield of aircraft fuel per barrel of crude oil, but only at the expense of reducing the yield of other products. In a situation of general shortage of petroleum, there would be a need to consider end-use priorittes in addition to yield patterns. 
to safety and emissions. Concerning (3), it was stated that higher aromaticity would lead to higher maintenance cost. Inverting this point, and applying it to jet fuels derivable from coal, it appears that a high degree of hydrogenation would produce fuels giving rise to minimum maintenance costs. However, there would be a trade-off in cost between hydrogenation (during fuel processing) and maintenance (associated with aircraft operation).

Another aspect of maintenance is the frequency with which engine parts are replaced such that, in effect, an engine may be completely replaced within a period of five years or less. In principle, this would permit small, incremental changes to be made to both fuels and engines. Operationaliy, this form of "dynamic optimization" would require careful planning and cooperation among airlines (since it would not seem practical to supply a different quality of fuel to each).

Some of the observations made for air transportation also apply to marine and railroad activities. In each case, the goal is to provide transportation of people or freight as economically as possible. The introduction of new fuels is not a goal of companies providing transportation services. A general conclusion may be inferred from this fact: any alternate fuel with properties similar to those of the fuel currently used, which will also minimize the capital requirements and operating expenses of the fuel user, will be preferred to an alternate fuel that is dissimilar, thereby causing additional capital expense and handling problems.

\subsubsection{Marine Transportation System}

Marine transportation is concerned, almost entirely, with the movement of goods (as distinct from air transportation, which is primarily concerned with moving people). With some exceptions, e.g. container ships and movements covered ty the Jones Act, U. S. flag vessels do not compete effectively with foreign flag vessels. This fact is of great concern to the Maritime Administration of the U. S. Department of Commerce. Accordingly, MARAD has been and is seeking ways to improve the future situation of both U.S. shipbuilders and U. S. flag vessels. For example, MARAD is trying to identify specific future marine transportation needs and the pertinent technology that could be developed to improve the competitive position and productivity of the U. S. shipping industry. Under these circumstances, and considering the worldwide surplus of most forms of marine transportation capacity, it seems probable that fuel quality will continue to be dominated by system costs, i.e.: cost of fuel, cost of maintenance, and cost of new capital investment. Thus, any "new" fuel that would not minimize the aggregate of these three elements of cost is certain to be resisted by both the U. S. and foreign shipping industries.

The still growing surplus of maritime transportation capacity is evidenced by the shipbuilding statistics in Table 16-2 and by the following statement from "The Economist" of London(16-3,16-4):

"The EEC has tried (and falled) to allocate cuts in shipbullding capacity among 1 ts members. But the OECD's Working Party 6 is providing a forum for the Japanese and Europeans to confront/consult each other (the Americans do not take part). Its success has been modest: it has not achieved any agreed carve-up of the dwindling market, nor prevented rival national subsidy schemes in what is left." 
TABLE 16-2

Decline in Shipbuilding Activity by OECD* Members

Million Compensated Gross Registered Tons

Ships Completed

\begin{tabular}{|c|c|c|c|c|c|}
\hline & 1974 & 1975 & 1976 & 1977 & 1978 \\
\hline $\begin{array}{l}\text { EEC***} \\
\text { Other W. Europe } \\
\text { Japan }\end{array}$ & $\begin{array}{l}4.1 \\
3.0 \\
7.9 \\
\end{array}$ & $\begin{array}{l}5.0 \\
3.1 \\
7.3\end{array}$ & $\begin{array}{l}5.0 \\
2.7 \\
7.8 \\
\end{array}$ & $\begin{array}{l}4.0 \\
2.8 \\
7.4 \\
\end{array}$ & $\begin{array}{l}4.3 \\
3.0 \\
5.6\end{array}$ \\
\hline Total & 15.0 & 15.4 & 15.5 & 14.3 & 12.9 \\
\hline
\end{tabular}

\section{Scheduled Delivery**}

\begin{tabular}{cc}
1979 & 1980 \\
1.7 & 0.4 \\
1.6 & 0.1 \\
1.2 & 0.3 \\
\hline 4.5 & 0.8
\end{tabular}

*Organization for Economic Cooperation and Development

$\star \star A c c o r d i n g$ to Spring Order Books

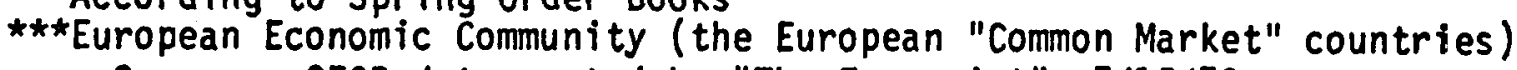

Source: OECD data quoted by "The Economist", 7/15/78

(Note: OECD does not include U.S. data in its shipbuilding statistics) 
Provided that international trade continues to expand, the surplus of ships will eventually be eroded by scrappage. However, another uncertainty is on the horizon. There is a fairly general expectation that world oil production will have peaked by the end of the century; the uncertainty concerns the exact time that the peaking will occur. A peaking of crude oil production would affect marine transportation because:

(1) The volume of total crude oil production that moves by water is increasing now, but would decrease once total production peaked.

(2) Some countries that now export crude oil will export less as their domestic requirements increase and, later, in anticipation of shortage, may be expected to conserve their petroleum resources for their own use. *

(3) A general perception of constrained petroleum supply would be expected to generate pressures for reducing the amount of oil consumed in the transportation of 0 il.

Any one of the above items suggests that changes in inter-fuel cost parities would occur as the result of an imminent, or actual, constraint of petroleum supply. If this is so, then the order of the events becomes an important consideration. For example, widespread production limitations (item 2) in advance of producibility limitations (item 1) would be expected to delay the production peak, reduce its magnitude, and possibly cause an extended plateau of maximum production rather than a sharp peak. Moreover, a plateau would provide more time and, hence, make it easier to accomplish fuel substitution (item 3) than would a sharp peak.

Four tentative conclusions are possibie:

(1) For the near - and mid-terms, changes in marine fuel quality are likely only if system costs are thereby reduced.

(2) International maritime competition strengthens the probability of (1).

(3) In the long-term, substitution of other marine fuels for petroleum seems possible.

(4) Substitutions for petroleum will probably occur in other sectors before they occur in marine transportation in the non-highway sector.

\footnotetext{
*Canada has already adopted thi.s policy.
} 


\subsubsection{Railroad Transportation System}

The direct impact of international considerations on the RR transportation system will be extremely small, since it will be confined to certain rail linkages between the U.S. and Canada. Moreover, there is a similarity of natural resources on either side of the U. S./Canadian border, which suggests that the same economic choices may apply to the overlapping RR systems of both countries.

Indirect impacts appear far more important, because the $U$. S. is a significant exporter of RR locomotives. It is unlikely that $U$. S. manufacturers would undertake separate equipment developments for domestic and foreign markets. Incremental improvements to existing power systems are more likely. A new locomotive model is not introduced until performance and reliability have been demonstrated by years of testing. And the accumulation of satisfactory performance on $U$. S. roads is a sales factor in locomotive exports. It is concluded that the net effect will be to raise the hurdle of economic superiority required of a new RR fuel system before it is likely to displace the continuing development pattern of the existing system. 


\section{REFERENCES}

(16-1) "The 011 Import Question", a report on the relationship of oil imports to the national securlty, Cabinet Task force on 011 Import Control, February 1970.

(16-2) J. G. Borger, "Alternate Fuels for Air Transportation", Symposium on Utilization of Alternative Fuels for Trnasportation, Santa Clara, June 1978.

(16-3) "The Ships that Launched a Thousand Rows", Pp. 73-74, The Economist, London, Juty 15, 1978.

(16-4) "Protectionism", p. 86, The Economist, London, July 22, 1978. 


\section{INSTITUTIONAL ISSUES AND CONSTRAINTS}

M. H. Farmer

\subsection{Change Processes}

Change processes take time, whether the change is technological or institutional. With the former, however, it is easy to understand that many years may be needed to develop a new technology from laboratory through pllot plant scale and then, plan, construct, and start up a i. large manufacturing plant. It may be less easy, especially for technologists, to recognize and accept why there may be a long delay between the time that an institutional problem or constraint is identified and the time that it is resolved. Sir Geoffrey Vickers has observed $(17-1)$ :
"All Western socleties for the last two hundred years. . . have exaggerated the scope for design open to their socleties in the social no less than the technological field. . I have attributed this to their lack of understanding of systemic IImitations. This understanding is now dawning austerely and rapidly in the technological field. It is far less in evidence and far more needed in the cultural field."

\subsection{National Research Council Report}

NRC's Commission on Private Sector Participation* recently prepared a report $(17-2)$ that included the examination of a number of institutional and legal difficultles in the transfer to the private sector of technology developed under Government sponsorship. Two statements from NRC's report are cited here as 111 ustrations of the widely held view that institutional problems may be more difficult to overcome than technical problems:

"The history of government/industry collaboration on synfuels projects has been less than a happy one. Technical issues have raised some problems, but the major controversies arose over project management policies, environmental restrictions, cost-sharing formulas, pricing, and even federai land-leasing polictes." (page 20)

"The successful diffusion of a new technology in the market depends on strong market-pull forces -. These factors cannot be neatly tabulated, evaluated, and then translated into a successful market deciston. In most cases, the assessment is highly subjective, and is sometimes contrary to the avallable objective evidence. Corporate managers routinely make judgments based on their perception of, and sensitivity to, these factors." (page 13)

\footnotetext{
Thalrman: Martin Goland, Southwest Research Institute.
} 


\subsection{Institutional Problems of Introducina a New Fuel}

Institutional problems may be economic, political, administrative, furisdictional, environmental, legal or social .- and, in many cases, a complex mixture of these elements interwoven with uncertainties about the f.dture. One aspect of such uncertainties is that they often becloud the rrdering of the priorities of change, even though these priorities may seem quite clear to those engaged in technology development. Some empirical evidence regarding uncertainty and priorities is presented in a following section on cross-impact analysis. In this section the remaining discussion is confined to institutional problems that are unique to the field of transportation. The problems concern the introduction of new fuel fuels for mobile equipment.

For the purpose of this discussion a new fuel is defined as one that cannot be used effectively in existing equipment. Therefore, the problem to be considered is that of simultaneous introduction of the new fuel and new (or radically modified) NHT equipment in which the fuel is to be used. Parentheticaliy, it may be added that a new fuel that could be used in existing NHT equipment need not pose serious institutional problems. In this case, the potential problems would be to demonstrate favorable economics, reliable performance, and adequate availabllity. However, the simultaneous need for new equipment in which to utilize a new fuel would increase the institutional difficulties to be overcome by an order of magnitude.

An essential feature of an NHT system, other than a pipeline, is that the equipment moves from place to place and must be able to obtain fuel wherever it is needed $(7-3)$. This creates a situation in which a number of conditions must be satisfied simultaneousiy:

(1) the NHT equipment industry, or some segment of it, must decide to introduce a new engine or to sponsor radical modifications of 1 ts existing engines

(2) independently of (1), the fuels industry must decide to introduce a new fuel

(3) preferably, for compet1tive reasons, several companies in both industries should declde independently to introduce the respective new products

(4) NHT equipment users must be willing to purchase the new products (otherwise commerclal introduction will be a fallure)

(5) except in spectal applications where fuel could be provided at a single point*, the new fuel must be widely avallable

(6) the new system should offer cost or performance advantages over conventional or other al ternatives, and should not present any major disadvantage.

\footnotetext{
*e.g. for mobile equipment used in mining.
} 
Most NHT equipment is expected to have a long useful life, 1.e. It is expected to be durable. Proof of durability of new equipment cannot be obtained quickly, and may require several years of testing under field conditions. Clearly, such a test program will be expensive to the equipment manufacturer -- tut he has no al ternative if he wishes customers to purchase (expensive) new equipment. Clearly, also, an equipment manufacturer is unlikely to develop new equipment solely for the benefit of a fuel producer who wishes to sell a new fuel. In general, the reverse of this proposition would hold also, namely that a fuel manufacturer would be unlikely to make a multimillion* dollar investment in facilitles to produce a new fuel product for commercially unproven NHT equipment.

In contrast, no serious evolutionary problem is seen on the fuel side if the new NHT equipment can use conventional fuels (regardless of their raw materials source). Similarly, no serious evolutionary problems will be associated with the introduction of a new fuel if it can be used by a (large) segment of the existing NHT equipment population or if there is some (iarge) established demand for the new fuel regardless of the end-use application. What is important to the new fuel manufacturer is that there should be a market for his product. Also important is that the fuel should be produced in a (large) economicallv-sized plant, $\therefore$ otherwise it will not be competitive* with conventional fuels. But the economy of scale possible in a large plant will not apply if the plant cannot be operated at close to its capacity. Therefore, an instant market must be found for close to the full capacity of the plant producing the new fuel. Hence, the producer of a new transportation fuel product will, in general, be at a marked disadvantage relative to the incremental producer of a conventional fuel (regardiess of the raw material source of the fuel; whether conventional or unconventional).

Yet another current problem is that conventional transportation fuels are being sold at what approxtmates an average cost (plus profit margin) rather than at the marginal cost of new production (plus profit margin). The problem here is that an alternate fuel might compete economically with the marginal cost of (new) conventional fuel production and still be uncompetftive in the market place because the price of conventional fuels is based on historical average costs.

The above discussion emphasizes the considerable difficulties that are anticipated with the introduction of a new fuel, but it does not imply that the task is impossible. In fact, advance recognition of the difficulties should make the task somewhat easier. Nevertheless, the magnitude of the transitional problems with new fuels (that are incompatible with existing equipment) are such that evolutionary changes to fuel. composition (that do not create incompatibllity) seem more likely.

Fin the case of synthetic fuels plants, the capttal investment required may exceed $\$ 1$ bllition for a single plant.

** without subsidies or the like.

***i.e. the higher cost marginal production of conventional fuels is "rolled into" the average cost of all production of conventional fuels. Alternate fuels that are fully compatible with conventional fuels have the potential advantage of being rolled into the transportation fuel supply system before being sold to consumers. Novel or incompatible fuels would not have this advantage. 


\section{$17-4$}

\section{REFERENCES}

(17-1) Sir Geoffrey Vickers, "The Future of Culture", Futures Research, Addison-Wesiey Publishing Co., 1977.

(17-2) "Private Sector Participation In Federal Energy R,D\&D Planning", Commisston on Natural Resources, National Research Counc1l, National Academy of Srifences, 1978.

(17-3) F. H. Kant, et al.. "Feasibility Study of Alternative Fuels for Automotive Transportation", Section 7.1, "The New Engine/New Fuel Dil emma", EPA-460/3-74-009-b, June 1974. 


\section{EXPERIMENT IN PROBABILISTIC FORECASTING}

M. H. Farmer

The projections made in this study depend on assumptions that are discussed elsewhere in the report. In general, as in the Energy Information Administration's projections reviewed earlier, the projections may be considered "baseline". Quoting from the Foreword to EIA's report: "Generally, Forecasts must be uncertain. This fact implies that to be fully useful a forecast should carry with it a trustworthy indication of just how much uncertainty does attach to $1 t . "$ Providing such an Indication "s a difficult task. It has been attempted, however, using some of the concepts that underlle a forecasting technique called "cross-impact analysis." Some notes on cross-impact analys is are given in Apsendix 18-1.

The first questionnaire concerned types of "event" that are likely to affect alternative fuels for NHT systems:

(1) The time-frame in which world crude oll production is expected to peak.

(2) The expected "pattern" of change in the price of crude 011 during the period 1980 to 2000.

(3) The expected priorities for curtaliment of petroleum consumption at the time a peaking of production, occurs.

Each of the above "events" is extrinsic or exogenous to NHT systems per se. The main purposes of the subjective forecasts are to:

- Suggest the range of uncertainty that exists today with respect to some of the factors ilkely to affect the future development of alternate fuels and NHT systems. (Put differently, if it were possible to define each of these factors with certainty then, instead of a "baseline case," it would be possibie to define a highly probable case.)

- Show how the change of a single key assumption (simulated in the second questionnaire as assumed events) can lead to significant changes in the perceived probabllities of other events.

The two questionnalres used to generate estimates of subjective and conditional probabilities are reproduced in Appendix 18-2. The questionnaires were pretested by a small group of Exxon Research(ER) employees, and were then modified to remove ambigulties in wording. The revised questionnaires were then submitted to another group of ER employees and responses were also obtained from a group assembled by the DOE project monitor.

The detalled results of the questionnaires are reported in Appendix 18-3, while key findings are discussed below. 


\subsection{Pattern of Responses}

Experimental evidence was obtained that there is considerable uncertainty about "energy futures" when measured by individual perceptions. Specific inferences, or tentative conclusions, are:

(1) Patterns of response by the ER and DOE groups were very similar.

(2) There were considerable differences in response within each group. These differences are attributable to different assumptions made by individuals.

(3) Polarized projections were made for value-laden issues such as curtailment priority of fuel use for personal automobiles. The same polarization was observed in both ER and DOE groups.

(4) Some individuals in each group had difficulty with probabilistic forecasting.

(5) In spite of the pretest, some ambiguities in wording of questions and instructions remained in the questionnaires. Even the silghtest ambiguity leads to misunderstandings.

(6) The ER group's responses appeared to weight correlation or association as much or more than causation (in the estimation of conditional probabilities). The DOE group appeared to be concerned primarily with causation. This was the only matter for which a materlal difference was observed between the two groups.

\subsection{Discussion and Interpretation of Experimental Results}

The first questionnaire contained three sets of questions ("A", "B", and "C"). The "A" and "B" sets required subjective estimates of probability with respect to the time-frame in which world crude oil production is expected to peak and the pattern of change in the world price of crude oil during the period 1980 to 2000. The "C" set of questions required a rank ordering of curtaliment priorities for six different uses of petroleum in the event of a limitation of crude oll supply. The " $C$ " questions were posed in terms of the respondents" expectations of what would (not should) occur. The second questionnaire used the " $A$ " and " $C$ " questions in the form of a cross-impact matrix. Each of the questions, in turn, was assumed to be an "event". The respondents were asked to estimate the impact of each of these "events" on the other activities in the matrix, and were asked to do this by estimating whether a particular event $(P=1)$ would significantly change the estimate given in response to the first questionnalre. Put differently, the task was to judge whether the conditional probabilities were significantly different from the pertinent subjective probabilities estimated previously. 
The purpose of these questionnalres was not to generate al ternative projections of energy futures. The purposes were to illustrate:

(1) the range of uncertainty that exists (among eneryy technologists) about energy futures.

(2) that plausible* changes of assumption regarding a given possibility can affect the probabilities estimated for other events.

(3) that inferences may be derived from such indications of uncertainty.

Combination of all responses* to the first questionnaire gives the following results for the " $A$ " set of questions:

\begin{tabular}{llc} 
& $\begin{array}{c}\text { Peaking of World } \\
\text { Crude OiI Production }\end{array}$ & \multicolumn{2}{c}{$\begin{array}{c}\text { P Probability Estimated } \\
\text { By All Respondents }\end{array}$} \\
B-1 & before 1985 & 7 \\
A-2 & between 1985 and 1990 & 25 \\
A-3 & between 1990 and 2000 & 42 \\
A-4 & after year 2000 & 26
\end{tabular}

The estimates imply a "greatest probability" around 1995, which is close to several published expectations. However, the probability distribution is very flat, and approximates a $4 \%$ probability of a peak in any year after 1985. This view reflects considerable uncertainty and is not typical of published expectations.

Similarly, combination of all responses to the "B" set of questions gives the following picture:

Pattern of World Oil Prices During Period 1980-2000

B-1 no price increase in constant dollars

B-2 smooth exponential increased in real terms

B-3 one or more discontinuous, but sharp, increases in real terms

B-4 relatively small but steady increases

to 1990, followed by sharper increases

to 2000
\% Probability Estimated by All Respondents

8
19
32

32

41

\footnotetext{
*At the time of writing this report, the Administration has just published its proposed contingency plans for allocating crude oil in the event of continued curtailment of ofl exports from Iran. Related plans for gasoline rationing are being developed (New York Times, 1/12/79).

* 21 responses from ER personnel and 10 responses from the DOE/outside group.
} 
Most published forecasts make assumptions equivalent to $B-1$ or B-2, or use these assumptions to represent two different cases. Respondents to the questionnaire assigned relatively low probabilities to $B-1$ and $B-2$ and higher probabllities for more turbulent price behavior -again interpretable as a higher level of both qualitative and quantitative uncertainty than is portrayed in most published forecasts. The latter tend to focus on quantification in terms of energy resources rather than on the possible behavior of the energy system. In fact, the perceptions of the respondents to the questionnaires may be compatible with the quantitative projections. However, their format and focus is different thereby making it possible to derive different implications. A comnon orientation of the quantitative projections is toward supply planning, whereas the indications of uncertainty may be conceived as inputs to contingency or strategic planning especially in relation of $R \& D$.

The "C" set of questions is not to be found in published form (where supply and demand are hypothetically balanced). The combined responses may be grouped into three categories of "curtaflment priority in the event of an actual shortage of petroleum". The rating scale used by individuals ran from 1 (highest priorlty) to 6 (lowest priority):

\begin{tabular}{llc}
\multicolumn{2}{c}{ Fuel Use Curtalled } & Group Rating \\
\hline $\mathrm{C}-2$ & personal auto & 2.4 \\
$\mathrm{C}-1$ & afr travel & 2.9 \\
$\mathrm{C}-4$ & industrial fuel ofl & 3.0 \\
$\mathrm{C}-5$ & chem. feedstock & 3.8 \\
$\mathrm{C}-6$ & marine fuel & 3.9 \\
$\mathrm{C}-3$ & home heating ofl & 4.9
\end{tabular}

For the two non-highway transportation modes represented, air travel was judged more likely to be curtalled than marlne fuel use. The rating of 2.9 for air travel is not significantly different from the 3.0 rating for industrial fuel oil. It may be noted that an approach to curtailment of the use of Industrial fuel ofl is present in the Powerplant and Industrial Fuel Use Act of 1978*.

The dispersion of the curtallment priority ratings by the individual respondents is illustrated in figure 18-1. The pooled ratings, from 2.4 for $C-2$ (personal auto) to 4.9 for home heating ofl (C-3) are repeated on the center, horizontal scale. For each petroleum use, there is a dashed, vertical i ine that connects numbers in parenthesis. Each of these numbers** denotes the number of respondents who assigned the pertinent curtailment priority (in left hand vertical scale) to the particular fuel use. For example, it may be seen that 18 (or 58\%) of the respondents assigned the lowest curtallment priority to home heating 011 , while 17 (or 55\%) of the respondents assigned the highest curtaliment priority to personal auto use. Similarity of response is evident for air travel

*One of the five bills comprising the National Energy Act of 1978. **Multiplying any of these numbers by 3.2 converts them to a percentage response. 
THIS PAGE

\section{WAS INTENTIONALLY LEFT BLANK}


and industrial fuel 011 , and also for chemical feedstock and marine fuel. It is apparent that the respondents made different assumptions when they were estimating priorities. It would be very interesting to know what these assumptions were, but such investigation was beyond the scope of the present study.

The second questionnalre had the format of a cross-impact matrix, and respondents were asked to judge whether the conditional probabilities resulting from assumed events were significantly different from the pertinent subjective probabilities estimated previously. About $45 \%$ of the responses fell into this category. For 13 out of 60 positions in the matrix, the conditional responses of the DOE group differed from those of the ER group. Avallable evidence does not permit more than an (unconfirmed) hypothesis that the ER group's responses may have attached as much, or more, importance to association as to causation, while the DOE group appeared to be concerned primarlly with causation. For example, on the average:

- the ER group may have felt that something as serfous (in an economic or social sense) as the curtailment of air travel would not occur unless world oll production had peaked or was expected to do so imminently.

- the DOE group may have felt that curtallment of air travel would avert or postpone the peaking of world oll production.

It is believed that the assumptions made by individuals concerning energy futures and prlorities are important to the resolution of institutional probiems. Different assumptions lead to differing perceptions of priority. It may be difficult to resolve conflicts in priority without first identifying and trying to resolve the differing assumptions that underlie the conflicts.

The limited scope of the experiment did not permit identification of the assumptions used by the participants. Any future work should include the identification and, if possible, the interactive discussion of key subjective assumptions.

If credence is given to the degree of uncertainty manifest in the responses to the two questionnalres, then some tentative inferences may be drawn for technology development. For example, there may be considerable risk in acting upon a direct and precise answer to the question: "when will Technology ' $X$ ' be economically competitive with current technology?" since, by analogy with the "A" set of estimated probabilities, "when" may occur at any time during the next several decades -- due to the impact of exogenous events, rather than because of quantitatively predictable changes in the relative costs of Technology " $X$ " and the existing technology that " $X$ " is intended to replace. A principal alternative to looking for certainty where it may not exist, is to develop contingency plans that will "fall safe" under a varlety of different assumptions. In this approach, the assumptions, which model different uncertainties, are combined into different scenarios. It is then possible to assess a given technology not only in relation to an individual scenarlo but also with respect to a group of scenarios that encompass a wide range of future possibllities. 
NOTES ON CROSS-IMPACT ANALYSIS

The concept of cross-impact analysis as a forecasting technique and the use of a cross-impact matrix were formalized just over a decade ago. The inventors, Theodore J. Gordon and Olaf Helmer, devised the technique to overcome an objection to their earlier "Delphi" method of using panels of experts to make projections about future events. The Delphi technique required the panelists to concentrate on onf event at a time. Hence, the panelists were not able to take into account possible interactions among the events they were forecasting. Cross-impact analysis permitted the subjective probability estimates (of Delphi) to be modified, subsequently, by estimates of conditional probability. However, the use of a cross-impact matrix is not limited to being an "add on" to Deiphi forecasting. In fact, it can be applied to consideration of the interactions among future "events", without regard to the source of the forecast. Martino observes that cross-impact analysis "is likely to be even more valuable when the forecasts have been obtained from several sources, since it is less likely that interactions (among the forecasts) were taken into account by the different sources", f.e. that a partial, but unstructured, cross-impact analys is has already occurred.

Because of its application to decision-making under uncertainty and because there is a rather general perception that uncertainty about the future is increasing, the techniques of cross-impact analysis are under rapid development and now inciude adjuncts such as trend impact analys is (TIA) and probabilistic system dynamics, (PSD).

It is generally, but not universally, accepted that the utility of forecasts is more important than their precision, especially when the purpose of the forecast is to guide current decisions. A realistic goal is to seek comparative advantage rather than perfection.

A review of futures research and forecasting techniques is outside the scope of this study. However, a few pertinent citations are made below; their source will be apparent from the abbreviated bibliography that follows.

\section{Citation \#1}

"A cross-impacting forecasting approach takes into account the mutual impacts of different events or trends. . . There are four kinds of cross-impacts that should be distinguished:

(1) Time series or trends may interact...

(2) The probabilities of different unique events may interact. For example, development of cheap fusion power may preclude the development of cheap geothermal power. 
(3) Events may impact trends.

(4) Trends may affect the probabilities of events."

\section{C1tation \#2}

"Temporal order effects may also be significant; which of two events occurs first may be all-1mportant in determining the impact on a third event or on some trend."

Citation \#3

"Forecasting is rarely an end in itself. Rather it is usually a means to an end, and that end is typically a correct decision, whose achievement is to be facilitated by the forecast. Note: The decision is normally in the present, at the time that the users or consumers of the forecast receive or consider the forecast."

Citation \#4

"Let us start with a few observations and assumptions about the nature of futures research:

(1) It is utility-oriented. . .

(2) It is intrinsically global in approach. .

(3) Blas is inevitable. .

(4) Bias is desirable. .

(5) Dissemination of futures research affects the future. .

(6) Resistance plays a role in acceptance of results. . ."

Citation \#5

"The various futures must not all be minor variations of a single theme, nor should the deck be stacked by the inclusion of only one 'preferred ' future and several totally unacceptable alternatives."

\section{Citation \#6}

"Rellance on the intultive judgment of experts thus is not just a temporary expedient but a necessary ingredient of futures research, becuase they are needed in all phases of the effort. They are called upon (1) to supply judgmental data about the future, based on their intuitive, though often theoretically unstructured, insights into real-world phenomena; (2)..."

\section{Citation \#7}

"A sizeable number of the respondents believe that the only sensible way of trying to improve forecasting is by trying to forecast." 
Abbrevlated Bibliography

(1) T. J. Gordon and H. Hayward, "Initfal Experiments with the Cross-Impact Matrix Method of Forecasting," Futures, December 1968, pp 100-116.

(2) T. j. Gordon, "Cross-Impact Matrices," Futures, December 1969, Pp 427431.

(3) Murray Turoff, "An Alternative Approach to Cross-Impact Analysis," Technological Forecasting and Social Change, 1972, No. 3, Pp 309-339.

(4) Joseph P. Martino, "Technological Forecasting for Decision Making," Edsevier, New York, 1975, p 272.

(5) Wayne 1. Boucher, editor, "The Study of the Future: An Agenda for Research," prepared with the support of the National Sclence Foundation;, copyright by The Futures Institute, Inc., 1977.*

The following references are a part of (5) above; tftles of the papers from which citations were taken are ifsted below:

Citation \#1: Herbert Gerjuoy, "A New Perspective on Forecasting Methodology,". Chapter 2, page 21.

Cltation \#2: ibid, page. 22.

Citation \#3: ibid, page 31.

Citation, 4: Willis W. Harman, "On Normative Forecasting," pp 76-77.

C1tation \#5: Joseph P. Martino, "Forecasting and its Impact on PolicyMaking," page 119.

Citation \#6: Olaf Helmer, "An Agenda. for Futures Research," page 245.

Cltation \#7: Wayne I: Boucher and John V. Helb, "Results from the Survey of Current Forecasting Efforts,", page 280.

*Reproduction in whole or part permitted for any purpose of the U.S. Government. 
APPENDIX 18-2.

QUESTIONNAIRES USED IN FORECASTING EXPERIMENT 
ALTERNATIVE ENERGY SOURCES FOR NON-HIGHWAY TRANSPORTATION

- We are seeking your help with an alternate fuels study we are making for DOE.

- We need answers to 2 short questionnaires. Pre-testing suggests that about 30 minutes of your time will be needed. Each questionnafre has a "code number"; your individual responses will be kept confidential.

- Base case projections have already been made. The purpose of the questionnaires is to explore some al ternative assumptions. Your responses will help us to scope these alternatives.

- The first questionnaire has a Delphi format (but there wili be no iterations of the questionnaire as in a standard Delphi forecast). Your individual (subjectlve) estimates are wanted. Please complete the first questionnatre before tackling the second.

- The second questionnaire has the format of the "first round" of a crossimpact analysis. (There will be no iterations.) 
This question concerns the future production of crude 011. Some of the possibilities that have been suggested are:

A-1: World crude oil production will peak before 1985.

A-2: World crude oll production will peak between 1985 and 1990.

A-3: World crude oil production will peak between 1990 and 2000.

A-4: World crude oll production will peak after 2000.

- Please estimate these possibilities as percentage probabilities (which should add to 100).

- Please place an * next to your probability estimate if you belleve that : peaking will occur as the consequence of producer actions rather than. physical (resource) iimitations.

\begin{tabular}{|l|}
\hline Your Estimates \\
\hline$A-1=$ \\
$A-2=$ \\
$A-3=$ \\
$A-4=\frac{}{100}$ \\
\hline
\end{tabular}


Question "B"

This question concerns the pattern of future world oil prices during the period 1980 to 2000.

Possibllities that have been suggested are:

B-1: No price increase relative to general inflation, 1.e. no increase in "constant dollars per barrel".

B-2: A price increase pattern that approximates $x \%$ per year, 1.e. a "smooth" exponential increase in real terms.

B-3: One or more discontinuous but sharp price increases in real terms.

B-4: Relatively small but steady price increases during the period 1980 to 1990, followed by sharper increases during the period 1990 to 2000 .

- Please estimate these possibflities as percentage probabilities.

\begin{tabular}{|l|}
\hline Your Estimates \\
\hline$B-1=$ \\
$B-2=$ \\
$B-3=$ \\
$B-4=$ \\
\hline
\end{tabular}

- If none of the above possibilities comes close to your expectation, please describe this expectation as brlefly as you can: 
Question "C"

This question makes the assumption that the U.S. will experience a shortage of petroleum at some time in the future, and that the shortage will be more than transitory, e.g. at the time it occurs there will be a general perception that the shortage will last for at least a year.

Under conditions of actual shortage, some uses of petroleum would have to be curtalled (not ellminated, but reduced in extent).

- Regardiess of the mechanisms by which curtaliment might be achleved, please rank order* what you judge the curtailment priorities would be for the following uses of petroleum liquids:

C-1: Air travel

C-2: Personal automoblie use

C-3: Domestic heating ofl use

C-4: Industrial fuel ofl use

C-5: Chemical feedstock use (of petroleum liquids)

C-6: Marine bunker and marine diesel fuel use

\begin{tabular}{|l|}
\hline Your Estimates \\
\hline$C-1=$ \\
$C-2=$ \\
$C-3=$ \\
$C-4=$ \\
$c-5=$ \\
$C-6=$ \\
\hline
\end{tabular}

$\star 1$ = highest priority or most likely to be curtalled.

$\sigma$ = lowest priority or least likely to be curtalled. 
Questionnaitre No. 2

Cross-Impact Analys is

- This questionnaire has the format of a "cross-impact" matrix.

- The task is to estimate the impact of assumed events on other Items in the matrix. For this purpose, each of the items in the top horizontal row $(A-1$ to $A-4$, and $C-1$ to $C-6)$, is to be considered separately as a future event. Then, the subsequent impact of this assumed event on each of the items in the vertical column under the event is to be estimated.

- Because an event could not change what had already taken place, some "boxes" in the matrix are not meaningful and have been blacked out.

- You may find it easier to complete the matrix if you have your answers to the " $A$ " and " $C$ " questions of Questionnatre No. I In front of you. The vertical column at the left of the matrix provides space for your answers.

- The required estimate is of how you judge the assumed event would change the probabilities that you have already estimated in Questionnaire No. 1.

$\boxplus$ If you judge that the occurrence of the assumed event would increase a previously estimated probability, put a + in the pertinent box of the matrix. (please do this even if you do not belfeve the event is likely.)

$\rightarrow$ If you judge an event would decrease a previously estimated probability, put a - in the pertinent box.

0 If you feel that a given event would have little or no impact on your previously estimated probability, put a 0 in the box.

四 If the question is unclear or, for any reason, you do not wish to answer $1 t$, put an $N$ in the box. 


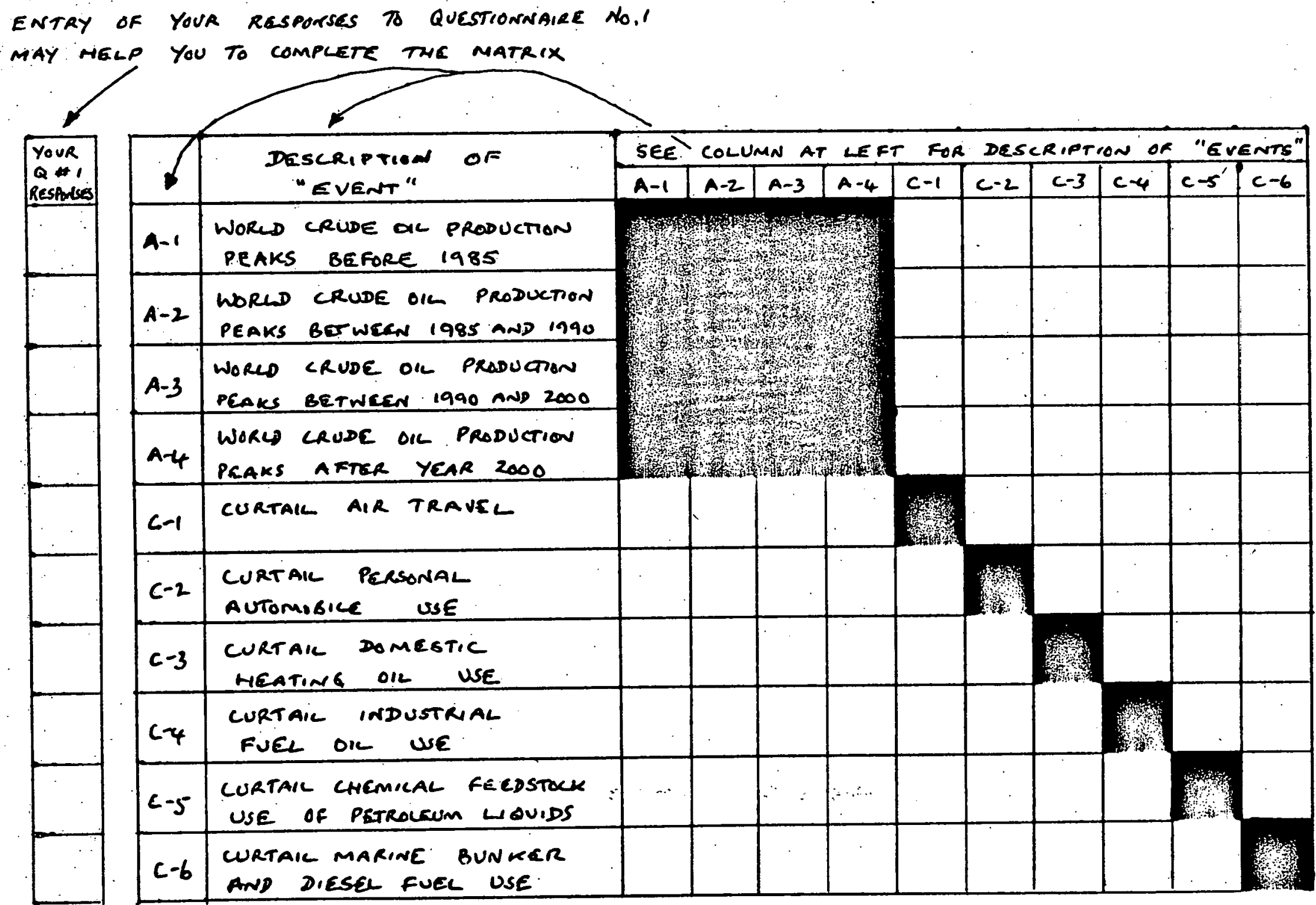


RESULTS OF DELPHI-TYPE AND CROSS-IMPACT TYPE QUESTIONNAIRES

1. Introductio:

A pre-test of the questionnaires in Appendix 18-2 was given to eight professional staff at Linden*. These individuals have considerable experience with the development of energy technology but not, in general, with probabilistic forecasting techniques. The principal purpose of the pre-test was to find out what needed to be changed in the questionnalres in order to reduce ambiguity and to make them more useful as tools of inquiry. As a result of the pre-test:

- minor changes of wording were made to Questionnatre No. 1 to reduce ambiguity.

- drastic simplification of Questionnaire No. 2 was made to reduce its complexity and ambiguity.

\section{Results of Pre-Tests of Questionnaires}

Even with its imperfectlons, the pre-test of Questionnaire No. 1 indicated a wide divergence of views about "energy futures" among a group of individuals who, by many conventional measures, might be regarded as similar. The divergence was most evident when the response involved personal attitudes or values, e.g. toward curtallment priorities in the event of a petroleum shortage. The results are reported in Table 18-1, and are summarized below:

- relatively low probabilitles were estimated for a peaking of world ofl production before $1985(7 \%)$ or after the year $2000(14 \%)$. The majority felt that a producer peak (as distinct from a physical producibility ifmit) would occur between 1985 and 2000 .

- relatively low probabilities were estimated for constant dollar world oll prices (11\%) or smooth "x\% per year" increases (22\%) during the perfod 1980 to 2000 . Opinion was divided between sharp, discontinuous increases (31\%) and small increases prior to 1990 followed by sharper increases thereafter $(36 \%)$.

- curtallment priorities fell into three groups:

(1) highest priority: air travel (2.5), personal automobile use (2.7), and industrlal fuel ofl (2.8); no statistically significant difference among these ratings.

(2) medium priority: chemical feedstock (3.9) and marine fuel (4.0).

(3) lowest priority: home heating ofl (5.0).

*seven of these individuals were employees of the Government Research Laboratories of Exxon Research and Engineering Company; the elghth while not a, GRL professlonal, was engaged in government contract work. 
TABLE 18-7

PRE-TEST RESPONSES TO QUESTIONNAIRE NO. 1

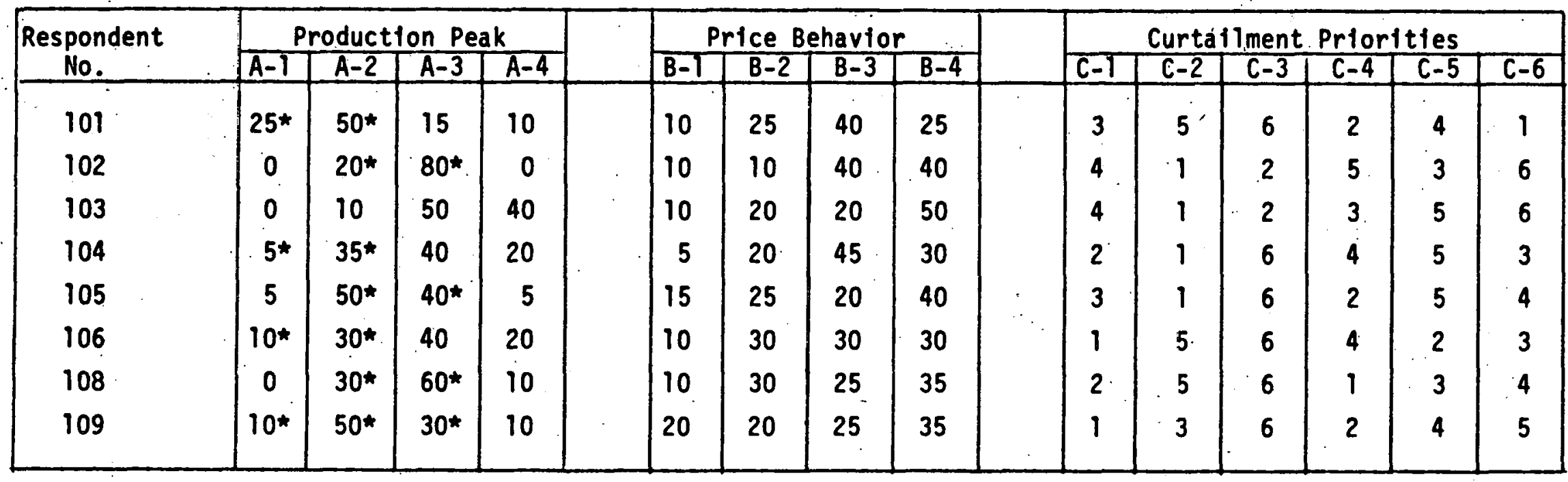

\begin{tabular}{|c|c|c|c|c|c|c|c|c|c|c|c|c|c|c|}
\hline Range & $\begin{array}{r}0 \\
25\end{array}$ & $\begin{array}{l}10 \\
50\end{array}$ & $\begin{array}{l}15 \\
80\end{array}$ & $\begin{array}{r}0 \\
40\end{array}$ & $\begin{array}{r}5 \\
15\end{array}$ & $\begin{array}{l}10 \\
30\end{array}$ & $\begin{array}{l}20 \\
45\end{array}$ & $\begin{array}{l}25 \\
50\end{array}$ & $\begin{array}{l}1 \\
4\end{array}$ & $\begin{array}{l}1 \\
5\end{array}$ & $\begin{array}{l}2 \\
6\end{array}$ & $\begin{array}{l}1 \\
5\end{array}$ & $\begin{array}{r}2 \\
5\end{array}$ & $\begin{array}{l}1 \\
6\end{array}$ \\
\hline Mean & 7 & 34 & 45 & 14 & 11 & 22 & 31 & 36 & 2.5 & 2.7 & 5.0 & 2.8 & 3.9 & 4.0 \\
\hline
\end{tabular}


The pre-test responses to Questionnaire No. 2* are not recorded because, in its original form, it did not yield valid results.

3. Results of Questionnaire No. 1

A group of thirteen professionalstk participated in the (revised) tests. The professional experience of these individuals was very similar to that of the pre-test group. Responses are reported in Table 18-2, and are summarized below:

- relatively low probabilitles were estimated for a peaking of world oll production before $1985(7 \%)$ or in the period 1985 to $1990(18 \%)$. The estimated $75 \%$ probabllity of a post-1990 peak was divided into (a) between 1990 and 2000 $(41 \%)$ and (b) after $2000(34 \%)$.

- unlike the pre-test group, few individuals expected a producer peak instead of a producibllity limitation.

- the response pattern to the price behavior questions was virtually identical to that of the pre-test group.

- curtallment priorities could be arranged into three groups, but it is not clear whether air travel should be in the highest priority or the medium priority group:

(1) highest priority: personal automoblie use (2.4), industrial fuel ofl (2.8) and, possibly, air travel (3.2).

(2) medium priority: marine fuel (3.6) and chemical feeds tock $(4.0)$.

(3) lowest priority: home heating ofl (5.0). in Table 18-3.

A comparison of the pre-test and test responses is given

For the "A" (production peak) and "B" (price behavior) questions both the dispersion of the Individual responses and the group means are not surprising. "Moreover, the fact that some questions were silghtly reworded preciudes a precise compartson of the pre-test and subsequent test responses. Nevertheless, the degree of certainty expressed in some answers. is worth noting:

- In the pre-test, three individuals estimated zero probability of a peak in world crude ofl production (even by a producer IImitation) before 1985. One of these individuals also estimated a zero probability of a peak after the year 2000 .

Which differed in form and content from the simplified version in Appendix 18-2.

**dffferent individuals, but also drawn primarliy from ERE's Government Research Laboratories. 
TABLE 18-2

TEST RESPONSES TO QUESTIONNAIRE NO. 1

\begin{tabular}{|c|c|c|c|c|c|c|c|c|c|c|c|c|c|c|}
\hline \multirow{2}{*}{$\begin{array}{l}\text { Respondent } \\
\text { No. }\end{array}$} & \multicolumn{4}{|c|}{ Production Peak } & \multicolumn{4}{|c|}{ Price Behavtor } & \multicolumn{6}{|c|}{ Curtallment Priorities } \\
\hline & $A-1$ & $A-2$ & $A-3$ & $A-4$ & $B-1$ & $\overline{B-2}$ & $B-3$ & $\mathrm{~B}-4$ & $c-1$ & $c-2$ & $c-3$ & $c-4$ & $c-5$ & $C-6$ \\
\hline 200 & 10 & 30 & 40 & 20 & 20 & 40 & 20 & 20 & 4 & 6 & 5 & 1 & 3 & 2 \\
\hline 201 & 10 & 20 & 50 & 20 & 5 & 30 & 15 & 50 & 5 & 1 & 2 & 3 & 6 & 4 \\
\hline 202 & 10 & 30 & 50 & 10 & 20 & 10 & 50 & 20 & 2 & 1 & 6 & 4 & 3 & 5 \\
\hline 203 & 25 & 50 & 20 & 5 & 5 & 35 & 10 & 50 & 4 & 2 & 6 & 1 & 3 & 5 \\
\hline 204 & 5 & 10 & $50^{\star}$ & $35^{\star}$ & 5 & .15 & 45 & $25^{\phi}$ & 2 & 1 & 6 & 4 & 5 & 3 \\
\hline 205 & 0 & 10 & 40 & 50 & 0 & 40 & 30 & 30 & 2 & 1 & 3 & 4 & 5 & 6 \\
\hline 206 & 5 & 10 & 80 & 5 & 0 & 10 & 10 & 80 & 2 & 1 & 6 & 4 & 5 & 3 \\
\hline 207 & 0 & 10 & 40 & 50 & 5 & 20 & 45 & 30 & 5 & 6 & 4 & 2 & 3 & 1 \\
\hline 208 & 10 & 20 & 30 & 40 & 10 & 40 & 20 & 30 & 1 & 3 & 6 & 5 & 4 & 2 \\
\hline 209 & 0 & 25 & 50 & 25 & 0 & 0 & 25 & 75 & 3 & 1 & 6 & 2 & 5 & 4 \\
\hline 210 & 10 & 20 & 50 & 20 & 10 & 10 & 40 & 40 & 4 & 6 & 5 & 2 & 3 & 1 \\
\hline 211 & 0 & 5 & 10 & $85^{\star}$ & 5 & 5 & 85 & 5 & 5 & 1 & 4 & 2 & 3 & 6 \\
\hline 212 & 0 & 0 & $20^{*}$ & 80 & 0 & 20 & 30 & 50 & 2 & 1 & 6 & 3 & 4 & 5 \\
\hline
\end{tabular}

\begin{tabular}{|l|r|r|r|r|r|r|r|r|r|r|r|r|r|r|r|r|}
\hline Range & $\begin{array}{r}0 \\
25\end{array}$ & $\begin{array}{r}10 \\
50\end{array}$ & 80 & 85 & & $\begin{array}{r}0 \\
20\end{array}$ & $\begin{array}{r}0 \\
40\end{array}$ & $\begin{array}{r}10 \\
85\end{array}$ & $\begin{array}{r}5 \\
80\end{array}$ & & 5 & 6 & 6 & 5 & 6 & 6 \\
\hline Mean & 7 & 18 & 41 & 34 & & 7 & 21 & 33 & 39 & & 3.2 & 2.4 & 5.0 & 2.8 & 4.0 & 3.6 \\
\hline
\end{tabular}

DThts set of responses adds to $90 \%$. 
TABLE 18-3

COMPARISON OF GROUP MEAN RESPONSES TO QUESTIONNAIRE NO. 1

World crude ofl production w1ll -

A-1 - peak before 1985

A-2 - peak between 1985 and 1990

A-3 - peak between 1990 and 2000

A-4 - peak a fter 2000

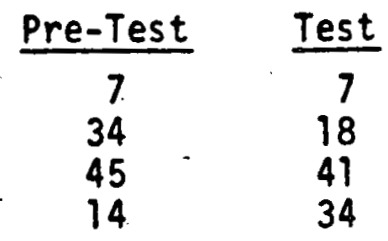

Pattern of world oil prices during period

1980 - 2000:

B-1 no increase in constant dollars per barrel

B-2 smooth exponential, annual increase

B-3 one or more discontinuous but sharp price increases

B-4 relatively small and steady to 1990; sharper Increases $1990-2000$

Expectations other than $B-1, B-2, B-3$ or $B-4$

11

22

31

36

nit

7

21

33

39

nit

Curtailment priorities* $(1=$ most likely. to be curtalled)

C-1 atr travel

C-2 personal automobile use

$\mathrm{C}-3$ domestic heating ofl use

C-4 industrial fuel ofl use

C-5. chemical feedstock use (of petroleum 1 iquids)

C-6 marine bunker and martne diesel fuel use

* in the event of an oll shortage and a general perception that the shortage will last for at least a year. 
- In the subsequent test, five individuals (aimost $40 \%$ of the group) estimated a zero probability of a peak before 1985. One of these individuals also estimated a zero probabllity of a peak before 1990. Three of these same individuals and one other saw no possibility of world crude oil prices remining stable in constant dollars during the period 198:) to 2000.

Nevertheless, most individuals in both groups made estimates that indicated considerable uncertainty about the future.

Analytically, the most interesting responses were given to the "C" questions (curtaflment prioritles), which require value judgments to be made. The pre-test group gave a polarized response to the curtailment priority for personal automobile use:

- 4 respondents estimated a "I" (highest priority)

- I respondent estimated a " 3 "

- 3 respondents estimated a "5" (next to lowest priority)

The polarization was even more marked in the responses of the subsequent test group:

- 8 respondents estimated a "l" (highest priority)

- I respondent estimated a " 2 "

- I respondent estimated a "3"

- 3 respondents estimated a "6" (lowest priority)

It is apparent that the respondents made different assumptions when they were estimating priorities. It would be very interesting to know what these assumptions were. Such investigation was beyond the scope of the present study.

\section{Additional Testing of Questionnaire Non 1}

It was recognized that additional insight might be provided If responses were obtained from non-Exxon Research employees. Accordingly, the DOE Project officer arranged for the questionnaires to be submitted to several DOE employees and to an outside group. The ten responses so obtained are recorded in Table 18-4, which also repeats the mean responses of the ER test group. The responses of the DOE/outside group may be summartzed:

- low probabilities were estimated for a peaking of world crude 011 production before $1985(8 \%)$ or in the perfod 1985 to 1990 $(25 \%)$. The estimated $67 \%$ probabllity of a post-1990 peak was divided into (a) between 1990 and 2000 (41\%) and (b) after 2000 (26\%). This pattern of response was simflar to that of the ER test group.

- one individual felt that the peak in production would be induced by high prices, 1.e. by a peaking of demand.

- the price behavior responses were very similar to those of the ER test group. 
TABLE 18-4

DOE AND OUTSIDE GROUP RESPONSES TO QUESTIONNAIRE NO. 1

\begin{tabular}{|c|c|c|c|c|c|c|c|c|c|c|c|c|c|c|}
\hline \multirow{2}{*}{$\begin{array}{c}\text { Respondent } \\
\text { No. }\end{array}$} & \multicolumn{4}{|c|}{ Production Peak } & \multicolumn{4}{|c|}{ Price Behavtor } & \multicolumn{6}{|c|}{ Curtailment Priorfties } \\
\hline & $A-1$ & $A-2$ & $A-3$ & $A-4$ & $B-1$ & $B-2$ & $\mathrm{~B}-3$ & $B-4$ & $c-1$ & $c-2$ & $c-3$ & $c-4$ & $c-5$ & $C-6$ \\
\hline 2102 & 0 & 10 & 50 & 40 & 0 & 0 & 60 & 40 & 2 & 1 & 6 & 4 & 5 & 3 \\
\hline 2104 & 0 & 25 & 45 & 30 & 0 & 30 & 0. & 70 & 4. & 1 & 5 & 2 & 3 & 6 \\
\hline 2105 & 10 & 20 & 50 & 20 & 10 & 25 & 40 & 25 & 1 & 2 & 6 & 3 & 5 & 4 \\
\hline 2106 & 5 & 5 & 10 & 80 & 2 & 3 & 20 & 75 & 4 & 5 & 6 & 2 & 1 & 3 \\
\hline$\times 210$ & $5^{*}$ & $35^{\star}$ & $30^{*}$ & 30 & 5 & 10 & $37^{\varnothing}$ & $48^{\varnothing}$ & 4 & 3 & 5 & 1 & 2 & 6 \\
\hline$\times 211$ & 10 & 25 & 60 & 5 & 10 & 10 & 70 & 10 & 5 & 1 & 2. & 3 & 4 & 6 \\
\hline$\times 212$ & 12 & 30 & 45 & 13 & 10 & 15 & 40 & 35 & 2 & 1 & 6 & 3 & 4 & 5 \\
\hline$\times 220$ & 10 & 50 & 40 & 0 & 20 & 0 & 10 & 70. & 1 & 5 & 6 & 4 & 2 & 3 \\
\hline$\times 221$ & 5 & 20 & 45 & 30 & 20 & 20 & 20 & 40 & 1 & 2. & 3 & 6 & 5 & 4 \\
\hline X222 & 20 & 30 & $40 *$ & 10 & 0 & 30 & 20. & 50 & 6 & 1 & 2 & 5 & 4 & 3 \\
\hline
\end{tabular}

\begin{tabular}{|c|c|c|c|c|c|c|c|c|c|c|c|c|c|c|}
\hline Range & $\begin{array}{r}0 \\
20\end{array}$ & $\begin{array}{r}5 \\
50\end{array}$ & $\begin{array}{l}10 \\
60\end{array}$ & $\begin{array}{r}0 \\
80\end{array}$ & $\begin{array}{r}0 \\
20\end{array}$ & $\begin{array}{r}0 \\
30\end{array}$ & $\begin{array}{r}0 \\
70\end{array}$ & $\begin{array}{l}10 \\
70\end{array}$ & $\begin{array}{l}1 \\
6\end{array}$ & $\begin{array}{l}1 \\
5\end{array}$ & $\begin{array}{l}2 \\
6\end{array}$ & $\begin{array}{l}1 \\
6\end{array}$ & $\begin{array}{l}1 \\
5\end{array}$ & $\begin{array}{l}3 \\
6\end{array}$ \\
\hline Mean & 8 & 25 & 41 & 26 & 8 & 14 & 32 & 46 & 3.0 & 2.2 & 4.7 & 3.3 & $3: 5$ & 4.3 \\
\hline
\end{tabular}

ER Test Group

$\begin{array}{lllll}\text { Meand } & & & & \end{array}$

$7.21 \quad .33 \quad 39$

$3.2 \quad 2.4$

$\begin{array}{llll}5.0 & 2.8 & 4.0 & 3.6\end{array}$

This respondent assigned a $20 \%$ probabtlity to B-3, $30 \%$ to $B-4$, and $35 \%$ to a combination of $B-3$ and $B-4$. For the purpose of Table 4 , the $35 \%$ probabllity of the comblnation was divided between B-3 and B-4.

drom final column of Table 3 . 
- curtallment priorities could again be arranged into three groups:

(1) highest priority: personal automobile (2.2), and air travel $(3.0)$.

(2) medium priority: Industrial fuel ofl (3.3), chemical feedstock (3.5) and marine fuel (4.3).

(3) lowest priority: home heating ofl (4.7).

- the polarization of the responses to certain questions was similar to that of the ER groups.

When the curtailment priorities of all respondents (both ER groups and the DOE/outside group) are aggregated, there is a further validation of the observation of clustering into three categories:

(1) highest curtafiment priority: personal automobile (2.4), air travel (2.9), and industrial fuel ofl (3.0).

(2) medium priority: chemical feedstock (3.8) and marine fuel (3.9).

(3) lowest priority: home heating oil (4.9).

Perhaps the most interesting set of responses were those given to question C-2 (curtaliment priority for personal automobile use). In each of the three responding groups, at least half assigned the highest curtailment priority to personal automobile use while one quarter of each group assigned the lowest curtaflment priority to this fuel use. When all responses are aggregated, the polarized result is:

highest or next highest curtailment priority medium priority

\begin{tabular}{c}
$\%$ \\
\hline 64 \\
10 \\
26
\end{tabular}

5. Results of Questionnatre No. 2

Eleven of the thirteen ER respondents to the first questionnaire also responded to the cross-impact questions in the second questionnaire. One of the non-respondents objected to the concept of conditional probability. The other non-respondent felt that the questions were unanswerable without prior specification of the time of occurrence of a particular event (e.g. curtallment of industrlal fuel ofl use). All ten DOE/other group participants responded to the second questionnaire, but one of the responses was fragmentary. Another respondent was concerned about prior specification of time of occurrence.

The task involved the estimation of conditional probabllities (i.e. the probability of event El occurring, given the occurrence of event $\left.E_{2}\right)$. Separately, each $E_{2}$ event was assumed to occur $(P=1)$. and the task was to estimate whether its occurrence would increase $(t)$, not significantly affect $(0)$, or decrease $(-)$ the pertinent probabilities previously estimated in the first questionnaire. 
The responses of the ER group are summarized in Tables 18-5 and 18-7. while the DOE/outside group's responses are given in Tables 18-6 and 18.-8. Several general points will be made before discussing and comparing the responses of the two test groups:

- while there are no unfquely correct responses (to e1 her of the questionnaires), certain responses are logicaily incorrect. For example, it is not posstble for each of the four " $A$ " activity probabilities to increase (or decrease) relative to the estimates given in response to Questionnatre No. I (since the sum of these four probablitities must be 100\%). Some respondents in both test groups did not recognize this constraint.

- the second questionnatre permitted the response "N" ("if the question is unclear or, for any reason, you do not wish to answer $(t ")$. In fact, only one respondent in each group made any use of " $N$ ". In one case, the response was restricted to the impact of the "C" events on activity A-I. In the other case, " $N$ " was applied to the impact of the " $C$ " events on each of the four $A$ activities. Superficially, the virtual absence of "N" responses indicates that all of the questions/tasks were clear. Unfortunately, however, there is other evidence (e.g. personal comments, 1 llogical responses) that suggests otherwise. Moreover, in spite of the anonymity of the questionnaires, it is possible that some participants did not wish to reveal a lack of understanding -- even though the fault may have been in the design and wording of the questions.

- In the first questionnaire, responses to the " $C$ " questions required a ranking of curtailment priorities from 1 to 6 . The second questionnatre did not provide for re-ranking of "C" priorlties, but only for changes in impact relative to the responses given previously.* Hence, a "+" response, for example, has been interpreted as meaning that a given fuel use curtallment would be more likely than previously estimated.

- there were many "O" responses: 54\% of the ER group's and $57 \%$ of the DOE/outside group's responses fell in this category. Considering the nature of the "events", it might be reasoned that a change from an estimated fractional probability (in Questionnaire No. i) to a forced assumption of certainty (In Questionnaire No. 2) would produce estimates of significant changes of impact in most cases. The fact that significantly changed impacts were estimated in only about $45 \%$ of the cases has at least four possible explanations:

\#This is recognized, now, as a flaw in the design of the second questionnaire. 
TABLE 18-5

ER GROUP'S CONDITIONAL RESPONSES TO "A" EVENTS

\begin{tabular}{|c|c|c|c|c|c|c|c|c|c|c|c|c|}
\hline \multirow{3}{*}{$\begin{array}{l}\text { Fuel Use Impacted } \\
\text { by Event }\end{array}$} & \multicolumn{12}{|c|}{ Event } \\
\hline & \multicolumn{3}{|c|}{$\begin{array}{c}A-1 \\
\text { Peaks before } \\
1985\end{array}$} & \multicolumn{3}{|c|}{$\begin{array}{l}A-2 \\
\text { Peaks between } \\
1985 \text { and } 1990\end{array}$} & \multicolumn{3}{|c|}{$\begin{array}{l}\text { A-3 } \\
\text { Peaks between } \\
1990 \text { and } 2000\end{array}$} & \multicolumn{3}{|c|}{$\begin{array}{l}\text { A-4 } \\
\text { Peaks after } \\
\text { Year } 2000 \\
\end{array}$} \\
\hline & + & 0 & - & + & 0 & $=$ & + & 0 & - & \pm & 0 & - \\
\hline $\begin{array}{c}c-1 \\
\text { (air travel) }\end{array}$ & 6 & 4 & 1 & 6 & 4 & 1 & 4 & 7 & 0 & 3 & 5 & 3 \\
\hline $\begin{array}{c}c-2 \\
\text { (personal auto use) }\end{array}$ & 6 & 4 & 1 & 6 & -3 & 2 & 4 & 6 & 1 & 2 & 6 & 3 \\
\hline $\begin{array}{c}\text { C-3 } \\
\text { (heating ofl use) }\end{array}$ & 3 & 8 & 0 & 3 & 8 & 0 & 2 & 8 & 1 & 1 & 7 & 3 \\
\hline $\begin{array}{l}\text { C-4 } \\
\text { (ind. fuel ofl use) }\end{array}$ & 7 & 4 & 0 & 6 & 4 & 1 & 4 & 6 & 1 & 3 & 7 & 1 \\
\hline $\begin{array}{l}\text { (chem. feed use) } \\
\text { (che }\end{array}$ & 6 & 5 & 0 & 5 & 6 & 0 & 4 & 6 & 1 & 2 & 7 & 2 \\
\hline $\begin{array}{c}\text { C-6 } \\
\text { (marine fuel use) }\end{array}$ & 7 & 3 & 1 & 4 & 7 & 0 & 3 & 8 & 0 & 2 & 7 & 2 \\
\hline
\end{tabular}

\begin{tabular}{ccccc}
\multicolumn{5}{c}{ Excess of + over - Responses } \\
\cline { 2 - 3 }$C-1$ & 5 & $\frac{A-2}{A-1}$ & $\frac{A-3}{4}$ & $\frac{A-4}{0}$ \\
\cline { 2 - 3 }$C-2$ & 5 & 4 & 4 & -1 \\
$C-3$ & 3 & 3 & 3 & -2 \\
$C-4$ & 7 & 5 & 1 & 2 \\
$C-5$ & 6 & 5 & 3 & 0 \\
$C-6$ & 6 & 4 & 3 & 0
\end{tabular}


TABLE 18-6

DOE/OUTSIDE GROUP'S CONDITIONAL RESPONSES TO "A" EVENTS

\begin{tabular}{|c|c|c|c|c|c|c|c|c|c|c|c|c|}
\hline \multirow{3}{*}{$\begin{array}{l}\text { Fuel Use Impacted } \\
\text { by Event }\end{array}$} & \multicolumn{12}{|c|}{ Event } \\
\hline & \multicolumn{3}{|c|}{$\begin{array}{c}\text { A-l } \\
\text { Peaks before } \\
1985\end{array}$} & \multirow{2}{*}{\multicolumn{3}{|c|}{$\begin{array}{l}A-2 \\
\text { Peaks between } \\
1985 \text { and } 1990\end{array}$}} & \multicolumn{3}{|c|}{$\begin{array}{l}\text { A-3 } \\
\text { Peaks between } \\
1990 \text { and } 2000\end{array}$} & \multirow{2}{*}{\multicolumn{3}{|c|}{$\begin{array}{l}\text { A-4 } \\
\text { Peaks after } \\
\text { Year } 2000 \\
\end{array}$}} \\
\hline & \pm & 0 & $=$ & \pm & & - & \pm & 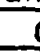 & - & & 0 & - \\
\hline (atr travel) & 6 & 2 & 1 & 4 & 4 & 1 & 4 & 4 & 1 & 3 & 3 & 3 \\
\hline $\begin{array}{l}\text { C-2 } \\
\text { (personal auto use) }\end{array}$ & 5 & 3 & 1 & 3 & 5 & 1 & 4 & 4 & 1 & 2 & 3 & 4 \\
\hline $\begin{array}{l}\text { C-3 } \\
\text { (heating } 011 \text { use) }\end{array}$ & 3 & 5 & 1 & 1 & 8 & 0 & 2 & & 1 & 1 & 4 & 4 \\
\hline $\begin{array}{l}\text { (Ind. fuel ofl use) } \\
\text { (f-4 }\end{array}$ & 6 & 3 & 0 & 5 & 3 & 1 & 4 & 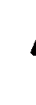 & 1 & 2 & 4 & 3 \\
\hline $\begin{array}{l}\text { (chem. feed use) } \\
\text { (che }\end{array}$ & 5 & 4 & 0 & 5 & 4 & 0 & 4 & . & 1 & 2 & 4 & 3 \\
\hline $\begin{array}{c}\text { C- } 6 \\
\text { (marine fuel use) }\end{array}$ & 6 & 3 & 0 & 3 & 5 & 1 & 3 & 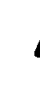 & 2 & 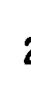 & 3 & 4 \\
\hline
\end{tabular}

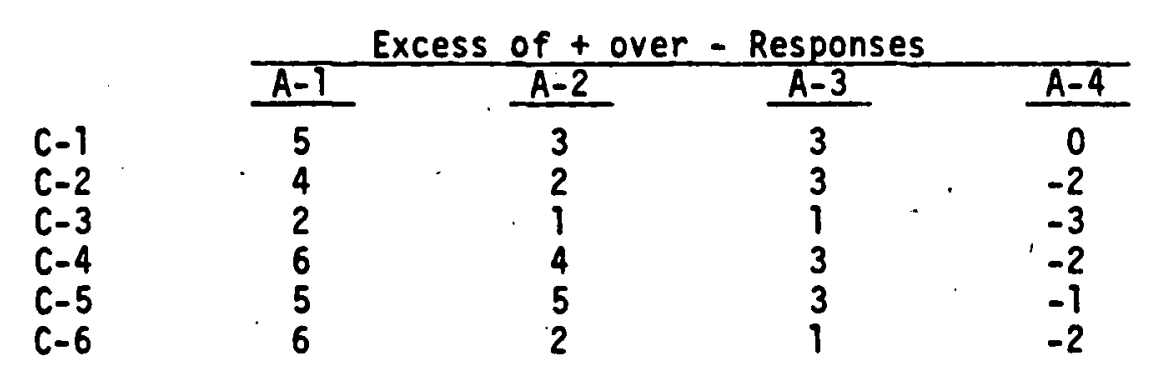

Note: one DOE/outside group participant did not respond to the "A" items. 


\section{TABLE $18-7$}

ER GROUP'S CONDITIONAL RESPONSES TO "C" EVENTS

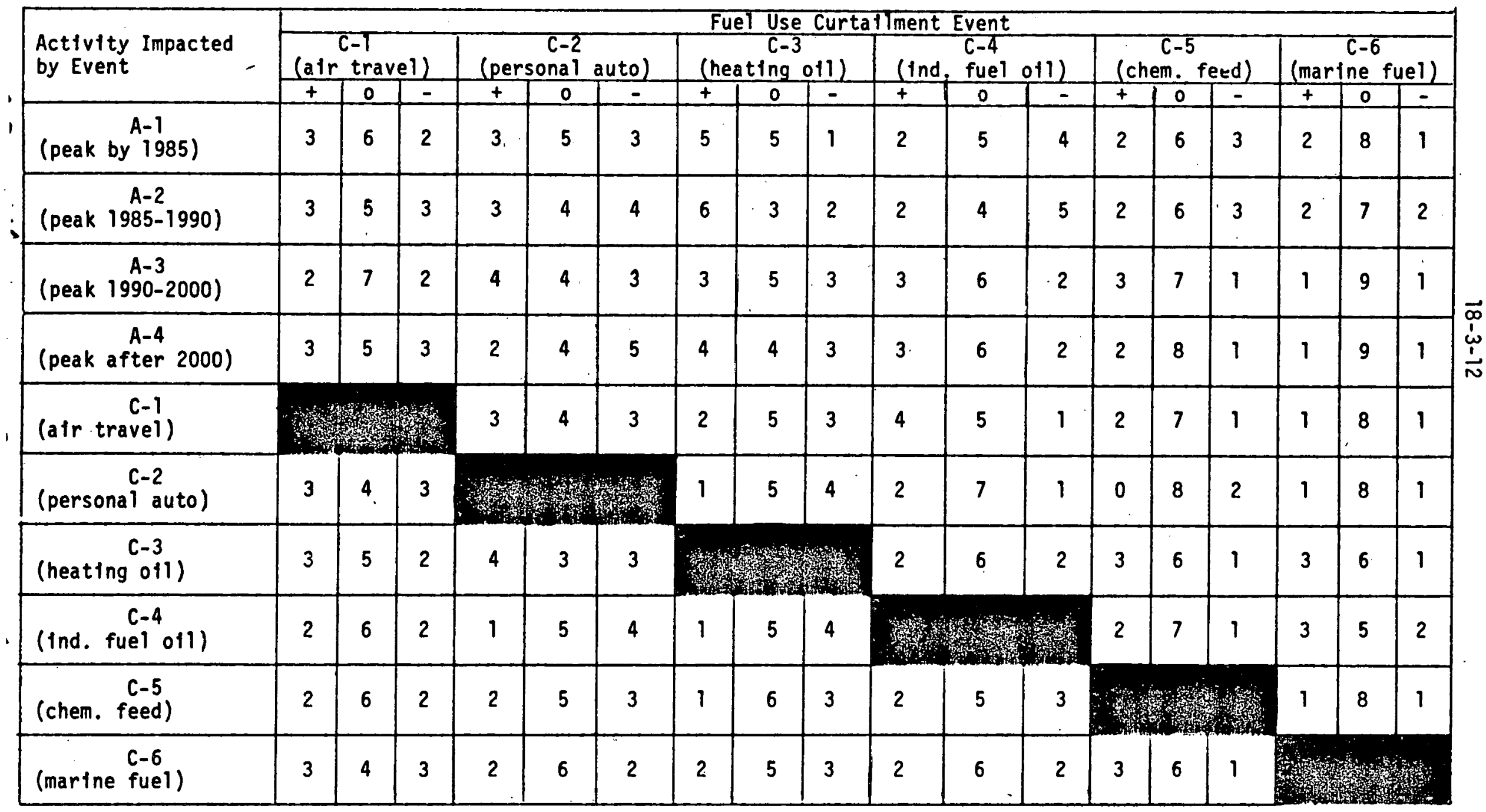


TABLE 18-7 (continued)

Excess of + over - Responses

A-1

$A-2$

A-3

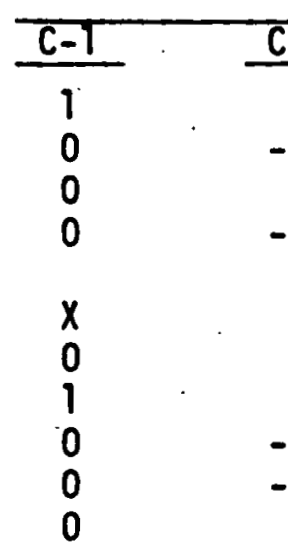

A-4

C-1

C-2

C-3

C-4

C-5

C-6

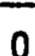

$-1$

1

C-3 $\quad$ C

$\frac{C-4}{-2} \quad \frac{C-5}{-1} \quad \frac{C-6}{1}$

$4 .-3$

1. $\quad 1$

$-$

3.

$\begin{array}{rr}0 & -1 \\ x & -3 \\ 1 & x \\ -3 & -3 \\ -1 & -2 \\ 0 & -1\end{array}$

Note: one ER participant did not respond to the "C" ftems (1.e. the impact of a " $C$ " event on other " $C$ " activities). 
TABLE 18-8

DOE/OUTSIDE GROUP'S CONDITIONAL RESPONSES TO "C" EVENTS

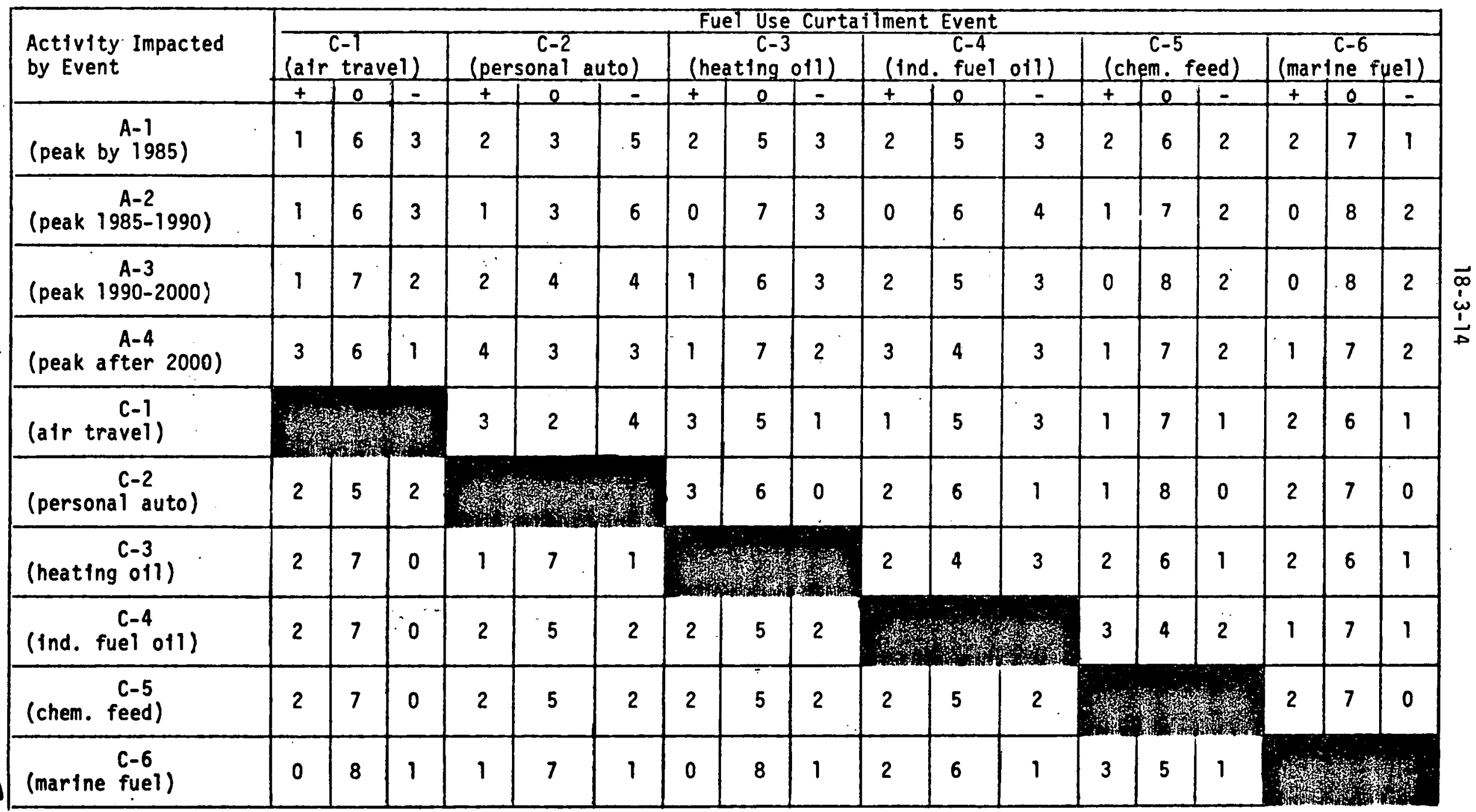


TABLE 18-8 (continued)

\begin{tabular}{|c|c|c|c|c|c|c|}
\hline & \multicolumn{6}{|c|}{ Excess of + over - Responses } \\
\hline & $c=1$ & $c-2$ & $c-3$ & $c-4$ & $\mathrm{C}-5$ & $C-6$ \\
\hline $\begin{array}{l}A-1 \\
A-2 \\
A-3 \\
A-4\end{array}$ & $\begin{array}{r}-2 \\
-2 \\
-1 \\
2\end{array}$ & $\begin{array}{r}-3 \\
-5 \\
-2 \\
1\end{array}$ & $\begin{array}{l}-1 \\
-3 \\
-2 \\
-1\end{array}$ & $\begin{array}{r}-1 \\
-4 \\
-1 \\
0\end{array}$ & $\begin{array}{l}0 \\
-1 \\
-2 \\
-1\end{array}$ & $\begin{array}{r}1 \\
-2 \\
-2 \\
-1\end{array}$ \\
\hline $\begin{array}{l}c-1 \\
c-2 \\
c-3 \\
c-4 \\
c-5 \\
c-6\end{array}$ & $\begin{array}{r}x \\
0 \\
2 \\
2 \\
2 \\
-1\end{array}$ & $\begin{array}{c}-1 \\
x \\
0 \\
0 \\
0 \\
0\end{array}$ & $\begin{array}{r}2 \\
3 \\
x \\
0 \\
0 \\
-1\end{array}$ & $\begin{array}{r}-2 \\
1 \\
-1 \\
x \\
0 \\
1\end{array}$ & $\begin{array}{l}0 \\
1 \\
1 \\
1 \\
x \\
2\end{array}$ & $\begin{array}{l}1 \\
2 \\
1 \\
0 \\
2 \\
x\end{array}$ \\
\hline
\end{tabular}

Note: one DOE/outside group participant did not respond to the " $\mathrm{C}$ " items (1.e. the Impact of a "C" event on other "C" activities). 
(1) the participants suffered from fatigue and, in cases of doubt, found " 0 " to be a conveniently neutral response.

(2) the required adjustment to previously estimated subjective probabllitles was hard to make.

(3) some participants may have felt either "I've already given my estimate, and I don't intend to change 1t" or "I don't accept the assumption that I'm being asked to make. Therefore, my previous estimate stands."

(4) it was difficult to make causal or correlative linkages between events, i.e. In the absence of explicit and predefined causalities the participants would have to create their own mental models using their own assumptions. Within practical time constraints, this may have been very difficult.

The responses of both test groups to the " $A$ " events (see Tables 18-5 and 18-6) were very similar. However, as for the first questionnaire, individual responses within each group varled greatly. As shown in the lower portion of each table, the excess of " + " over "-" responses declined as the conditioning event, the peaking of world crude oil production, is assumed to occur later in the future. The pattern of response in Tables 18-5 and 18-6 is what would be expected (logically) from the results of the first questionnaire, thereby suggesting that this segment of the second questionnaire was clear to the majority of respondents in both test groups.

The responses of the test groups to the " $C$ " events were quite simflar in the case of 47 impacts, but differed for the thirteen impacts recorded in Table 18-9. The reasons for these differences are not known beyond the obvious implication that the assumptions made by the test groups must have differed on the average. For example, the change in the mean response of the ER group to an assumption of air travel curtailment was that a peaking of world oil production by 1985 would be more likely, whereas the DOE/other group's mean response was in the opposite direction. A very important distinction may underlie these differences in perception:

- on the average, the ER group may have felt that something as serfous (in a social and economic sense) as the curtailment of air travel would not occur unless world ofl production had peaked or was expected to do so imminently; 1.e. a correlative rather, than a causative linkage may have been assumed.

- on the average, the DOE/other group may have felt that curtallment of air travel would avert or postpone the peaking of world o1l production; 1.e. a causative linkage may have been assumed.

\footnotetext{
* Nevertheless, one of the principal values of the cross-impact analysis is to generate the thinking required to estimate impacts.
} 
TABLE 18-9

DIVERGENCIES IN RESPONSES OF ER AND DOE/OTHER GROUPS TO "C" EVENTS (SEE TABLES 7 AND 8)

- Assumed event $C-1$ (air travel curtalled)

Impacted event $A-1$ (world ofl production peaks by 1985)

$\begin{array}{lcccc}\text { ER group } & + & 0 & - & \frac{+1-\Delta}{1} \\ \text { DOEloutside group } & 3 & 6 & 2 & -2\end{array}$

- Assumed event C-2 (personal auto use curtalled) Impacted event $A-1$ (world ofl production peaks by 1985)

ER group

DOE/outside group

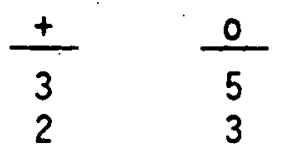

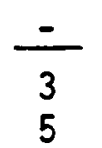

$\pm 1-\Delta$
0
-3

Impacted event A-2 (world oll production peaks between 1985 and 1990)

ER' group

DOE/outside group

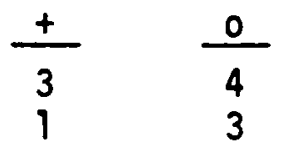

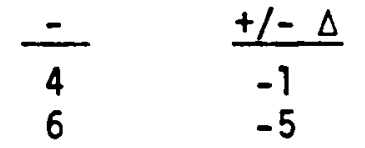

Impacted event A-3 (world o1l production peaks between 1990 and 2000)

ER group

DOE/outside group

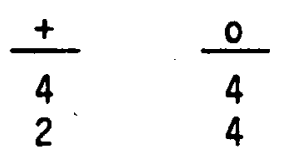

4

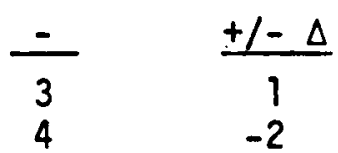

Impacted event A-4 (world oil production peaks after year 2000)

ER group

DOE/Outside group

$\begin{array}{llll}+ & 0 \\ 2 & \frac{1}{4} & \frac{+1-\Delta}{-3} & 1\end{array}$

Impacted event C-4 (curtaflment of ind. fuel oil use)

ER group

DOE/outside group

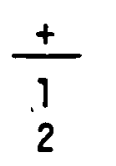

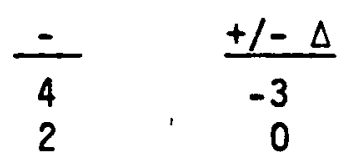


TABLE 18-9 (continued)

- Assumed event C-3 (domestic heating ofl use curtafled)

Impacted event A-I (worla ofl production peaks by 1985)

ER group

DOE/outside group

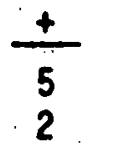

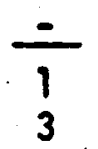

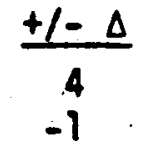

Impacted event A-2 (world oll production peaks between 1985 and 1990)

ER group

DOE/Outside group

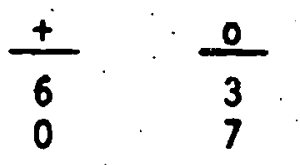

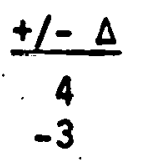

Impacted event $c-1$ (air travei curtalled)

ER group

DOE/outside group

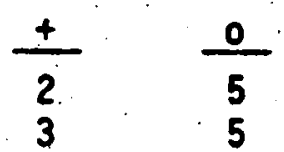

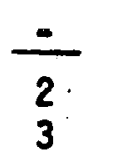

$\frac{-}{3}$

Impacted event $\mathrm{C}-2$ (personal auto use curtafled)

ER group DOE/outside group

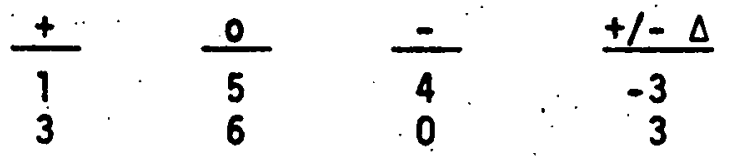

Impacted event C-4 (ind. fuel o1l use curtalled)

ER group

DOE/outside group

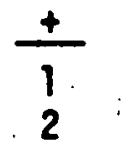

$+1-\Delta$

$-3$

- Assumed event C-4 (1nd. fuel ofl use curtalled) Impacted event $C-T$ (afir travel curtafled)

ER group

DOE/outside group

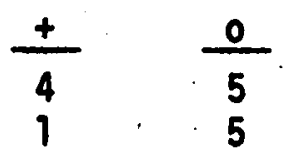

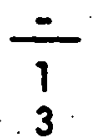

$\frac{+1-\Delta}{3}$

- Assumed event C-5 (chemical feedstock use curtalled) Impacted event $A-3$ (world of production peaks between 1990 and 2000)

ER group

DOE/outside group

$\frac{+}{3}$

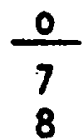

$+1-\Delta$ 
Almost all of the other divergencles may be rationalized in the same way, but the data do not permit this rationalization to be confirmed.

On the average, the ER group judged that curtailment of personal auto use would lessen the chance of curtaliment of the use of indus orial fuel ofl, whereas the DOE/outside group's response was neutral. Apparently, the ER group's judgment was that saving automotive fuel would obviate or mitigate the need for saving fuel ofl.

All of the divergencles in response to event $C-3$ (assumed curtallment of heating ofl use) may be rationalized on the bas is that the ER group may have been more concerned with correlation or association than with causation. This also applies the divergent responses to events C-4 and C-5.

\section{Conclusions}

The results obtained from the two questionnaires provide experimental evidence that there is considerable uncertainty about energy futures when measured in terms of individual perceptions. Because of the relatively small size of the test groups and in recognition of imperfections in the tests themselves, the results should be regarded as indications rather than as having been validated scientifically. Such validation would require further work, which may be justified if the indications are judged to be sufficiently interesting and important to be worth confirming or disproving. The principal inferences, or tentative conclusions, are as follows:

(1) The patterns of response by ER groups and by a DOE/outside group were very simllar, as were the mean responses of each group.

(2) Within each group there were considerable differences in response that, in the case of value laden issues like personal automobile use, amounted to polarization. (The same polarization was observed in both the ER and DOE/outside groups.)

(3) Some individuals in each group had difficulty with probabilistic forecasting. In part, this difficulty is attributable to deficiencies in the design and wording of the questionnaires. In part, however, the difficulty appears to reflect lack of famlifarity with the subject.

(4) Extreme care is needed in the wording of questions and instructions. Even the silightest ambiguity ieads to misunderstandings.

(5) For the cross-impact responses, it is possible that the ER group's response weighted correlation or association of events as much or more than causation. The latter appears to have been the guiding perception of the DOE/ outside group. This was the one respect in which a material difference was observed between the two test groups. 
(6) Except for uncertainty introduced by ambiguous wording (which does not appear to be the princtpal variables) 14 . appears that the within-group differences are attributable to differen: assumptions. The 1 imited experiment did not permit these assumptions to be made explicit.

Wi thout ariy supporting evidence from the experiment itself, it is belleved that the assumptions made by groups and individuals about energy futures and priorlties are important to the resolution of institutional problems. Put differently, different assumptions lead to differing perceptions of priority. Hence, it may be difficult to resolve conflicts in priority without first identifying and trying to resolve the differing assumptions that underile the conflicts. 
Figure 18-1

POOLED RESPONSES TO "C" QUESTIONS

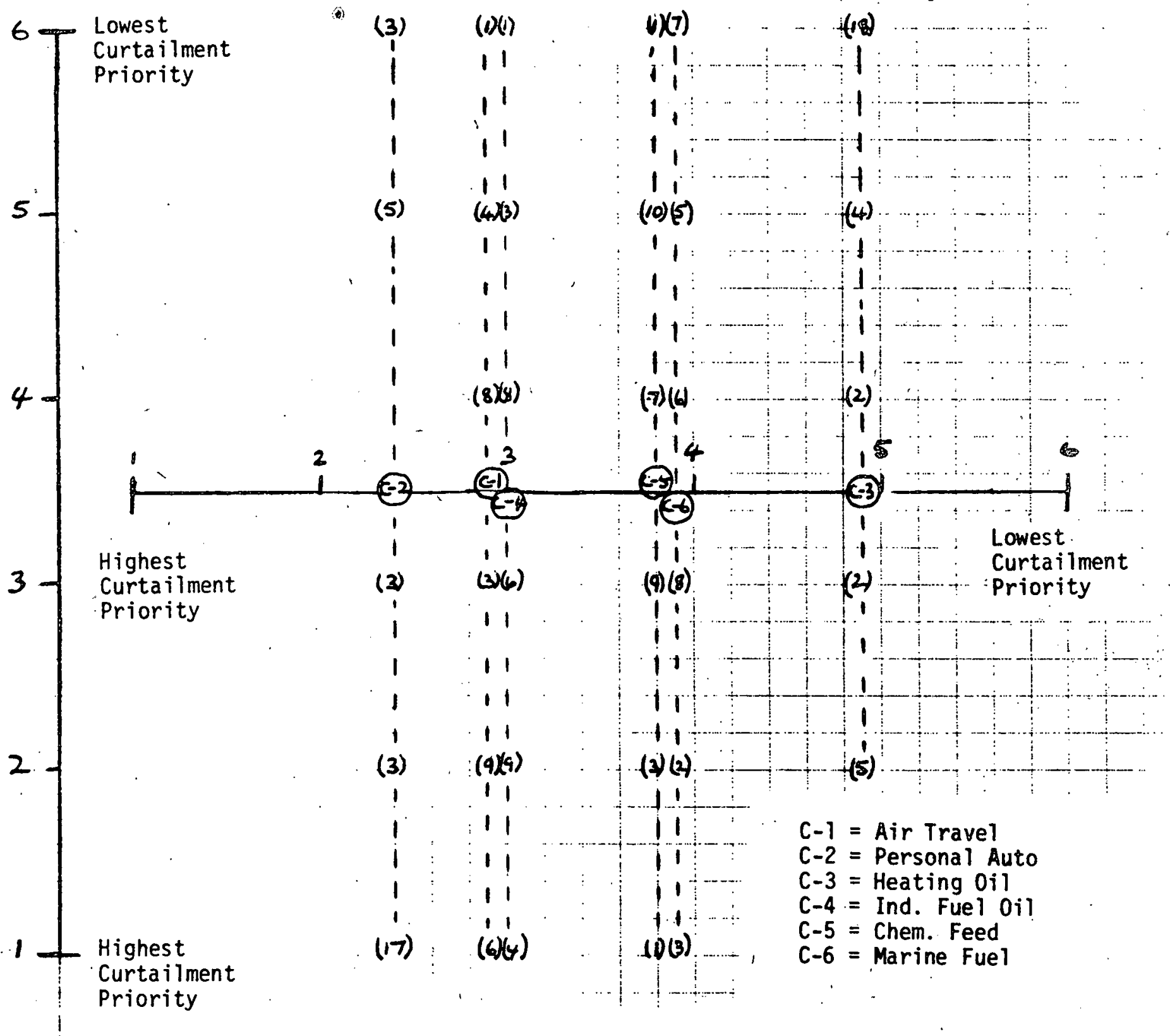

Shows position of pooled curtailment rating for each type of petroleum use on scale of 1 (= highest curtailment priority) to 6 (= lowest curtailment priority).

() Shows number of respondents who assigned the pertinent curtailment priority rating to each petroleum use. 


\begin{tabular}{|c|c|c|}
\hline $\begin{array}{l}\begin{array}{l}\text { BIBLLOGRAPHIC OATA } \\
\text { SHEET }\end{array} \text { 1. RePOR No. } \\
\end{array}$ & $\sqrt{2}$ & 3. Recipient's Acecssion No. \\
\hline \multirow{2}{*}{\multicolumn{2}{|c|}{$\begin{array}{l}\text { 4. Tille and Subritle } \\
\text { Alternative Energy Sources for Non-Highway Transportation } \\
\text { - Volume III -- Appendices }\end{array}$}} & 5. Regori Dale 1979 \\
\hline & & 6. \\
\hline \multicolumn{2}{|l|}{$\begin{array}{l}\text { 7. Author(s) } \\
\text { E. N. Cart, Jr., M. H. Farmer }\end{array}$} & $\begin{array}{l}\text { 8. Petloming Orenization-Repx. } \\
\text { No. ExXON/GRU.6T.79 }\end{array}$ \\
\hline \multicolumn{2}{|l|}{ 9. Performing Orgacizasion Name aod Address } & 10. Project/Task/Tork Unit No. \\
\hline \multicolumn{2}{|l|}{$\begin{array}{l}\text { Government Research Laboratories } \\
\text { Exxon Research and Engineering Company } \\
\text { P. } 0.80 \times 8 \\
\text { Linden, New Jersey } 07036\end{array}$} & $\begin{array}{l}\text { 11. Contract/Grans No. } \\
\text { DE-ACO5-77CSO5438 }\end{array}$ \\
\hline \multirow{2}{*}{\multicolumn{2}{|c|}{$\begin{array}{l}12 \text { Sponsoriaz Oreanization Name and Addrece } \\
\text { Non-Highway Systems Branch } \\
\text { T:ansportation - Energy Conservation Division } \\
\text { Office of Conservation and Solar Applications } \\
\text { Department of Energy, Washington, D.C. }\end{array}$}} & $\begin{array}{l}13 \text { Type of Repgar: Period } \\
\text { Covered FINAL } \\
\text { Sept. 1977-June } 1979\end{array}$ \\
\hline & & 14. \\
\hline
\end{tabular}

15. Supplementary Noces

16. Absiracts

A planning study has been made for DOE on alternate fuels for non-highway transportation (aircraft, rail, marine and pipeline). The purpose of the study was to. provide DOE with a recommendation of what alternate fuels may be of interest to, nonhighway transportation users from now through 2025 and to recommend R\&D needed to allow non-petroleum derived fuels to be used in non-highway transportation.

In the near term (present 1985), there is unilikely to be any major change in the fuels used in any of the four modes of transportation except that the average quality of the marine fuel is likely to get worse. In the mid-term period (1985-2000), there will be a transition to non-petroleum fuels, based primarily on shale oil derived liquids assuming a shale oil industry is started during this time.

(over)

17. Key Words and Doeument Analysis. 17a. Descriprors

Alternate Fuels

Marine

Aircraft

Pipeline

Railroads

Energy Supply/Demand

Military Considerations

17b. Identifiers/Open-Ended Terms
International Considerations

Institutional Issues

Probabilistic Forecasting

Cross-Impact Analys is

17e. CosATI Field/Group

18. Availability Statement

APPROVED FOR PUBLIC RELEASE; DISTRIBUTION UNLIMITED

19. Security C.lass (This

21. No. of Fares

$\begin{array}{ll}20.5 e c u r t y & \end{array}$

Pare UNCLASSIFIED 


\section{Abstracts (cont.)}

The future outlook for possible prime movers and potential fuel sources for the long term $(2000+)$ is as follows. In the marine area, steam engines burning coal or diesel engines with unrefined shale oil or coal slurries are the prime candidates. With the aircraft gas turbine, either synthetic liquids from shale or coal would appear to be the most desirable fuels. Railroads will probably remain with the diesel/ electric prime mover using shale oil as a source of distillate. Pipelines will probably use electr'c motors as the major type of prime mover.

This Apper dix covers the demand-related issues and the institutional problems. 
United States

Department of Energy

Washington, DC 20585

PENALTY FOR PRIVATE USE TO AVOID PAYMENT OF POSTAGE, $\$ 300$

DOE 350

\section{ASS MAIL}

